\title{
A Hydrostratigraphic Model and Alternatives for the Groundwater Flow and Contaminant Transport Model of Corrective Action Unit 99: Rainier Mesa-Shoshone Mountain, Nye County, Nevada
}

\author{
Prepared for \\ U.S. Department of Energy \\ National Nuclear Security Administration \\ Nevada Site Office \\ Las Vegas, Nevada \\ Prepared by \\ Geotechnical Sciences Group \\ National Security Technologies, LLC \\ Las Vegas, Nevada
}

March 2007 


\section{DISCLAIMER STATEMENT}

Reference herein to any specific commercial product, process, or service by trade name, trademark, manufacturer, or otherwise, does not necessarily constitute or imply its endorsement, recommendation, or favoring by the U.S. Government or any agency thereof or its contractors or subcontractors.

\section{AVAILABILITY STATEMENT}

Available to the public, in paper from-

U.S. Department of Commerce

National Technical Information Service

5285 Port Royal Road

Springfield, VA 22161-0002

Telephone: 800.553.6847

Fax: 703.605.6900

E-mail: orders@ntis.gov

Online ordering: http://www.ntis.gov/ordering.htm

Available electronically at http://www.osti.gov/bridge

Available for a processing fee to U.S. Department of Energy and its contractors, in paper, from-

U.S. Department of Energy

Office of Scientific and Technical Information

P.O. Box 62

Oak Ridge, TN, 37831-0062

Telephone: 865.576 .8401

Fax: 865.576.5728

E-mail: reports@adonis.osti.gov 


\section{A Hydrostratigraphic Model and Alternatives for the Groundwater Flow and Contaminant Transport Model of Corrective Action Unit 99: Rainier Mesa-Shoshone Mountain, Nye County, Nevada}

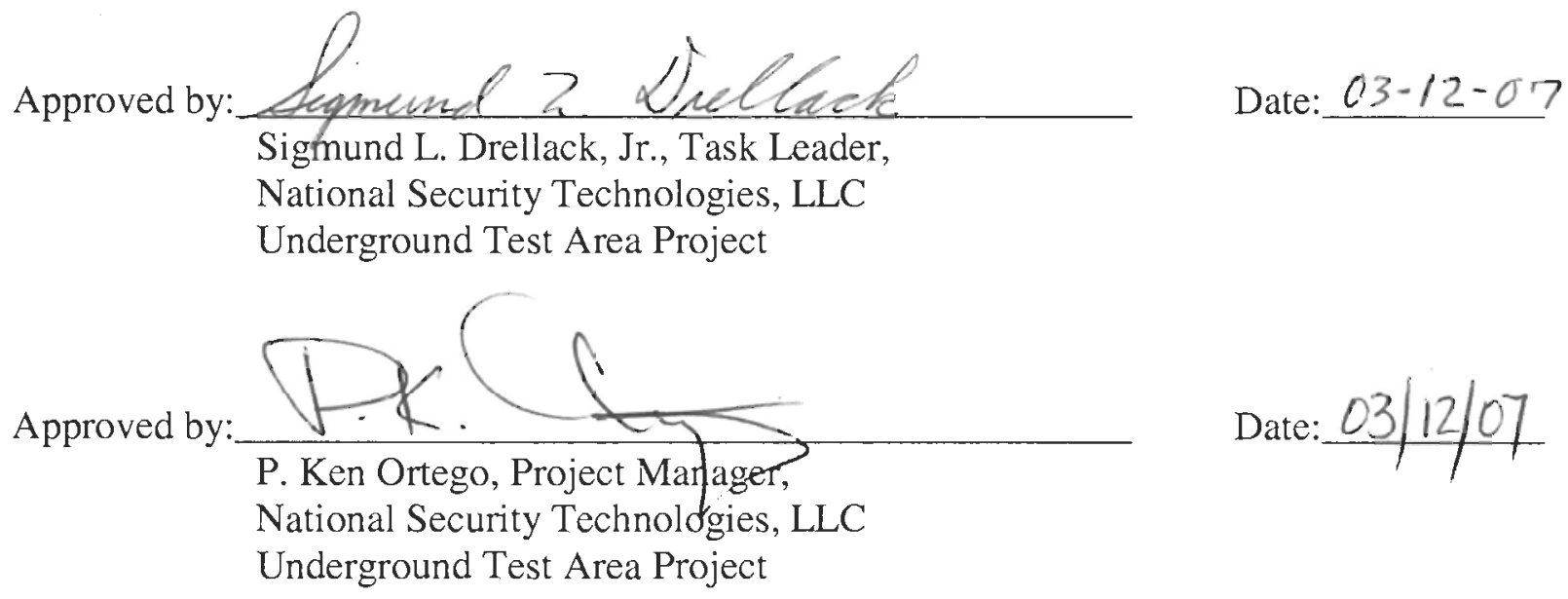


This page intentionally left blank. 
The three-dimensional hydrostratigraphic framework model for the Rainier Mesa-Shoshone Mountain Corrective Action Unit was completed in Fiscal Year 2006. The model extends from eastern Pahute Mesa in the north to Mid Valley in the south and centers on the former nuclear testing areas at Rainier Mesa, Aqueduct Mesa, and Shoshone Mountain. The model area also includes an overlap with the existing Underground Test Area Corrective Action Unit models for Yucca Flat and Pahute Mesa.

The model area is geologically diverse and includes un-extended yet highly deformed Paleozoic terrain and high volcanic mesas between the Yucca Flat extensional basin on the east and caldera complexes of the Southwestern Nevada Volcanic Field on the west. The area also includes a hydrologic divide between two groundwater sub-basins of the Death Valley regional flow system.

A diverse set of geological and geophysical data collected over the past 50 years was used to develop a structural model and hydrostratigraphic system for the model area. Three deep characterization wells, a magnetotelluric survey, and reprocessed gravity data were acquired specifically for this modeling initiative. These data and associated interpretive products were integrated using EarthVision ${ }^{\circledR}$ software to develop the three-dimensional hydrostratigraphic framework model. Crucial steps in the model building process included establishing a fault model, developing a hydrostratigraphic scheme, compiling a drill-hole database, and constructing detailed geologic and hydrostratigraphic cross sections and subsurface maps. The more than 100 stratigraphic units in the model area were grouped into 43 hydrostratigraphic units based on each unit's propensity toward aquifer or aquitard characteristics. The authors organized the volcanic units in the model area into 35 hydrostratigraphic units that include 16 aquifers, 12 confining units, 2 composite units (a mixture of aquifer and confining units), and 5 intrusive confining units. The underlying pre-Tertiary rocks are divided into six hydrostratigraphic units, including three aquifers and three confining units. Other units include an alluvial aquifer and a Mesozoic-age granitic confining unit. The model depicts the thickness, extent, and geometric relationships of these hydrostratigraphic units ("layers" in the model). The model also incorporates 56 Tertiary normal faults and 4 Mesozoic thrust faults. 
The complexity of the model area and the non-uniqueness of some of the interpretations incorporated into the base model made it necessary to formulate alternative interpretations for some of the major features in the model. Four of these alternatives were developed so they can be modeled in the same fashion as the base model.

This work was done for the U.S. Department of Energy, National Nuclear Security Administration Nevada Site Office in support of the Underground Test Area Subproject of the Environmental Restoration Project. 


\section{Table of Contents}

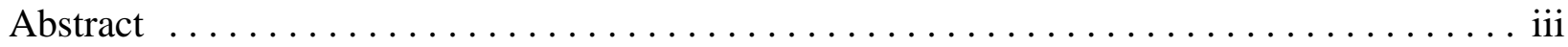

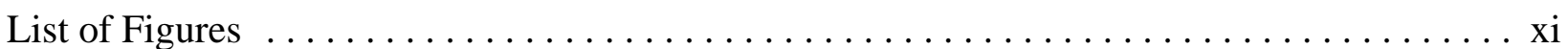

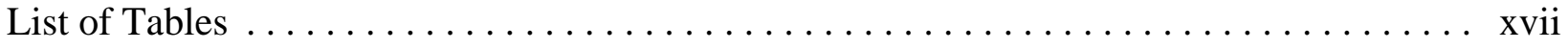

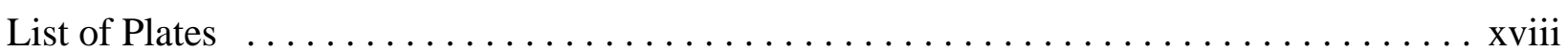

List of Acronyms and Abbreviations $\ldots \ldots \ldots \ldots \ldots \ldots \ldots \ldots \ldots \ldots \ldots \ldots \ldots \ldots \ldots \ldots \ldots \ldots \ldots$

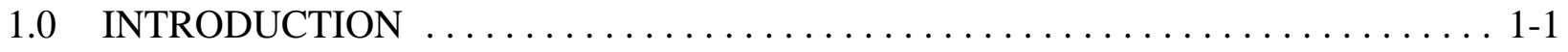

1.1 Background Information for the Hydrostratigraphic Framework Model Task . . 1-1

1.2 Document Organization $\ldots \ldots \ldots \ldots \ldots \ldots \ldots \ldots \ldots \ldots \ldots \ldots \ldots \ldots \ldots \ldots \ldots \ldots \ldots, 2$

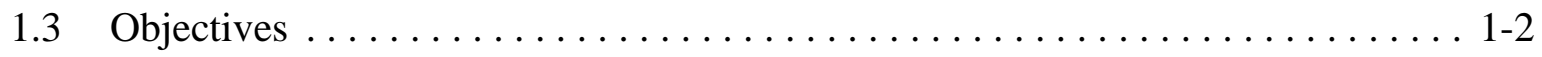

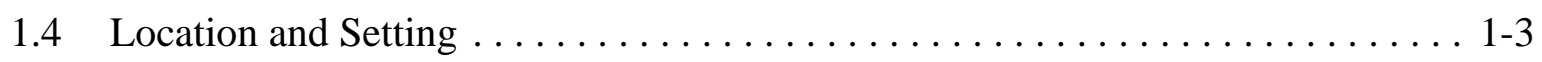

1.4.1 Underground Nuclear Tests in Rainier Mesa and Shoshone Mountain

Test Areas .................................. 1-3

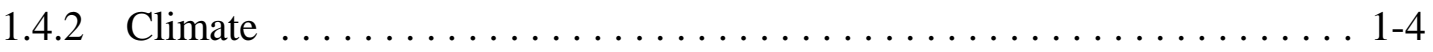

1.4 .3 Physiography $\ldots \ldots \ldots \ldots \ldots \ldots \ldots \ldots \ldots \ldots \ldots \ldots \ldots \ldots \ldots \ldots \ldots \ldots \ldots \ldots, 4$

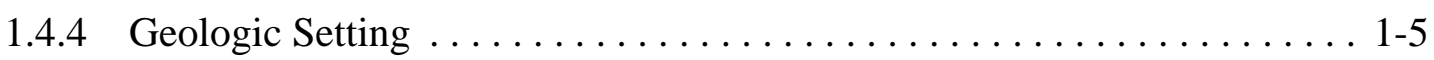

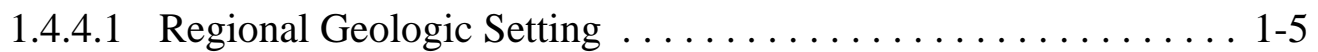

1.4.4.2 Geology Overview of Rainier Mesa ................ 1-6

1.4.4.3 Geology Overview of Shoshone Mountain ............ 1-7

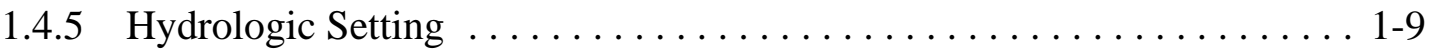

1.4.5.1 Surface Water . . . . . . . . . . . . . . . . . . . . . . . 1-9

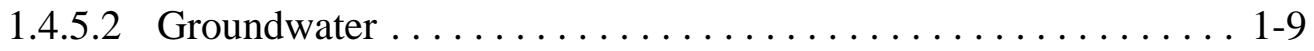

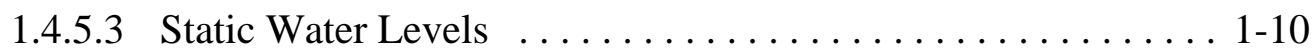

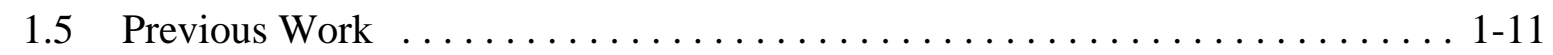

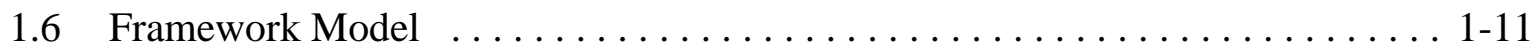

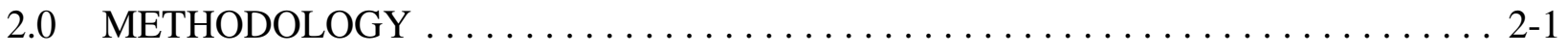

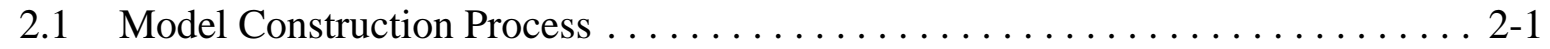

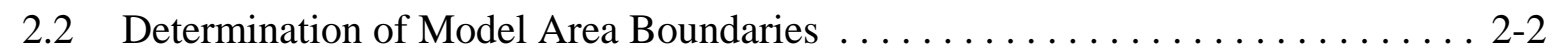

2.3 Data, Interpretive Products, and Other Information Used in

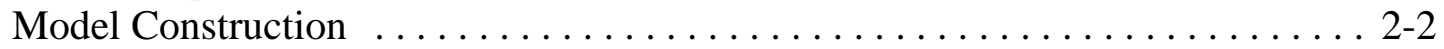

2.3 .1 Existing Geological and Geophysical Maps ................ 2-6

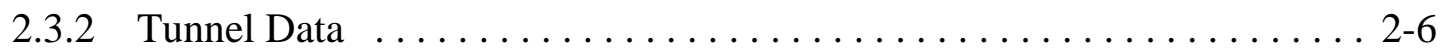

2.3.2.1 B-Tunnel ................................ 2-7

2.3.2.2 E-Tunnel .................................. 2-8

2.3.2.3 G-Tunnel .............................. 2-9 
2.3.2.4 N-Tunnel $\ldots . \ldots \ldots \ldots \ldots \ldots \ldots \ldots \ldots \ldots \ldots \ldots \ldots . .2-10$

2.3.2.5 P-Tunnel .............................. 2-11

2.3.2.6 T-Tunnel $\ldots \ldots \ldots \ldots \ldots \ldots \ldots \ldots \ldots \ldots \ldots \ldots \ldots . .2-11$

2.3.2.7 Other Tunnel Complexes ...................... 2-12

2.3.2.8 U16a Tunnel Complex ....................... 2-13

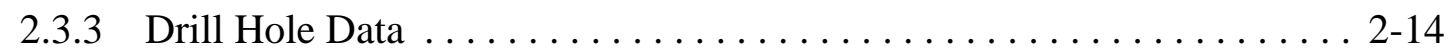

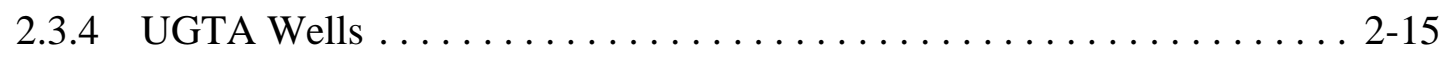

2.3.4.1 Well ER-12-1 .......................... 2-15

2.3.4.2 Well ER-12-2 ........................... 2-16

2.3.4.3 Well ER-12-3 .......................... 2-16

2.3.4.4 Well ER-12-4 .......................... 2-17

2.3.4.5 Well ER-16-1 ......................... 2-17

2.3.4.6 Well ER-19-1 ......................... 2-18

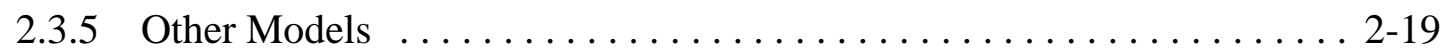

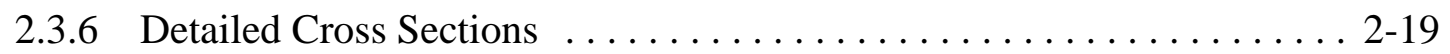

2.3.7 Surface Effects from Underground Nuclear Explosions $\ldots \ldots \ldots \ldots .2-20$

2.3 .8 Geophysical Investigations . . . . . . . . . . . . . . . . . . . 2-20

2.3.8.1 Gravity Data ......................... 2-21

2.3.8.2 Ground Magnetic Data ......................... 2-22

2.3.8.3 Aeromagnetic Data ....................... 2-22

2.3.8.4 Natural Source Magnetotelluric Survey .............. 2-22

2.3.8.5 Other Resistivity Surveys . . . . . . . . . . . . . . . 2-23

2.3.8.6 Seismic Refraction Surveys . . . . . . . . . . . . . . . . 2-23

2.3.8.7 Two-Dimensional Seismic Reflection Surveys .......... 2-23

2.3 .9 Studies at Gold Meadows Stock ....................... 2-24

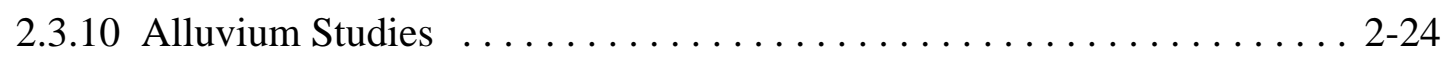

2.3.10.1 U-1a Complex ........................... 2-25

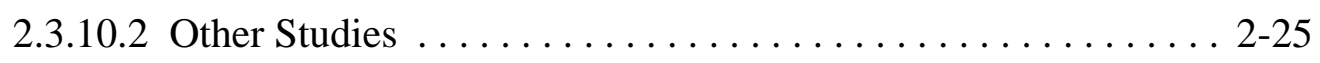

2.3.11 Mineralogic Studies of Volcanic Rocks ................... 2-25

2.3.11.1 Tuff Confining Unit Study . . . . . . . . . . . . . . . . .

2.3.11.2 Reactive Mineral Characterization of Volcanic and

Sedimentary Rocks $\ldots \ldots \ldots \ldots \ldots \ldots \ldots \ldots \ldots . \ldots . \ldots .2-26$

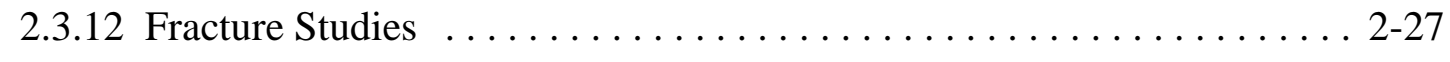

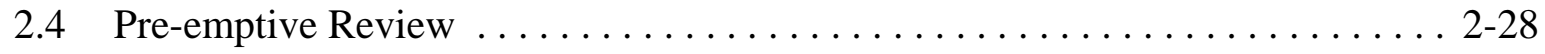

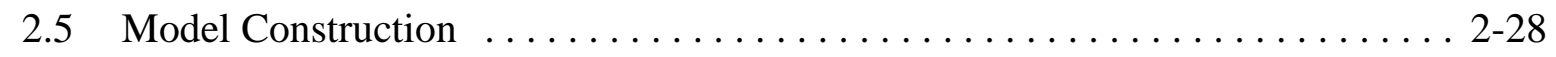




\section{Table of Contents, continued}

2.5.1 Use of Computer Software to Construct the Model . . . . . . . . . . 2-28

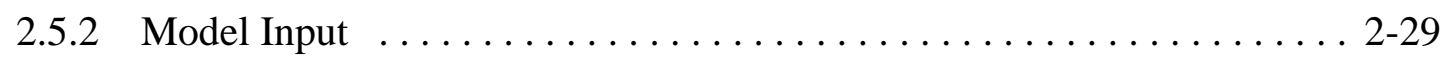

2.5 .3 Quality Control and Model Review .................. 2-30

2.5 .4 Alternative Models ... . . . . . . . . . . . . . . . . 2-31

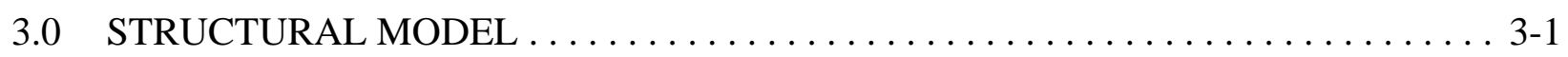

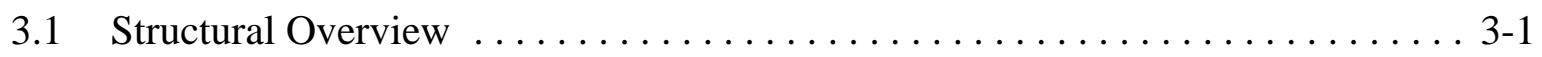

3.1.1 Pre-Tertiary Contractional Deformation $\ldots \ldots \ldots \ldots \ldots \ldots \ldots$. . . . . . .

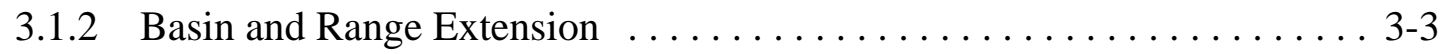

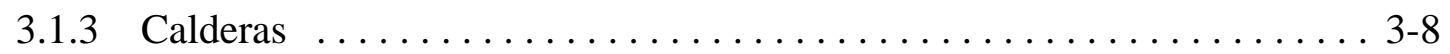

3.1.3.1 Redrock Valley Caldera . . . . . . . . . . . . . . . . . . 3-8

3.1.3.2 Silent Canyon Caldera Complex . . . . . . . . . . . . . 3-9

3.1.3.3 Rainier Mesa Caldera . . . . . . . . . . . . . . . . . . . . 3-9

3.2 Hydrologic Characteristics of Faults $\ldots \ldots \ldots \ldots \ldots \ldots \ldots \ldots \ldots$

4.0 HYDROSTRATIGRAPHY $\ldots \ldots \ldots \ldots \ldots \ldots \ldots \ldots \ldots \ldots \ldots \ldots \ldots \ldots . . .4$

4.1 Development of the Hydrostratigraphic Classification System . . . . . . . . . . 4-1

4.2 Stratigraphy of the Rainier Mesa-Shoshone Mountain Model Area . . . . . . . 4-2

4.3 Unit Thickness ........................... 4-3

4.4 Hydrogeologic Units of the Rainier Mesa-Shoshone Mountain Model Area . . . 4-3

4.4 .1 Alluvial HGU . . . . . . . . . . . . . . . . . 4-8

4.4.2 Volcanic HGUs . . . . . . . . . . . . . . . . . . . . . . . . 4-8

4.4 .3 Pre-Tertiary HGUs $\ldots \ldots \ldots \ldots \ldots \ldots \ldots \ldots \ldots \ldots \ldots . . \ldots \ldots$

4.5 Hydrostratigraphic Units of the Rainier Mesa-Shoshone Mountain

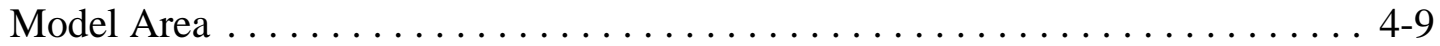

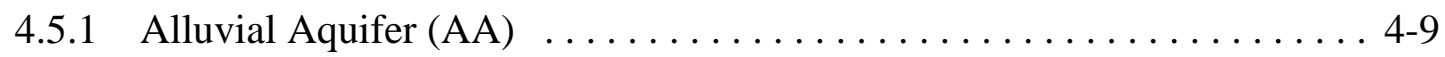

4.5.2 Fortymile Canyon Composite Unit (FCCM) . . . . . . . . . . . . . 4-20

4.5 .3 Timber Mountain Hydrostratigraphic Units . . . . . . . . . . . . . . 4-21

4.5.3.1 Timber Mountain Upper Vitric-Tuff Aquifer (TM-UVTA) . . 4-22

4.5.3.2 Timber Mountain Welded-Tuff Aquifer (TM-WTA) . . . . . . 4-22

4.5.3.3 Timber Mountain Lower Vitric-Tuff Aquifer (TM-LVTA) . . 4-23

4.5.3.4 Timber Mountain Composite Unit (TMCM) . . . . . . . . . . . . 4-24

4.5.3.5 Rainier Mesa Breccia Confining Unit (RMBCU) . . . . . . . . . 4-25

4.5.4 Sub-Caldera Volcanic Confining Unit (SCVCU) . . . . . . . . . . . . . 4-25

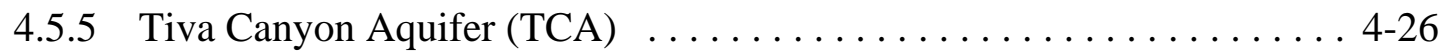




\section{Table of Contents, continued}

4.5.6 Paintbrush Vitric Tuff Aquifer (PVTA) $\ldots \ldots \ldots \ldots \ldots \ldots \ldots \ldots .4 .26$

4.5 .7 Upper Tuff Confining Unit (UTCU) $\ldots \ldots \ldots \ldots \ldots \ldots \ldots \ldots \ldots . . \ldots \ldots$

4.5 .8 Topopah Spring Aquifer (TSA) $\ldots \ldots \ldots \ldots \ldots \ldots \ldots \ldots \ldots \ldots . . \ldots \ldots .27$

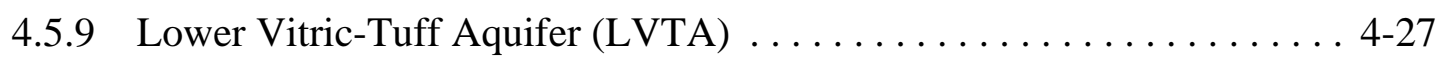

4.5.10 Calico Hills Vitric-Tuff Aquifer (CHVTA) …............ 4-28

4.5.11 Yucca Mountain Calico Hills Lava-Flow Aquifer (YMCHLFA) . . . . 4-28

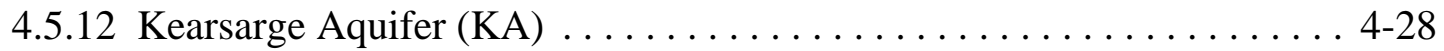

4.5 .13 Upper Tuff Confining Unit 2 (UTCU2) $\ldots \ldots \ldots \ldots \ldots \ldots \ldots \ldots .4 .28$

4.5.14 Stockade Wash Aquifer (SWA) . ..................... 4-29

4.5.15 Lower Vitric-Tuff Aquifer 2 (LVTA2) …............... 4-29

4.5.16 Bullfrog Confining Unit (BFCU) ..................... 4-30

4.5.17 Upper Tuff Confining Unit 1 (UTCU1) $\ldots \ldots \ldots \ldots \ldots \ldots \ldots \ldots .4-30$

4.5 .18 Belted Range Aquifer (BRA) $\ldots \ldots \ldots \ldots \ldots \ldots \ldots \ldots \ldots \ldots \ldots .4 .6 \ldots$

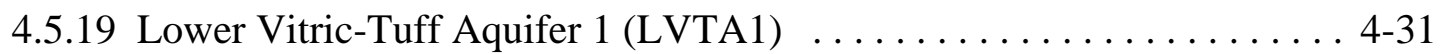

4.5.20 Belted Range Confining Unit (BRCU) . . . . . . . . . . . . . . . . 4-31

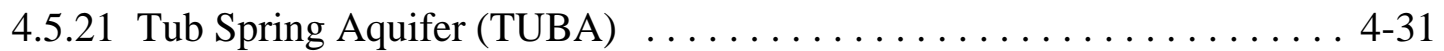

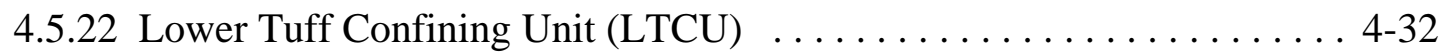

4.5.23 Oak Spring Butte Confining Unit (OSBCU) …............ 4-32

4.5.24 Redrock Valley Aquifer (RVA) $\ldots \ldots \ldots \ldots \ldots \ldots \ldots \ldots \ldots \ldots . \ldots \ldots . \ldots \ldots$

4.5.25 Redrock Valley Breccia Confining Unit (RVBCU) ............. 4-34

4.5.26 Lower Tuff Confining Unit 1 (LTCU1) . . . . . . . . . . . . . . 4-34

4.5 .27 Twin Peaks Aquifer (TPA) ....................... 4-34

4.5.28 Argillic Tuff Confining Unit (ATCU) .................... 4-35

4.5.29 Caldera-Related Intrusive Confining Units . . . . . . . . . . . . . 4 4-35

4.5.29.1 Ammonia Tanks Intrusive Confining Unit (ATICU) . . . . . 4 4-36

4.5.29.2 Rainier Mesa Intrusive Confining Unit (RMICU) … . . . 4 4-36

4.5.29.3 Silent Canyon Intrusive Confining Unit (SCICU) … . . . . 4-37

4.5.29.4 Redrock Valley Intrusive Confining Unit (RVICU) . . . . . . . 4-37

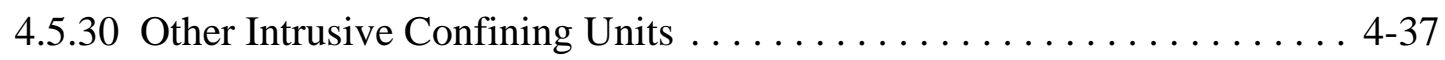

4.5.30.1 Calico Hills Intrusive Confining Unit (CHICU) . . . . . . . . 4-38

4.5.30.2 Mesozoic Granitic Confining Unit (MGCU) . . . . . . . . . 4 4-38

4.5.31 Lower Clastic Confining Unit 1 - Thrust Plate (LCCU1) . ......... 4-38

4.5 .32 Lower Carbonate Aquifer - Thrust Plate (LCA3) . . . . . . . . . . . 4-39

4.5 .33 Upper Carbonate Aquifer (UCA) $\ldots \ldots \ldots \ldots \ldots \ldots \ldots \ldots \ldots .4 .40$ 


\section{Table of Contents, continued}

4.5 .34 Upper Clastic Confining Unit (UCCU) . . . . . . . . . . . . . . 4 4-40

4.5.35 Lower Carbonate Aquifer (LCA) . . . . . . . . . . . . . . . 4 4-41

4.5.36 Lower Clastic Confining Unit (LCCU) . . . . . . . . . . . . . . 4-42

4.6 Relationship of Hydrostratigraphic Units and the Water Table . . . . . . . . 4 4-42

5.0 ALTERNATIVE SCENARIOS $. . \ldots \ldots \ldots \ldots \ldots \ldots \ldots \ldots \ldots \ldots \ldots \ldots . . \ldots \ldots$

5.1 Process of Addressing Alternatives to the Base Model . . . . . . . . . . 5-1

5.2 Alternative Models . . . . . . . . . . . . . . . . . . . . . 5-8

5.2 .1 No Redrock Valley Caldera $\ldots \ldots \ldots \ldots \ldots \ldots \ldots \ldots \ldots \ldots$. . . . . .

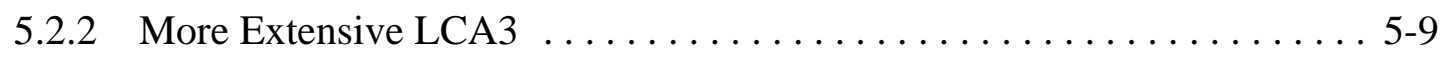

5.2.3 Shoshone Mountain Thrust Sheet . . . . . . . . . . . . . 5-10

5.2.4 LCA3 at Bottom of Well ER-12-1 . . . . . . . . . . . . 5-11

6.0 SUMMARY $\ldots \ldots \ldots \ldots \ldots \ldots \ldots \ldots \ldots \ldots \ldots \ldots \ldots \ldots \ldots \ldots \ldots \ldots .1$

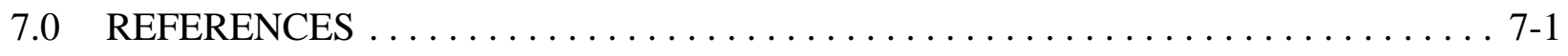

DISTRIBUTION LIST

\section{APPENDICES}

A Hydrostratigraphic Drill Hole Database for the Rainier Mesa-Shoshone Mountain Area

B Graphical Presentations for Selected UGTA Wells in the Rainier Mesa-Shoshone Mountain Model Area Showing Stratigraphy, Lithology, Alteration, and Hydrogeologic Units

C Hydrostratigraphic Profiles through the Rainier Mesa-Shoshone Mountain Base Model 
This page intentionally left blank. 


\section{List of Figures}

\section{NOTE: Figures are located at the end of each section.}

1-1 Map Showing Locations of all UGTA Model Areas

1-2 Satellite Image of the Rainier Mesa-Shoshone Mountain Model Area Showing Physiographic Features and Locations of Underground Nuclear Tests

1-3 Locations of Underground Nuclear Tests within the RM-SM Model Area

1-4 Color Relief Map Showing Locations of the Basin and Range Physiographic and Great Basin Hydrographic Provinces

1-5 Generalized Geologic Map of the Rainier Mesa-Shoshone Mountain Area

1-6 Northwest-Southeast Geologic Cross Section through Well ER-12-4 on Aqueduct Mesa

1-7 West-East Geologic Cross Section through Well ER-16-1 at Tippipah Point

1-8 Natural Springs and Seeps on the Nevada Test Site

1-9 Groundwater Subbasins of the Nevada Test Site and Vicinity

2-1 Shaded Relief Map of the Rainier Mesa Area Showing Locations of Tunnel Complexes

2-2 Shaded Relief Map of the Shoshone Mountain Area Showing Location of Tunnel Complex

2-3 Locations of Hydrostratigraphic Cross Sections Constructed for the Rainier MesaShoshone Mountain Model

2-4 Map Showing an Example of Surface Effects from Underground Nuclear Tests at $\mathrm{N}$-Tunnel in Area 12

2-5 Locations of Gravity Stations in the Rainier Mesa-Shoshone Mountain Model Area

2-6 Depth to Pre-Tertiary Rocks in the RM-SM Model Area Based on Gravity Data

2-7 Locations of Magnetotelluric Survey Stations in the RM-SM Model Area

2-8 3-D Display from EarthVision ${ }^{\circledR}$ of the Rainier Mesa-Shoshone Mountain Model Volume

2-9 Comparison of Calculated Predicted Elevation Values from the Rainier Mesa-Shoshone Mountain Model Versus Well-Pick Data

2-10 Histogram of Differences in Elevation between the Rainier Mesa-Shoshone Mountain Model and Well-Pick Data for the Timber Mountain Lower Vitric-Tuff Aquifer

3-1 Pre-Tertiary Structural Features within the Rainier Mesa-Shoshone Mountain Model Area

3-2 Normal Faults within the Rainier Mesa-Shoshone Mountain Model Area

3-3 Fault-Tree Model of the Rainier Mesa-Shoshone Mountain Model Showing Normal Faults Included in the Model 


\section{List of Figures, continued}

4-1 Simplified Stratigraphic Section for Rainier Mesa

4-2 Simplified Stratigraphic Section for the Shoshone Mountain Area

4-3 Correlation of Stratigraphic and Hydrostratigraphic Units of the Rainier Mesa-Shoshone Mountain Model Area

4-4 Block Model View Showing Hydrostratigraphic Units at the Surface within the RM-SM Model Area

4-5 Block Model View Showing Extent of the Alluvial Aquifer (AA) within the RM-SM Model Area

4-6 Block Model View Showing Extent of the Fortymile Canyon Composite Unit (FCCM) within the RM-SM Model Area

4-7 Schematic West-East Cross Section across Rainier Mesa-Shoshone Mountain Showing Variability in Hydrogeologic Character of the Timber Mountain Hydrostratigraphic Units

4-8 Block Model View Showing Extent of the Timber Mountain Upper Vitric-Tuff Aquifer (TM-UVTA) within the RM-SM Model Area

4-9 Depth to the Timber Mountain Upper Vitric-Tuff Aquifer in the RM-SM Model Area

4-10 Block Model View Showing Extent of the Timber Mountain Welded-Tuff Aquifer (TM-WTA) within the RM-SM Mountain Model Area

4-11 Depth to the Timber Mountain Welded-Tuff Aquifer in the RM-SM Model Area

4-12 Schematic Hydrostratigraphic Cross Section Showing the Relationships of the Alluvial and Volcanic HSUs in the Southern Portion of the Rainier Mesa-Shoshone Mountain Area

4-13 Schematic West-East Hydrostratigraphic Cross Section through Well ER-16-1 Showing Relationships of Hydrostratigraphic Units

4-14 Block Model View Showing Extent of the Timber Mountain Lower Vitric-Tuff Aquifer (TM-LVTA) within the RM-SM Model Area

4-15 Depth to the Timber Mountain Lower Vitric-Tuff Aquifer in the RM-SM Model Area

4-16 Block Model View Showing Extent of the Timber Mountain Composite Unit (TMCM) within the Rainier Mesa-Shoshone Mountain Model Area

4-17 Depth to the Timber Mountain Composite Unit in the RM-SM Model Area

4-18 Block Model View Showing Extent of the Rainier Mesa Breccia Confining Unit (RMBCU) within the RM-SM Model Area

4-19 Block Model View Showing Extent of the Subcaldera Volcanic Confining Unit (SCVCU) within the RM-SM Model Area

4-20 Block Model View Showing Extent of the Tiva Canyon Aquifer (TCA) within the RM-SM Model Area

4-21 Block Model View Showing Extent of the Paintbrush Vitric Tuff Aquifer (PVTA) within the RM-SM Model Area 


\section{List of Figures, continued}

4-22 Block Model View Showing Extent of the Upper Tuff Confining Unit (UTCU) within the RM-SM Model Area

4-23 Schematic South-North Cross Section through the Northern Half of the Rainier MesaShoshone Mountain Area Showing Relationships of the Tuff Confining Unit and the Welded Tuff Aquifer Hydrostratigraphic Units

4-24 Block Model View Showing Extent of the Topopah Spring Aquifer (TSA) within the RM-SM Model Area

4-25 Depth to the Topopah Spring Aquifer in the RM-SM Model Area

4-26 Block Model View Showing Extent of the Lower Vitric-Tuff Aquifer (LVTA) within the RM-SM Model Area

4-27 Block Model View Showing Extent of the Calico Hills Vitric-Tuff Aquifer (CHVTA) within the RM-SM Model Area

4-28 Block Model View Showing Extent of the Yucca Mountain Calico Hills Lava Flow Aquifer (YMCHLFA) within the RM-SM Model Area

4-29 Block Model View Showing Extent of the Kearsarge Aquifer (KA) within the RM-SM Model Area

4-30 Block Model View Showing Extent of the Upper Tuff Confining Unit 2 (UTCU2) within the RM-SM Model Area

4-31 Block Model View Showing Extent of the Stockade Wash Aquifer (SWA) within the Rainier Mesa-Shoshone Mountain Model Area

4-32 Block Model View Showing Extent of the Lower Vitric Tuff-Aquifer 2 (LVTA2) within the RM-SM Model Area

4-33 Block Model View Showing Extent of the Bullfrog Confining Unit (BFCU) within the RM-SM Model Area

4-34 Block Model View Showing Extent of the Upper Tuff Confining Unit 1 (UTCU1) within the RM-SM Model Area

4-35 Block Model View Showing Extent of the Belted Range Aquifer (BRA) within the RM-SM Model Area

4-36 Depth to the Belted Range Aquifer in the RM-SM Model Area

4-37 Block Model View Showing Extent of the Lower Vitric Tuff Aquifer 1 (LVTA1) within the RM-SM Model Area

4-38 Block Model View Showing Extent of the Belted Range Confining Unit (BRCU) within the RM-SM Model Area

4-39 Block Model View Showing Extent of the Tub Spring Aquifer (TUBA) within the RM-SM Model Area

4-40 Depth to the Tub Spring Aquifer in the RM-SM Model Area 


\section{List of Figures, continued}

4-41 Block Model View Showing Extent of the Lower Tuff Confining Unit (LTCU) within the RM-SM Model Area

4-42 Block Model View Showing Extent of the Oak Spring Butte Confining Unit (OSBCU) within the RM-SM Model Area

4-43 Block Model View Showing Extent of the Redrock Valley Aquifer (RVA) within the RM-SM Model Area

4-44 Depth to the Redrock Valley Aquifer in the RM-SM Model Area

4-45 Block Model View Showing Extent of the Redrock Valley Breccia Confining Unit (RVBCU) within the RM-SM Model Area

4-46 Block Model View Showing Extent of the Lower Tuff Confining Unit 1 (LTCU1) within the RM-SM Model Area

4-47 Block Model View Showing Extent of the Tuff of Twin Peaks (TPA) within the RM-SM Model Area

4-48 Depth to the Tuff of Twin Peaks in the RM-SM Model Area

4-49 Block Model View Showing Extent of the Argillic Tuff Confining Unit (ATCU) within the RM-SM Model Area

4-50 Block Model View Showing Extent of the Four Caldera-Related Intrusive Confining Units and the CHICU within the RM-SM Model Area

4-51 West-East Model Profile Showing the Gold Meadows Granitic Intrusive

4-52 Block Model View Showing Extent of the Mesozoic Granitic Confining Unit (MGCU) within the RM-SM Model Area

4-53 Block Model View Showing Extent of the Lower Clastic Confining Unit 1 (LCCU1) within the RM-SM Model Area

4-54 Block Model View Showing the Extent of the Lower Carbonate Aquifer-Thrust Plate (LCA3) within the RM-SM Model Area

4-55 Depth to the Lower Carbonate Aquifer-Thrust Plate in the RM-SM Model Area

4-56 Block Model View Showing Extent of the Upper Carbonate Aquifer (UCA) within the RM-SM Model Area

4-57 Block Model View Showing Extent of the Upper Clastic Confining Unit (UCCU) within the RM-SM Model Area

4-58 Block Model View Showing Extent of the Lower Carbonate Aquifer (LCA) within the RM-SM Model Area

4-59 Depth to the Lower Carbonate Aquifer in the RM-SM Model Area

4-60 Block Model View Showing Extent of the Lower Clastic Confining Unit (LCCU) within the RM-SM Model Area

4-61 Map View of Hydrostratigraphic Units at the Water Table in the Rainier Mesa-Shoshone Mountain Hydrostratigraphic Framework Model 


\section{List of Figures, continued}

5-1 Comparison of the Base Model with the More Extensive LCA3 Alternative

5-2 West-East Profiles Through the Base Model and the No Redrock Valley Caldera Alternative Model

5-3 Comparison of the Base Model with the Shoshone Mountain Thrust Sheet Alternative

5-4 West-East Profiles through the Base Model and the Shoshone Mountain Thrust Sheet Alternative

5-5 West-East Profiles through the Base Model and the LCA3 at Bottom of ER-12-1 Alternative

5-6 Block Model Views Showing Lateral Extents of the LCA3-1 and UCCU1 in the LCA3 at Bottom of ER-12-1 Alternative

B-1 Graphical Presentation Showing Stratigraphy, Lithology, Alteration, and Hydrogeologic Units for UGTA Well ER-12-1

B-2 Graphical Presentation Showing Stratigraphy, Lithology, Alteration, and Hydrogeologic Units for UGTA Well ER-12-2

B-3 Graphical Presentation Showing Stratigraphy, Lithology, Alteration, and Hydrogeologic Units for UGTA Well ER-12-3

B-4 Graphical Presentation Showing Stratigraphy, Lithology, Alteration, and Hydrogeologic Units for UGTA Well ER-12-4

B-5 Graphical Presentation Showing Stratigraphy, Lithology, Alteration, and Hydrogeologic Units for UGTA Well ER-16-1

B-6 Graphical Presentation Showing Stratigraphy, Lithology, Alteration, and Hydrogeologic Units for UGTA Well ER-19-1

C-1 Location of Hydrostratigraphic Profiles through the RM-SM Base Model

C-2 North-South Model Profile (A-A') at Well ER-16-1

C-3 West-East Model Profile (B-B') through the Northern Portion of the Model Area at Drill Hole UE-19t

C-4 West-East Model Profile (C-C') through Aqueduct Mesa at Well ER-12-4

C-5 West-East Model Profile (D-D') through the Redrock Valley Caldera at Drill Hole UE-2ce

C-6 West-East Model Profile (E-E') through the Central Portion of the Model Area at Drill Hole UE-17e

C-7 West-East Model Profile (F-F') through the Northern End of Shoshone Mountain at Well ER-16-1

C-8 West-East Model Profile (G-G') through Mid Valley at Drill Hole UE-14b 
This page intentionally left blank. 


\section{List of Tables}

Number

Title

Page

1-1 Boundaries of the Rainier Mesa-Shoshone Mountain Model Area ............. 1-3

2-1 Geologic Quadrangle Maps (Scale 1:24,000) Used in Construction of the Rainier Mesa-Shoshone Mountain Hydrostratigraphic Framework Model . . . . . . . . . 2-4

2-2 Special-Purpose Geologic Maps Used in Construction of the Rainier Mesa-Shoshone Mountain Hydrostratigraphic Framework Model $\ldots . \ldots . . . \ldots . . . . . . .2-4$

2-3 Miscellaneous Special-Purpose Maps and Geophysical Studies Used in the Construction of the Rainier Mesa-Shoshone Mountain Hydrostratigraphic Framework Model . . . . . 2-5

2-4 Examples of Maps, Detailed Cross Sections, and Other Geologic Information Originally Prepared for WTP Projects and Early UGTA Modeling Efforts . . . . . . 2-6

3-1 Normal Faults in the Rainier Mesa-Shoshone Mountain Framework Model . . . . . . 3-5

4-1 Quaternary, Tertiary, and Mesozoic Stratigraphic Units of the Rainier Mesa-

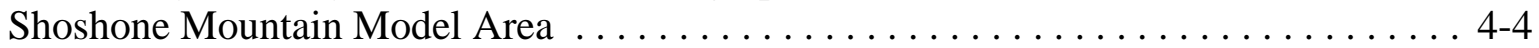

4-2 Proterozoic and Paleozoic Stratigraphic Units of the Rainier Mesa-Shoshone Mountain Model Area $\ldots \ldots \ldots \ldots \ldots \ldots \ldots \ldots \ldots \ldots \ldots \ldots . \ldots . \ldots \ldots$

4-3 Hydrogeologic Units of the Rainier Mesa-Shoshone Mountain Model . . . . . . . . . . . 4-7

4-4 Hydrostratigraphic Units of the Rainier Mesa-Shoshone Mountain Hydrostratigraphic Framework Model ......................... 4-10

4-5 Correlation of Hydrostratigraphic Units of the Rainier Mesa-Shoshone Mountain Model and Earlier Models . . ............................ 4-17

5-1 Abridged List of Alternative Scenarios for the Rainier Mesa-Shoshone Mountain Hydrostratigraphic Framework Model ........................ 5-2

A-1 Well Data for Selected Drill Holes within the Rainier Mesa - Shoshone Mountain

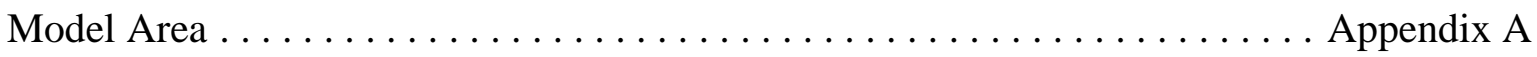

A-2 Geologic and Hydrostratigraphic Drill Hole Database for the Rainier Mesa Shoshone Mountain Model Area ......................... Appendix A

A-3 Hydrostratigraphic Data for Selected Drill Holes in the Rainier Mesa - Shoshone Mountain CAU Model Area ............................ Appendix A 


\section{List of Plates}

Plate 1 Geologic Map of the Rainier Mesa-Shoshone Mountain Model Area

Plate 2 Hydrostratigraphic Surface Map of the Rainier Mesa-Shoshone Mountain Model Area

Plate 3 Generalized Geologic Map Showing Locations of Drill Holes Utilized for Construction of the RM-SM Hydrostratigraphic Framework Model 


\section{List of Acronyms and Abbreviations}

2-D two-dimensional

3-D three-dimensional

AA alluvial aquifer; valley fill aquifer

ARG argillic reactive mineral category

ATCU argillic tuff confining unit

ATICU

Ammonia Tanks intrusive confining unit

BFCU

Bullfrog confining unit

BN

Bechtel Nevada

BRA

Belted Range aquifer

BRCU

Belted Range confining unit

CA

carbonate aquifer

CAU

Corrective Action Unit

$\mathrm{CC}$

calcic reactive mineral category

CCU

clastic confining unit

CHICU

Calico Hills intrusive confining unit

CHVTA

Calico Hills vitric-tuff aquifer

DEM

digital elevation model

DMP

devitrified mafic-poor reactive mineral category

DMR

devitrified mafic-rich reactive mineral category

DoD

U.S. Department of Defense

DOE

U.S. Department of Energy

FCCM

Fortymile Canyon composite unit

FFACO

Federal Facility Agreement and Consent Order

$\mathrm{ft}$

feet (foot)

gpm

gallons per minute

HGU

hydrogeologic unit

HSU

hydrostratigraphic unit

IICU

intra-caldera intrusive confining unit

IT

International Technologies Corporation (also IT Corp.)

KA Kearsarge aquifer

km kilometer(s)

LANL Los Alamos National Laboratory

LCA

lower carbonate aquifer

LCA3

lower carbonate aquifer - thrust plate

LCCU

lower clastic confining unit

LCCU1

lower clastic confining unit 1

LFA

lava-flow aquifer

LLNL

Lawrence Livermore National Laboratory 


\section{List of Acronyms and Abbreviations (continued)}

\begin{tabular}{ll} 
lpm & liter(s) per minute \\
LTCU & lower tuff confining unit \\
LTCU1 & lower tuff confining unit 1 \\
LVTA & lower vitric-tuff aquifer \\
LVTA1 & lower vitric-tuff aquifer 1 \\
LVTA2 & lower vitric-tuff aquifer 2 \\
m & meter(s) \\
Ma & Mega anna (i.e., million years ago) \\
mi & mile(s) \\
MGCU & Mesozoic granite confining unit \\
MT & magnetotelluric \\
NAD & North American Datum \\
NNSA/NSO & U.S. Department of Energy, National Nuclear Security Administration Nevada \\
& Site Office \\
NTS & Nevada Test Site \\
NSTec & National Security Technologies, LLC \\
OSBCU & Oak Spring Butte confining unit \\
PM-OV & Pahute Mesa-Oasis Valley \\
PVTA & Paintbrush vitric tuff aquifer \\
RMBCU & Rainier Mesa breccia confining unit \\
RMICU & Rainier Mesa intrusive confining unit \\
RM-SM & Rainier Mesa-Shoshone Mountain \\
RVA & Redrock Valley aquifer \\
RVBCU & Redrock Valley breccia confining unit \\
RVICU & Redrock Valley intrusive confining unit \\
RMC & reactive mineral category \\
SC & silicic reactive mineral category \\
SCCC & Silent Canyon caldera complex \\
SCICU & Silent Canyon intrusive confining unit \\
SCVCU & sub-caldera volcanic confining unit \\
SMSD & Shoshone Mountain structural divide \\
SNJV & Stoller-Navarro Joint Venture \\
SWA & Stockade Wash aquifer \\
SWL & static water level \\
SWNVF & Southwestern Nevada Volcanic Field \\
TCA & Tiva Canyon aquifer \\
TCU & tuff confining unit \\
TD & total depth \\
\hline & \\
\hline
\end{tabular}




\section{List of Acronyms and Abbreviations (continued)}

TMCC Timber Mountain caldera complex

TMCM Timber Mountain composite unit

TM-LVTA Timber Mountain lower vitric-tuff aquifer

TM-UVTA Timber Mountain upper vitric-tuff aquifer

TM-WTA Timber Mountain welded-tuff aquifer

TPA Twin Peaks aquifer

TSA Topopah Spring aquifer

TWG Technical Working Group

TUBA Tub Spring aquifer

UCA upper carbonate aquifer

UCCU upper clastic confining unit

UCCU1 upper clastic confining unit 1

UGT underground nuclear test

UGTA Underground Test Area

USGS U.S. Geological Survey

UTCU upper tuff confining unit

UTCU1 upper tuff confining unit 1

UTCU2 upper tuff confining unit 2

VMP vitric mafic-poor reactive mineral category

VMR vitric mafic-rich reactive mineral category

VTA vitric-tuff aquifer

WTA welded-tuff aquifer

WTP weapons testing program

YMCHLFA Yucca Mountain Calico Hills lava-flow aquifer

YMP Yucca Mountain Project

ZEOL zeolitic reactive mineral category 
This page intentionally left blank. 


\subsection{INTRODUCTION}

The Environmental Restoration Project of the U.S. Department of Energy (DOE), National Nuclear Security Administration Nevada Site Office (NNSA/NSO) initiated the Underground Test Area (UGTA) subproject to investigate the extent of groundwater contamination at the Nevada Test Site (NTS) and surrounding areas due to past underground nuclear testing. The UGTA investigation focuses on the geology and hydrology of the NTS to estimate the direction and rate at which contaminants are transported by groundwater flow. This report describes the Phase I hydrostratigraphic framework model constructed for the Rainier Mesa-Shoshone Mountain (RM-SM) area. This model will be used to develop groundwater flow and contaminant transport models for the former underground nuclear testing areas in the RM-SM area.

\subsection{Background Information for the Hydrostratigraphic Framework Model Task}

A regional three-dimensional (3-D) computer groundwater model (International Technologies Corporation [IT], 1996a) was developed in the initial stages of the UGTA project to identify any immediate risk, and to provide a basis for developing more detailed models of specific nuclear testing areas designated as Corrective Action Units (CAUs). The CAU-specific models, of which four are planned, geographically cover the six former NTS underground nuclear testing areas (Figure 1-1). CAU-specific groundwater-flow and contaminant-transport models will be used to determine contaminant boundaries based on the extent of contaminant migration at specified regulatory limits. The models will also be used to refine a monitoring network to ensure public health and safety.

Construction of CAU-specific groundwater-flow and contaminant-transport models requires a hydrostratigraphic framework that depicts the character and extent of hydrostratigraphic units in three dimensions. CAU-specific framework models will give modelers the ability to test a range of potential groundwater flow and contamination scenarios by allowing them to apply flow and transport algorithms and vary parameters for each hydrostratigraphic unit.

This report provides information about how the hydrostratigraphic framework model for the RM-SM CAU was developed, presents a description of the model, and provides documentation of data sources used to produce the model. This document addresses only the hydrostratigraphic framework model; separate data documentation packages containing detailed descriptions of the hydrologic data, modeling process, and other pertinent flow and transport information will be prepared after such efforts are complete. 
The RM-SM model area extends over several operational areas of the NTS (Figure 1-2) and includes former underground nuclear testing locations in Areas 12 and 16. The area referred to as "Rainier Mesa” includes the geographical area of Rainier Mesa proper and the contiguous Aqueduct Mesa. Shoshone Mountain is located approximately 20 kilometers $(\mathrm{km})$ (12.4 miles [mi]) south of Rainier Mesa, but is included within the same CAU because of similarities in their geologic setting and in the nature and types of nuclear tests conducted (Federal Facility Agreement and Consent Order [FFACO, 1996). Except for two tests conducted in vertical emplacement holes on Rainier Mesa, all underground nuclear tests (UGTs) in the RM-SM CAU were conducted within tunnel complexes in the two areas.

The RM-SM hydrostratigraphic framework model was developed by a multi-disciplinary team of scientists of the National Security Technologies, LLC (NSTec) (formerly Bechtel Nevada [BN]) Geotechnical Sciences group and Stoller-Navarro Joint Venture (SNJV). The team also received valuable input from scientists at Los Alamos National Laboratory (LANL), Lawrence Livermore National Laboratory (LLNL), and the U.S. Geological Survey (USGS), with guidance from the NNSA/NSO and the NNSA/NSO UGTA Technical Working Group (TWG).

The model presented here consists of a base model and four alternatives. Because of the geologic complexity of the model area and non-unique interpretations incorporated into the base model, different geologic interpretations were developed for some features in the model area. These alternative interpretations can be tested to determine if they produce an impact on groundwater flow or on the fate and transport of possible contaminants.

\subsection{Document Organization}

This section contains background information for the development of the RM-SM hydrostratigraphic framework model, including location, setting, and previous work. Section 2.0 provides descriptions of the processes, methods, and data used to construct the model, including discussions of data obtained within the last two years specifically to support the development of the RM-SM CAU model. Section 3.0 presents a discussion of the structural elements of the model, and Section 4.0 describes all the hydrostratigraphic units included in the model.

Alternative models are described in Section 5.0. Section 6.0 presents a document summary, and relevant references are listed in Section 7.0.

\subsection{Objectives}

The primary objective of the RM-SM hydrostratigraphic modeling effort was to produce a 3-D hydrostratigraphic framework model and permissive alternative models that depict the geometric relationships of hydrostratigraphic units (HSUs) and structural features in the RM-SM model 
area. The RM-SM hydrostratigraphic framework model and the alternative scenarios will be used to model groundwater flow and contaminant transport for the RM-SM CAU.

\subsection{Location and Setting}

The hydrostratigraphic framework model for the RM-SM area encompasses more than 750 square kilometers (290 square miles) in the central part of the NTS, in southern Nye County, Nevada (Figure 1-1). The model area is located approximately $153 \mathrm{~km}$ (95 mi) northwest of Las Vegas, Nevada, and includes lands managed by the U.S. Air Force (Nevada Test and Training Range), in addition to the north-central portion of the NTS. The model area also encompasses a buffer area surrounding the CAU that includes important rock outcrop data and drill-hole control that help constrain geologic interpretations. The model area includes the Rainier Mesa topographic mesa and the Shoshone Mountain highlands. The model area also includes portions of Yucca Flat and Mid Valley located southeast and south of Rainier Mesa, respectively (Figure 1-2). The model has a north-south dimension of $45 \mathrm{~km}(28 \mathrm{mi})$ and an east-west dimension of $18 \mathrm{~km}$ (11 mi); it includes geologic units as deep as $5.1 \mathrm{~km}$ (3.2 mi) below mean sea level. Boundaries for the RM-SM model area are listed in Table 1-1.

Table 1-1

Boundaries of the Rainier Mesa-Shoshone Mountain Model Area

\begin{tabular}{||l|c|c||}
\hline & $\begin{array}{c}\text { Central Nevada State } \\
\text { Planar Coordinates } \\
\text { (NAD 27; feet) } \mathrm{a}, \mathrm{b}\end{array}$ & $\begin{array}{c}\text { Universal Transverse } \\
\text { Mercator (Zone 11) } \\
\text { (NAD 83; meters) }\end{array}$ \\
\hline \hline Northern Boundary, Along Northing & $\mathrm{N} \mathrm{933,000}$ & $\mathrm{N} \mathrm{4,129,800}$ \\
\hline Southern Boundary, Along Northing & $\mathrm{N} \mathrm{786,175}$ & $\mathrm{N} \mathrm{4,085,050}$ \\
\hline Western Boundary, Along Easting & $\mathrm{E} \mathrm{605,005}$ & $\mathrm{E} \mathrm{561,500}$ \\
\hline Eastern Boundary, Along Easting & $\mathrm{E} \mathrm{659,990}$ & $\mathrm{E} \mathrm{578,300}$ \\
\hline
\end{tabular}

a $\quad$ NAD $27=1927$ North American Datum

b $N=$ North; $E=$ East

\subsubsection{Underground Nuclear Tests in Rainier Mesa and Shoshone Mountain Test Areas}

Between 1957 and 1992, 61 UGTs were conducted at Rainier Mesa and Aqueduct Mesa; 6 tests were detonated beneath Tippipah Point at the north end of Shoshone Mountain between 1961 and 1971 (DOE, 2000). All UGTs conducted in the RM-SM area are listed in DOE (2000) and their locations are shown in Figure 1-3. UGTs that are located within the RM-SM model area but which are outside the RM-SM CAU may not be included in final flow and transport models. 
Most of the UGTs were conducted in horizontal, mined tunnels within these mesas, but two were conducted in vertical drill holes at Rainier Mesa. All tests were conducted above the regional water table. Underground geologic mapping data from the numerous tunnel complexes, and lithologic and geophysical data from hundreds of exploratory drill holes, provide a wealth of geologic and hydrologic information for this relatively small underground test area.

Most of the UGTs at Rainier Mesa were conducted by the U.S. Department of Defense (DoD) Defense Nuclear Agency (predecessor of the Defense Threat Reduction Agency), but a few other organizations, notably LLNL and Sandia National Laboratories, also conducted several tests there. Rainier Mesa was named after the first U.S. nuclear test designed to be contained. The RAINIER test was detonated in 1957 in the tunnel now known as B-Tunnel (or U12b Tunnel).

The Shoshone Mountain nuclear test area is located in Area 16, about $20 \mathrm{~km}(12 \mathrm{mi})$ south of Rainier Mesa. The U16a horizontal tunnel complex was constructed between 1961 and 1971 by the DoD, with additional exploratory work continuing through 1973. Six low-yield nuclear tests were conducted in the U16a tunnel complex: four weapons-effects tests, and two Vela Uniform seismic verification tests. The underground portions of the testing area have been inactive since 1973; however, in recent years the portal area has been used for high-explosive testing by the DoD.

\subsubsection{Climate}

The NTS is located in the high desert, with annual precipitation totals averaging approximately 10 centimeters (4 inches) in the lower valleys, such as Yucca Flat, and 25 centimeters (10 inches) in the higher mountain ranges (DOE, 1996; 2003). Precipitation in the area is sporadic, typically falling as small amounts of rain or snow during isolated, short-duration winter and summer storms. Severe weather can occur in the region, usually in the form of summer thunderstorms with intense lightning, strong winds and, localized heavy rainfall. Daily temperatures vary with elevation, with extremes ranging from minus 15 to 45 degrees Celsius (5 to 113 degrees Fahrenheit) (DOE, 2003).

\subsubsection{Physiography}

The model area is located in the southern part of the Great Basin and the northern portion of the Basin and Range physiographic province (Figure 1-4). Rainier Mesa is a high volcanic plateau dissected by young drainages. The mesa is preserved by the presence of a thick caprock of welded tuff, which overlies much less resistant bedded tuff layers. The top of the mesa is relatively flat, though incised in some areas by deep canyons. Ground-level elevations on Rainier Mesa are generally over 2,225 meters (m) (7,300 feet [ft]) above mean sea level, and 
average about 2,286 $\mathrm{m}(7,500 \mathrm{ft})$. The highest point on the NTS, 2,341 $\mathrm{m}(7,679 \mathrm{ft})$, is on Rainier Mesa. Aqueduct Mesa has slightly rougher and lower terrain, generally above 1,920 m $(6,300 \mathrm{ft})$ in elevation. The edges of the mesas drop off quite spectacularly on the west, south, and east sides.

Shoshone Mountain is a topographically high area located west of Yucca Flat, approximately $17 \mathrm{~km}$ (10.5 mi) due south of the U12g Tunnel, the southernmost tunnel complex in Rainier Mesa. Ground-level elevations at Shoshone Mountain range from 1,707 to 2,073 m (5,600 to 6,800 ft), but are generally above 1,830 m (6,000 ft). Tippipah Point, located at the north end of Shoshone Mountain and above the U16a Tunnel, has an elevation of 2,015 m (6,612 ft). The lowest region within the RM-SM model area is approximately 1,400 m (4,600 ft) in Mid Valley, located in the southeast portion of the model area.

The model area includes Mid Valley and Shoshone Mountain on the south, the western portion of Yucca Flat on the east, and the southeastern portion of Pahute Mesa on the north (Figure 1-2).

\subsubsection{Geologic Setting}

This section provides descriptions of the geologic setting of the NTS region and the RM-SM area. This summary was compiled from various sources, including BN (2006; 2002a), Gonzales and Drellack (1999), Gonzales et al. (1998), Winograd and Thordarson (1975), Laczniak et al. (1996), Byers et al. (1976; 1989), and Cole (1997), where additional information can be found. A summary of the regional geology of the NTS area is presented in Subsection 1.4.4.1. More detailed discussions of the structure and stratigraphy of the Rainier Mesa/ Aqueduct Mesa area are provided in Subsection 1.4.4.2, and for Shoshone Mountain, in Subsection 1.4.4.3. For detailed stratigraphic descriptions, see Sawyer et al. (1994) and Slate et al. (1999).

\subsubsection{Regional Geologic Setting}

The NTS area is geologically complex, encompassing several Tertiary-age calderas, many

relatively young basin-and-range-style normal faults, and Mesozoic-age thrust faults and intrusive bodies, all superimposed on a basement complex of highly deformed Proterozoic and Paleozoic sedimentary and metasedimentary rocks. Geologic units exposed at the surface in the NTS area can be categorized as approximately 40 percent alluvium-filled basins and 20 percent Paleozoic and uppermost Precambrian sedimentary rocks; the remainder is Tertiary-age volcanic rocks, and a few intrusive masses (Orkild, 1983; Slate et al., 1999). A generalized geologic map of the NTS area is given in Figure 1-5. 
The NTS area is dominated by Tertiary volcanic rocks that were erupted from various vents in the Southwestern Nevada Volcanic Field (SWNVF), located on and adjacent to the northwestern part of the NTS. At least six major calderas have been identified in this multi-caldera silicic volcanic field that formed by the voluminous eruption of zoned ignimbrites between 16 and 7.5 million years ago (Ma) (Sawyer et al., 1994) (Figure 1-5). The volcanic rocks are covered in many areas by a late Tertiary and Quaternary surficial deposits such as alluvium, colluvium, eolian deposits, spring deposits, basalt lavas, lacustrine, and playa deposits.

The volcanic rocks include primarily ash-flow tuff, ash-fall tuff, and reworked tuff, whose thickness and extent vary, partly due to the irregularity of the underlying depositional surface, and partly due to the presence of topographic barriers and windows between depositional areas and the source calderas to the northwest and southwest. The area includes more than 300 described Tertiary-age volcanic units (Warren et al., 2003). As a matter of practicality, some units are grouped together, especially those of limited areal extent or thickness. An additional discussion of volcanic units is provided Section 4.0.

Underlying the Tertiary volcanic rocks are Paleozoic and Proterozoic sedimentary and metasedimentary rocks, including dolomite, limestone, quartzite, and argillite, some of which form the primary regional aquifer and the regional hydrologic "basement." During Precambrian and Paleozoic time, as much as 10,000 m (32,800 ft) of marine sediments were deposited in the NTS region (Cole, 1997). These rocks were severely deformed by compressional movements during Mesozoic time, which resulted in the formation of folds and thrust faults (e.g., Belted Range and CP thrust faults). A detailed discussion of the structural geology of the RM-SM model area is provided in Section 3.0. During the middle Late Cretaceous, granitic bodies intruded these deformed rocks. The two granitic intrusive bodies at the NTS, the Gold Meadows and Climax granitic stocks, are located just north of Rainier Mesa and at the north end of Yucca Flat, respectively (Snyder, 1977; Gibbons et al., 1963; Maldonado, 1977; Houser and Poole, 1960).

\subsubsection{Geology Overview of Rainier Mesa}

Rainier Mesa consists of a layered rock sequence, with each layer exhibiting significantly differing physical and mechanical properties. The geology of the mesa can be briefly summarized as a thick sequence of relatively young Tertiary-age volcanic tuffs draped over an irregular substrate of much older Paleozoic sedimentary and Mesozoic intrusive rocks (Figure 1-6). The lower bedded tuffs have undergone significant in-situ alteration as a result of water percolating through them. In most places, the lower zeolitized section is overlain by a section of vitric bedded tuff, which lies just below the welded tuff caprock (Sargent and Orkild, 
1973). Most nuclear tests at Rainier Mesa were executed within zeolitized tuff, though a few early tests were conducted in the upper vitric rocks. All Rainier Mesa tests were located 365 to $715 \mathrm{~m}$ (1,200 to 2,345 ft) (depending on the elevation of the particular tunnel complex) above the regional static water table, which is located in pre-Tertiary rocks (DOE, 2006a; 2006b).

The geologic structure of the volcanic rocks of Rainier Mesa is well documented. Several high-angle normal faults have been mapped in the volcanic rocks, however, faults with greater than about $30 \mathrm{~m}(100 \mathrm{ft})$ of displacement are notably absent. The structure of the pre-Tertiary section is poorly known, though some workers speculate that the trace of the Belted Range thrust fault is present in the pre-Tertiary rocks beneath Rainier Mesa. A broad synclinal feature mapped at the surface (Sargent and Orkild, 1973) and in the tuffs of Rainier and Aqueduct Mesas may reflect a paleo-topographic low beneath the tuffs (Figure 1-6), but the exact character of this feature is unknown. It may be a "strike valley” related to the Belted Range thrust fault.

The structure of the pre-Tertiary rocks is complex and poorly known, but it is important because the pre-Tertiary section is very thick and extensive, and includes units which form regional aquifers. The main pre-Tertiary structures in the RM-SM model area are related to the east-vergent Belted Range thrust fault which placed Late Proterozoic to Cambrian-age rocks over rocks as young as Late Mississippian (Cole, 1997; Cole and Cashman, 1999). In several places along the western margin of Yucca Flat, east-vergent structures related to the Belted Range thrust were deformed by younger west-vergent structural activity (Cole and Cashman, 1999). This west-vergent deformation is related to the CP thrust fault which also placed older Paleozoic-age carbonate rocks over younger Paleozoic-age rocks (commonly the Eleana Formation or Chainman Shale) (Caskey and Schweickert, 1992).

The more recent large-scale extensional faulting in the NTS area is significant because the faults have profoundly affected the hydrogeology of the Tertiary volcanic units by controlling to a large extent their alteration potential and final geometry. In addition, the faults themselves may facilitate flow of potentially contaminated groundwater from sources in the younger rocks into the underlying regional aquifers. The major Tertiary-age faults generally strike in a northerly direction.

\subsubsection{Geology Overview of Shoshone Mountain}

The U16a Tunnel complex is located at an elevation of about 1,649 m (5,410 ft) above sea level, in zeolitized ash-fall and ash-flow tuffs (Davis, 1962), similar in age and physical properties to the rocks that are found at the southern end of Rainier Mesa (e.g., U12g and U12e tunnels). A simplified description of the geologic section at U16a includes, from the top of the mesa: 
a welded tuff "caprock" of Tiva Canyon Tuff approximately $15 \mathrm{~m}$ (50 ft) thick; moderately to densely welded and related bedded tuff of the Topopah Spring Tuff about $150 \mathrm{~m}$ (450 ft) thick; a sequence of bedded, vitric ash-fall tuffs related to the Calico Hills Formation, approximately $38 \mathrm{~m}$ (125 ft) thick; and another 335-m (1,100-ft) thick sequence of zeolitized ash-fall and interbedded welded ash-flow tuffs related to the Tunnel Formation and older tuffs (Orkild, 1963; Slate et al., 1999). Figure 1-7 illustrates the geology at Tippipah Point. The Shoshone Mountain UGTs were located approximately $893 \mathrm{~m} \mathrm{(2,930} \mathrm{ft)} \mathrm{above} \mathrm{the} \mathrm{regional} \mathrm{static} \mathrm{water} \mathrm{table,} \mathrm{which}$ is located in Paleozoic carbonate rocks (DOE, 2006c).

The pre-Tertiary section in the vicinity of Shoshone Mountain consists of up to $300 \mathrm{~m}(1,000 \mathrm{ft})$ of Tippipah Limestone overlying several hundred to perhaps a thousand meters of Eleana Formation/Chainman Shale. The Eleana Formation/Chainman Shale conformably overlies the thick section of Paleozoic carbonate rocks that form the lower carbonate aquifer (LCA).

The structural geology of the U16a area is quite complex, with many faults and fractures found throughout the tunnel system. Fault displacements range from a few centimeters (inches) to more than $30 \mathrm{~m}(100 \mathrm{ft})$. The strata strike generally north-south, and dip to the west. The dip of bedding measured along the tunnels ranges from about 8 to 18 degrees, with an average dip of approximately 15 degrees. This general attitude is mirrored in the gravity-postulated pre-Tertiary surface which also dips gently toward the west. The pre-Tertiary surface below Shoshone Mountain was only recently penetrated by drilling of UGTA characterization Well ER-16-1.

Several faults have been mapped at Shoshone Mountain, but in general the structure is less well known there than at Rainier Mesa. Faults at Shoshone Mountain are apparently more numerous and of larger displacement than those found in areas of comparable size in Rainier or Aqueduct

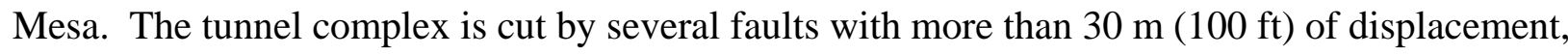
and the strikes of the larger-displacement faults are more variable in orientation.

A conservative interpretation of the large-displacement faults found at tunnel level would indicate at least the potential for additional surface faulting, and an apparently large-

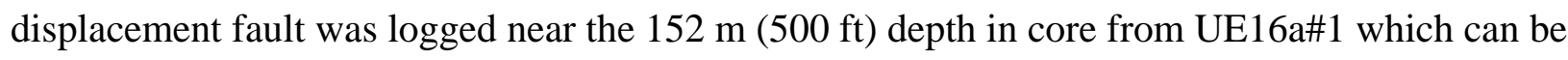
easily projected to the surface. Also, post-test surface mapping following the last UGT in the U16a Tunnel complex revealed a rather lengthy north-south striking fault with up to $1.0 \mathrm{~m}$ (3.3 ft) of displacement. 


\subsubsection{Hydrologic Setting}

The hydrologic character of the NTS and vicinity reflects the regions arid climatic conditions and complex geology (D’Agnese et al., 1997). The hydrology of the NTS has been extensively studied for over 50 years (DOE, 1996), and numerous scientific reports and large databases are available (refer to references in Section 7.0 for more detailed information). The following subsections present an overview of the hydrologic setting of the NTS and vicinity, including summary descriptions of surface water and groundwater, hydrogeologic framework, and finally a summary of the hydrogeology for the RM-SM area.

\subsubsection{Surface Water}

The NTS is located within the Great Basin, a closed hydrographic province that includes numerous closed hydrographic basins (Figure 1-4). The closed hydrographic basins of the NTS (most notably Yucca Flat and Frenchman Flat) are sub-basins of the Great Basin. Streams in the region are ephemeral, flowing only in response to precipitation events or snow-melt. Runoff is conveyed through normally dry washes toward the lowest areas of the closed hydrographic subbasins, and collects on playas.

A few minor springs emanate from local perched groundwater systems in the foothills surrounding the Rainier/Aqueduct Mesa (Figure 1-8). These include the Gold Meadows, Rainier, Tongue Wash, Captain Jack, and Whiterock springs (Hansen et al., 1997). Tippipah Spring is located just northeast of Shoshone Mountain. Most water discharged from springs travels only a short distance from the source before evaporating or infiltrating into the ground.

\subsubsection{Groundwater}

The NTS is located within the Death Valley regional groundwater flow system, one of the major hydrologic subdivisions of the southern Great Basin (Waddell et al., 1984; Laczniak et al., 1996). Groundwater in southern Nevada is conveyed within several flow-system sub-basins within the Death Valley regional flow system (a groundwater sub-basin is defined as the area that contributes water to a major surface discharge area [Laczniak et al., 1996]). Three principal groundwater sub-basins, named for their down-gradient discharge areas, have been identified within the NTS region: the Ash Meadows, Oasis Valley, and Alkali Flat-Furnace Creek Ranch sub-basins (Waddell et al., 1984) (Figure 1-9). Rainier Mesa lies along the boundary between the Ash Meadows and the Alkali Flat-Furnace Creek Ranch groundwater sub-basins. Shoshone Mountain lies within the western portion of the Ash Meadows groundwater sub-basin.

The groundwater-bearing rocks at the NTS have been classified into several aquifers and confining units, of which the most important is the lower carbonate aquifer, a thick sequence of 
Paleozoic carbonate rock. This unit extends throughout the subsurface of central and southeastern Nevada, and is considered to be a regional aquifer (Winograd and Thordarson, 1975; Laczniak et al., 1996; IT, 1996a). Various volcanic and alluvial aquifers are also locally important as water sources. Groundwater chemistry ranges from a sodium-potassiumbicarbonate type to a calcium-magnesium-carbonate type, depending on the mineralogical composition of the aquifer source (Chapman, 1994).

The depth to groundwater in wells at the NTS varies from about $210 \mathrm{~m}(690 \mathrm{ft})$ below the land surface under the Frenchman Flat playa in the southeastern NTS, to more than $610 \mathrm{~m}$ (2,000 ft) below the land surface in the northwestern NTS, beneath Pahute Mesa (IT, 1996b; Reiner et al., 1995). Perched groundwater (isolated lenses of water lying above the regional groundwater level) occurs locally throughout the NTS, mainly within the volcanic rocks.

Recharge areas for the Death Valley groundwater system are the higher mountain ranges of central and southern Nevada, where there can be significant precipitation and snow-melt. Groundwater flow is generally from these upland areas to natural discharge areas in the south and southwest. Groundwater at the NTS is also derived from underflow from basins up-gradient of the area (Harrill et al., 1988). The direction of groundwater flow may locally be influenced by structure, rock type, or other geologic conditions. Existing water-level data (Reiner et al., 1995; IT, 1996b; DOE, 2003) and results of modeling groundwater flow (IT, 1996a; D’Agnese et al., 1997) indicate that the general groundwater flow direction within major water-bearing units beneath the NTS is to the south and southwest (Figure 1-9).

Most of the natural discharge from the Death Valley flow system is via transpiration by plants or evaporation from soil and playas in the Amargosa Desert and Death Valley. Groundwater discharge at the NTS is minor, consisting of small springs which drain perched water lenses, and artificial discharge at a limited number of water supply wells.

Two water supply wells within the RM-SM model area provide both potable and non-potable water to the NTS. These are Water Well 8 in northeastern Area 18 and Well UE-16d in the northeastern corner of Area 16.

\subsubsection{Static Water Levels}

The static water level (SWL) in the RM-SM model area is deep, but measured depths vary depending on the land elevation from which each well was drilled. At the Rainier Mesa and Shoshone Mountain test locations, SWLs measured in recent UGTA wells range from $782.7 \mathrm{~m}$ (2,568 ft) at Well ER-12-4 (USGS/DOE Cooperative Studies in Nevada Web site), to 1,247.5 m 
(4,093 ft) at Well ER-16-1 (DOE, 2006c). The corresponding water elevations are 1,315.5 m

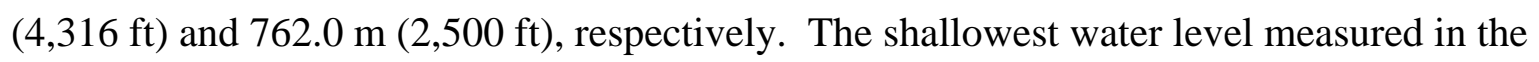
model area is at Water Well UE-16d near Syncline Ridge, where the SWL depth is $229.2 \mathrm{~m}$ (752 ft) (elevation of 1,197.5 m [3,929 ft]) (Fenelon, 2005).

Throughout much of the model area, the regional SWL is located within the carbonate aquifer. However, in the extreme northern, eastern, and western portions of the model area, the SWL can be present within the volcanic units, while in the deeper structural basins (i.e., Mid Valley), the lower portion of the alluvium may also be saturated.

In Mid Valley, southwest of Yucca Flat (Figure 1-2), depth to water is $507.2 \mathrm{~m}(1,664 \mathrm{ft})$ at drill hole UE-14b (Fenelon, 2005; Reiner et al., 1995). With a ground-level elevation of 1,326.8 m (4,353 ft), this equates to an elevation of $819.6 \mathrm{~m}$ (2,689 ft). At this central Mid Valley location the SWL is within the Rainier Mesa Tuff, a volcanic aquifer. The relatively shallow water at Water Well UE-16d mentioned above may be perched within the Tippipah Limestone, which overlies the Chainman Shale.

Perched water occurs in poorly connected fractures and fault zones within the tuff confining unit at Rainier Mesa at a depth below the top of the mesa of about 365.8 to $426.7 \mathrm{~m}$ (1,200 to $1,400 \mathrm{ft})$. This perched water table is about $610 \mathrm{~m}(2,000 \mathrm{ft})$ above the regional water table within the underlying lower carbonate aquifer (Winograd and Thordarson, 1975).

\subsection{Previous Work}

Hydrostratigraphic framework models for the adjacent Yucca Flat-Climax Mine and Central and Western Pahute Mesa CAUs (BN, 2006; 2002a) were the starting point for the development of the Phase I RM-SM CAU-scale model. Interpretive products produced in support of the UGTA Phase I regional model (IT, 1996a) were also available (IT, 1996b; 1996c; 1996d), as well as published maps and geologic reports, and unpublished geologic and geophysical data originally collected in support of other NTS programs (e.g., DOE weapons testing program [WTP], Yucca Mountain Project [YMP], and DoD projects).

\subsection{Framework Model}

The RM-SM hydrostratigraphic framework model described in this document is based largely on the hydrologic framework described by Winograd and Thordarson (1975) for the NTS area. This early work was further developed by Laczniak et al. (1996), and by the UGTA hydrostratigraphic regional modeling team (IT, 1996a; 1996b; 1996c). Most recently, much of 
the detailed hydrostratigraphic system had been established for the Phase I CAU modeling efforts for Yucca Flat-Climax Mine (BN, 2006) and Western and Central Pahute Mesa (often referred to as the Pahute Mesa-Oasis Valley [PM-OV] model; BN, 2002a). 


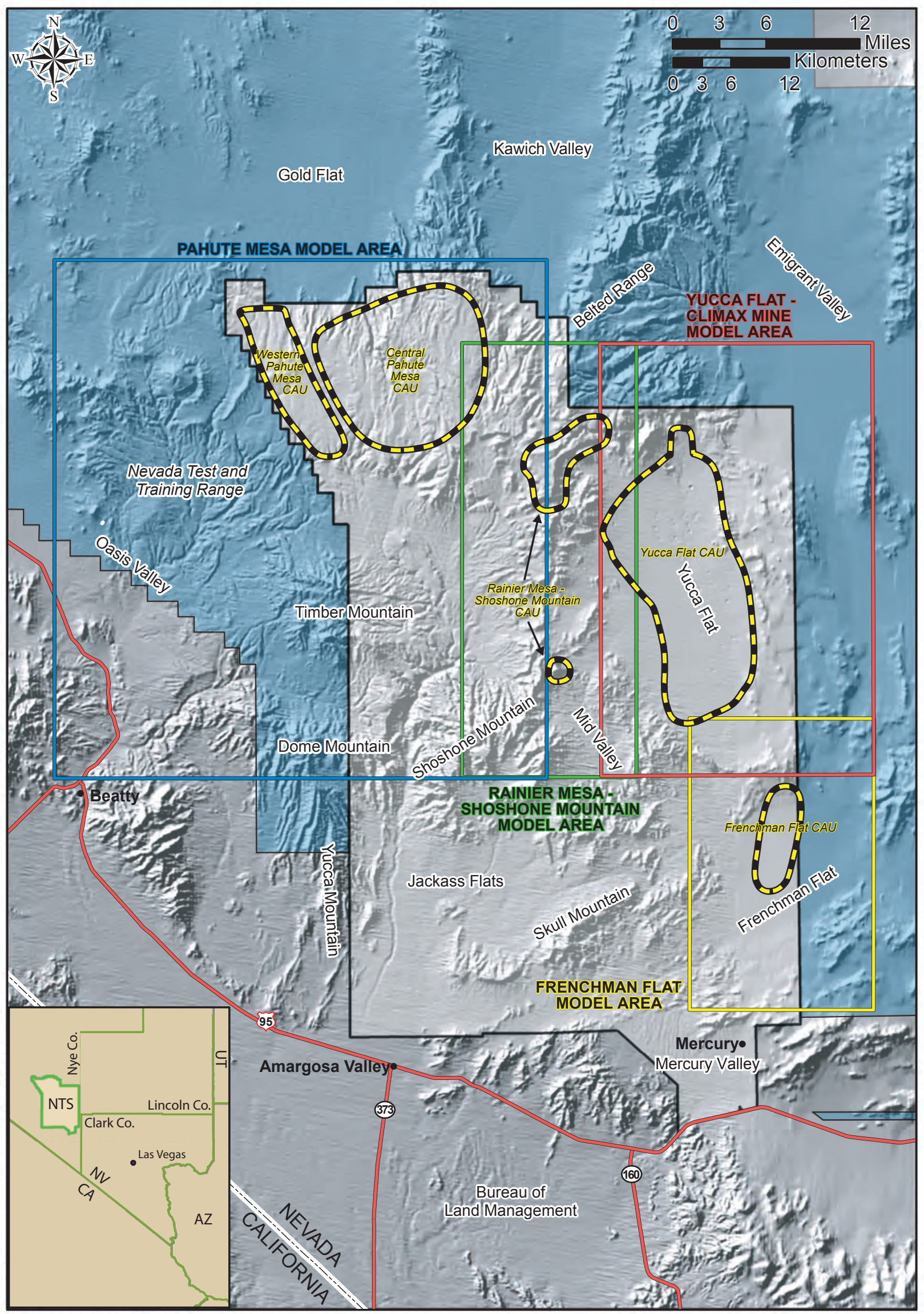

Figure 1-1

Map Showing Locations of all UGTA Model Areas 


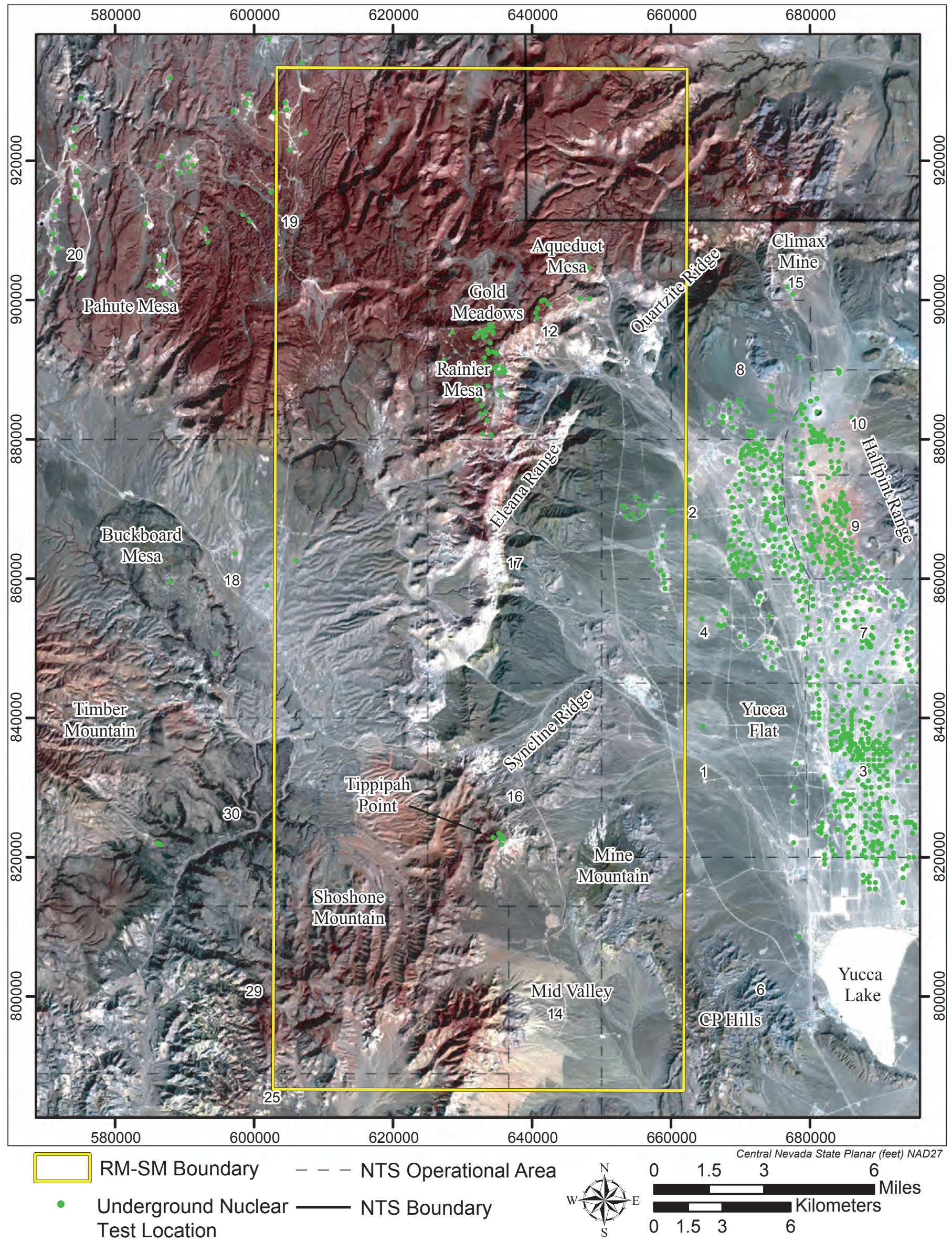

Figure 1-2

Satellite Image of the Rainier Mesa-Shoshone Mountain Area Showing

Physiographic Features and Location of Underground Nuclear Tests 


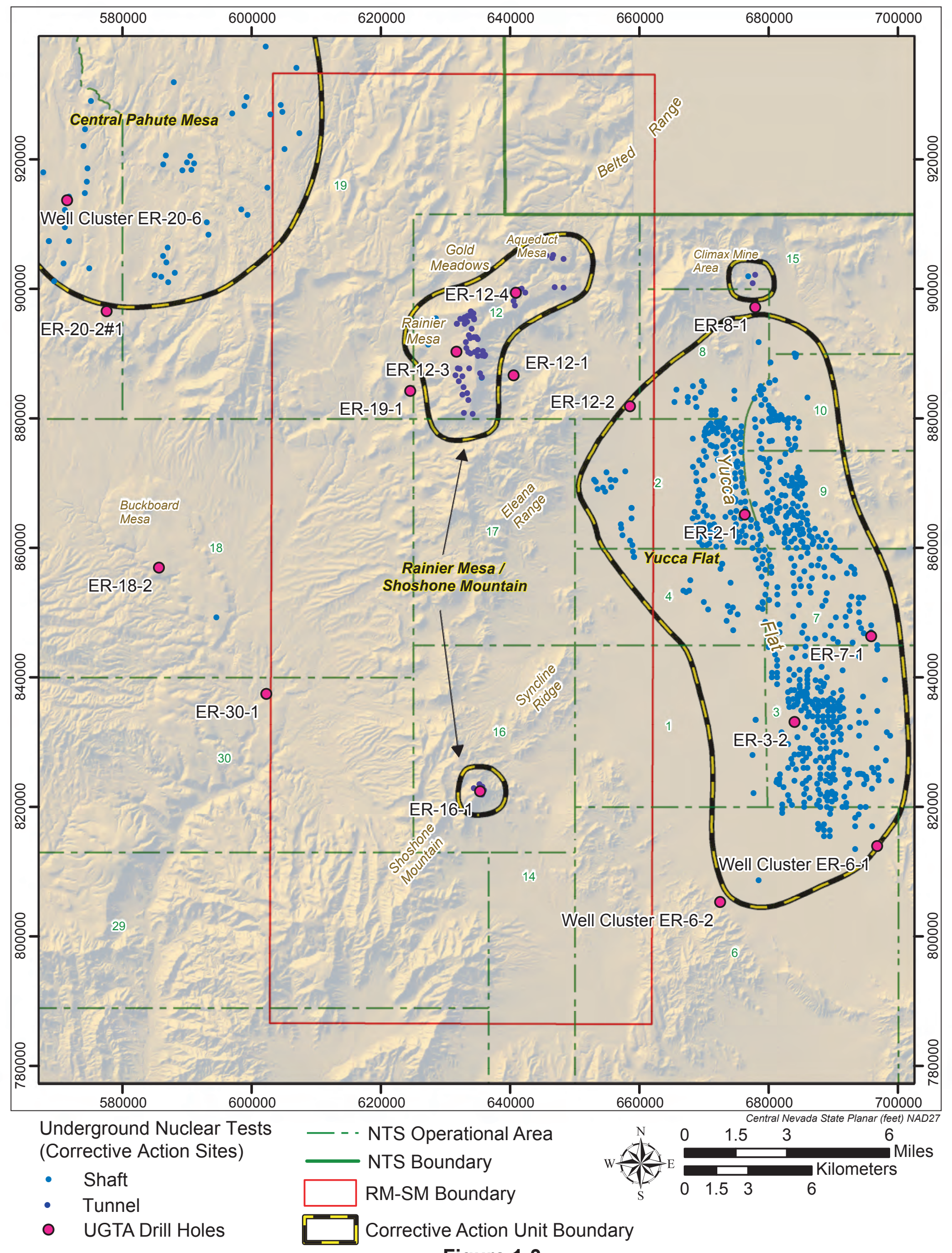

Figure 1-3 


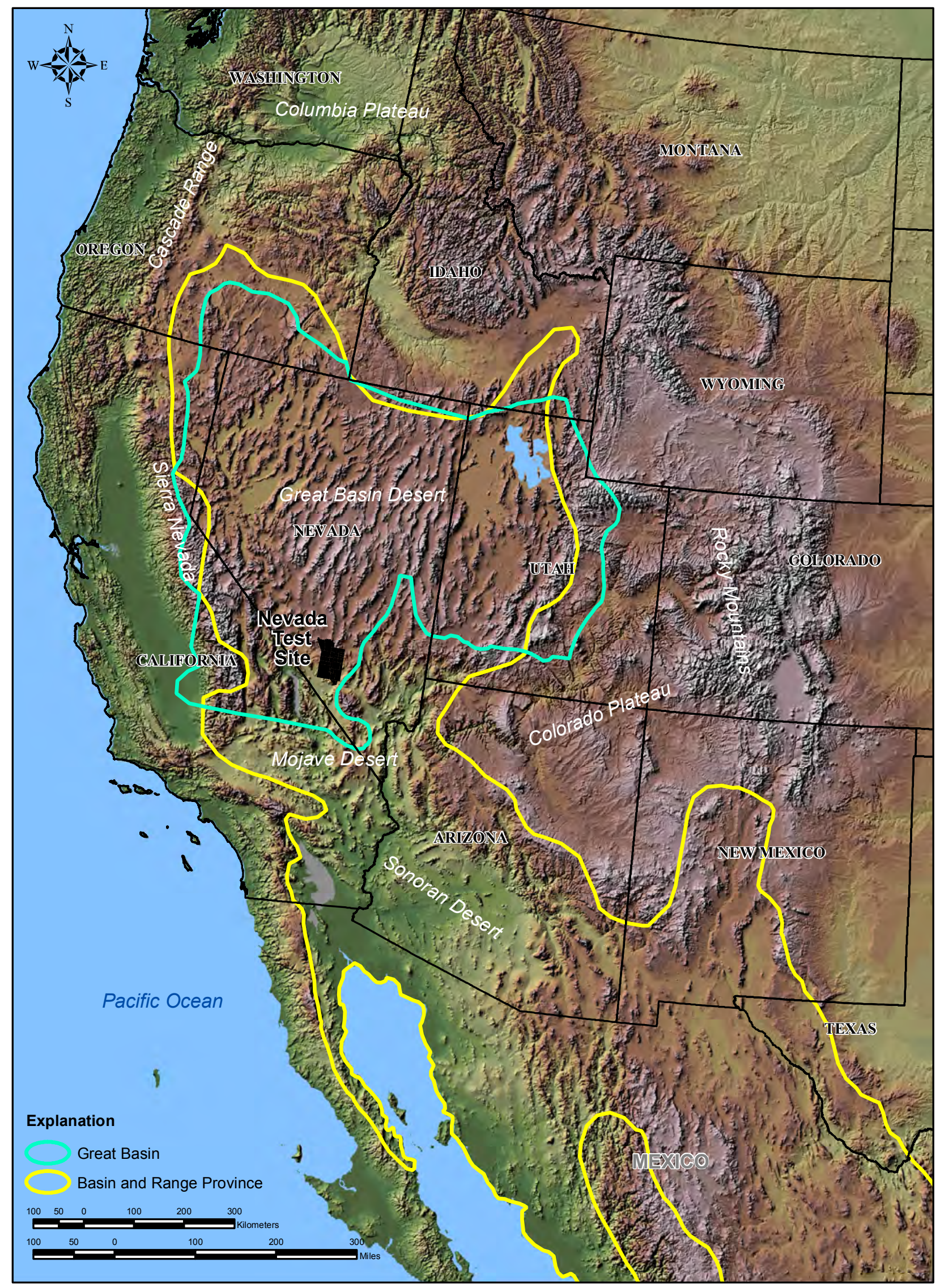

Figure 1-4

Color Relief Map Showing Locations of the Basin and Range Physiographic and Great Basin Hydrographic Provinces 


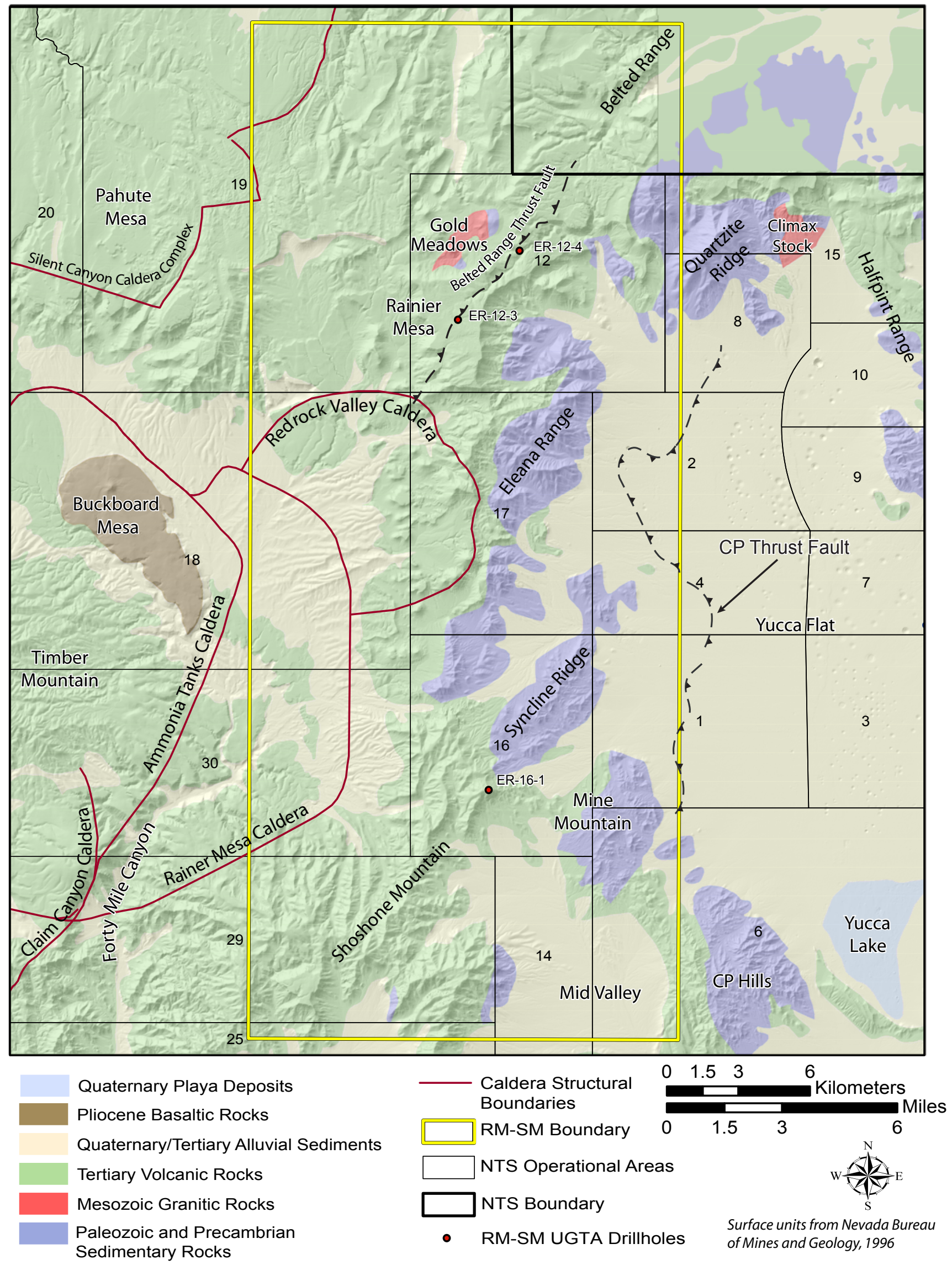

Figure 1-5

Generalized Geologic Map of the Rainier Mesa-Shoshone Mountain Model Area 


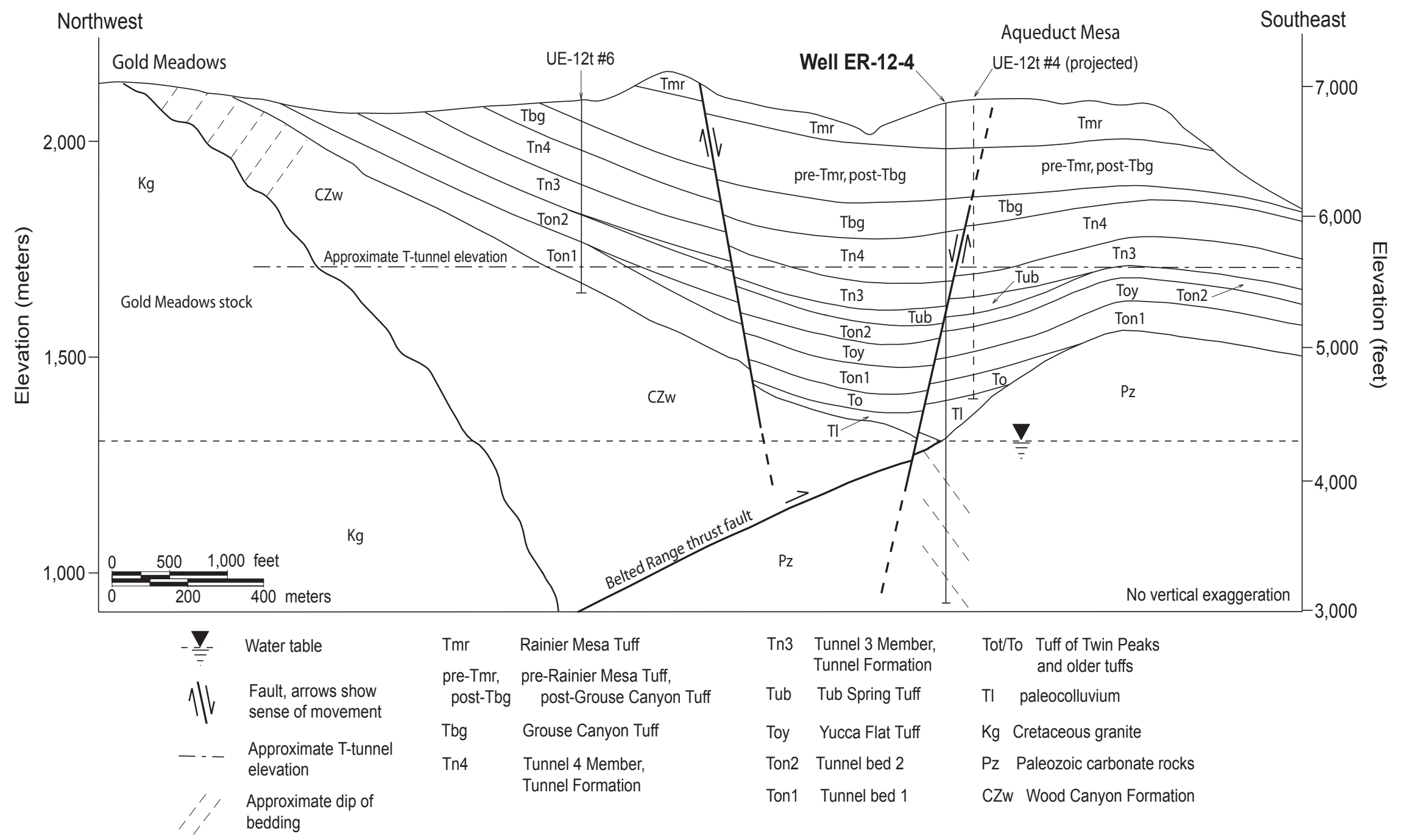

Figure 1-6

Northwest - Southeast Geologic Cross Section through Well ER-12-4 on Aqueduct Mesa

(from BN, 2006b) 


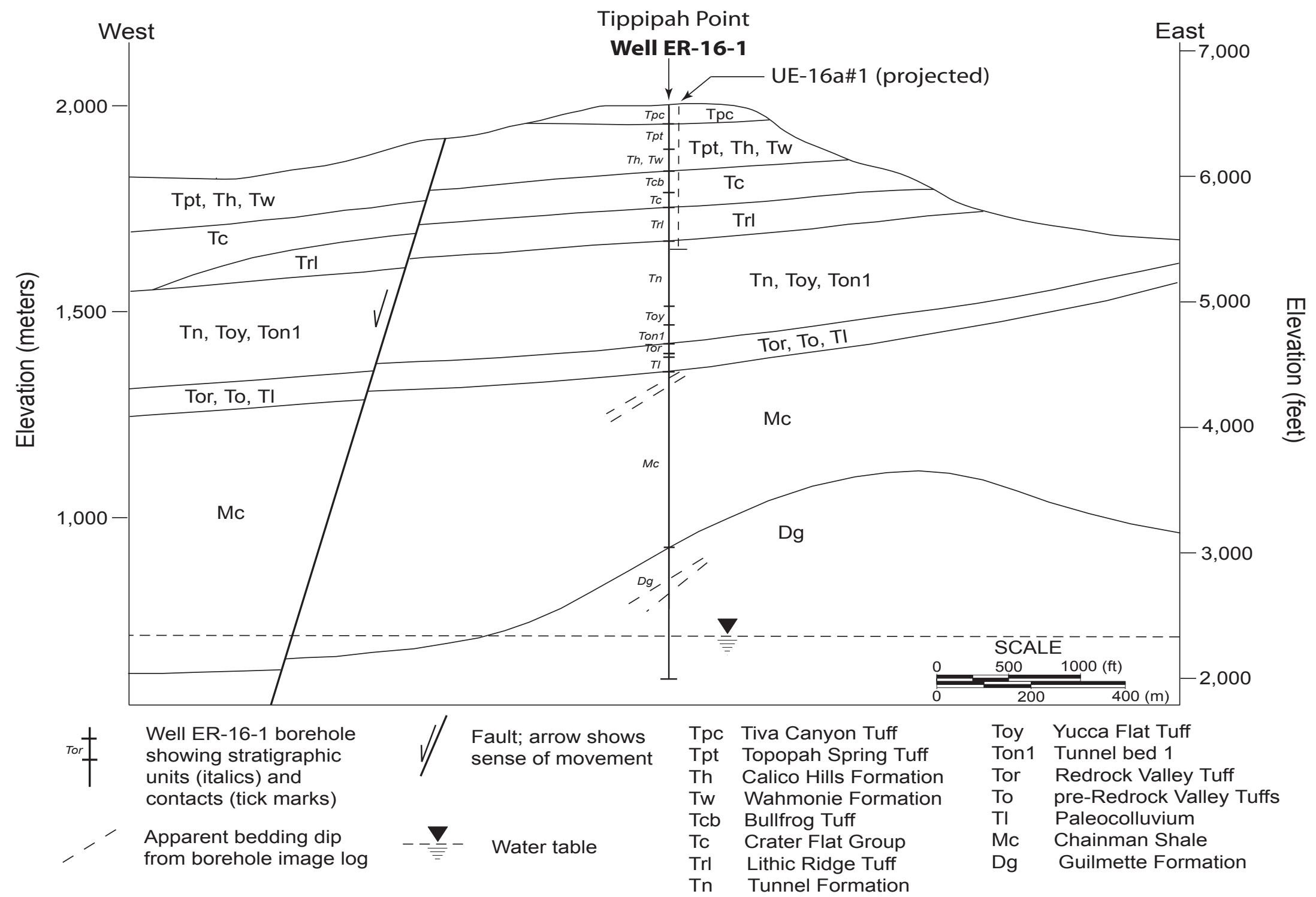

Figure 1-7

West-East Geologic Cross Section through Well ER-16-1 at Tippipah Point

(from BN, 2006c) 


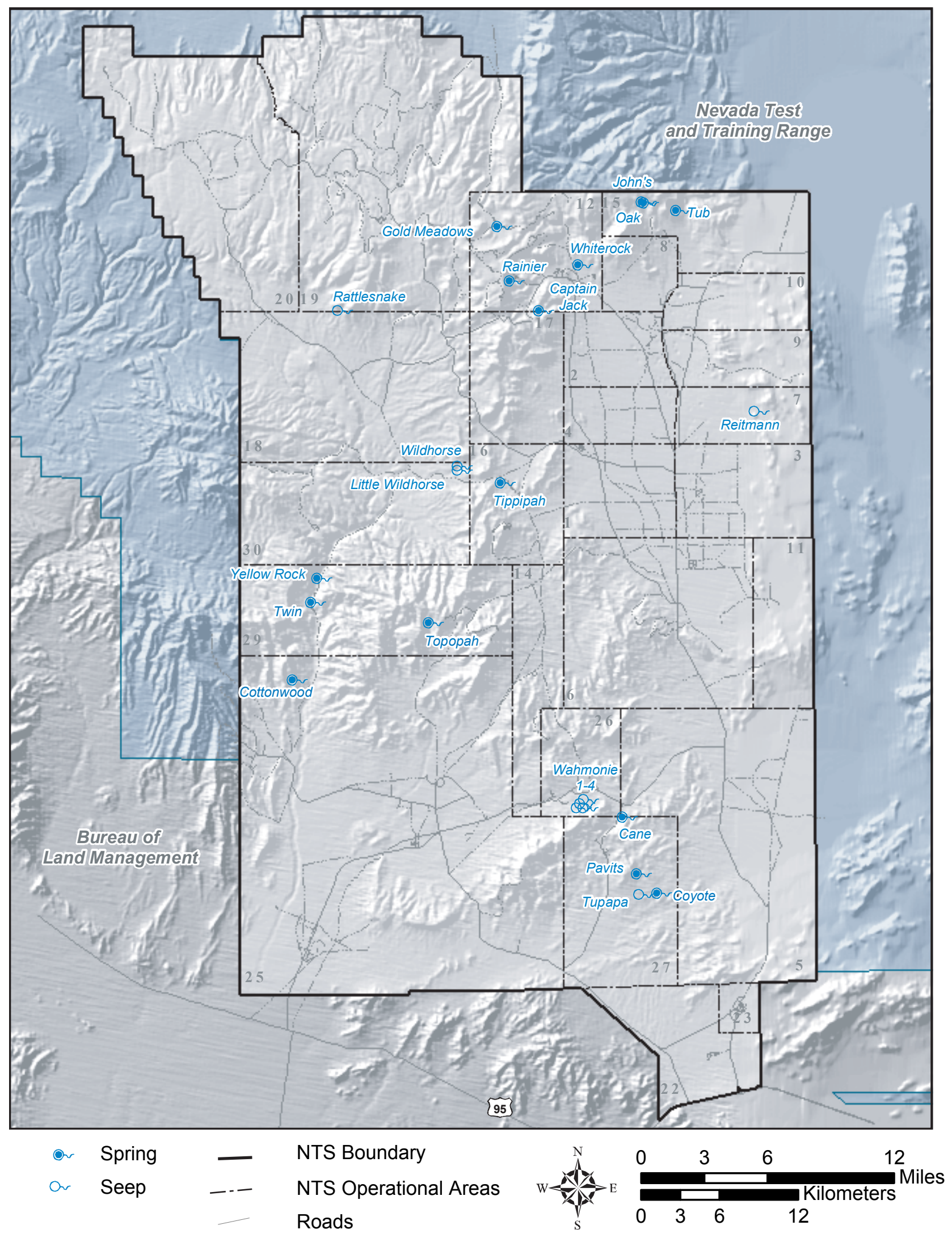

Figure 1-8

Natural Springs and Seeps on the Nevada Test Site

(After Hansen et al., 1997) 


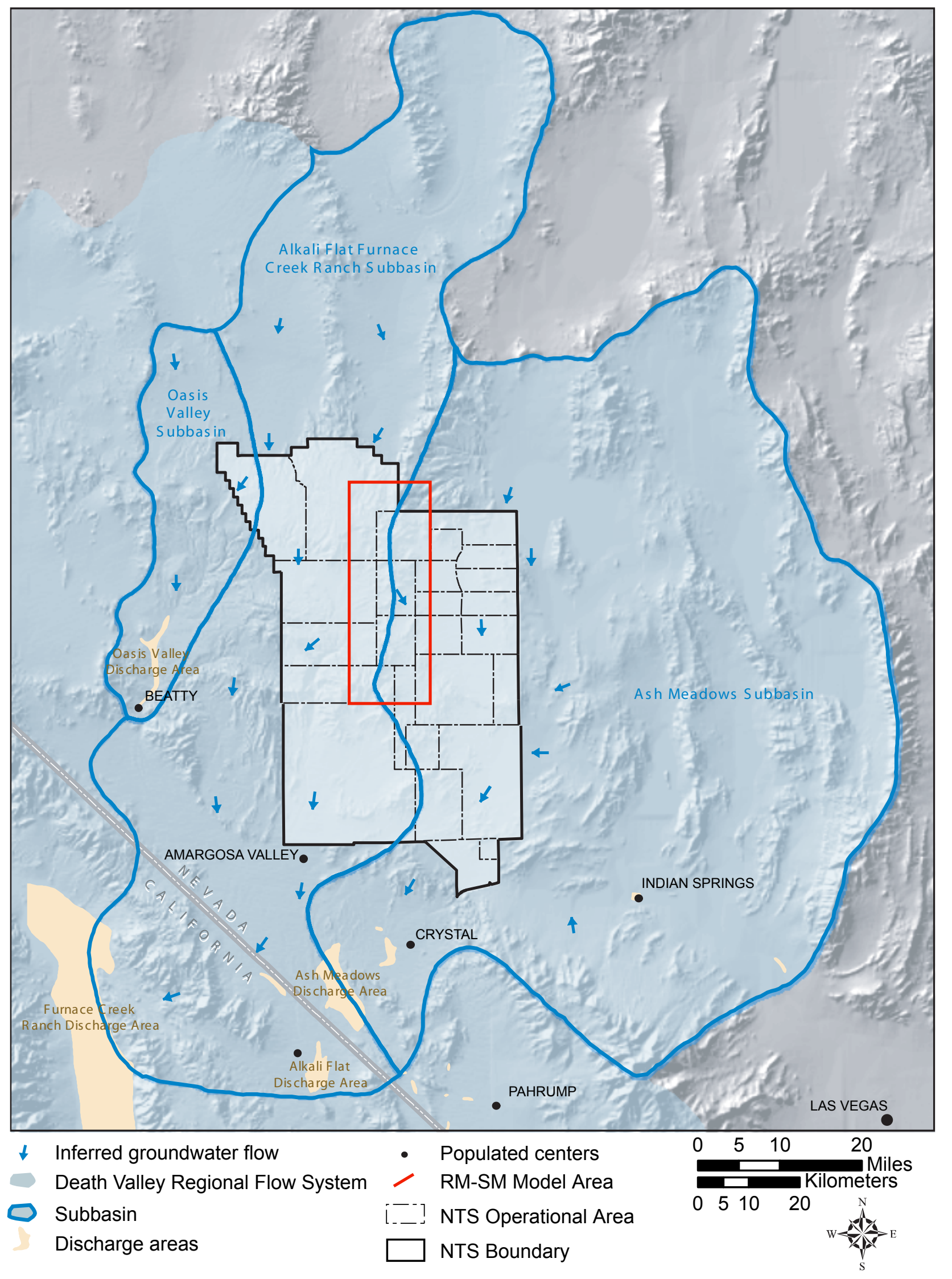

Figure 1-9

Groundwater Subbasins of the Nevada Test Site and Vicinity (Modified from Waddell et al., 1984, and Laczniak et al., 1996) 


\subsection{METHODOLOGY}

This section describes the process, methods, and data utilized to construct the RM-SM hydrostratigraphic framework model.

\subsection{Model Construction Process}

A summary of the general work-flow for model construction is provided below. The summary bullets below list, in general chronological order, individual tasks accomplished to build the final framework model.

\section{Fiscal Year 2005: Began compiling data.}

a. Completed three new deep characterization wells.

b. Assembled stratigraphic, lithologic, and alteration data for all vertical drill holes within the model area.

\section{Fiscal Year 2006: Produced a draft hydrostratigraphic framework model of the RM-SM} CAU.

a. Established and defined the boundaries of the model area.

b. Assembled other existing geologic data and interpretive products including geologic maps and cross sections, and geophysical investigations:

- Relevant hydrostratigraphic cross sections originally prepared for adjacent models

- Special-purpose maps, cross sections, and other data originally prepared in support of the DOE WTP

c. Developed a hydrostratigraphic system for the RM-SM model using stratigraphic, lithologic, and alteration data; hydrologic well data; and information from earlier hydrologic investigations and preceding UGTA modeling efforts (e.g., BN, 2002a; 2005; 2006).

d. Built upon existing stratigraphic databases to create an expanded database for the RM-SM model.

e. Integrated data from the three new characterization wells.

f. Refined the structural model as necessary for the study area.

g. Constructed interpretive hydrostratigraphic cross sections, pseudo drill holes/control points, and unit extent and outcrop maps for each HSU.

h. Input hard data and interpretive products into EarthVision ${ }^{\circledR}$ modeling platform.

i. Resolved relational problems and modified the hydrostratigraphic framework model as necessary.

j. Conducted pre-emptive review meeting (Section 2.4).

k. Conducted alternative scenario elicitation meeting. 
1. Built alternative models.

m. Documented the data used, their sources, interpretive approach, methods, etc.

n. Submitted model and documentation for technical reviews by the UGTA community.

\subsection{Determination of Model Area Boundaries}

The model boundaries were constrained by the needs of the hydrologic modelers and by the limitations and benefits of using computer modeling software. The model area had to be large enough to encompass all potential regulatory boundaries and any subsequent or derivative flow and transport models. However, the area covered by the RM-SM 3-D hydrostratigraphic framework model may not necessarily be the same as that covered in subsequent flow and transport models. The area of the RM-SM hydrostratigraphic framework model encompasses all of the underground testing locations (i.e., source areas) in the RM-SM CAU. The model includes all relevant geologic features, including known and inferred geologic structures. It also encompasses plausible flow paths from the source areas, based on the regional flow model (DOE, 1997) and on known hydrologic features. The RM-SM hydrostratigraphic framework model overlaps with existing UGTA CAU-scale models on two sides, and thus, if necessary, the model could easily be expanded to the west or east.

Geographic coordinates that define the boundaries for the RM-SM model area are given in Table 1-1. Vertically, the model extends from the ground surface to $5.1 \mathrm{~km}$ (3.2 mi) below mean sea level. The base of the model is below the top of the Proterozoic sedimentary rocks that underlie the regional aquifer. This deep confining unit is referred to as the "hydrologic basement."

\subsection{Data, Interpretive Products, and Other Information Used in Model Construction}

Despite the numerous drill holes and mined tunnels in portions of the model area (Appendix A, this report, and Plate 3) subsurface information over much of the model area is sparse, particularly around its margins and in the southern half of the model in general (outside of the WTP-use areas).

However, geoscientists have been working in the NTS region for more than fifty years (Byers et al., 1989), and many sources of geologic and geophysical information and data relevant to the RM-SM model area are available. For example, a tremendous amount of information is available for the former testing areas at Rainier and Aqueduct mesas from horizontal tunnels (Figure 2-1) and from vertical and horizontal drill holes, including numerous core holes. Also, most of the geologic units in the model are exposed at the surface within the NTS region, 
allowing direct observation of rock properties and characteristics. Drill hole and surface geophysical data are also available for these units. Numerous studies of similar geologic terrains have been conducted in other parts of the NTS and Nevada, and serve as analogs for some parts of the model area. Data recently collected as part of the Phase I data acquisition (particularly the three deep characterization wells) also added to the quality of subsurface data available for the model area.

As mentioned earlier, the adjacent hydrostratigraphic models for PM-OV and Yucca Flat (BN, 2002a; 2006) were the starting point for the development of the Phase I RM-SM model. Interpretive products produced in support of the UGTA Phase I regional model (IT, 1996a) were also available, as well as published maps and geologic reports, and unpublished geologic and geophysical data originally collected in support of other NTS programs (e.g., WTP, YMP, and DoD). Ground surface elevations were imported from a digital elevation model (DEM) data set. This DEM was compiled from 10-m DEM data derived from NTS-specific aerial photography reconnaissance in 1998 by the Remote Sensing Laboratory (BN, 2002b). Surface and nearsurface geologic information was derived from the USGS geologic maps of the study area (see Tables 2-1 and 2-2). The most important sources of data used to develop the subsurface interpretation presented in this model are listed below and discussed in more detail in following paragraphs. Individual data sources are identified where appropriate in Sections 3.0, 4.0, and 5.0 of this report. A complete list of references is provided in Section 7.0.

Geologic data for the RM-SM model area were compiled from existing data sets and from studies conducted specifically for this task. The subsurface interpretation is based on a variety of information sources, including the following:

a. Twelve USGS geologic quadrangle maps (Table 2-1)

b. Other geologic maps (Table 2-2)

c. Surface gravity and aeromagnetic investigations (Table 2-3)

d. High-resolution 10-m DEM data (BN, 2002b)

e. Various USGS reports (e.g., Cole and Cashman, 1997 and 1999; Cole et al., 1997)

f. Seismic surveys conducted for WTP by LLNL

g. Drill hole data (Fernald et al., 1975; Maldonado et al., 1979; Drellack and Thompson, 1990; Wagoner and Richardson, 1986; Townsend and Townsend [2003, 2004];

Appendix A; this report) 
Table 2-1

Geologic Quadrangle Maps (Scale 1:24,000) Used in Construction of the Rainier Mesa-Shoshone Mountain Hydrostratigraphic Framework Model

\begin{tabular}{||l|l||}
\hline \multicolumn{1}{|c||}{ Quadrangle Name } & \multicolumn{1}{c|}{ Authors $^{\text {a }}$} \\
\hline \hline Dead Horse Flat & Noble et al., 1967 \\
\hline Quartet Dome & Sargent et al., 1966 \\
\hline Oak Spring Butte & Rogers and Noble, 1969 \\
\hline Ammonia Tanks & Hinrichs et al., 1967 \\
\hline Rainier Mesa & Gibbons et al., 1963 \\
\hline Oak Spring & Barnes et al., 1963 \\
\hline Buckboard Mesa & Byers et al., 1966 \\
\hline Tippipah Spring & Orkild, 1963 \\
\hline Yucca Flat & Colton and McKay, 1966 \\
\hline Topopah Spring & Orkild and O'Connor, 1970 \\
\hline Mine Mountain & Orkild, 1968 \\
\hline Yucca Lake & McKeown et al., 1976 \\
\hline \hline
\end{tabular}

a See full citations in Section 7.0

Table 2-2

Special-Purpose Geologic Maps Used in Construction of the Rainier Mesa-Shoshone Mountain Hydrostratigraphic Framework Model

\begin{tabular}{||l|l||}
\hline \multicolumn{1}{|c|}{ Map Title and Scale } & \multicolumn{1}{|c||}{ Authors $^{\text {a }}$} \\
\hline \hline Geologic Map of Nevada (1:500,000) & Stewart and Carlson, 1978 \\
\hline $\begin{array}{l}\text { Digital Geologic Map of the Nevada Test Site and Vicinity, Nye, Lincoln, } \\
\text { and Clark Counties, Nevada and Inyo County, California (1:120,000) }\end{array}$ & Slate et al., 1999 \\
\hline $\begin{array}{l}\text { Geologic Map of the Death Valley Groundwater Model Area, Nevada and } \\
\text { California (1:250,000) }\end{array}$ & Workman et al., 2002a \\
\hline $\begin{array}{l}\text { Subcrop Geologic Map of the Pre-Tertiary Rocks in the Yucca Flat and } \\
\text { Northern Frenchman Flat Areas, Nevada Test Site, Southern Nevada }\end{array}$ & Cole et al., 1997 \\
\hline $\begin{array}{l}\text { Geologic Map of the Wheelbarrow Peak-Rainier Mesa Area, Nye } \\
\text { County, Nevada (1:48,000) }\end{array}$ & Sargent and Orkild, 1973 \\
\hline $\begin{array}{l}\text { Geologic Map of Pahute Mesa, Nevada Test Site and Vicinity, Nye } \\
\text { County, Nevada (1:48,000) }\end{array}$ & Orkild et al., 1969 \\
\hline
\end{tabular}

a See full citations in Section 7.0 
Table 2-3

Miscellaneous Special-Purpose Maps and Geophysical Studies Used in the Construction of the Rainier Mesa-Shoshone Mountain Hydrostratigraphic Framework Model

\begin{tabular}{|c|c|}
\hline Map or Study Title and Scale & Authors $^{a}$ \\
\hline $\begin{array}{l}\text { Geologic Surface Effects of Underground Nuclear Testing, Buckboard } \\
\text { Mesa, Climax Stock, Dome Mountain, Frenchman Flat, Rainier/Aqueduct } \\
\text { Mesa, and Shoshone Mountain, Nevada Test Site, Nevada }\end{array}$ & Grasso, 2003 \\
\hline $\begin{array}{l}\text { GIS Surface Effects Archive of Underground Nuclear Detonations } \\
\text { Conducted at Yucca Flat and Pahute Mesa, Nevada Test Site, Nevada }\end{array}$ & Grasso, 2001 \\
\hline $\begin{array}{l}\text { Preliminary Aeromagnetic Map of the Nevada Test Site and Vicinity, } \\
\text { Nevada }\end{array}$ & Kirchoff-Stein et al., 1989 \\
\hline $\begin{array}{l}\text { Digital Aeromagnetic Map of the Nevada Test Site Area, Nye, Lincoln, and } \\
\text { Clark Counties, Nevada, and Inyo County, California }(1: 100,000)\end{array}$ & Ponce, 1999 \\
\hline $\begin{array}{l}\text { Complete Bouguer Gravity Map of the Nevada Test Site and Vicinity, } \\
\text { Nevada }\end{array}$ & Healey et al., 1987 \\
\hline Isostatic Gravity Map of the Nevada Test Site and Vicinity, Nevada & Ponce et al., 1988 \\
\hline $\begin{array}{l}\text { Digital Isostatic Gravity Map of the Nevada Test Site Area, Nye, Lincoln, } \\
\text { and Clark Counties, Nevada, and Inyo County, California }(1: 100,000)\end{array}$ & Ponce et al., 1999 \\
\hline $\begin{array}{l}\text { Maps of the Thickness of Cenozoic Deposits and the Isostatic Residual } \\
\text { Gravity over Basement for Nevada }\end{array}$ & $\begin{array}{l}\text { Jachens and Moring, } \\
1990\end{array}$ \\
\hline $\begin{array}{l}\text { Aeromagnetic and Gravity Anomaly Maps of the Southwestern Nevada } \\
\text { Volcanic Field, Nevada and California }(1: 250,000)\end{array}$ & $\begin{array}{l}\text { McCafferty and Grauch, } \\
1997\end{array}$ \\
\hline Geophysical Study of the Subsurface Distribution of the Climax stock & Jachens, 1999 \\
\hline $\begin{array}{l}\text { Modeling of Climax Stock and Related Plutons Based on the Inversion of } \\
\text { Magnetic Data, Southwest Nevada }\end{array}$ & Phelps et al., 2004 \\
\hline $\begin{array}{l}\text { Inversion of Gravity Data to Define the Pre-Cenozoic Surface and Regional } \\
\text { Structures Possibly Influencing Groundwater Flow in the Rainier Mesa } \\
\text { Region, Nye County, Nevada. }\end{array}$ & Hildenbrand et al., 2006 \\
\hline
\end{tabular}

a See full citations in Section 7.0

h. Maps, detailed cross sections, and other information originally prepared for WTP projects and early UGTA modeling efforts (examples in Table 2-4)

i. UGTA wells in the RM-SM area:

»Wells ER-12-1, ER-12-2, ER-12-3, ER-12-4, ER-16-1, and ER-19-1

j. Magnetotelluric (MT) surveys 
Table 2-4

Examples of Maps, Detailed Cross Sections, and Other Geologic Information Originally Prepared for WTP Projects and Early UGTA Modeling Efforts

\begin{tabular}{||l|l||}
\hline \multicolumn{1}{|c||}{ Investigation Title } & \multicolumn{1}{|c||}{ Authors $^{\text {a }}$} \\
\hline \hline $\begin{array}{l}\text { A Hydrostratigraphic Model and Alternatives for the Groundwater Flow } \\
\text { and Contaminant Transport Model of Corrective Action Units 101 and } \\
\text { 102: Central and Western Pahute Mesa, Nye County, Nevada. }\end{array}$ & BN, 2002a \\
\hline $\begin{array}{l}\text { A Hydrostratigraphic Model and Alternatives for the Groundwater Flow } \\
\text { and Contaminant Transport Model of Corrective Action Unit 97: Yucca } \\
\text { Flat-Climax Mine, Lincoln and Nye Counties, Nevada }\end{array}$ & BN, 2006 \\
\hline $\begin{array}{l}\text { Supplementary Lithologic Logs of Selected Vertical Drill Holes in Area 12, } \\
\text { Nevada Test Site }\end{array}$ & Maldonado et al., 1979 \\
\hline $\begin{array}{l}\text { Lithologic Logs and Stratigraphic Identification for Vertical Drill Holes in } \\
\text { Area 12, Nevada Test Site. }\end{array}$ & Miller, 1970 \\
\hline $\begin{array}{l}\text { A Petrographical, Geochemical and Geophysical Database and } \\
\text { Framework for the Southwestern Nevada Volcanic Field }\end{array}$ & Warren et al., 2003 \\
\hline \hline
\end{tabular}

a See full citations in Section 7.0

\subsubsection{Existing Geological and Geophysical Maps}

Geologists working for the USGS have been mapping in the NTS area since the 1950s, and have produced numerous high quality geologic quadrangle maps at a scale of 1:24,000. Table 2-1 lists the twelve USGS maps that include portions of the RM-SM model area. Other surface geologic maps at larger scales were also used (Table 2-2). Table 2-3 lists some of the specialpurpose geological maps and geophysical studies that were considered during model construction.

\subsubsection{Tunnel Data}

Six large and several smaller tunnel complexes were constructed at Rainier Mesa for underground nuclear testing, starting in the 1950s and continuing through the early 1990s, when the current nuclear testing moratorium began (Figure 2-1). (Nuclear tests were also conducted in vertical drill holes U12r and U12q on Rainier Mesa, which are not described here.) In addition, the U16a tunnel at Tippipah Point in NTS Area 16 was also used to conduct similar tests in the 1960s and early 1970s (Figure 2-2).

Most of these tunnel complexes have in common a history of intense geologic study. For most tunnel tests, extensive geologic, geomechanical, and geophysical studies were made of the test bed to support engineering design, containment design, and containment evaluation. 
Geotechnical studies conducted for a typical site characterization program included suites of physical and mechanical properties of the rocks, obtained from testing of many core samples in the laboratory, and in-situ determination of the larger-scale rock properties through various types of geophysical surveys conducted within the tunnels. Mineralogical studies were conducted to develop the initial stratigraphic framework of the area, and to verify the presence of alteration such as argillization adjacent to individual test locations, which could cause containment problems.

The following sections provide, for each of the six larger tunnel complexes, brief historical summaries, descriptions of the geologic setting, and information on the extent of mining and drilling of exploratory boreholes. Similar information is also provided for U16a tunnel in Subsection 2.3.2.8, and the smaller Rainier Mesa tunnel complexes are addressed together in Subsection 2.3.2.7.

\subsubsection{B-Tunnel}

The U12b tunnel complex, located in the north-central portion of Rainier Mesa, was constructed between 1956 and 1963, and consists of 4,903.3 linear meters [16,087 linear feet] of mined drifts. B-Tunnel was the site of America's first fully contained UGT in 1957, code-named RAINIER. Five other nuclear tests were conducted in B-Tunnel, in addition to comprehensive reentry investigations of the RAINIER test. Although no horizontal exploratory core holes were drilled from the B-Tunnel complex, many samples taken from the underground workings were analyzed and tested by the USGS and the LLNL. One vertical exploratory core hole (intermittently cored) was drilled in conjunction with the U12b investigations. This hole, U12b.07-C, also known as Rainier Mesa Exploratory \#1, is the deepest exploratory hole drilled from the surface of Rainier Mesa (1,168.3 m [3,833 ft]). Several other holes were drilled in the vicinity of B-Tunnel, and many have intermittent core samples and geophysical log data available for study. A unique feature of the B-Tunnel complex is the U12b.07 shaft. This

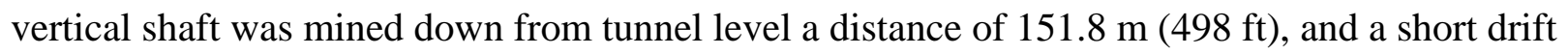
was mined horizontally north from the base of the shaft. This project was abandoned for operational reasons which included significant water inflow from faults and fractures encountered during mining.

The geologic setting of B-Tunnel is unique because of the relatively higher portal elevation $(2,016.3 \mathrm{~m}[6,615 \mathrm{ft}])$, compared to the other three major tunnels in Rainier Mesa proper $(1,841.6 \mathrm{~m}[6,042 \mathrm{ft}]$ average). The portal of the tunnel is in the upper portion of Tunnel Formation, Tunnel 4 Member, and the tunnel was driven up-section through both the lower and upper portions of the Grouse Canyon Formation; the majority of the tunnel is within the 
pre-Rainier/post-Grouse Canyon section. The major structures mapped in the tunnel system include a southwest-trending syncline and a single northwest-trending normal fault. The syncline has a southwesterly strike and plunges 2 degrees southwest. Bedding dips reach as high as 28 degrees toward the axis of the syncline. The single major fault strikes southeast-northwest, dips steeply to the southwest, and has displacement greater than $4.6 \mathrm{~m}(15 \mathrm{ft})$. Some portions of the tunnel complex penetrate the upper level of pervasive zeolitization, a situation encountered elsewhere only in the U12p tunnel complex (see Subsection 2.3.2.5).

Little water was encountered during the initial mining or reentry mining of the B-Tunnel drifts, with the exception of the U12b.07 vertical shaft, mentioned above. It is likely that the relatively high stratigraphic position of the tunnel openings and the resultant low fault and fracture frequency are responsible for the dryness of the U12b Tunnel complex.

\subsubsection{E-Tunnel}

The U12e horizontal tunnel complex was constructed in the east-central part of Rainier Mesa between 1957 and 1977, and comprises 15,149.2 linear meters (49,702 linear feet) of mined drifts. Nine UGTs were conducted in E-Tunnel, including three early tests (1958-61) conducted by LLNL. Ten horizontal exploratory core holes greater than $152.4 \mathrm{~m} \mathrm{(500} \mathrm{ft)} \mathrm{in} \mathrm{length}$ $(4,712.2 \mathrm{~m}[15,460 \mathrm{ft}]$ of core $)$ were drilled from various locations underground to explore the E-Tunnel area, and five vertical exploratory holes $(3,270.8 \mathrm{~m}[10,731 \mathrm{ft}]$ of core) were drilled from the surface of Rainier Mesa to examine the entire section of rocks near the E-Tunnel testing areas. In addition, two vertical exploratory core holes (602.0 $\mathrm{m}[1,975 \mathrm{ft}]$ of core) were drilled from underground locations to further investigate the pre-Tertiary rocks beneath E-Tunnel.

The portal of the U12e tunnel is located at $1,865.7 \mathrm{~m}(6,121 \mathrm{ft})$ above sea level, and the average overburden thickness for the six later tests (post-1968) is $401.1 \mathrm{~m}(1,316 \mathrm{ft}$ ) (two of the early tests were not conducted under the topographic edge [caprock] of the mesa). Mining of the access tunnel began in Paleozoic-age dolomite, and progressed stratigraphically up-section through tunnel beds 1 and 2, Tub Spring Tuff, and Tunnel Formation, Tunnel 3 and 4 Members. With the exception of the dolomite at the portal, all rocks within the tunnel complex are zeolitized ash-fall tuff and nonwelded ash-flow tuff of Tertiary age. Structurally, most of the tunnel complex was constructed across several small-amplitude depositional synclines and anticlines that generally trend northeast-southwest. Because of the varied structure, the attitude of bedding varies considerably, and the bedding dips range from a few degrees to about 20 degrees. Most faults in the portions of the complex used for UGTs trend northwest-southeast and the displacements in the tunnels are generally less than $3 \mathrm{~m}(10 \mathrm{ft})$. One fault located west 
of the drifts (known only from drilling data) is thought to have a displacement of 15.2 to $30.5 \mathrm{~m}$ (50 to $100 \mathrm{ft}$ ). Faults are more numerous in access drifts and outer areas of the complex that are closer to the topographic edge of the mesa.

Water was encountered during all phases of construction of the U12e tunnel complex. The volumes encountered were generally small, ranging from seeps to flows of 18.9 to 75.7 liters per minute (lpm) (5 to 20 gallons per minute [gpm]). No single source of water was ever identified in the E-Tunnel area, but the collective complex continues to produce water to this day, at rates of 30.3 to $56.8 \mathrm{lpm}$ (8 to15 gpm).

\subsubsection{G-Tunnel}

The U12g horizontal tunnel complex was constructed between 1961 and 1989, and was utilized for five UGTs. G-Tunnel consists of $11,667.1 \mathrm{~m}(38,278 \mathrm{ft})$ of mined drifts, and two hemispherical chambers, each $21.3 \mathrm{~m}(70 \mathrm{ft})$ in radius. One of the hemispheres was used as the site of a nuclear test and has since collapsed, but the other remain standing. A small portion of G-Tunnel was also utilized for a series of rock-mechanics experiments, which required the mining of a drift within the welded tuff of the Grouse Canyon Formation, approximately $22.9 \mathrm{~m}$ $(75 \mathrm{ft})$ above the average tunnel level. Two horizontal exploratory core holes $(782.7 \mathrm{~m} \mathrm{[2,568 \textrm {ft } ]}$ of core) were drilled within the complex, in addition to hundreds of shorter holes drilled to provide data for individual experiments. Six vertical exploratory core holes $(2,412.5 \mathrm{~m}$ $[7,915 \mathrm{ft}]$ of core) were drilled from the mesa surface to tunnel level in support of hydraulic fracturing experiments. Following the last UGT in G-Tunnel (1971), the drift complex was utilized by several organizations as an underground laboratory, where high-explosive tests, the above-mentioned rock mechanics experiments, and many other types of non-nuclear experiments were conducted.

The G-Tunnel complex is located in the southernmost portion of Rainier Mesa. The tunnel portal is $1,863.5 \mathrm{~m}(6,114 \mathrm{ft})$ above sea level, and the average overburden thickness at test locations is $431.6 \mathrm{~m}(1,416 \mathrm{ft})$. The tunnel complex was mined entirely within zeolitized bedded tuff and nonwelded ash-flow tuff of Tertiary-age tunnel bed 2, Tunnel 3 and 4 Members of the Tunnel Formation, and the bedded Grouse Canyon Formation. Access to the densely welded portion of the Grouse Canyon Formation was gained by mining of an inclined drift above tunnel level. Structurally, the G-Tunnel area is less complex than any other tunnel complex within Rainier Mesa proper. Small-amplitude depositional anticlinal and synclinal features were mapped in several locations, and bedding dips are generally less than 15 degrees. Faulting and fracturing of the tuffs is quite limited, with few displacements of more and a few meters (feet), and only one larger-displacement fault, which was mapped in the main access drift. 
No large-volume (more than a few gallons per minute) sources of water were encountered during mining and drilling in the G-Tunnel complex. However, small amounts of water were found in several faults and fractures within the welded rocks of the Grouse Canyon Formation, located significantly above tunnel level, and some water continues to flow from this source.

\subsubsection{N-Tunnel}

The U12n horizontal tunnel complex was constructed between 1961 and 1993, and 25,146 linear meters $(82,500$ linear feet) of tunnels were mined to conduct 20 low-yield nuclear tests and one 1.07-kiloton chemical explosion. In addition to the mining, 26 horizontal exploratory core holes $(11,485 \mathrm{~m}$ [37,682 ft] of core) were drilled beyond existing tunnels from underground locations, and 17 vertical exploratory core holes $(7,952 \mathrm{~m}$ [26,088 ft] of core) were drilled from the mesa surface in the immediate vicinity of N-Tunnel to further understand the geologic setting. The character of the pre-Tertiary rocks beneath the $\mathrm{N}$-Tunnel complex was investigated by drilling of the vertical core holes mentioned above and through various geophysical studies.

The portal of the U12n tunnel complex is $1,835.8 \mathrm{~m}(6,023 \mathrm{ft})$ above sea level, and the average overburden thickness at the test locations ranges from 344.4 to $415.7 \mathrm{~m}$ (1,130 to 1,364 $\mathrm{ft}$ ), varying due to the rugged surface topography. The tunnel complex was mined entirely in zeolitized bedded tuff and nonwelded ash-flow tuffs of the Tertiary-age Tunnel Formation, the bedded Grouse Canyon Formation, Tub Spring Tuff, and tunnel beds 1 and 2. Structurally speaking, the complex penetrates both limbs of a broad depositional syncline. The axis of this syncline trends northeast-southwest, plunging towards the southwest. The bedding dips from 0 to 18 degrees, depending on position relative to the syncline. Many faults and fractures were mapped in the tunnels and drill holes. The dominant structural trend in the area is northwestsoutheast, with displacements ranging from a few centimeters (inches) to approximately $15.2 \mathrm{~m}$

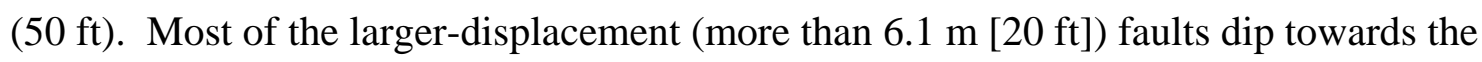
southwest and are displaced down to the southwest.

Small volumes of water (less than $3.8 \mathrm{lpm}$ [1 gpm]) were infrequently encountered on fault and fracture planes during mining, and more significant volumes (18.9 to $75.7 \mathrm{lpm}$ [5 to $20 \mathrm{gpm}$ ) were seen during the drilling of several horizontal exploratory holes. A large volume of water was encountered in the mining of the U12n.03 drift in the northeastern portion of N-Tunnel. Water emanated from a fracture system exposed in the drift at a rate of $208.2 \mathrm{lpm}$ (55 gpm) initially, and continued to flow at lesser rates for many years. 


\subsubsection{P-Tunnel}

The U12p tunnel complex is located in the northeastern portion of Aqueduct Mesa. Mining of the tunnel complex began in 1962, when a single drift was driven $610.8 \mathrm{~m}(2,004 \mathrm{ft})$ into the mesa. However, no additional mining was accomplished at the site until 1984, when it was reactivated for underground nuclear testing. The P-Tunnel complex currently consists of $7,192.4 \mathrm{~m}$ (23,597 ft) of mined drifts, including one partially constructed test site, and was the location for four UGTs (1987 to 1992). Seven continuously cored, vertical exploratory holes were drilled in the vicinity of P-Tunnel (3,545.1 $\mathrm{m}[11,631 \mathrm{ft}]$ of core) to investigate the geology above and below the test areas, and one horizontal exploratory hole was drilled at tunnel level (830.6 m $[2,725 \mathrm{ft}]$ of core).

The portal of the U12p tunnel is located at an elevation of 1,676.4 $\mathrm{m}(5,500 \mathrm{ft})$ above sea level. The overburden thickness at test locations in P-Tunnel ranges from 236.5 to $270.7 \mathrm{~m}$ (776 to $888 \mathrm{ft}$ ). Stratigraphically, the tunnel complex is located entirely within pre-Rainier/post-Grouse Canyon units, approximately $91.4 \mathrm{~m}$ (300 ft) below the base of the Rainier Mesa Member and approximately $152.4 \mathrm{~m}$ (500 ft) above the top of the Grouse Canyon Formation. The upper level of pervasive zeolitization is at or slightly below tunnel level in the northeastern portion of the tunnel complex and a few feet above tunnel level in the western area. Extensive x-ray diffraction and scanning electron microscopy studies were conducted on samples from P-Tunnel to further the understanding of the process of zeolitization of the volcanic rocks.

There are no significant structural features present in the immediate P-Tunnel area. The major faults that control the regional structure are located more than $1.6 \mathrm{~km}(1 \mathrm{mi})$ east and west of P-Tunnel. The stratigraphic bedding strikes essentially north-south, and dips 4 to 5 degrees east. Small erosional channel features were mapped throughout the complex, but the physical and mechanical properties of the fill material apparently differ only slightly from the surrounding rock.

Because of the lack of faults and fractures, free water was rarely encountered during the construction of the U12p tunnel complex. As discussed for the U12b tunnel complex, the tunnel position relative to the upper level of zeolitization is probably a factor in the low fracture frequency and insignificant occurrence of perched water in the otherwise saturated tuff.

\subsubsection{T-Tunnel}

The U12t horizontal tunnel complex was constructed between 1968 and 1988 in the northern extension of Rainier Mesa, known also as Aqueduct Mesa. Six UGTs were conducted within the U12t tunnel complex. The tunnel system consists of 10,642 linear meters (34,913 linear feet) of 
drifts ranging in size from 0.6 by $0.6 \mathrm{~m}$ ( 2 by $2 \mathrm{ft}$ ) to 10 by $11.6 \mathrm{~m}$ ( 33 by $38 \mathrm{ft}$ ), the latter being the largest-diameter tunnel at the NTS. Eleven horizontal exploratory core holes $(7,130 \mathrm{~m}$ $[23,391 \mathrm{ft}]$ of core) were drilled beyond the existing drifts to evaluate the geology surrounding the test areas, and eight vertical exploratory core holes $(4,339 \mathrm{~m}$ [14,234 ft] of core) were drilled from the mesa surface in the general vicinity of T-Tunnel to better understand the geology above and below the tunnel horizons.

The portal of the U12t tunnel complex is $1,707 \mathrm{~m}(5,600 \mathrm{ft})$ above sea level, and the overburden thickness at the test locations ranges from 348 to $424 \mathrm{~m}(1,143$ to $1,391 \mathrm{ft})$, varying with the surface topography. The tunnel complex was mined entirely within the Tertiary-age volcanic rocks of the Tunnel 3 and 4 Members of the Tunnel Formation, Tub Spring Tuff, and tunnel bed 2. These rocks are zeolitized ash-fall and nonwelded ash-flow tuff. The drifts were mined across both limbs of a depositional syncline that trends southwest-northeast, gently plunging towards the northeast. The bedding dips generally range from 5 to 20 degrees, with the steeper dips generally found lower in the stratigraphic section. Many faults and fractures were mapped in the drifts and logged in the core from exploratory borings. The dominant structural trend is approximately north-south. Fault displacements range from a few centimeters (inches) to more

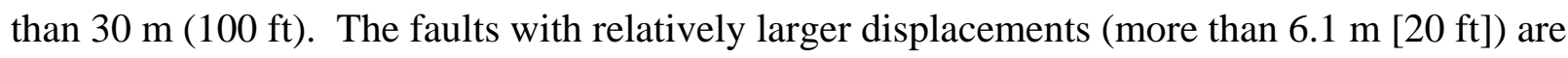
generally down-thrown to the west.

Significant volumes of water (more than a few gallons per minute) were encountered during mining of the T-Tunnel complex at only two locations, one in the main access drift, approximately $610 \mathrm{~m}(2,000 \mathrm{ft})$ from the portal, and the other near the terminus of the bypass drift in the U12t.03 complex. However, large volumes of water (more than 1,514 lpm [400 gpm]) were encountered during the drilling of several horizontal exploratory holes located northwest of the drifts. The water was determined to be flowing from fault and fracture systems located entirely beyond the open drifts, which were interconnected over distances of greater than $30 \mathrm{~m}$ (100 ft). The water flow diminished over time, but stabilized and continued to flow until the holes were sealed.

\subsubsection{Other Tunnel Complexes}

Two other tunnel complexes and five single tunnels were constructed in Rainier and Aqueduct Mesas in support of the nuclear testing program.

The U12a tunnel (also known as the USGS Tunnel) was mined in 1956 to provide a highexplosive test bed in support of planning for the impending RAINIER nuclear experiment. A-Tunnel consisted of an access drift and two test drifts at right angles (186.8 $\mathrm{m}[613 \mathrm{ft}]$ in total 
length). The two tests, in which ten and fifty tons of high explosive were used, were conducted a little over a month apart, approximately five months prior to the RAINIER test. The U12a tunnel was constructed in zeolitized tuff.

The U12c tunnel complex (91.4 m [300 ft] of mined drifts) was constructed adjacent to and just south of B-Tunnel, but at the somewhat higher elevation of 2,045.8 m (6,712 ft). Three nuclear safety tests were conducted there in 1957-58. SATURN, the first test in C-Tunnel, was actually the first nuclear test conducted in Rainier Mesa (40 days prior to RAINIER), but it achieved zero yield (DOE, 2000). The NEPTUNE test, an important cratering experiment, was also conducted in the U12c tunnel. Mining of C-Tunnel began in the lower (bedded) Grouse Canyon Formation and progressed up-section through a thin welded zone, into the lower part of the pre-Rainier/ post-Grouse Canyon.

The U12d tunnel was driven from the same portal area as U12c and U12f (elevation 2,049.8 $\mathrm{m}$ $[6,725 \mathrm{ft}])$, and consisted of a single drift $67.1 \mathrm{~m}(220 \mathrm{ft})$ long. This site was used for the safety test code-named VENUS in 1958. The geology was essentially the same as at C- and F-Tunnels,

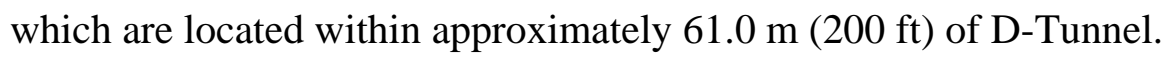

The U12f tunnel complex, located adjacent to the U12c complex, was constructed at the same portal elevation, and consisted of four test areas for which 350.5 linear meters (1,150 linear feet) of drifts were mined. However, only two safety tests (MERCURY, MARS) were conducted in F-Tunnel. The geologic setting of F-Tunnel is nearly identical to that of C-Tunnel.

The U12i, U12j, and U12k tunnels are located in the extreme southeastern portion of Aqueduct Mesa. All three tunnels were driven from the same portal facility in 1959, to be used as nuclear test sites. Each complex consists of approximately $762.0 \mathrm{~m}(2,500 \mathrm{ft})$ of mined drifts (portal elevations all 1,717.5 m [5,635 ft]), but only U12k and U12j were used for nuclear tests (PLATTE and DES MOINES, respectively), conducted in 1962 (DOE, 2000). I-Tunnel was abandoned as mined, following the containment failures in the two adjacent tunnel complexes. These three tunnel complexes were constructed in the vitric (non-zeolitized) portion of the preRainier/post-Grouse Canyon, and were dry.

\subsubsection{U16a Tunnel Complex}

The U16a horizontal tunnel complex was constructed beneath Tippipah Point (at the north end of Shoshone Mountain; Figure 2-2) between 1961 and 1971, with additional exploratory work continuing through 1973. Six low-yield UGTs were conducted in the U16a tunnel complex. 
The U16a tunnel complex is located at an elevation of about 1,649 $\mathrm{m}(5,410 \mathrm{ft})$ above sea level, in zeolitized ash-fall and ash-flow tuffs, similar in age and character to the rocks found at the southern end of Rainier Mesa (U12g and U12e tunnels). Many faults and fractures were mapped throughout the tunnel system, with fault displacements ranging from a few centimeters (inches) to more than $30 \mathrm{~m}(100 \mathrm{ft})$. The attitude of the bedding in the tuffs is generally north-south, dipping 8 to 18 degrees to the west. Available mining records include nothing to indicate the presence of significant quantities of water encountered during mining or exploratory drilling.

Construction of test beds for the six UGTs required approximately 1,105 linear meters (3,625 linear feet) of mined tunnel, with an average cross-sectional size of about 3.7 by $3.7 \mathrm{~m}$ (12 by $12 \mathrm{ft}$ ). All tunnel drifts were mapped by the USGS, and the results are presented on several maps; however, there is no single map with all available data. Six horizontal exploratory core holes (totaling 1,620 m [5,314 ft] of drilling) were drilled within the complex. One vertical exploratory core hole was drilled from the surface to the tunnel elevation, and another was drilled from the tunnel invert down $76.2 \mathrm{~m}(250 \mathrm{ft})$. Data for the deeper units in the U16a area were obtained from UGTA Well ER-16-1 (DOE, 2006c; Subsection 2.3.4.5). See Appendix A for all relevant drill hole data.

\subsubsection{Drill Hole Data}

More than a thousand holes have been drilled in the RM-SM model area for various purposes, including water production and monitoring wells, emplacement holes and post-shot holes for UGTs, exploratory holes (Raytheon Services Nevada, 1990), and holes for underground instrumentation. Over a hundred holes relevant to the RM-SM model were drilled by the DOE in support of NTS programs, but data from most of these were held primarily in NTS agency files. During development of the UGTA Phase I regional model, some of these data were compiled, analyzed, and organized into databases for import into modeling software applications (circa 1996). For the RM-SM CAU-scale modeling initiative, a much more intensive data compilation and evaluation effort was implemented (Townsend and Townsend, 2003; 2004). Boreholes providing input for the RM-SM model are listed in Appendix A and shown on Plate 3. The boreholes provide information on the geologic and hydrologic character and distribution of subsurface units.

Although much of the drill-hole information provided in Appendix A is typically referred to as data, it should be remembered that such information is a result of a rigorous interpretive process based on an integrated analysis of drill cuttings, rock core, geophysical logs, and nearby surface exposures. Results from laboratory analyses such as petrography, x-ray diffraction, and x-ray fluorescence are also commonly integrated into the stratigraphic interpretation. 


\subsubsection{UGTA Wells}

Three wells (ER-12-3, ER-12-4, and ER-16-1) were drilled and completed as part of the UGTA Phase I data acquisition initiative for the RM-SM CAU. Three other UGTA wells were drilled within the model area for earlier UGTA initiatives. These characterization wells provide important information and constraints for the framework model. The RM-SM Phase I wells were intended to provide detailed supplemental information for the RM-SM hydrogeologic model, and new, detailed information about the geology, hydrogeology, and water chemistry in the immediate vicinity of the nuclear testing in tunnels at Rainier Mesa and Shoshone Mountain. The purpose and expectations of the FY 2005 drilling initiative are spelled out in the Rainier Mesa-Shoshone Mountain Hydrogeologic Investigation Wells Drilling and Completion Criteria (SNJV, 2005a). Objectives of the earlier wells, ER-12-1, ER-12-2, ER-19-1, drilled before 2004, are described in separate drilling and completion reports (Russell et al., 1996; DOE, 2004; 1995a, respectively). Each of these UGTA wells is described briefly in the following paragraphs, and hydrogeological information is provided in graphical form in Appendix B.

\subsubsection{Well ER-12-1}

Well ER-12-1 is located at the eastern base of Rainier Mesa within Area 12 (Plate 3) and was drilled to a total depth (TD) of 1,093.6 $\mathrm{m}(3,588 \mathrm{ft})$ in 1991. The primary purpose of constructing Well ER-12-1 was to determine the hydrogeology of Paleozoic carbonate rocks and of the Eleana Formation, a regional aquitard, in an area potentially down-gradient from nuclear testing in the tunnels of Rainier Mesa (Russell et al., 1996).

Well ER-12-1 encountered a complex sedimentary rock sequence consisting of alternating intervals of carbonate and siliciclastic rocks of mostly Devonian and Mississippian ages that result, hydrogeologically, in alternating intervals of carbonate aquifer and clastic confining units (Figure B-1). This sedimentary sequence is likely the result of complex foreland imbricate thrusting within the footwall of the east-directed Belted Range thrust fault (see Section 3.0). The well bottomed in igneous intrusive rock classified mineralogically as a lamprophyre, and dated at approximately 100 million years. The lamprophyre is probably related to other small mafic intrusive dikes that are present east of the well around the northern margins of Yucca Flat (Slate et al., 1999). Although it is difficult to extrapolate the detailed geology encountered in Well ER-12-1 because of the lack of similar sections in outcrop or nearby drill holes, the geology is consistent with the general structural regime of the area that involves contractional deformation related to east-directed thrusting associated with the Belted Range thrust fault system. 


\subsubsection{Well ER-12-2}

Well ER-12-2 is located in the northwest part of Yucca Flat east of Rainier Mesa in Area 12 (Plate 3). The well was drilled to a TD of 2,097.9 m (6,883 ft) in 2002 (DOE, 2004). The purpose of the well was to gather subsurface data to better characterize the pre-Tertiary rocks within the area, and to provide a depth to the regional water table (DOE, 2004).

Well ER-12-2 penetrated a thin veneer of alluvium and volcanic rocks overlying 1,912.0 m $(6,273 \mathrm{ft})$ of Mississippian siliciclastic rocks assigned to the Chainman Shale and Eleana Formation (Figure B-2). The well bottomed within the Eleana Formation at a depth of 2,097.9 m $(6,883 \mathrm{ft})$. This is the thickest interval of Mississippian siliciclastic rocks encountered in any drill hole at the NTS, and shows that these rocks, which are classified hydrogeologically as clastic confining units, are very thick in the northwestern portion of Yucca Flat, consistent with data from other deep drill holes (e.g., UE-17e and UE-1L; see Appendix A) located further south along the western side of Yucca Flat, and with MT data collected across Yucca Flat.

\subsubsection{Well ER-12-3}

Well ER-12-3 is located near the center of Rainier Mesa in Area 12 (Plate 3) and was drilled to a TD of 1,496.0 $\mathrm{m}(4,908 \mathrm{ft})$ in 2005 . The purpose of drilling this well was to obtain subsurface data to better characterize the hydrogeology of central Rainier Mesa, especially in the older Tertiary volcanic rocks and Paleozoic sedimentary rocks. This well also provided information about the stratigraphy, structure, and water levels of the area (DOE, 2006a).

Because of the excellent surface and subsurface control in the area, the geology encountered by Well ER-12-3 is similar to that predicted prior to drilling. The well penetrated a 673.6-m (2,210-ft) thick volcanic section typical of the Rainier Mesa area (Figure B-3). The volcanic rocks lie unconformably on Paleozoic carbonate rocks, which are classified as carbonate aquifer. The carbonate rocks are part of an imbricate thrust sheet that formed in front of, and structurally below, the main east-directed Belted Range thrust fault (see Section 3.0). The carbonate rocks are interpreted to structurally correlate to the carbonate rocks in Well ER-12-4 (Subsection 2.3.4.4) and the carbonate rocks in the upper portion of Well ER-12-1. Thus, the carbonate rocks are part of the same imbricate thrust sheet. Well ER-12-3 penetrated $822.4 \mathrm{~m}$ $(2,698 \mathrm{ft})$ of carbonate rocks before reaching TD in carbonate at a depth of 1,496.0 m $(4,908 \mathrm{ft})$, and thus provides a minimum thickness constraint for the imbricate thrust sheet of carbonate aquifer below the central portion of Rainier Mesa.

Prior to drilling it was predicted that a thin interval of early Paleozoic to late Precambrian siliciclastic rocks classified as clastic confining unit, and representing the leading edge of the 
Belted Range thrust sheet, would be encountered below the volcanic rocks and above Paleozoic carbonate rocks. The absence of siliciclastic rocks in Well ER-12-3 indicates that the Belted Range thrust fault and associated thrust sheet composed of clastic confining unit are west of the well's location.

\subsubsection{Well ER-12-4}

Well ER-12-4 is located on Aqueduct Mesa (considered to be part of Rainier Mesa) in Area 12 (Plate 3) and was drilled to a TD of 1,132.3 m (3,715 ft) in 2005. The purpose of this well was to provide information regarding the radiological and physical environment near UGTs conducted in U12t Tunnel, information on the pre-Tertiary rocks in the area, and depth to the regional water table (DOE, 2006b).

The geology encountered at Well ER-12-4 is very similar to that predicted prior to drilling. This is mainly the result of excellent surface and subsurface control in the area. The well penetrated a 674.2-m (2,212-ft) thick volcanic section typical of the Rainier Mesa area, and similar to the volcanic section at Well ER-12-3 (Figure B-4). Below the volcanic rocks, the well penetrated $84.1 \mathrm{~m}$ ( $276 \mathrm{ft}$ ) of tuffaceous sediments and paleocolluvium that contain significant amounts of clay and are together classified as a confining unit. These sediments probably filled a substantial topographic low, which suggests that considerable topographic relief characterized the Rainier Mesa area prior to the beginning of volcanism.

Paleozoic-age carbonate rocks were encountered at a depth of $758.3 \mathrm{~m}(2,488 \mathrm{ft})$ in Well ER-12-4. These rocks, which are classified as carbonate aquifers, are part of the same imbricate thrust sheet encountered in Well ER-12-3 and the upper part of Well ER-12-1. Well ER-12-4 reached TD in carbonate rocks after penetrating $374.0 \mathrm{~m}(1,227 \mathrm{ft})$, and thus provides a minimum thickness constraint for the imbricate thrust sheet of carbonate aquifer below this part of Aqueduct Mesa. The absence of early Paleozoic to late Precambrian siliciclastic rocks in Well ER-12-4 indicates that the leading edge of the Belted Range thrust fault is west of the well.

\subsubsection{Well ER-16-1}

Well ER-16-1 is located on Tippipah Point near the northern end of Shoshone Mountain in the southern part of NTS Area 16 (Plate 3). The well was initially drilled to a TD of 1,220.7 m (4,005 ft) in 2005, and was deepened to 1,391.7 m (4,566 ft) in 2006 (DOE, 2006c). The purpose of the well was to gather subsurface data to better characterize the hydrogeology of the northern Shoshone Mountain area, especially for the lower Tertiary volcanic rocks and for the underlying Paleozoic sedimentary rocks (SNJV, 2005a). 
Well ER-16-1 penetrated $611.4 \mathrm{~m}(2,006 \mathrm{ft})$ of volcanic rocks and tuffaceous paleocolluvium that unconformably overly Paleozoic sedimentary rocks (Figure B-5). The volcanic section is generally as predicted prior to drilling, and consists of unaltered (i.e., vitric and devitrified) welded and nonwelded tuff overlying altered (i.e., zeolitic) nonwelded tuff. Paleocolluvium that occurs at the base of the section contains substantial amounts of clay.

The Paleozoic rocks encountered in the borehole are significantly different than predicted prior to drilling. The top of Paleozoic rocks was encountered at a depth of $646.8 \mathrm{~m}(2,122 \mathrm{ft})$, which is $67.7 \mathrm{~m}(222 \mathrm{ft})$ deeper than predicted. It was predicted that approximately $183 \mathrm{~m}(600 \mathrm{ft}) \mathrm{of}$ Pennsylvanian Tippipah Limestone, a carbonate aquifer, would be penetrated above the underlying Mississippian Chainman Shale, a clastic confining unit. However, below the volcanic section the borehole first encountered Chainman Shale, indicating that the Tippipah Limestone was eroded off at the well location. It was also predicted that the well would reach TD within the Chainman Shale at 1,219 $\mathrm{m}$ (4,000 ft) after penetrating approximately $457 \mathrm{~m}$ $(1,500 \mathrm{ft})$ of the formation. However, after penetrating $424.9 \mathrm{~m}(1,394 \mathrm{ft})$ of Chainman Shale (at the depth of $1,071.7 \mathrm{~m}[3,516 \mathrm{ft}])$, the borehole encountered the top of the Guilmette Formation which stratigraphically underlies the Chainman Shale in the region, and is interpreted to be part of the regional carbonate aquifer. The Chainman Shale penetrated at Well ER-16-1 is thinner than regional estimates, indicating that the upper portion of this clastic confining unit has also been eroded off at the well location, although the possibility that faulting in the area is responsible for some of the thinning, as well as other stratigraphic relationships observed, can not be ruled out.

\subsubsection{Well ER-19-1}

Well ER-19-1 is located southwest of Rainier Mesa in Area 19 (Plate 3) and was drilled to a TD of $1,095.8 \mathrm{~m}(3,595 \mathrm{ft})$ in 1993 (DOE, 1995a). The purpose of this well was to provide subsurface data to help characterize the hydrogeology southwest of Rainier Mesa within the lower Tertiary volcanic rocks and for the underlying pre-Tertiary sedimentary section (DOE, 1995a).

Well ER-19-1 penetrated $872.3 \mathrm{~m}(2,862 \mathrm{ft})$ of volcanic rocks that unconformably overlie early Paleozoic to late Precambrian sedimentary rocks. The volcanic rocks consist mostly of altered (i.e., zeolitic) nonwelded and bedded tuffs that form tuff confining units (Figure B-6). Welded ash-flow tuffs, which form welded-tuff aquifers, are intercalated within the nonwelded and bedded tuffs in the lower portion of the section. These older ash-flow tuffs, assigned to the Redrock Valley Tuff and Tuff of Twin Peaks, are conspicuously thicker in Well ER-19-1 than in holes to the east beneath Rainier Mesa, and possibly indicate a nearby source for these ash-flow 
tuffs. Below the volcanic rocks, the well encountered siltstone, quartzite, and minor sandstone of the Wood Canyon Formation, a clastic confining unit. These rocks are part of the overthrust sheet associated with the east-directed Belted Range thrust fault. The well penetrated $733 \mathrm{ft}$ of the Wood Canyon Formation before bottoming in the formation at 1,095.8 m (3,595 ft).

\subsubsection{Other Models}

Several organizations have produced, or are in the process of producing, geologic and hydrologic models of various sizes and degrees of complexity for areas that adjoin or include portions of the UGTA RM-SM area. The UGTA hydrostratigraphic framework models that served as a starting point for the RM-SM framework model have already been mentioned: the PM-OV model (BN, 2002a) and the Yucca Flat-Climax Mine model (BN, 2006). The Death Valley regional groundwater flow model (Belcher, 2004; D'Agnese et al., 1997; Workman et al., 2002a, 2002b; Sweetkind et al., 2001; Faunt, 1998; Faunt et al., 1999) was developed by the USGS at the request of a multi-organizational consortium that includes the National Park Service, the Bureau of Land Management, the state of Nevada, and NNSA/NSO for the YMP. At this stage in the UGTA CAU model-building program, the coarser regional models did not offer much in terms of hydrogeologic or structural information. However, the RM-SM CAU-scale model will be inserted into the Death Valley regional model to acquire groundwater flux information for the RM-SM model boundaries.

\subsubsection{Detailed Cross Sections}

Construction of scaled geologic cross sections is a necessary and important step in the process of understanding subsurface geology. Nineteen detailed hydrostratigraphic cross sections were constructed for the RM-SM model at a scale of 1:24,000 (Figure 2-3). This level of detail was chosen to correlate with other input data (e.g., USGS Geologic Quadrangle Maps, drill hole and tunnel data, etc.) and to produce the desired level of detail for the final EarthVision ${ }^{\circledR}$ model. Drill hole data, tunnel data, surface geology, surface effects produced by UGTs, age dates for Paleozoic carbonate rocks, geophysical data, and the structural model (especially with regards to the location and geometry of the thrust faults) were integrated in the construction of these detailed cross sections.

The locations for the hydrostratigraphic cross sections were chosen to ensure that geologic and hydrologic information would be developed in an effective way for as much of the RM-SM CAU as possible, with enhanced coverage in areas with hydrostratigraphic or structural complexities. Although each hydrostratigraphic cross section is simplified to depict only HSUs and larger (potentially hydrologically significant) structures, it is important to note that many of the HSUs in the model area represent a single stratigraphic unit (e.g., Tiva Canyon aquifer, 
Topopah Spring aquifer, Kearsarge aquifer, Stockade Wash aquifer, Belted Range aquifer, Tub Spring aquifer, etc.) or a single hydrogeologic unit (HGU) between these stratigraphic marker beds.

The hydrostratigraphic cross sections served as direct input to the model and were an intermediate step in the creation of other interpretive products (e.g., structure contour maps representing the tops of selected HSUs). Model profiles along seven of the cross section lines are provided in Appendix C.

\subsubsection{Surface Effects from Underground Nuclear Explosions}

The confirmation and locations of some of the faults in the RM-SM model are based on surface effects produced by UGTs. Surface cracks were the dominant features documented, however, other effects such as faults (i.e., cracks displaying vertical displacement), disturbed ground, and block chatter were also documented (Allen et al., 1997). These features were routinely mapped after each test and provide a unique source of geologic information.

Cracks produced by UGTs commonly formed preferentially along pre-existing zones of weakness, such as faults, joints, or lineaments. Cracks also formed preferentially on or along man-made or "prepared" surfaces such as roads or on drill pads, and along topographic features such as drainage ways and mesa rims. The type and intensity of explosion-induced surface effects is a result of a complex interaction of factors including yield of the explosion, depth of burial, strength of surface strata, existing geologic structure, the ambient stress field, etc.

Cracks may be randomly oriented, but usually trend along certain preferred directions or patterns relative to the surface ground zero that can be categorized as linear, concentric or circumferential, or radial. Figure 2-4 presents a representative portion of a composite crack map for Rainier Mesa which shows several sets of relatively long linear trends of post-test surface cracks that represent the surface traces of faults (after Grasso, 2003).

\subsubsection{Geophysical Investigations}

Numerous geophysical investigations have been conducted in the area of the RM-SM model since the 1950s and include gravity, magnetic, resistivity, and seismic. Most of the geophysical surveys were conducted in active testing areas such as Yucca Flat and Rainier Mesa in support of the WTP. A series of geophysical investigations was conducted in the vicinity of Syncline Ridge to evaluate the potential of the area to store high level radioactive waste (Hoover et al., 1982). In 
addition, Mid Valley was the site of geophysical investigations, particularly seismic, to evaluate the area as a potential site for underground nuclear testing (Burkhard and McArthur, 1985; McArthur and Burkhard, 1986).

Many of the geophysical surveys conducted within the RM-SM area, particularly at Rainier Mesa, were designed to address very specific and local geological issues related to a specific UGT and, thus, are of limited use in constructing CAU-scale hydrostratigraphic framework models. These data include mainly tunnel and borehole velocity and resistivity measurements (Carroll, 1986; 1990; 1994; Carroll and Kibler, 1983).

The only new geophysical data collected specifically for the RM-SM modeling effort were obtained from an MT survey conducted by the USGS (Asch et al., 2006). The USGS also analyzed existing gravity data using the inversion method to produce a depth-to-basement map of the pre-Tertiary surface (Hildenbrand et al., 2006).

Data and results of geophysical investigations conducted in the area of the RM-SM model were reviewed during model construction and, where appropriate, integrated into the hydrostratigraphic framework model. Information from geophysical investigations was integrated with surface geology and drill hole data to develop a structural model of the area and determine the distribution of HSUs. The geophysical data were also utilized during development of alternative scenarios. All of the various geophysical data collected in the RM-SM area, including site-specific data of limited use at the CAU level, are discussed below in general terms to illustrate the amount and variety of geophysical data that helped build the geologic knowledge base available for the RM-SM hydrostratigraphic framework model.

\subsubsection{Gravity Data}

The collection and analysis of gravity data have been an integral part of geologic investigations at the NTS since the early 1960s (McCafferty and Grauch, 1997; Grauch et al., 1997; Healey et al., 1987; Jachens and Moring, 1990; Ponce et al., 1988; Ponce et al., 1999). Gravity data have been used to help define basin architecture, locate buried faults, and estimate depth to pre-Tertiary rocks buried by volcanic rocks and alluvium. Gravity data played a critical role in the recognition and characterization of buried calderas such as the Silent Canyon caldera complex (Healey, 1968) and, more recently, the Redrock Valley caldera (this report).

During the past 40 years, gravity data have been collected from 4,969 stations located throughout the RM-SM model area (Figure 2-5). Hildenbrand et al. (2006) utilized this historical data set to produce a depth-to-basement map of the model area using a modern gravity 
inversion method (Figure 2-6). Information from this depth-to-basement map was instrumental in the recognition and subsequent modeling of the Redrock Valley caldera. The map also provided important information for estimating the depth to pre-Tertiary rocks in areas with significant volcanic and alluvial cover.

\subsubsection{Ground Magnetic Data}

Ground magnetic surveys were conducted during special geologic and geophysical studies within the former testing areas of Yucca Flat, Pahute Mesa, and Rainier Mesa, mainly in support of the WTP (Bath et al., 1983; Orkild et al., 1983). The surveys were typically used to identify buried faults by determining the configuration of the near surface volcanic rocks. Other ground magnetic surveys were conducted in support of individual UGTs, for example, to help locate faults in areas with thin alluvial cover.

\subsubsection{Aeromagnetic Data}

Numerous aeromagnetic surveys and investigations have been conducted at the NTS in the past several decades mainly in support of the WTP (Kirchoff-Stein et al., 1989; McCafferty and Grauch, 1997; Ponce, 1999). Aeromagnetic data have typically been utilized at the NTS to delineate buried structures by identifying linear magnetic anomalies within buried volcanic rocks. However, subsurface structural interpretations of aeromagnetic data at the NTS generally are poorly constrained due mostly to the great thickness of alluvium within the basins and the presence of both normally and reversely magnetized volcanic units (e.g., the Ammonia Tanks and Rainier Mesa tuffs).

\subsubsection{Natural Source Magnetotelluric Survey}

A natural-source MT survey was conducted in the vicinity of the RM-SM model area in 2005 as part of Phase I data collection activities (Asch et al., 2006). The survey was conducted to better characterize pre-Tertiary stratigraphy and structure within the CAU. The survey, conducted by personnel from the USGS, consisted of 26 stations spaced approximately 2 to $3 \mathrm{~km}(1.2$ to $1.9 \mathrm{mi}$ ) apart along 5 generally east-west oriented lines across the model area (Figure 2-7). The survey was designed to provide westward extensions of Yucca Flat MT lines collected in 2003 (BN, 2006). Like the Yucca Flat survey, the RM-SM MT data were collected with both highand low-frequency MT systems. USGS personnel processed the MT data and provided twodimensional (2-D) inverted resistivity model profiles along each line to NSTec geologists for interpretation and integration into the RM-SM hydrostratigraphic framework model (Asch, 2005a). USGS personnel also performed 2-D forward modeling of the data to address questions presented by NSTec geologists (Asch, 2005b). 
The complex pre-Tertiary structure of the model area, particularly the presence of imbricate thrusting, and limited deep drill hole control resulted in poorly constrained interpretations of the MT data. The MT data proved useful, however, in the development of alternative interpretations (see Section 5.0).

\subsubsection{Other Resistivity Surveys}

Local studies, particularly in the Rainier Mesa tunnels and underground boreholes, were conducted to characterize rock alteration at UGT locations. These investigations provided information on the degree of zeolitization and argillization of the bedded tuffs, especially around fault zones in the tunnels.

\subsubsection{Seismic Refraction Surveys}

Half-refraction surveys were conducted in Yucca Flat for the WTP in an attempt to map the preTertiary surface near select UGT locations (App, 1981). Seismic refraction surveys were conducted in many drifts and boreholes in the Rainier Mesa and Shoshone Mountain tunnel complexes, primarily for determination of the velocity of the medium as input to ground shock calculations for UGTs (Carroll, 1986; 1994; Carroll and Kibler, 1983). Data from some of these surveys were also used to characterize regions of damage following UGTs (Carroll, 1983).

\subsubsection{Two-Dimensional Seismic Reflection Surveys}

Two-dimensional seismic reflection surveys have been conducted in two portions of the RM-SM model area. In Yucca Flat, approximately $225 \mathrm{~km}$ (140 mi) of 2-D seismic lines have been conducted, some of which are in western Yucca Flat, and thus extend into the eastern portion of the model area. Most of these data were acquired between 1970 and 1985 in support of the WTP at the NTS (App, 1981; Burkhard, 1981). A seismic survey consisting of three lines was conducted in Mid Valley (McArthur and Burkhard, 1986) to evaluate the area for underground nuclear testing.

Seismic reflection surveys in Yucca Flat and Mid Valley were successful in imaging the general geology above the pre-Tertiary surface, including the contact between the alluvium and underlying volcanic rocks, the distribution of welded volcanic rocks, and the major faults that offset these units. Due to a variety of geologic and geophysical factors seismic reflection method has been mostly unsuccessful imaging pre-Tertiary stratigraphy and structure beneath basins at the NTS (Burkhard, 1981). 


\subsubsection{Studies at Gold Meadows Stock}

Investigations at the Gold Meadows stock, a granitic (quartz monzonite) body were summarized by Snyder (1977). Studies began in the 1960s when the granitic body was initially mapped. A gravity survey of the area was conducted in 1963, but was thought not to accurately delineate the subsurface configuration of the stock because the granitic rocks and the surrounding quartzite are similar in density. In 1965, hole U12s was drilled as a potential emplacement hole for a UGT, to a TD of $486.5 \mathrm{~m}(1,596 \mathrm{ft})$ within the quartz monzonite. An age date of $91.8 \pm 2.6 \mathrm{Ma}$ was determined for the stock (Snyder, 1977).

Exposures of granitic rocks are found at the NTS in only two locations. In addition to the Gold Meadows stock, the Climax Stock has been mapped in Area 15, $11.3 \mathrm{~km}$ (7 mi) east of Area 12. Snyder (1977) implied that the two stocks may be connected at depth, but had no conclusive data. In recent studies using existing magnetic and gravity data from the Rainier Mesa and Climax stock areas with newer data-processing and modeling techniques, Phelps et al. (2004) and Hildenbrand et al. (2006) concluded that the two stocks are connected at depth, indicating a fairly large pluton with outcrops at two widely separate locations. The Climax stock can thus be considered an analog for the Gold Meadows stock, and the more extensive data-sets for physical and hydraulic properties of the Climax granitic body may be used to develop data for modeling of the Gold Meadows stock in the RM-SM model.

Several intervals of water flow were encountered in the U12s borehole and the site was never used for a UGT. The borehole remains open and groundwater levels are monitored by the USGS. The most recent tag, in 2006, found a depth to groundwater of approximately $277.4 \mathrm{~m}$ (910 ft) below the ground surface (USGS/DOE Cooperative Studies in Nevada Web site). Based on the numerous water-inflow depths, a reported decrease in flow rates, and the deep regional groundwater level, the water encountered in the borehole was interpreted to be perched or semi-perched groundwater (Snyder, 1977).

\subsubsection{Alluvium Studies}

The alluvial deposits that fill the Yucca Flat and Mid Valley basins (Figure 1-5) form an important HSU because the deposits are fairly thick, and many of the UGTs in Yucca Flat were conducted within the alluvium. The Tertiary-age gravels filling the eastern portion of the Timber Mountain moat (central-western edge of the RM-SM model area) are on the order of $76 \mathrm{~m}$ (250 ft) thick. Though generally unsaturated, the alluvium is saturated in the deeper sub-basins, particularly in south-central Yucca Flat and central Mid Valley (Plate 1). Except for these two basins, the alluvial sediments in the RM-SM model area are not saturated. Extensive studies of the alluvium in Yucca Flat have been conducted on behalf of several NTS programs, 
including the WTP (Rayburn et al., 1989; Wagoner and McKague, 1984). Information from these sources, described below, along with the extensive drill hole and sample database, (especially for the overlap area with the Yucca Flat model) was incorporated into the RM-SM framework model.

\subsubsection{U-1a Complex}

The U-1a complex, located in south-central Yucca Flat (east of the RM-SM model boundary), comprises two vertical shafts, several large-diameter cable access holes, and several kilometers of horizontal drifts mined within alluvium, $292.6 \mathrm{~m}$ (960 ft) below the surface. Geologic mapping and related work at the U-1a Complex afford a unique opportunity to observe and evaluate the characteristics of alluvium in the subsurface of Yucca Flat, and to compare the results with alluvium data from surface and drill hole studies. The U-1a efforts are well documented in Allen (1995) and Drellack et al. (1989).

\subsubsection{Other Studies}

The surficial alluvial deposits of the NTS have been studied, mapped and correlated by USGS personnel and are documented by Hoover et al. (1981) and Fernald et al. (1968).

\subsubsection{Mineralogic Studies of Volcanic Rocks}

Hydrologic source-term modeling has shown that radionuclide transport is highly sensitive to the abundance and availability of certain reactive minerals (Pawloski et al., 2000; Tompson et al., 1999; Zavarin et al., 2004). Although a thorough mineralogic assessment of the rocks in the RM-SM model area was beyond the scope of this CAU-scale modeling effort, mineralogic characteristics were an important factor in the process of defining HSUs. As described in more detail in Section 4.1, the altered volcanic rocks tend to be confining units and unaltered volcanic rocks tend to be aquifers. The final mineralogy of the formations can be further modified by devitrification of the original glass, and various minerals can be deposited by groundwater solutions in the matrix or in fractures.

The lowermost volcanic units in the NTS area tend to be zeolitic and are classified hydrologically as a tuff confining unit (TCU; see Section 4.1 for a discussion about HGUs). The basal TCU in Yucca Flat was subdivided into three HSUs based on relative abundances of major mineral assemblages by Prothro (2005), as summarized in Subsection 2.3.11.1. Because of the stratigraphic and hydrogeologic similarities between Yucca Flat and portions of the RM-SM model area, this same TCU subdivision scheme was applied to the RM-SM model. 


\subsubsection{Tuff Confining Unit Study}

Altered volcanic rocks that form the TCU HGU beneath much of the NTS (especially Yucca Flat, Frenchman Flat and Rainier Mesa) consist mainly of three major mineral assemblages: zeolites, felsic minerals, and clay minerals (Prothro, 2005). Based on these three mineral assemblages, the TCU can be subdivided into three zones representing differences in the abundance of these mineral assemblages. This three-layer model includes:

a. An upper zone that comprises both the upper and lower tuff confining units (UTCU and LTCU, respectively; see Subsections 4.5.7 and 4.5.22), HSUs that are characterized by the abundance of the zeolite mineral clinoptilolite with lesser amounts of felsic and clay minerals

b. A middle zone that correlates to the Oak Spring Butte confining unit (OSBCU; Subsection 4.5.23), an HSU with felsic minerals generally dominant over clinoptilolite and clay minerals

c. A basal argillic zone that correlates to the argillic tuff confining unit (ATCU; Subsection 4.5.28), with clay minerals dominant over felsic minerals and clinoptilolite

Mineralogic data (x-ray diffraction) from 17 holes, along with lithologic, stratigraphic, and geophysical log data from approximately 500 drill holes, were interpreted to develop a 3-layer mineralogic model for the TCU in Yucca Flat, which shows that all 3 zones are extensive beneath the eastern half of Yucca Flat within the Yucca Flat basin proper. Only the basal argillic zone occurs beneath western Yucca Flat within the western sub-basin. Based on drill hole data, all three zones are present beneath Rainier and Aqueduct mesas, and are interpreted to be present in much of the rest of the RM-SM model. The LTCU is, on average, the thickest of the 3 zones, typically ranging between 200 and $300 \mathrm{~m}(650$ and $980 \mathrm{ft})$, followed by the OSBCU at 100 to $200 \mathrm{~m}(330$ and $650 \mathrm{ft})$ thick, and finally the ATCU at about $60 \mathrm{~m}(200 \mathrm{ft})$ thick.

\subsubsection{Reactive Mineral Characterization of Volcanic and Sedimentary Rocks}

Zeolitic and argillic alteration is commonly observed in the volcanic rocks at the NTS. Zeolitic alteration generally results in the formation of clinoptilolite, with lesser amounts of other higher temperature zeolite minerals such as analcime and mordenite. Argillic alteration commonly is characterized by the presence of the clays smectite and illite. In addition to decreasing the hydraulic conductivity of the rock, these secondary alteration minerals are reactive with respect to radionuclide transport. Clinoptilolite and smectite, for example, have a strong sorptive affinity for certain radionuclides (Zavarin et al., 2004). The confining unit HSUs in the RM-SM model (e.g., the UTCU and LTCU) contain a significant amount of zeolite minerals (typically more than 30 percent). The ATCU contains a significant percentage of clays (generally more than 30 percent). In addition to the zeolite and clay minerals mentioned above, the list of 
reactive minerals for radionuclide transport includes iron oxides (hematite), and certain mafic minerals such as biotite, and calcite. These reactive minerals are found in the rock matrix, in lithic fragments, as phenocrysts, or in the fracture fillings and coatings.

When relating these reactive minerals to geologic processes relevant to the rocks at the NTS, several natural categories emerge. The reactive mineral categories (RMCs) for NTS volcanic rocks are vitric mafic-poor (VMP), vitric mafic-rich (VMR), devitrified mafic-poor (DMP), devitrified mafic-rich (DMR), zeolitic (ZEOL), and argillic (ARG). The RMCs for Paleozoic sedimentary rocks are calcic (CC) for the carbonate rocks, ARG for clay-rich shaley rocks, and silicic (SC) for the siliciclastic rocks. In general, the volcanic confining units relate to the ZEOL RMC, the welded-tuff aquifers relate to the DMR or DMP, the vitric-tuff aquifers relate to VMR or VMP, and the ATCU relates to the ARG RMC. The carbonate aquifers relate to the CC and the siliciclastic confining units relate to the SC if mostly quartzite or the ARG if mostly shale.

The contaminant-transport modeling team may build upon the RM-SM hydrostratigraphic framework model, incorporating RMC information to establish an initial geometry for the distribution of reactive minerals. These derivative reactive-mineral models will, in turn, result in more realistic contaminant transport models of the RM-SM CAU.

\subsubsection{Fracture Studies}

Numerous fracture studies have been conducted at the NTS, including studies specific to Pahute Mesa, Yucca Flat, and Rainier Mesa. Winograd and Thordarson (1975) describe fractures and their role in groundwater flow in the NTS region, including fracture characteristics of HGUs. Fractures were identified using borehole image logs from Wells ER-12-1, ER-12-3, ER-12-4, and ER-16-1 (SNJV, 2006b). Other studies relevant to RM-SM include fracture studies for the UGTA Yucca Flat CAU modeling effort based on borehole image logs (SNJV, 2005b) and on conventional core holes (Prothro, 1998). These studies emphasized hydrologic properties of fractures. Other UGTA fracture studies include a detailed study of fractures in volcanic rocks beneath Pahute Mesa (Drellack et al., 1997). Fracture data from these and other studies in the NTS region are compiled in SNJV (2005c). Fracture data for the tunnel complexes were also collected during investigations for the WTP (e.g., Davis, 1962; Hasler, 1963; and Fairer et al., 1979). Hydrogeologic designations in the RM-SM framework model are based to a large degree on the fracture characteristics described in these data sets. 


\subsection{Pre-emptive Review}

Before the RM-SM hydrostratigraphic model was constructed, the UGTA TWG initiated a preemptive review process. The purpose of these reviews was to provide a forum for the TWG to evaluate the model and the model-building process at various stages during construction of the Phase I model. The pre-emptive review subcommittee consisted of scientists from Desert Research Institute, LANL, LLNL, SNJV, and the USGS. Pre-emptive reviews for the RM-SM model were conducted on January 13, 2005 (to establish model boundaries); December 14, 2005; April 25, 2006; via e-mail and conference calls in August 2006; and on November 28, 2006, to discuss the technical reviews of the draft base model and the four alternative models. The subcommittee assessed the data sets, the status of the base model, alternative interpretations, and the path forward from both technical and programmatic perspectives. Comments and suggestions from the subcommittee members were addressed as appropriate. Some of the subcommittee's findings are discussed in Section 5.0, Alternative Scenarios.

\subsection{Model Construction}

Prior to the actual digital construction of the 3-D framework model, two important tasks had to be completed. First, a structural model of the area was developed that included the locations and orientations of all the faults deemed relevant in the model area. Fault information was imported into EarthVision ${ }^{\circledR}$, a 3-D computer modeling program (Subsection 2.5.1) to form a fault-tree model that depicts all the model faults in 3-D space. The fault-tree model formed the framework on which the hydrostratigraphic model was built. A detailed discussion of the structural model is provided in Section 3.0 of this report.

Although the framework of the RM-SM hydrostratigraphic model is the fault-tree, the foundation of the model is the hydrostratigraphic classification system. The second important step was to develop a hydrostratigraphic system through a rigorous analysis of stratigraphic and lithologic data in and around RM-SM. The RM-SM hydrostratigraphic system consists of 43 HSUs that form volumes in the model. A detailed description of the hydrostratigraphic classification system developed for the RM-SM model is provided in Section 4.0 of this report.

Alternative models created to explore the effects of other possible geologic interpretations in some areas of the model with non-unique solutions are discussed in Section 5.0 of this report.

\subsubsection{Use of Computer Software to Construct the Model}

Computer software designed to handle large data sets and numerous interpretive products is used to present the hydrostratigraphic framework for the use of the flow-and-transport modelers. The 
size of the study area, the large amount of data to be manipulated, and the complexity of the geologic setting of the NTS and vicinity demand sophisticated algorithms for production of realistic interpretations.

EarthVision ${ }^{\circledR}$ software (Version 7.5, by Dynamic Graphics) accepts spatially located data such as the elevations of the tops of stratigraphic units in boreholes, outcrop traces, locations and orientations of faults, and other data such as seismic profiles or other geophysically derived surfaces. The software then applies geology-based geometric "rules" to determine the most likely 3-D interpretation of the geology in the model area that honors the input data. After the data and interpretive products are input, the computer's rendition can be adjusted to suit the geologist's concept, to incorporate additional information, or to test alternate hypotheses. Adjustments usually involve fixing areas where EarthVision ${ }^{\circledR}$ produced geologically unlikely solutions. All input data are honored during model adjustments. It is possible to thoroughly evaluate a geologic model built in EarthVision ${ }^{\circledR}$ and examine relationships of the individual elements. Because the interpretive rules are geology-based, the model automatically satisfies many fundamental geometric requirements for geologic structure, so the geologist spends less time checking and adjusting interpretations than with the earlier modeling software applications. EarthVision ${ }^{\circledR}$ can be used to produce maps and profiles that illustrate the structure and distribution of HSUs for any portion of the model.

The final hydrostratigraphic model will be provided in digital form to the UGTA flow-andtransport modelers who will use this framework to model groundwater flow and contaminant movement within the RM-SM area. The figures (plates, maps, and profiles) included with this documentation report are intended to provide only general illustrations of the physical framework, structure, and distributions of the HSUs to aid the reader. The flow-and-transport modelers will receive the complete digital, 3-D model (represented graphically in Figure 2-8).

\subsubsection{Model Input}

As mentioned previously, the Yucca Flat-Climax Mine and PM-OV models were used as the initial starting point for the RM-SM Phase I hydrostratigraphic framework model. Details regarding the construction of the models were reported in BN, 2006 and BN, 2002a, respectively. Input into the RM-SM model consisted of interpretive products such as hydrostratigraphic cross sections and "hard" data such as DEM, drill-hole data, surface geologic maps converted to HSUs, etc. "Soft" data, such as interpretations of the top of the pre-Tertiary surfaces from inversion of gravity-data (see Subsection 2.3.8.1), were input to use as guides. After an initial 3-D framework model was built in EarthVision ${ }^{\circledR}$, this preliminary model was checked and modified as necessary in an iterative fashion by the authors. 
Interpretive products produced to serve as input to the model include a drill hole database of HSUs (Appendix A); surface (i.e., outcrop and faults; Plate 1) HSU maps derived from USGS geologic quadrangle maps (Table 2-1); unit extent maps for each HSU; hydrostratigraphic cross sections; and traces of surface faults. The fault traces and unit extent and outcrop maps were digitized by SNJV personnel. These new interim interpretive products were developed by NSTec geologists from a variety of sources (see Section 2.3).

\subsubsection{Quality Control and Model Review}

The Phase I model was checked and modified as necessary by the SNJV and NSTec team members during model construction. This was an iterative process utilizing the capabilities of EarthVision ${ }^{\circledR}$ to cut profiles anywhere through the model. The geologists then interactively viewed individual or groups of HSUs in 3-D, and visually compared various data sets such as drill hole tops and surface-grid points with HSU layers in the model. Traditional 2-D products such as structure contour maps and thickness maps were also produced from the model, and these were used to further evaluate the model. Modifications were made to address geometric conflicts, assure that geologic conventions were honored, assure conformation to drill hole, outcrop, and geophysical data, and incorporate geologic interpretations in areas of limited data. The various versions of the model produced during this process are electronically archived at the offices of SNJV in Las Vegas, Nevada. The final RM-SM "base" model, including four alterative scenarios and electronic data sets, resides on workstations and electronic archival media at the offices of SNJV in Las Vegas, Nevada.

Several quality control processes were performed to ensure that model surfaces honor available data. These included a total-depth check, a horizon-grid back-interpolation, and a fault-pick back-interpolation. These assessments indicated that the computer-generated HSU surfaces tie well with the drill hole data (Figure 2-9), with associated errors typically less than $2 \mathrm{~m}$ (6.6 ft). Figure 2-10 is an example of a histogram showing the difference between the EarthVision ${ }^{\circledR}$ model surface and the drill-hole data input for the Timber Mountain lower vitric-tuff aquifer. In this case, the interpolation algorithm honors most of the drill hole data to within a few meters. Error associated with outcrop data is greater due to the complexity of the topographic surface, but is still considered to be relatively small.

Quality control for the alternative models followed the same process as used for the base model. Additionally, the alternative models were compared against the base model and differences were mapped. This process ensured that the changes associated with the alternative models are restricted to appropriate areas. Review of the model and alternatives was conducted within the UGTA pre-emptive review process as described in Subsection 2.4. 


\subsubsection{Alternative Models}

As briefly summarized in Subsection 1.4.4 and discussed in more detail in Sections 3.0 and 4.0, the RM-SM model area is geologically very complex. Many of the major features are buried beneath younger units, and subsurface data are scarce in some areas. Portions of the model are thus necessarily simplified, and represent non-unique solutions to the 3-D distribution of HSUs.

To address non-unique aspects of different interpretations within the base model, alternative interpretations were developed for portions of the base model. Most of the ideas for alternative scenarios were conceived and evaluated during construction of the base model. The alternative models were constructed after the base model was completed, generally using the same model construction techniques. Each alternative model is equally bound by all the data and interpretation methods used for development of the base model. However, each alternative scenario is of limited geographic extent, and thus affects only a portion of the base model. The alternatives are fully functional replicas of the base model that can be used to test whether the alternative interpretations affect flow and transport.

The TWG pre-emptive review subcommittee also participated in the development of alternative scenarios. This working group was also tasked with defining what constitutes an alternative scenario, compiling a list of possible alternatives, establishing criteria and guidelines for prioritizing the scenarios, and grouping and prioritizing the viable scenarios. Three types of hydrogeologic scenarios were developed: recommended changes to the base model; viable alternative scenarios, to be modeled separately; and proposed alternatives that might be better addressed during the hydrologic modeling phase, rather than in the hydrostratigraphic framework model. Members of the pre-emptive review subcommittee also served as peer reviewers of the draft base model presented to them for development of alternative scenarios, and some of their suggestions were incorporated directly into the base model.

An electronic copy of the base model was used in developing each alternative, and only those areas of the base model affected by the alternative interpretation were modified to produce the alternative model. Ultimately, four scenarios were selected for further development as alternative models, and two scenarios were identified that might be better addressed later during hydrologic modeling. The UGTA pre-emptive review subcommittee participated in the development of alterative interpretations by reviewing the interpretations throughout the model construction process, including the final alternative interpretations. The process for addressing alternative interpretations is described in more detail, along with the interpretations themselves, in Section 5.0. 
This page intentionally left blank. 


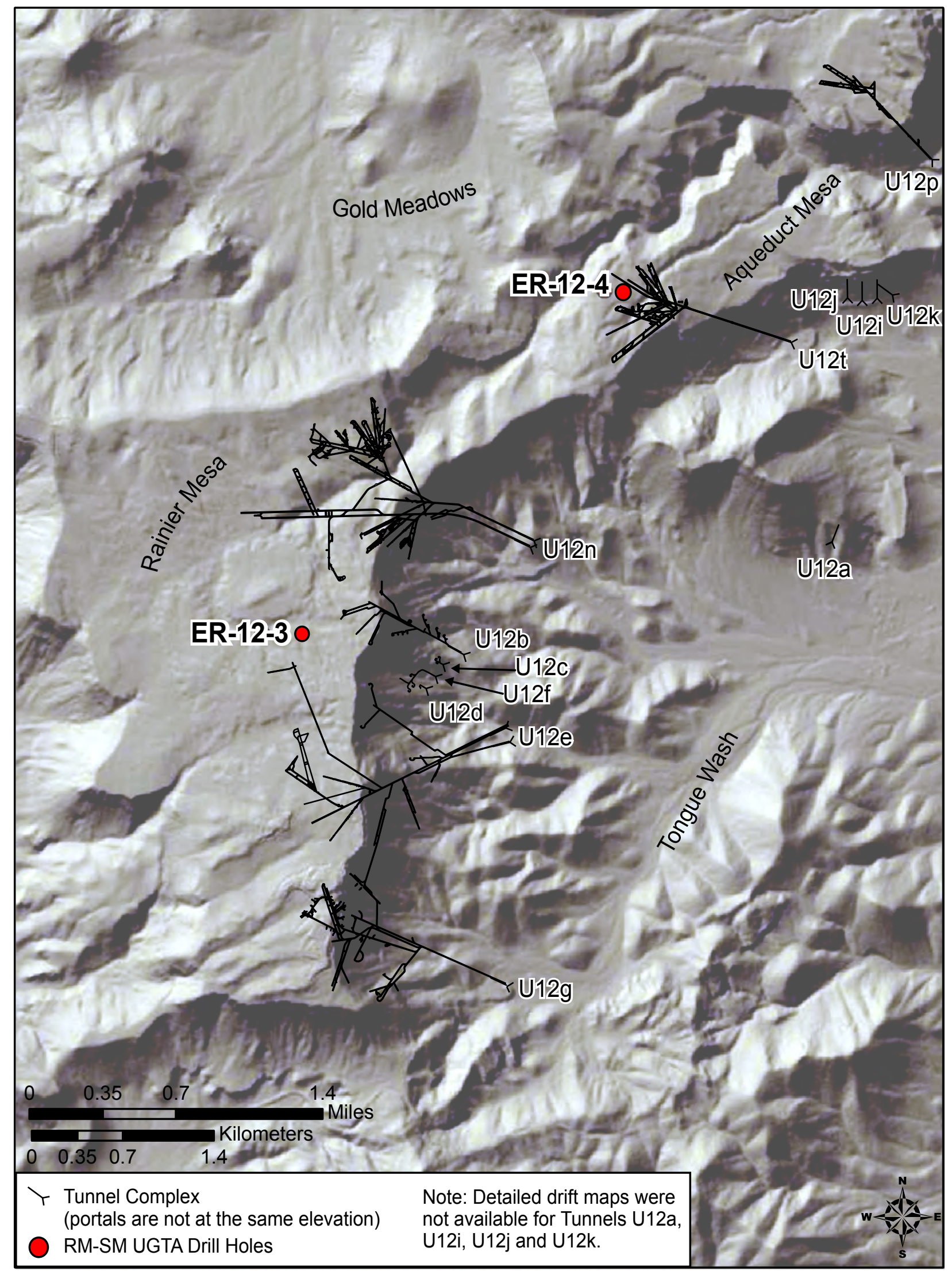

Figure 2-1

Shaded Relief Map of the Rainier Mesa Area Showing Locations of Tunnel Complexes 


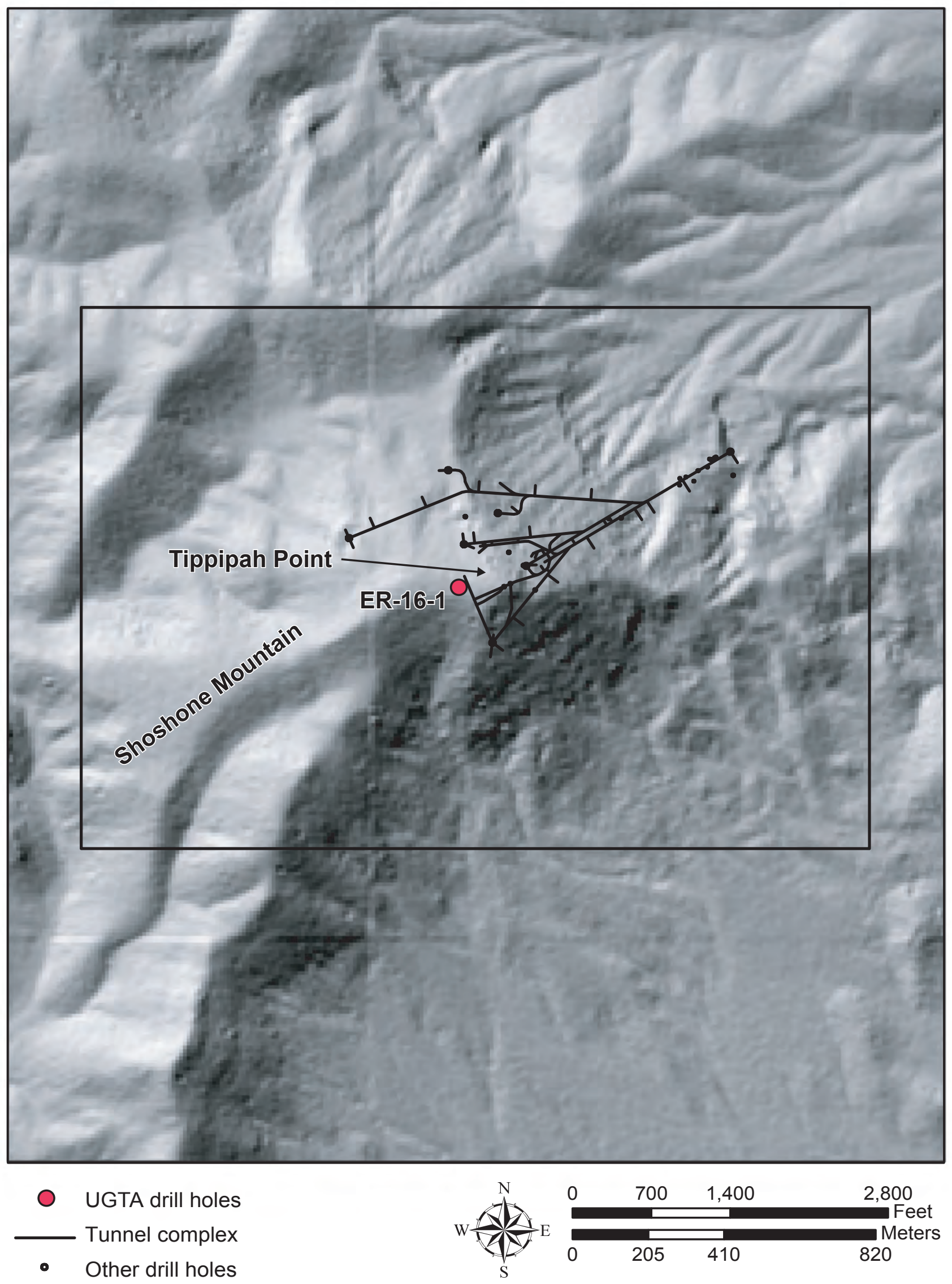

Figure 2-2

Shaded Relief Map of the Shoshone Mountain Area

Showing Location of Tunnel Complex 


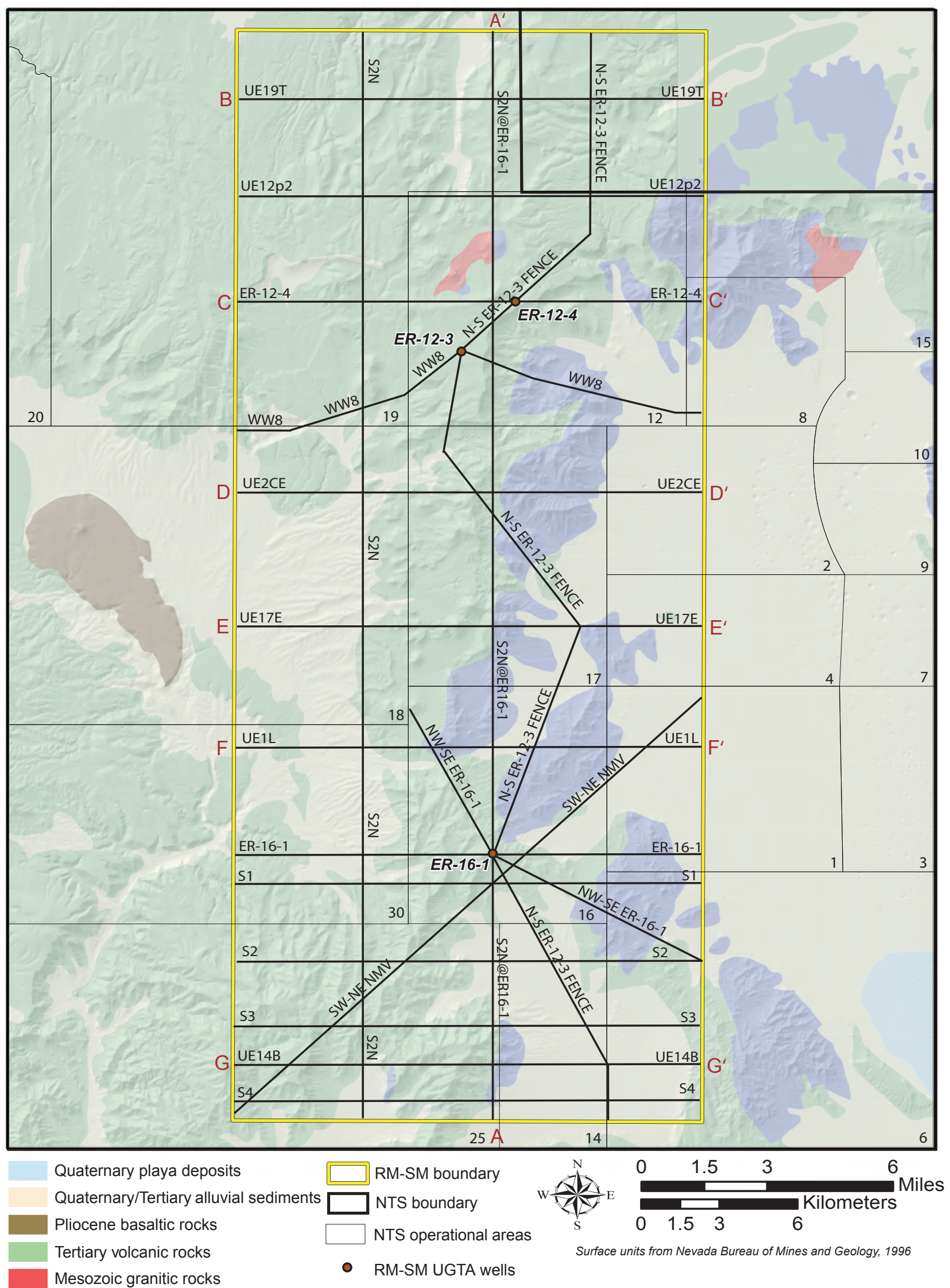

Mesozoic granitic rocks

Paleozoic and Precambrian rocks

Red letters correspond to model profiles in Appendix C.

Figure 2-3

Locations of Hydrostratigraphic Cross Sections Constructed for the RM-SM Model 


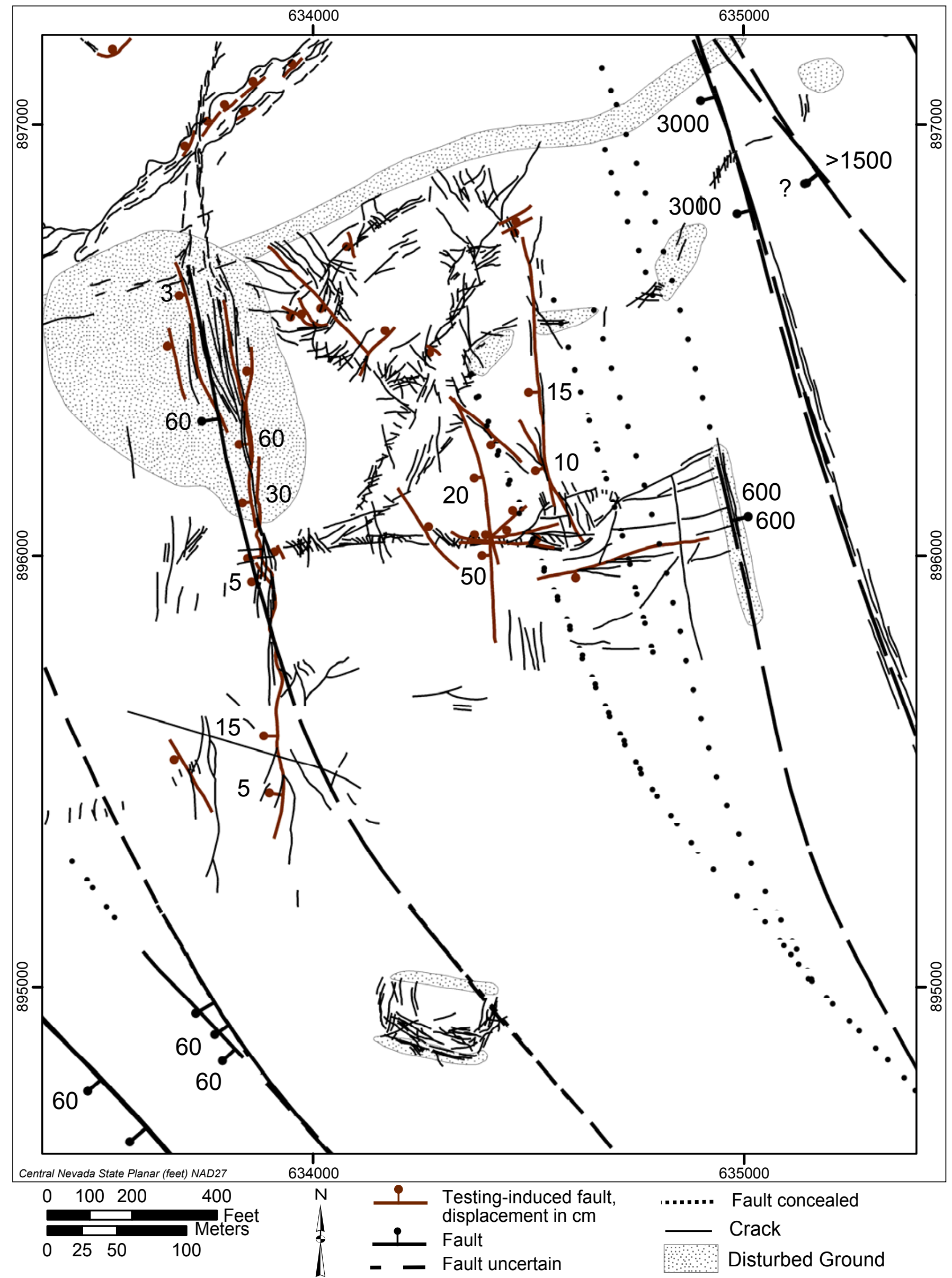

Figure 2-4

Map Showing an Example of Surface Effects from Underground Nuclear Tests at N-Tunnel in Area 12 


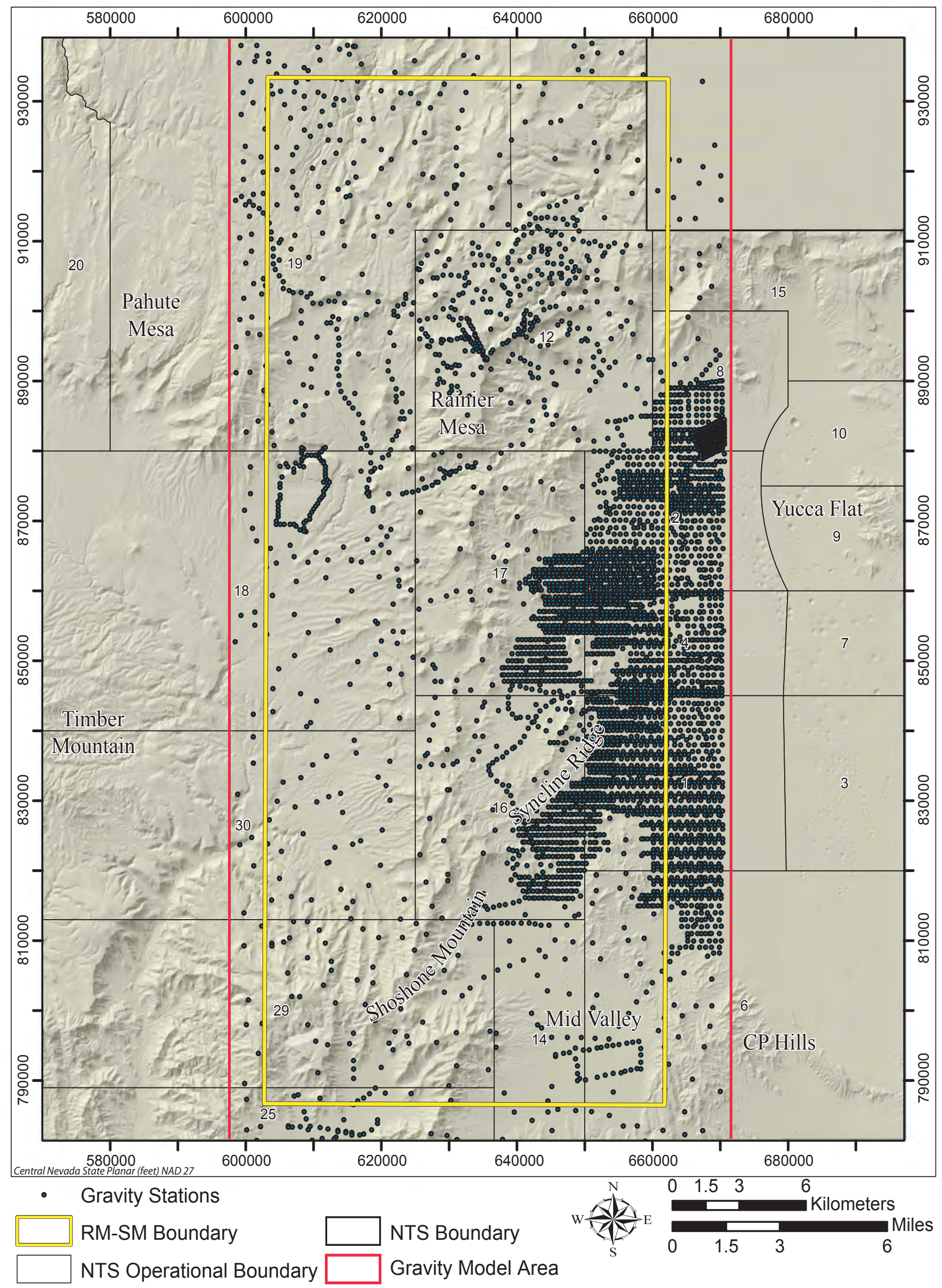

Figure 2-5

Locations of Gravity Stations in the Rainier Mesa-Shoshone Mountain Model Area 


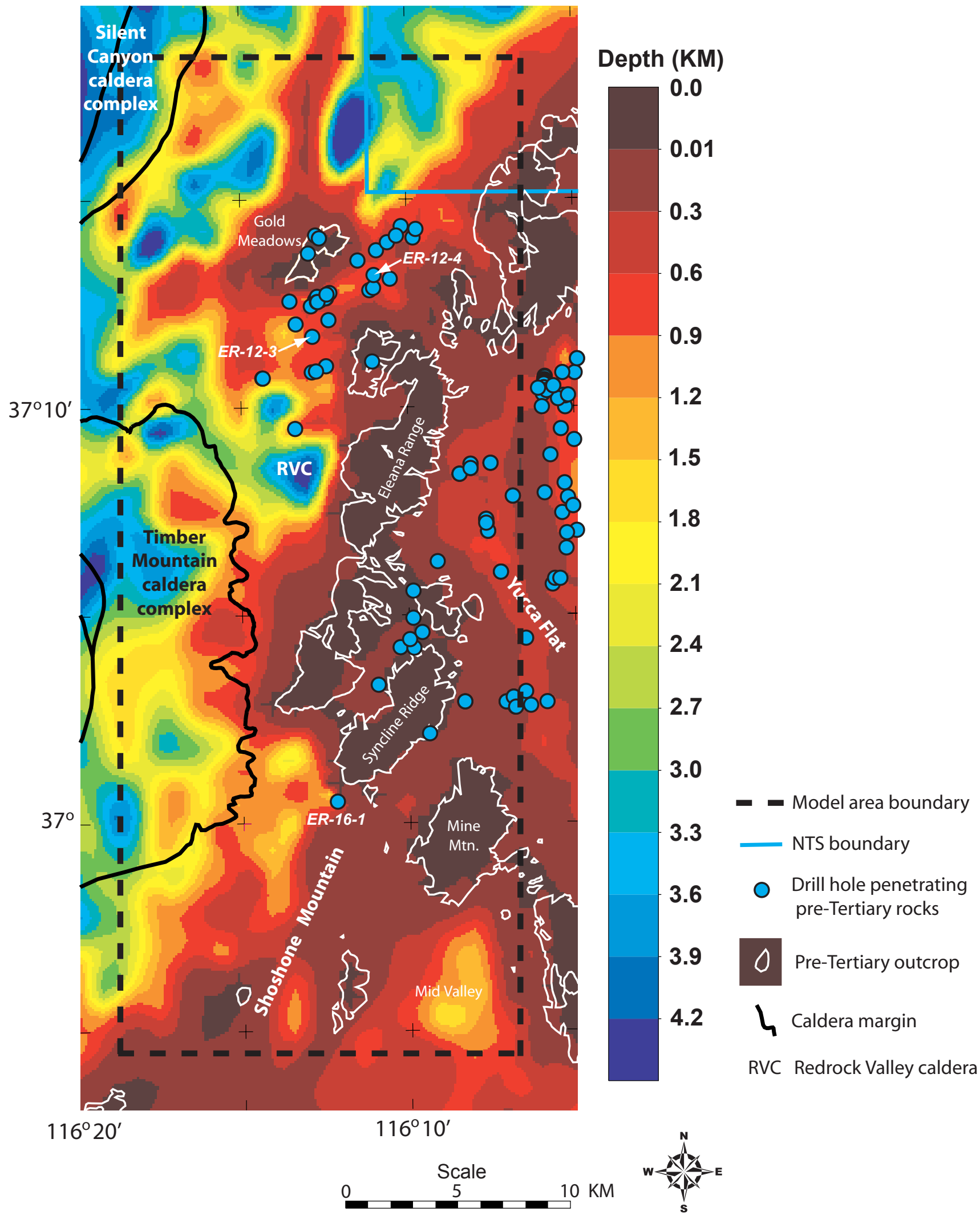

Figure 2-6

Depth to Pre-Tertiary Rocks in the RM-SM Model Area Based on Gravity Data (Modified from Hildenbrand et al., 2006) 


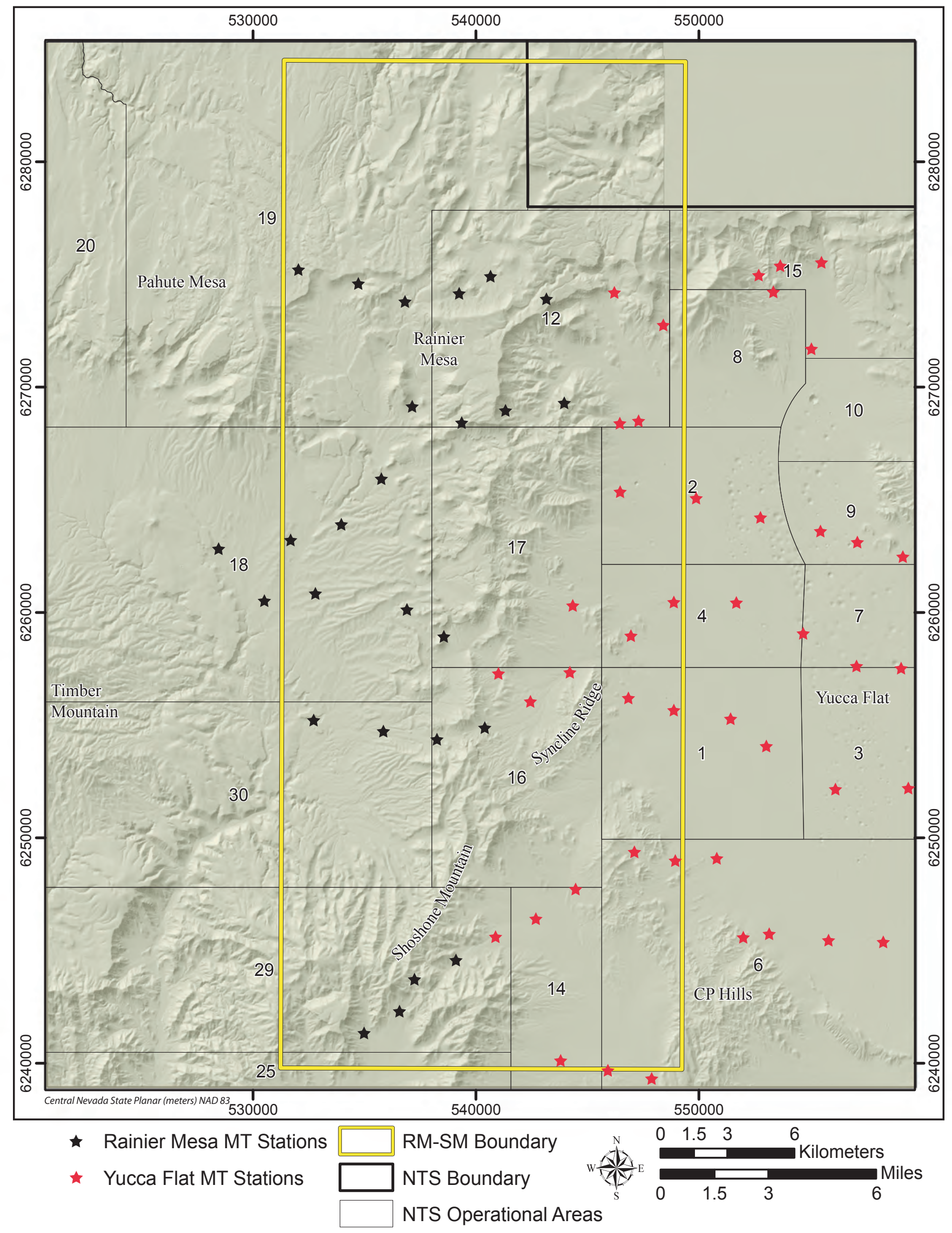

Figure 2-7

Locations of Magnetotelluric Survey Stations in the Rainier Mesa- Shoshone Mountain Model Area 


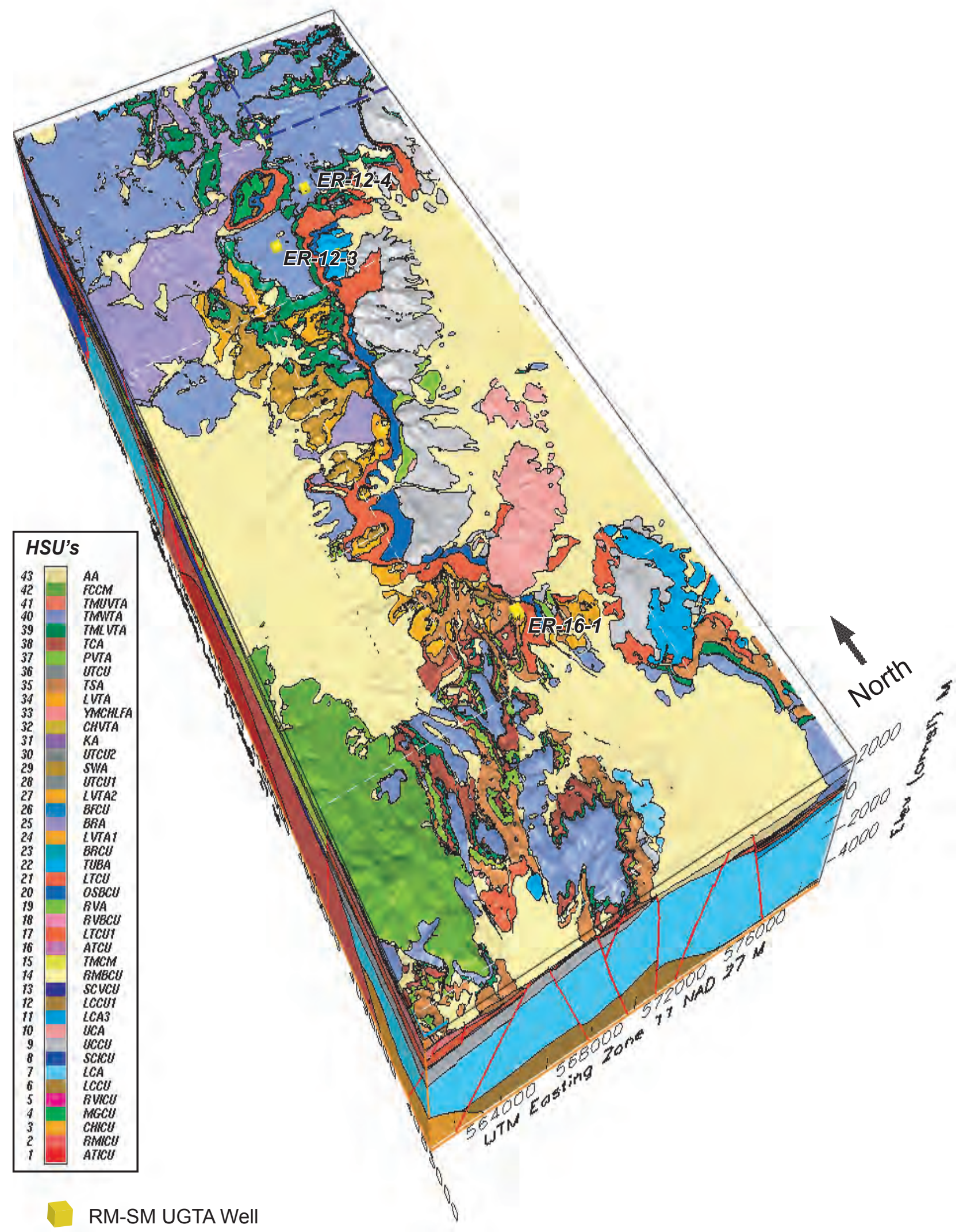

Figure 2-8

3-D Display from EarthVision ${ }^{\circledR}$ of the Rainier Mesa-Shoshone Mountain Model Volume 


\section{RAINIER MESA/SHOSHONE MOUNTAIN HSU MODEL CALCULATED VALUES}

vs WELL PICK DATA
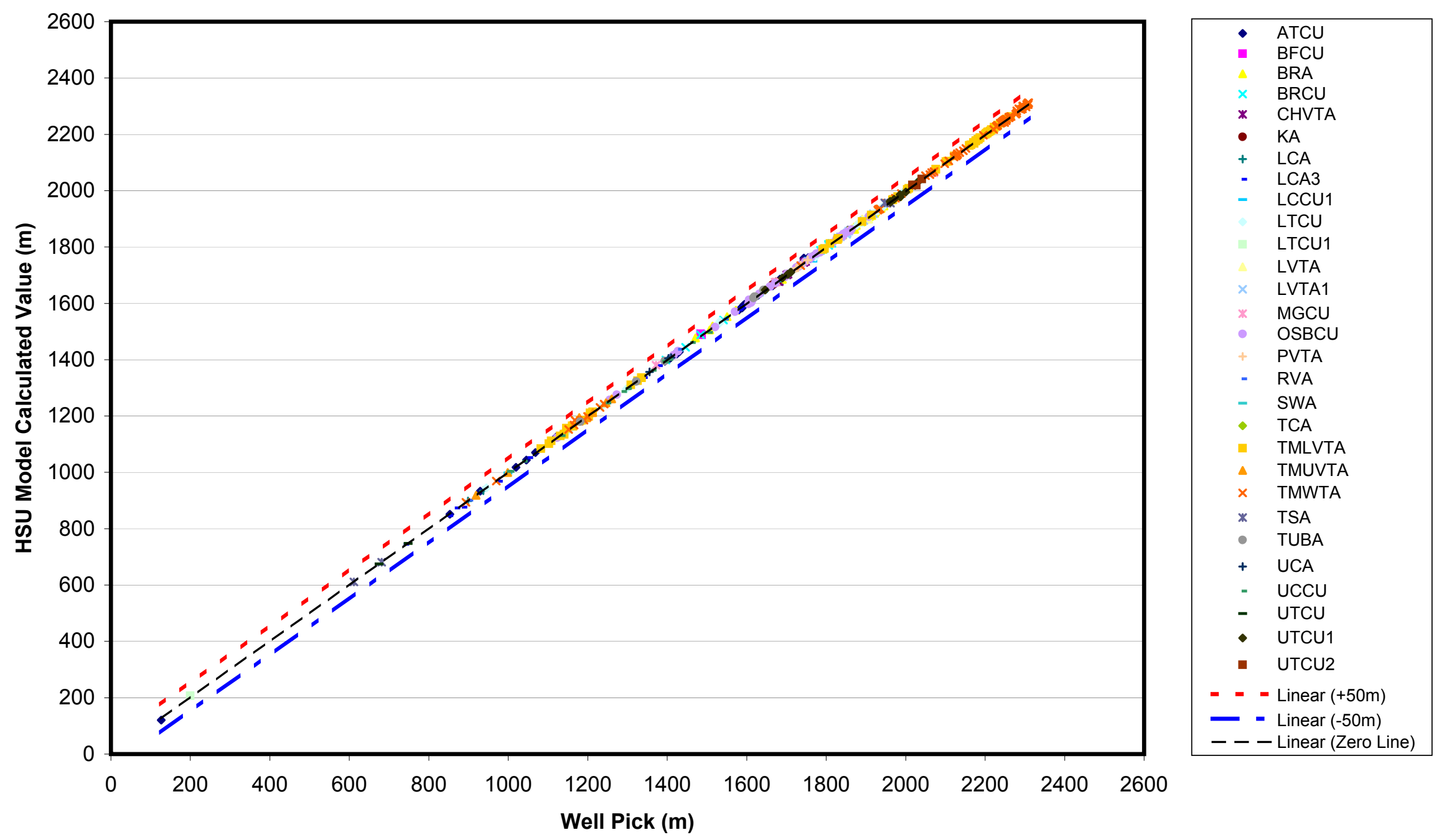

Figure 2-9

Comparison of Calculated Predicted Elevation Values from the Rainier Mesa-Shoshone Mountain Model Versus Well-Pick Data 


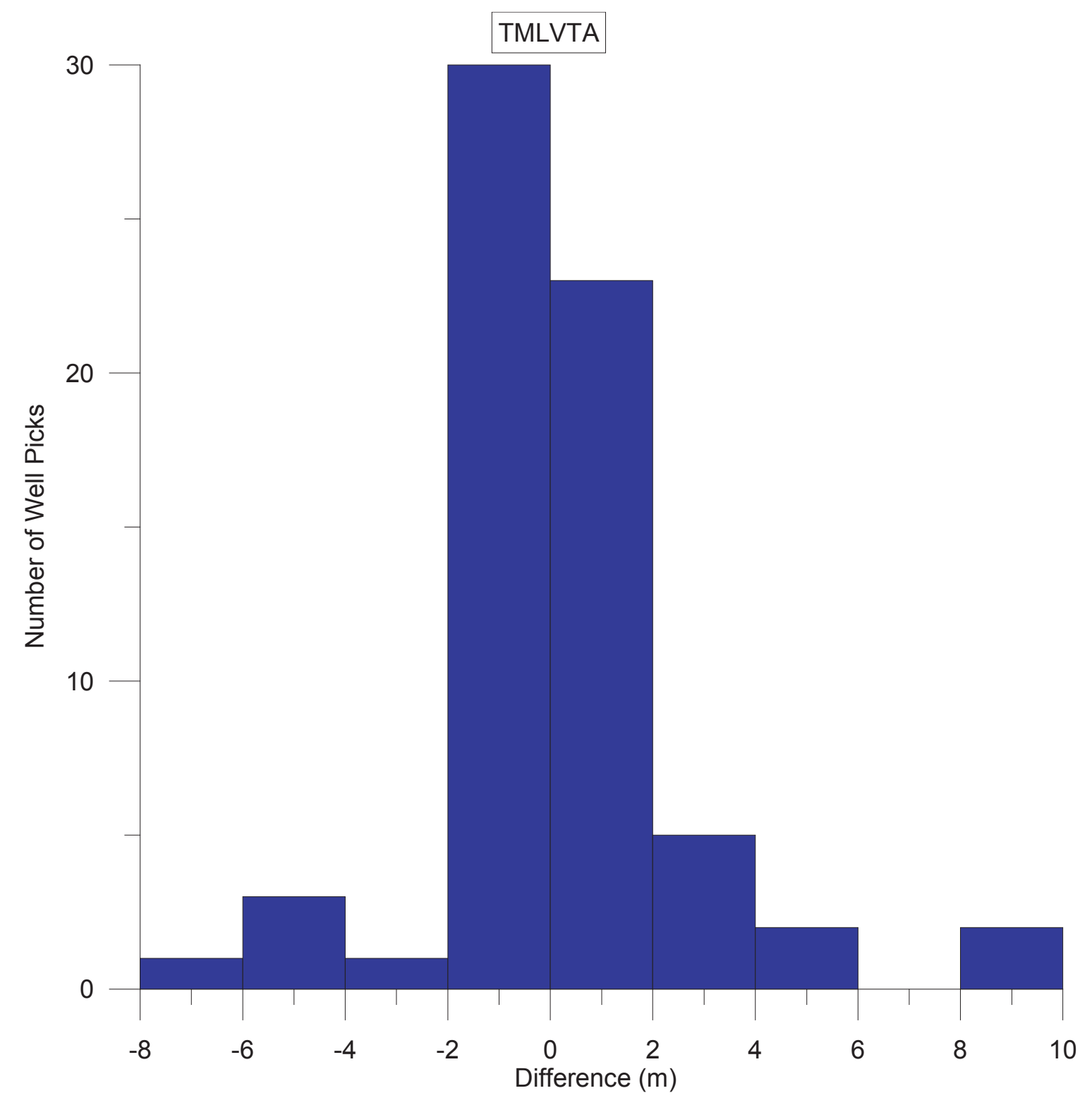

Figure 2-10

Histogram of Differences in Elevation Between the

Rainier-Mesa-Shoshone Mountain Model and Well-Pick Data for the Timber Mountain Lower Vitric-Tuff Aquifer 


\subsection{STRUCTURAL MODEL}

Structures define the geometric configuration of the RM-SM model area, including the distribution, thickness, and orientation of units, and thus are an important part of the hydrogeologic regime of the area. Faults had a strong influence on depositional patterns of alluvial deposits, as well as the present extent, thickness, and structural elevation of volcanic and pre-Tertiary sedimentary units. Some faults place units with different hydrologic properties in juxtaposition, which may have significant hydrogeologic consequences. Also, the structures may themselves act as either conduits of groundwater flow, if characterized by open fractures, or barriers to flow, if associated with fine-grained gouge or increased alteration of nearby rocks. This section describes the structural elements of the model area, and includes discussions of how they were identified and spatially defined for the model.

\subsection{Structural Overview}

The interpretation of the structural geology in the RM-SM area is difficult because complex pre-Tertiary contractional deformation was overprinted by more recent extensional deformation. In addition, thick deposits of volcanic rocks and alluvium completely or partially bury many of the major structural features. Fortunately, much of the RM-SM model area is composed of uplands that lie between the Timber Mountain and Silent Canyon caldera complexes on the west and Yucca Flat on the east, and thus is fairly well dissected, resulting in good geologic exposures. Much of the model area is also relatively un-extended. This results in pre-Tertiary rocks being structurally high in many places. The area also includes the leading edges of both east- and west-directed thrusting, as well as the un-thrusted terrain between the two converging thrust systems. The western portion of the model area includes portions of four volcanic calderas, ranging in age from 11.6 to $15.5 \mathrm{Ma}$.

\subsubsection{Pre-Tertiary Contractional Deformation}

Pre-Tertiary deformation in the RM-SM model area is mainly the result of east-west-directed contractional deformation related to the Cordilleran Orogeny (Barnes et al., 1968; Caskey, 1991; Cole and Cashman, 1999). Exposures of pre-Tertiary rocks within and adjacent to the model area, in such places as the CP Hills, Mine Mountain, Syncline Ridge, Eleana Range, and Quartzite Ridge, show complex contractional deformation in the form of both east- and westdirected thrusting and associated over-folding (Figure 3-1).

East-directed contractional deformation within the model area is the result of movement along the Belted Range thrust fault and associated foreland imbricate faults (Gibbons et al., 1963; Barnes et al., 1968; Cole and Cashman, 1999) (Figure 3-1). Although the trace of the Belted 
Range thrust fault is not exposed, the location of the fault is fairly well constrained in the northern portion of the model area by exposed stratigraphic relationships and deep drill holes in the vicinity of Gold Meadows and Rainier Mesa, where the fault places Cambrian to late Precambrian siliciclastic rocks over Devonian carbonate and Mississippian siliciclastic rocks (Gibbons et al., 1963; Cole et al., 1997). Foreland imbricate faults associated with the Belted Range thrust fault are exposed east of the main thrust fault in the Eleana Range, Mine Mountain, and Shoshone Mountain (Gibbons et al., 1963; Orkild, 1963; Orkild, 1968; Cole and Cashman, 1999). These imbricate faults form a complex series of stacked thrust slices involving mostly Devonian carbonate and Mississippian siliciclastic rocks within the footwall of the Belted Range thrust fault. Examples include Devonian carbonate rocks exposed at the east base of Rainier Mesa that have been thrust eastward over Mississippian siliciclastic rocks (see Plate 1). The Mine Mountain thrust fault also places Devonian carbonate rocks over Mississippian siliciclastic rocks. Alternating intervals of Devonian carbonate and Mississippian siliciclastic rocks penetrated in Well ER-12-1 (Russell et al., 1996) likely represent complex imbricate thrusting associated with the Belted Range thrust fault. In the southern portion of the model area a small outcrop of Devonian carbonate has been thrust eastward over Chainman Shale (Cole, 2005). Additional east-directed imbricate thrusting occurs in the southern Eleana Range and involves mainly Mississippian siliciclastic rocks (Orkild, 1963; Cole and Cashman, 1999).

West-directed contractional deformation is observed just east of the model area in the CP Hills, and east of Quartzite Ridge (McKeown et al., 1976; Caskey, 1991; Cole and Cashman, 1999). This deformation is associated with the CP thrust fault which is exposed only in the CP Hills, where a small window in the hanging wall shows Cambrian and late Precambrian rocks emplaced over rocks as young as Mississippian and Pennsylvanian (McKeown et al., 1976; Caskey, 1991). The fault, however, can be traced beneath the western portion of Yucca Flat based on stratigraphic relationships from deep drill holes (Cole et al., 1997; BN, 2006). The CP thrust fault and related contractional deformation are slightly younger than the Belted Range thrust fault (Cole and Cashman, 1999). Only the western edge of the CP thrust fault occurs within the model area.

The timing of contractional deformation in the NTS region is poorly constrained. Deformation must have occurred after the Pennsylvanian (approximately $280 \mathrm{Ma}$ ) because rocks of this age are deformed within the footwall of a thrust fault in the CP Hills (McKeown et al., 1976; Caskey, 1991; Cole and Cashman, 1999) and folded into a broad syncline at Syncline Ridge.

Contractional deformation in the region is probably older than Middle Cretaceous because 
approximately 100-Ma granite intrudes hanging wall rocks of the Belted Range thrust fault in the northern portion of the NTS (Barnes et al., 1963; Gibbons et al., 1963; Naeser and Maldonado, 1981).

The RM-SM framework model includes most of the known thrust faults within the model area, including the Belted Range thrust fault and its associated imbricates, as well as the western portion of the $\mathrm{CP}$ thrust fault. The imbricate thrust faults in the southern Eleana Range are not included in the base model because they juxtapose rocks of similar hydrologic character (i.e., Mississippian siliciclastic rocks) where exposed at the surface. To the west and at depth, however, rocks of different hydrologic character may be juxtaposed, as described later in Subsection 5.2.4. With the exception of the hanging-wall rocks of the Mine Mountain thrust and the small thrust at Shoshone Mountain, both of which are well above the water table, the model considers all the rocks between the Belted Range fault system and the CP thrust fault as autochthonous (i.e., not thrusted). The RM-SM framework model also depicts individual thrust sheets as riding on the highly bedded and less competent Mississippian siliciclastic rocks, as indicated in mapped surface exposures and drill hole intercepts in and adjacent to the model area.

\subsubsection{Basin and Range Extension}

High-angle normal faults associated with Basin-and-Range extension occur throughout the model area, but are more prevalent in the southern third and along the eastern margin of the area (Figure 3-2). These faults typically strike in a northerly direction and dip both east and west, reflecting generally east-west-directed extensional deformation. The greater abundance of faults in the southern third of the model area results from greater amounts of extension in this area relative to the northern portion of the model area. Stratal tilts of Tertiary volcanic rocks in the southern portion are greater than in the northern portion, consistent with more extension. This area of greater extension is part of a larger area of extension located south of the Timber Mountain caldera complex that includes Crater Flat, Jackass Flats, and Mid Valley. The number of faults, amount of offset, and stratal tilts of volcanic rocks decrease rather abruptly at the north end of Shoshone Mountain near Well ER-16-1 (Orkild, 1963). The cluster of buried faults along the eastern margin is associated with the extended terrain of Yucca Flat. Some of the faults that offset Tertiary volcanic rocks at Rainier Mesa in the northern portion of the model area may be the result of differential compaction of volcanic units over underlying irregularities in the preTertiary surface (Townsend, 2006). 
A structural divide occurs in the southern portion of the model area. This divide, herein called the Shoshone Mountain structural divide (SMSD) (Figure 3-2), is a north-northeast-trending horst that separates areas of different normal fault orientations and associated stratal tilts. The larger normal faults west of the SMSD generally dip west resulting in an eastward tilt of volcanic units. These structural orientations are consistent with regional orientations. The larger normal faults east of the SMSD dip east resulting in a westward tilt of volcanic units. These latter orientations are consistent with structural orientations in the Yucca Flat vicinity which are anomalous compared to regional trends (BN, 2006; Prothro, 2006). Pre-Tertiary rocks within the SMSD are structurally high.

Numerous normal faults offset and tilt the Ammonia Tanks Tuff in the southern portion of the model area (Orkild and O'Connor, 1970; Orkild, 1968; Orkild, 1963), indicating that much of the extensional deformation in the area is younger than $11.45 \mathrm{Ma}$. In the southwestern portion of the model area west of the SMSD, mostly unfaulted lava flows of Rhyolite of Shoshone Mountain overlie Ammonia Tanks Tuff in an angular unconformable relationship (Orkild and O'Connor, 1970), and indicates that extensional deformation had mostly ceased by $10.3 \mathrm{Ma}$ in this area. East of the SMSD, extensional deformation lasted longer. Mid Valley, located in the southeastern portion of the model area, is a small extensional basin filled with as much as $400 \mathrm{~m}$ $(1,300 \mathrm{ft})$ of alluvial debris shed from the surrounding highlands during basin development (McArthur and Burkhard, 1986). Mid Valley is probably similar in age to Yucca and Frenchman Flats where extension and associated basin development continued well after $8 \mathrm{Ma}$ (BN, 2005; 2006).

Fifty-six high-angle normal faults are included in the framework model (Table 3-1 and Figure 3-3). Although hundreds of high-angle normal faults have been identified within the RM-SM model area, computer modeling limitations dictate that only a small subset of the known faults can be incorporated into the framework model. Normal faults in the model include both faults mapped at the surface and shown on surface geologic maps, as well as buried faults inferred from drill hole and geophysical data.

Most of the faults in the model are based on surface exposures as shown on USGS geologic quadrangle maps listed in Table 2-1. It was assumed that the larger faults (typically with greater than $61 \mathrm{~m}$ [200 ft] of offset) that provide the main control on topography, outcrop, and structural fabric, are also the faults most likely to provide the major controls on groundwater flow. The traces of these surface faults were digitized from the published geologic maps. 
Table 3-1

Normal Faults in the Rainier Mesa-Shoshone Mountain Framework Model

\begin{tabular}{|c|c|c|c|c|}
\hline Fault Name & $\begin{array}{c}\text { Approximate } \\
\text { Strike }\end{array}$ & $\begin{array}{l}\text { Dip Magnitude } \\
\text { and Direction } \\
\end{array}$ & $\begin{array}{l}\text { Approximate } \\
\text { Offset (feet) } \\
\end{array}$ & Comments \\
\hline Almendro & $\mathrm{N} 15^{\circ} \mathrm{E}$ & $80^{\circ} \mathrm{NW}$ & 400 & $\begin{array}{l}\text { Terminates south against the } \\
\text { SPMSZ in the PM-OV model }\end{array}$ \\
\hline Big Burn Valley & $\mathrm{N}$ & $\begin{array}{l}\text { Match with } \\
\text { PM-OV model }\end{array}$ & $\begin{array}{l}300-500 \text { at } \\
\text { surface; } \\
4,000 \text { at } P Z\end{array}$ & $\begin{array}{l}\text { Terminates southwestward } \\
\text { against TM_Rainier. Becomes } \\
\text { the Redrock Valley caldera fault } \\
\text { at depth. }\end{array}$ \\
\hline ETCSZ & W-E & $80^{\circ} \mathrm{N}$ & 2,800 & $\begin{array}{l}\text { Terminates east against Split } \\
\text { Ridge }\end{array}$ \\
\hline Mine Mtn. & NE & $85^{\circ} \mathrm{SE}$ & $1,000-1,500$ & Some strike-slip movement \\
\hline $\begin{array}{l}\text { Northwest } \\
\text { T-Tunnel Fault }\end{array}$ & NE & $75^{\circ} \mathrm{SE}$ & 50 & None \\
\hline NTMMSZ & $\mathrm{N} 64^{\circ} \mathrm{W}$ & $80^{\circ} \mathrm{SW}$ & 500 & None \\
\hline PM_SE & NS & $75^{\circ} \mathrm{W}$ & 200 & $\begin{array}{l}\text { Terminates northwest against } \\
\text { the TM_Rainier fault }\end{array}$ \\
\hline Richey & $\mathrm{W} 16^{\circ} \mathrm{E}$ & $80^{\circ} \mathrm{WNW}$ & 5,200 & None \\
\hline RRVSM & NE (curves) & $80^{\circ} \mathrm{SE}$ & 820 & $\begin{array}{l}\text { Terminates southwestward } \\
\text { against TM_Rainier and } \\
\text { northeast against Big Burn } \\
\text { Valley fault }\end{array}$ \\
\hline RRVTM & NE & $80^{\circ} \mathrm{SE}$ & 650 & $\begin{array}{l}\text { Terminates northeast against } \\
\text { Big Burn Valley fault }\end{array}$ \\
\hline RM1 & NW & $75^{\circ} \mathrm{SW}$ & 125 & None \\
\hline RM3 & $N-N E$ & $75^{\circ} \mathrm{W}$ & 300 & None \\
\hline RM4 & NE & $85^{\circ} \mathrm{NW}$ & 300 & None \\
\hline RM5 & NE & $80^{\circ} \mathrm{NW}$ & 70 & $\begin{array}{l}\text { Cuts Well ER-12-4: removed } \\
\text { welded Tub Spring Tuff. } \\
\text { Terminates at depth against } \\
\text { east-dipping fault(s). }\end{array}$ \\
\hline SCSZE & NS & vertical & 75 & $\begin{array}{l}\text { Terminates south against } \\
\text { ETCSZ }\end{array}$ \\
\hline SM1 & NE & $75^{\circ} \mathrm{SE}$ & 500 & Terminates against SM2 \\
\hline SM2 & NE & $75^{\circ} \mathrm{NW}$ & 1,000 & None \\
\hline SM3 & NE & $75^{\circ} \mathrm{NW}$ & 750 & $\begin{array}{l}\text { Terminates laterally against } \\
\text { SM4 }\end{array}$ \\
\hline SM4 & $\mathrm{N}$ & $75^{\circ} \mathrm{W}$ & 500 & $\begin{array}{l}\text { Terminates against YF-inferred } \\
\text { fault }\end{array}$ \\
\hline
\end{tabular}


Table 3-1

Normal Faults in the Rainier Mesa-Shoshone Mountain Framework Model (continued)

\begin{tabular}{|c|c|c|c|c|}
\hline Fault Name & $\begin{array}{c}\text { Approximate } \\
\text { Strike }\end{array}$ & $\begin{array}{l}\text { Dip Magnitude } \\
\text { and Direction }\end{array}$ & $\begin{array}{l}\text { Approximate } \\
\text { Offset (feet) }\end{array}$ & Comments \\
\hline SM5 & NW & $75^{\circ} \mathrm{SW}$ & 1,000 & $\begin{array}{l}\text { Southern half does not offset } \\
\text { post-Ammonia Tanks Tuff units. } \\
\text { Fault is buried by Volcanics of } \\
\text { Fortymile Canyon. }\end{array}$ \\
\hline SM6 & NNE & $75^{\circ} \mathrm{NW}$ & $1,000-1,500$ & $\begin{array}{l}\text { Southern half does not offset } \\
\text { post-Ammonia Tanks Tuff units. } \\
\text { Fault is buried by Volcanics of } \\
\text { Fortymile Canyon. }\end{array}$ \\
\hline SM10 & $\mathrm{N}$ & $65^{\circ} \mathrm{W}$ & $300-2,000$ & None \\
\hline SM15 & NNW & $75^{\circ} \mathrm{W}$ & 300 & $\begin{array}{l}\text { Terminates southward against } \\
\text { SM20 }\end{array}$ \\
\hline SM16 & NNW & $75^{\circ} \mathrm{W}$ & 300 & $\begin{array}{l}\text { Terminates southward against } \\
\text { SM20 }\end{array}$ \\
\hline SM20 & $\mathrm{N}$ & $75^{\circ} \mathrm{W}$ & $100-500$ & None \\
\hline SM24 & NW & $75^{\circ} \mathrm{SW}$ & 300 & None \\
\hline SM25 & N & $75^{\circ} \mathrm{E}$ & $200-700$ & Terminates against SM30 \\
\hline SM30 & $\mathrm{NE}$ & $75^{\circ} \mathrm{SE}$ & 1,000 & None \\
\hline SM31 & NNE & $75^{\circ} \mathrm{SE}$ & 300 & $\begin{array}{l}\text { Terminates northward against } \\
\text { SM30 }\end{array}$ \\
\hline SM32 & NE & $75^{\circ} \mathrm{NW}$ & 200 & $\begin{array}{l}\text { Terminates northward against } \\
\text { SM40 and at depth against } \\
\text { SM30 and SM31 }\end{array}$ \\
\hline SM33 & $\mathrm{NE}$ & $75^{\circ} \mathrm{SE}$ & $200-750$ & None \\
\hline SM34 & ENE & $75^{\circ} \mathrm{NW}$ & $200-400$ & $\begin{array}{l}\text { Terminates northeastward } \\
\text { against Mine Mtn. fault and at } \\
\text { depth against SM33 }\end{array}$ \\
\hline SM40 & WNW & $75^{\circ} \mathrm{NE}$ & $1,500-2,000$ & $\begin{array}{l}\text { Terminates southward against } \\
\text { Mine Mtn. fault }\end{array}$ \\
\hline SM41 & $\mathrm{N}$ & $75^{\circ} \mathrm{E}$ & $500-1,000$ & None \\
\hline SM42 & NW & $75^{\circ} \mathrm{SW}$ & $750-1,000$ & $\begin{array}{l}\text { Terminates northwestward } \\
\text { against SM41; southeast } \\
\text { against Mine Mtn. fault; and at } \\
\text { depth against SM40 and SM41 }\end{array}$ \\
\hline SM43 & $\mathrm{N}$ & $75^{\circ} \mathrm{E}$ & $750-1,500$ & $\begin{array}{l}\text { Terminates southward against } \\
\text { SM42 }\end{array}$ \\
\hline
\end{tabular}


Table 3-1

Normal Faults in the Rainier Mesa-Shoshone Mountain Framework Model (continued)

\begin{tabular}{|c|c|c|c|c|}
\hline Fault Name & $\begin{array}{c}\text { Approximate } \\
\text { Strike }\end{array}$ & $\begin{array}{l}\text { Dip Magnitude } \\
\text { and Direction }\end{array}$ & $\begin{array}{l}\text { Approximate } \\
\text { Offset (feet) }\end{array}$ & Comments \\
\hline SM50 & $\mathrm{N}$ & $75^{\circ} \mathrm{E}$ & 2,500 & $\begin{array}{l}\text { Merges northward with Mine } \\
\text { Mtn. fault }\end{array}$ \\
\hline SM51 & $\mathrm{N}$ & $75^{\circ} \mathrm{W}$ & 1,000 & None \\
\hline Split Ridge & $\mathrm{N} 5^{\circ} \mathrm{E}$ & $80^{\circ} \mathrm{W}$ & 5,200 & None \\
\hline TM_Rainier & $\begin{array}{c}\text { NS } \\
\text { (curves W) }\end{array}$ & $80^{\circ} \mathrm{W}$ & $3,000-5,000$ & None \\
\hline TM_TM main & NS (curves) & $80^{\circ} \mathrm{W}$ & 50 & None \\
\hline $\begin{array}{l}\text { T-Tunnel Main } \\
\text { Drift Fault }\end{array}$ & $\mathrm{N}$ & $75^{\circ} \mathrm{E}$ & $100-200$ & None \\
\hline YF $6 a$ & NNE & $80^{\circ}$ ESE & 150 & None \\
\hline YF 6b & NNE & $75^{\circ}$ ESE & 130 & None \\
\hline YF 12 & NNE & $75^{\circ} \mathrm{ESE}$ & 100 & None \\
\hline YF 14a 16a & NS & $75^{\circ} \mathrm{E}$ & 150 & None \\
\hline YF 16b & NS & $75^{\circ} \mathrm{E}$ & 300 & None \\
\hline YF 18 & NS & $75^{\circ} \mathrm{E}$ & 180 & None \\
\hline YF 22b & NNW & $75^{\circ} \mathrm{E}$ & 130 & None \\
\hline YF 22c & NW-N & $75^{\circ} \mathrm{E}$ & 65 & None \\
\hline YF 22d & NW & $75^{\circ} \mathrm{NE}$ & 70 & None \\
\hline YF 23 & NS & $75^{\circ} \mathrm{W}$ & 50 & Terminates against YF_U_2cma \\
\hline YF 25N 27 & NS & $75^{\circ} \mathrm{W}$ & 50 & Terminates against $Y F \_U \_2 c m a$ \\
\hline YF_t_2cma & & & 100 & None \\
\hline YF U_2cmb & N-NNE & $80^{\circ} \mathrm{E}$ & 100 & None \\
\hline YF WGH & NS & $75^{\circ} \mathrm{W}$ & 300 & Terminates against $Y F \_U \_2 c m a$ \\
\hline
\end{tabular}


Buried normal faults include faults from the adjacent Yucca Flat hydrostratigraphic framework model and are based on drill hole and geophysical data (BN, 2006). Several buried faults and structural zones are from the PM-OV model, and these are also based on drill hole and geophysical data (BN, 2002a). The larger normal faults at Rainier Mesa are included, although they have offsets typically less than $30.5 \mathrm{~m}$ (100 ft). The locations and characteristics of these faults are based mainly on drill hole and tunnel data.

Unless otherwise indicated on published geologic maps, normal faults are typically modeled with a 75-degree dip. This approximate dip is based on measured dips of normal faults exposed around the NTS region, which typically range from 50 to 85 degrees, and the stratal tilt of the Rainier Mesa and Ammonia Tanks tuffs which is typically less than 15 degrees. Each fault is modeled as a single fault plane that extends to the base of the model. Some faults, however, terminate against other faults.

\subsubsection{Calderas}

The central caldera cluster of the SWNVF is located just west of the model area (Figure 1-5), and is the source for most of the volcanic rocks in the NTS region (Sawyer et al., 1994). The eastern portions of four of the calderas occur within the western portion of the model area. Each caldera is briefly discussed in the following sections.

\subsubsection{Redrock Valley Caldera}

A possible source (i.e., caldera) for the 15.25-Ma Redrock Valley Tuff (Sawyer et al., 1994) is a deep gravity low located southwest of Rainier Mesa ("RVC" in Figure 2-6). Although a Redrock Valley caldera has not been previously recognized, the RM-SM framework model incorporates a buried caldera to account for the deep gravity low. The caldera must be older than 13.7 Ma because the Grouse Canyon Tuff, whose source is the Grouse Canyon caldera located to the northwest, is exposed within the area of the gravity low. Thick occurrences of Redrock Valley Tuff are described in nearby holes (e.g., Water Well 8, Well HTH-1, and Well ER-19-1), possibly indicating a nearby source for the ash-flow tuff. Also, most of the limited surface exposures of Redrock Valley Tuff in the NTS region are in the Eleana Range just east of the gravity low. Thick occurrences of tuff of Twin Peaks in Water Well 8 and Well HTH-1 may indicate that the caldera is also the source of the tuff of Twin Peaks.

The gravity low is broadly bounded on the east by the conspicuous Big Burn Valley fault, which has an unusually long surface trace and exhibits an anomalous concave-to-the-west arcuate shape (Figure 3-2; Plate 1). This fault offsets volcanic rocks as young as the Rainier Mesa Tuff (11.6 Ma) (Sawyer et al., 1994). Although at depth the fault is modeled with as much as $600 \mathrm{~m}$ 
$(2,000 \mathrm{ft})$ of displacement, displacement at the surface is generally less than $100 \mathrm{~m}(300 \mathrm{ft})$ (see Model Profile D-D' in Appendix C). It is interpreted that the surface exposure of the fault represents reactivation of the buried caldera margin as a result of the formation of younger calderas such as the Rainier Mesa caldera, differential compaction across the fault, or basin-andrange extension.

Because the Redrock Valley caldera is completely buried by younger units, no direct evidence (e.g., surface exposures, intra-caldera drill holes) exists for the caldera. Therefore the caldera interpretation is not well constrained. Because the area is potentially down-gradient from UGTs at Rainier Mesa, an alternative interpretation was developed that removes the caldera and models the basement low as a pre-volcanic topographic low (see Subsection 5.2.2).

\subsubsection{Silent Canyon Caldera Complex}

The extreme northwestern portion of the model area includes a small portion of the Silent Canyon caldera complex (Figure 1-5). This caldera complex is composed of two nested calderas: the Grouse Canyon and younger Area 20 calderas (Sawyer and Sargent, 1989). These calderas were the sources for the Grouse Canyon and Bullfrog Tuffs, respectively. The Grouse Canyon caldera erupted 13.7 Ma and the Area 20 caldera 13.25 Ma (Sawyer et al., 1994).

\subsubsection{Rainier Mesa Caldera}

The western portion of the model area includes the eastern portion of the Rainier Mesa caldera (Figure 1-5). This caldera is 11.6 Ma and the source of the Rainier Mesa Tuff (Sawyer et al., 1994). Within the margins of the caldera the Rainier Mesa Tuff is densely welded and probably obtains a thickness exceeding $600 \mathrm{~m}(2,000 \mathrm{ft})$, though it is now buried by younger volcanic units and alluvial deposits (Byers et al., 1976). Outside the caldera the unit is considerably thinner and caps many of the highlands east of the caldera such as Rainier and Aqueduct mesas and Shoshone Mountain (Gibbons et al., 1963; Orkild, 1968; Orkild and O'Connor, 1970).

\subsection{Hydrologic Characteristics of Faults}

It is typical for rocks to be more fractured near faults, and thus a rock's properties tend to be different near and adjacent to faults. However, thrust faulting (including the Belted Range and CP thrusts) and associated fracturing are older than approximately 100 million years at the NTS. Therefore, fractures associated with thrusting are more likely to be healed or filled than fractures associated with more recent basin-and-range normal faulting in the RM-SM area. Reactivation of the older thrust structures during basin-and-range extension, such as that described for the $\mathrm{CP}$ thrust fault and documented at Mine Mountain (Cole and Cashman, 1999; BN, 2006), likely created new fractures and could have reopened preexisting fractures associated with the old 
thrust structures. However, it is difficult to predict if (and where) an older thrust fault may have undergone reactivation due to later structural activity, particularly if the thrust fault is poorly exposed or unexposed.

Surface mapping and seismicity studies indicate that tectonic stress has apparently been released as a result of underground nuclear testing (Rogers et al., 1991). Rogers et al. (1977) recorded aftershocks from 8 UGTs on Pahute Mesa and found that most aftershocks occurred within $6 \mathrm{~km}$ (4 mi) of ground zero and from 4 to $10 \mathrm{~km}$ ( 2 to $6 \mathrm{mi}$ ) below the surface. Aftershocks appeared to occur along steeply dipping faults, although they did not appear to align with any known faults. Thus, some fault reactivation has likely occurred at the NTS as a result of underground nuclear testing. In brittle units, such as welded tuff and carbonate, testing-induced fault reactivation may have produced local zones of enhanced fracture permeability adjacent to reactivated faults. 


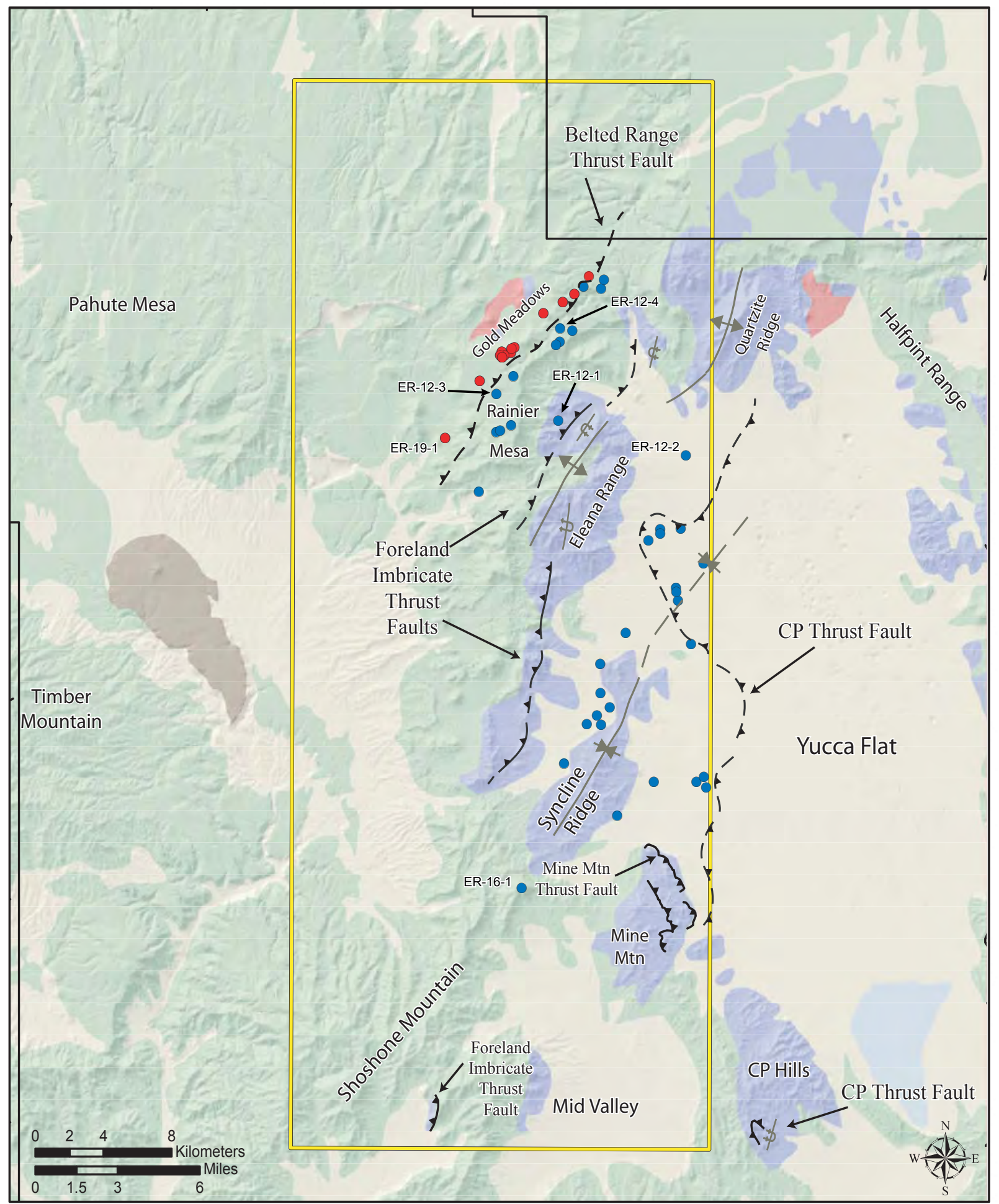

- Drill holes that tag Precambrian rocks $/ 4$ Anticline

- Drill holes that tag Paleozoic rocks

RM-SM Boundary

Nevada Test Site Boundary

Kyncline (dashed where buried)

Quaternary Playa Deposits

\ Thrust Fault (dashed where buried)

\& Overturned beds

Surface units from Nevada Bureau of Mines and Geology, 1996

Structural features modified from Cole et. al. 1997, and Cole and Cashman, 1999

Quaternary Playa Deposits
Pliocene Basaltic Rocks
Quaternary/Tertiary Alluvium
Tertiary Volcanic Rocks
Mesozoic Granitic Rocks
Paleozoic and Precambrian Rocks

Figure 3-1

Pre-Tertiary Structural Features within the Rainier Mesa-Shoshone Mountain Model Area 


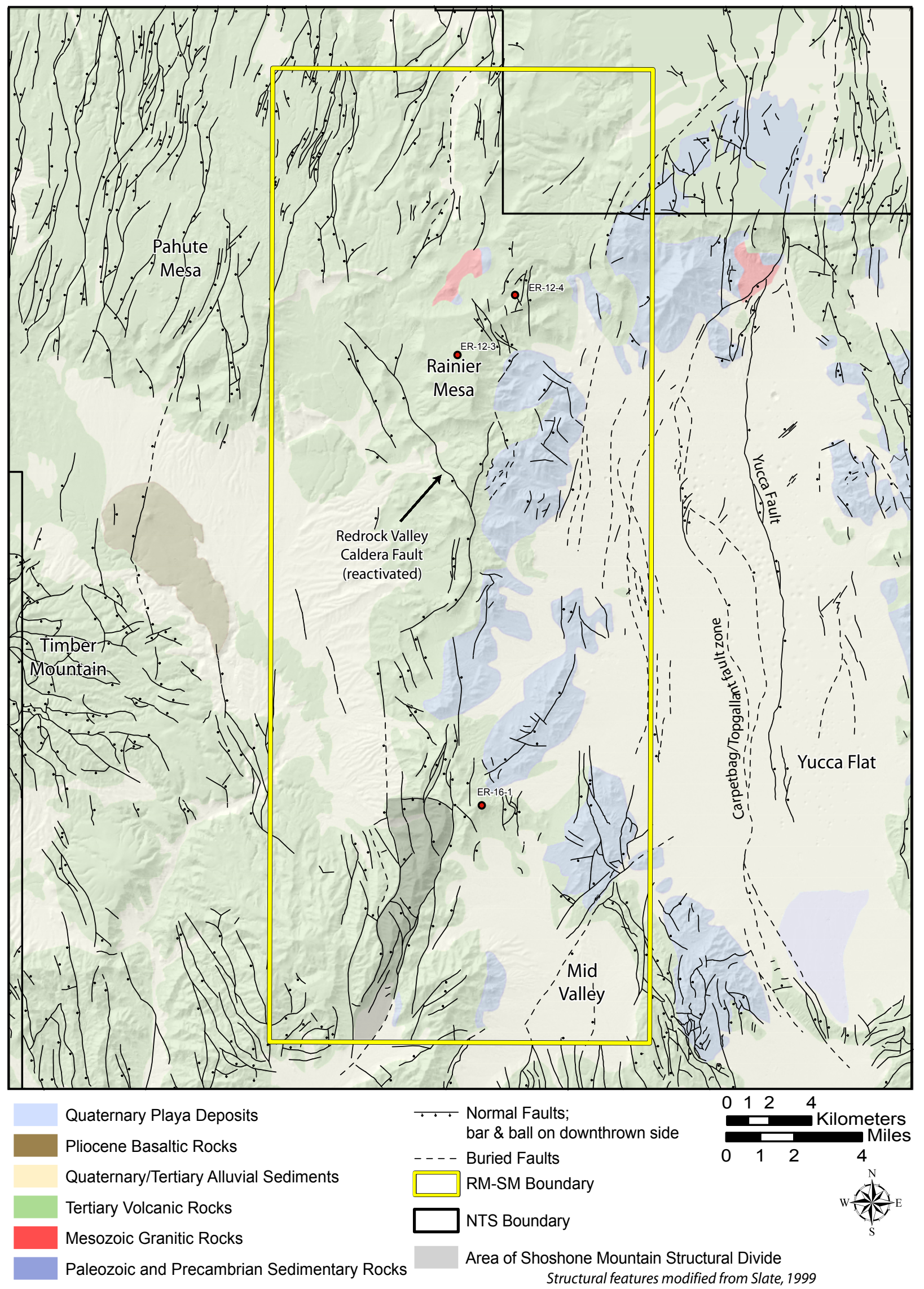

Figure 3-2

Normal Faults within the Rainier Mesa-Shoshone Mountain Model Area 


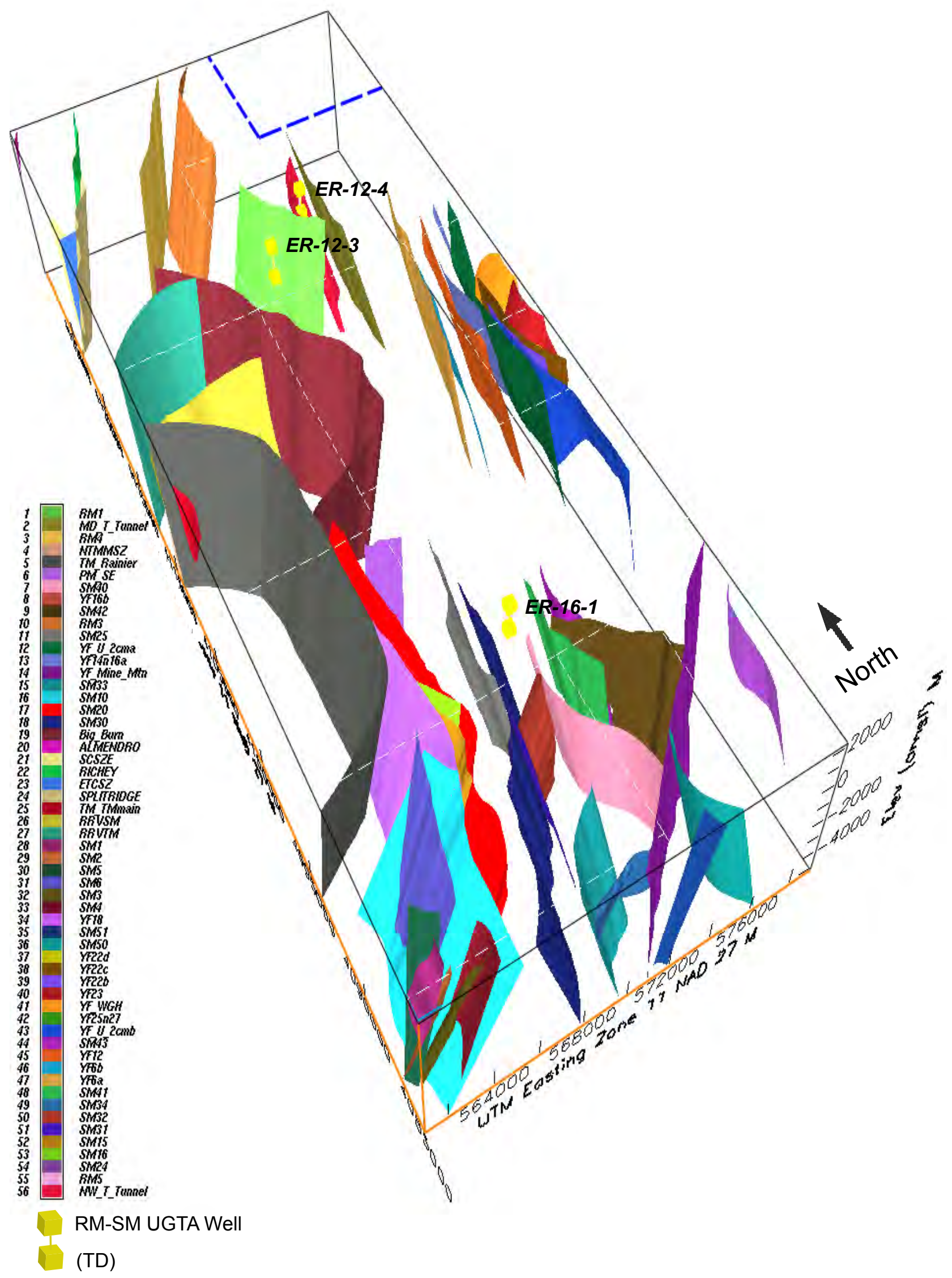

Figure 3-3

Fault-Tree Model of the Rainier Mesa-Shoshone Mountain Model Showing Normal Faults Included in the Model 


\subsection{HYDROSTRATIGRAPHY}

As introduced in Section 2.0, a hydrostratigraphic classification system for depicting the hydrologic character of complexly inter-fingering rocks of a wide range of lithologic and hydrologic characteristics had to be developed for use in the digital framework model. The hydrogeologic framework for the NTS and vicinity established by Winograd and Thordarson (1975) provided the foundation for most subsequent hydrogeologic studies in the area. As described in this section, the rocks of the NTS have been classified for hydrologic modeling using a two-level classification scheme, in which HGUs are grouped to form HSUs (IT, 1996a; BN, 2002a; 2006).

\subsection{Development of the Hydrostratigraphic Classification System}

The development of the hydrostratigraphic classification system for the RM-SM model area followed the same three-step process used during construction of the previous three UGTA hydrostratigraphic framework models (BN, 2002a; 2005; 2006). The first step was to acquire a thorough understanding of the character and 3-D distribution of the rocks, both lithologically and stratigraphically, within the model area. This critical first step was accomplished through a rigorous analysis of published surface geologic maps and descriptions, and drill hole and tunnel data, and geophysical data.

In the second step, rocks in the RM-SM area were classified as one of nine HGUs based on the rock's ability to transmit groundwater, which is mainly a function of the rock's primary lithology, type and degree of post-depositional alteration, and propensity to fracture (Winograd and Thordarson, 1975; BN, 2002a; 2006). The most important factor affecting how groundwater flows through a body of rock is the rock's original primary lithology, which exerts a strong influence on the other two important processes, post-depositional alteration and fracturing. Hard, dense, brittle rocks such as welded tuff, lava, and carbonate generally have low primary porosity and matrix permeability, but tend to fracture readily in response to tectonic forces and, as in the case of welded tuffs and lavas, also as a result of contraction during cooling. In addition, the low primary porosity and matrix permeability of these rocks tend to inhibit significant secondary alteration such as zeolitization which typically changes the hydrologic character of the rocks. These rocks are considered aquifers and have been shown to be prolific water producers at the NTS. Less dense rocks such as alluvium and bedded and nonwelded tuff, typically do not support extensive fracture systems and thus usually have low fracture-related effective porosity. However, some low density rocks such as nonwelded tuff and alluvium can have relatively high primary effective porosity and these units are also considered aquifers where they are unaltered. The high primary effective porosity of these rocks, particularly nonwelded 
tuff, makes them susceptible to post-depositional alteration processes such as zeolitization, which can significantly reduce the effective porosity of altered rocks. Nonwelded tuff units that have undergone zeolitic or argillic alteration are considered confining units because of their very low effective porosity.

The third step in the development of the RM-SM hydrostratigraphic classification system was to group individual HGUs of similar character into larger HSUs to facilitate mapping and 3-D model construction. HSUs serve as 3-D bodies that are represented in the finite element mesh for the UGTA groundwater modeling process (IT, 1996d). An additional criterion for this particular model was that the hydrostratigraphy must conform to that of the adjacent UGTA CAU models (PM-OV to the west and Yucca Flat-Climax Mine to the east). As with the preceding UGTA modeling efforts, a critical component of this step was the careful integration of RM-SM stratigraphy. The integration of stratigraphic concepts is important to assure that individual HGUs grouped within HSUs, and the HSUs themselves, properly correlate within the model. Therefore, HSUs can be thought of as groupings of contiguous stratigraphic units that have a particular hydrogeologic character, such as aquifer or confining unit (generally following the definitions of Maxey [1974] and Seaber [1988]). For the RM-SM model, HSUs generally consist of a single HGU (e.g., the Timber Mountain lower vitric-tuff aquifer essentially is 100 percent vitric-tuff aquifer). There are five exceptions: the Timber Mountain upper vitrictuff aquifer, the Timber Mountain welded-tuff aquifer, the Topopah Spring aquifer, the Oak Spring Butte confining unit, and the Stockade Wash aquifer. These HSUs may consist of several HGUs, but are defined so that a single general type of HGU dominates (e.g., mostly welded-tuff aquifer). These exceptions are noted in the appropriate paragraphs and tables presented in Section 4.5 below.

Sections 4.2, 4.3, and 4.4 describe the stratigraphy, unit thicknesses, and the HGUs of the RM-SM area. Each of the 43 HSUs in the RM-SM hydrostratigraphic framework model is described in Section 4.5.

\subsection{Stratigraphy of the Rainier Mesa-Shoshone Mountain Model Area}

To define appropriate HSUs to serve as layers in the framework model, the modelers had to start from a well understood stratigraphic system. Refinement of the stratigraphy of the area was a continuous process during the decades in which geoscientists associated with the WTP worked to understand the complex volcanic setting (Byers et al., 1976; 1989). The need to develop detailed geologic models in support of the UGTA program intensified this process, and the recognition of smaller and smaller distinct volcanic units permitted a greater understanding of the 3-D configuration of the various types of rocks, which has been incorporated into the model 
via the hydrostratigraphic framework. Efforts to understand the structure and stratigraphy of the non-volcanic rocks (pre-Tertiary) have also continued to a lesser degree. The most widespread and significant Quaternary- and Tertiary-age (mainly volcanic) units of the RM-SM model area are listed in Table 4-1. Refer to Table 4-2 for a list of Paleozoic and Proterozoic (sedimentary) units. Figure 4-1 illustrates the stratigraphy of rocks in the Rainier Mesa area and Figure 4-2 illustrates the stratigraphy of rocks in the Shoshone Mountain area.

The stratigraphic section for the RM-SM area consists of Proterozoic and Paleozoic siliciclastic and carbonate rocks, Mesozoic intrusive rocks, Tertiary-age volcanic rocks, and Tertiary- and Quaternary-age alluvium (Figures 4-1 and 4-2). Throughout most of the NTS, middle to upper Miocene volcanic rocks that originated from vents located to the west and northwest of the area unconformably overlie pre-Tertiary carbonate and siliciclastic rocks (Orkild, 1983).

\subsection{Unit Thickness}

The alluvial fill of the RM-SM area ranges in thickness from a thin veneer mainly along drainages and valley edges to over $410 \mathrm{~m}(1,345 \mathrm{ft})$ in Mid Valley. The volcanic units are interpreted to be up to $1,108 \mathrm{~m}(3,635 \mathrm{ft})$ thick in the central part of Rainier Mesa, as determined from outcrops and drill holes (drill hole database, Appendix A). The thicknesses of the pre-Tertiary units (Table 4-2) were derived from estimates given by Cole and Cashman, (1999) and Poole et al. (1961). Data for these units from the USGS geologic quadrangle maps, particularly Rainier Mesa, Quartet Dome, Topopah Spring, Oak Spring, Tippipah Spring, and Mine Mountain (Gibbons et al., 1963; Sargent et al., 1966; Orkild and O'Connor; 1970, Barnes et al., 1963; Orkild, 1963; Orkild, 1968) (Table 2-1) and from drill holes (Appendix A), were also incorporated.

\subsection{Hydrogeologic Units of the Rainier Mesa-Shoshone Mountain Model Area}

All the rocks of the RM-SM model area are classified as one of the following nine HGUs: alluvial aquifer, welded-tuff aquifer, vitric-tuff aquifer, lava-flow aquifer, tuff confining unit, intra-caldera intrusive confining unit, granitic confining unit, clastic confining unit, and carbonate aquifer (Table 4-3). 
Table 4-1

Quaternary, Tertiary, and Mesozoic Stratigraphic Units of the Rainier Mesa-Shoshone Mountain Model Area

\begin{tabular}{|c|c|}
\hline Stratigraphic Assemblages and Major Units ${ }^{\text {a, b }}$ & Volcanic Sources $^{c}$ \\
\hline $\begin{array}{l}\text { Quaternary and Tertiary Sediments } \\
\text { Young alluvium (Qay) } \\
\text { Quaternary - Tertiary colluvium (QTc) } \\
\text { Intermediate alluvium (Qai) } \\
\text { Quaternary-Tertiary alluvium (QTa) } \\
\text { Basin-fill sediments (Tgy) } \\
\text { Moat-filling sediments (Tgc) }\end{array}$ & Not applicable \\
\hline \begin{tabular}{|l} 
Volcanics of Fortymile Canyon (Tf) \\
Rhyolite of Shoshone Mountain (Tfs) \\
Lavas of Dome Mountain (Tfd) \\
Beatty Wash Formation (Tfb)
\end{tabular} & $\begin{array}{l}\text { Diverse vent areas in and around the } \\
\text { Timber Mountain caldera complex. }\end{array}$ \\
\hline $\begin{array}{l}\text { Timber Mountain Group (Tm) } \\
\text { Ammonia Tanks Tuff (Tma) } \\
\text { bedded Ammonia Tanks Tuff (Tmab) } \\
\text { Rainier Mesa Tuff (Tmr) } \\
\text { tuff of Holmes Road (Tmrh) } \\
\end{array}$ & $\begin{array}{l}\text { Timber Mountain Caldera Complex } \\
\text { Ammonia Tanks Caldera } \\
\text { Rainier Mesa Caldera }\end{array}$ \\
\hline $\begin{array}{l}\text { Paintbrush Group (Tp) } \\
\text { Tiva Canyon Tuff (Tpc) } \\
\text { Topopah Spring Tuff (Tpt) }\end{array}$ & $\begin{array}{c}\text { Claim Canyon Caldera } \\
\text { Unknown }\end{array}$ \\
\hline Calico Hills Formation (Th; formerly Tac) & Unknown \\
\hline $\begin{array}{r}\text { Wahmonie Formation (Tw) } \\
\text { tuff of Wahmonie Flat (Twlb) }\end{array}$ & Wahmonie Volcanic Center \\
\hline $\begin{array}{l}\text { Crater Flat Group (Tc) } \\
\text { Prow Pass Tuff (Tcp) } \\
\text { Rhyolite of Kearsarge (Tcpk) } \\
\text { Bullfrog Tuff (Tcb) } \\
\text { Stockade Wash lobe (Tcbs) } \\
\text { Tram Tuff (Tct) } \\
\text { Belted Range Group (Tb) } \\
\text { Deadhorse Flat Formation (Tbd) } \\
\text { Grouse Canyon Tuff (Tbg) } \\
\text { Comendite of Split Ridge (Tbgs) } \\
\text { Comendite of Quartet Dome (Tbq) }\end{array}$ & $\begin{array}{l}\text { Silent Canyon Caldera Complex } \\
\text { Area } 20 \text { Caldera } \\
\text { Grouse Canyon Caldera }\end{array}$ \\
\hline $\begin{array}{c}\text { Tram Ridge Group (Tr) } \\
\text { Lithic Ridge Tuff (Trl) }\end{array}$ & Unknown \\
\hline
\end{tabular}


Table 4-1

Quaternary, Tertiary, and Mesozoic Stratigraphic Units of the

Rainier Mesa-Shoshone Mountain Model Area (continued)

\begin{tabular}{|c|c|}
\hline Stratigraphic Assemblages and Major Units ${ }^{a, b}$ & Volcanic Sources $^{c}$ \\
\hline $\begin{array}{l}\text { Tunnel Formation (Tn) } \\
\text { Tunnel } 4 \text { Member (Tn4) } \\
\text { Tunnel } 3 \text { Member (Tn3) }\end{array}$ & Unknown \\
\hline $\begin{array}{l}\text { Volcanics of Big Dome (Tu) } \\
\text { Comendite of Ocher Ridge (Tuo) } \\
\text { Tub Spring Tuff (Tub) }\end{array}$ & Unknown \\
\hline $\begin{array}{l}\text { Volcanics of Oak Spring Butte (To) } \\
\text { tunnel bed } 2 \text { (Ton2) } \\
\text { Yucca Flat Tuff (Toy) } \\
\text { tunnel bed } 1 \text { (Ton1) } \\
\text { Redrock Valley Tuff (Tor) } \\
\text { tuff of Twin Peaks (Tot) } \\
\text { Older Volcanics, undivided (To) }\end{array}$ & $\begin{array}{c}\text { Unknown } \\
\text { Redrock Valley Caldera } \\
\text { Unknown }\end{array}$ \\
\hline $\begin{array}{l}\text { Paleocolluvium (TI) } \\
\text { Paleocolluvium, undivided } \\
\end{array}$ & Not applicable \\
\hline $\begin{array}{l}\text { Plutonic Rocks (Kg) } \\
\text { Gold Meadows stock (Kgg) }\end{array}$ & Not applicable \\
\hline
\end{tabular}

a Compiled from Slate et al. (1999) and Ferguson et al. (1994).

b Letters in parentheses are stratigraphic unit map symbols.

c Sources, where known, from Sawyer et al. (1994); Redrock Valley Caldera, this report.

Refer to Table 4-2 for lists of Paleozoic and Proterozoic sedimentary rock formations. 
Table 4-2

Proterozoic and Paleozoic Stratigraphic Units of the

Rainier Mesa-Shoshone Mountain Model Area

\begin{tabular}{|c|c|c|c|c|}
\hline Map Unit ${ }^{a}$ & $\begin{array}{c}\text { Stratigraphic } \\
\text { Unit Map } \\
\text { Symbol } \\
\end{array}$ & $\begin{array}{c}\text { Stratic } \\
\text { Thic } \\
\text { Feet } \\
\end{array}$ & $\begin{array}{l}\text { raphic } \\
\text { aness } \\
\text { Meters } \\
\end{array}$ & Dominant Lithology \\
\hline Tippipah Limestone & PPt & 4,100 & 1,250 & Limestone \\
\hline Chainman Shale/Eleana Formation & Mc/MDe & $7,700^{b}$ & $2,350^{b}$ & Shale, Argillite, and Quartzite \\
\hline Guilmette Formation & $\mathrm{Dg}$ & 1,400 & 430 & Limestone/Dolomite \\
\hline Simonson Dolomite & Ds & 1,100 & 330 & Dolomite \\
\hline Sevy Dolomite & DSs & 690 & 210 & Dolomite \\
\hline Laketown Dolomite & SI & 650 & 200 & Dolomite \\
\hline Ely Springs Dolomite & Oes & 340 & 105 & Dolomite \\
\hline Eureka Quartzite & Oe & 400 & 125 & Quartzite \\
\hline Antelope Valley Limestone & $\mathrm{Oa}$ & 1,530 & 466 & Limestone \\
\hline Ninemile Formation & On & 335 & 102 & Limestone \\
\hline Goodwin Limestone & $\mathrm{Og}$ & 685 & 209 & Limestone \\
\hline Nopah Formation & $\mathrm{Cn}$ & 2,050 & 620 & Limestone \\
\hline Bonanza King Formation & $\mathrm{Cb}$ & 4,350 & 1,330 & Limestone/Dolomite \\
\hline Carrara Formation & $\mathrm{Cc}$ & 925 & 280 & Limestone/Shale/Siltstone \\
\hline Zabriskie Quartzite & $\mathrm{Cz}$ & 200 & 60 & Quartzite \\
\hline Wood Canyon Formation & $C Z w$ & 2,300 & 700 & Micaceous Quartzite \\
\hline Stirling Quartzite & Zs & 2,900 & 890 & Quartzite \\
\hline Johnnie Formation & $\mathrm{Zj}$ & 3,000 & 914 & Quartzite/Siltstone/Limestone \\
\hline
\end{tabular}

a Stratigraphic and lithologic units adapted from Cole, 1992 and Slate et al., 1999.

b Estimates of combined thickness range from 2,350 meters (Poole et al., 1961) to 1,300 meters (Cole and Cashman, 1999). 
Table 4-3

Hydrogeologic Units of the Rainier Mesa-Shoshone Mountain Model

(Adapted from Winograd and Thordarson [1975]; IT [1996a]; and Laczniak et al. [1996])

\begin{tabular}{|c|c|c|}
\hline Hydrogeologic Unit & Typical Lithologies & Hydrologic Significance \\
\hline $\begin{array}{c}\text { Alluvial aquifer } \\
\text { (AA) } \\
\text { (AA is also an HSU } \\
\text { in the RM-SM } \\
\text { hydrogeologic model.) }\end{array}$ & $\begin{array}{l}\text { Unconsolidated to partially } \\
\text { consolidated gravelly sand, } \\
\text { eolian sand, and colluvium }\end{array}$ & $\begin{array}{l}\text { Has characteristics of a highly conductive } \\
\text { aquifer, but less so where lenses of clay-rich } \\
\text { paleocolluvium or zeolitic alteration are } \\
\text { present. }\end{array}$ \\
\hline $\begin{array}{l}\text { Welded-tuff aquifer } \\
\text { (WTA) }\end{array}$ & $\begin{array}{l}\text { Welded ash-flow tuff; vitric } \\
\text { to devitrified }\end{array}$ & $\begin{array}{l}\text { Degree of welding greatly affects interstitial } \\
\text { porosity (i.e., less porosity as degree of } \\
\text { welding increases) and permeability (i.e., } \\
\text { greater fracture permeability as degree of } \\
\text { welding increases). }\end{array}$ \\
\hline $\begin{array}{l}\text { Vitric-tuff aquifer } \\
\text { (VTA) }\end{array}$ & $\begin{array}{l}\text { Bedded tuff; ash-fall and } \\
\text { reworked tuff; vitric }\end{array}$ & $\begin{array}{l}\text { Constitutes a volumetrically minor HGU. } \\
\text { Generally does not extend far below the static } \\
\text { water level due to tendency of tuff to become } \\
\text { zeolitic under saturated conditions, which } \\
\text { drastically reduces permeability. Significant } \\
\text { interstitial porosity (i.e., } 20 \text { to } 40 \text { percent). } \\
\text { Generally insignificant fracture permeability. }\end{array}$ \\
\hline $\begin{array}{l}\text { Lava-flow aquifer } \\
\text { (LFA) }\end{array}$ & $\begin{array}{l}\text { Rhyolite, basalt and dacite } \\
\text { lava flows; includes flow } \\
\text { breccia (commonly at base) }\end{array}$ & $\begin{array}{l}\text { Generally occurs as small, moderately thick } \\
\text { (rhyolite) to thin (basalt) local flows. } \\
\text { Hydrologically complex, showing a wide range } \\
\text { of transmissivity values. Fracture density and } \\
\text { interstitial porosity differ with lithologic } \\
\text { variations. }\end{array}$ \\
\hline $\begin{array}{l}\text { Tuff confining unit } \\
\text { (TCU) }\end{array}$ & $\begin{array}{l}\text { Zeolitic bedded tuff with } \\
\text { interbedded, but less } \\
\text { significant, zeolitic, } \\
\text { nonwelded to partially } \\
\text { welded ash-flow tuff }\end{array}$ & $\begin{array}{l}\text { May be saturated but measured transmissivity } \\
\text { values are very low. May cause semi-perched } \\
\text { conditions. }\end{array}$ \\
\hline $\begin{array}{l}\text { Intra-caldera intrusive } \\
\text { confining unit (IICU) }\end{array}$ & $\begin{array}{l}\text { Highly altered, highly } \\
\text { injected/intruded country } \\
\text { rock and granitic material }\end{array}$ & $\begin{array}{l}\text { Assumed to be impermeable. Conceptually } \\
\text { underlies each of the SWNVF calderas. } \\
\text { Developed for this study to designate } \\
\text { basement beneath calderas as different from } \\
\text { basement outside calderas. }\end{array}$ \\
\hline $\begin{array}{l}\text { Granite confining unit } \\
\text { (GCU) }\end{array}$ & Quartz monzonite & $\begin{array}{l}\text { Saturated at depth but because of low } \\
\text { intergranular porosity and permeability, plus } \\
\text { the lack of inter-connecting fractures, is } \\
\text { considered a confining unit. }\end{array}$ \\
\hline $\begin{array}{l}\text { Clastic confining unit } \\
\text { (CCU) }\end{array}$ & Argillite, siltstone, quartzite & $\begin{array}{l}\text { Siliciclastic rocks are relatively impermeable; } \\
\text { coarser-grained siliciclastic rocks are fractured, } \\
\text { but with fracture porosity generally sealed due } \\
\text { to secondary mineralization. }\end{array}$ \\
\hline $\begin{array}{l}\text { Carbonate aquifer } \\
\text { (CA) }\end{array}$ & Dolomite, limestone & $\begin{array}{l}\text { Transmissivity values differ greatly and are } \\
\text { directly dependent on fracture frequency. }\end{array}$ \\
\hline
\end{tabular}




\subsubsection{Alluvial HGU}

Within the RM-SM area, the alluvial aquifer (AA; also an HSU) consists mainly of gravelly sand and sandy gravel eroded from the surrounding mountains during basin development, and deposited on alluvial fans by debris flow and sheet-flood processes. Similar deposits that filled the low moat area of the Timber Mountain caldera complex are also included in this HGU. The description for the AA HSU is included in Subsection 4.5.1.

\subsubsection{Volcanic HGUs}

The volcanic rocks within the study area are categorized into four HGUs based on primary lithologic properties, degree of fracturing, and secondary mineral alteration. In general, the altered volcanic rocks, which are typically zeolitized and support few fractures (Prothro, 1998), act as confining units, and the unaltered rocks form aquifers. The aquifer units are further divided into welded-tuff and vitric-tuff aquifers (depending on degree of welding) and lava-flow aquifers. Denser rocks, such as welded ash-flow tuff and lava flows, tend to fracture more readily and, therefore, have relatively high permeability (Blankennagel and Weir, 1973; Winograd and Thordarson, 1975; Laczniak et al., 1996; IT, 1996a; Prothro and Drellack, 1997).

An additional volcanic HGU, designated as the intra-caldera intrusive confining unit (IICU) was defined for the PM-OV model (BN, 2002a) and is included here to address the overlap area of the two models. Conceptually, an IICU underlies each of the SWNVF calderas. Although modeled as single intrusive masses, the exact nature of the rocks beneath the calderas is unknown, as no drill holes penetrate these rocks. It is assumed that these rocks range from highly altered, highly injected or intruded country rock to granite. The IICUs are considered to behave as confining units due to low primary porosity and low permeability where measured at other localities (such as in the granite of Climax stock [Walker, 1962]). Most fractures are probably filled with secondary minerals. The Climax stock in extreme northern Yucca Flat (Houser et al., 1961; Walker, 1962; Maldonado, 1977) and the Gold Meadows stock just north of Rainier Mesa (Snyder, 1977) may serve as analogs to the IICUs, though the effects of greater depth of the IICUs cannot be addressed by these analogs.

\subsubsection{Pre-Tertiary HGUs}

The hydrogeology of the pre-Tertiary sedimentary rocks at the NTS follows the framework developed by Winograd and Thordarson (1975), which was used in the Phase I regional modeling effort (IT, 1996a; 1996b; 1996c) and subsequent CAU-scale models (BN, 2002a; $2005 ; 2006)$. Within the study area, pre-Tertiary rocks are categorized as aquifer or confining unit HGUs based on lithology. The siliciclastic rocks, such as quartzite, siltstone, and shale, are 
classified as clastic confining units. The granitic intrusive rocks are classified as confining units. Carbonate rocks, such as limestone and dolomite, are classified as carbonate aquifers (Winograd and Thordarson, 1975; Laczniak et al., 1996).

\subsection{Hydrostratigraphic Units of the Rainier Mesa-Shoshone Mountain Model Area}

The following sections describe all the HSUs in the RM-SM hydrostratigraphic framework model. They are generally listed in descending order from the top of the model to the bottom, though some are laterally rather than vertically contiguous, and not all units are present in all parts of the model area. Summaries of the characteristics of each HSU in the RM-SM model are given in Table 4-4. Table 4-5 shows the correlation of RM-SM HSUs with HSUs of other hydrostratigraphic framework models of the NTS region.

The geometric configuration of the HSUs, as defined in the model, is represented in 3-D perspective views and 2-D plan maps and profiles in various figures throughout this report. Contour maps depicting depth to saturated aquifer HSUs are introduced as necessary to aid in the description of the HSUs. The correlation of stratigraphic units and hydrostratigraphic units of the RM-SM model area is depicted graphically in Figure 4-3. Figure 4-4 is an HSU surface map (see also Plate 2, the same map produced at a larger scale). Profiles A-A' through G-G', which illustrate the relationships of the HSUs and structures in various vertical planes, can be found in Appendix C. The locations of these profile lines are shown on Figures 2-3 and C-1, and on Plate 2.

\subsubsection{Alluvial Aquifer (AA)}

This HSU consists of Quaternary- and Tertiary-age basin-filling alluvium such as that mapped at the surface in the western, eastern, and southern portions of the model area (labeled as Qay, QTc, Qai, QTa, Tgy, and Tgc in Slate et al., 1999) (Figure 1-5; Plates 1 and 2). Although the AA is considered the highest (i.e., youngest) HSU in the model (Figure 4-3), stratigraphically, it consists of alluvial debris as young as recent alluvium found in active drainages, and as old as tuffaceous gravels that may correlate time-stratigraphically with the Volcanics of Fortymile Canyon, which were erupted between 11.45 and 9.4 Ma (Sawyer et al., 1994).

The alluvium throughout most of the NTS area, including the RM-SM model area, is a friable to moderately consolidated, poorly sorted mixture of detritus derived from volcanic and Paleozoic sedimentary rocks, ranging in particle size from clay to boulders. Sediment deposition is largely in the form of alluvial fans which coalesce to form discontinuous, gradational, and poorly sorted deposits. 
Table 4-4

Hydrostratigraphic Units of the Rainier Mesa-Shoshone Mountain Hydrostratigraphic Framework Model

\begin{tabular}{|c|c|c|c|c|}
\hline Hydrostratigraphic Unit & $\begin{array}{c}\text { Dominant } \\
\text { Hydrogeologic } \\
\text { Units }^{\text {a }}\end{array}$ & $\begin{array}{c}\text { Typical } \\
\text { Lithologies }\end{array}$ & $\begin{array}{l}\text { Stratigraphic } \\
\text { Unit Map } \\
\text { Symbol(s) } \\
\end{array}$ & Hydrologic Significance \\
\hline $\begin{array}{l}\text { Alluvial aquifer } \\
\text { (AA) }\end{array}$ & AA & $\begin{array}{l}\text { Alluvium: Gravelly } \\
\text { sand; also includes } \\
\text { colluvium and older } \\
\text { moat-filling } \\
\text { sediments around } \\
\text { the Timber Mtn. } \\
\text { caldera }\end{array}$ & $\begin{array}{l}\text { Qay, QTc, Qai, } \\
\text { QTa, Tgy, Tgc }\end{array}$ & Generally unsaturated except in deepest basins. \\
\hline $\begin{array}{l}\text { Fortymile Canyon } \\
\text { composite unit } \\
\text { (FCCM) }\end{array}$ & $\begin{array}{l}\text { LFA, TCU, } \\
\text { lesser WTA }\end{array}$ & $\begin{array}{l}\text { Lava flows, lesser } \\
\text { ash-flow and } \\
\text { bedded tuffs }\end{array}$ & $\begin{array}{l}\text { Tfu, Tfs, Tfd, Tfr, } \\
\text { Tfb, Tfl, Tff }\end{array}$ & $\begin{array}{l}\text { Consists of a complex and poorly understood distribution } \\
\text { of lava and associated tuff of the Volcanics of Fortymile } \\
\text { Canyon. Generally confined within the moat of the Timber } \\
\text { Mountain caldera complex, where the unit forms a ring } \\
\text { around Timber Mountain. Unit is also present in areas } \\
\text { southwest of the Timber Mountain caldera complex. }\end{array}$ \\
\hline $\begin{array}{l}\text { Timber Mountain upper } \\
\text { vitric-tuff aquifer } \\
\text { (TM-UVTA) }\end{array}$ & $\begin{array}{l}\text { VTA, } \\
\text { minor WTA }\end{array}$ & $\begin{array}{l}\text { Includes vitric } \\
\text { nonwelded to } \\
\text { partially welded } \\
\text { ash-flow and } \\
\text { bedded tuff }\end{array}$ & Tma, Tmab & $\begin{array}{l}\text { Typically saturated only in the deepest structural basins } \\
\text { (i.e., Yucca Flat and Mid Valley). This HSU comprises } \\
\text { only the non- to partially welded Ammonia Tanks Tuff, } \\
\text { which stratigraphically overlies the TM-WTA in Yucca Flat } \\
\text { and Mid Valley. }\end{array}$ \\
\hline $\begin{array}{l}\text { Timber Mountain } \\
\text { welded-tuff aquifer } \\
\text { (TM-WTA) }\end{array}$ & $\begin{array}{l}\text { WTA } \\
\text { minor VTA }\end{array}$ & $\begin{array}{l}\text { Partially to densely } \\
\text { welded ash-flow } \\
\text { tuff; vitric to } \\
\text { devitrified, minor } \\
\text { nonwelded tuff }\end{array}$ & Tma, Tmab, Tmr & $\begin{array}{l}\text { Typically saturated only in deep structural basins (i.e., Mid } \\
\text { Valley). Strongly welded zones typically sandwiched } \\
\text { between less welded zones. Prolific aquifer where } \\
\text { saturated. }\end{array}$ \\
\hline $\begin{array}{l}\text { Timber Mountain lower } \\
\text { vitric-tuff aquifer } \\
\text { (TM-LVTA) }\end{array}$ & VTA & $\begin{array}{l}\text { Nonwelded ash- } \\
\text { flow and bedded } \\
\text { tuff; vitric }\end{array}$ & $\begin{array}{l}\text { Tma, Tmab, Tmr, } \\
\text { Tmrh, Tp, Th, } \\
\text { Tw, Tc; may also } \\
\text { include Tbgb, } \\
\text { and Tn }\end{array}$ & $\begin{array}{l}\text { Typically includes the nonzeolitized, nonwelded lower } \\
\text { portion of the Rainier Mesa Tuff and post-Tunnel } \\
\text { Formation units. However, in places this HSU } \\
\text { encompasses all nonzeolitized, nonwelded and bedded } \\
\text { units below the welded Rainier Mesa Tuff and above the } \\
\text { upper level of pervasive zeolitization. Unaltered } \\
\text { nonwelded and ash-fall tuffs generally not found at depths } \\
\text { much below the static water level due to tendency to } \\
\text { become zeolitized (which drastically reduces permeability) } \\
\text { under saturated conditions. }\end{array}$ \\
\hline
\end{tabular}


Table 4-4

Hydrostratigraphic Units of the Rainier Mesa-Shoshone Mountain Hydrostratigraphic Framework Model (continued)

\begin{tabular}{|c|c|c|c|c|}
\hline Hydrostratigraphic Unit & $\begin{array}{c}\text { Dominant } \\
\text { Hydrogeologic }^{\text {Units }}{ }^{\text {a }} \\
\end{array}$ & $\begin{array}{c}\text { Typical } \\
\text { Lithologies }\end{array}$ & $\begin{array}{l}\text { Stratigraphic } \\
\text { Unit Map } \\
\text { Symbol(s) } \\
\end{array}$ & Hydrologic Significance \\
\hline $\begin{array}{l}\text { Timber Mountain } \\
\text { composite unit } \\
\text { (TMCM) }\end{array}$ & $\begin{array}{l}\text { TCU (altered } \\
\text { tuffs, lavas) and } \\
\text { unaltered WTA } \\
\text { and lesser LFA }\end{array}$ & $\begin{array}{l}\text { Welded ash-flow } \\
\text { tuffs, lava flows }\end{array}$ & $\begin{array}{c}\text { Tmay, Tmaw, } \\
\text { Tma, Tmx, Tmat, } \\
\text { Tmt, Tmr }\end{array}$ & $\begin{array}{l}\text { Consists mainly of intra-caldera, strongly welded ash-flow } \\
\text { tuff of the Timber Mountain Group, and is confined within } \\
\text { the Timber Mountain caldera complex. Although } \\
\text { consisting mainly of strongly welded tuff which is assumed } \\
\text { to be considerably fractured and thus behave as an } \\
\text { aquifer, the TMCM is designated as a composite unit } \\
\text { because of the potential for hydrothermal alteration within } \\
\text { this deep intra-caldera setting. Alteration would have } \\
\text { significantly altered the hydraulic properties of the rocks, } \\
\text { particularly filling fractures with secondary minerals such } \\
\text { as quartz. }\end{array}$ \\
\hline $\begin{array}{l}\text { Rainier Mesa breccia } \\
\text { confining unit } \\
\text { (RMBCU) }\end{array}$ & TCU/AA & Landslide breccias & Tmrx & $\begin{array}{l}\text { Very limited areal extent; wedge-shaped volume inside } \\
\text { the structural margin of caldera. Breccia blocks within an } \\
\text { argillic matrix. }\end{array}$ \\
\hline $\begin{array}{l}\text { Sub-caldera volcanic } \\
\text { confining unit } \\
\text { (SCVCU) }\end{array}$ & TCU & $\begin{array}{l}\text { Highly altered pre- } \\
\text { Tm volcanic units }\end{array}$ & $\begin{array}{l}\text { Tm, Tp, Tc, and } \\
\text { older } \\
\text { undifferentiated } \\
\text { tuffs }\end{array}$ & $\begin{array}{l}\text { A highly conjectural unit that is modeled as consisting of } \\
\text { highly altered volcanic rocks that occur stratigraphically } \\
\text { between the Rainier Mesa Tuff and basement rocks } \\
\text { (ATICU and RMICU) within the deeper portions of the } \\
\text { Timber Mountain caldera complex. }\end{array}$ \\
\hline $\begin{array}{c}\text { Tiva Canyon aquifer } \\
\text { (TCA) }\end{array}$ & WTA & $\begin{array}{l}\text { Welded ash-flow } \\
\text { tuff }\end{array}$ & Tpc & Includes only the welded Tiva Canyon Tuff \\
\hline $\begin{array}{l}\text { Paintbrush vitric } \\
\text { tuff aquifer } \\
\text { (PVTA) }\end{array}$ & VTA & Bedded tuff, vitric & $\mathrm{Tp}(\mathrm{b})$ & $\begin{array}{l}\text { Unaltered bedded tuffs between the welded Tpc and Tpt } \\
\text { ash-flow tuffs. Included with the TM-LVTA where welded } \\
\text { Tpc is not present. }\end{array}$ \\
\hline $\begin{array}{l}\text { Upper } \\
\text { tuff confining unit } \\
\text { (UTCU) }\end{array}$ & TCU & $\begin{array}{l}\text { Zeolitized bedded } \\
\text { tuff }\end{array}$ & $\begin{array}{c}\text { Tmr (lowermost), } \\
\text { Tmrh, Tp }\end{array}$ & $\begin{array}{l}\text { Defined to encompass the zeolitized bedded tuffs which } \\
\text { stratigraphically overlie the Topopah Spring aquifer (TSA). } \\
\text { Although some geologic units of the UTCU are laterally } \\
\text { continuous with those of the LTCU, the UTCU is limited } \\
\text { areally to extreme southern Yucca Flat and Mid Valley } \\
\text { where the welded Topopah Spring Tuff is an important } \\
\text { aquifer present between the two tuff confining units } \\
\text { (UTCU and LTCU). }\end{array}$ \\
\hline
\end{tabular}


Table 4-4

Hydrostratigraphic Units of the Rainier Mesa-Shoshone Mountain Hydrostratigraphic Framework Model (continued)

\begin{tabular}{|c|c|c|c|c|}
\hline Hydrostratigraphic Unit & $\begin{array}{c}\text { Dominant } \\
\begin{array}{c}\text { Hydrogeologic } \\
\text { Units }^{\text {a }}\end{array} \\
\end{array}$ & $\begin{array}{c}\text { Typical } \\
\text { Lithologies }\end{array}$ & $\begin{array}{l}\text { Stratigraphic } \\
\text { Unit Map } \\
\text { Symbol(s) } \\
\end{array}$ & Hydrologic Significance \\
\hline $\begin{array}{l}\text { Topopah Spring aquifer } \\
\text { (TSA) }\end{array}$ & $\begin{array}{l}\text { WTA } \\
\text { minor VTA }\end{array}$ & $\begin{array}{l}\text { Welded ash-flow } \\
\text { tuff }\end{array}$ & Tpt & $\begin{array}{l}\text { Distribution in the RM-SM model area is limited to the } \\
\text { southern portion. Hydrogeologic properties are similar to } \\
\text { those of the TM-WTA. Prolific aquifer where saturated. }\end{array}$ \\
\hline $\begin{array}{l}\text { Lower vitric tuff aquifer } \\
\text { (LVTA) }\end{array}$ & VTA & $\begin{array}{l}\text { Nonwelded and } \\
\text { bedded tuff; vitric }\end{array}$ & Th (formerly Tac) & $\begin{array}{l}\text { Relatively thin VTA unit below the TSA. Grouped with the } \\
\text { TM-LVTA where the TSA welded ash-flow tuff is not } \\
\text { present. }\end{array}$ \\
\hline $\begin{array}{l}\text { Calico Hills } \\
\text { vitric-tuff aquifer } \\
\text { (CHVTA) }\end{array}$ & VTA & $\begin{array}{l}\text { Nonwelded and } \\
\text { bedded tuff; vitric }\end{array}$ & Th & $\begin{array}{l}\text { Structurally high, vitric, nonwelded tuffs of the Calico Hills } \\
\text { Formation. Present in the northwestern portion of the } \\
\text { model area beneath the eastern portion of Area 19. May } \\
\text { become partly zeolitic in the lower portions. }\end{array}$ \\
\hline $\begin{array}{l}\text { Yucca Mountain Calico } \\
\text { Hills lava-flow aquifer } \\
\text { (YMCHLFA) }\end{array}$ & LFA & Lava flow & Th & $\begin{array}{l}\text { Minor HSU in the southwest corner of the model area. } \\
\text { Consists mainly of rhyolitic lava flows. }\end{array}$ \\
\hline $\begin{array}{l}\text { Kearsarge aquifer } \\
\text { (KA) }\end{array}$ & LFA & Lava flow & Tcpk & $\begin{array}{l}\text { Minor HSU in the Pahute Mesa area that consists of the } \\
\text { lava-flow lithofacies of rhyolite of Kearsarge. Unit is } \\
\text { present as a small isolated occurrence in the northwestern } \\
\text { portion of the model area. }\end{array}$ \\
\hline $\begin{array}{l}\text { Upper } \\
\text { tuff confining unit } 2 \\
\text { (UTCU2) }\end{array}$ & TCU & $\begin{array}{l}\text { Zeolitized bedded } \\
\text { tuff }\end{array}$ & $\mathrm{Tp}(\mathrm{b}), \mathrm{Tc}$ & $\begin{array}{l}\text { Defined to encompass the zeolitized bedded tuffs which } \\
\text { stratigraphically overlie the Stockade Wash welded tuff } \\
\text { aquifer (SWA). Although some geologic units of the } \\
\text { UTCU2 are laterally continuous with those of the UTCU1, } \\
\text { the UTCU2 is limited areally to the Rainier Mesa area } \\
\text { where the welded Stockade Wash Tuff is present within } \\
\text { zeolitic bedded tuff confining units (defined here as } \\
\text { UTCU2 and UTCU1). }\end{array}$ \\
\hline $\begin{array}{l}\text { Stockade Wash aquifer } \\
\text { (SWA) }\end{array}$ & $\begin{array}{l}\text { WTA } \\
\text { minor VTA }\end{array}$ & $\begin{array}{l}\text { Weakly welded } \\
\text { ash-flow tuff }\end{array}$ & Tcbs, Tcb & $\begin{array}{l}\text { Distribution in the RM-SM model area is limited to the } \\
\text { central portion. Hydrogeologic properties are believed to } \\
\text { be between those of the TM-WTA and the TM-LVTA. }\end{array}$ \\
\hline
\end{tabular}


Table 4-4

Hydrostratigraphic Units of the Rainier Mesa-Shoshone Mountain Hydrostratigraphic Framework Model (continued)

\begin{tabular}{|c|c|c|c|c|}
\hline Hydrostratigraphic Unit & $\begin{array}{c}\text { Dominant } \\
\text { Hydrogeologic }_{\text {Units }^{\mathrm{a}}} \\
\end{array}$ & $\begin{array}{c}\text { Typical } \\
\text { Lithologies }\end{array}$ & $\begin{array}{l}\text { Stratigraphic } \\
\text { Unit Map } \\
\text { Symbol(s) } \\
\end{array}$ & Hydrologic Significance \\
\hline $\begin{array}{l}\text { Lower vitric-tuff aquifer } 2 \\
\text { (LVTA2) }\end{array}$ & VTA & $\begin{array}{l}\text { Nonwelded and } \\
\text { bedded tuff; vitric }\end{array}$ & Tc, Tn & $\begin{array}{l}\text { Relatively thin VTA unit below the SWA. Grouped with } \\
\text { the TM-LVTA or LVTA where the SWA welded ash-flow } \\
\text { tuff is not present. }\end{array}$ \\
\hline $\begin{array}{l}\text { Bullfrog confining unit } \\
\text { (BFCU) }\end{array}$ & TCU & $\begin{array}{l}\text { Zeolitic nonwelded } \\
\text { tuff }\end{array}$ & $\mathrm{Tcb}$ & $\begin{array}{l}\text { Major confining unit in the northwestern (Pahute Mesa) } \\
\text { portion of the model area. Unit consists of thick intra- } \\
\text { caldera, zeolitic, mostly nonwelded tuff of the Bullfrog } \\
\text { Formation. }\end{array}$ \\
\hline $\begin{array}{l}\text { Upper tuff confining unit } 1 \\
\text { (UTCU1) }\end{array}$ & TCU & $\begin{array}{l}\text { Zeolitized bedded } \\
\text { tuff }\end{array}$ & Th, Tc & $\begin{array}{l}\text { Defined to encompass the zeolitized bedded tuffs which } \\
\text { stratigraphically overlie the BRA. Although some geologic } \\
\text { units of the UTCU1 are laterally continuous with those of } \\
\text { the LTCU and/or the UTCU2, the UTCU1 is limited areally } \\
\text { to the northern portion of the model area where the } \\
\text { welded Grouse Canyon Tuff is present between the two } \\
\text { tuff confining units (UTCU1 and LTCU). }\end{array}$ \\
\hline $\begin{array}{l}\text { Belted Range aquifer } \\
\qquad \text { (BRA) }\end{array}$ & LFA and WTA & $\begin{array}{l}\text { Lava and welded } \\
\text { ash-flow tuff }\end{array}$ & $\mathrm{Tb}$ & $\begin{array}{l}\text { Consists mainly of devitrified welded ash-flow tuff and } \\
\text { lava, with lesser amounts of associated zeolitic } \\
\text { nonwelded tuff and lava. Stratigraphically, these rocks } \\
\text { are mostly assigned to the Belted Range Group. The } \\
\text { BRA is present in the northern portion of the model area, } \\
\text { where it is typically unsaturated. }\end{array}$ \\
\hline $\begin{array}{l}\text { Lower vitric tuff aquifer } 1 \\
\text { (LVTA1) }\end{array}$ & VTA & Bedded tuff; vitric & $\operatorname{Tbg}(b), \operatorname{Tn} 4$ & $\begin{array}{l}\text { Relatively thin VTA unit below the BRA. Grouped with the } \\
\text { TM-LVTA or LVTA where the BRA welded ash-flow tuff is } \\
\text { not present. }\end{array}$ \\
\hline $\begin{array}{l}\text { Belted Range } \\
\text { confining unit } \\
\text { (BRCU) }\end{array}$ & TCU & $\begin{array}{l}\text { Zeolitized bedded } \\
\text { tuff }\end{array}$ & Tn, Tn4, Tn3 & $\begin{array}{l}\text { Generally includes all zeolitized tuffs between the } \\
\text { (welded) Grouse Canyon Tuff and the (welded) Tub } \\
\text { Spring Tuff. Limited to the northern NTS. }\end{array}$ \\
\hline $\begin{array}{l}\text { Tub Spring aquifer } \\
\text { (TUBA) }\end{array}$ & WTA & $\begin{array}{l}\text { Welded ash-flow } \\
\text { tuff }\end{array}$ & Tub & $\begin{array}{l}\text { Comprises only the welded Tub Spring Tuff and is, thus, } \\
\text { limited to the northeastern NTS. }\end{array}$ \\
\hline
\end{tabular}


Table 4-4

Hydrostratigraphic Units of the Rainier Mesa-Shoshone Mountain Hydrostratigraphic Framework Model (continued)

\begin{tabular}{|c|c|c|c|c|}
\hline Hydrostratigraphic Unit & $\begin{array}{c}\text { Dominant } \\
\text { Hydrogeologic }^{\text {Units }}{ }^{\mathrm{a}} \\
\end{array}$ & $\begin{array}{c}\text { Typical } \\
\text { Lithologies }\end{array}$ & $\begin{array}{c}\text { Stratigraphic } \\
\text { Unit Map } \\
\text { Symbol(s) }^{b} \\
\end{array}$ & Hydrologic Significance \\
\hline $\begin{array}{l}\text { Lower } \\
\text { tuff confining unit } \\
(\text { LTCU) }\end{array}$ & $\mathrm{TCU}$ & $\begin{array}{l}\text { Zeolitized bedded } \\
\text { tuffs with } \\
\text { interbedded but } \\
\text { less significant } \\
\text { zeolitized, } \\
\text { nonwelded to } \\
\text { partially welded } \\
\text { ash-flow tuffs }\end{array}$ & $\begin{array}{l}\text { Tmrh, Tp, Th, } \\
\text { Tw, Tc, Tn, Tub, } \\
\text { Ton2, To, Tlt }\end{array}$ & $\begin{array}{l}\text { Generally includes all older zeolitized tuffs in the central } \\
\text { and eastern NTS area. Stratigraphically the LTCU may } \\
\text { include all units from the base of the Rainier Mesa Tuff to } \\
\text { the top of the Paleozoic rocks. The strongly argillized } \\
\text { older tuffs and paleocolluvium that immediately overlie } \\
\text { pre-Tertiary rocks may also be included. The uppermost } \\
\text { zeolitized bedded tuffs overlying the TSA in central and } \\
\text { eastern NTS form a separate HSU (the UTCU). } \\
\text { Subdivided into the LTCU, OSBCU and ATCU where } \\
\text { there is sufficient drill-hole control. }\end{array}$ \\
\hline $\begin{array}{l}\text { Oak Spring Butte } \\
\text { confining unit } \\
\text { (OSBCU) }\end{array}$ & $\mathrm{TCU}$ & $\begin{array}{l}\text { Devitrified to } \\
\text { zeolitic non- to } \\
\text { partially welded } \\
\text { tuffs and } \\
\text { intervening bedded } \\
\text { tuffs }\end{array}$ & $\begin{array}{l}\text { Ton2, To, Toy, } \\
\text { Ton1, Tor, Tot }\end{array}$ & $\begin{array}{l}\text { Includes altered older ash-flow tuff units and the } \\
\text { intervening bedded tuffs (e.g., tunnel bed } 1 \text { and } \\
\text { undifferentiated older bedded tuffs; if Tub Spring Tuff is } \\
\text { present, then tunnel bed } 2 \text { is also included). Welding in } \\
\text { the older ash-flow units may increase overall hydraulic } \\
\text { conductivity. Devitrification of the ash flow units may have } \\
\text { limited zeolitization. Differentiated, data permitting. }\end{array}$ \\
\hline $\begin{array}{l}\text { Redrock Valley aquifer } \\
\text { (RVA) }\end{array}$ & WTA & $\begin{array}{l}\text { Welded ash-flow } \\
\text { tuff, devitrified }\end{array}$ & Tor, Tot & $\begin{array}{l}\text { Includes only the welded lithofacies of the Redrock Valley } \\
\text { Tuff in central and northern NTS. Where not strongly } \\
\text { welded, lumped with the OSBCU or the LTCU. }\end{array}$ \\
\hline $\begin{array}{l}\text { Redrock Valley breccia } \\
\text { confining unit } \\
\text { (RVBCU) }\end{array}$ & TCU/AA & Landslide breccias & Torx & $\begin{array}{l}\text { Very limited areal extent; wedge-shaped volume inside } \\
\text { the structural margin of caldera. Breccia blocks within an } \\
\text { argillic matrix. }\end{array}$ \\
\hline $\begin{array}{l}\text { Lower tuff confining unit } 1 \\
\qquad \text { (LTCU1) }\end{array}$ & TCU & $\begin{array}{l}\text { Zeolitized bedded } \\
\text { tuffs }\end{array}$ & To & $\begin{array}{l}\text { Zeolitic bedded tuffs below the welded Redrock Valley } \\
\text { Tuff. Separates overlying RVA from pre-Tertiary units } \\
\text { and/or ATCU. }\end{array}$ \\
\hline $\begin{array}{l}\text { Twin Peaks aquifer } \\
\text { (TPA) }\end{array}$ & WTA & $\begin{array}{l}\text { Welded ash-flow } \\
\text { tuff }\end{array}$ & Tot & $\begin{array}{l}\text { Includes only the welded lithofacies of the tuff of Twin } \\
\text { Peaks in central and northern NTS. Where not strongly } \\
\text { welded, is lumped with the OSBCU or the LTCU. Defined } \\
\text { only for the "No Redrock Valley Caldera" alternative; } \\
\text { otherwise lumped with the RVA. }\end{array}$ \\
\hline
\end{tabular}


Table 4-4

Hydrostratigraphic Units of the Rainier Mesa-Shoshone Mountain Hydrostratigraphic Framework Model (continued)

\begin{tabular}{|c|c|c|c|c|}
\hline Hydrostratigraphic Unit & $\begin{array}{c}\text { Dominant } \\
\text { Hydrogeologic } \\
\text { Units }^{\text {a }}\end{array}$ & $\begin{array}{c}\text { Typical } \\
\text { Lithologies }\end{array}$ & $\begin{array}{c}\text { Stratigraphic } \\
\text { Unit Map } \\
\text { Symbol(s) } \\
\text { by }\end{array}$ & Hydrologic Significance \\
\hline $\begin{array}{l}\text { Argillic tuff confining unit } \\
\text { (ATCU) }\end{array}$ & TCU & $\begin{array}{l}\text { Argillic bedded } \\
\text { tuffs, minor } \\
\text { paleocolluvium }\end{array}$ & To, Tlt & $\begin{array}{l}\text { Includes the argillic, lowermost Tertiary volcanic units and } \\
\text { paleocolluvium that immediately overlie the pre-Tertiary } \\
\text { rocks. }\end{array}$ \\
\hline $\begin{array}{l}\text { Ammonia Tanks } \\
\text { intrusive } \\
\text { confining unit } \\
\text { (ATICU) }\end{array}$ & $\mathrm{IICU}$ & $\begin{array}{l}\text { Intrusive (granite?) } \\
\text { and altered, older } \\
\text { host rocks }\end{array}$ & Tmai & \multirow{4}{*}{$\begin{array}{l}\text { Although modeled as single intrusive masses beneath } \\
\text { each of the Ammonia Tanks, Rainier Mesa, and Silent } \\
\text { Canyon calderas, and the Calico Hills area, the actual } \\
\text { nature of these units is unknown. They may consist } \\
\text { exclusively of igneous intrusive rocks, or older volcanic } \\
\text { and pre-Tertiary sedimentary rocks that are intruded to } \\
\text { varying degrees by igneous rocks ranging in composition } \\
\text { from granite to basalt. }\end{array}$} \\
\hline $\begin{array}{l}\text { Rainier Mesa } \\
\text { intrusive } \\
\text { confining unit } \\
\text { (RMICU) } \\
\end{array}$ & $\mathrm{IICU}$ & $\begin{array}{l}\text { Intrusive (granite?) } \\
\text { and altered, older } \\
\text { host rocks }\end{array}$ & Tmri & \\
\hline $\begin{array}{l}\text { Calico Hills } \\
\text { intrusive } \\
\text { confining unit } \\
(\mathrm{CHICU})\end{array}$ & $\mathrm{IICU}$ & $\begin{array}{l}\text { Intrusive (granite?) } \\
\text { and altered, older } \\
\text { host rocks }\end{array}$ & Thi & \\
\hline $\begin{array}{l}\text { Silent Canyon } \\
\text { intrusive confining unit } \\
\text { (SCICU) }\end{array}$ & $\mathrm{IICU}$ & $\begin{array}{l}\text { Highly altered older } \\
\text { volcanic rocks and } \\
\text { pre-Tertiary } \\
\text { sedimentary rocks } \\
\text { and granitic } \\
\text { intrusive masses. }\end{array}$ & $\mathrm{Tc}, \mathrm{Tb}$ & \\
\hline $\begin{array}{l}\text { Redrock Valley intrusive } \\
\text { confining unit } \\
\text { (RVICU) }\end{array}$ & $\mathrm{IICU}$ & $\begin{array}{l}\text { Highly altered } \\
\text { injected/intruded } \\
\text { country rock and } \\
\text { granitic material }\end{array}$ & Tori, Toti & $\begin{array}{l}\text { Although modeled as a single intrusive mass beneath the } \\
\text { caldera, the actual nature of this unit is unknown. It may } \\
\text { consist exclusively of igneous intrusive rocks, or older } \\
\text { volcanic and pre-Tertiary sedimentary rocks that are } \\
\text { intruded to varying degrees by igneous rocks ranging in } \\
\text { composition from granite to basalt. }\end{array}$ \\
\hline
\end{tabular}


Table 4-4

Hydrostratigraphic Units of the Rainier Mesa-Shoshone Mountain Hydrostratigraphic Framework Model (continued)

\begin{tabular}{|c|c|c|c|c|}
\hline Hydrostratigraphic Unit & $\begin{array}{c}\text { Dominant } \\
\text { Hydrogeologic }^{\text {Units }^{\mathrm{a}}} \\
\end{array}$ & $\begin{array}{c}\text { Typical } \\
\text { Lithologies }\end{array}$ & $\begin{array}{l}\text { Stratigraphic } \\
\text { Unit Map } \\
\text { Symbol(s) }\end{array}$ & Hydrologic Significance \\
\hline $\begin{array}{l}\text { Mesozoic granite } \\
\text { confining unit } \\
\text { (MGCU) }\end{array}$ & GCU & $\begin{array}{l}\text { Granodiorite and } \\
\text { quartz monzonite }\end{array}$ & $\mathrm{Kgc}, \mathrm{Kgg}$ & $\begin{array}{l}\text { Includes two intrusives: Climax and Gold Meadows. } \\
\text { Based on observations at the Climax site, the granite has } \\
\text { very low permeability, and is considered to be a confining } \\
\text { unit. Locally may have perched water contained within } \\
\text { fractures. The two stocks may be connected at depth and } \\
\text { are suspected to be the primary component of a } \\
\text { hydrologic barrier at the north end of the NTS. }\end{array}$ \\
\hline $\begin{array}{l}\text { Lower clastic confining } \\
\text { unit - upper thrust plate } \\
\text { (LCCU1) }\end{array}$ & $\mathrm{CCU}$ & $\begin{array}{l}\text { Quartzite and } \\
\text { siltstone }\end{array}$ & $\begin{array}{l}\text { Lower Cc, Cz, } \\
\text { CZw, Zs, Zj }\end{array}$ & $\begin{array}{l}\text { Includes upper Proterozoic through lower Cambrian units } \\
\text { that have been thrust over younger units. }\end{array}$ \\
\hline $\begin{array}{l}\text { Lower carbonate aquifer - } \\
\text { upper thrust plate } \\
\text { (LCA3) }\end{array}$ & $\mathrm{CA}$ & $\begin{array}{l}\text { Limestone and } \\
\text { dolomite }\end{array}$ & $\begin{array}{l}\text { Dg through } \\
\text { upper Cc }\end{array}$ & $\begin{array}{l}\text { Includes the Cambrian through Devonian units that have } \\
\text { been thrust over the Eleana Formation and the Chainman } \\
\text { Shale. }\end{array}$ \\
\hline $\begin{array}{l}\text { Upper carbonate aquifer } \\
\text { (UCA) }\end{array}$ & $\mathrm{CA}$ & Limestone & PPt & $\begin{array}{l}\text { Includes the Tippipah Limestone (correlative with the Bird } \\
\text { Spring Formation) which stratigraphically overlies the } \\
\text { Chainman Shale at Syncline Ridge and, thus, may contain } \\
\text { perched water. }\end{array}$ \\
\hline $\begin{array}{l}\text { Upper clastic } \\
\text { confining unit } \\
\quad \text { (UCCU) }\end{array}$ & $\mathrm{CCU}$ & $\begin{array}{l}\text { Argillite and } \\
\text { quartzite }\end{array}$ & Mc, MDe & $\begin{array}{l}\text { As much as } 2,745 \mathrm{~m}(9,000 \mathrm{ft}) \text { thick. Typically forms foot } \\
\text { walls of Mesozoic thrust faults in NTS region. }\end{array}$ \\
\hline $\begin{array}{l}\text { Lower carbonate aquifer } \\
\text { (LCA) }\end{array}$ & $\mathrm{CA}$ & $\begin{array}{l}\text { Dolomite and } \\
\text { limestone }\end{array}$ & $\begin{array}{l}\text { Dg through } \\
\text { upper Cc }\end{array}$ & $\begin{array}{l}\text { Important regional aquifer underlying most of southern } \\
\text { Nevada. Composite thickness up to } 4,430 \mathrm{~m}(14,500 \mathrm{ft}) \text {. } \\
\text { Transmissivity values vary greatly and are directly } \\
\text { dependent on fracture and fault frequency. }\end{array}$ \\
\hline $\begin{array}{l}\text { Lower clastic } \\
\text { confining unit } \\
\quad \text { (LCCU) }\end{array}$ & $\mathrm{CCU}$ & $\begin{array}{l}\text { Quartzite and } \\
\text { siltstone }\end{array}$ & $\begin{array}{l}\text { Lower Cc, Cz, } \\
\text { CZw, Zs, Zj }\end{array}$ & $\begin{array}{l}\text { Significant regional confining unit. Composite thickness } \\
\text { about } 2,870 \mathrm{~m}(9,400 \mathrm{ft}) \text {. May present barrier to deep } \\
\text { regional groundwater flow where structurally high. (e.g., } \\
\text { northeastern Yucca Flat). Hydrologic "basement" present } \\
\text { at great depth in the model area. }\end{array}$ \\
\hline
\end{tabular}

a See Table 4-3 for definitions of hydrogeologic units.

b See Tables 4-1 and 4-2 for definitions of stratigraphic unit map symbols. 
Table 4-5

Correlation of Hydrostratigraphic Units of the Rainier Mesa-Shoshone Mountain Model and Earlier Models

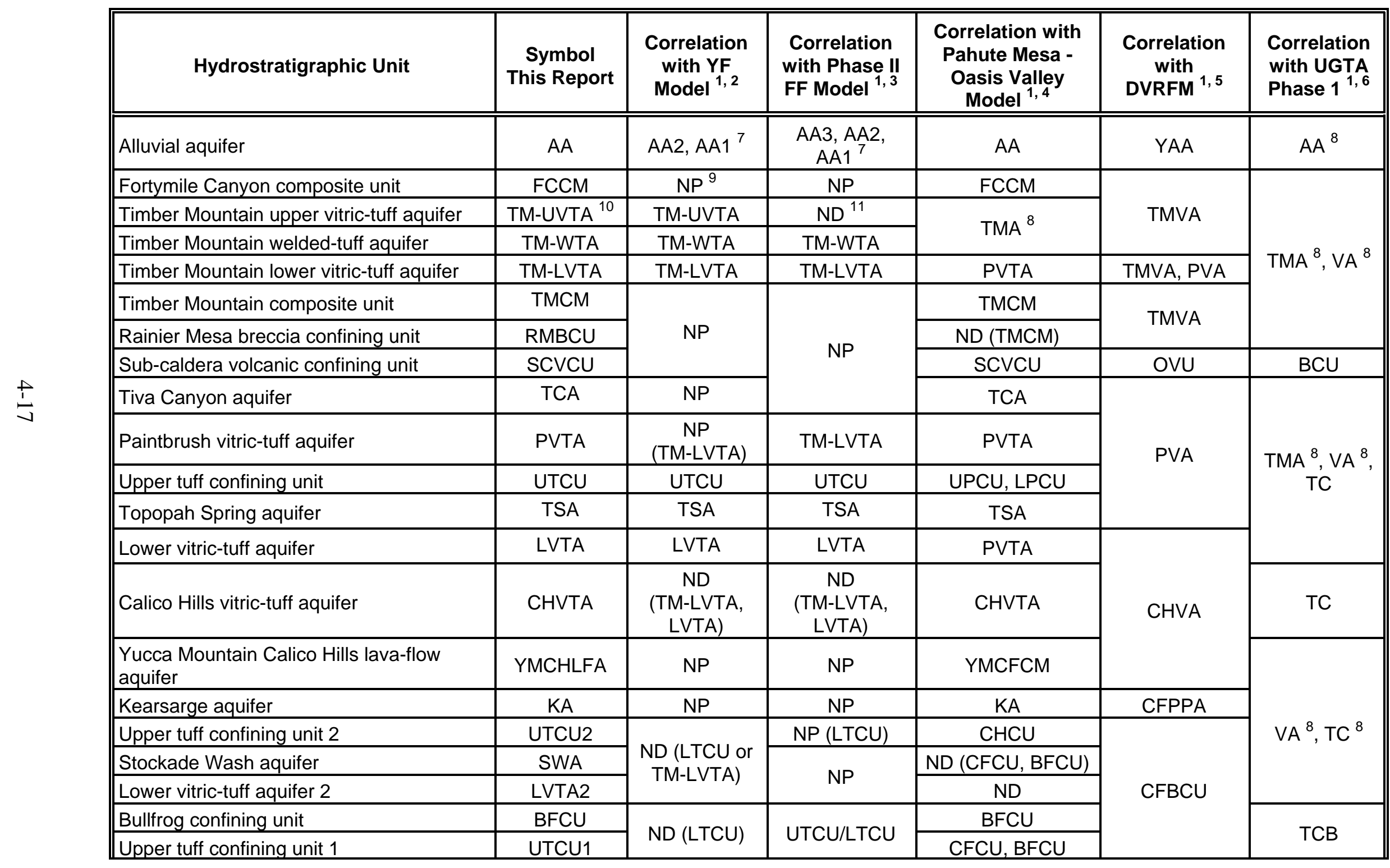


Table 4-5

Correlation of Hydrostratigraphic Units of the Rainier Mesa-Shoshone Mountain Model and Earlier Models

(continued)

\begin{tabular}{|c|c|c|c|c|c|c|}
\hline Hydrostratigraphic Unit & $\begin{array}{c}\text { Symbol } \\
\text { This Report }\end{array}$ & $\begin{array}{l}\text { Correlation } \\
\text { with YF } \\
\text { Model }^{1,2}\end{array}$ & $\begin{array}{l}\text { Correlation } \\
\text { with Phase II } \\
\text { FF Model }^{1,3}\end{array}$ & $\begin{array}{c}\text { Correlation with } \\
\text { Pahute Mesa - } \\
\text { Oasis Valley } \\
\text { Model } 1,4 \\
\end{array}$ & $\begin{array}{c}\text { Correlation } \\
\text { with } \\
\text { DVRFM }^{1,5}\end{array}$ & $\begin{array}{l}\text { Correlation } \\
\text { with UGTA } \\
\text { Phase } 11,6\end{array}$ \\
\hline Belted Range aquifer & BRA & BRA & NP & BRA & \multirow{3}{*}{ BRU } & \multirow{4}{*}{ TBA } \\
\hline Lower vitric-tuff aquifer 1 & LVTA1 & $\begin{array}{c}\text { ND } \\
(\text { TM-LVTA) }\end{array}$ & ND (TM-LVTA) & NP & & \\
\hline Belted Range confining unit & BRCU & BRCU & NP & NP & & \\
\hline Tub Spring aquifer & TUBA & TUBA & NP & ND (BRA) & \multirow{8}{*}{ OVU } & \\
\hline Lower tuff confining unit & LTCU & LTCU & \multirow{3}{*}{$\begin{array}{l}\text { LTCU, } \\
\text { LTCU1 }^{7}\end{array}$} & $\begin{array}{l}\text { CFCU, BFCU, } \\
\text { PBRCM }\end{array}$ & & \multirow{5}{*}{$\mathrm{VCU}^{7}, \mathrm{BCU}^{8}$} \\
\hline Oak Spring Butte confining unit & OSBCU & OSBCU $^{12}$ & & \multirow{4}{*}{$\mathrm{PBRCM}^{8}$} & & \\
\hline Redrock Valley aquifer & RVA & $\begin{array}{c}\mathrm{ND} \\
\left(\mathrm{OSBCU}^{12}\right) \\
\end{array}$ & & & & \\
\hline Redrock Valley breccia confining unit & RVBCU & NP & NP & & & \\
\hline Lower tuff confining unit 1 & LTCU1 & $\begin{array}{l}\text { LTCU/ } \\
\text { OSBCU }\end{array}$ & $\begin{array}{l}\text { LTCU, } \\
\text { LTCU1 }^{7}\end{array}$ & & & \\
\hline $\begin{array}{l}\text { Tuff of Twin Peaks } \\
\text { (alternative model only) }\end{array}$ & TPA & NP(OSBCU) & NP & PBRCM & & VCU, BCU \\
\hline Argillic tuff confining unit & ATCU & ATCU & ND (LTCU) & ND (PBRCM) & & $\mathrm{BCU}$ \\
\hline Ammonia Tanks intrusive confining unit & ATICU & NP & NP & ATICU & ICU & $\mathrm{BCU}$ \\
\hline Rainier Mesa intrusive confining unit & RM ICU & NP & NP & RMICU & ICU & $\mathrm{BCU}$ \\
\hline Calico Hills intrusive confining unit & $\mathrm{CH} \mathrm{ICU}$ & NP & NP & $\mathrm{CHICU}$ & ICU & $\mathrm{BCU}$ \\
\hline Silent Canyon intrusive confining unit & SCICU & NP & NP & SCIUC & $\mathrm{ICU}$ & $\mathrm{BCU}$ \\
\hline Redrock Valley intrusive confining unit & RV ICU & NP & NP & NP & ICU & $\mathrm{BCU}$ \\
\hline Mesozoic granite confining unit & MGCU & MGCU & NP & MGCU & ICU & 1 \\
\hline Lower clastic confining unit 1-thrust plate & LCCU1 & LCCU1 & NP & NP & LCCU_T1 & NP \\
\hline Lower carbonate aquifer-thrust plate & LCA3 & LCA3 & LCA3 & LCA3 & LCA_T1 & LCA3 \\
\hline
\end{tabular}


Table 4-5

Correlation of Hydrostratigraphic Units of the Rainier Mesa-Shoshone Mountain Model and Earlier Models

(continued)

\begin{tabular}{|c|c|c|c|c|c|c|}
\hline Hydrostratigraphic Unit & $\begin{array}{c}\text { Symbol } \\
\text { This Report }\end{array}$ & $\begin{array}{l}\text { Correlation } \\
\text { with YF } \\
\text { Model }^{1,2}\end{array}$ & $\begin{array}{l}\text { Correlation } \\
\text { with Phase II } \\
\text { FF Model 1, } 3\end{array}$ & $\begin{array}{c}\text { Correlation with } \\
\text { Pahute Mesa - } \\
\text { Oasis Valley } \\
\text { Model }{ }^{1,4}\end{array}$ & $\begin{array}{c}\text { Correlation } \\
\text { with } \\
\text { DVRFM }^{1,5}\end{array}$ & $\begin{array}{l}\text { Correlation } \\
\text { with UGTA } \\
\text { Phase } 1\end{array}$ \\
\hline Upper carbonate aquifer & UCA & UCA & NP & NP & UCA & LCA3 \\
\hline Upper clastic confining unit & UCCU & UCCU & UCCU & UCCU & UCCU & UCCU \\
\hline Lower carbonate aquifer & LCA & LCA & LCA & LCA & LCA & LCA \\
\hline Lower clastic confining unit & LCCU & LCCU & LCCU & LCCU & LCCU & LCCU \\
\hline
\end{tabular}

1 If correlative to more than one HSU, all HSUs are listed.

2 See BN, 2006 for explanation of Yucca Flat model nomenclature.

3 See BN, 2005 for explanation of Frenchman Flat HSU nomenclature.

4 See BN, 2002a for explanation of Pahute Mesa/Oasis Valley HSU nomenclature.

5 See Belcher, 2004 for explanation of the Death Valley Regional Flow Model.

6 See IT, 1996a for explanation of the UGTA Phase I HSU nomenclature.
7 Subdivisions, though hydrogeologically equivalent, are necessary to satisfy operational requirements of the EarthVision ${ }^{\circledR}$ modeling software.

8 Not subdivided.

9 Not present.

10 Subdivided only in Yucca Flat and Mid Valley.

11 Not defined.

12 Subdivided only in areas with sufficient drill hole control. 
The alluvial aquifer is not an important aquifer in the RM-SM model area because it is unsaturated in most of the RM-SM area. Where saturated, the unit is considered an aquifer because of its relatively high hydraulic conductivity. High hydraulic conductivity and specific capacity values have been measured in the NTS wells completed within the AA (e.g., Water Wells 5a, 5b, and 5c in Frenchman Flat [Claassen, 1973; IT, 1996b]; Well A, Well 3 [IT, 1996b], and Well ER-3-2 in Yucca Flat [DOE, 1995b]). However, the more tuffaceous intervals within the AA may have zeolitic alteration that could locally reduce the unit's ability to transmit water. The AA is $366 \mathrm{~m}$ (1,200 ft) thick at borehole UE-14b located in Mid Valley and up to $275 \mathrm{~m}$ $(900 \mathrm{ft})$ thick in west-central Yucca Flat, along the eastern edge of the RM-SM model. The extent of the alluvial aquifer is shown in Figure 4-5.

\subsubsection{Fortymile Canyon Composite Unit (FCCM)}

This HSU consists of a complex and poorly understood assemblage of lava and associated tuff of the Volcanics of Fortymile Canyon of Ferguson et al. (1994). Stratigraphic units that make up the FCCM include (generally from oldest to youngest) rhyolite of Fleur-de-lis Ranch, tuff of Leadfield Road, Beatty Wash Formation (with subunits, rhyolite of Beatty Wash, tuff of Cutoff Road, and rhyolite of Chukar Canyon), rhyolite of Rainbow Mountain, lavas of Dome Mountain, and rhyolite of Shoshone Mountain (Table 4-1). Together, these stratigraphic units compose an interval containing a variety of interfingering lithologic units, including rhyolitic and mafic lava, welded and nonwelded ash-flow tuff, bedded tuff, and tuffaceous gravels. Information from outcrops and drill holes suggests that its lithologic composition varies geographically, as well. Mafic and rhyolitic lava and nonwelded and bedded tuff appear to be the main components in the southeastern portion of the FCCM, with mafic lava more prevalent than in other areas. The northeastern portion of the FCCM, in the vicinity of drill hole UE-18t, is dominated by nonwelded and bedded tuffs.

The Volcanics of Fortymile Canyon were erupted from various vent sources in the area of the Timber Mountain caldera complex (TMCC) between approximately 11.4 and 9.5 Ma (Slate et al., 1999), and deposits of significant thickness are largely confined within the moat of the TMCC, where they form a ring around Timber Mountain. An exposure of the rhyolite of Shoshone Mountain in the southwestern portion of the model area is the only sizeable outcrop of an FCCM unit outside of the TMCC moat (Figure 4-6 and Plates 1 and 2).

The FCCM is designated a composite unit because of the complex distribution of lithologic units with considerably different hydrogeologic characteristics. The welded ash-flow tuffs and lavas 
within the HSU form welded-tuff and lava-flow aquifers. Where nonwelded and bedded tuffs are zeolitized, they form confining units (BN, 2002a). The FCCM is typically unsaturated in the RM-SM model area.

\subsubsection{Timber Mountain Hydrostratigraphic Units}

The Timber Mountain HSUs consists largely of rocks that are assigned stratigraphically to the Rainier Mesa Tuff and the younger Ammonia Tanks Tuff, both formations of the Timber Mountain Group (Table 4-1 and Figure 4-3). These units were erupted from the Rainier Mesa and Ammonia Tanks calderas, and deposited as outflow sheets and ash-fall deposits in areas outside the margins of the calderas. For hydrostratigraphic purposes the unaltered bedded tuffs immediately underlying the Timber Mountain Group units are included with the Timber Mountain HSUs. Lithologically, the Timber Mountain HSUs consist mostly of welded ash-flow tuff and lesser amounts of vitric (i.e., unaltered) nonwelded ash-flow tuff and bedded tuff.

The hydrology of this part of the geologic section is complicated by the presence of one or more ash-flow tuff units that are quite variable in properties both vertically and laterally. The unaltered volcanic rocks of the Timber Mountain Group within the RM-SM model area and the overlapping Yucca Flat-Climax Mine and the PM-OV models are divided into three HSUs to help address this complexity. The Timber Mountain Group includes ash-flow tuffs that might be either welded-tuff aquifers or vitric-tuff aquifers, depending on the degree of welding.

Within the eastern part of the RM-SM model, where it overlaps with the Yucca Flat model, the entire Rainier Mesa Tuff is classified as the Timber Mountain lower vitric tuff aquifer (TM-LVTA), where the Rainier Mesa Tuff is less than about $76 \mathrm{~m}$ (250 ft) thick. In this situation, the Rainier Mesa Tuff is typically poorly welded. In locations where the Rainier Mesa Tuff is more than $76 \mathrm{~m}(250 \mathrm{ft})$ thick, all but the bottom $30 \mathrm{~m}(100 \mathrm{ft})$ is classified as the Timber Mountain welded-tuff aquifer (TM-WTA), and the bottom $30 \mathrm{~m}$ (100 ft) of nonwelded ash-flow tuff is generally included in the TM-LVTA. The overlying Ammonia Tanks Tuff is included with the TM-WTA when either Ammonia Tanks Tuff or Rainier Mesa Tuff is sufficiently thick to be welded. Where the Ammonia Tanks Tuff is not welded and the Rainier Mesa Tuff is welded (i.e., TM-WTA), such as in the southeastern part of the model area, the Ammonia Tanks Tuff is considered to be a vitric-tuff aquifer, and is designated as the TM-UVTA. In the western side of the RM-SM model, where it overlaps with the PM-OV model, both the Ammonia Tanks and the Rainier Mesa tuffs are incorporated into the TM-WTA. The relationships of these HSUs are depicted in Figure 4-7. 
The thicknesses of the TM-WTA and TM-LVTA in the north-central portion of the model area are well constrained where numerous drill holes penetrate them. In this area the Timber Mountain volcanic aquifers are as much as $152 \mathrm{~m}(500 \mathrm{ft})$ thick.

The designation of the these units as aquifers is based on the predominance of welded tuff (which is assumed to be fractured and transmissive) and unaltered, nonwelded and bedded tuff. This designation is consistent with water production data from Water Wells 4 and $4 \mathrm{a}$ in CP Basin (Reiner, 2002). Other hydrologic data from outflow sheets of welded Ammonia Tanks and Rainier Mesa tuffs relevant to the RM-SM model area (e.g., in Wells UE-14a and UE-14b located in Mid Valley) indicate these units are significant aquifers where saturated (IT, 1996c).

\subsubsection{Timber Mountain Upper Vitric-Tuff Aquifer (TM-UVTA)}

The TM-UVTA is defined to include the non- to partially welded, nonzeolitized ash-flow and bedded tuffs of the Ammonia Tanks Tuff, which lie above the TM-WTA. The TM-UVTA may include a small percentage of welded-tuff aquifer in some areas, if the welded portions of the Ammonia Tanks ash-flow tuff are inconsistent, thin, or otherwise not mappable. Where the Ammonia Tanks Tuff is consistently welded, it is included with the underlying TM-WTA. These rocks are included in the laterally more extensive TM-LVTA when the TM-WTA is not present, or where the Rainier Mesa Tuff is less than $76 \mathrm{~m} \mathrm{(250} \mathrm{ft)} \mathrm{thick} \mathrm{(and} \mathrm{thus} \mathrm{no} \mathrm{welded}$ horizon formed), such as in parts of the eastern-central portion of the model area. The upper and lower Timber Mountain vitric-tuff aquifers may be laterally continuous at the distal, nonwelded edges of the Ammonia Tanks Tuff, where Timber Mountain Group rocks are not welded (see Figure 4-7 for an example of this configuration). It is saturated only in the deeper basins of the NTS (i.e., Mid Valley). Based on observed lithologic characteristics, the hydraulic properties of the TM-UVTA are probably similar to those of the TM-LVTA. The distribution of the TM-UVTA is shown in Figure 4-8. Figure 4-9 is a contour map showing the depth to this aquifer.

\subsubsection{Timber Mountain Welded-Tuff Aquifer (TM-WTA)}

The TM-WTA typically consists of outflow sheets of welded ash-flow tuff assigned to the Rainier Mesa and Ammonia Tanks tuffs. The unit is generally confined to Rainier Mesa, Aqueduct Mesa, and outcrops in the northwest part of the model area. The TM-WTA is mostly unsaturated within the RM-SM model area, except in Mid Valley. The distribution of the TM-WTA is shown in Figure 4-10. The relationship of the TM-WTA with other Timber Mountain HSUs in the north and south part of the model is depicted in Figure 4-7, and its relationship with other volcanic HSUs in the southern portion of the model is shown in Figure 4-12. Note that the TM-WTA may contain up to 20 percent vitric-tuff aquifer. This is to 
accommodate the nonwelded top of the Rainier Mesa Tuff, which is typically thin and not easily mapped for a CAU-scale model. In cases where the overlying Ammonia Tanks Tuff is welded, and therefore included in the TM-WTA (see Subsection 4.5.3), some intervening nonwelded tuff and bedded tuff (the bedded Ammonia Tanks Tuff; see Table 4-1 and Figure 4-1) are necessarily incorporated into the TM-WTA. A contour map showing the depth to the TM-WTA is presented in Figure 4-11.

The extent of the TM-WTA is fairly well constrained (Figure 4-10). Extensive outcrops and numerous drill-hole penetrations in Rainier and Aqueduct mesas provide unambiguous information as to its location and hydrogeologic character in the model area. This HSU is a fracture-controlled aquifer, and wells completed in the TM-WTA are highly productive (e.g., Wells UE-14a and UE-14b in Mid Valley, Water Wells 4 and 4a in CP Basin, and Well Cluster ER-5-3 in northern Frenchman Flat [DOE, 2005]).

\subsubsection{Timber Mountain Lower Vitric-Tuff Aquifer (TM-LVTA)}

In general, the TM-LVTA includes all unaltered, bedded and reworked ash-fall, and nonwelded ash-flow tuff units present above the level of pervasive zeolitization. However, where welded ash-flow tuff units are present (e.g., the Tiva Canyon or Topopah Spring tuffs [Paintbrush Group], or the Stockade Wash Tuff [Crater Flat Group]) which form the Tiva Canyon Aquifer (TCA), Topopah Spring aquifer (TSA), and Stockade Wash aquifer (SWA), the hydrostratigraphy becomes much more complex. For example, unaltered nonwelded tuffs below the TSA are grouped within a separate HSU called the lower vitric-tuff aquifer (LVTA) (Subsection 4.5.9). See Figures 4-3, 4-12, and 4-13 for more details. Welded tuff of the Timber Mountain Group is included in the TM-WTA (Subsection 4.5.3.2). Stratigraphically, the TM-LVTA typically includes formations of the Timber Mountain Group and Paintbrush Group, but may also include unaltered units within the Calico Hills Formation, Wahmonie Formation, and Crater Flat Group (Figure 4-3). Older (deeper) units are generally zeolitized, and are therefore categorized as confining units and placed with the lower tuff confining unit (LTCU).

The TM-LVTA has a larger distribution than the TM-WTA. The distribution of the TM-LVTA is shown in Figure 4-14. The relationship of the TM-LVTA with other volcanic HSUs is shown in Figures 4-3, 4-7, and 4-12. Figure 4-15 is a contour map showing the depth to this aquifer.

In the RM-SM model area, the TM-LVTA units are saturated only in the deep central portion of Mid Valley (Figure 4-61). The TM-LVTA exhibits significant interstitial porosity, ranging from 
about 20 to 40 percent (App and Marusak, 1997). However, because these lithologies tend to be poorly to moderately indurated, fractures are not common (Drellack et al., 1997). So even though interstitial porosity may be high, transmissivity is not great.

\subsubsection{Timber Mountain Composite Unit (TMCM)}

The TMCM consists mainly of intra-caldera units of the Timber Mountain Group, most notably the Rainier Mesa and Ammonia Tanks tuffs. The eruption of these two units resulted in the formation of the Rainier Mesa and Ammonia Tanks calderas 11.6 and 11.45 Ma, respectively (Sawyer et al., 1994). These two nested calderas comprise the Timber Mountain caldera complex (Byers et al., 1976). The TMCM also includes units related to the Ammonia Tanks Tuff, such as tuff of Buttonhook Wash, tuff of Crooked Canyon, and trachyte of East Cat Canyon, which erupted shortly after the Ammonia Tanks Tuff (Slate et al., 1999; Figure 4-3 and Table 4-4). Timber Mountain landslide breccia, deposited during caldera collapse, is designated a separate HSU, the Rainier Mesa breccia confining unit (RMBCU) (see Subsection 4.5.3.5), and locally may comprise a significant portion of the unit.

Lithologically, the TMCM consists mainly of densely welded ash-flow tuff that ponded to great thicknesses within the subsiding calderas. Densely welded tuff typically is considerably fractured, and thus assumed to behave as an aquifer. However, the TMCM is designated a composite unit because of the possibility that hydrothermal alteration within this deep intracaldera setting has altered the hydraulic properties of the rocks significantly, in particular, filling fractures with secondary minerals such as quartz. Moderate hydrothermal alteration is observed in lithologic samples from holes drilled within the Timber Mountain caldera complex, which penetrate a significant depth into the TMCM, such as drill holes UE-18r and UE-18t, and Wells ER-18-2, ER-EC-2a, and ER-EC-5 (BN, 2002a; Warren et al., 2000). Except where the TMCM has been elevated by caldera-related resurgence, such as at Timber Mountain, the TMCM generally occurs below the water table (Figure 4-17; Model Profile E-E').

Although the TMCM is relatively deeply buried in many places, its lateral extent is fairly well constrained because it is confined exclusively within the margins of the Timber Mountain caldera complex (Figure 4-16). The caldera margins are fairly well constrained by surface geology, drill hole data, and geophysical data (see Subsection 3.3.4). The unit is exposed extensively on Timber Mountain, where more than $884 \mathrm{~m}(2,900 \mathrm{ft})$ of intra-caldera Ammonia Tanks Tuff is present (Slate et al., 1999). However, the base of the TMCM is nowhere exposed or penetrated by a drill hole, so the thickness of the unit is poorly constrained. Intra-caldera

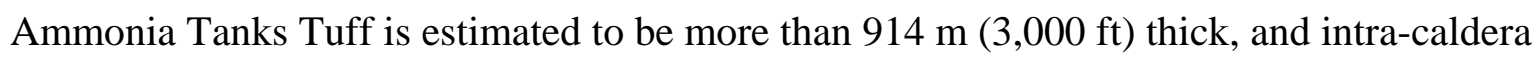
Rainier Mesa Tuff is believed to be more than $488 \mathrm{~m}$ (1,600 ft) thick (Byers et al., 1976; Grauch 
et al., 1997; Slate et al., 1999). Thus the maximum thickness of TMCM is likely more than 1,372 $\mathrm{m}(4,500 \mathrm{ft})$. Significant thicknesses of TMCM encountered in drill holes immediately west of the RM-SM model area include 1,201 $\mathrm{m}(3,939 \mathrm{ft})$ at UE-18r, $506 \mathrm{~m}(1,661 \mathrm{ft})$ at UE-18t, and $532 \mathrm{~m}(1,745 \mathrm{ft})$ at Well ER-18-2. In the model, the unit thickness is approximately $1,000 \mathrm{~m}(3,300 \mathrm{ft})$ in the extreme eastern portion of the Rainier Mesa caldera.

The TMCM is modeled as a separate HSU because its components, the Ammonia Tanks and Rainier Mesa Tuffs, are important, well-defined, mappable units in the model region, which are critical for understanding and defining major volcano-tectonic features such as the Timber Mountain caldera complex. The stratigraphic, lithologic, and hydrogeologic composition of the unit is fairly well understood and certain, in sharp contrast with underlying HSUs, which are poorly understood and highly uncertain; the TMCM also differs considerably in composition from the overlying FCCM. Also, the TMCM is vastly different in thickness than its extracaldera equivalent, the Timber Mountain hydrostratigraphic units (see Subsection 4.5.3), and may have significantly different hydraulic properties. Figure 4-17 is a contour map showing the depth to this HSU.

\subsubsection{Rainier Mesa Breccia Confining Unit (RMBCU)}

This HSU is limited in areal extent and is only found inside the Rainier Mesa caldera structural margin, in association with the fault at the structural margin (Figure 4-18). Typically, mass wasting and landslide processes occur along caldera rims during collapse and formation of calderas, resulting in the accumulation of breccia deposits within calderas (Lipman, 2000). These landslide deposits formed by slumping at the ring-fault scarp, and can be quite extensive, with thicknesses greater than 1,000 m (3,300 ft). Within the Timber Mountain caldera complex, caldera-related breccia deposits have been identified in outcrops in the Transvaal Hills and along the eastern and northern margins of the caldera complex (Plate 1), and in drill holes UE-18r (Carr et al., 1981) and UE-18t (Byers and Hawkins, 1981) located just west of the RM-SM model area.

The RMBCU rings the inside of the caldera and has a triangular cross section. The thickest part is up against the caldera structural margin and thins toward the center of the caldera. The unit consists mostly of breccia blocks within an argillic matrix, therefore, it is designated as a confining unit.

\subsubsection{Sub-Caldera Volcanic Confining Unit (SCVCU)}

The SCVCU is a highly conjectural unit (Figure 4-19). The unit is not exposed at the surface, and it has not been encountered in any drill hole. Its existence is based primarily on the presence 
of deep basement (or low density regions) beneath the TMCC, as defined by gravity measurements (Figure 2-5; Mankinen et al., 1999). Without the presence of some other lowerdensity volcanic rocks in some of these deep basement lows, the Rainier Mesa and Ammonia Tanks Tuffs would have to approach 4,572 $\mathrm{m}$ (15,000 ft) in thickness to account for the measured gravity field. Although such an intra-caldera thickness for the Timber Mountain Group rocks is possible, the model constrains the maximum thickness of these rocks at less than 3,048 $\mathrm{m}$ (10,000 ft). Thus in the model, volcanic rocks older than the Rainier Mesa Tuff are interpreted to underlie the TMCM in these basement lows.

If the SCVCU exists beneath the TMCC at the depths depicted in the model, then the rocks comprising the HSU are likely to be highly altered and intruded. This would probably significantly reduce the ability of these rocks to transmit groundwater, and thus they are considered a confining unit in the model.

\subsubsection{Tiva Canyon Aquifer (TCA)}

The TCA consists of a single welded-tuff aquifer composed of welded ash-flow tuff of the Tiva Canyon Tuff (Figures 4-2 and 4-3). Within the model area, the unit is unsaturated. It occurs in the southern portion of the RM-SM model area (Figure 4-20; Model profiles E-E', F-F', and G-G').

\subsubsection{Paintbrush Vitric-Tuff Aquifer (PVTA)}

In the central and southern portion of the model area, the PVTA consists of vitric bedded tuffs that occur stratigraphically between the Tiva Canyon and Topopah Spring tuffs (Figure 4-13). On Pahute Mesa, in the northwest corner of the model, the PVTA consists of vitric bedded and nonwelded tuffs that occur stratigraphically between the base of the Rainier Mesa Tuff and the top of Echo Peak lava. In this part of eastern Pahute Mesa, the PVTA mainly includes the stratigraphic units, tuff of Holmes Road, Tiva Canyon Tuff, and rhyolite of Delirium Canyon.

The occurrences of the PVTA in the RM-SM model area are shown in Figure 4-21. The PVTA is unsaturated in the model area.

\subsubsection{Upper Tuff Confining Unit (UTCU)}

The zeolitized nonwelded tuffs that overlie the TSA welded-tuff aquifer (Subsection 4.5.8) in southern Yucca Flat and Mid Valley are designated as the UTCU. Stratigraphically, the UTCU may include units from the base of the welded Rainier Mesa Tuff (i.e., TM-WTA) to the top of welded Topopah Spring Tuff (i.e., TSA). The areal extent of the UTCU is therefore the same as for the TSA, and the UTCU in the RM-SM model is confined to Mid Valley. The rocks in this 
HSU are equivalent stratigraphically and hydrogeologically to the upper portion of the LTCU in which they are grouped outside the extent of the underlying TSA (see Figure 4-12). This subdivision is necessary to satisfy operational requirements of the EarthVision ${ }^{\circledR}$ software. The distribution of the UTCU in the RM-SM model area is shown in Figure 4-22. The relationship of the UTCU with other volcanic HSUs is shown in Figure 4-12. Other required subdivisions of tuff confining units overlying welded-tuff aquifers are designated upper tuff confining units 2 and 1 (UTCU2 and UTCU1, respectively; see Figure 4-23 and Subsections 4.5.13 and 4.5.17).

In Mid Valley, the UTCU is mostly saturated except for a narrow area around the basin perimeter. The hydrologic properties of the two tuff confining units (the UTCU and the LTCU; see Subsection 4.5.22 below) are considered to be essentially identical.

\subsubsection{Topopah Spring Aquifer (TSA)}

The TSA consists of a single welded-tuff aquifer composed of welded ash-flow tuff of the Topopah Spring Tuff, a formation of the Paintbrush Group (Figures 4-2 and 4-3). The TSA may also contain up to 15 percent vitric-tuff aquifer, which represents the nonwelded top and base of this generally welded ash-flow tuff. In the RM-SM model area the TSA is present within the southern quarter of the model area and is saturated only in Mid Valley. The relationship of the TSA with other volcanic HSUs is shown in Figures 4-12 and 4-13. The distribution of the TSA is shown in Figure 4-24. Figure 4-25 is a contour map showing the depth to this aquifer.

The TSA is typically well fractured and therefore highly transmissive. Overall, the hydraulic properties of the TSA are similar to those of the TM-WTA (see Subsection 4.5.3.2).

\subsubsection{Lower Vitric-Tuff Aquifer (LVTA)}

The LVTA includes all unaltered bedded, ash-fall, reworked, and nonwelded ash-flow tuff units below the TSA and above the next deeper confining unit in the model area. The LVTA is only differentiated where the TSA is present; these rocks would otherwise be included in the TM-LVTA (Figure 4-7). Overlying welded tuffs are included in the TSA welded-tuff aquifer (Subsection 4.5.8). Stratigraphically, the LVTA may include members of the Calico Hills and Wahmonie Formations, and formations of the Crater Flat Group. Older units are generally zeolitized, and are therefore categorized as confining units and assigned to the LTCU.

The relationship of the LVTA with other HSUs is shown in Figures 4-12 and 4-13. The LVTA is unsaturated and present only in the central portion of the model area, near the north end of Shoshone Mountain (Figure 4-26). 
The LVTA exhibits significant interstitial porosity, ranging from about 20 to 40 percent. However, because these lithologies tend to be poorly to moderately indurated, fractures are not common.

\subsubsection{Calico Hills Vitric-Tuff Aquifer (CHVTA)}

This aquifer consists of mainly vitric, bedded and nonwelded tuff of the mafic-poor member of the Calico Hills Formation (Figure 4-3). The unit occurs in Area 19 where the Calico Hills Formation is structurally high, and thus, mostly vitric (Figure 4-27).

\subsubsection{Yucca Mountain Calico Hills Lava-Flow Aquifer (YMCHLFA)}

The YMCHLFA is a minor HSU located in the southwestern portion of the model area (Figure 4 28). The HSU consists of vitrophyric to devitrified rhyolite lava flows that occur below the Topopah Spring Tuff (Orkild and O'Connor, 1970). The unit is exposed at the southern end of Shoshone Mountain and thickens to the west (Model Profiles F-F' and G-G').

This HSU occurs well above the regional water table, although several springs (i.e., Topopah Spring) are present within the unit in the upper reaches of Topopah Wash (Figure 1-8). These springs likely represent local discharge of water derived from the higher elevations of Shoshone Mountain.

\subsubsection{Kearsarge Aquifer (KA)}

The Kearsarge aquifer comprises a single interval of lava-flow aquifer, composed of rhyolite lava of the rhyolite of Kearsarge. It is limited in extent and relatively thin, having a maximum thickness of approximately $198 \mathrm{~m}$ ( $650 \mathrm{ft})$. The KA is present only in the northwest corner of the model area where it is partially saturated (Figure 4-29).

\subsubsection{Upper Tuff Confining Unit 2 (UTCU2)}

The zeolitized nonwelded tuffs that overlie the SWA (Subsection 4.5.14) in the central portion of the RM-SM model area are designated as the UTCU2. Stratigraphically, the UTCU2 may include units from the base of the welded Rainier Mesa Tuff (i.e., TM-WTA) to the top of welded Stockade Wash Tuff (i.e., SWA) (Figure 4-3). The rocks in this HSU are equivalent stratigraphically and hydrogeologically to the upper portion of the UTCU1 outside the extent of the underlying SWA (see Figure 4-23). This subdivision is necessary to satisfy operational requirements of the EarthVision ${ }^{\circledR}$ software because EarthVision ${ }^{\circledR}$ requires all units to stack up in layers. Thus, if a unit such as an ash-flow tuff (i.e., welded-tuff aquifer) ends laterally (i.e., pinches out), then the rocks above and below the unit must have different names even though 
they may be hydrologically similar and are grouped together beyond the limits of the hydrologically different intervening unit.

The distribution of the UTCU2 in the RM-SM model area is very limited, as shown in Figure 4-30. The relationship of the UTCU2 with other volcanic HSUs is shown in Figure 4-23.

The hydrologic properties of the tuff confining units (the UTCU2, UTCU1, Belted Range Confining unit [BRCU], and the LTCU; see Subsections 4.5.13, 4.5.17, 4.5.20, and 4.5.22, respectively) are considered to be essentially identical.

\subsubsection{Stockade Wash Aquifer (SWA)}

The SWA consists of a single partially welded ash-flow tuff. This is not an extensive HSU, and is limited to an area west-southwest of Rainier Mesa. The distribution of the SWA is shown in Figure 4-31. The relationship of the SWA with other volcanic HSUs is shown in Figure 4-23. Because the SWA is typically partially welded, it is more fractured than nonwelded vitric tuff, but less fractured than moderately to densely welded ash-flow tuffs. Consequently, the hydrologic properties of the SWA are likely to be between those of the TM-WTA and the TM-LVTA. The SWA is not saturated in the RM-SM model area.

\subsubsection{Lower Vitric-Tuff Aquifer 2 (LVTA2)}

The LVTA2 includes all unaltered bedded, ash-fall, reworked tuff, and nonwelded ash-flow tuff units below the SWA and above the next deeper confining unit in the RM-SM model area. The LVTA2 is only differentiated where the SWA is present; these rocks would otherwise be included in the TM-LVTA (Figure 4-23). Overlying welded tuffs are included in the SWA welded-tuff aquifer (Subsection 4.5.14). Stratigraphically, the LVTA2 may include members of the Crater Flat Group and Tunnel 4 Member of the Tunnel Formation (Figure 4-3). Older units are generally zeolitized, and are therefore categorized as confining units and assigned to the LTCU.

The relationship of the LVTA2 with other HSUs is shown in Figure 4-23. The distribution of the LVTA2 is shown in Figure 4-32.

The LVTA2 exhibits significant interstitial porosity, ranging from about 20 to 40 percent. However, because these lithologies tend to be poorly to moderately indurated, fractures are not common. So even though interstitial porosity may be high, transmissivity is not great. The LVTA2 is not saturated in the RM-SM model area. 


\subsubsection{Bullfrog Confining Unit (BFCU)}

The BFCU consists of zeolitic nonwelded ash-flow tuff of the Area 20 caldera-forming Bullfrog Tuff (Figure 4-3). The Bullfrog Tuff is unusually thick and extensive for a nonwelded ash-flow tuff. It is believed that the abundance of lithic fragments within the formation effectively quenched the ash-flow tuff before welding could occur (Warren et al., 1989; Ferguson et al., 1994).

The BFCU occurs within the western corner of the model area, particularly within the Area 20 caldera where it has a rather uniform thickness of approximately $610 \mathrm{~m} \mathrm{(2,000} \mathrm{ft)} \mathrm{(Figure} \mathrm{4-33).}$ The main body of the BFCU is truncated by erosion along its northern, western, and eastern margins (Model Profile B-B'), and the boundary of the Timber Mountain caldera complex forms the southern boundary.

\subsubsection{Upper Tuff Confining Unit 1 (UTCU1)}

The zeolitized nonwelded tuffs that overlie the Belted Range aquifer (BRA; Subsection 4.5.18) in the Rainier-Aqueduct Mesa area are designated as the UTCU1. Stratigraphically, the UTCU1 may include units from the base of the Stockade Wash Tuff (i.e., SWA) if present, or the top of pervasive zeolitization which could include bedded tuffs of the Paintbrush Group to the top of welded Grouse Canyon Tuff (i.e., BRA) (Figure 4-3). The areal extent of the UTCU1 is therefore dependent upon the areal extent of the BRA. The rocks in this HSU are equivalent stratigraphically and hydrogeologically to the upper portion of the LTCU outside the extent of the underlying Tub Spring aquifer (TUBA) and to the BRCU outside the extent of the underlying BRA (Figure 4-23). This subdivision is necessary to satisfy operational requirements of the EarthVision ${ }^{\circledR}$ software. The distribution of the UTCU1 in the RM-SM model area is shown in Figure 4-34. The relationship of the UTCU1 with other volcanic HSUs is shown in Figures 4-3 and 4-23.

The UTCU1 is saturated within the RM-SM model area. The hydrologic properties of the younger tuff confining units (the UTCU2, UTCU1, BRCU, and the upper LTCU; see Subsections 4.5.13, 4.5.17, 4.5.20, and 4.5.22) are considered to be essentially identical.

\subsubsection{Belted Range Aquifer (BRA)}

The BRA consists mainly of devitrified welded ash-flow tuff and lava, with lesser amounts of associated zeolitic nonwelded tuff and lava. Stratigraphically, these rocks are mostly assigned to the Belted Range Group. The BRA is present in the northern portion of the model area northwest of the Eleana Range and Quartzite Ridge (Figure 4-35). Southwest of Rainier Mesa, the BRA consists exclusively of devitrified welded ash-flow tuff of the Grouse Canyon Tuff. 
North of Rainier Mesa, the BRA is much more complex, and composed mainly of thick piles of devitrified lava with intervening intervals of zeolitic nonwelded tuff. The upper and lower portions of some lava flows are also zeolitic. Welded Grouse Canyon Tuff overlies the lavas in places north of Rainier Mesa, but it is relatively thin compared to the thickness of lava (Sargent and Orkild, 1973). The relationship of the BRA with the other HSUs is shown in Figure 4-23. Figure 4-36 is a contour map showing the depth to the BRA. The unit is typically unsaturated within the RM-SM model area.

\subsubsection{Lower Vitric-Tuff Aquifer 1 (LVTA1)}

The LVTA1 includes all unaltered bedded, ash-fall, reworked tuff, and nonwelded ash-flow tuff units below the BRA and above the level of pervasive zeolitization in the model area. The LVTA1 is differentiated only where the BRA is present; these rocks would otherwise be included in the TM-LVTA (Figure 4-3). Overlying welded tuffs are included in the BRA welded-tuff aquifer (Subsection 4.5.18). Stratigraphically, the LVTA1 may include members of the Belted Range Group and the youngest tunnel beds (i.e., Tunnel Formation, Tunnel 4 Member). Older units are generally zeolitized, and are therefore categorized as confining units and assigned to the LTCU. The relationship of the LVTA1 with other HSUs is shown in Figure 4-23. The distribution of the LVTA1 is shown in Figure 4-37.

The LVTA1 exhibits significant interstitial porosity, ranging from about 20 to 40 percent. However, because these lithologies tend to be poorly to moderately indurated, fractures are not common. So, even though interstitial porosity may be high, transmissivity is not great. The LVTA1 is not saturated in the RM-SM model area.

\subsubsection{Belted Range Confining Unit (BRCU)}

The BRCU generally consists of zeolitized bedded and non-welded tuffs that occur between the welded ash-flow tuff lithofacies of the Grouse Canyon Tuff (BRA) above and the Tub Spring Tuff (TUBA) below (Figure 4-3). The upper part of this unit locally may be vitric where the unit is unsaturated. Hydrologically, this tuff confining unit would behave similarly to the UTCU2 (Subsection 4.5.13), UTCU1 (Subsection 4.5.17), and the LTCU (Subsection 4.5.22). Outside the extent of the TUBA, BRCU-equivalent rocks are grouped within the LTCU. Figure 4-38 shows the distribution of the BRCU. The relationship of the BRCU with other HSUs is shown in Figure 4-23.

\subsubsection{Tub Spring Aquifer (TUBA)}

The TUBA consists only of the welded portion of the Tub Spring Tuff and is limited to two locales in the northern portion of the RM-SM model area, where it can be up to $90 \mathrm{~m}(300 \mathrm{ft})$ 
thick. The TUBA is a fairly extensive HSU in West Emigrant Valley and in the northeastern corner of the model area (Figure 4-39 and Profile B-B'), but it is saturated only in the deeper sub-basins of the area. Its hydraulic properties are similar to those of the BRA and the TM-WTA. A contour map showing the depth to the TUBA is presented in Figure 4-40.

\subsubsection{Lower Tuff Confining Unit (LTCU)}

The LTCU is an important hydrogeologic layer over much of the NTS because it is usually thick and extensive and lies between the volcanic aquifer units and the underlying regional LCA. The LTCU includes almost all the zeolitic tuff units from the top of the volcanics of Oak Spring Butte to the base of the Rainier Mesa Tuff (Figure 4-3). Zeolitic bedded tuff of the Tunnel Formation typically comprises much of the unit.

As mentioned in Subsection 4.5.13, where welded tuff units are intercalated within this sequence of zeolitic tuffs, the intervening zeolitized bedded tuffs are designated as separate HSUs. These more complex geometries are depicted in Figures 4-12, 4-13, and 4-23. The distribution of the LTCU is shown in Figure 4-41. The relationship of the LTCU, OSBCU, and the ATCU is shown in Figure 4-13.

The LTCU is saturated in the western third of the model, the extreme northern portion of the model, and in Mid Valley (Figure 4-61), however, measured transmissivities are very low (Hawkins et al., 1989).

\subsubsection{Oak Spring Butte Confining Unit (OSBCU)}

The OSBCU consists of zeolitic tuffs and tuffaceous sediments that occur stratigraphically below the Tub Spring Tuff within the RM-SM and Yucca Flat-Climax Mine CAU (BN, 2006) models. Hydrostratigraphically, the OSBCU occurs between the TUBA and the Redrock Valley aquifer (RVA; see Subsection 4.5.24). Stratigraphically, the OSBCU includes all nonwelded zeolitic rocks below the Tub Spring Tuff (or equivalent horizon) and above welded Redrock Valley Tuff and/or tuff of Twin Peaks (Table 4-1 and Figure 4-3). This typically includes tunnel bed 2, Yucca Flat Tuff, and tunnel bed 1. Where Redrock Valley Tuff and tuff of Twin Peaks are nonwelded and zeolitic, these units are also included within the OSBCU. Argillic paleocolluvial deposits that occur at the base of the volcanic section directly overlying pre-Tertiary rocks, which may be time-stratigraphically equivalent to OSBCU rocks, are included within the lower ATCU (Subsection 4.5.28). The distribution of the OSBCU is shown in Figure 4-42. 
Lithologically, the OSBCU includes zeolitic bedded tuff, ash-flow tuff (typically no more than partially welded), tuffaceous sandstone, and tuffaceous paleocolluvium. The relatively diverse lithologic composition of the OSBCU, particularly the presence of devitrified ash-flow tuff, may result in hydrologic properties somewhat different than those for the more lithologically homogeneous confining HSUs such as the LTCU. In addition, the lithologic diversity of the OSBCU results in a more diverse mineralogy that may have important ramifications with regard to retarding radionuclides via sorption and ion exchange processes (Prothro, 2005).

\subsubsection{Redrock Valley Aquifer (RVA)}

The RVA includes welded intervals of the 15.25-Ma Redrock Valley Tuff (Sawyer et al., 1994) and the 15.5-Ma tuff of Twin Peaks (Slate et al., 1999). Minor intervals of zeolitic bedded and nonwelded tuffs that occur between intervals of welded tuff are also included within the RVA. Intervals of zeolitic nonwelded tuffs assigned to the Redrock Valley Tuff and tuff of Twin Peaks, but which occur above the highest welded interval and below the deepest welded interval, are grouped within the over- and underlying HSUs (e.g., OSBCU and LTCU1). Argillic paleocolluvial deposits and nonwelded tuffs that occur at the base of the volcanic section directly overlying pre-Tertiary rocks, and that may be time-stratigraphically equivalent to RVA rocks, are included within the lower ATCU.

Hydrostratigraphically, the RVA occurs between the OSBCU and the LTCU1. The relationship of the RVA with other volcanic HSUs is shown in Figures 4-13 and 4-23.

Welded Redrock Valley Tuff occurs in the subsurface of Yucca Flat, but was not split out as a separate HSU because it is relatively thin, highly variable in thickness and extent, and lacks dense welding; few drill holes penetrate the unit. The relatively thin occurrence, variability in thickness and extent, and poor welding are due to 1) distance from the source and 2) in-filling of pre-existing topography. West of the pre-Tertiary rocks exposed along the western margin of Yucca Flat, Redrock Valley Tuff and tuff of Twin Peaks are considerably thicker and contain significant thicknesses of densely welded ash-flow tuff. Although drill hole control is sparse, several holes provide important information on the thickness, extent, and character of both units.

Due to burial by younger volcanic units, the Redrock Valley Tuff and tuff of Twin Peaks have limited surface exposures, with most exposures of the formations located in the Eleana Range and just south of Syncline Ridge (Slate et al., 1999). Significant thicknesses of the formations have been encountered in several drill holes in the model area, including Water Well 8, HTH-1, and UGTA Well ER-19-1 (see Appendix A). Welded Redrock Valley Tuff was also encountered in UGTA Well ER-16-1. 
The RVA occurs throughout much of the west-central portion of the model area (Figure 4-43). Because the Redrock Valley caldera (see Subsection 3.1.3.1) is interpreted to be the source of the Redrock Valley Tuff, the RVA is modeled as consisting of thick intra-caldera welded-tuff aquifer. The RVA is much thinner outside the margins of the Redrock Valley caldera (Model Profile D-D'). A contour map showing the depth to the RVA is presented in Figure 4-44.

\subsubsection{Redrock Valley Breccia Confining Unit (RVBCU)}

This conceptualized HSU is limited in areal extent and is only found inside the Redrock Valley caldera structural margin fault (Figure 4-45). The RVBCU rings the inside of the caldera and has a triangular cross section. The unit is thickest adjacent to the caldera structural margin, and thins and pinches out toward the center of the caldera. These landslide deposits are common within calderas, and are formed by slumping at the ring-fault scarp during caldera collapse (see discussion in Subsection 4.5.3.5). The unit probably consists mostly of breccia blocks within an argillic matrix, so it is designated as a confining unit.

\subsubsection{Lower Tuff Confining Unit 1 (LTCU1)}

Hydrostratigraphically, the LTCU1 occurs between the RVA and the ATCU. Stratigraphically, the LTCU1 includes all zeolitic nonwelded tuff that occurs below the deepest welded interval of Redrock Valley Tuff or tuff of Twin Peaks and above the first occurrence of argillic tuff and paleocolluvium (Figure 4-3). Typically it includes units older than the tuff of Twin Peaks, but may include zeolitic nonwelded tuffs assigned to the Redrock Valley Tuff and tuff of Twin Peaks that occur below the deepest welded interval.

The LTCU1 is differentiated only where the Redrock Valley Tuff is welded, thus forming the RVA HSU. If the Redrock Valley Tuff is not welded (no RVA present) these rocks are lumped with the LTCU or OSBCU (Figure 4-23). Consequently, the areal extent of the LTCU1 is similar to the RVA (Figure 4-46). Hydrologically, the LTCU1 should be treated the same as the LTCU. The relationship of the LTCU1 with other volcanic HSUs is shown in Figures 4-13 and 4-23.

\subsubsection{Twin Peaks Aquifer (TPA)}

The TPA consists of the welded portions of the tuff of Twin Peaks, and is best characterized within the model area at Water Well 8 and Well ER-19-1. The tuff of Twin Peaks was erupted 15.5 Ma (Slate et al., 1999), and is one of the oldest ash-flow tuffs within the SWNVF. The TPA was developed exclusively for the "No Redrock Valley Caldera" alternative (Section 5.2). The unit is not defined as a separate HSU in the base model, where it is included within the 
RVA. Within the "No Redrock Valley Caldera" alternative, the TPA occurs in the western portion of the model area (Figure 4-47). A contour map showing the depth to the TPA is presented in Figure 4-48.

\subsubsection{Argillic Tuff Confining Unit (ATCU)}

Volcanic rocks and tuffaceous sediments that occur at the base of the Tertiary section within most of the Yucca Flat and RM-SM model areas are commonly argillized (Prothro, 2005), and are assigned to the ATCU. The ATCU typically includes the oldest Tertiary-age units that lie directly on top of pre-Tertiary rocks beneath much of the NTS (Figure 4-3). Lithologically, the ATCU includes highly argillized bedded tuff, ash-flow tuff, tuffaceous sediments, and paleocolluvium.

The unit is typically saturated and laterally extensive, except over Paleozoic highlands (Figure 4-49). Its hydrostratigraphic position between the LTCU1 and pre-Tertiary HSUs is shown conceptually in Figures 4-3, 4-7, and 4-13 and on Model Profiles A-A' through G-G'

\subsubsection{Caldera-Related Intrusive Confining Units}

It is widely accepted that calderas form over shallow magmatic bodies (Lipman, 2000), however, pre-caldera intrusive processes are poorly understood. The intrusive bodies may be stock-like masses, a series of dikes rising up from a larger batholithic intrusion, a lacolithic intrusion, or various combinations of these types of intrusions. These bodies may consist almost exclusively of igneous intrusive rocks, as modeled here, or consist of a considerable amount of pre-Tertiary and older volcanic rocks that are intruded to varying degrees by igneous rocks.

Intrusive rocks likely behave as confining units because of their low primary porosity and permeability, as described in Subsection 4.5.30.2 for the Cretaceous granitic bodies in the model area. Although near-surface intrusive rocks are typically hard and brittle, and thus commonly fractured, the fractures in deeper bodies are probably filled with secondary minerals such as quartz, due to the circulation of hot, mineral-rich waters associated with deep magma bodies. It is likely that sedimentary and older volcanic rocks present under and around calderas originally had aquifer-like properties, but now behave as confining units due to contact metamorphism and hydrothermal alteration related to intrusive activity during caldera development.

Intrusive rocks are interpreted to underlie the calderas of the SWNVF (Byers et al., 1976; Christiansen et al., 1977; Fridrich et al., 1999), and are critical in the understanding of the major volcano-tectonic features of the Timber Mountain caldera complex. These intrusive rocks are treated as a separate HGU because they are thought to have hydraulic properties significantly 
different from those of adjacent and overlying units due to intense magmatic activity related to caldera formation. For ease of modeling, the intrusive rocks underlying each caldera are treated as a separate HSU (Figure 4-50). The four caldera-related intrusive confining units defined in the RM-SM model are described in the following paragraphs, beginning with the youngest.

\subsubsection{Ammonia Tanks Intrusive Confining Unit (ATICU)}

The ATICU represents only a very small volume at the center of the western edge of the RM-SM model. The ATICU has been modeled as a single intrusive mass, separate from the Rainier Mesa intrusive confining unit (Subsection 4.5.29.2) (Figure 4-50). As is common at many large calderas, the Ammonia Tanks magma chamber surged back toward the surface after caldera collapse, and formed a central dome (Timber Mountain resurgent dome) within the calderafilling rocks (Figure 1-5). The magma chamber was modeled by Byers et al. (1976) as a twolayered, compositionally zoned, magmatic intrusion. Byers et al. (1976) cite microgranite porphyry dikes, pipe-like and plug-like bodies of rhyolite, and quartz latite that intrude the upper part of the Ammonia Tanks Tuff on Timber Mountain dome as evidence for magma chamber zoning.

Because no drill holes penetrate the intrusive and it is not exposed at the surface, the extent (including the depth to the top) of the unit is poorly constrained. The unit is modeled as underlying the Timber Mountain composite unit (TMCM) at a depth of 1.8 to $2.4 \mathrm{~km}$ (1.1 to $1.5 \mathrm{mi}$ ), with the top of the unit bounded by the Ammonia Tanks structural caldera margin and with sides that dip outward at approximately 80 degrees to the base of the model at 8.5 to $9 \mathrm{~km}$ (5.3 to $5.6 \mathrm{mi}$ ) below ground surface (refer to Model Profiles B-B' and H-H' in BN, 2002a). The western edge of the RM-SM model barely intercepts the ATICU (Figure 4-50).

\subsubsection{Rainier Mesa Intrusive Confining Unit (RMICU)}

This HSU consists of a solidified pluton or magma body associated with the eruption of the lower member of the Timber Mountain Group, the Rainier Mesa Tuff (Figure 4-50). The formation of the nested Timber Mountain caldera complex began about 11.6 Ma with the eruption of the Rainier Mesa caldera (Byers et al., 1976). The less voluminous Ammonia Tanks member was erupted shortly thereafter, at about $11.45 \mathrm{Ma}$ (Sawyer et al., 1994) (Subsection 3.3.4).

Because no drill holes penetrate the intrusive and it is not exposed at the surface, the extent of the unit is poorly constrained. The RMICU is modeled as underlying the Timber Mountain composite unit (or the sub-caldera volcanic confining unit) at depths of 1,500 to $3,000 \mathrm{~m}$ $(5,000$ to $10,000 \mathrm{ft})$, with the top of the unit bounded by its structural caldera margin and with 
outward-dipping sides (approximately 80 degrees) to the base of the model at about $9 \mathrm{~km}$ (5.6 mi) below ground surface (Model Profiles E-E' and F-F'). The central portion of the RMICU has, for the most part, been intruded and replaced by the younger ATICU.

\subsubsection{Silent Canyon Intrusive Confining Unit (SCICU)}

The northwest corner of the RM-SM model intersects the Silent Canyon caldera complex (SCCC) (Figure 4-50). The SCICU is modeled as a single, highly altered and/or intruded mass that underlies the buried SCCC at a depth of about $5 \mathrm{~km}$ (3.1 mi) (Figure 4-50). The top of the unit is bounded by the caldera complex margin, and its sides (conceptually) dip inward at $80^{\circ}$ to the base of the model (Model Profiles B-B' and C-C').

The block model and the piecemeal collapse process suggested in the PM-OV model interpretation (BN, 2002a) have resulted in a complex final geometry for the floor of the SCCC. The SCICU is conceived to consist of a group of distinct structural blocks (though highly altered and/or intruded) related to basin-and-range faulting or caldera formation.

Drill hole UE-20f, currently the deepest drill hole on the NTS, is located on Pahute Mesa at the western edge of the SCCC. This borehole penetrated 4,171.5 m (13,686 ft) of Cenozoic tuffs, and was terminated within the Pre-Belted Range composite unit (PBRCM of the PM-OV model; BN, 2002a) which overlies the SCICU. This well thus indicates a minimum depth to the SCICU in the western portion of the SCCC.

\subsubsection{Redrock Valley Intrusive Confining Unit (RVICU)}

The Redrock Valley caldera is located southwest of Rainier Mesa (Figure 1-5). Support for its existence is presented in Subsection 3.1.3.1. As with the other SWNVF calderas, a single intrusive mass (or IICU) is modeled beneath the Redrock Valley caldera. The extent of the intrusive is poorly constrained. The intrusive is not exposed at the surface, and it is not penetrated by any drill holes. The top of this unit is bound by the oldest Tertiary units (in this case the ATCU and LTCU1) and the caldera structural margin, and its sides (conceptually) dip inward at $80^{\circ}$ to the base of the model (Model Profile D-D'). Distribution of RVICU is shown in Figure 4-50.

\subsubsection{Other Intrusive Confining Units}

Two other intrusive confining units are defined in the RM-SM model that are not related to calderas, as described in the following paragraphs. 


\subsubsection{Calico Hills Intrusive Confining Unit (CHICU)}

This HSU is located at the extreme southwestern part of the RM-SM model area (Figure 4-50) and like the ATICU, constitutes only a small volume of the RM-SM model. The CHICU is modeled here as a deep-seated pluton that intruded rocks of the lower clastic confining unit (LCCU) and the LCA, and is not associated with a known caldera. The CHICU has, in turn, been intruded by the younger RMICU from the northwest (Model Profiles F-F' and G-G').

Evidence for the intrusive includes doming of the Calico Hills and associated radial and concentric faults, and a strong magnetic anomaly. Core hole UE25a-3 was drilled to investigate the anomaly, and though an intrusive was not encountered, drilling terminated in marble (Maldonado et al., 1979). The extent of the intrusive (including depth to the top) is poorly constrained. The intrusive is not exposed at the surface, and no drill holes penetrate it. The unit is modeled as underlying the pre-Tertiary units at a depth of about $4 \mathrm{~km}(2.5 \mathrm{mi})$ within the model area, with the top of the unit within the LCA (Model Profile G-G').

\subsubsection{Mesozoic Granite Confining Unit (MGCU)}

The Mesozoic Era is represented only by intrusive igneous rocks in the model area (Figure 4-3). Cretaceous-age granitic rocks are exposed at Gold Meadows in the northern part of the model area just north of Rainier Mesa (Figure 4-51 and Plate 1). The Gold Meadows intrusive and the Climax stock, which lies $8 \mathrm{mi}(12.9 \mathrm{~km})$ east of the Gold Meadows stock, in northern Yucca Flat, are probably related in both source and time, and may be connected at depth (Snyder, 1977; Jachens, 1999; Phelps et al., 2004). The Gold Meadows intrusive body consists principally of quartz monzonite (Houser et al., 1961). However, the Climax stock is a composite granitic intrusive comprising an older medium-grained, equigranular granodiorite and a younger fine- to medium-grained, coarsely porphyritic quartz monzonite (Orkild et al., 1983). Recent re-analysis of magnetic data by Jachens (1999) and by Phelps et al. (2004) reaffirmed the general geometry and connection at depth of the Climax and Gold Meadows stocks. The Gold Meadows intrusive is grouped into the MGCU, the extent of which is shown on Figure 4-52 (see also Model Profile C-C'). Because of low intergranular porosities and permeabilities, and the lack of interconnecting fractures, (Walker, 1962) the MGCU is considered to be a confining unit.

\subsubsection{Lower Clastic Confining Unit 1 - Thrust Plate (LCCU1)}

In the central portion of the model area, the east-vergent Belted Range thrust fault has placed upper Precambrian clastic rocks over Devonian and Silurian carbonate rocks (LCA) that in turn have been thrust over Mississippian strata (Cole and Cashman, 1999) (see discussion of upper clastic confining unit [UCCU] in Subsection 4.5.34). Though the upper thrust plate includes some of the same units as the regional clastic confining unit (LCCU; Subsection 4.5.36), its 
position above younger HSUs requires that it be distinguished from the LCCU. Therefore, this HSU is designated LCCU1 (Figure 4-3) and its extent is shown in Figure 4-53.

Subsurface control for this HSU is poor. The LCCU1 has been encountered in only a few drill holes within the study area, including a few exploratory drill holes on Rainier Mesa and Well ER-19-1 (DOE, 1995a) (Plates 2 and 3). Model Profiles A-A', B-B', C-C', E-E', and G-G' depict the LCCU1 and Belted Range thrust fault geometry within the RM-SM model. Precambrian clastic rocks are mapped in outcrop around the Gold Meadows stock in the northcentral part of the model (Plate 1).

Fractures in these older siliciclastic sedimentary rocks tend to be healed/sealed with secondary silica. The LCCU rocks, including the over-thrust components, are classified as confining units in UGTA hydrostratigraphic models.

\subsubsection{Lower Carbonate Aquifer - Thrust Plate (LCA3)}

Cambrian through Devonian, mostly carbonate, rocks that form the hanging walls of imbricate thrust faults related to the Belted Range thrust fault are assigned to the LCA3. The Belted Range thrust and associated imbricate faults extend through the model area from the northeast portion of the model through Aqueduct and Rainier Mesas, and continue to the southwest, skirting the east edge of the Timber Mountain caldera complex. The fault system then continues westward out of the RM-SM model area. Deformation related to the east-vergent Belted Range thrust fault has placed these older LCA rocks over younger rocks of the UCCU and over stratigraphically equivalent LCA rocks (i.e., repeated section) (Figures 3-1 and 4-3). Thus the rocks of LCA3 are stratigraphically equivalent and probably hydrogeologically similar to the LCA, but are structurally separated from the LCA by Belted Range imbricate thrust faults (Subsection 3.1.1; Model Profiles A-A' through G-G'). The position of these rocks above the UCCU requires that they be distinguishable in the model from the regional aquifer (LCA).

The LCA3 is exposed on the east side of Rainier Mesa, at Mine Mountain, and in the extreme southern portion of the model area, just west of Mid Valley. The very small outcrop of carbonate rocks of Devonian age in the southwest corner of the model area (Figure 1-5; Plates 1 and 2) is interpreted to be an isolated remnant of a once-larger thrust sheet (LCA3) that covered the area. Note that an alternate interpretation depicts the LCA3 as a continuous sheet along the Belted Range thrust fault, traversing the central portion of the model (Subsection 5.2.1). Another alternative scenario (Subsection 5.2.3) models the carbonate rocks exposed along the west side of Mid Valley as part of an imbricate thrust sheet referred to here as the Shoshone Mountain thrust sheet, similar to the thrust sheets at Mine Mountain and Calico Hills. 
Although subsurface control for the LCA3 is generally poor, with only a few drill holes penetrating this HSU (Appendix A) and even fewer holes penetrating the thrust fault structures, its extent is fairly well constrained in the northern portion of the model area by exposed stratigraphic relationships and deep drill holes in the vicinity of Gold Meadows and Rainier Mesa. Additional subcrops of east-directed imbricate-thrusted carbonate and siliciclastic rocks occur in the Rainier/Aqueduct Mesa area and southern Eleana Range (Figures 4-54 and 4-55). Remnants of thrust plates are mapped in the Carbonate Wash area (Rogers and Noble, 1969), in the Eleana Range (Orkild, 1963), at Mine Mountain (Orkild, 1968), and in the CP Hills (McKeown et al., 1976). Alternating intervals of Devonian carbonate and Mississippian siliciclastic rocks penetrated at the bottom of Well ER-12-1 are modeled in an alternative scenario as part of another east-directed imbricate thrust sheet; the alternative designates these structurally lower carbonate rocks as LCA3-1 (Subsection 5.2.4). The interpreted extent of the LCA3 in the RM-SM base model is shown in Figure 4-54. A contour map showing the depth to the LCA3 is presented in Figure 4-55).

\subsubsection{Upper Carbonate Aquifer (UCA)}

The Tippipah Limestone (believed to be correlative with the Bird Spring Formation of southern Nevada; Table 4-2) is the only unit at the NTS known to represent deposition during late Pennsylvanian to Permian time. This unit is found at the surface only at Syncline Ridge (Figures 1-2 and 1-5; Plate 1), though it is believed to underlie a slightly larger area in the subsurface of the western part of Yucca Flat. This unit consists of thick limestone layers interbedded with mudstone and siltstone beds. Surface exposures are highly deformed and fractured. The UCA is present only in areas where the Tippipah Limestone is present. Figure 4-56 shows the distribution of the UCA. Groundwater is produced from the UCA at Water Well UE-16d, located in the west-central portion of the model area (Gillespie et al., 1996), averaging approximately 100 acre-feet per year (Fenelon, 2005).

\subsubsection{Upper Clastic Confining Unit (UCCU)}

Late Devonian and Mississippian siliciclastic rocks in the NTS vicinity are assigned to the Eleana Formation and the Chainman Shale (Cashman and Trexler, 1991; Cashman et al., 2001; Trexler et al., 1996). The Eleana Formation as originally defined by Poole et al. (1961) was partitioned by Cashman and Trexler (1991) on the basis of lithofacies variations and sediment source. The shaley lithofacies in the RM-SM model area are now generally grouped in the Chainman Shale, while the section bearing the non-shaley quartzite, sandstone, and conglomeratic lithofacies, retains the original formation name. The Mississippian and Devonian 
Eleana Formation and the Mississippian Chainman Shale form the UCCU. Hydrologically, the UCCU has very low permeability, and though saturated in parts of the model area, it yields very little water, as found at Well ER-12-2 (DOE, 2004).

The extent of the UCCU is shown on Figure 4-57. The subsurface control for this HSU is poor, with no drill holes fully penetrating UCCU within the model area. Well ER-12-2 was terminated in the UCCU after penetrating $1,912 \mathrm{~m}(6,273 \mathrm{ft})$ of this HSU (DOE, 2004), and approximately $1,566 \mathrm{~m}$ (5,139 ft) of UCCU was penetrated at Well UE-1L (Fernald et al., 1975). The most recent MT data (Subsection 2.3.7.4) helped identify where this relatively thick and electrically conductive unit is present or absent. There are extensive bedrock exposures of the UCCU in the Eleana Range, a north-northeast trending range through the central and northeastern portion of the model area (Figures 1-5 and 4-4; Plate 1). The subsurface configuration of this unit and its relation to nearby HSUs are depicted in Model Profiles B-B' through G-G'.

An alternative model recognizes a structurally isolated interval of Mississippian siliciclastic rocks in Well ER-12-1, and designates them as UCCU1 to distinguish the rocks from the structurally lower UCCU (Subsection 5.2.4)

\subsubsection{Lower Carbonate Aquifer (LCA)}

The LCA consists of thick sequences of Middle Cambrian through Upper Devonian carbonate rocks (Figure 4-3). This HSU serves as the regional aquifer for most of southern Nevada, and locally may be as thick as 5,000 m (16,400 ft) (Winograd and Thordarson, 1975; Cole, 1992). Measured transmissivity in LCA rocks differs from place to place, apparently reflecting the observed differences in fracture and fault densities and characteristics (Winograd and Thordarson, 1975).

The unit consists mostly of dolomite and interbedded limestone, but also contains thin shale, quartzite, and calcareous clastic units (Cole and Cashman, 1999; Sargent and Orkild, 1973; see also Table 4-2). The only LCA outcrop within the RM-SM model area is an exposure of carbonate rocks on the western margin of Mid Valley (Figures 1-5 and 4-4; Plate 1). An alternate scenario, described in Subsection 5.2.3, depicts a geometry in which this Paleozoic outcrop is LCA3. In virtually all parts of the model area the LCA underlies the younger Paleozoic HSUs such as the UCCU and displaced LCA3 and LCCU1 sheets described above, except where they have been intruded by the calderas of the SWNVF. Its extent is shown in Figure 4-58 and a structure contour map showing the depth to the LCA is presented in Figure 4-59. 


\subsubsection{Lower Clastic Confining Unit (LCCU)}

Proterozoic to Middle Cambrian rocks in the NTS region are largely quartzite and silicacemented siltstone (Barnes, 1962; Gibbons et al., 1963). This section includes the Johnnie Formation, Stirling Quartzite, Wood Canyon Formation, Zabriskie Quartzite, and the lower half of the Carrara Formation (Winograd and Thordarson, 1975). These units make up the LCCU, which is considered to be the regional hydrologic basement (Winograd and Thordarson, 1975; Laczniak et al., 1996; IT, 1996a). The base of the RM-SM model terminates within the LCCU. The composite thickness of the LCCU is about 2,870 $\mathrm{m}(9,400 \mathrm{ft})$. Although these rocks are brittle and commonly fractured, secondary mineralization seems to have greatly reduced formation permeability (Winograd and Thordarson, 1975). Where it is in a structurally high position, the LCCU may act as a barrier to deep regional groundwater flow. The present structural interpretation for the RM-SM model depicts the LCCU at great depth throughout the model area (Model Profiles A-A' through G-G'). The interpreted extent of the LCCU is shown in Figure 4-60.

\subsection{Relationship of Hydrostratigraphic Units and the Water Table}

The EarthVision ${ }^{\circledR}$ base framework model was electronically "sliced" along a surface that represents the water table (modified from IT, 1996a) to reveal the distribution of HSUs at the water table (Figure 4-61). (The perched water within the zeolitic tuffs of Rainier Mesa is not shown in this water table map.) Although the water table within the UCA along the eastern edge of the model is probably perched or semi-perched above the UCCU, it is reflected in this watertable surface. This figure represents a simplified preliminary interpretation of the water table in the model area, which will be revised as the RM-SM hydrologic modeling progresses.

Within much of the model area where the UCCU and LCA are structurally high, such as in the central and eastern portions, the water table is within the UCCU, LCA, or LCA3. In scattered areas throughout the southwestern and northern portion of the model area the water table is within the LTCU and OSBCU. Within much of the Pahute Mesa and eastern Mid Valley, the water table is within the volcanic aquifers (e.g., the BRA and KA in the northwest and the TSA and TM-WTA in Mid Valley). In the deepest portion of Mid Valley and immediately east of Syncline Ridge, the basin portion of the AA is saturated. In the eastern wing of the Timber Mountain Caldera (on the western edge of the model) the level of saturation is within the FCCM and the underlying TMCM. 


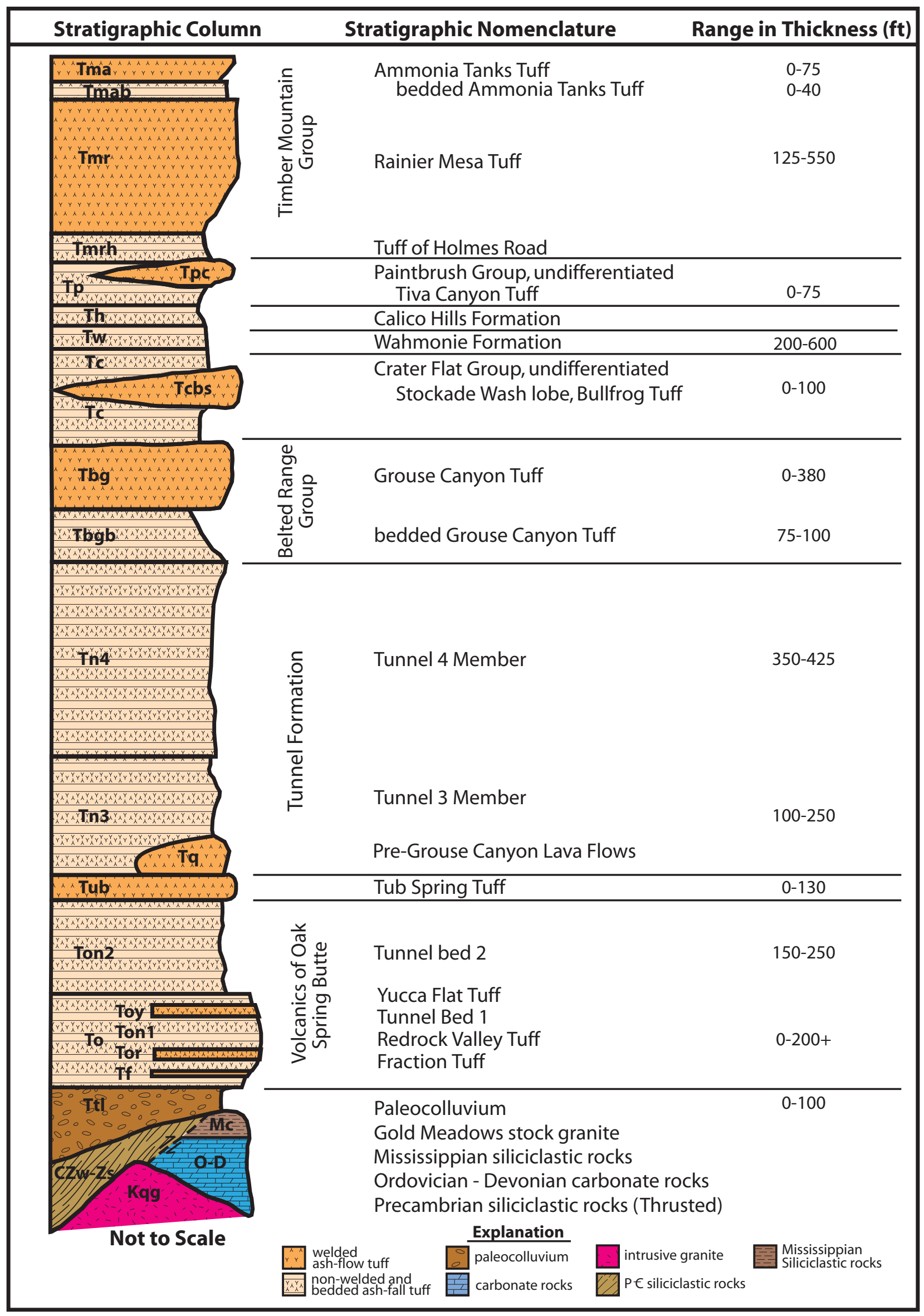

Figure 4-1

Simplified Stratigraphic Section for Rainier Mesa 


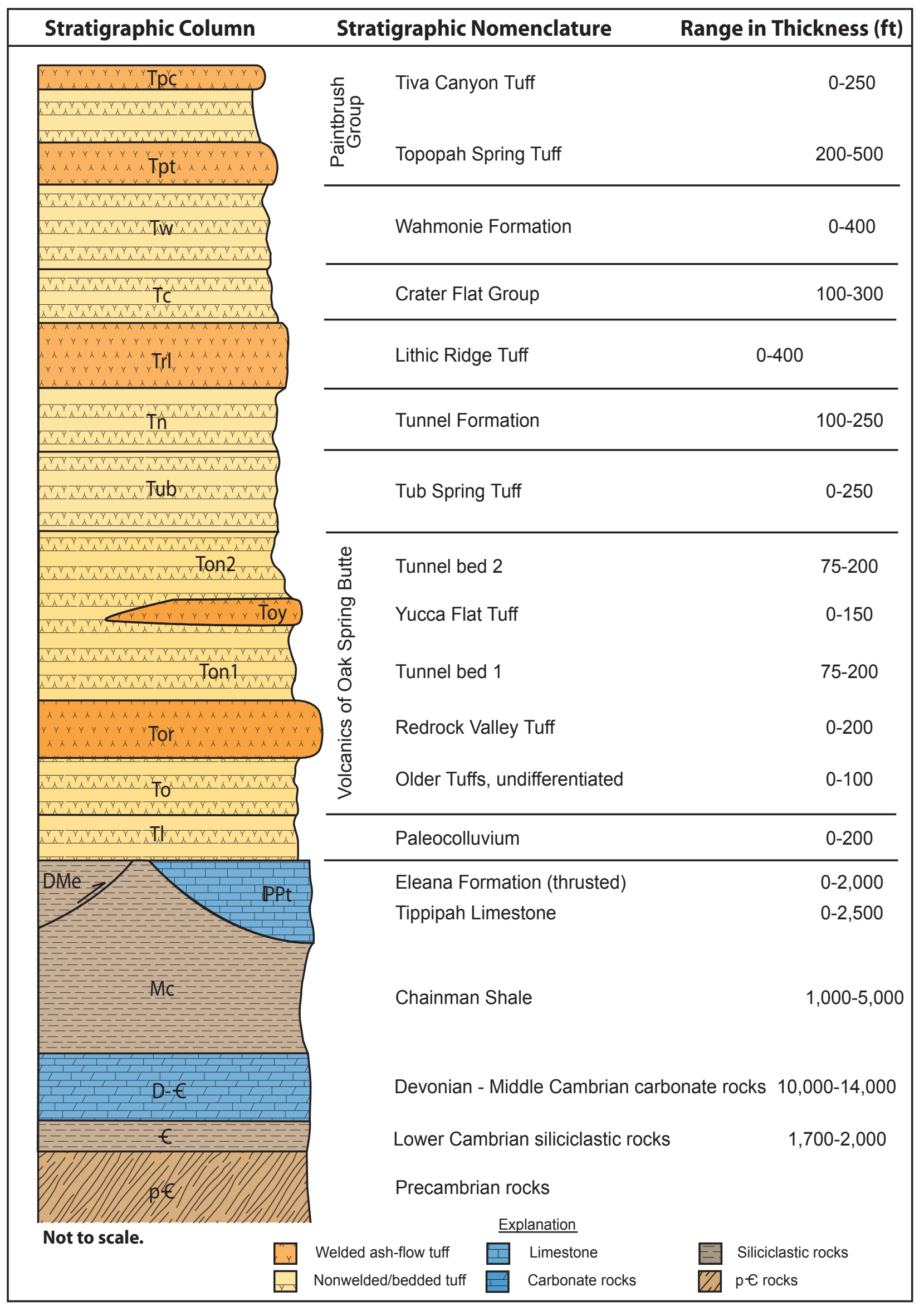

Figure 4-2 Simplified Stratigraphic Section for the Shoshone Mountain Area 


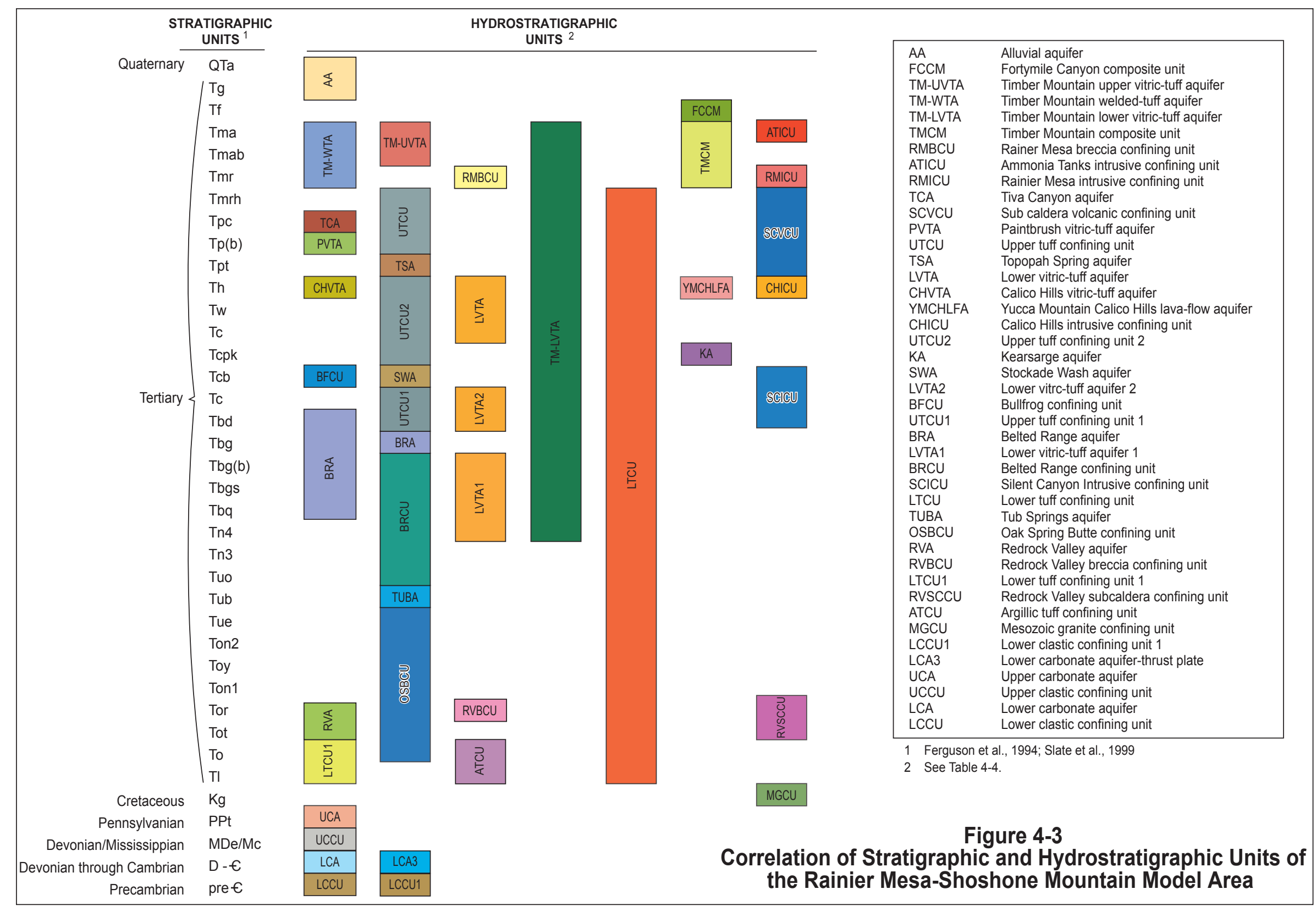




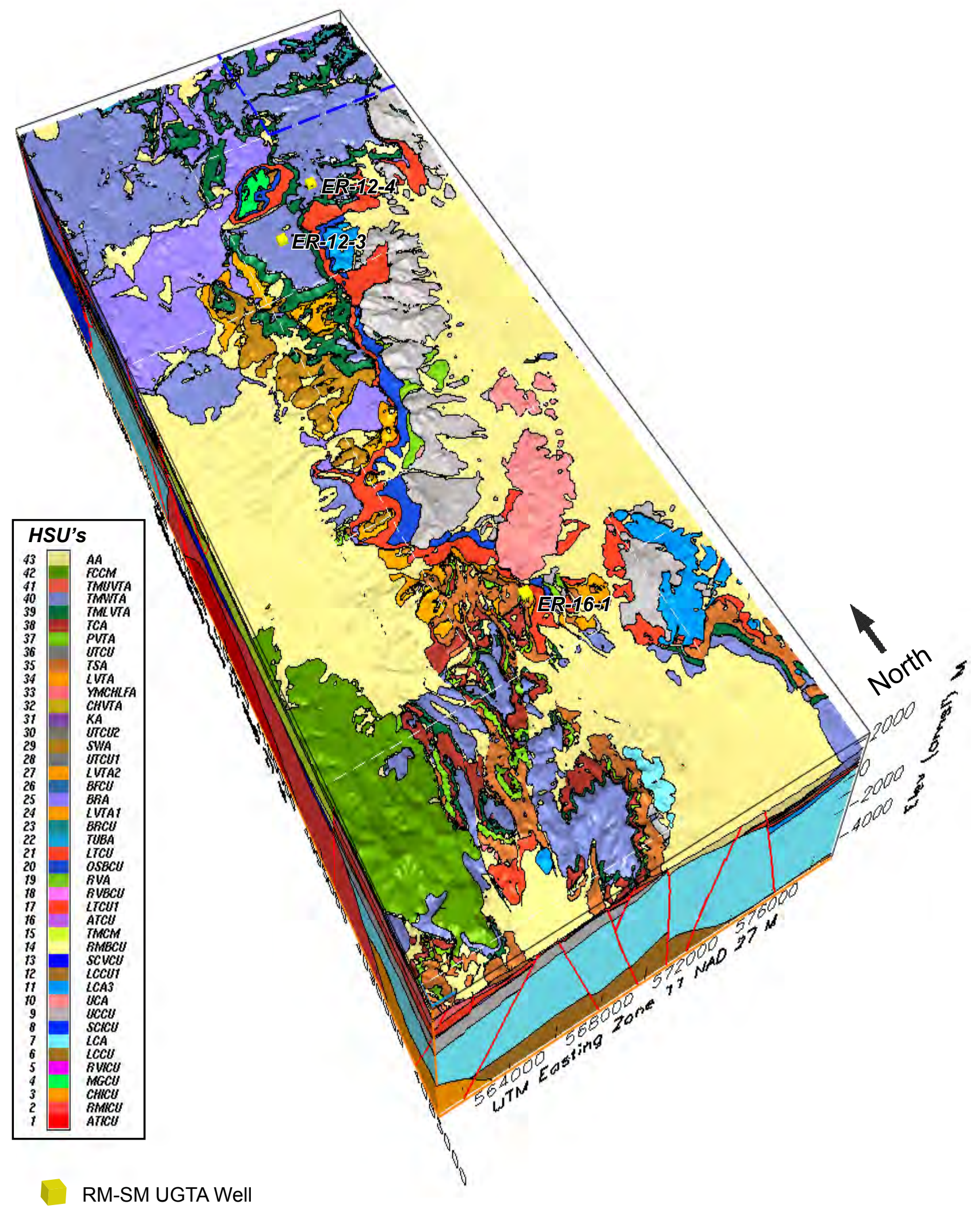

Figure 4-4

Block Model View Showing Hydrostratigraphic Units at the Surface within the RM-SM Model Area 


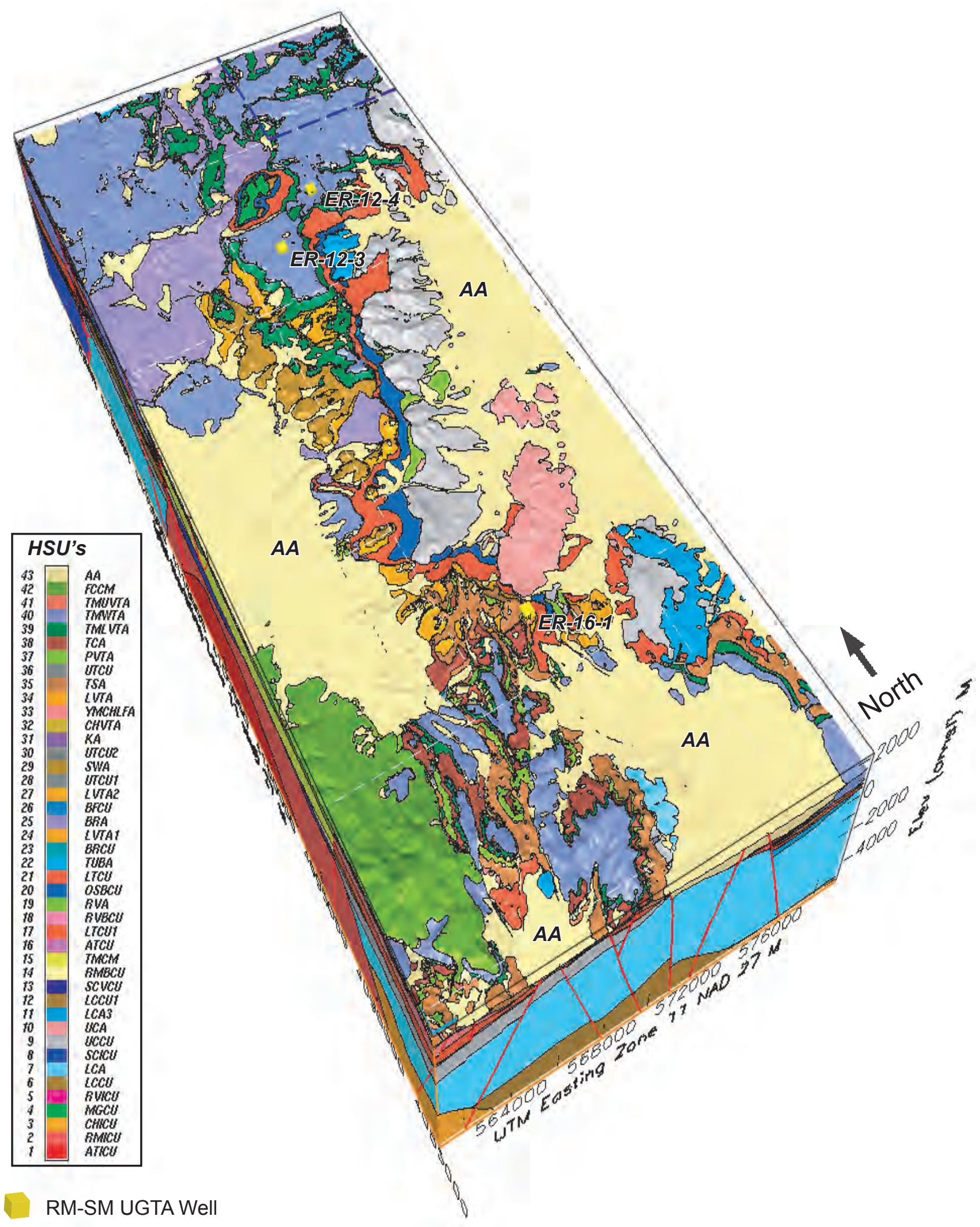

Figure 4-5

Block Model View Showing Extent of the Alluvial Aquifer (AA) within the RM-SM Model Area 


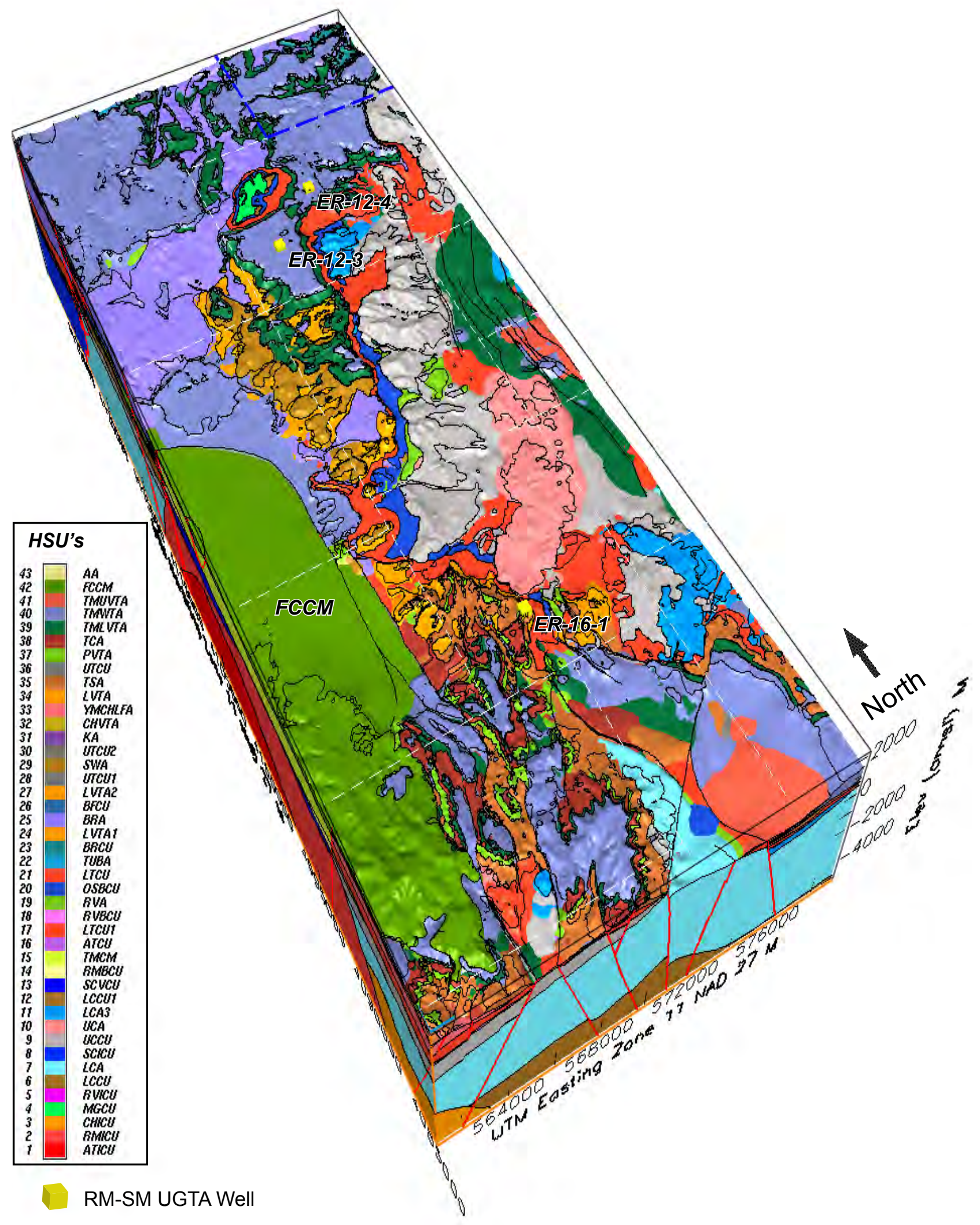

Figure 4-6

Block Model View Showing Extent of the Fortymile Canyon

Composite Unit (FCCM) within the RM-SM Model Area 
West

Pahute Mesa

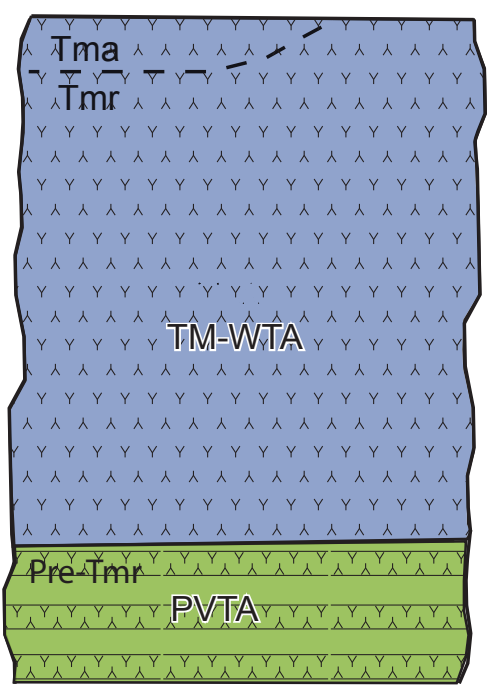

Hydrogeologic Units

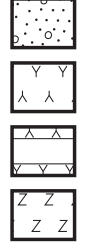

Alluvial aquifer

Welded-tuff aquifer

Vitric-tuff aquifer

Tuff confining unit
Rainier Mesa

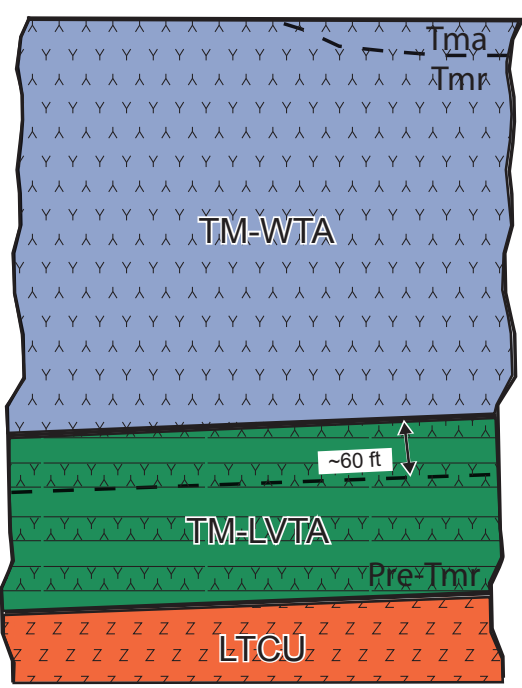

Hydrostratigraphic Units

AA

TM-UVTA

TM-WTA

TM-LVTA

LTCU

PVTA

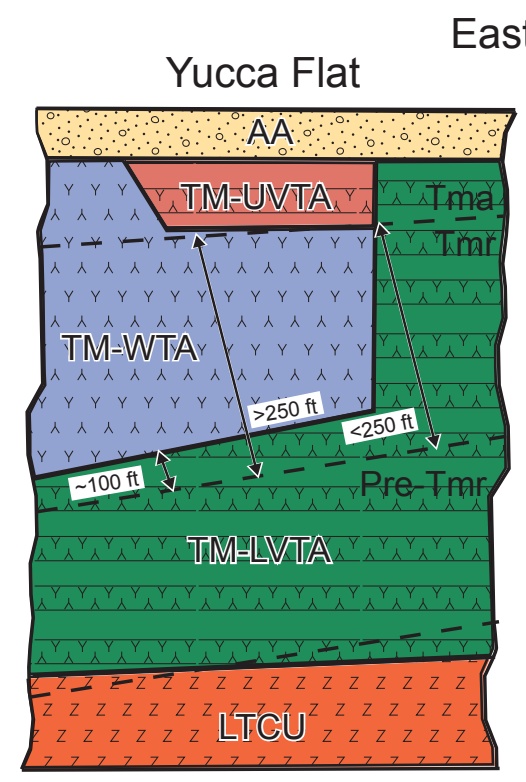

\section{Alluvial aquifer}

Timber Mountain upper vitric-tuff aquifer

Timber Mountain welded-tuff aquifer

Timber Mountain lower vitric-tuff aquifer

Lower tuff confining unit

Paintbrush vitric-tuff aquifer
Stratigraphic Units

NOT TO SCALE

\section{Tma Ammonia Tanks Tuff}

Tmr Rainier Mesa Tuff

\section{Figure 4-7}

Schematic West-East Hydrostratigraphic Columns Across Rainier Mesa-Shoshone Mountain Showing Variability in Hydrogeologic Character of the Timber Mountain Hydrostratigraphic Units 


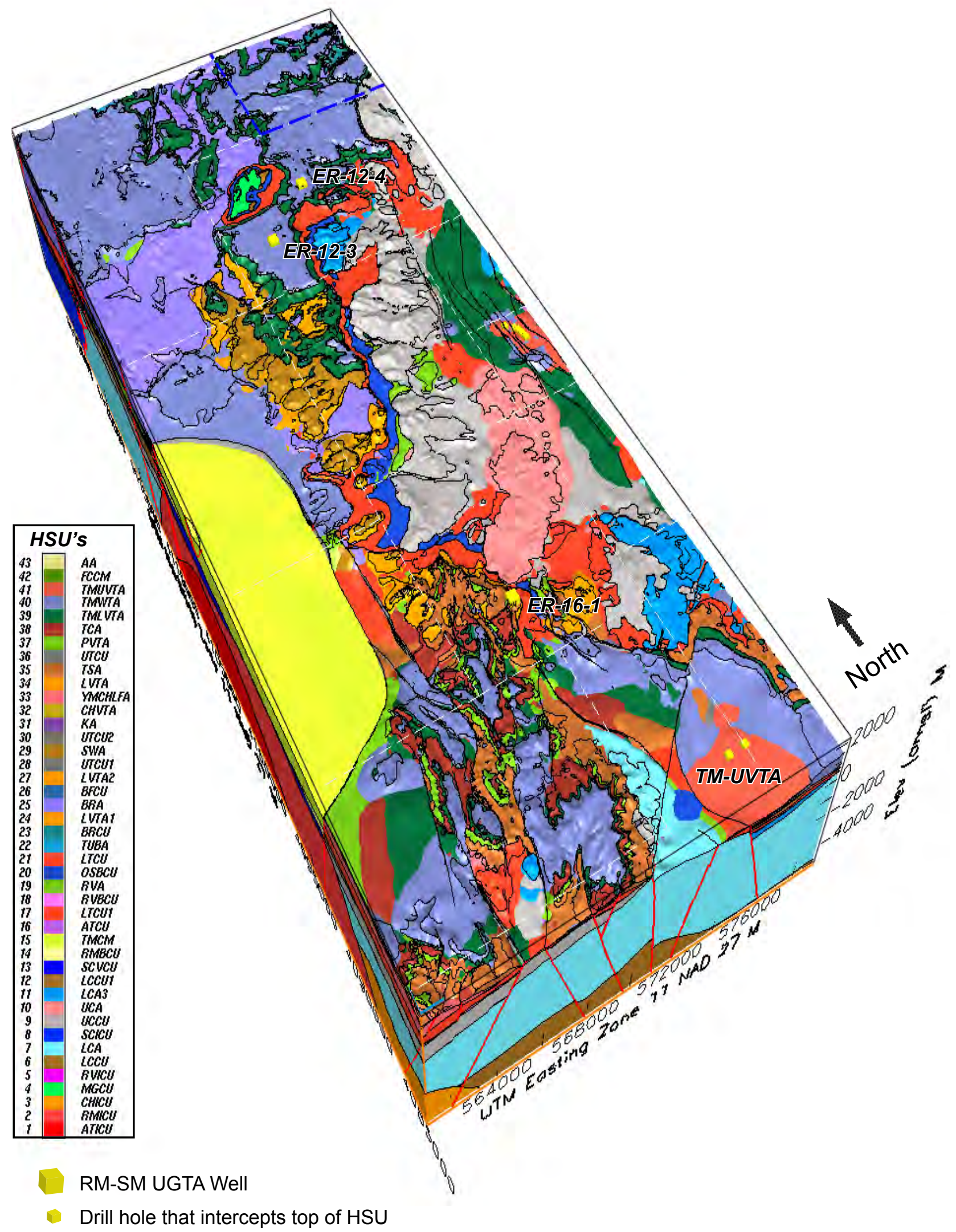

Figure 4-8

Block Model View Showing Extent of the Timber Mountain Upper Vitric-Tuff Aquifer within the RM-SM Model Area 


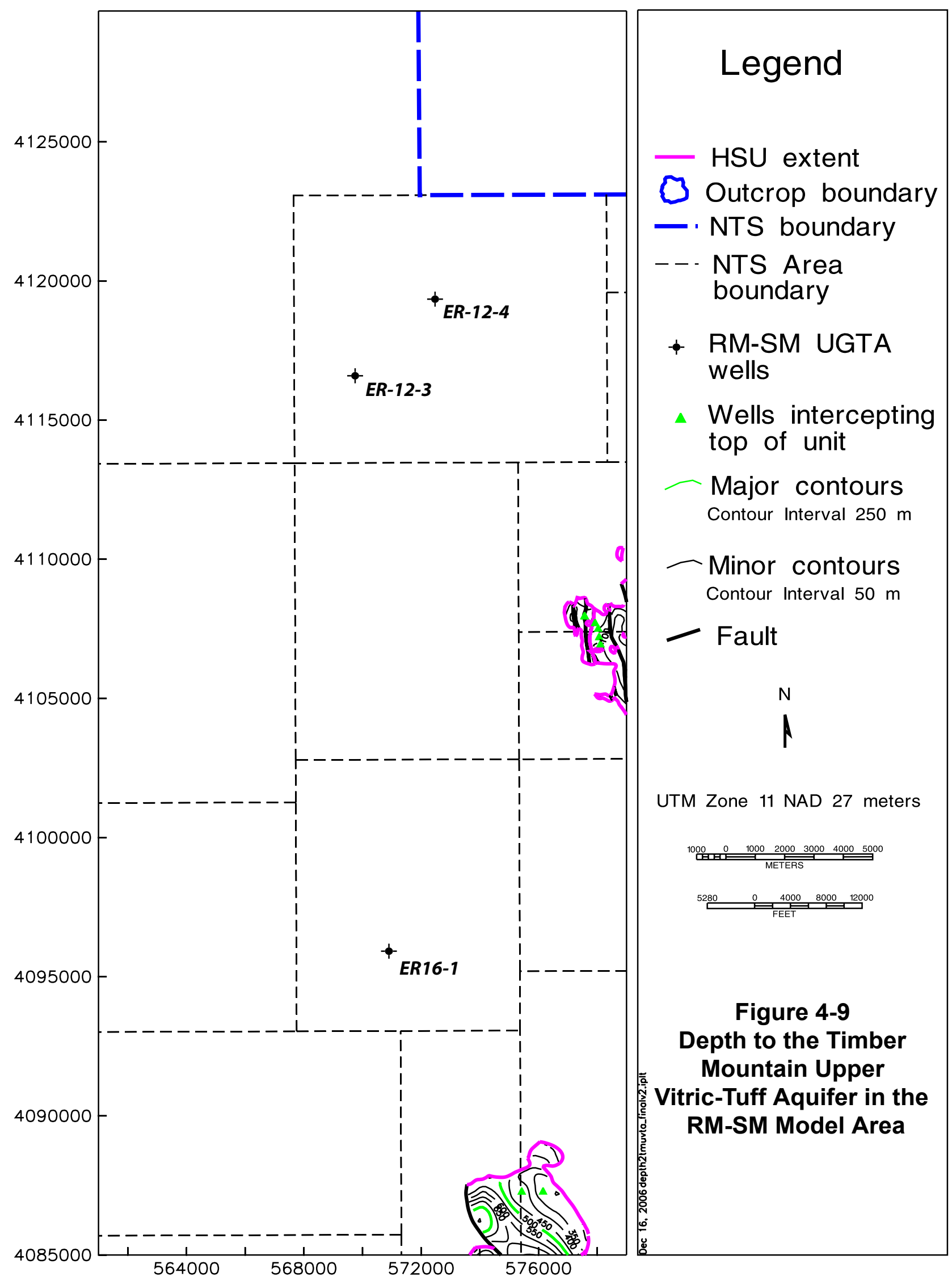




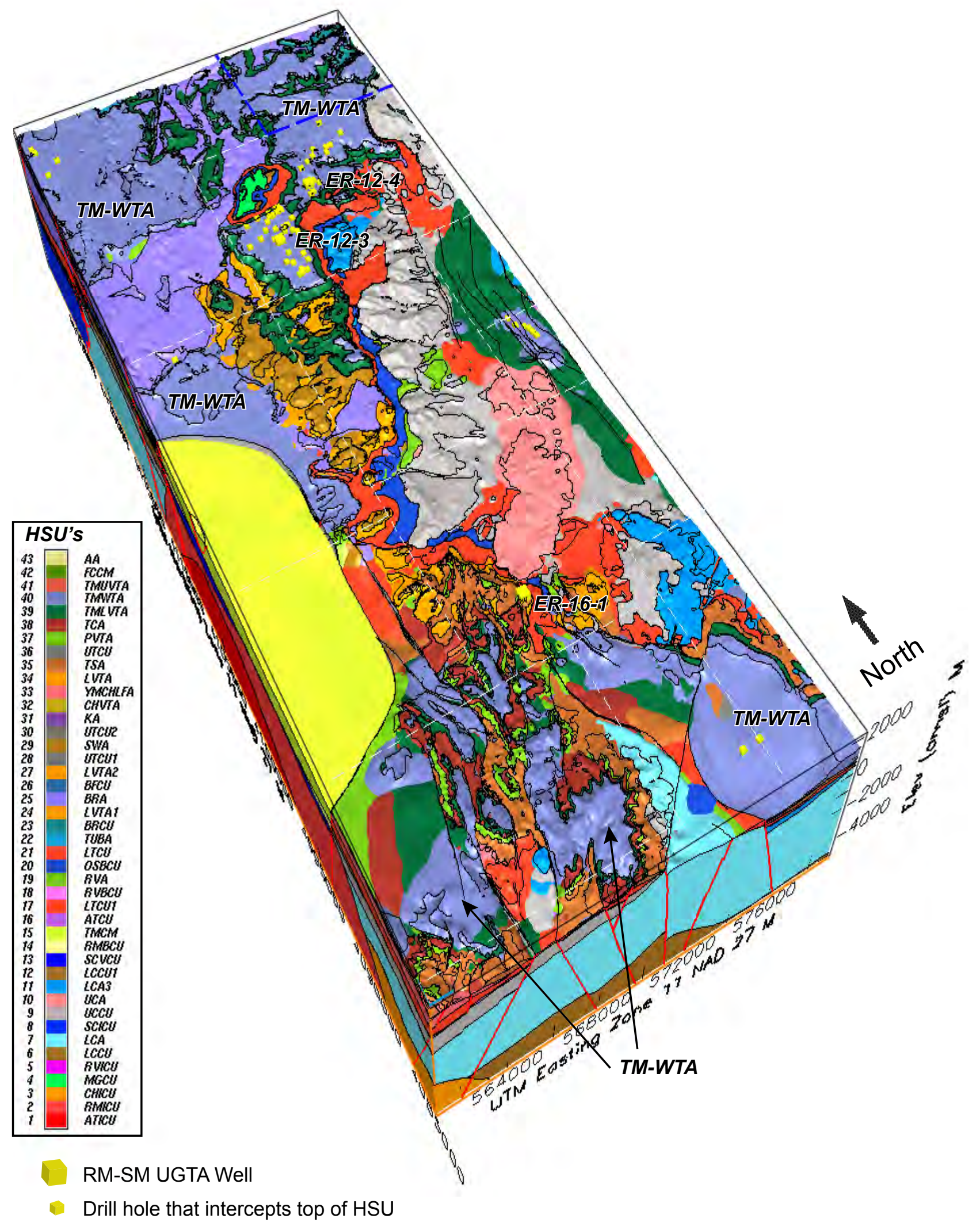

Figure 4-10

Block Model View Showing Extent of the Timber Mountain Welded-Tuff Aquifer (TM-WTA) within the RM-SM Model Area 


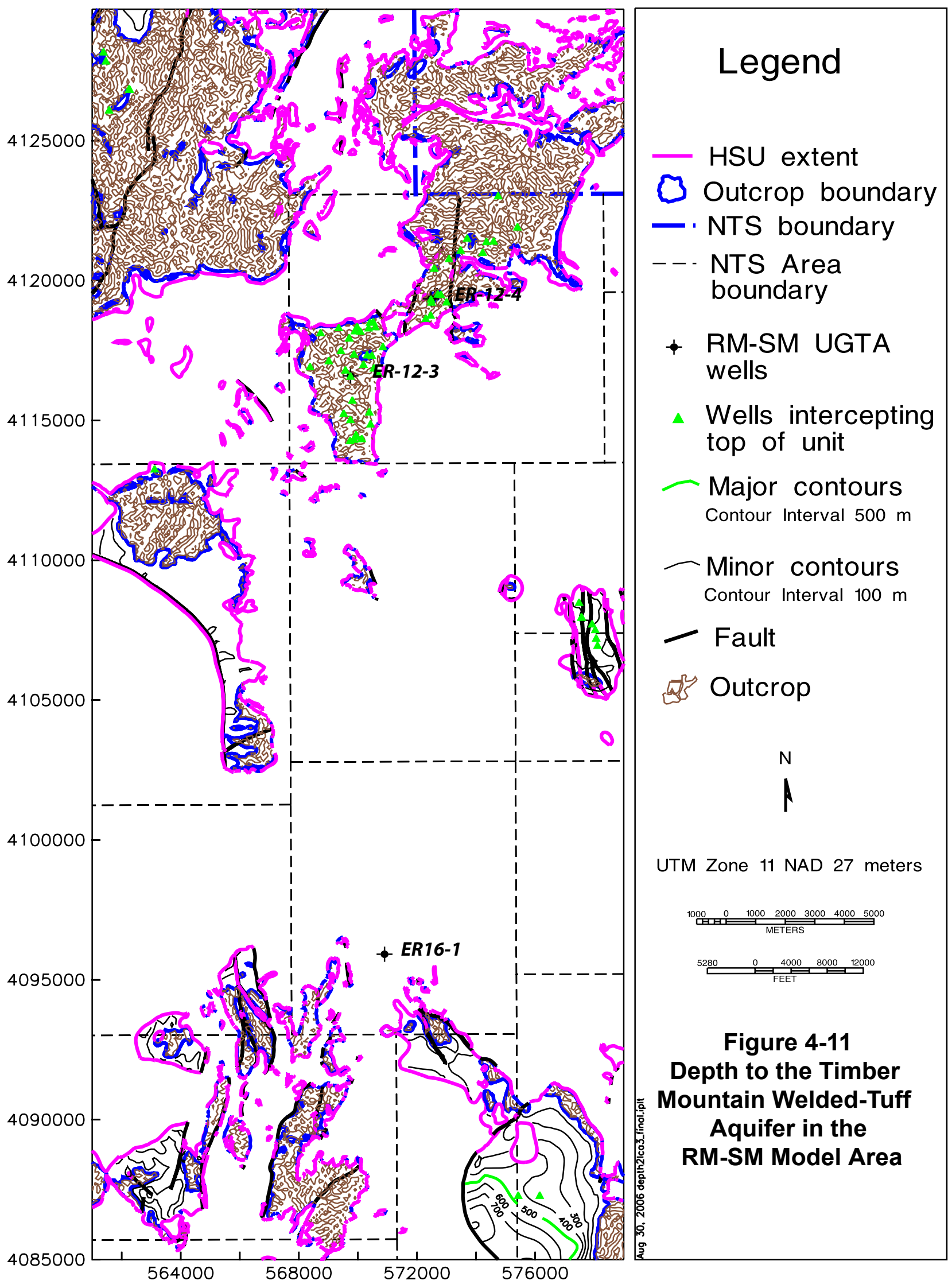




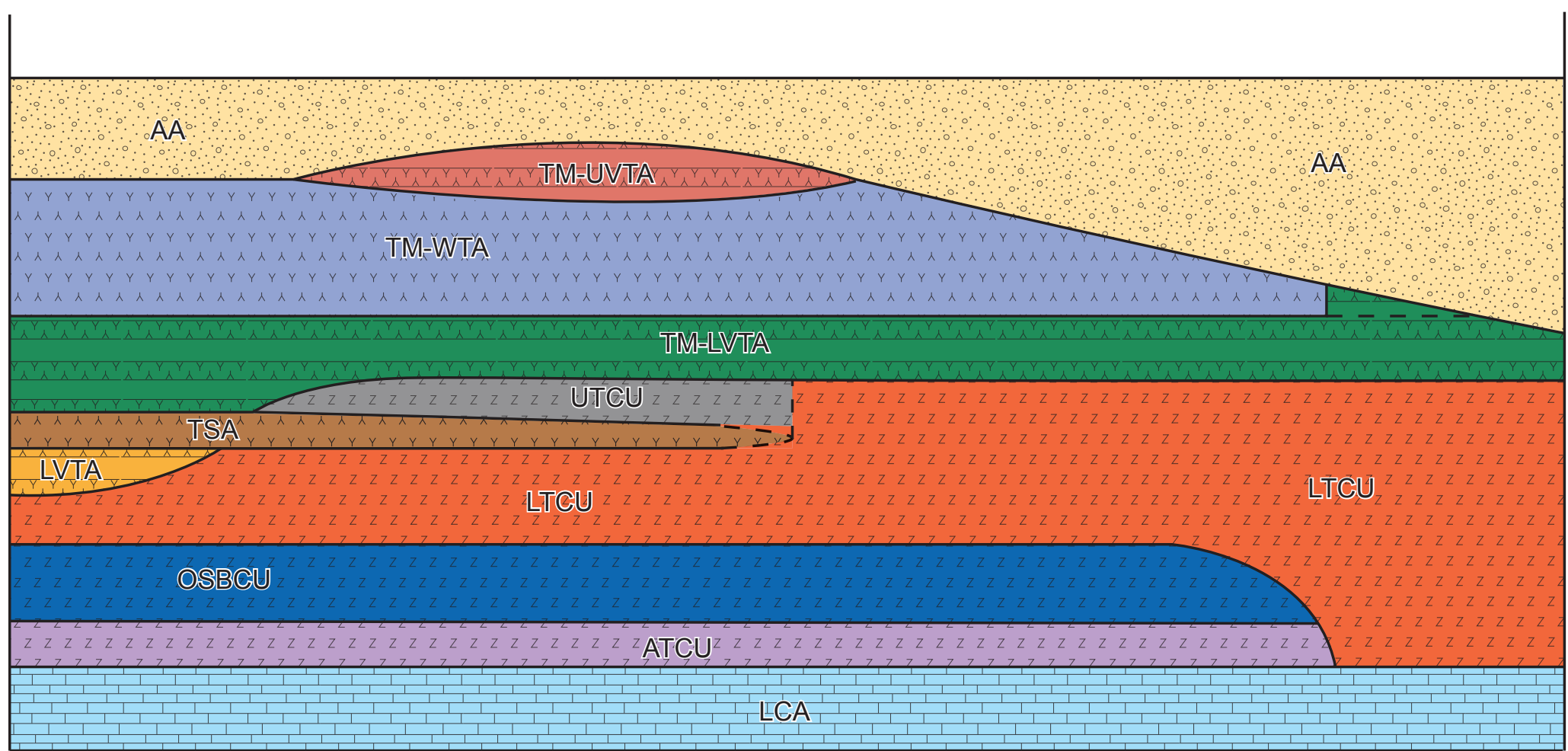

Hydrogeologic Units

\begin{tabular}{|c|c|}
\hline & Alluvial aquifer \\
\hline & Welded-tuff aquifer \\
\hline & Vitric-tuff aquifer \\
\hline & Tuff confining unit \\
\hline & Carbonate aquifer \\
\hline
\end{tabular}

Hydrostratigraphic Units

$\begin{array}{llll}\text { AA } & \text { Alluvial aquifer } & \text { LVTA } & \text { Lower vitric-tuff aquifer } \\ \text { TM-UVTA } & \text { Timber Mountain upper vitric-tuff aquifer } & \text { LTCU } & \text { Lower tuff confining unit } \\ \text { TM-WTA } & \text { Timber Mountain welded-tuff aquifer } & \text { OSBCU } & \text { Oak Spring Butte confining unit } \\ \text { TM-LVTA } & \text { Timber Mountain lower vitric-tuff aquifer } & \text { ATCU } & \text { Argillic tuff confining unit } \\ \text { UTCU } & \text { Upper tuff confining unit } & \text { LCA } & \text { Lower carbonate aquifer } \\ \text { TSA } & \text { Topopah Spring aquifer } & & \end{array}$

Figure 4-12

Schematic Hydrostratigraphic Cross Section Showing the Relationships of the Alluvial and Volcanic Hydrostratigraphic Units in the Southern Portion of the Rainier Mesa-Shoshone Mountain Model Area 


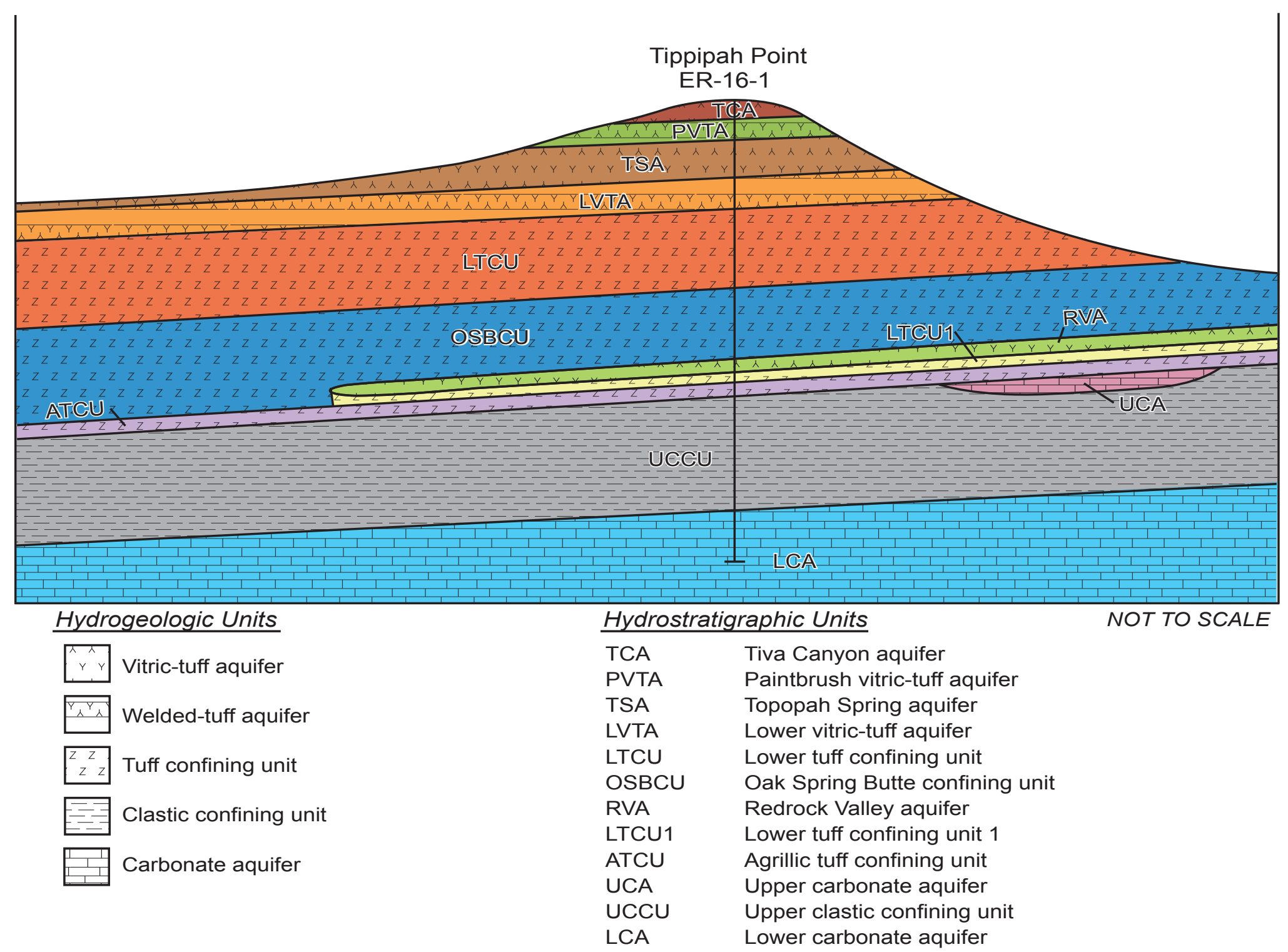

Figure 4-13

Schematic West-East Hydrostratigraphic Cross Section Through Well ER-16-1 Showing Relationships of Hydrostratigraphic Units 


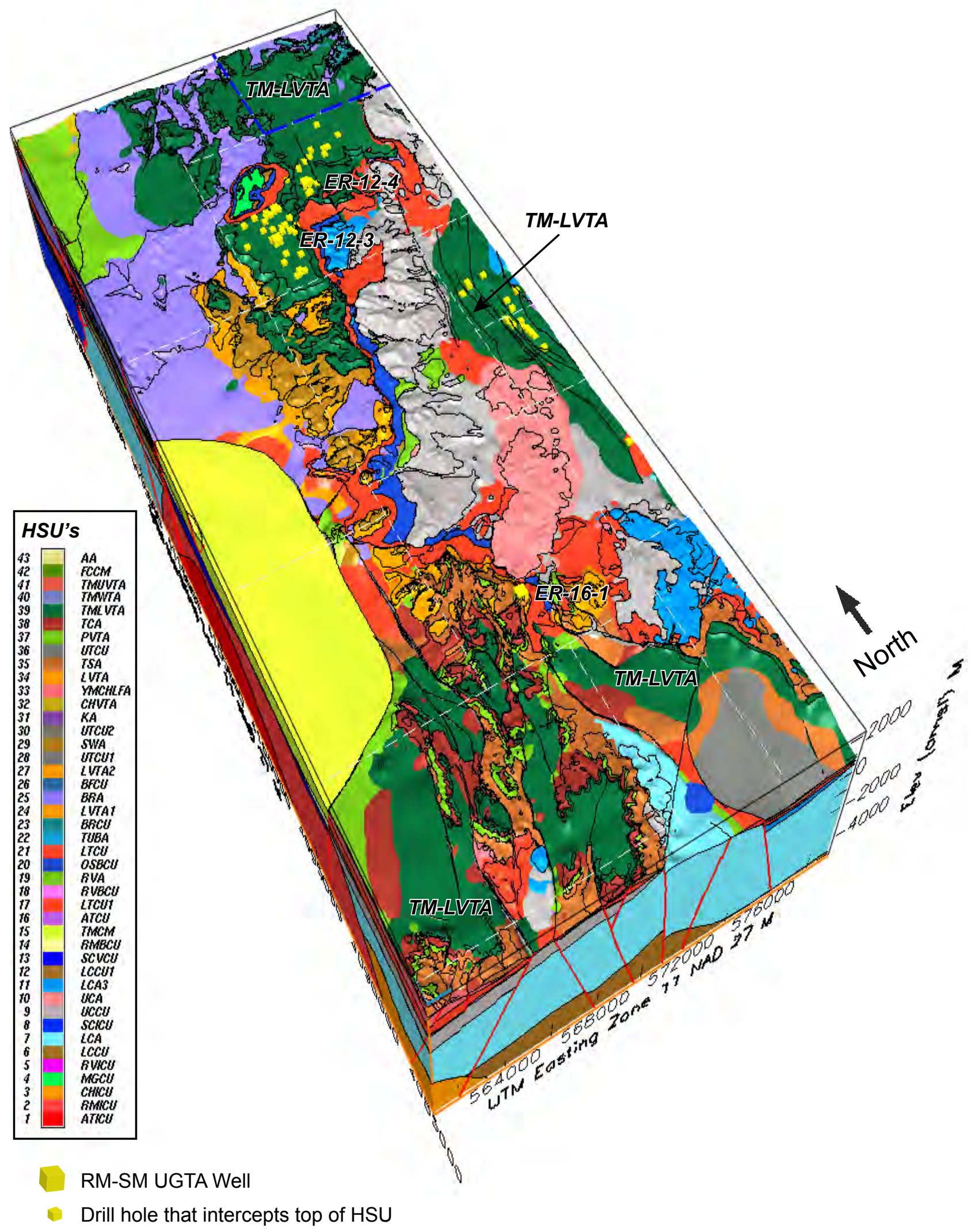

Figure 4-14

Block Model View Showing Extent of the Timber Mountain Lower Vitric-Tuff Aquifer (TM-LVTA) within the RM-SM Model Area 


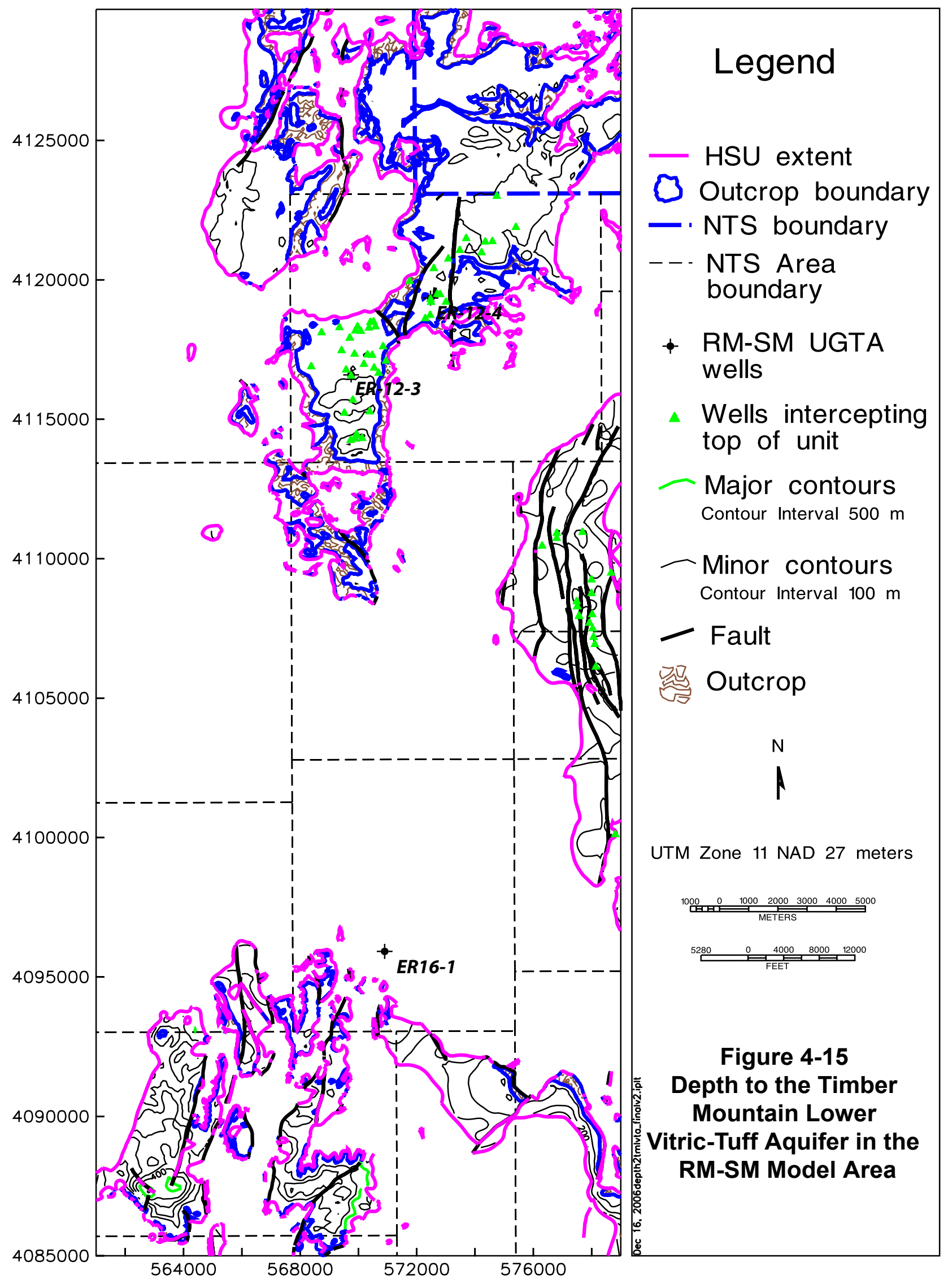




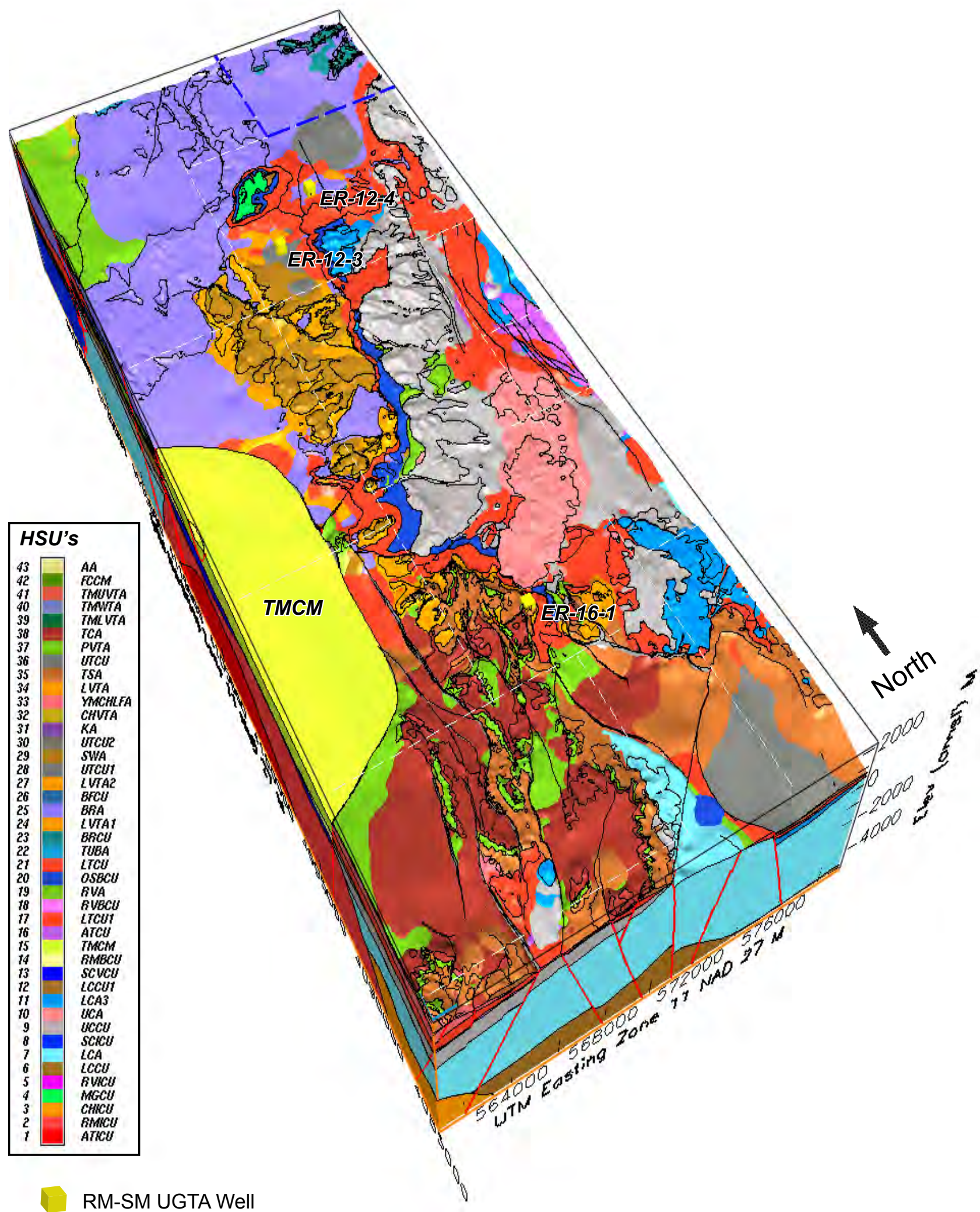

Figure 4-16

Block Model View Showing Extent of the Timber Mountain Composite Unit (TMCM) within the RM-SM Model Area 


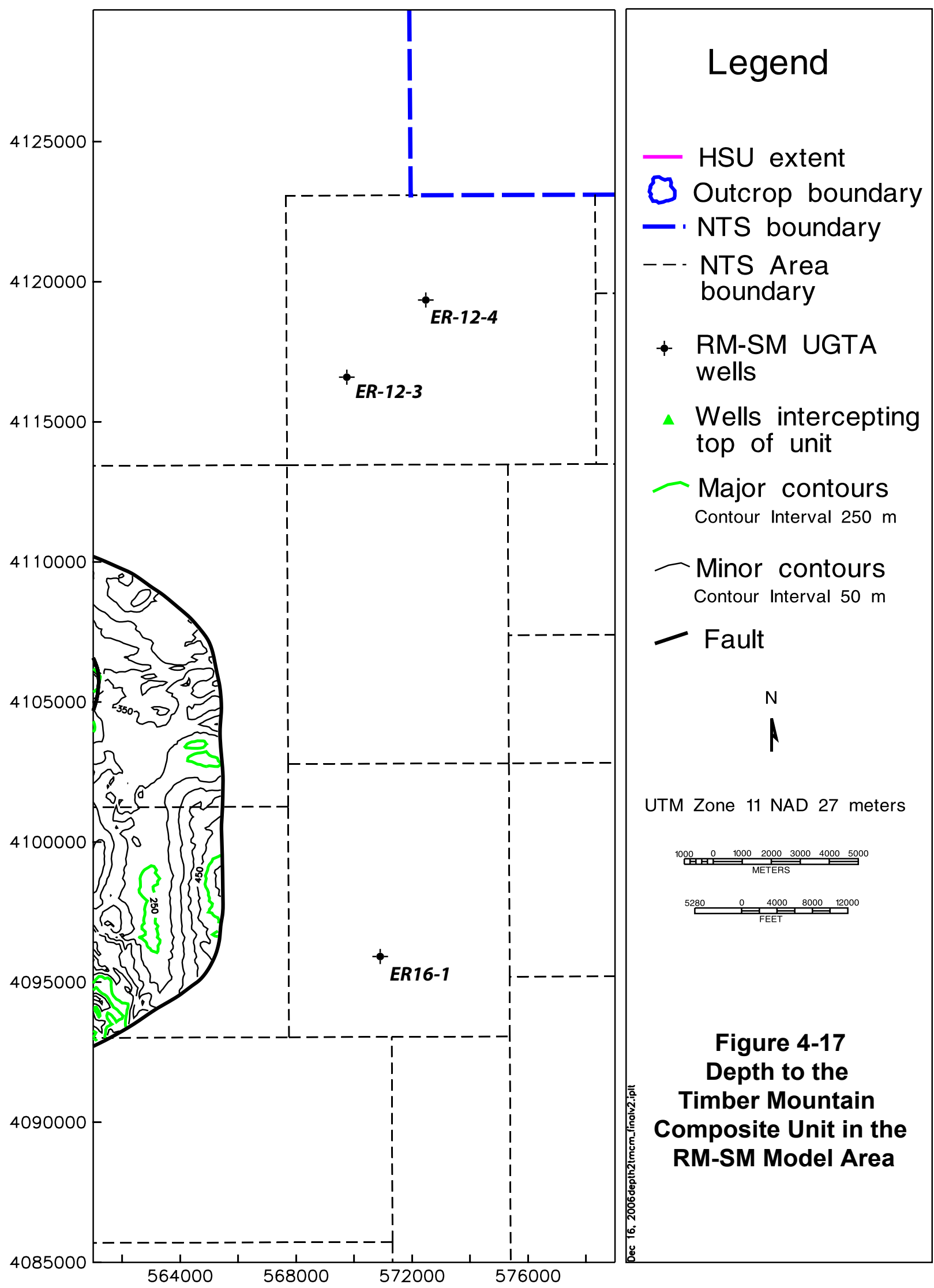




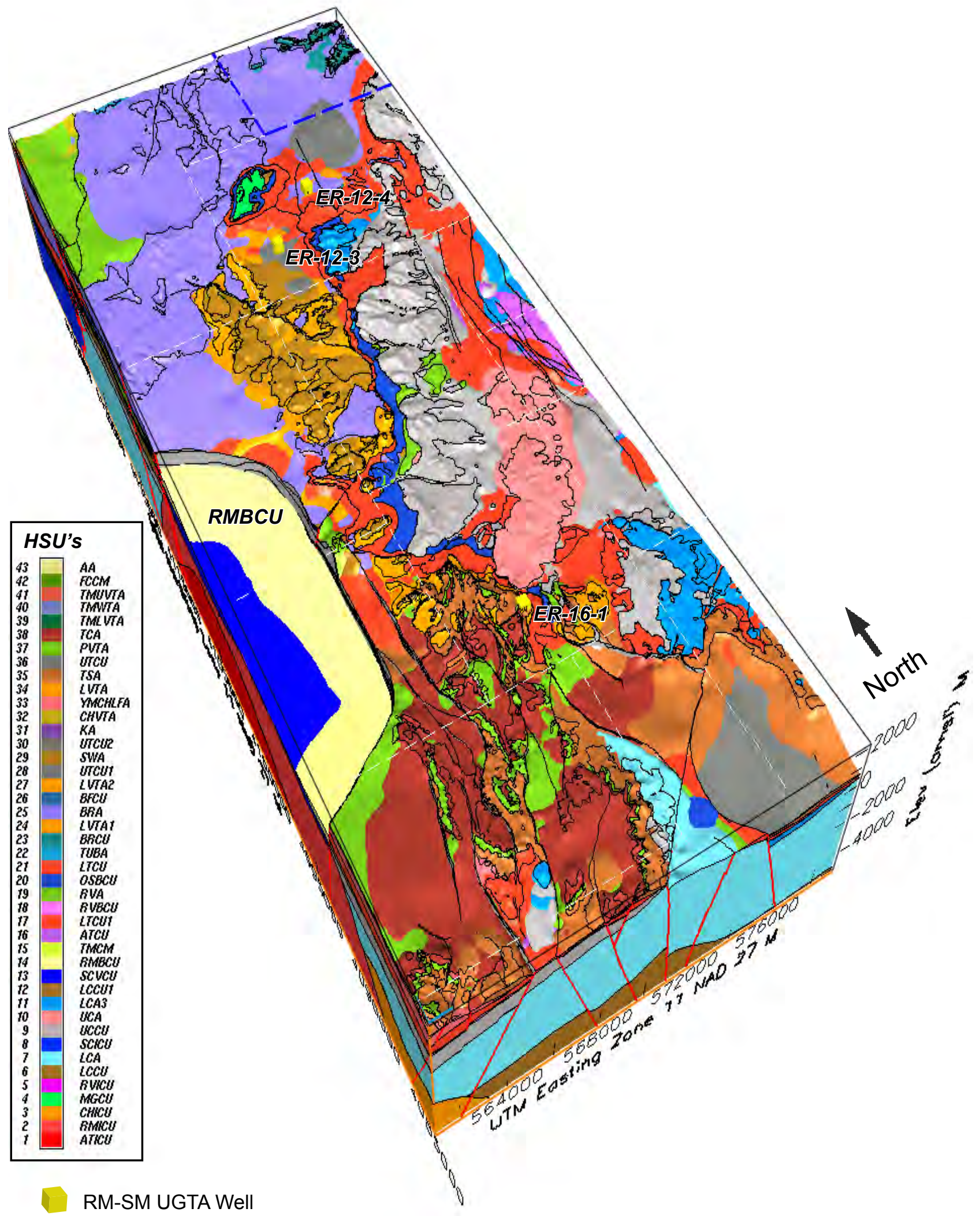

Figure 4-18

Block Model View Showing Extent of the Rainier Mesa Breccia Confining Unit (RMBCU) within the RM-SM Model Area 


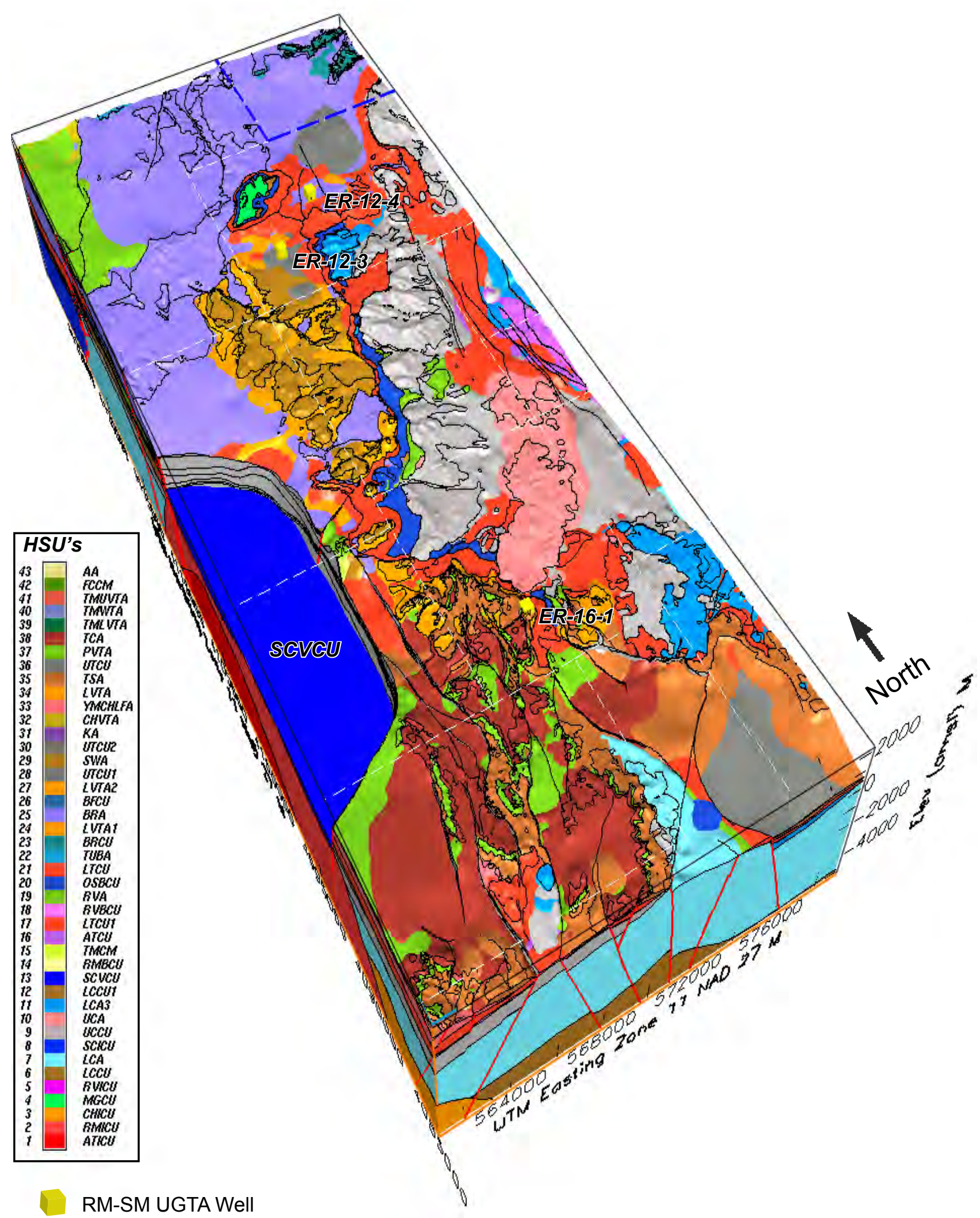

Figure 4-19

Block Model View Showing Extent of the Subcaldera Volcanic Confining Unit (SCVCU) within the RM-SM Model Area 


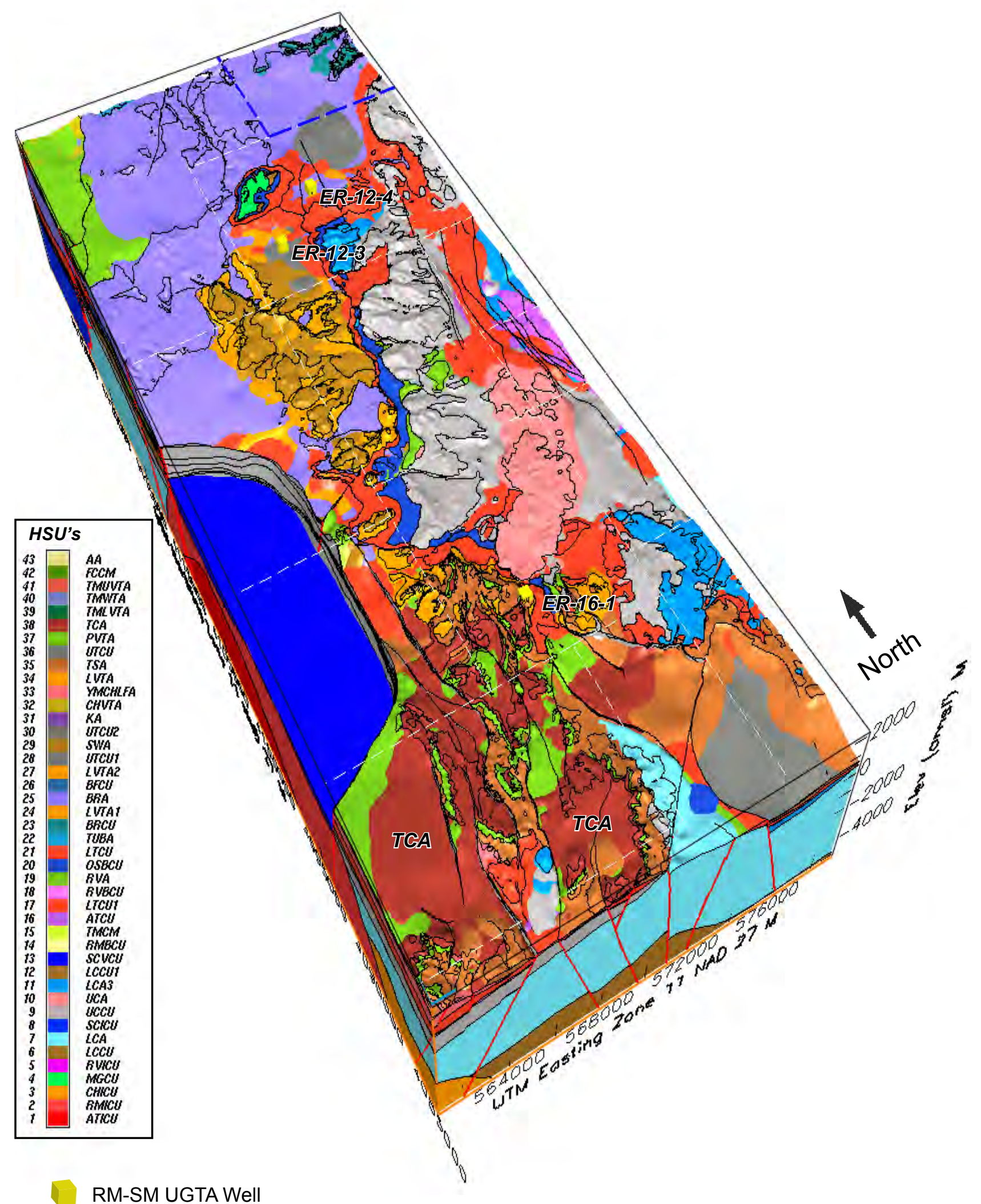

Figure 4-20

Block Model View Showing Extent of the Tiva Canyon Aquifer (TCA) within the RM-SM Model Area 


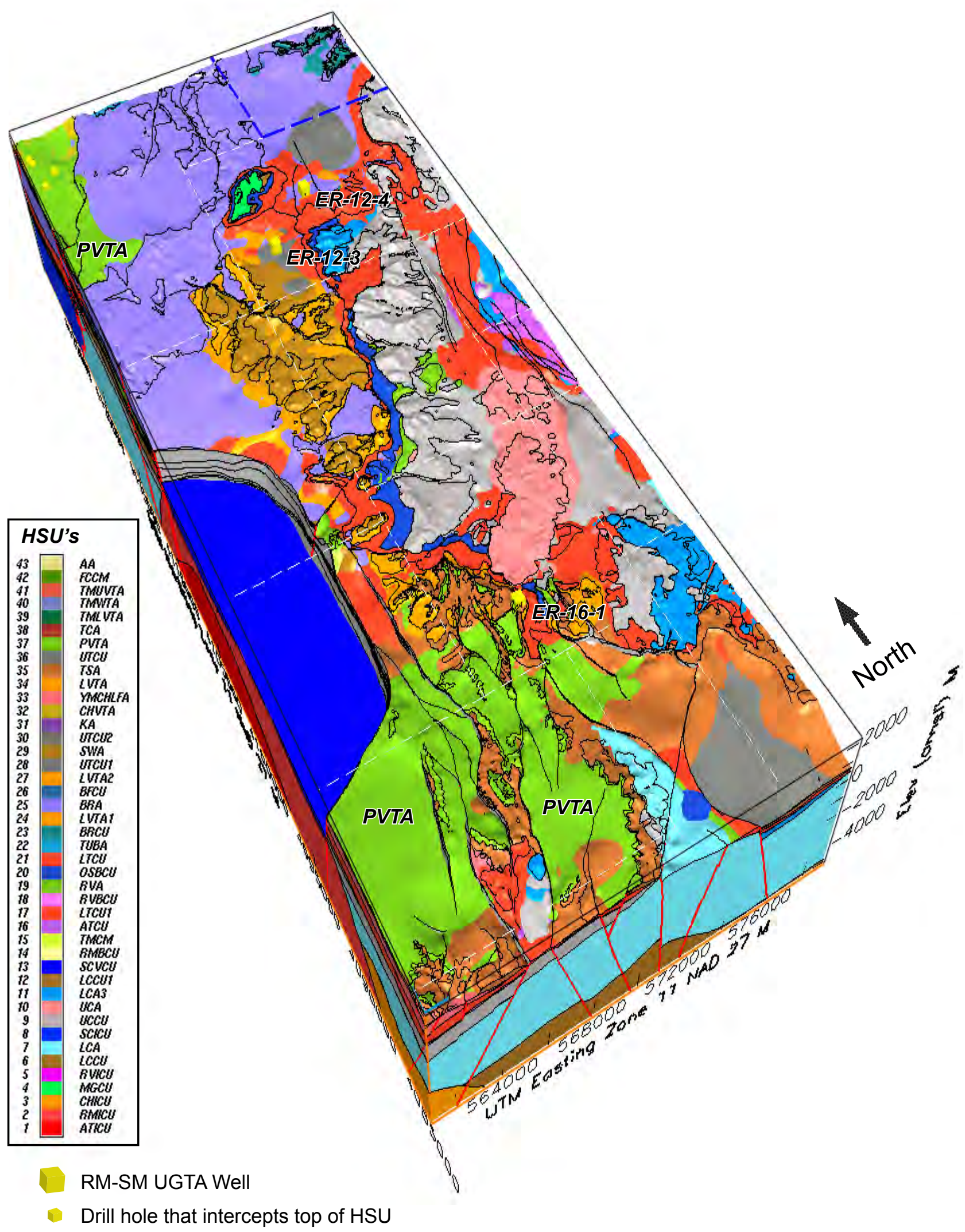

Figure 4-21

Block Model View Showing Extent of the Paintbrush Vitric Tuff Aquifer (PVTA) within the RM-SM Model Area 


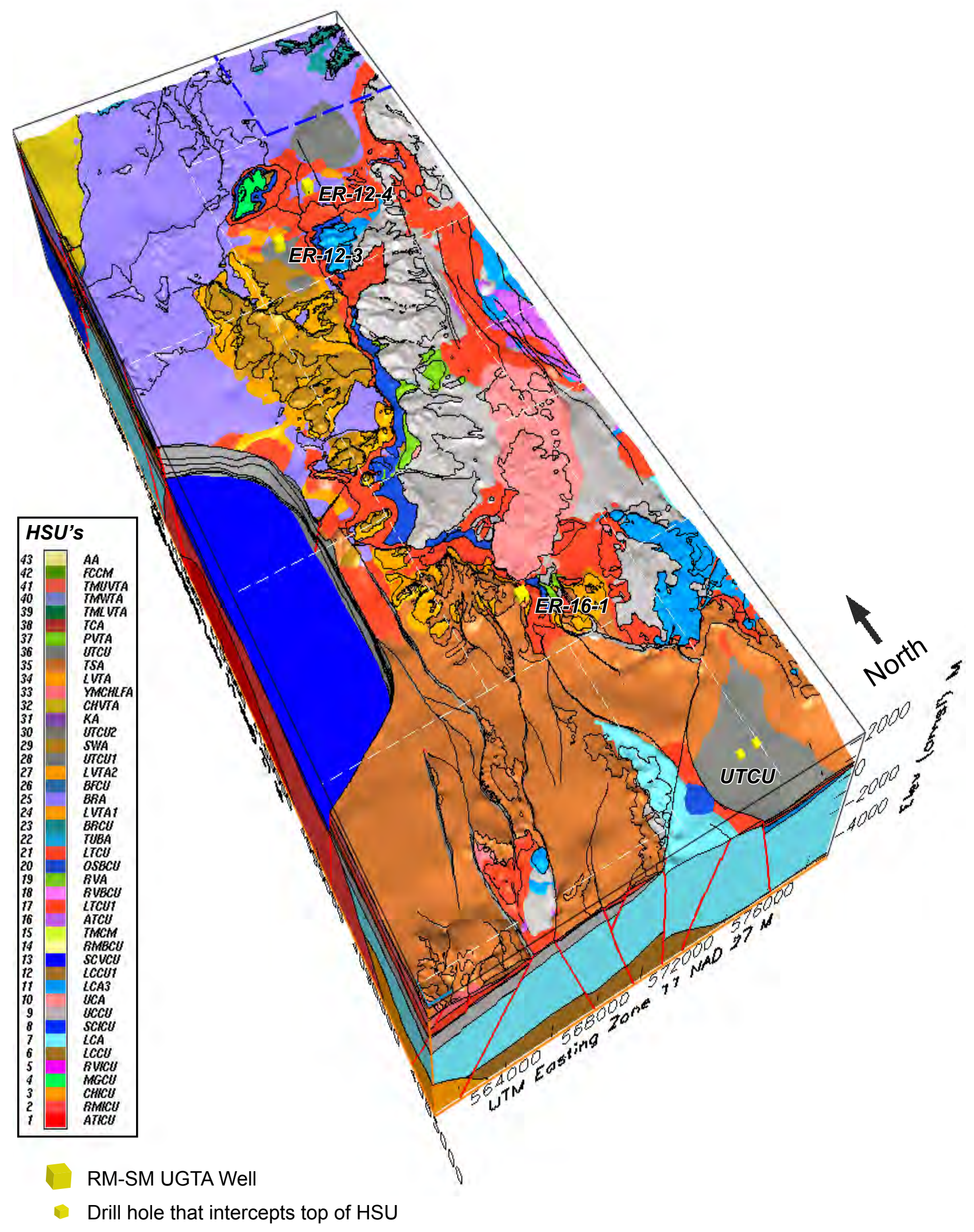

Figure 4-22

Block Model View Showing Extent of the Upper Tuff Confining Unit (UTCU) within the RM-SM Model Area 


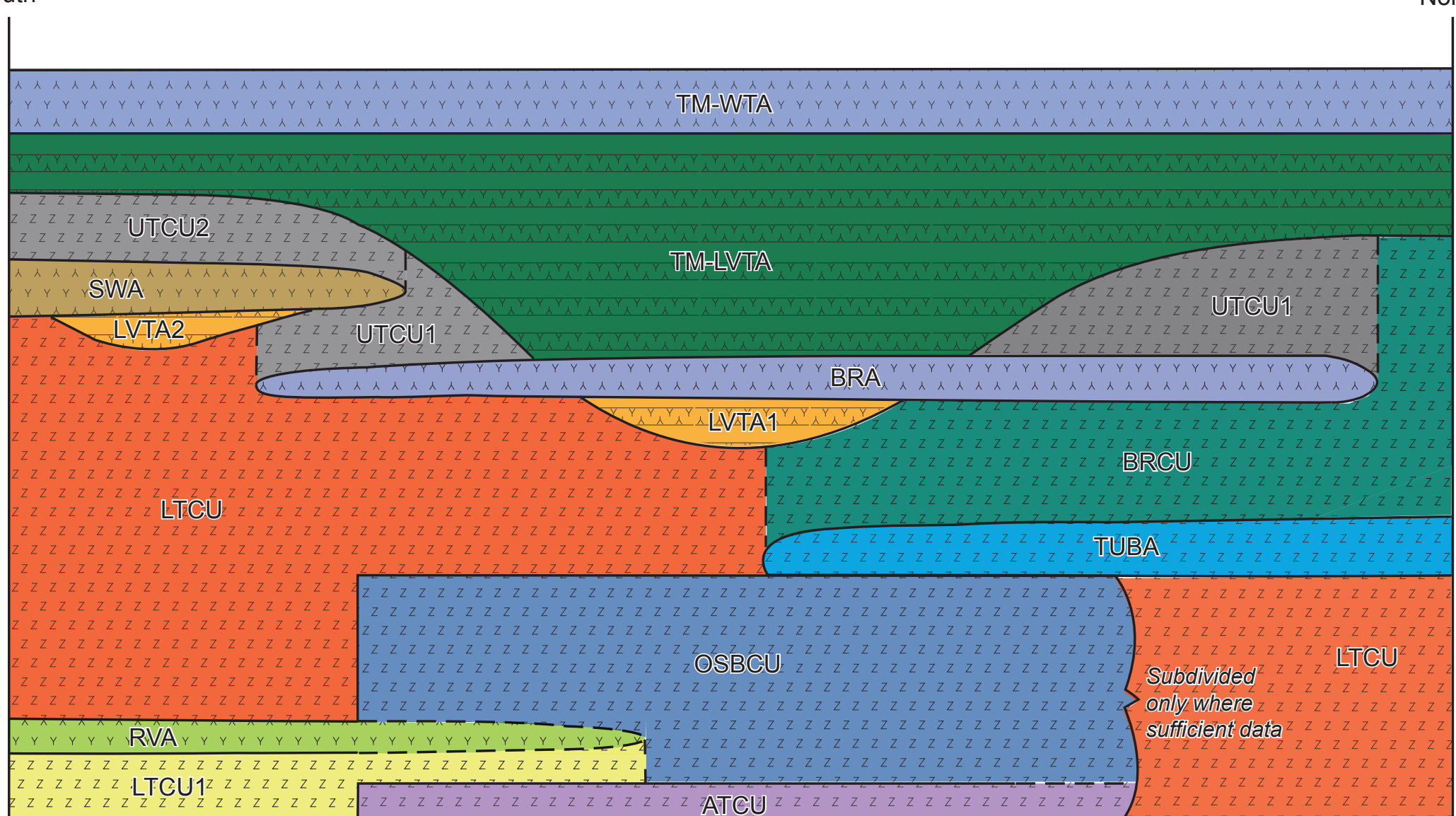

Hydrogeologic Units

Welded tuff aquifer

Vitric tuff aquifer

Tuff confining unit

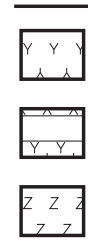

\begin{tabular}{ll} 
& \multicolumn{1}{c}{ Hydrostratigrap } \\
\hline TM-WTA & Timber Mountain welded-tuff aquifer \\
UTCU2 & Upper tuff confining unit 2 \\
SWA & Stockade Wash aquifer \\
LVTA2 & Lower vitric-tuff aquifer 2 \\
UTCU1 & Upper tuff confining unit 1 \\
BRA & Belted Range aquifer \\
LVTA1 & Lower vitric-tuff aquifer 1
\end{tabular}

BRCU Belted Range confining unit

TUBA Tub Spring aquifer

OSBCU Oak Spring Butte confining unit

RVA Redrock Valley aquifer

LTCU1 Lower tuff confining unit 1

ATCU Argillic tuff confining unit
NOT TO SCALE

\section{Figure 4-23 \\ Schematic South-North Hydrostratigraphic Cross Section through the Northern Half of the Rainier Mesa-Shoshone
Mountain Model Area Showing the Relationships of the TCU and WTA Hydrostratigraphic Units \\ Schematic South-North Hydrostratigraphic Cross Section through the Northern Half of the Rainier Mesa-Sho
Mountain Model Area Showing the Relationships of the TCU and WTA Hydrostratigraphic Units}




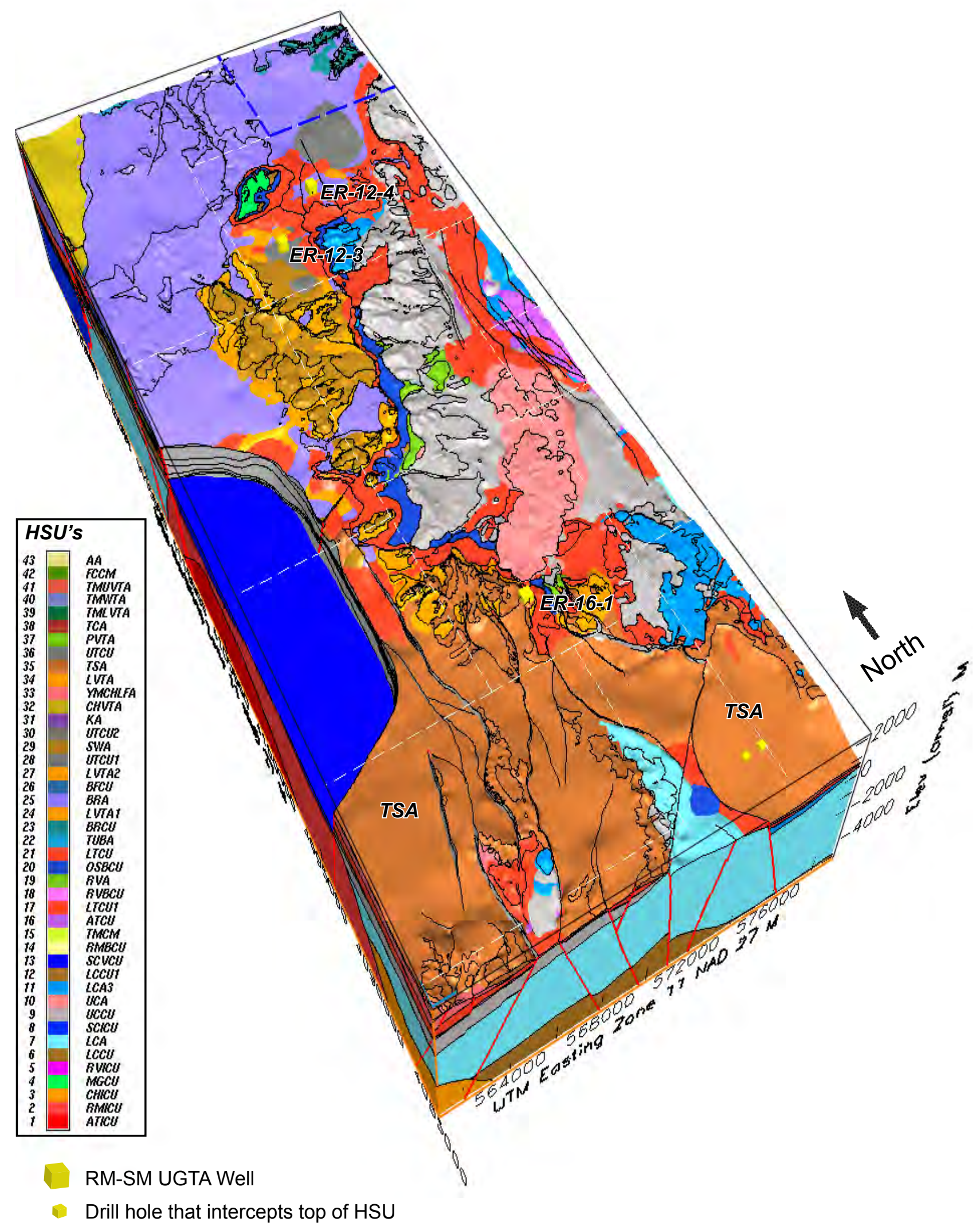

Figure 4-24

Block Model View Showing Extent of the Topopah Spring Aquifer (TSA) within the RM-SM Model Area 


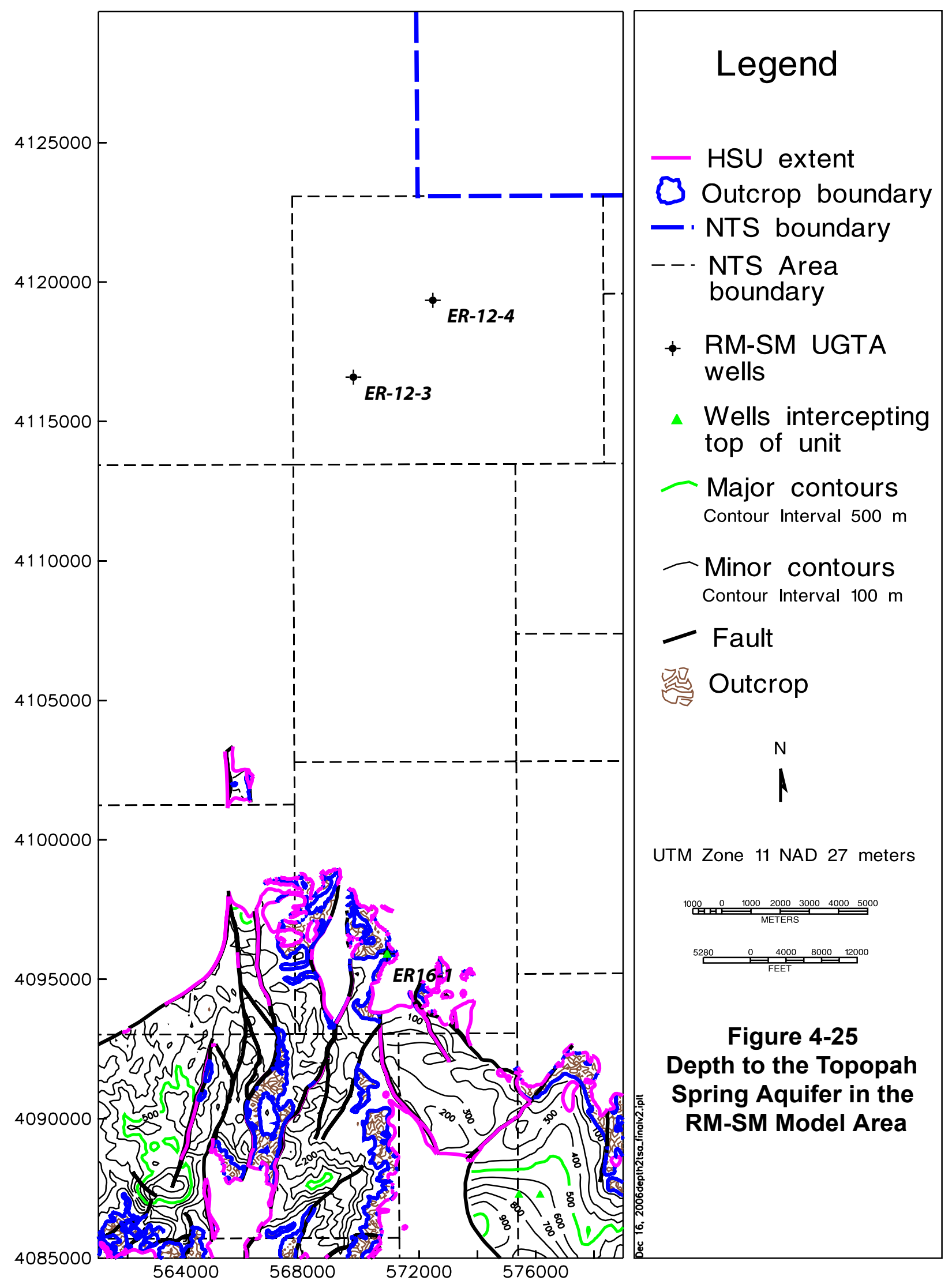




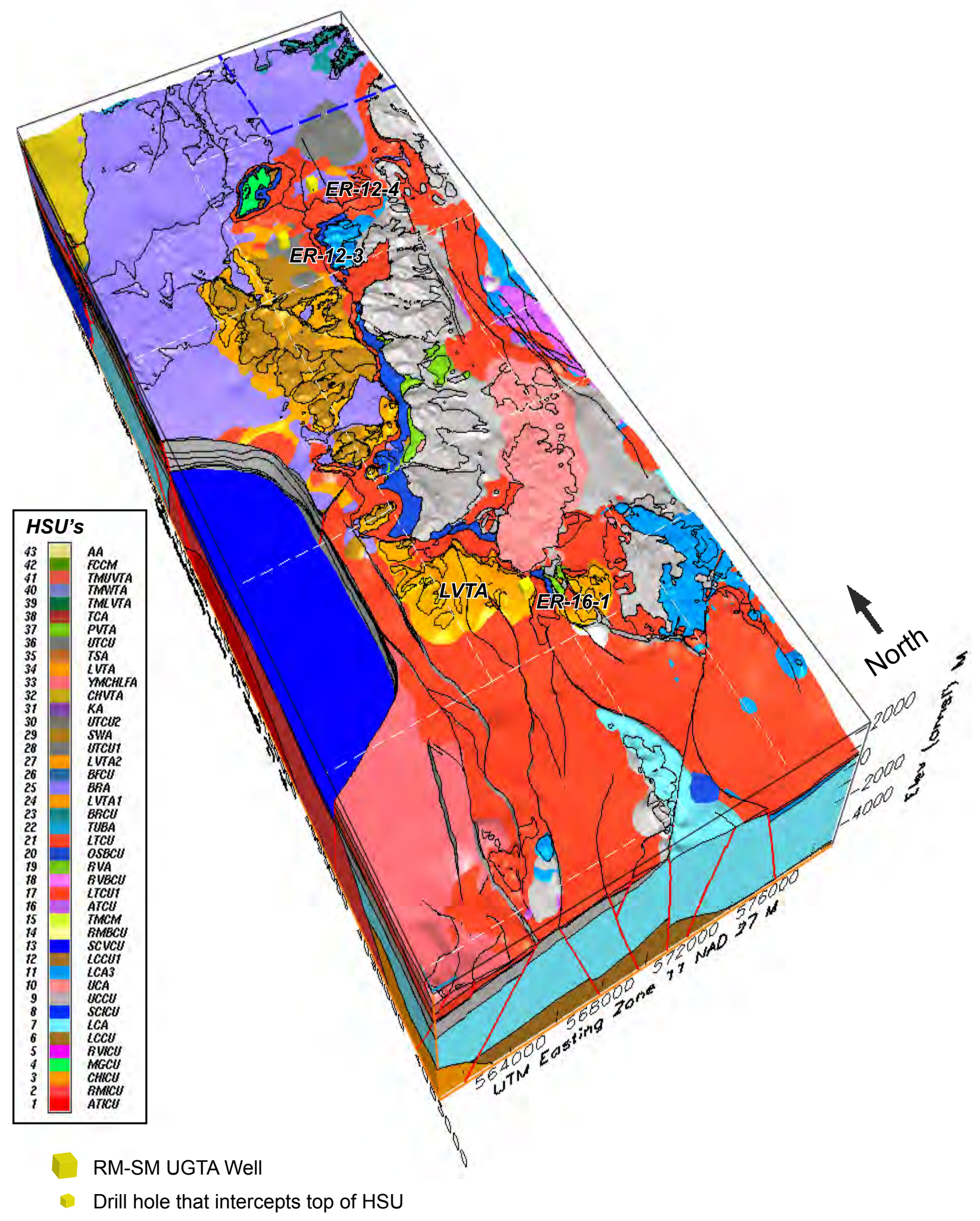

Figure 4-26

Block Model View Showing Extent of the Lower Vitric Tuff Aquifer (LVTA) within the RM-SM Model Area 


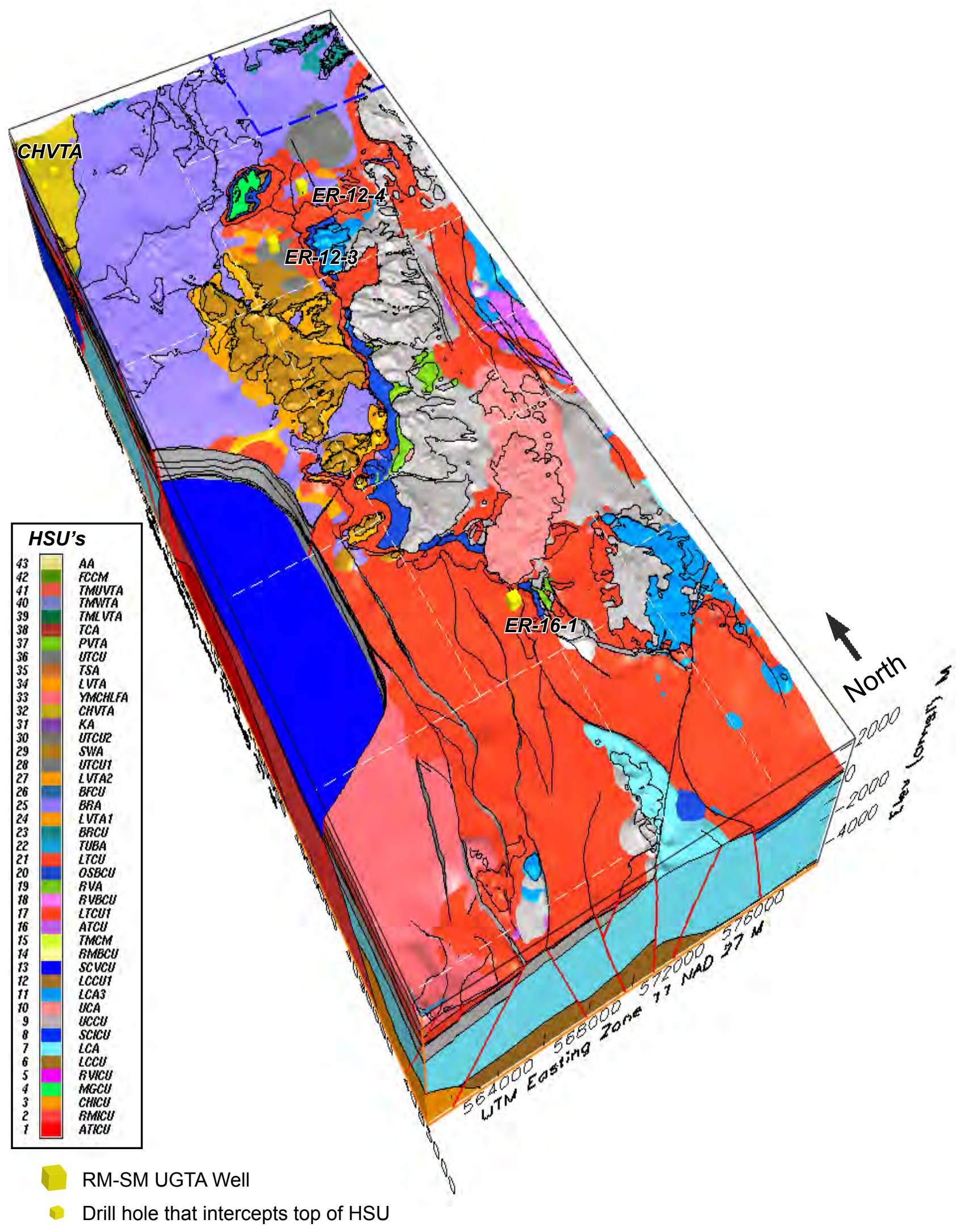

Figure 4-27

Block Model View Showing Extent of the Calico Hills Vitric-Tuff Aquifer (CHVTA) within the RM-SM Model Area 


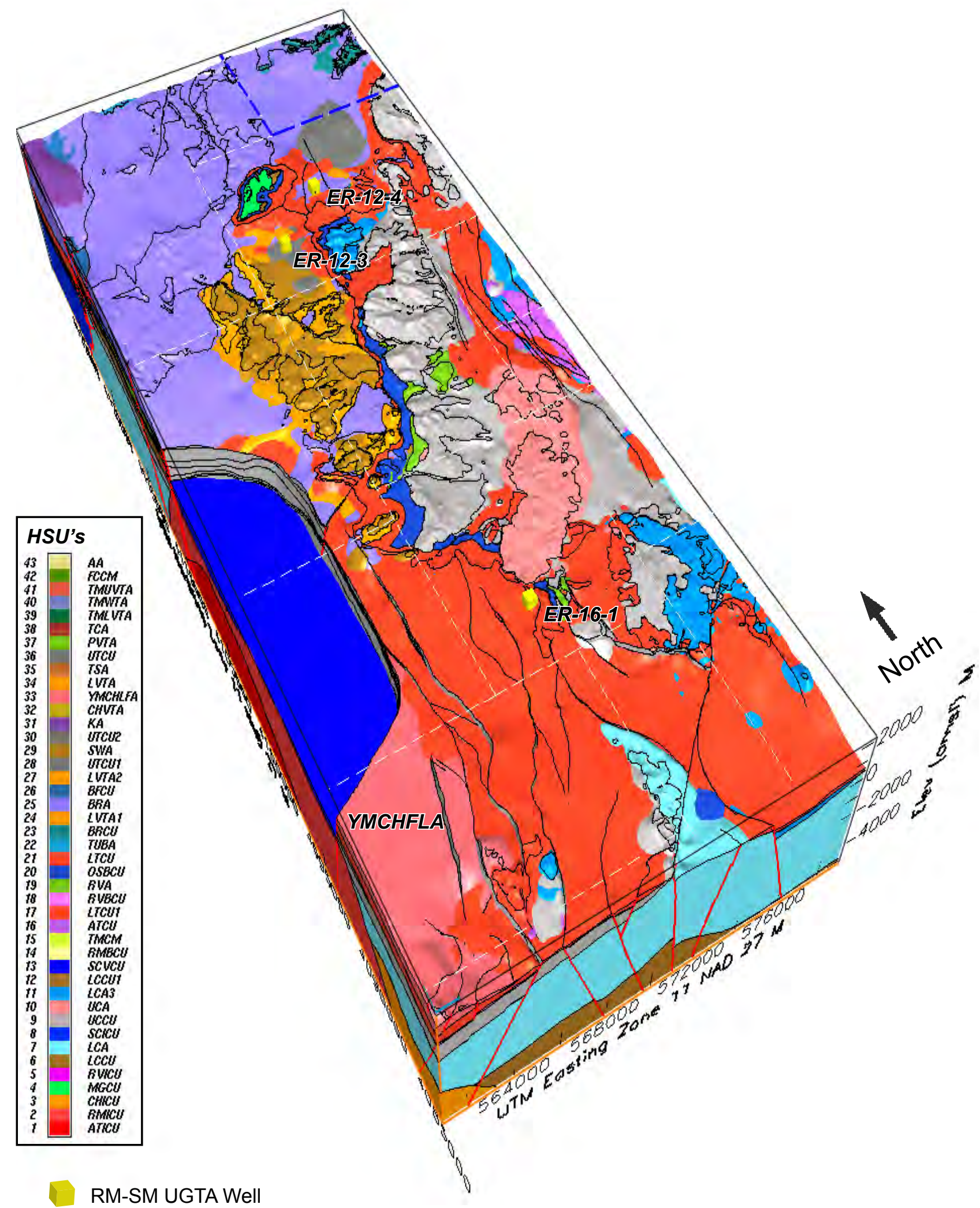

Figure 4-28

Block Model View Showing Extent of the Yucca Mountain Calico Hills Lava Flow Aquifer (YMCHFLA) within the RM-SM Model Area 


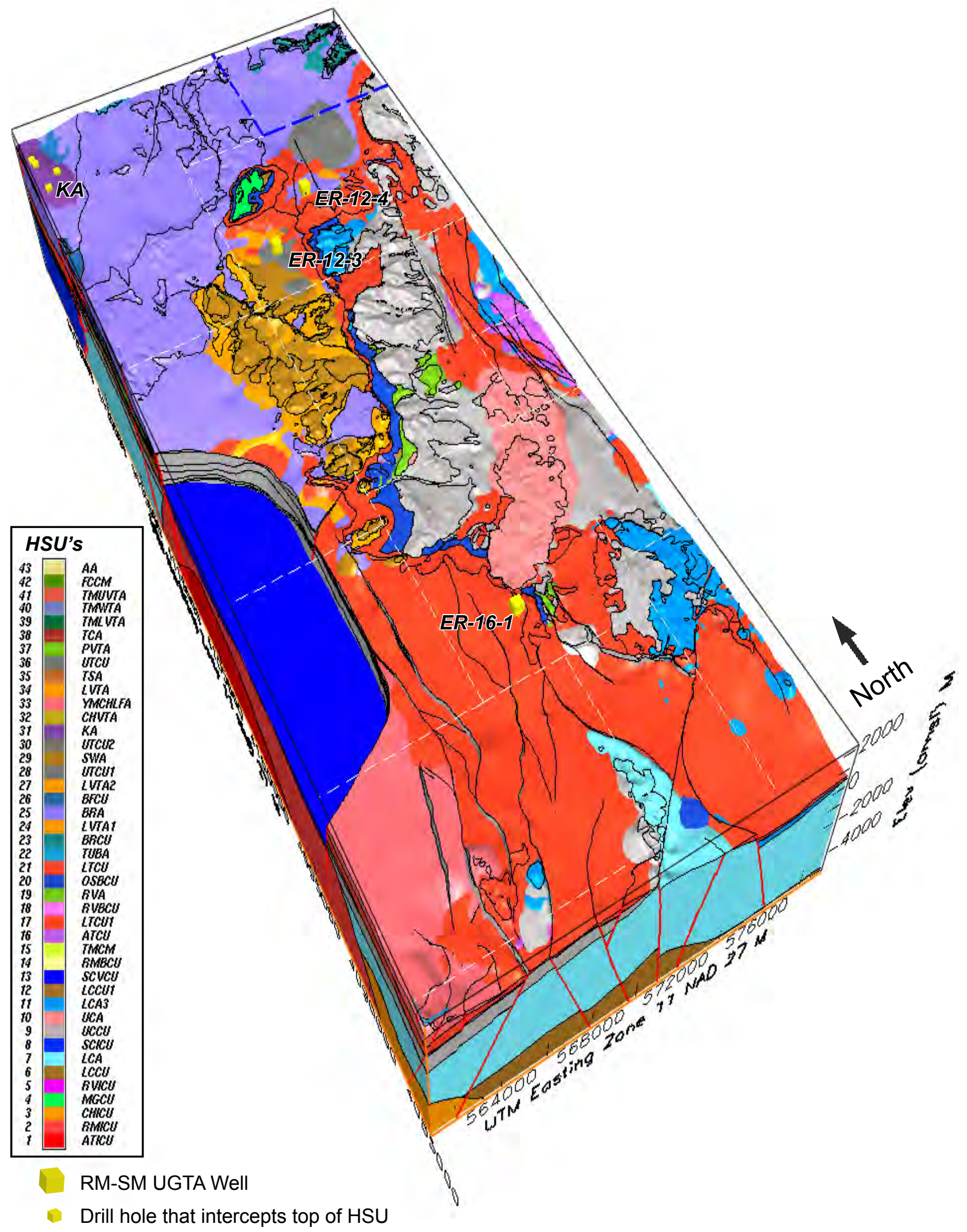

Figure 4-29

Block Model View Showing Extent of the Kearsarge Aquifer

(KA) within the RM-SM Model Area 


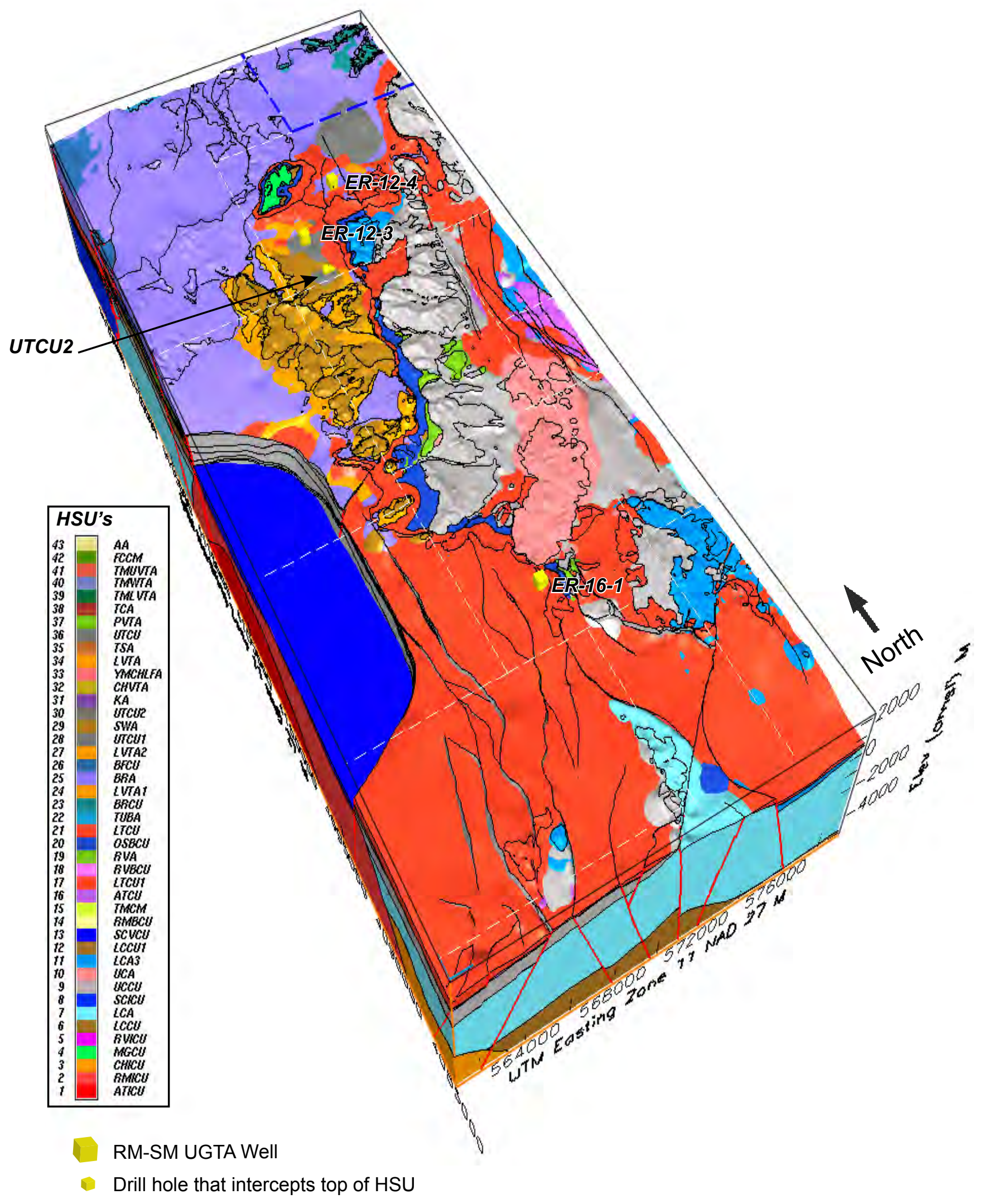

Figure 4-30

Block Model View Showing Extent of the Upper Tuff Confining Unit 2 (UTCU2) within the RM-SM Model Area 


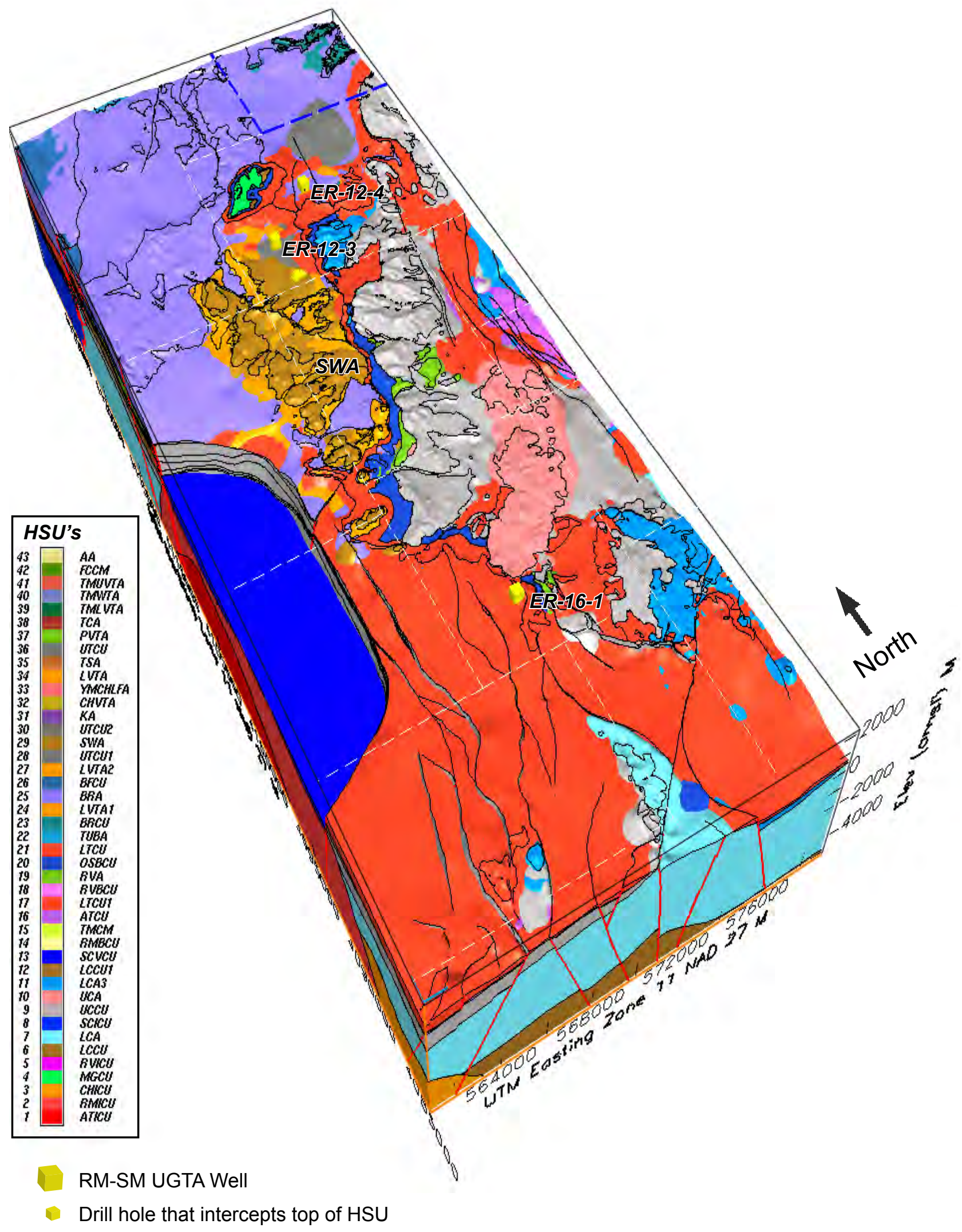

Figure 4-31

Block Model View Showing Extent of the Stockade Wash Aquifer (SWA) within the RM-SM Model Area 


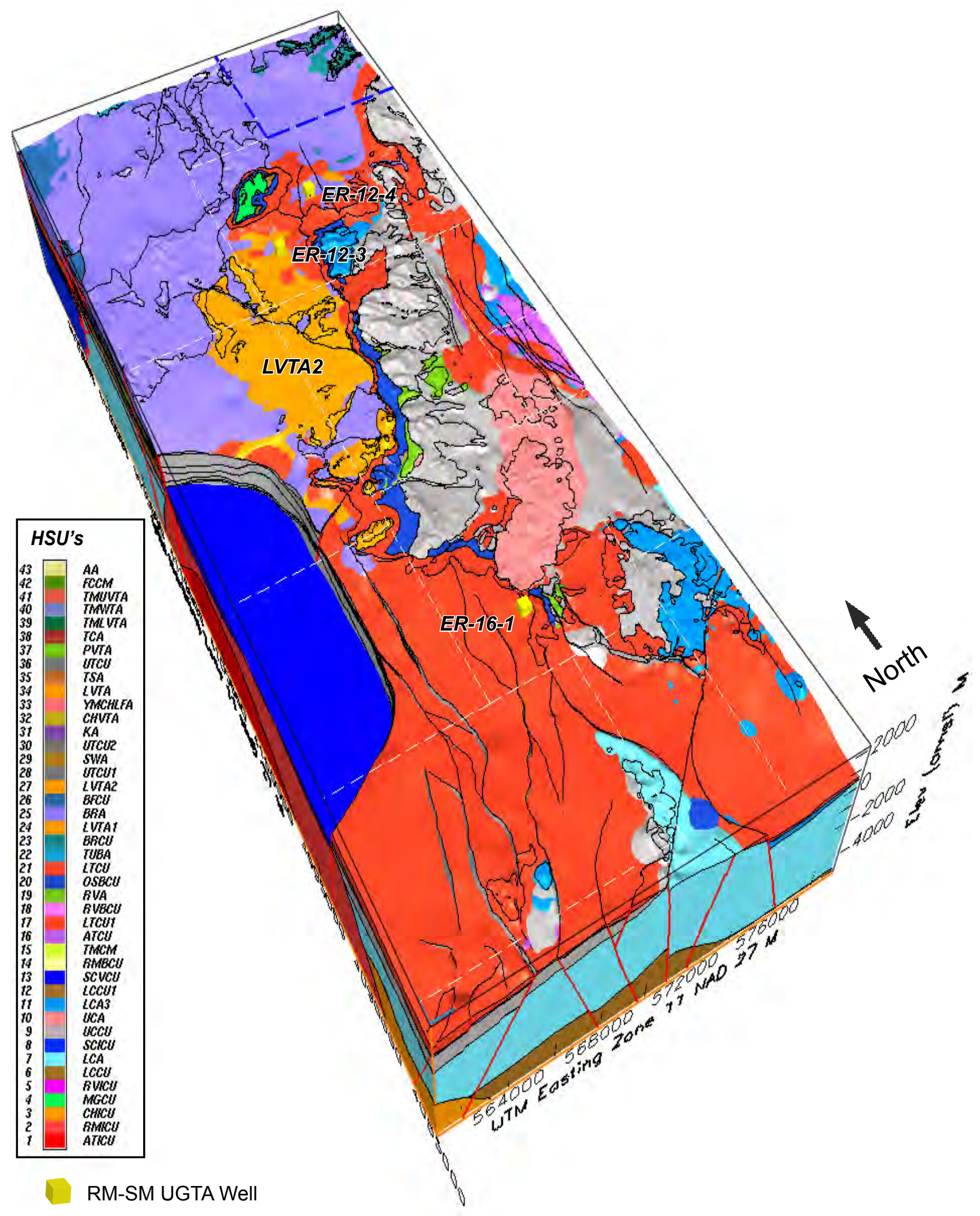

Figure 4-32

Block Model View Showing Extent of the Lower Vitric Tuff Aquifer 2 (LVTA2) within the RM-SM Model Area 


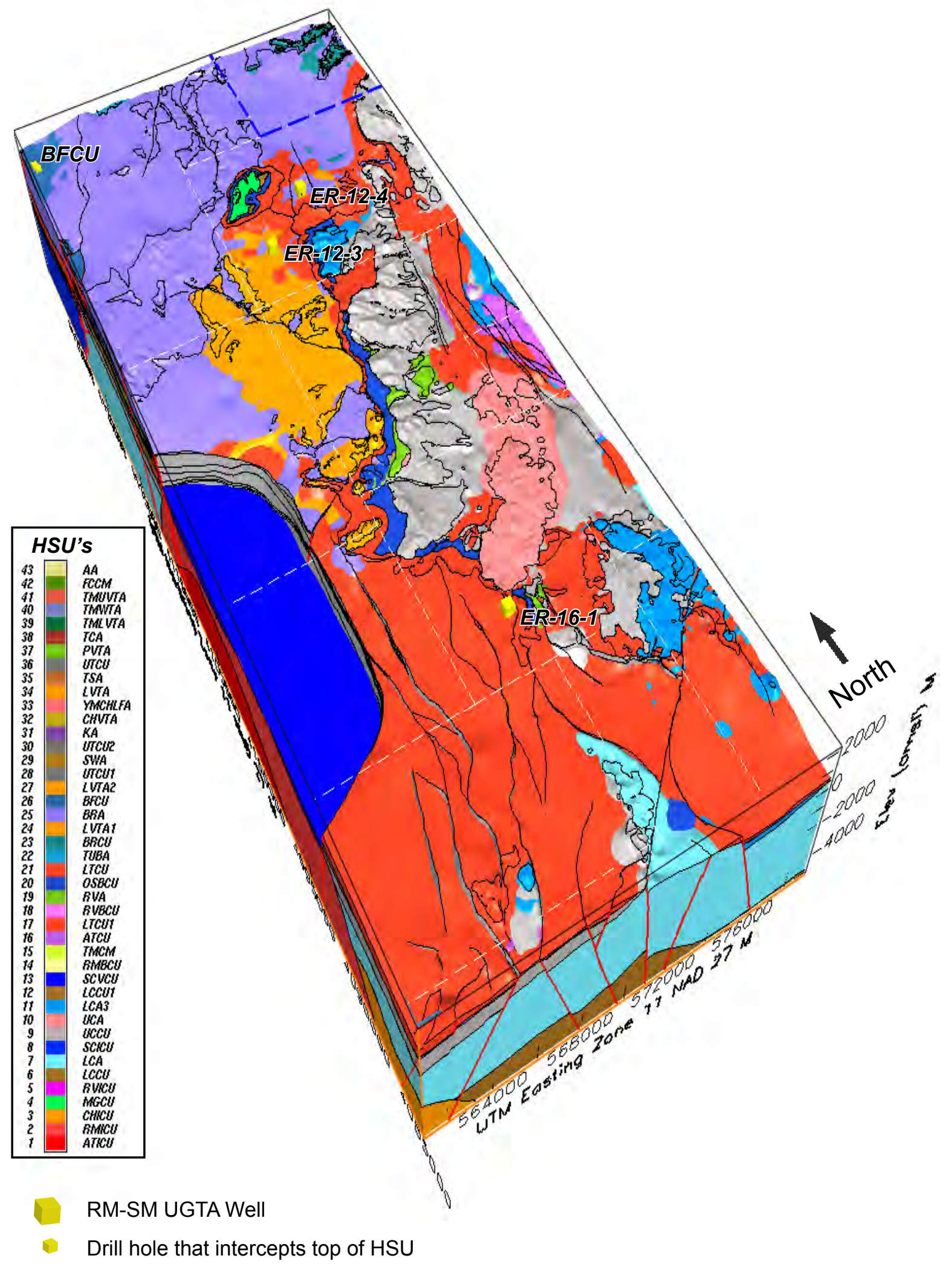

Figure 4-33

Block Model View Showing Extent of the Bullfrog Confining Unit (BFCU) within the RM-SM Model Area 


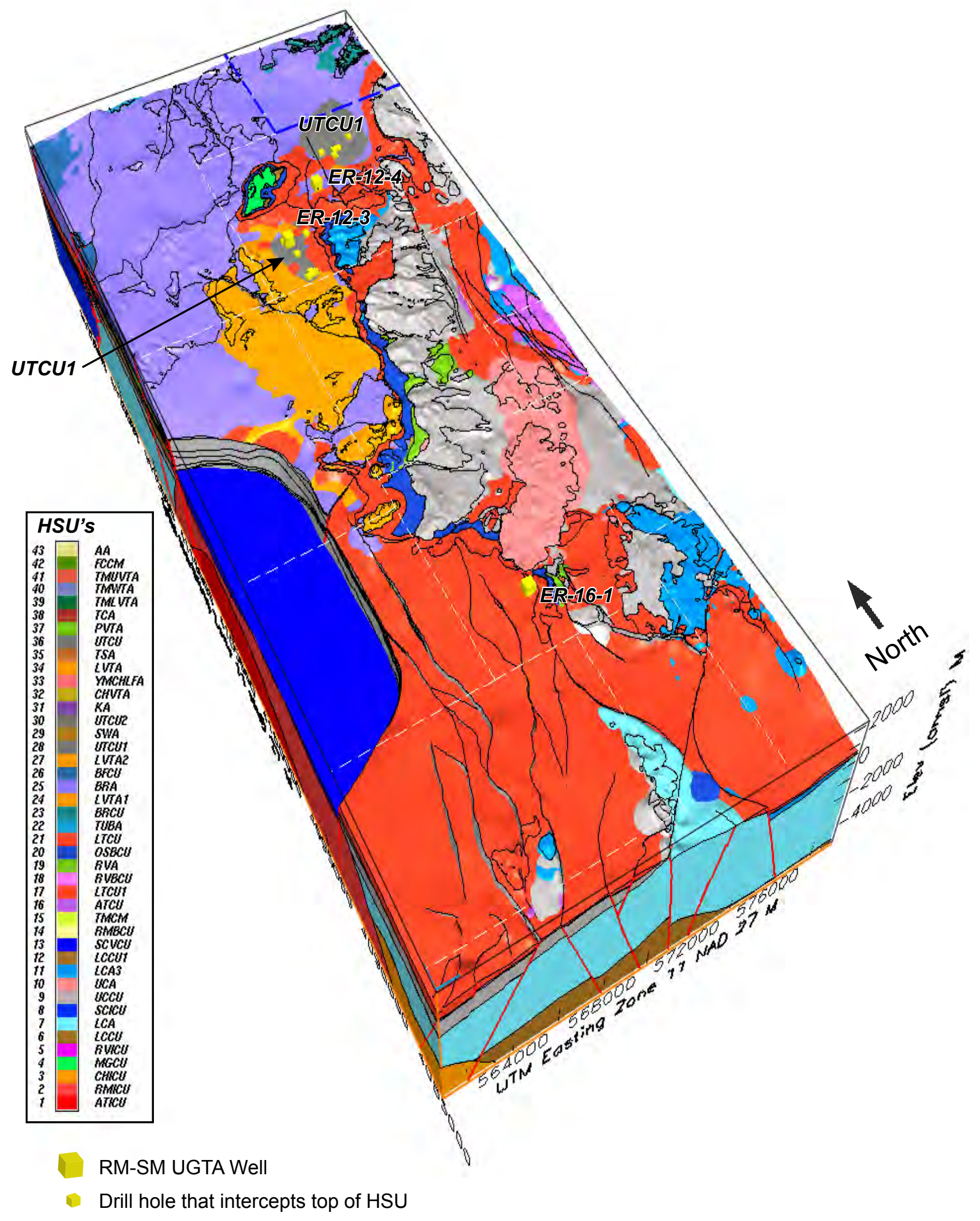

Figure 4-34

Block Model View Showing Extent of the Upper Tuff Confining Unit 1 (UTCU1) within the RM-SM Model Area 


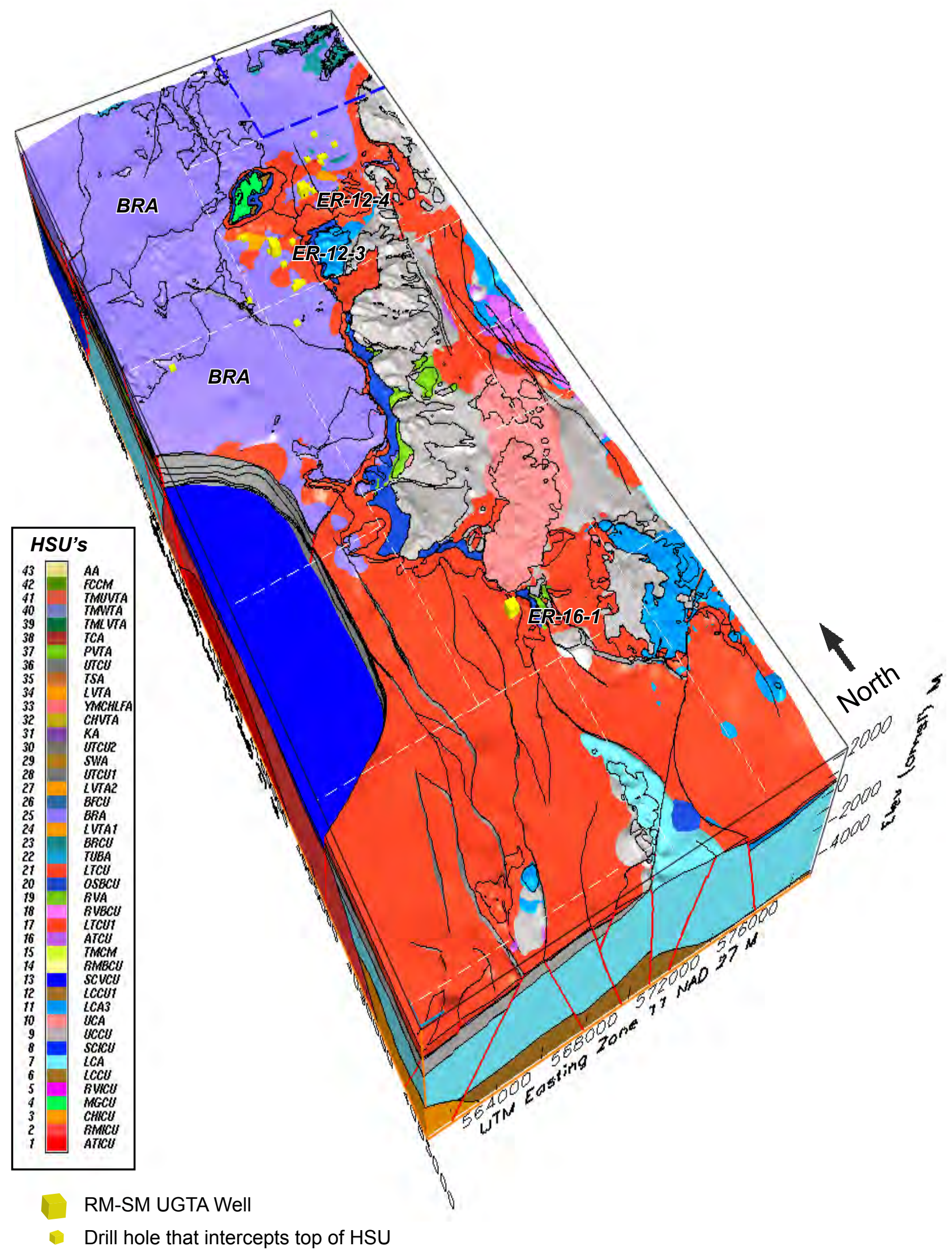

Figure 4-35

Block Model View Showing Extent of the Belted Range Aquifer (BRA) within the RM-SM Model Area 


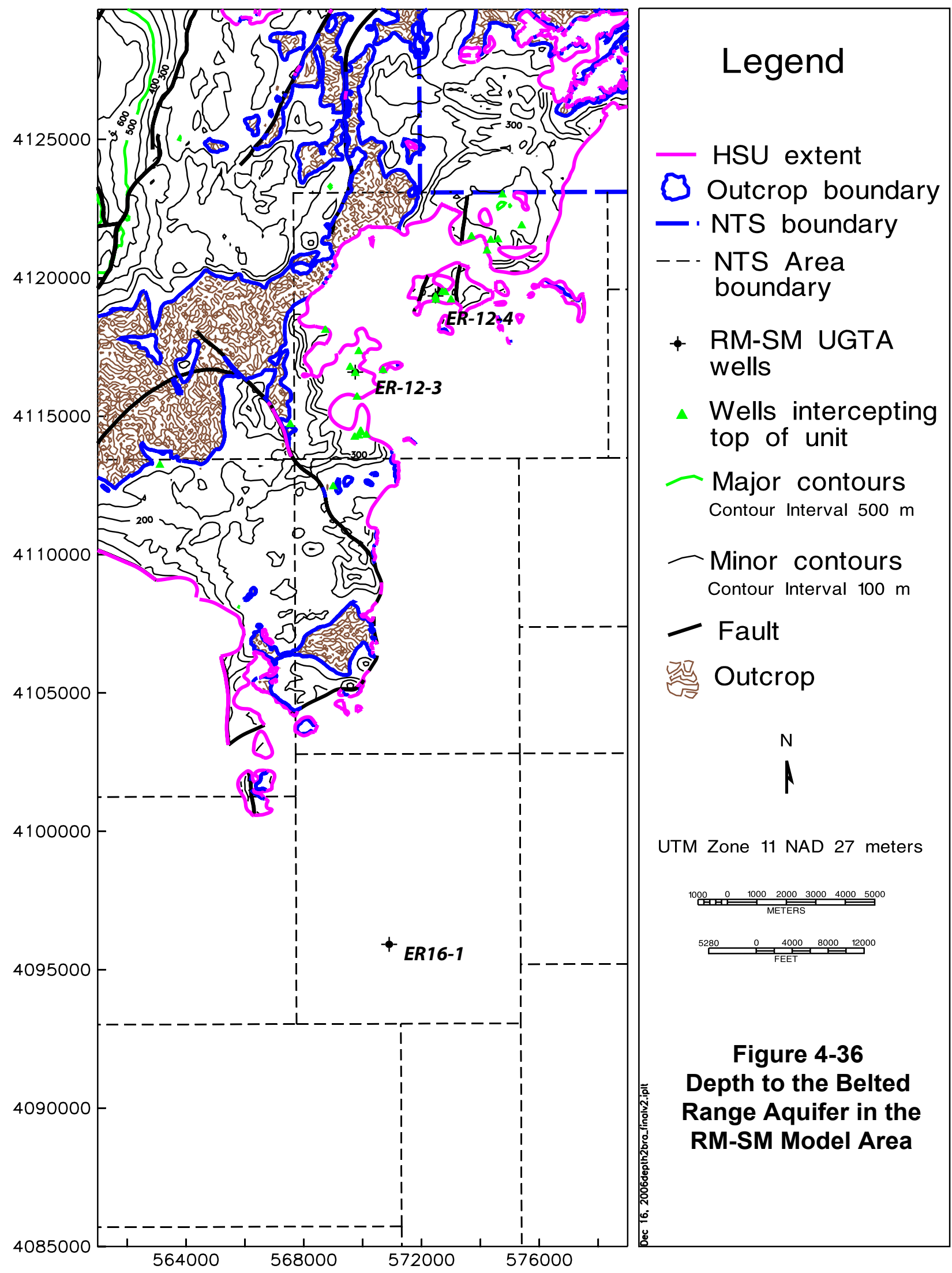




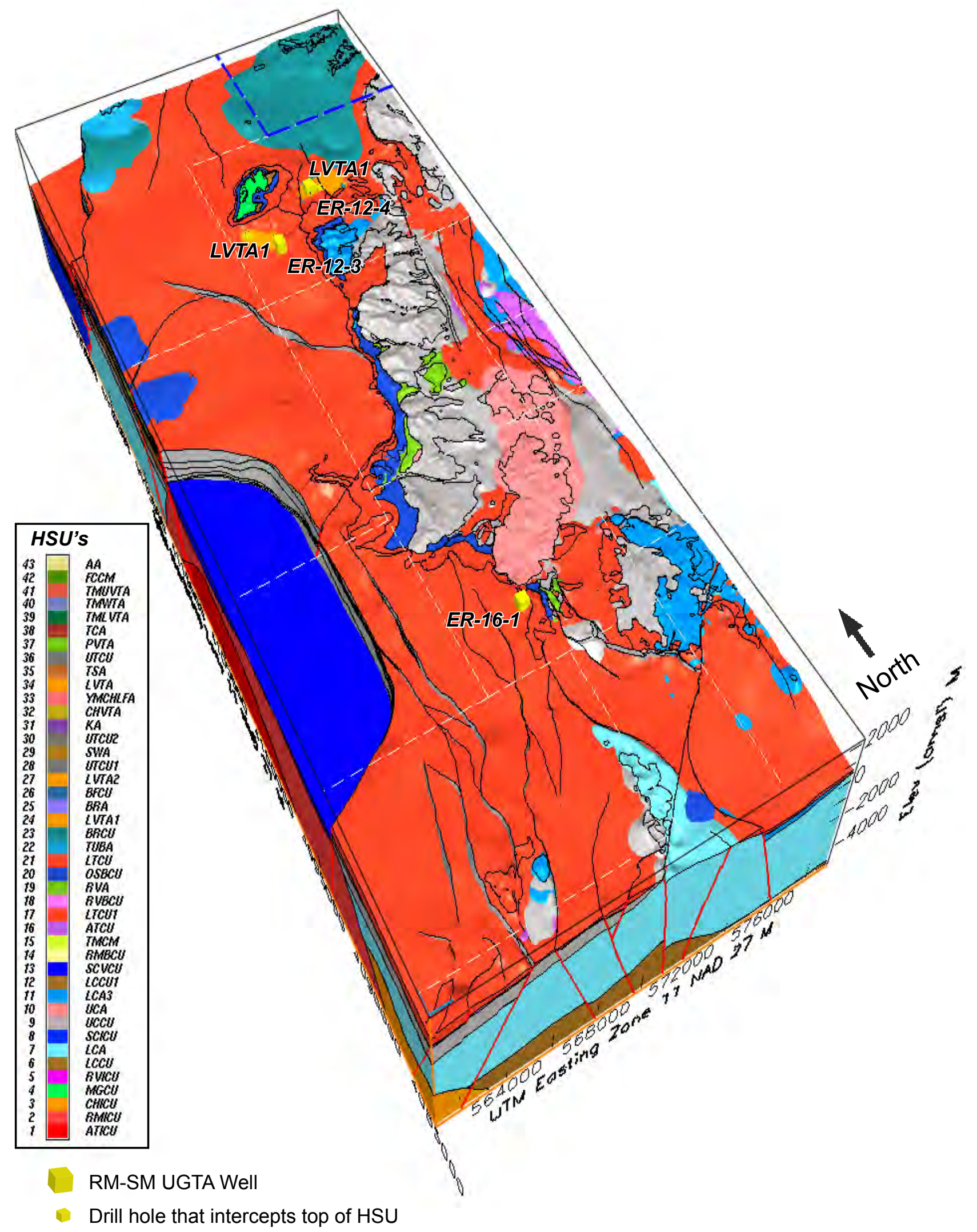

Figure 4-37

Block Model View Showing Extent of the Lower Vitric Tuff Aquifer 1 (LVTA 1) within the RM-SM Model Area 


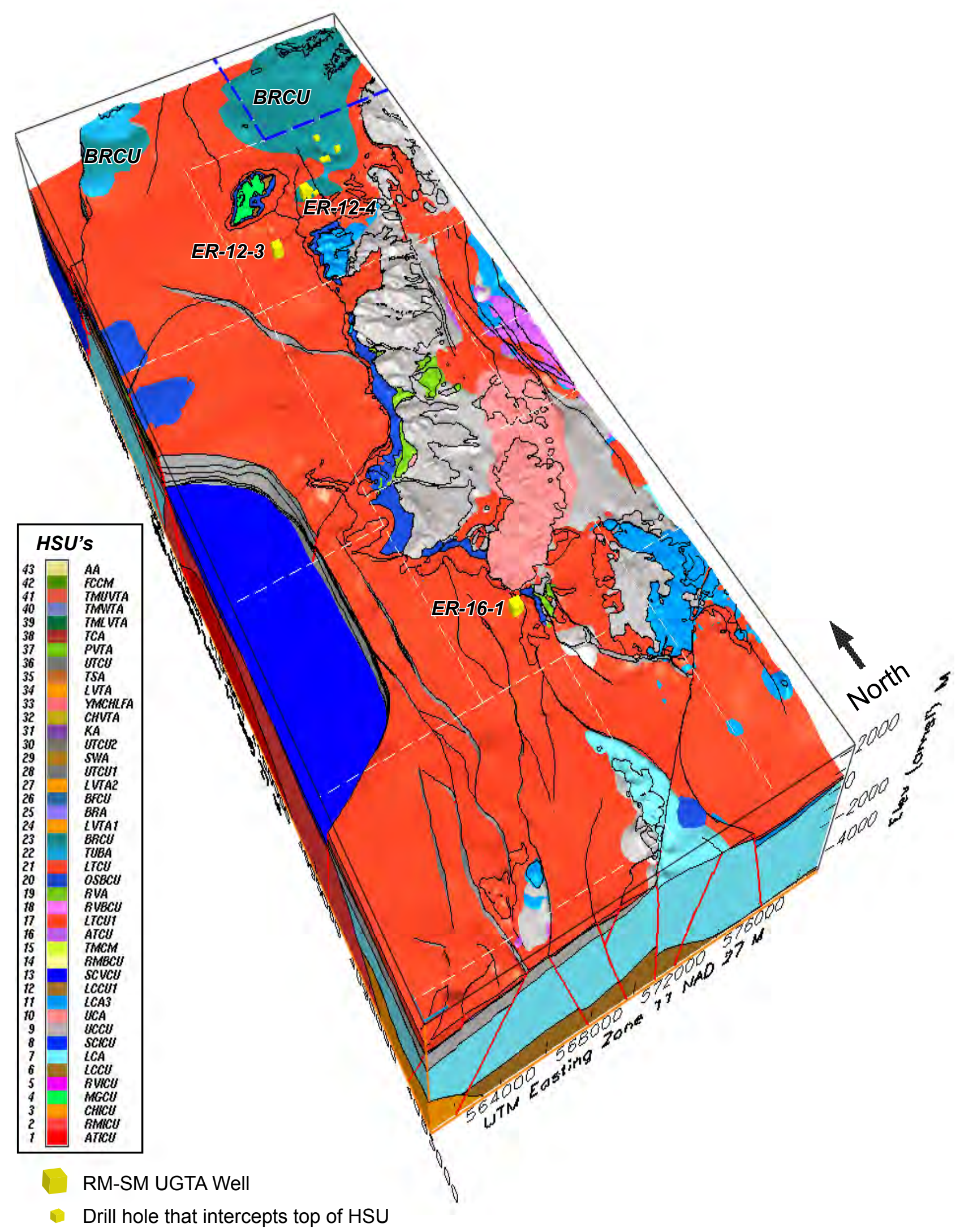

Figure 4-38

Block Model View Showing Extent of the Belted Range Confining Unit (BRCU) within the RM-SM Model Area 


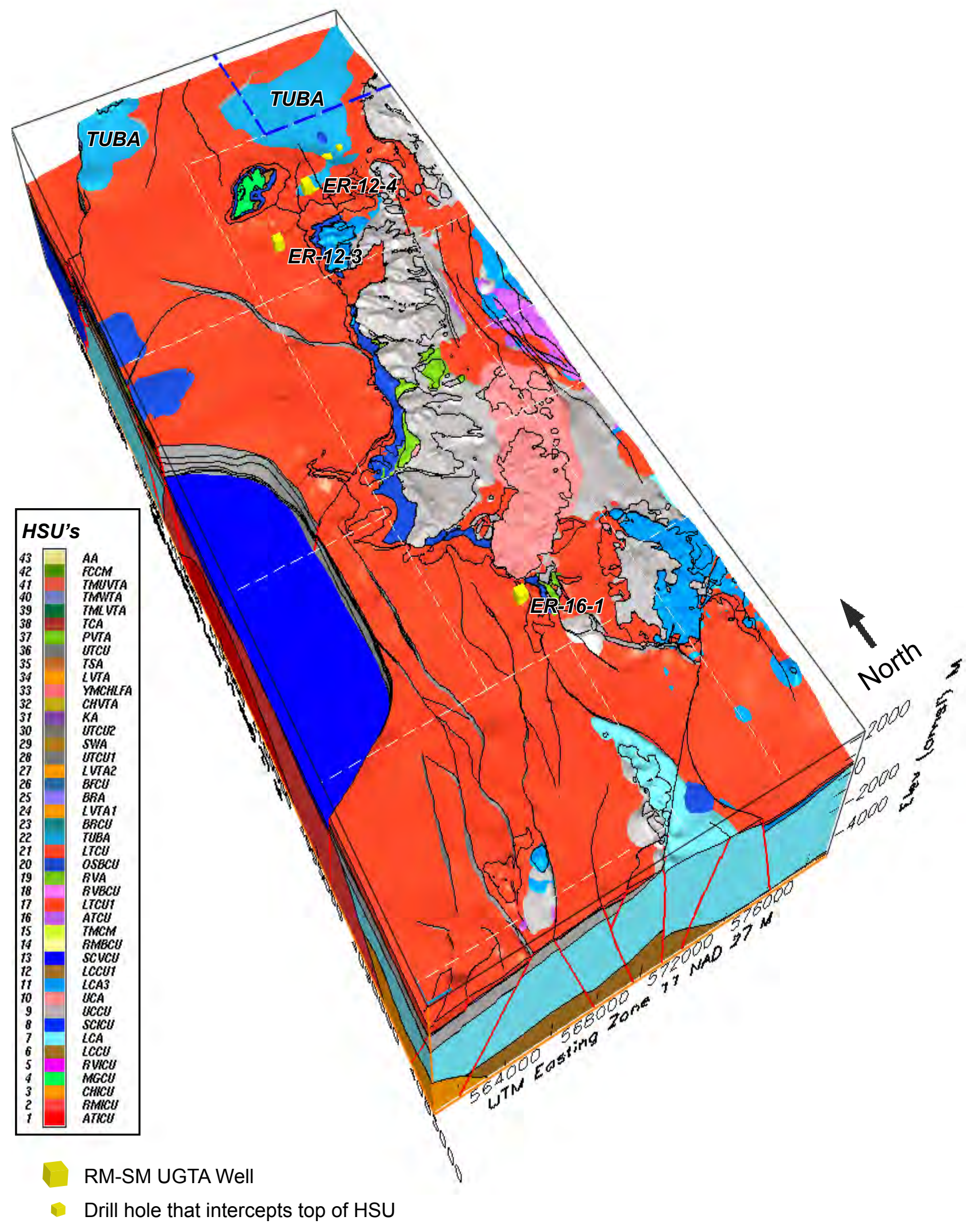

Figure 4-39

Block Model View Showing Extent of the Tub Spring Aquifer (TUBA) within the RM-SM Model Area 


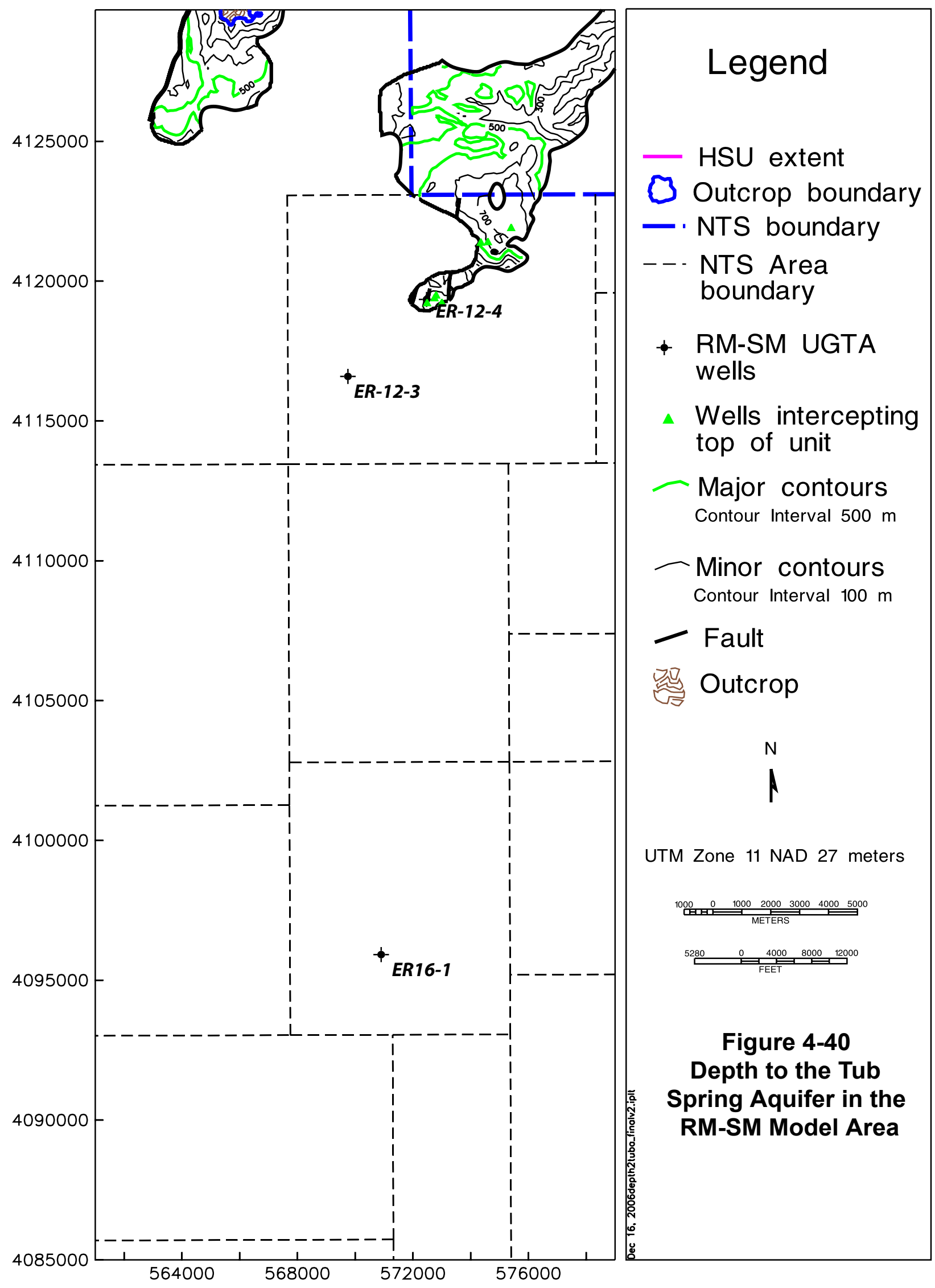




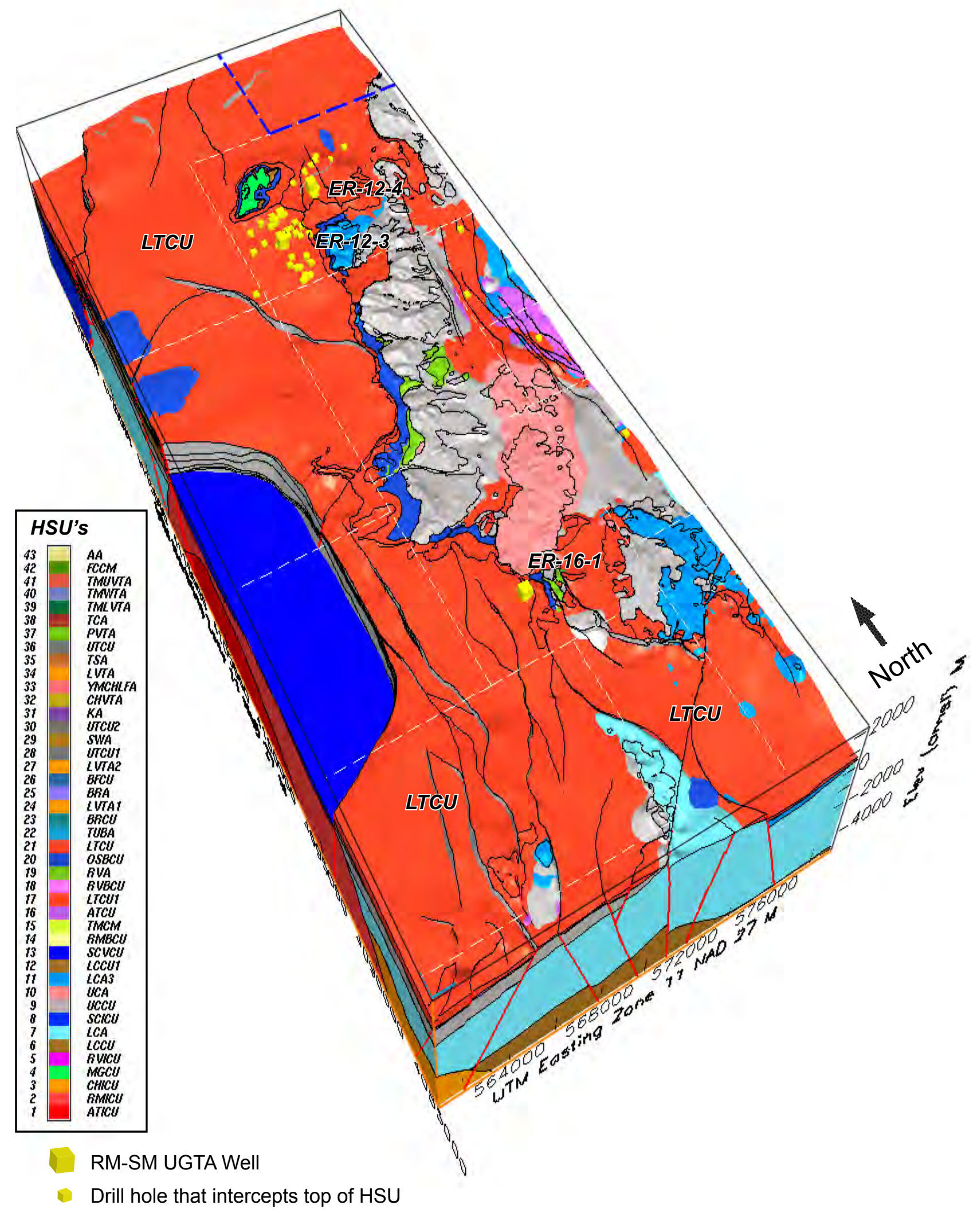

Figure 4-41

Block Model View Showing Extent of the Lower Tuff Confining Unit (LTCU) within the RM-SM Model Area 


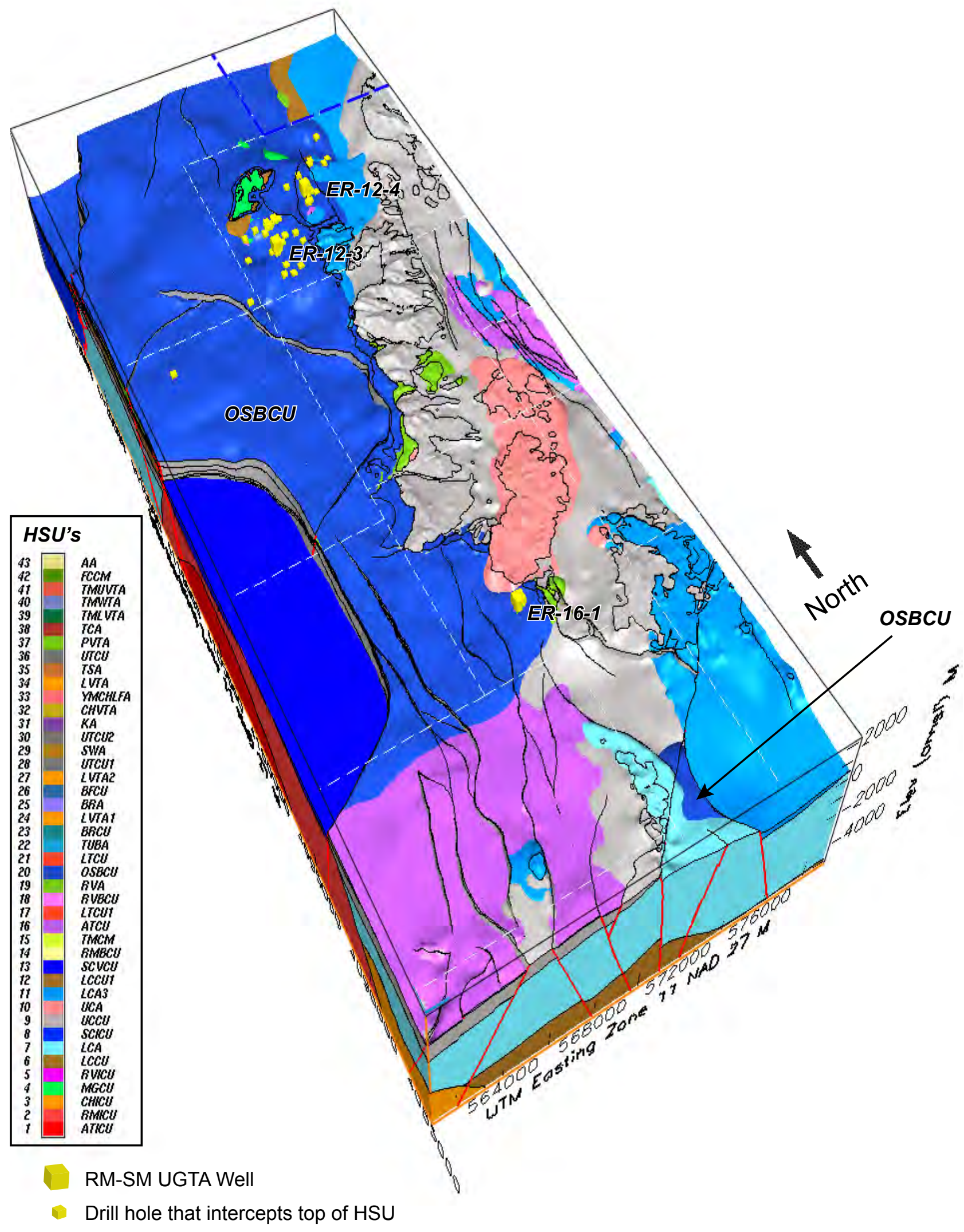

Figure 4-42

Block Model View Showing Extent of the Oak Spring Butte Confining Unit (OSBCU) within the RM-SM Model Area 


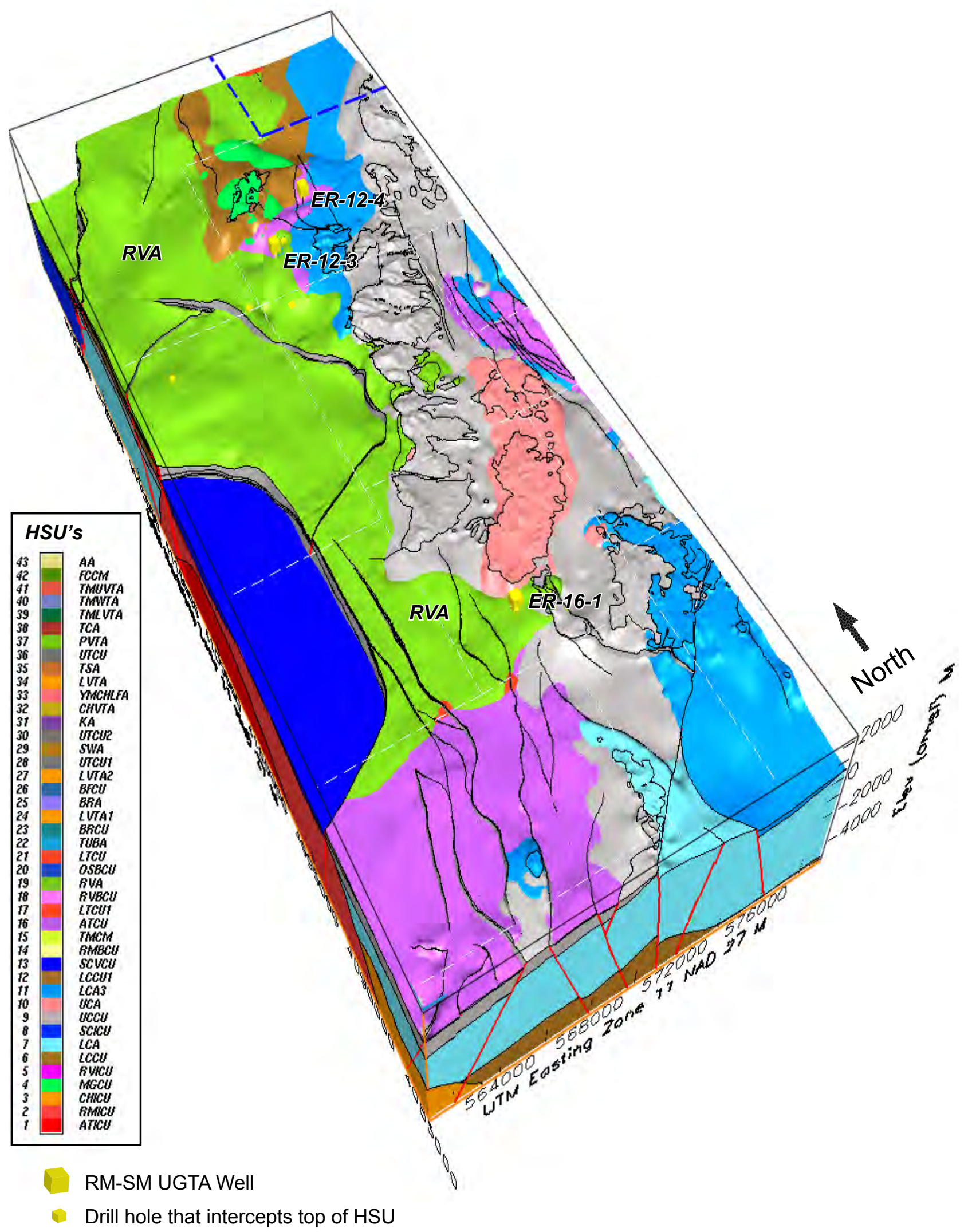

Figure 4-43

Block Model View Showing Extent of the Redrock Valley Aquifer (RVA) within the RM-SM Model Area 


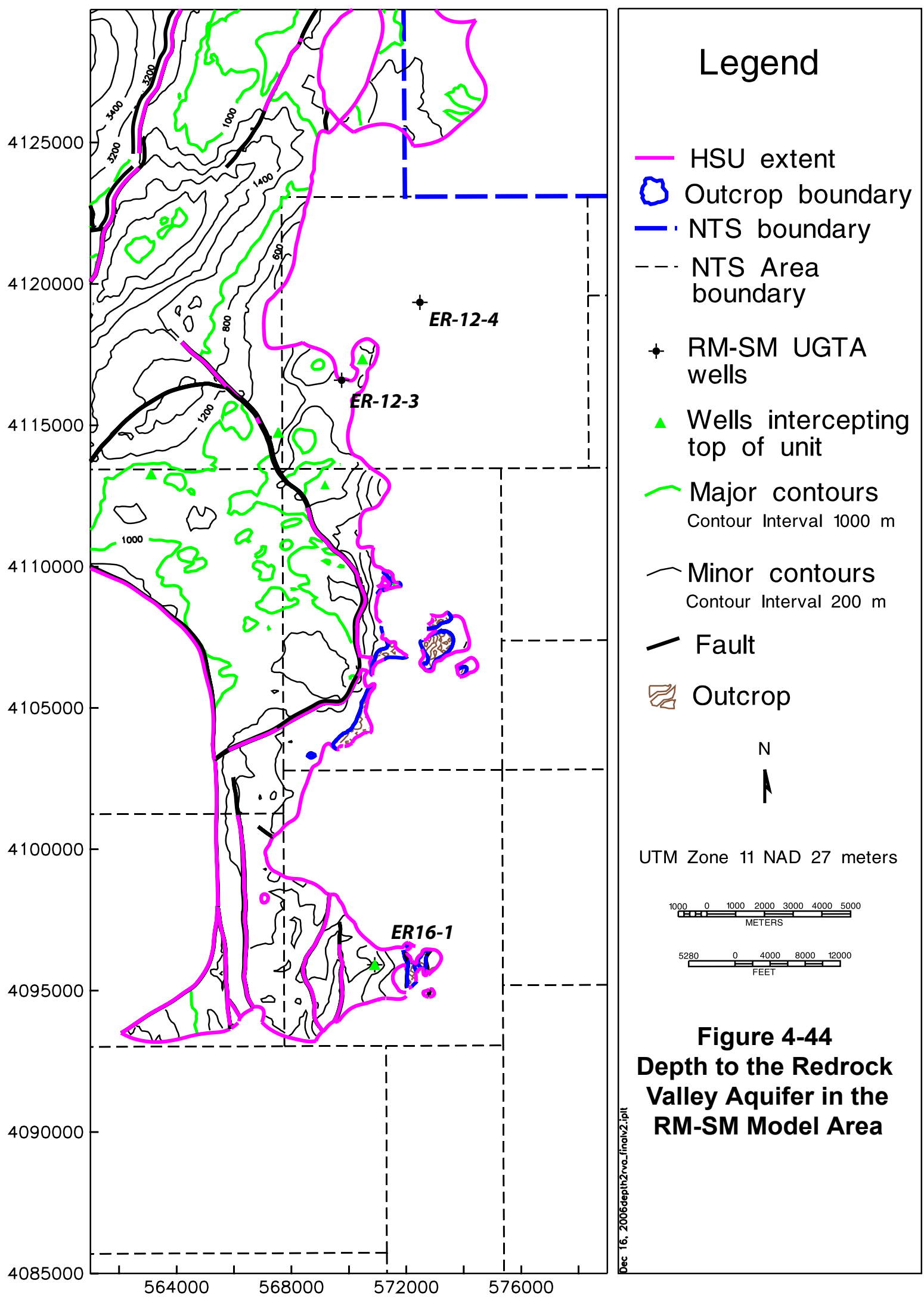




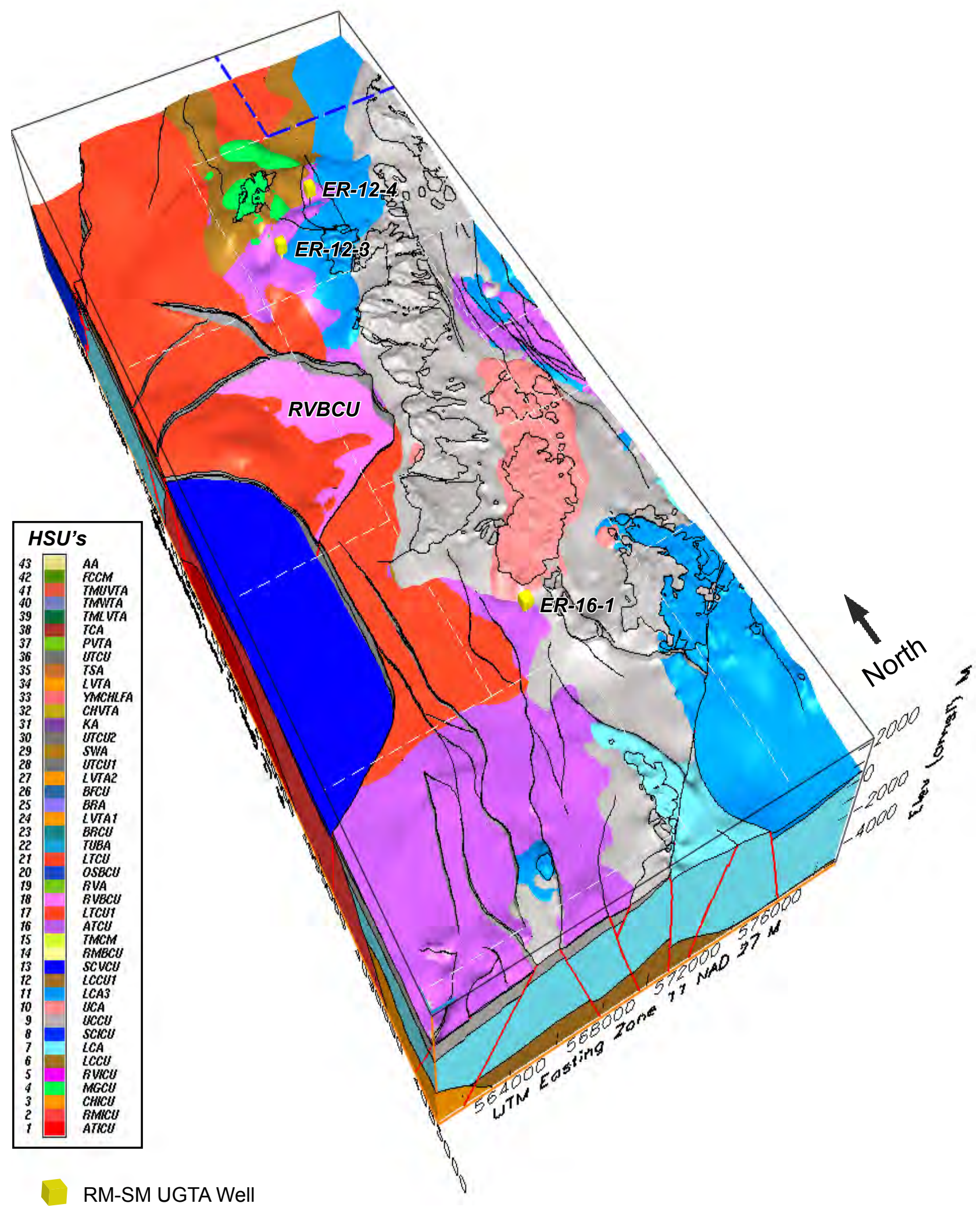

Figure 4-45

Block Model View Showing Extent of the Redrock Valley Breccia Confining Unit (RVBCU) within the RM-SM Model Area 


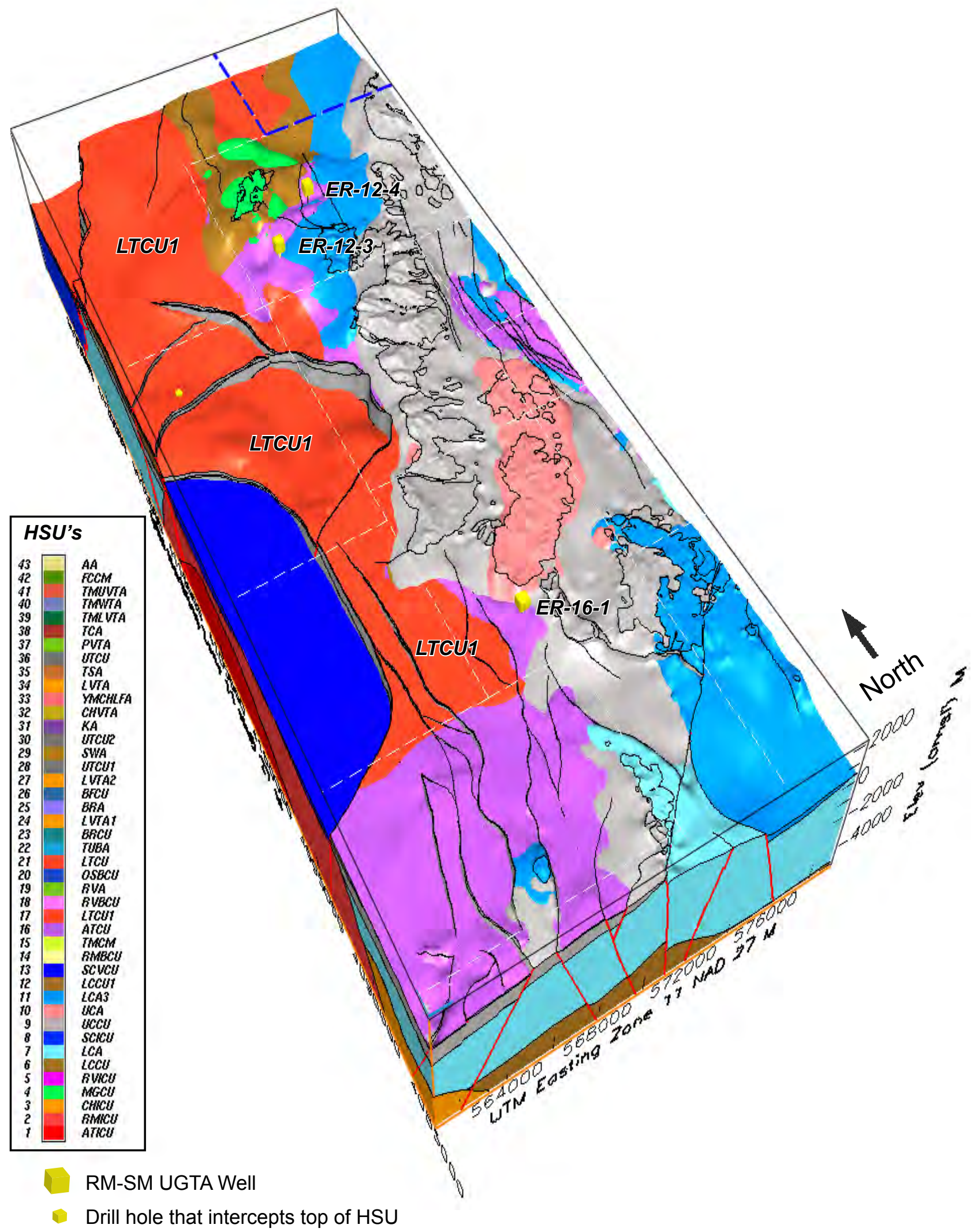

Figure 4-46

Block Model View Showing Extent of the Lower Tuff Confining Unit 1 (LTCU1) within the RM-SM Model Area 


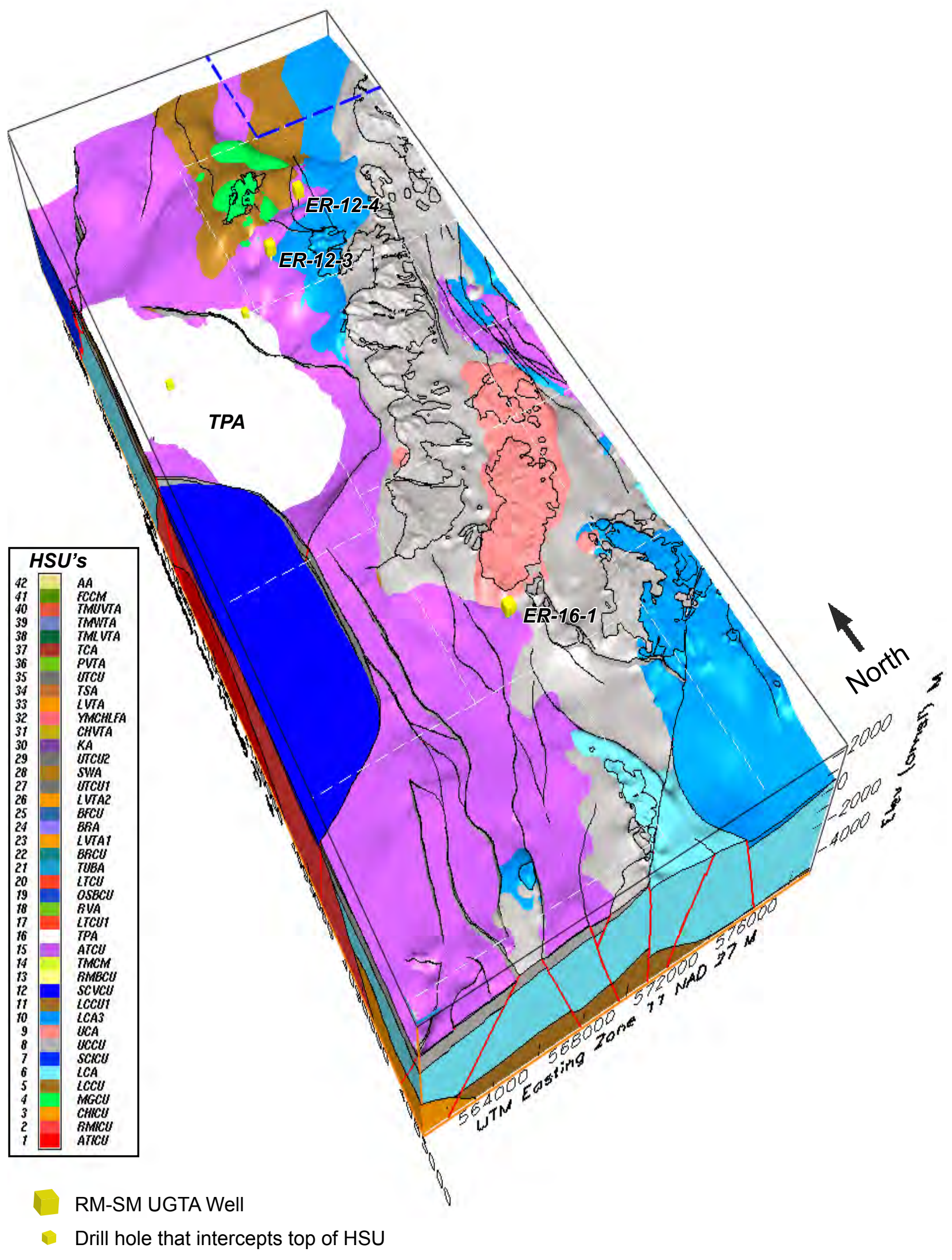

Figure 4-47

Block Model View Showing Extent of the Tuff of Twin Peaks (TPA) within the RM-SM Model Area 


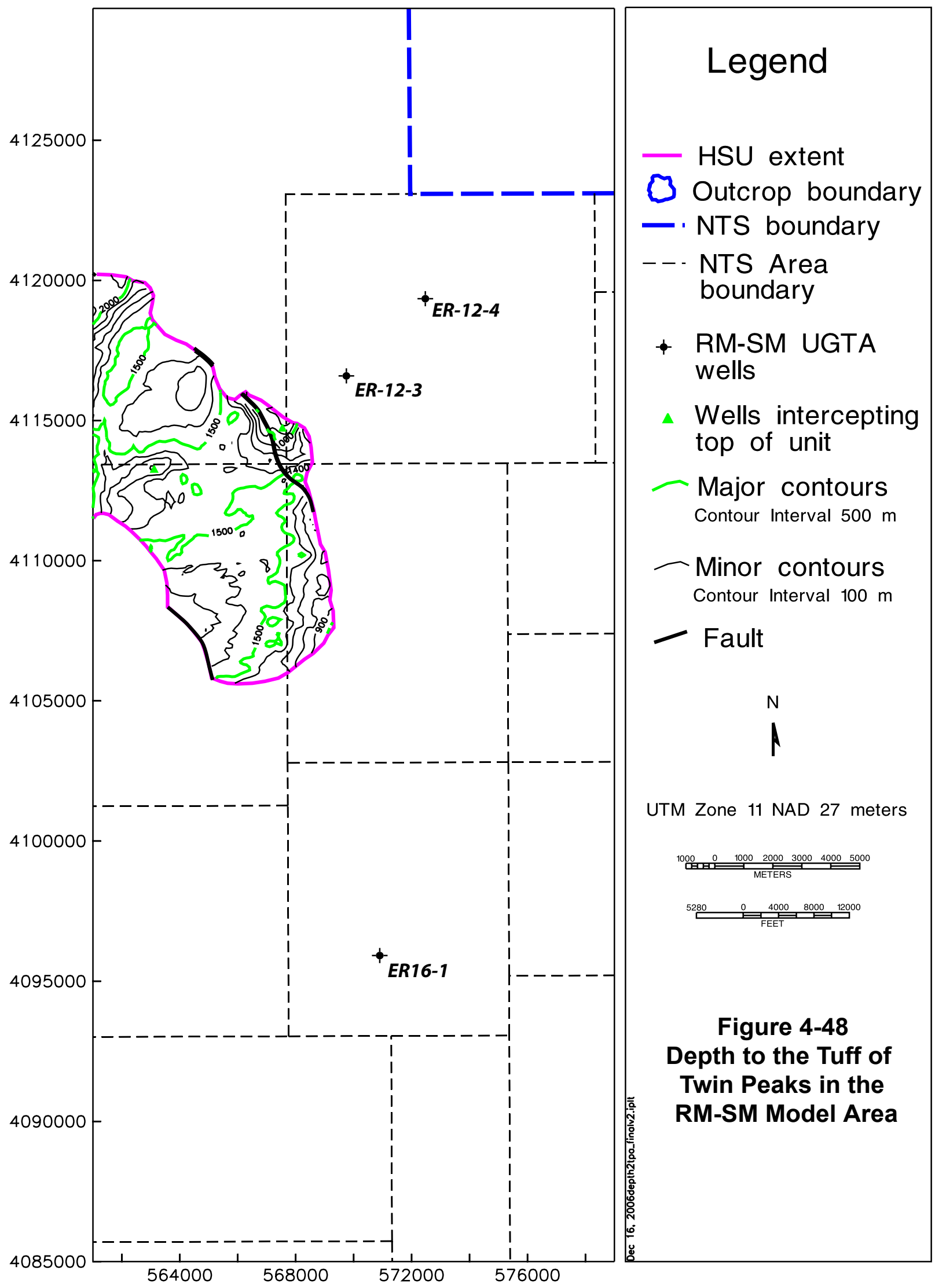




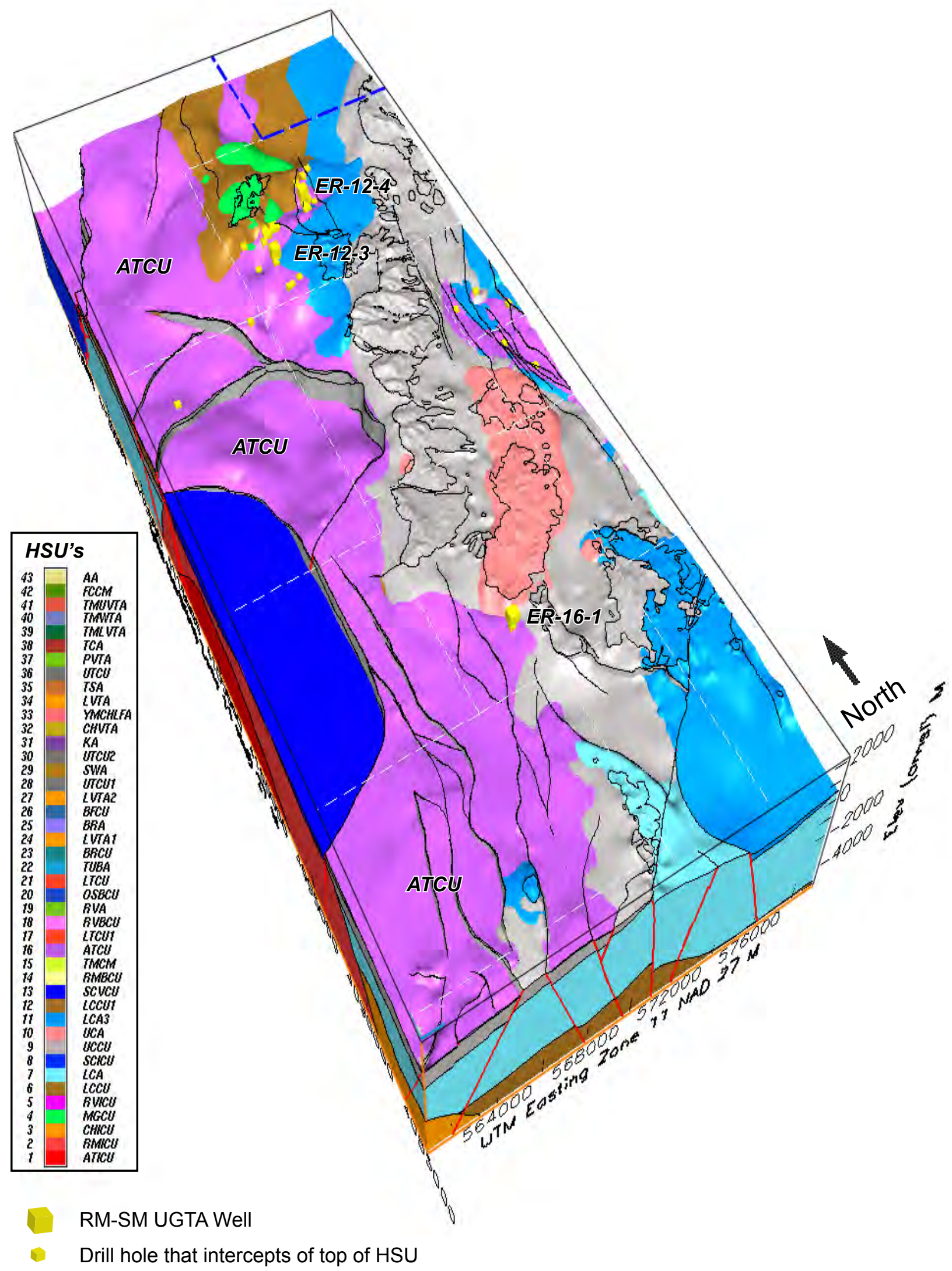

Figure 4-49

Block Model View Showing Extent of the Argillic Tuff Confining Unit (ATCU) within the RM-SM Model Area 


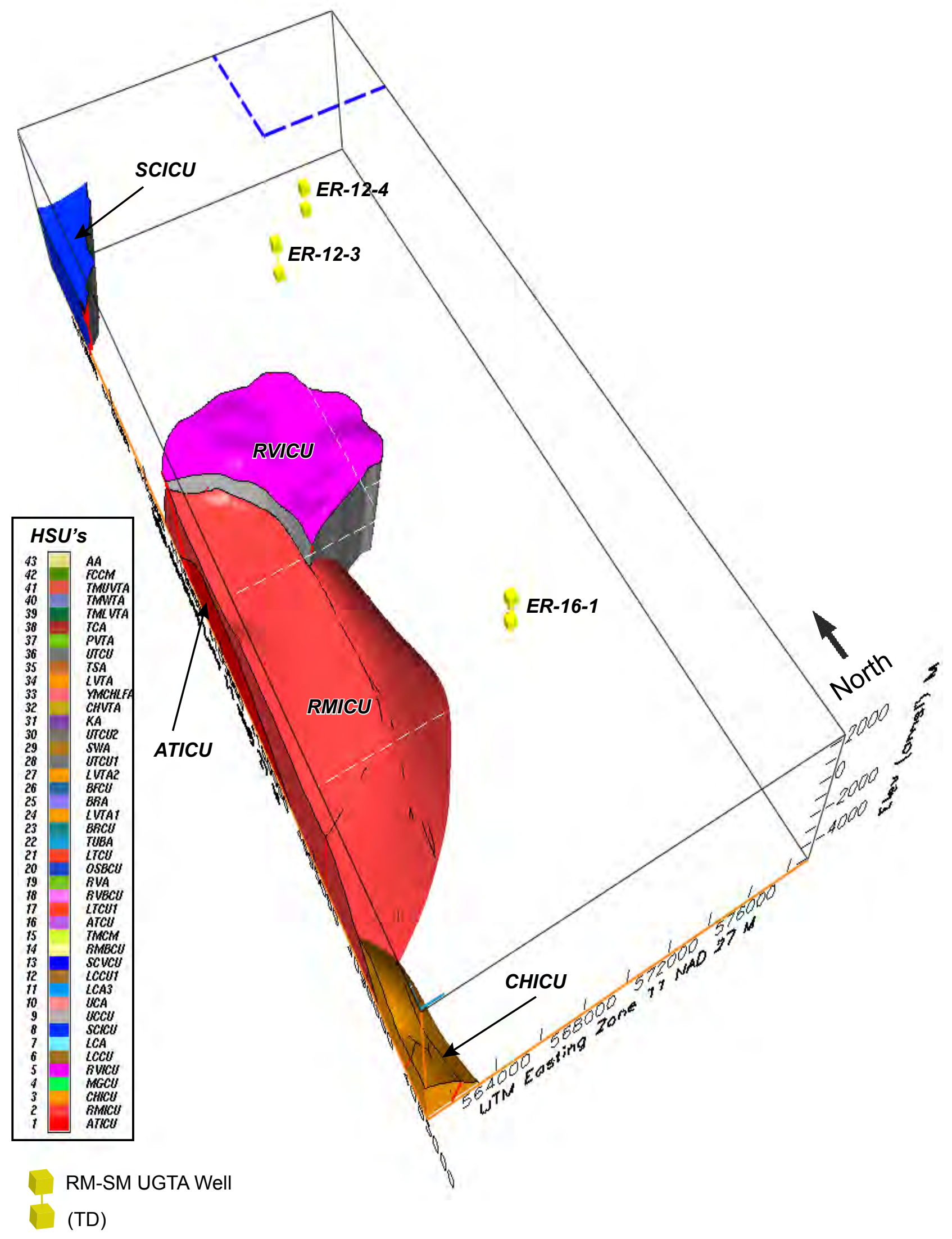

Figure 4-50

Block Model View Showing Extent of the Four Caldera-related Intrusive Confining Units and the CHICU within the RM-SM Model Area 


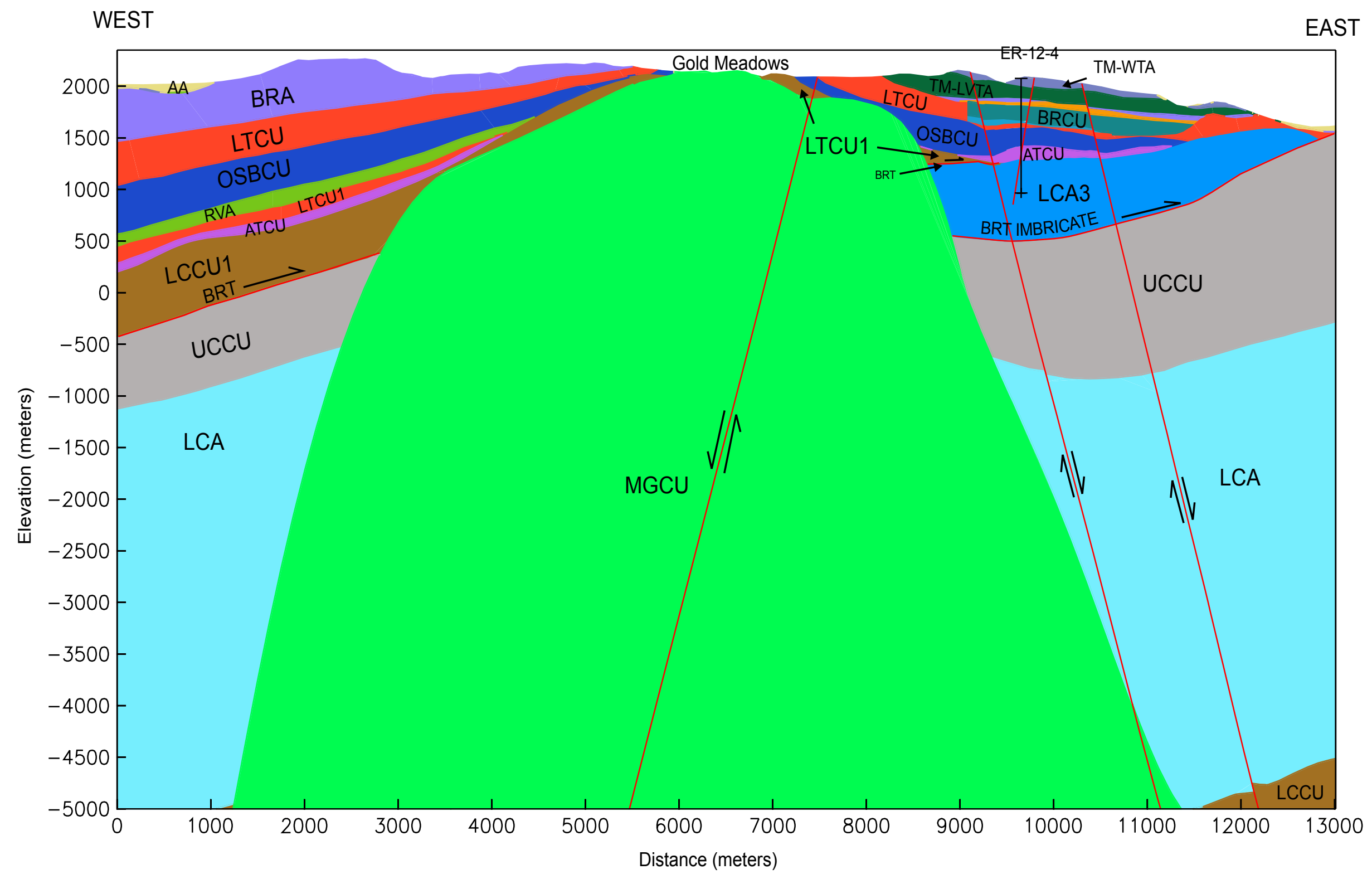

Figure 4-51

West - East Model Profile Showing the Gold Meadows Granitic Intrusive 


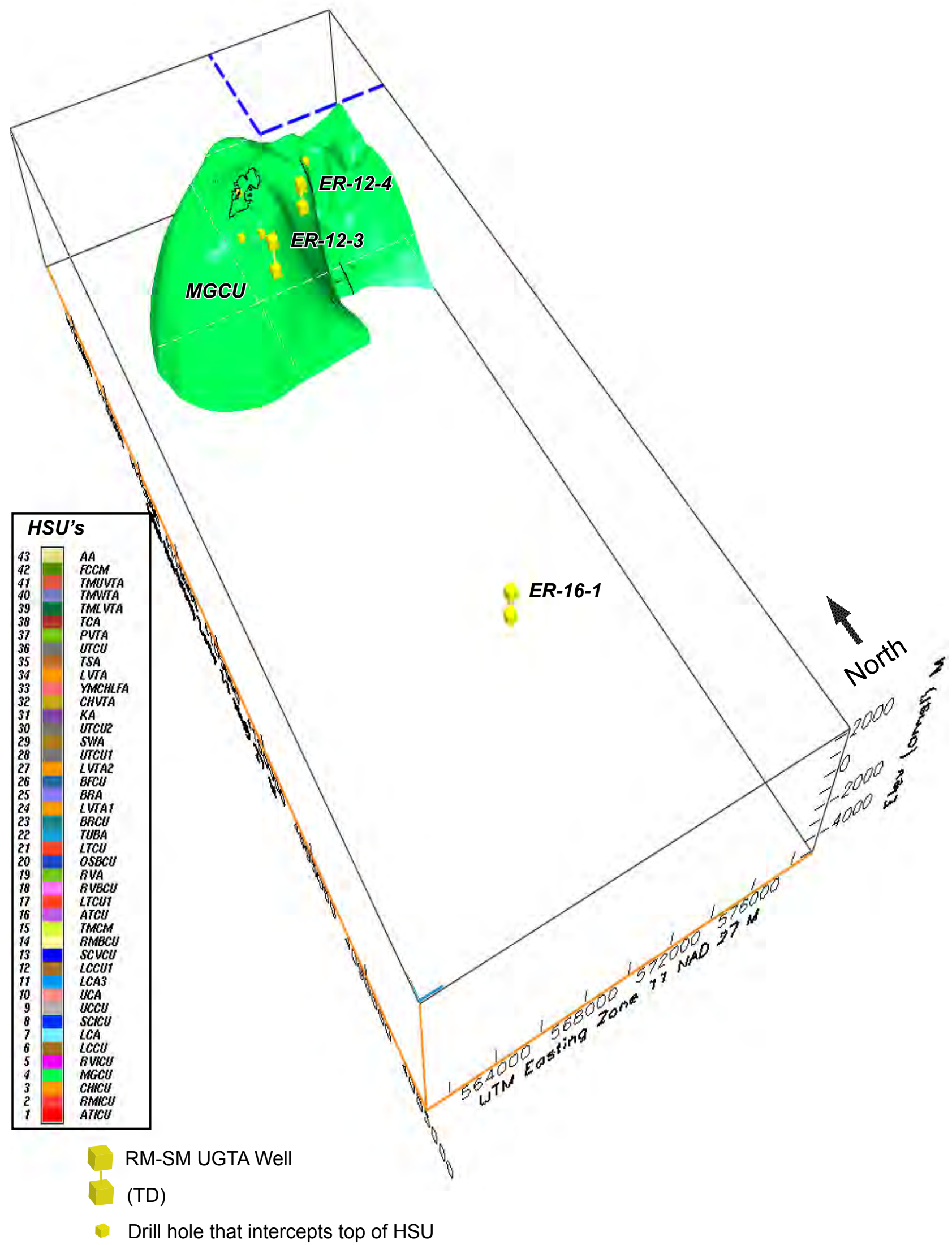

Figure 4-52

Block Model View Showing Extent of the Mesozoic Granitic Confining Unit (MGCU) within the RM-SM Model Area 


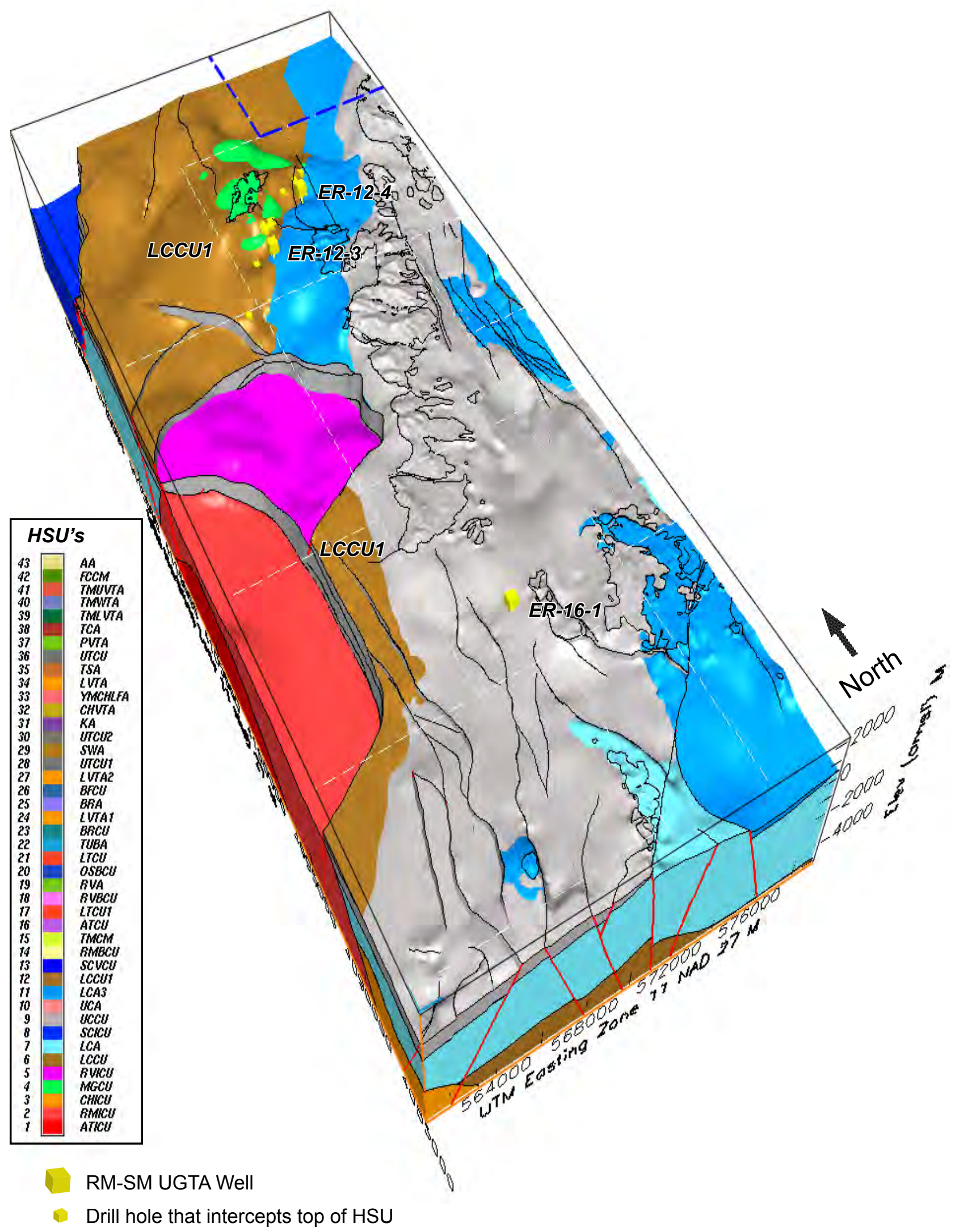

Figure 4-53

Block Model View Showing Extent of the Lower Clastic Confining Unit 1 (LCCU1) within the RM-SM Model Area 


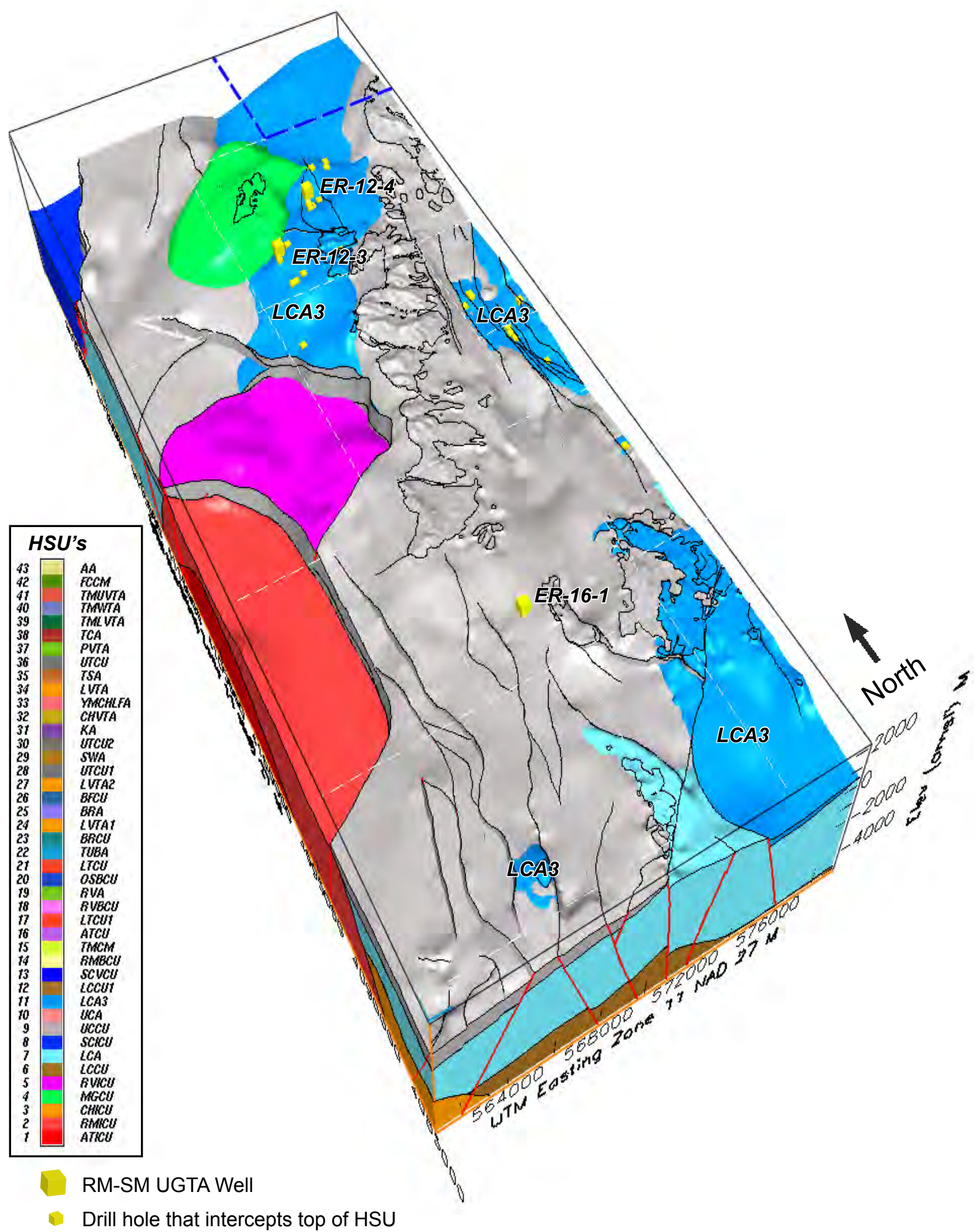

Figure 4-54

Block Model View Showing Extent of the Lower Carbonate AquiferThrust Plate (LCA3) within the RM-SM Model Area 


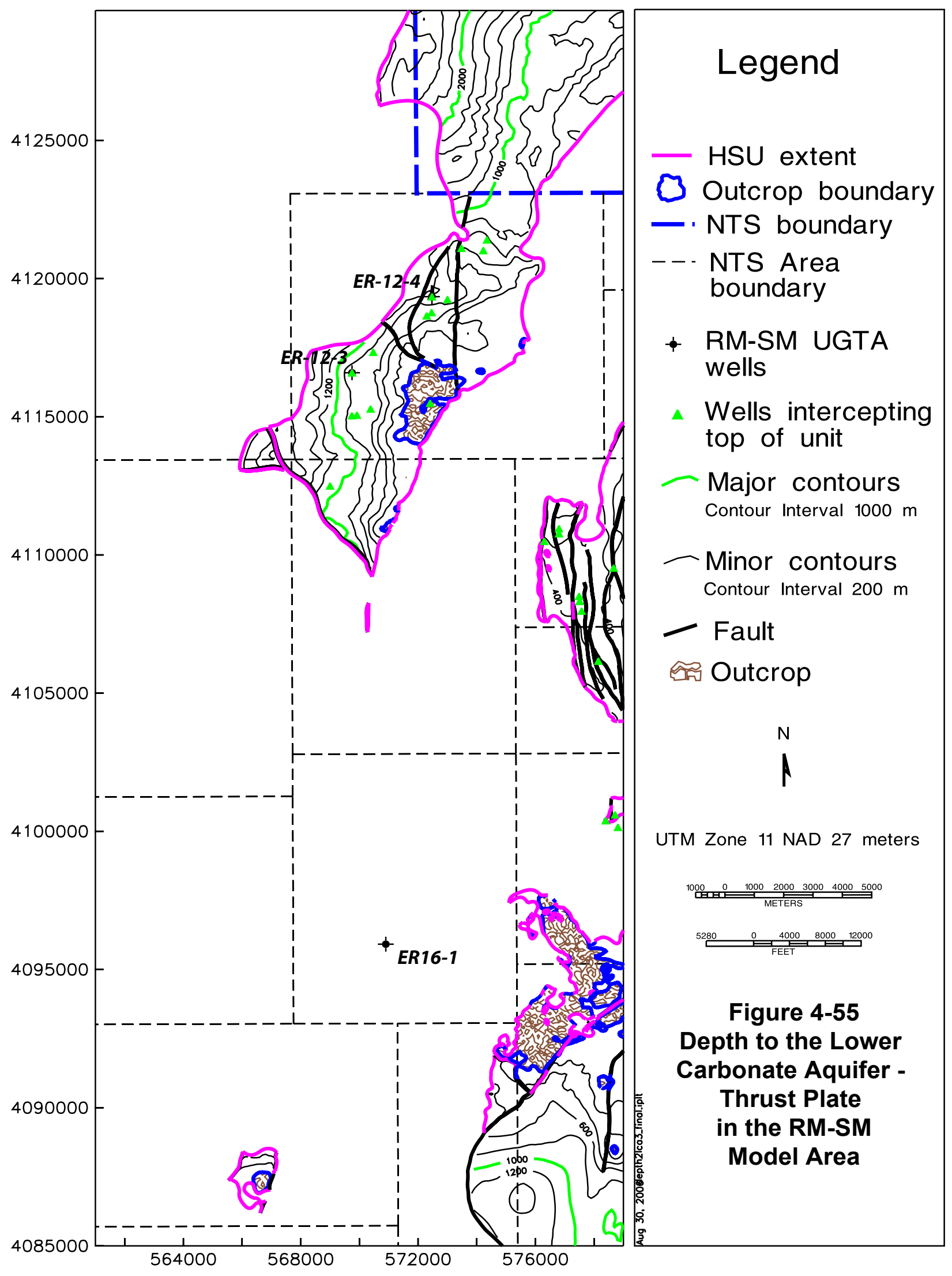




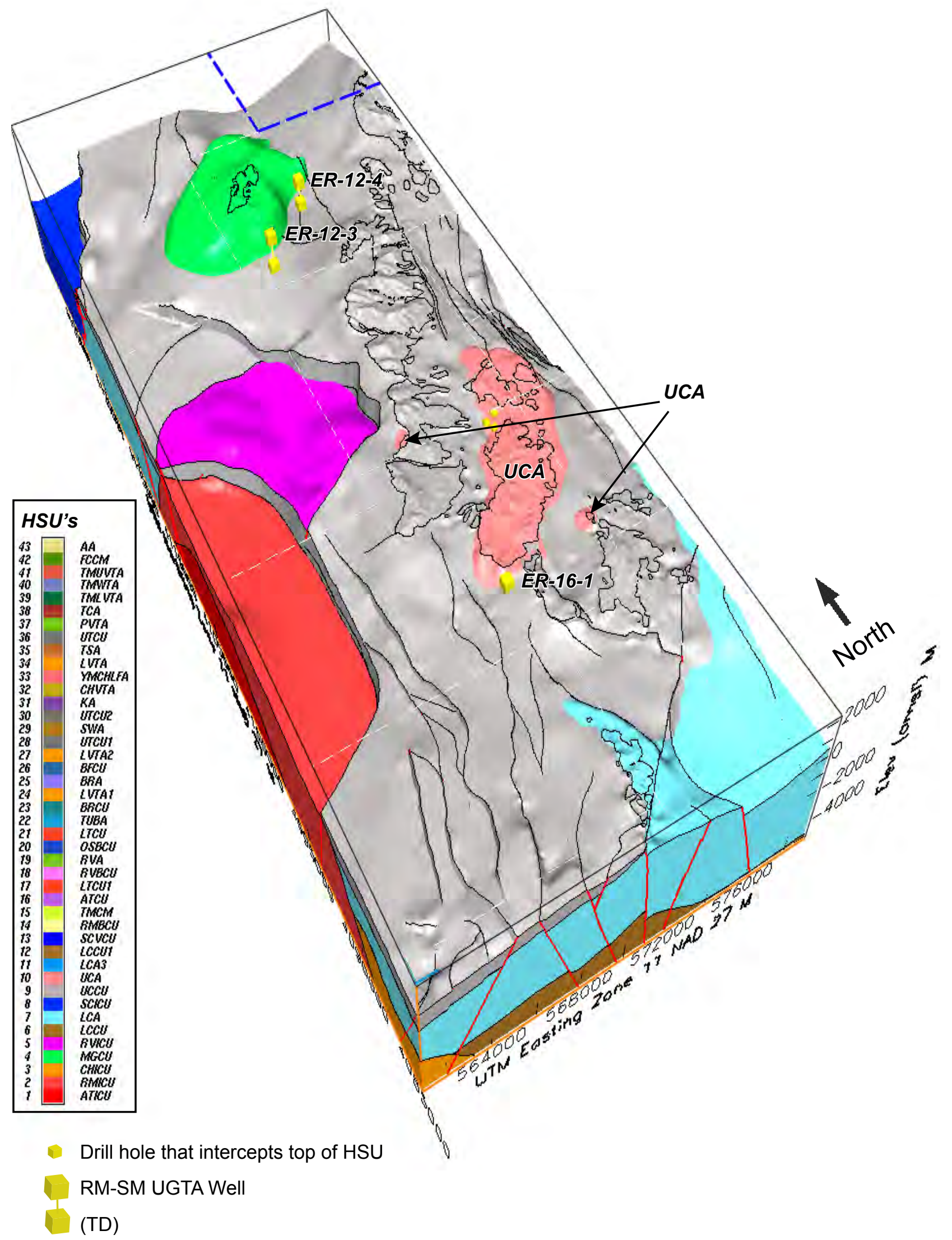

Figure 4-56

Block Model View Showing Extent of the Upper Carbonate Aquifer (UCA) within the RM-SM Model Area 


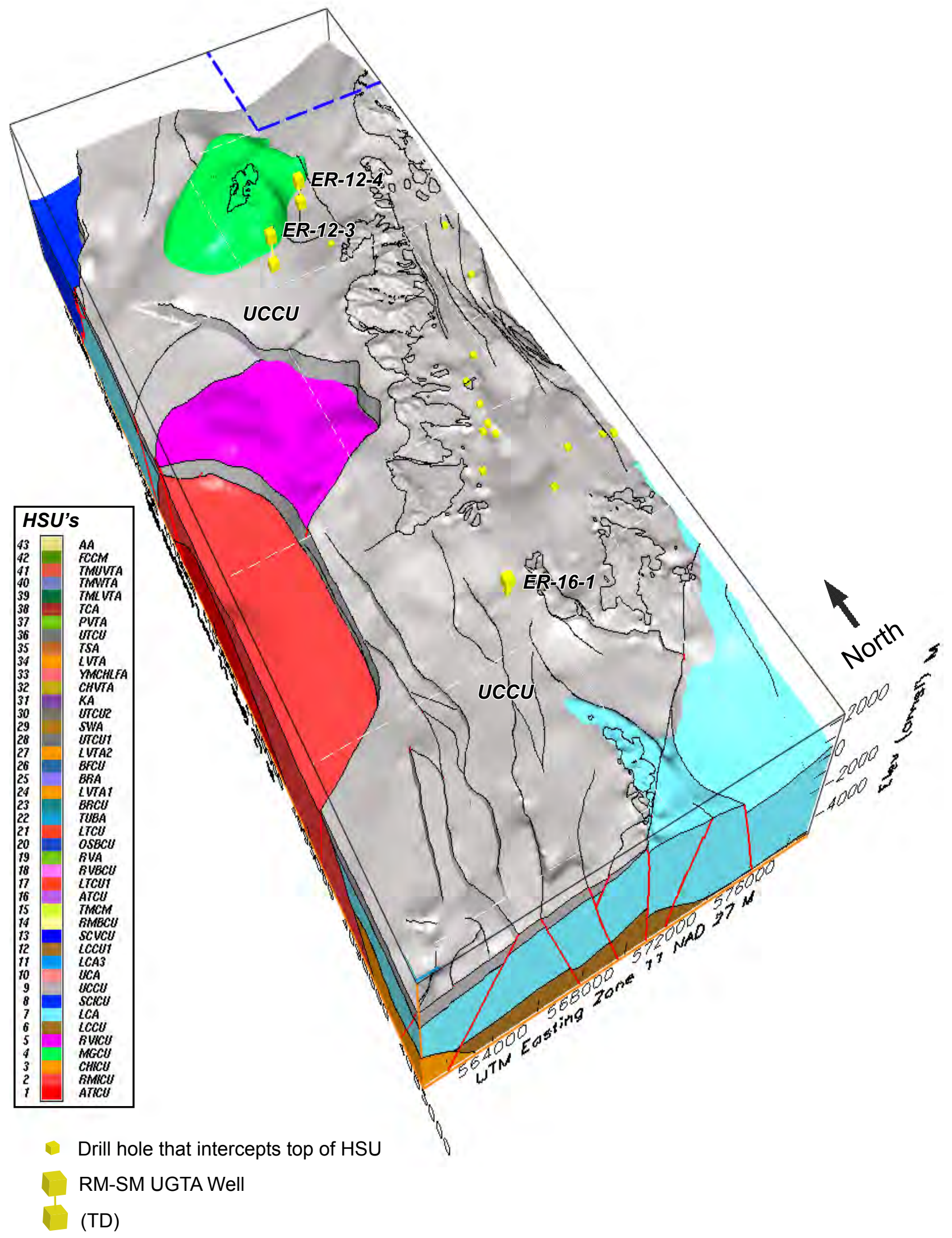

Figure 4-57

Block Model View Showing Extent of the Upper Clastic Confining Unit (UCCU) within the RM-SM Model Area 


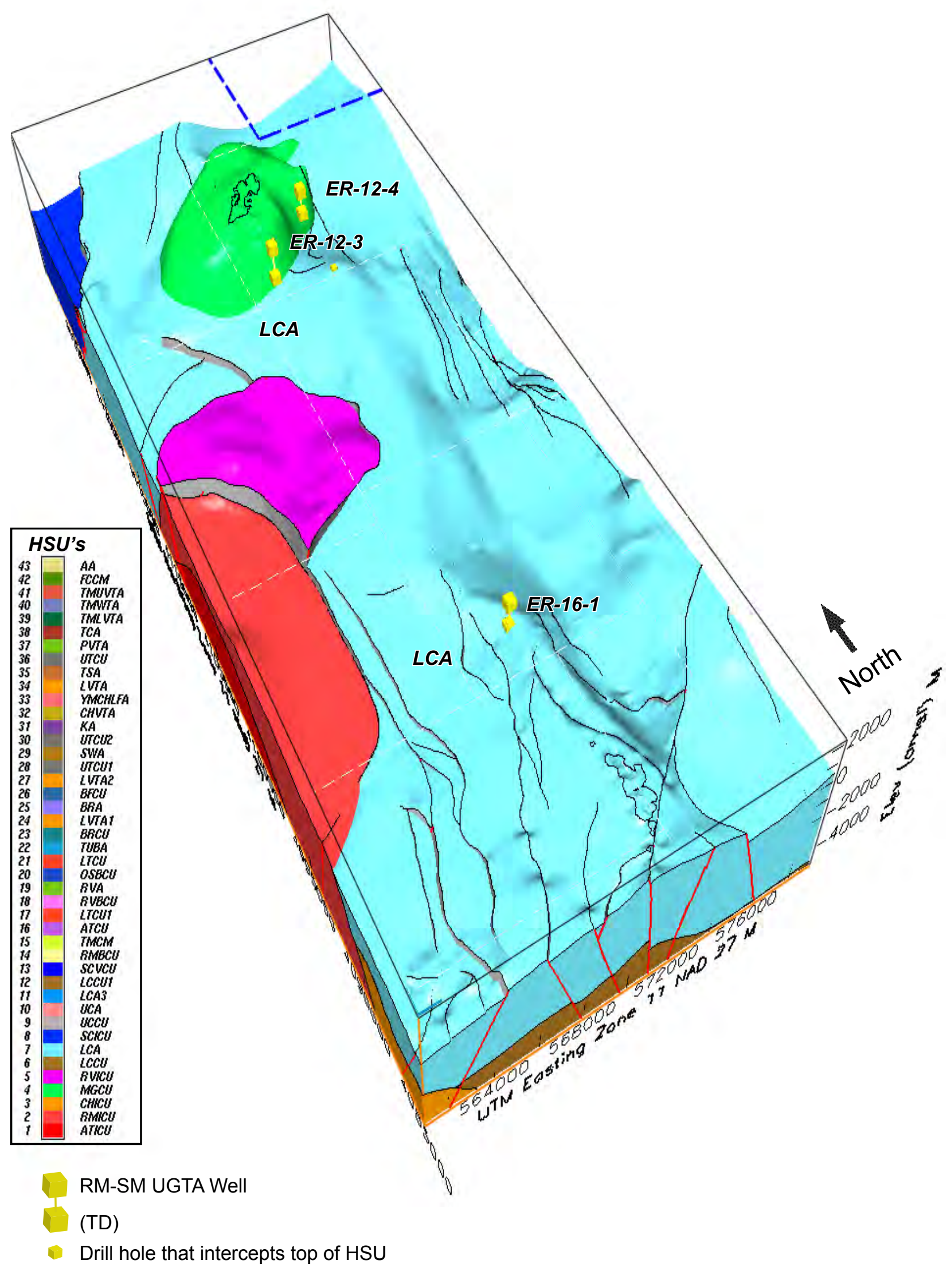

Figure 4-58

Block Model View Showing Extent of the Lower Carbonate Aquifer (LCA) within the RM-SM Model Area 


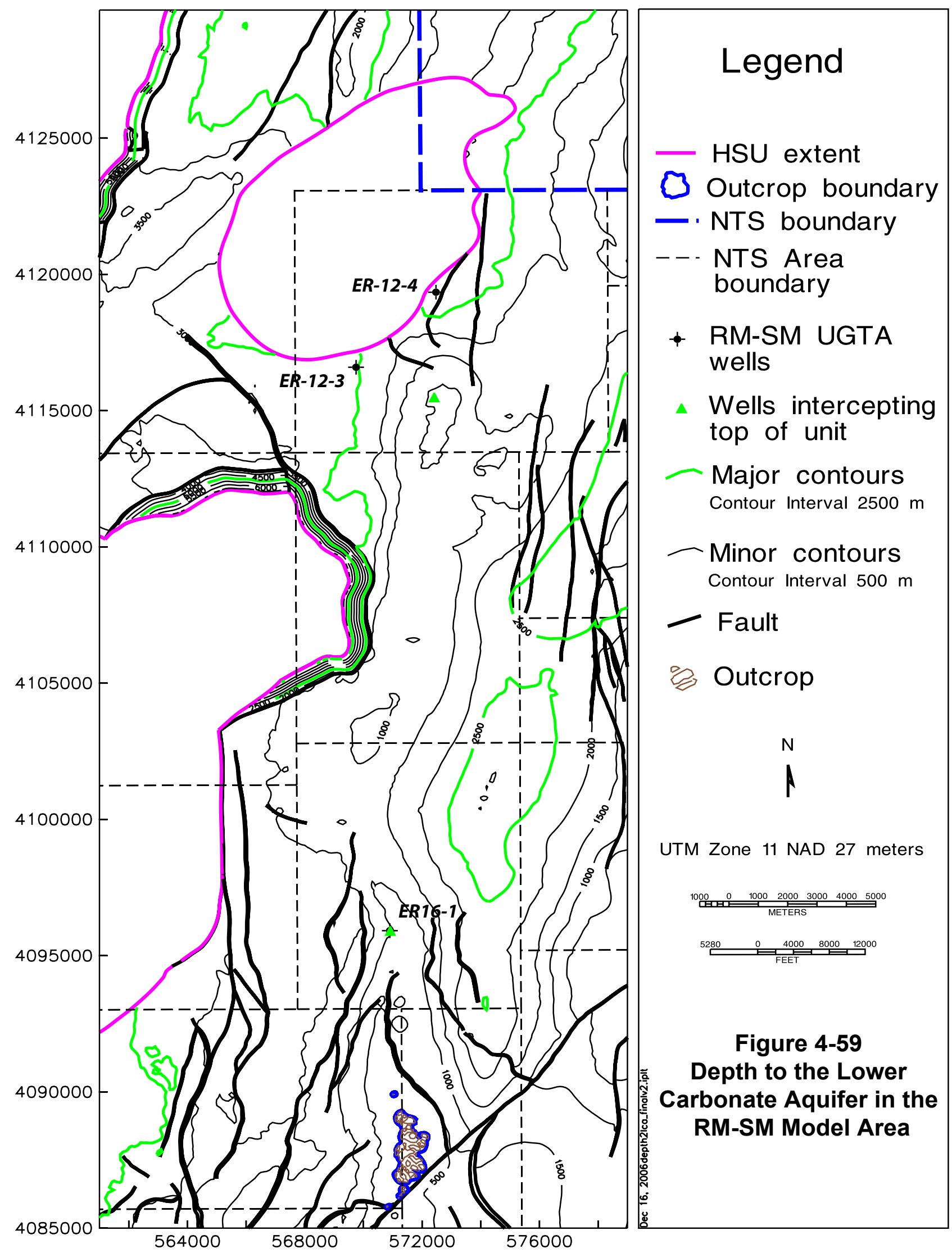




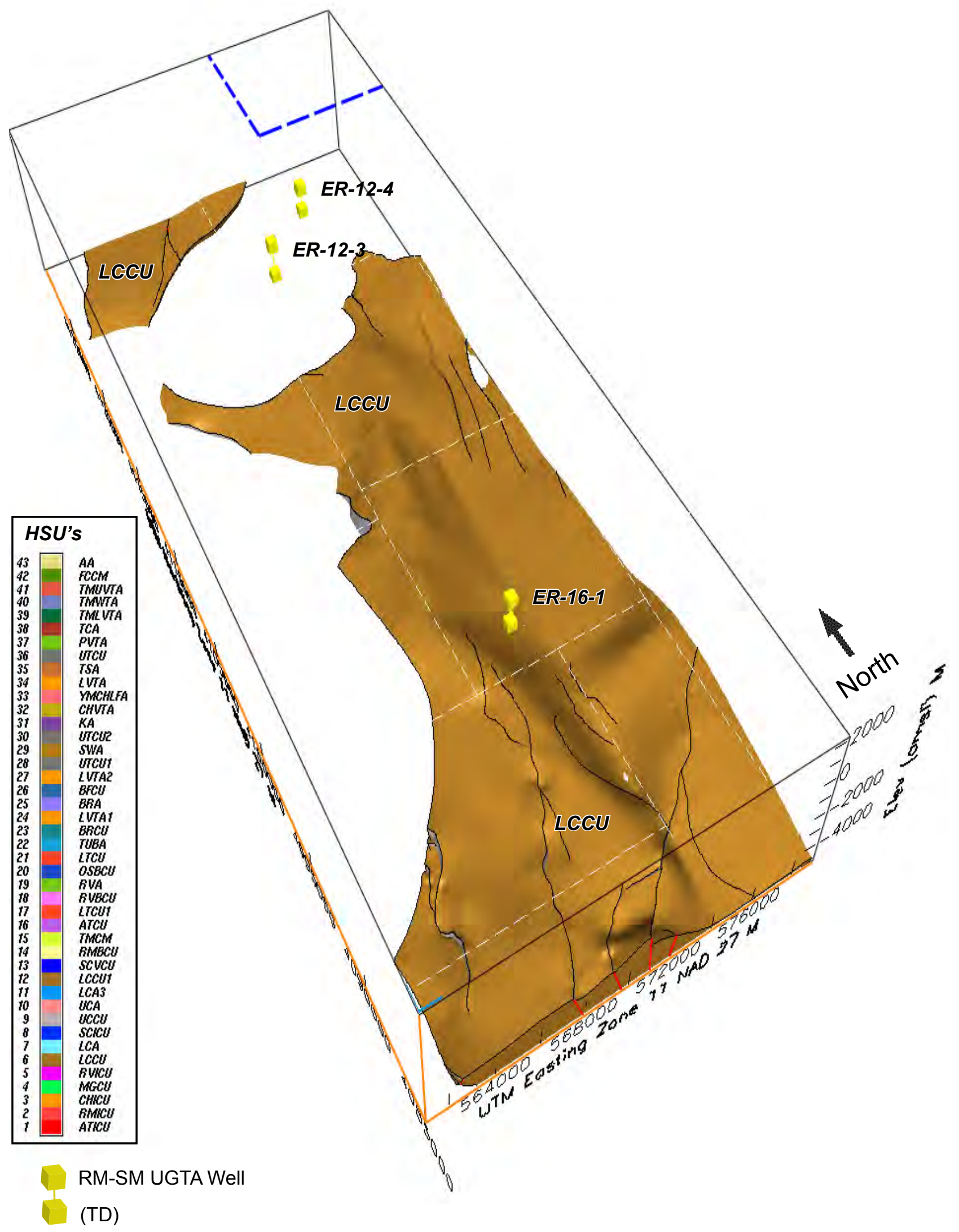

Figure 4-60

Block Model View Showing Extent of the Lower Clastic Confining Unit (LCCU) within the RM-SM Model Area 


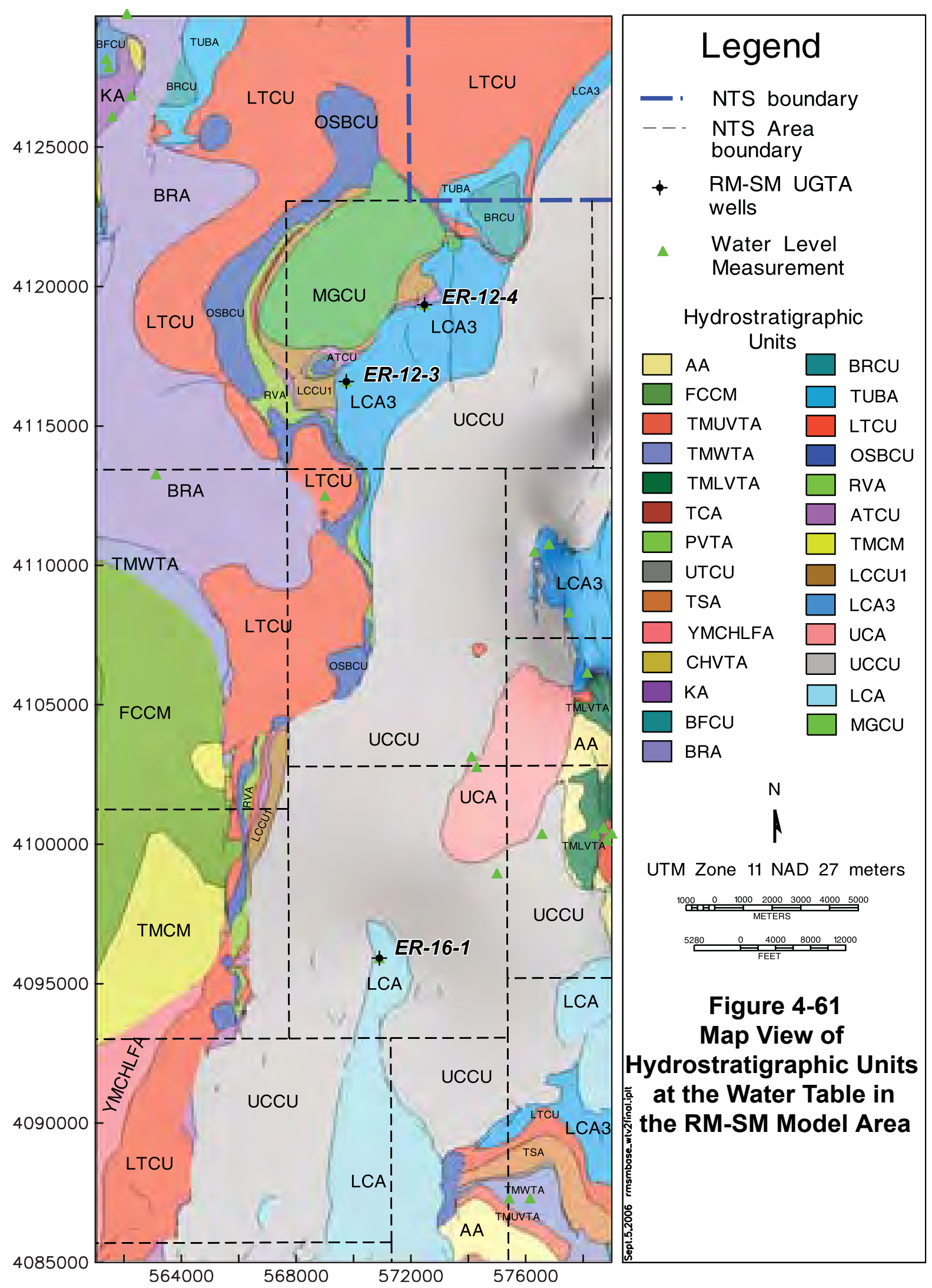




\subsection{ALTERNATIVE SCENARIOS}

As mentioned in previous sections of this report, the geologic complexity of the model area and non-unique interpretations incorporated into the base model made it necessary to develop alternative interpretations. This section describes the four alternative scenarios developed into separate independent models, as well as the process used to identify and construct the alternatives.

\subsection{Process of Addressing Alternatives to the Base Model}

Thirteen ideas for alternative interpretations to the base model were identified and evaluated during construction of the Phase I base framework model (Table 5-1). These alternative ideas were presented to the UGTA TWG pre-emptive review subcommittee on April 25, 2006, for their consideration and evaluation, and to solicit additional alternative ideas. Each alternative idea was evaluated and categorized. The main criterion for evaluating and categorizing alternatives was whether the proposed change or alternative interpretation had the potential to significantly affect groundwater flow and contaminant transport. The geological probability and how well each alterative idea is constrained were also considered. Simplification of portions and specific aspects of the base model were also considered to explore ways to reduce future flowand-transport modeling efforts without compromising the integrity of the base model.

The alternatives were grouped into four priority categories. Group A alternatives are ideas judged to be significant and viable enough to be included in the base model. Only one idea, the "Redrock Valley Caldera" alternative, was identified as Group A and incorporated directly into the base model. This alternative replaced the base model interpretation that was subsequently developed as an alternative model (see below).

Four alternative ideas were identified as Group B alternatives. These alternatives were judged to be significant enough to develop as separate models. Each alternative was inserted into a copy of the base model, resulting in four separate alternative models. One of these ("no Redrock Valley caldera") had originally been included in the draft base model, but was switched out for the alternative idea.

Group C alternatives were judged to be potentially significant, but could be evaluated through changes in parameters during calibration of flow models. These alternatives primarily represent parameter uncertainty rather than framework uncertainty of alternative models. Thus, separate alternative framework models were not developed for these ideas. 
Table 5-1

Abridged List of Alternative Scenarios for the Rainier Mesa-Shoshone Mountain Hydrostratigraphic Framework Model

\begin{tabular}{|c|c|c|}
\hline Proposed Alternative & $\begin{array}{l}\text { Priority } \\
\text { Group a }\end{array}$ & Comment/Discussion \\
\hline 1. Redrock Valley caldera & A & 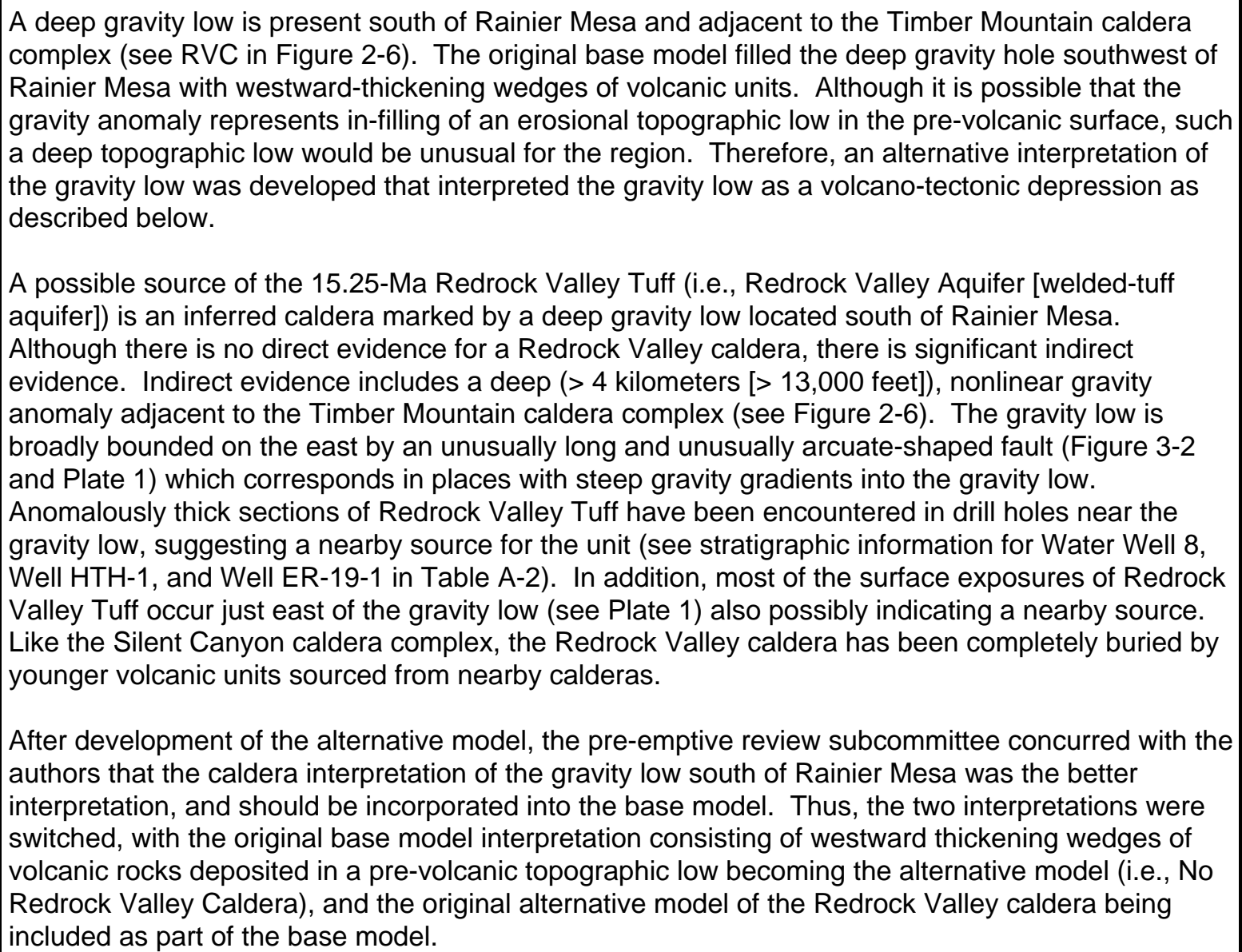 \\
\hline
\end{tabular}


Table 5-1

Abridged List of Alternative Scenarios for the Rainier Mesa-Shoshone Mountain Hydrostratigraphic Framework Model (continued)

\begin{tabular}{|c|c|c|}
\hline Proposed Alternative & $\begin{array}{l}\text { Priority } \\
\text { Group }^{\text {a }}\end{array}$ & Comment/Discussion \\
\hline $\begin{array}{l}\text { 2. Extend the LCA3 in the } \\
\text { Rainier Mesa area southward }\end{array}$ & B & $\begin{array}{l}\text { The base model includes an imbricate thrust slice of lower carbonate aquifer (LCA3) that extends } \\
\text { from the northern boundary of the model area southwestward to the Redrock Valley caldera. This } \\
\text { occurrence of LCA3 is structurally sandwiched between the overlying lower clastic confining unit } \\
\text { (LCCU1) in the upper plate of the Belted Range thrust fault and the underlying upper clastic } \\
\text { confining unit (UCCU). The LCA3 is exposed at the east base of Rainier Mesa and was } \\
\text { encountered in Wells ER-12-3 and ER-12-4 as well as other holes on Rainier and Aqueduct mesas. } \\
\text { This alternative would extend the LCA3 around the east side of the Redrock Valley caldera through } \\
\text { the narrow gap between the caldera margin and the Eleana Range (composed of UCCU) and into } \\
\text { the southwestern portion of the model area. The alternative would create a potential continuous flow } \\
\text { path within mostly carbonate aquifer from the Rainier Mesa testing area to the southwestern portion } \\
\text { of the model area. }\end{array}$ \\
\hline $\begin{array}{l}\text { 3. Alternative Structural Model } \\
\text { for the Southeastern Portion } \\
\text { of Model Area }\end{array}$ & B & $\begin{array}{l}\text { The base model designates the Devonian carbonate rocks exposed along the west side of Mid } \\
\text { Valley as lower carbonate aquifer (LCA), and thus as part of the regional carbonate aquifer. To the } \\
\text { east, beneath Mid Valley, the base model includes a contiguous sheet of carbonate rocks (LCA3) } \\
\text { thrusted over carbonate rocks that form the regional aquifer (i.e., LCA). Consequently, the extreme } \\
\text { southeastern portion of the model area is dominated by carbonate aquifer. No UCCU is present. } \\
\text { This configuration is consistent with the Yucca Flat-Climax Mine base model (BN, 2006). } \\
\text { Recently acquired MT data suggest that the carbonate rocks exposed along the west side of Mid } \\
\text { Valley may overlie UCCU and thus represent a thrust sheet of carbonate rocks (i.e., LCA3). The MT } \\
\text { data also suggest that Mid Valley is floored by UCCU, and that LCA3 overlies UCCU only beneath } \\
\text { the very western edge of the valley, thus LCA3 may not be present beneath much of Mid Valley. } \\
\text { This alternative would model the carbonate rocks along the west side of Mid Valley as LCA3, and } \\
\text { thus, the LCA would be considerably deeper in southwest portion of the model area. This alternative } \\
\text { would also model the underlying UCCU as a continuous layer throughout the southwestern portion } \\
\text { of the model area. }\end{array}$ \\
\hline
\end{tabular}


Table 5-1

Abridged List of Alternative Scenarios for the Rainier Mesa-Shoshone Mountain Hydrostratigraphic Framework Model (continued)

\begin{tabular}{|c|c|c|}
\hline Proposed Alternative & $\begin{array}{l}\text { Priority } \\
\text { Group a }\end{array}$ & Comment/Discussion \\
\hline $\begin{array}{l}\text { 4. Model carbonate rocks in the } \\
\text { bottom of Well ER-12-1 as } \\
\text { LCA3 }\end{array}$ & B & $\begin{array}{l}\text { The base model designates the carbonate rocks at the bottom of ER-12-1 as LCA. However, the } \\
\text { structural complexities (e.g., numerous thin thrust slices) encountered in the well make } \\
\text { interpretations difficult and uncertain. Some of the data, such as age of the rocks at the bottom of } \\
\text { the hole and water levels in the well, seem to suggest that the carbonate rocks at the bottom of } \\
\text { Well ER-12-1 may be LCA3. } \\
\text { This alternative will model the carbonate rocks encountered at the bottom of Well ER-12-1 as LCA3. } \\
\text { The LCA3 would then overlie UCCU, and thus the underlying LCA would be considerably deeper } \\
\text { beneath the eastern portion of Rainier Mesa in this alternative. This alternative would also include } \\
\text { an additional thin thrust slice of UCCU that was encountered in the well. }\end{array}$ \\
\hline $\begin{array}{l}\text { 5. Vary hydraulic properties of } \\
\text { certain faults }\end{array}$ & C & $\begin{array}{l}\text { The hydraulic properties of faults may vary from fault to fault, laterally along a fault trace, with depth, } \\
\text { by area, by HSU/HGU, etc. A wide range of attributes have been observed for faults encountered } \\
\text { during mining operations in the tunnels at Rainier Mesa. Some have produced (perched) water, } \\
\text { while others are dry. Some faults may have a significant open aperture and others are completely } \\
\text { filled with gouge. }\end{array}$ \\
\hline $\begin{array}{l}\text { 6. Vary hydraulic properties of } \\
\text { the LCA and LCA3 }\end{array}$ & C & $\begin{array}{l}\text { Recently acquired flow data for the carbonate aquifer at UGTA Wells ER-12-3 and ER-12-4 (SNJV, } \\
2006 a) \text { revealed very low flow rates. This is in stark contrast with the relatively high flow rates for } \\
\text { carbonate aquifer wells in Yucca Flat. This alternative would designate areas of higher and lower } \\
\text { conductivity based on structural domains (e.g., extended/basin terrain vs. un-extended terrain). }\end{array}$ \\
\hline $\begin{array}{l}\text { 7. Add hydrostratigraphic and } \\
\text { structural complexities to the } \\
\text { TMCM }\end{array}$ & D & $\begin{array}{l}\text { Currently, the Timber Mountain composite unit is a single thick and extensive HSU inside the Rainier } \\
\text { Mesa and Ammonia Tanks calderas. Only the eastern portion of the Rainier Mesa caldera is within } \\
\text { the RM-SM model area, and this alternative will affect only the west central edge of the model. } \\
\text { Refinement of the TMCM will result in more HSU layers and faults within TMCM. However, this thick } \\
\text { HSU is potentially down-gradient from Rainier Mesa and, therefore, could potentially influence } \\
\text { groundwater flow paths from Rainier Mesa. } \\
\text { Although the TMCM could be subdivided into more HSU layers, the full interval would still be } \\
\text { dominated by welded-tuff aquifer as described for the TMCM in Subsection } 4.5 .3 .4 \text {. The inclusion of } \\
\text { the RMBCU in the RM-SM framework model, which was previously grouped with the TMCM in the } \\
\text { PM-OV model (BN, 2002a), effectively subdivides the TMCM to some extent. Very few faults are } \\
\text { exposed within the extent of the TMCM, so adding more faults would be very conjectural. }\end{array}$ \\
\hline
\end{tabular}


Table 5-1

Abridged List of Alternative Scenarios for the Rainier Mesa-Shoshone Mountain Hydrostratigraphic Framework Model (continued)

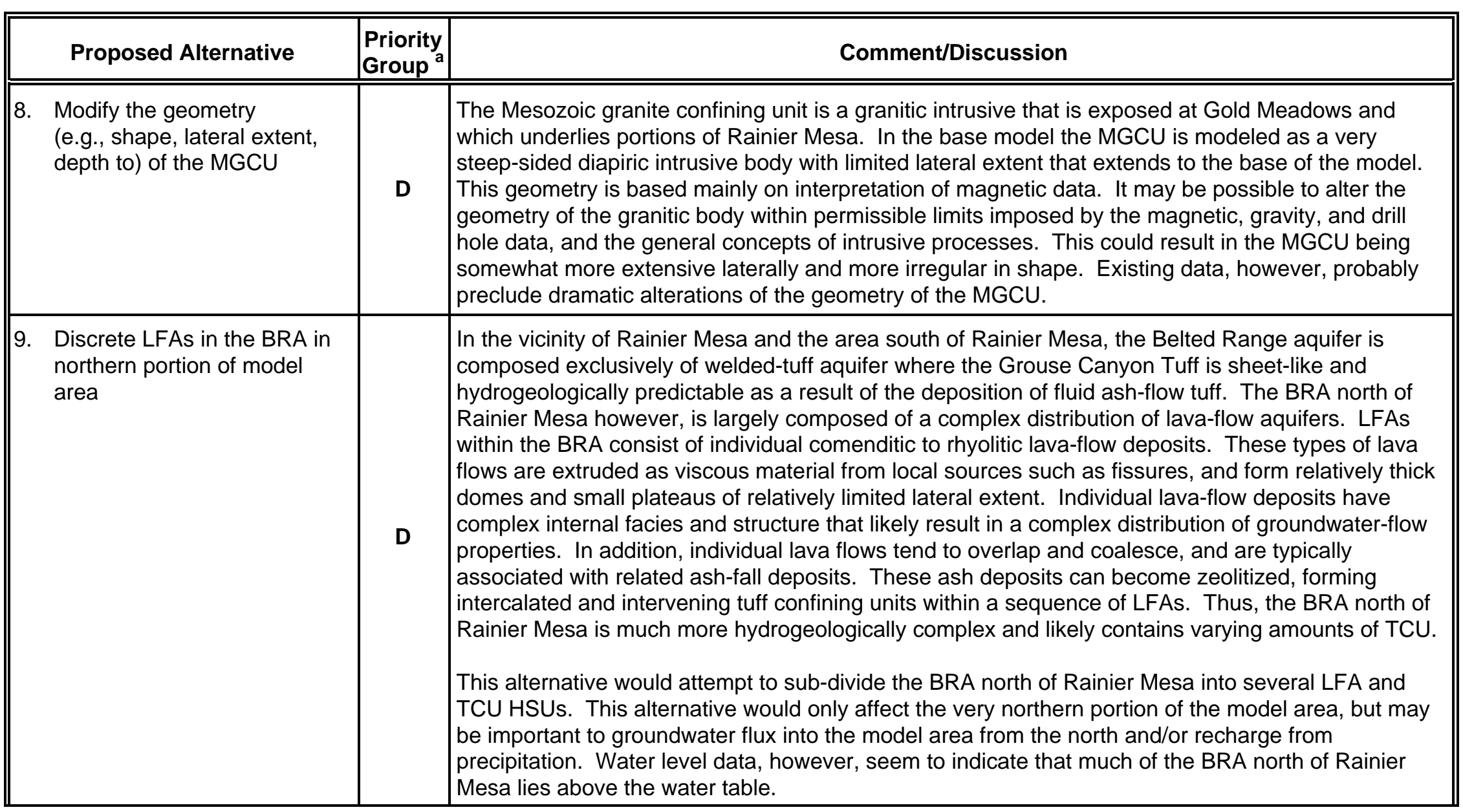


Table 5-1

Abridged List of Alternative Scenarios for the Rainier Mesa-Shoshone Mountain Hydrostratigraphic Framework Model (continued)

\begin{tabular}{|c|c|c|}
\hline Proposed Alternative & $\begin{array}{l}\text { Priority } \\
\text { Group }^{a} \\
\end{array}$ & Comment/Discussion \\
\hline $\begin{array}{l}\text { 10. Additional (small) normal } \\
\text { faults }\end{array}$ & D & $\begin{array}{l}\text { The base model contains only a small portion of the faults known to exist in the model area. This is } \\
\text { mainly because of computer modeling limitations and the grid size utilized for flow modeling. The } \\
\text { faults that are included in the base model are considered to be the major faults. These faults } \\
\text { typically have more than } 60 \text { meters of offset and significantly control topography and surface } \\
\text { exposures of HSUs (see Subsection 3.1.2). } \\
\text { This alternative would add more of the smaller faults identified in the model area. This would have } \\
\text { the greatest effect on the southern third of the model area which contains more faults due to greater } \\
\text { amount of extension in this portion of the model area. The area of more faulting is also south of the } \\
\text { Rainier Mesa and Shoshone Mountain testing areas. }\end{array}$ \\
\hline $\begin{array}{l}\text { 11. LCA3 over UCCU Beneath } \\
\text { Mid Valley }\end{array}$ & D & $\begin{array}{l}\text { The LCA3 in proposed alternative } 3 \text { is limited to the western margin of Mid Valley. This } \\
\text { interpretation, however, is not well constrained, and it is possible that LCA3 extends eastward } \\
\text { beneath Mid Valley where it forms a relatively thin layer of carbonate aquifer over the UCCU. } \\
\text { This alternative would model LCA3 as an extensive sheet beneath all of Mid Valley. The LCA3 } \\
\text { would overlie UCCU, which would also be extensive beneath the valley. The area affected by this } \\
\text { alternative would be small and well away from the UGT locations. }\end{array}$ \\
\hline $\begin{array}{l}\text { 12. Disrupted UCCU in the } \\
\text { vicinity of Well ER-16-1 }\end{array}$ & D & $\begin{array}{l}\text { The base model has continuous UCCU beneath the Well ER-16-1 area near the central portion of } \\
\text { the model area. However, the LCA was encountered considerably higher than expected and } \\
\text { consequently the overlying UCCU is thinner than expected. Because structural interpretations of the } \\
\text { pre-Tertiary rocks are poorly constrained in the area, the high LCA (and thin UCCU) at Well ER-16-1 } \\
\text { may allow the construction of an alternative that depicts the UCCU as having been completely } \\
\text { removed by erosion over a couple of LCA highs (i.e., anticlines). Thus, the UCCU would not be } \\
\text { continuous throughout the area, but disrupted, and preserved only in structural lows (i.e., synclines). } \\
\text { However, because the regional water table is within the LCA, the distribution of the overlying UCCU } \\
\text { probably has little effect on groundwater flow within the LCA. }\end{array}$ \\
\hline
\end{tabular}


Table 5-1

Abridged List of Alternative Scenarios for the Rainier Mesa-Shoshone Mountain Hydrostratigraphic Framework Model (continued)

\begin{tabular}{||c|c|c||}
\hline \hline Proposed Alternative & $\begin{array}{l}\text { Priority } \\
\text { Group }\end{array}$ & Comment/Discussion \\
\hline \hline $\begin{array}{l}\text { 13. Add paleo-topographic lows } \\
\text { and fill with older ash-flow } \\
\text { tuffs }\end{array}$ & D & $\begin{array}{l}\text { Paleo-topography has affected the distribution and thickness of the older ash-flow tuffs } \\
\text { (e.g., Redrock Valley Tuff, Yucca Flat Tuff, and tuff of Twin Peaks). Aquifer-like properties may } \\
\text { increase where these units have accumulated to significant thicknesses within paleo-topographic } \\
\text { lows. This alternative would evaluate lows within the pre-Tertiary surface and, where appropriate, } \\
\text { increase the thickness of the RVA. Consequently, underlying and overlying tuff confining unit HSUs } \\
\text { would probably be thinned. The locations of topographic lows and associated older ash-flow tuffs } \\
\text { are highly conjectural. If present, they probably would result in a discontinuous distribution of older } \\
\text { welded-tuff aquifers, and thus probably have minimal affect on groundwater flow. }\end{array}$ \\
\hline
\end{tabular}

a Group A is a change to the UGTA base model recommended by the alternative scenario working group, and is already implemented.

Group B are considered viable alternative scenarios that have been developed into alternative models.

Group $\mathbf{C}$ are proposed alternatives that would be better addressed during the hydrologic modeling phase rather than as alternatives to the base framework model.

Group D are proposed alternatives that were deemed by the pre-emptive review subcommittee to be low priority (due to perceived minimal consequences to groundwater flow and contaminant transport), not cost-effective, not practical (no data, conflict with data or geologic concepts, etc.), or simply not necessary to model at this time. 
The seven Group D alternatives were deemed by the pre-emptive review subcommittee not to be significant or viable enough to warrant development as alternative models. These alternative ideas, described in Table 5-1, will not be considered further.

The changes listed in Group A were implemented and are part of the base model as reported in this document.

\section{Group A - Recommended Changes to the Base Model}

(Numbers in parentheses refer to Table 5-1, where more information about these changes can be found.)

\section{- Redrock Valley caldera (1)}

The list of alternative scenarios which the subcommittee deemed important enough to pursue (Group B) are listed below in descending order of inferred potential impact.

\section{Group B - Viable Alternative Scenarios}

(Numbers in parentheses refer to Table 5-1, where more information about these changes can be found.)

- $\quad$ No Redrock Valley Caldera (initial base model swapped with alternative number 1)

- More extensive LCA3 (2)

- Shoshone Mountain thrust sheet (3)

- $\quad$ LCA3 at bottom of Well ER-12-1 (4)

Proposed alternatives that would be better addressed during the hydrologic modeling phase rather than as alternatives to the geologic framework model constitute Group C.

\section{Group C - Proposed Alternatives to Address During the Hydrologic Modeling Phase}

(Number in parentheses refers to Table 5-1, where more information about these changes can be found.)

- Vary hydraulic properties of certain faults (5)

- Vary hydraulic properties of the LCA (6)

\subsection{Alternative Models}

This section describes the four alternative models (Group B) developed for the RM-SM hydrostratigraphic framework model.

\subsubsection{No Redrock Valley Caldera}

Because the Redrock Valley caldera is completely buried by younger units and no drill holes are located within the caldera, no direct evidence exists for the caldera. Therefore, the caldera 
interpretation is not well constrained, and thus warrants an alternative interpretation, particularly since the area may be down-gradient from UGTs at Rainier Mesa.

This alternative removes the Redrock Valley caldera and fills the gravity-inferred basement low southwest of Rainier Mesa (Figure 2-6) with generally westward-thickening volcanic units consistent with volcanic deposition in a pre-volcanic topographic low in the pre-Tertiary surface (Figure 5-2). Displacement along the base model caldera fault is significantly reduced from approximately $600 \mathrm{~m}(2,000 \mathrm{ft})$ at depth to only about $75 \mathrm{~m}(250 \mathrm{ft})$, consistent with displacement observed at the surface. Also, the sub-caldera confining unit that floors the caldera is replaced with pre-Tertiary hydrostratigraphic units (e.g., LCA3, LCCU1, UCCU, LCA, LCCU) and structure (e.g., Belted Range thrust fault and associated imbricates) that represent the southwestern extension of the same pre-Tertiary units and structures beneath Rainier Mesa. Thick intra-caldera RVA in the base model is subdivided in the alternative to reflect extracaldera volcanic deposition.

Consequently, the RVA is considerably thinner in the alternative. The LTCU1 is thicker in the alternative and directly underlies the RVA. Another extra-caldera welded-tuff aquifer HSU, the TPA, is included (Figure 4-47). This HSU is defined strictly for this alternative and lies between the overlying LTCU1 and the underlying ATCU.

\subsubsection{More Extensive LCA3}

Devonian carbonate rocks exposed at the east base of Rainier Mesa are part of the hanging wall of an east-directed imbricate thrust fault associated with the Belted Range thrust fault system (Gibbons et. al., 1963; Cole and Cashman, 1999). These carbonate rocks have been thrust over Mississippian siliciclastic rocks, and likely form an isolated thrust sheet of carbonate aquifer designated LCA3, and separated from the regional carbonate aquifer (i.e., LCA) by Mississippian siliciclastic rocks that form the UCCU (Model Profiles B-B', C-C' and D-D'). To the west, beneath Rainier Mesa, the Belted Range thrust fault places early Cambrian to late Precambrian siliciclastic rocks (i.e., LCCU1) over the LCA3 (Model Profiles B-B' and C-C'). Structural orientations in the vicinity of Rainier Mesa indicate the LCA3 thrust sheet extends in a northeast-southwest direction (Figure 3-1). In the base model, the LCA3 imbricate thrust sheet is terminated by the Redrock Valley and Rainier Mesa calderas southwest of Rainier Mesa (Model Profile D-D') and, thus, its southwestward extent ends at the structural boundary of the Redrock Valley caldera (Figure 4-54). However, the southwestern extent of the LCA3 is not well constrained and it is possible that the LCA3 could be more extensive, particularly in the southwestern portion of the model area. 
This alternative extends the LCA3 around the east side of the Redrock Valley caldera through the narrow gap between the caldera margin and UCCU exposures in the Eleana Range, and into the southwestern portion of the model area (Figure 5-1). Thus, the LCA3 in the alternative model is continuous from the northern boundary to the southwestern boundary of the model area. To construct this alternative and allow for sufficient thickness of LCA3, it was necessary to lower the tops of the UCCU and LCA beneath the LCA3 sheet and thin the overlying LCCU1 southwest of the Redrock Valley caldera.

This alternative is similar to Alternative \#5 ("Contiguous Sheet of LCA3 Rocks") in the PM-OV model (BN, 2002a). Both of these alternative models include a continuous sheet of LCA3 west of Mid Valley. The "More Extensive LCA3" alternative to the RM-SM model results in a potentially continuous flow path through mostly carbonate aquifer from the Rainier Mesa testing area to the southwestern portion of the model area. A portion of the LCA3, however, is cut off by the Redrock Valley Caldera. Thus, along part of a southwestward flow path through the LCA3, some flow will likely be through the Redrock Valley Aquifer.

\subsubsection{Shoshone Mountain Thrust Sheet}

The base model designates the Devonian carbonate rocks exposed along the west side of Mid Valley as LCA and, thus, makes them part of the regional carbonate aquifer (Figure 4-4 and Plate 2). To the east beneath Mid Valley, the base model includes a contiguous sheet of LCA3 thrust over LCA (Model Profile G-G'). Consequently, the extreme southeastern portion of the base model is dominated by carbonate aquifer with LCA structurally high just west of Mid Valley. UCCU is not present in the southeast corner of the model area.

MT data (Subsection 2.3.8.4), however, suggest that the carbonate rocks exposed along the west side of Mid Valley may overlie UCCU and thus represent a thrust sheet of LCA3. The MT data also suggest that Mid Valley may be floored by UCCU, and that LCA3 overlies UCCU only beneath the very western edge of the valley, so that LCA3 may not be present beneath much of Mid Valley.

This alternative scenario models the carbonate rocks exposed along the west side of Mid Valley as part of an imbricate thrust sheet herein referred to as the Shoshone Mountain thrust sheet, similar to the thrust sheets at Mine Mountain and Calico Hills (Figure 5-3). The alternative also models the underlying UCCU as a continuous layer throughout the southeastern portion of the model area. As a result, the LCA is considerably lower in elevation west of Mid Valley (Figure 5-4) in this alternative. 
This alternative is similar to the Yucca Flat alternative "Continuous UCCU in Southwestern Yucca Flat" (BN, 2006). Both alternative models include a continuous layer of UCCU beneath Mid Valley.

\subsubsection{LCA3 at Bottom of Well ER-12-1}

Well ER-12-1 is a 1,093.6-m (3,588-ft) deep hole located at the eastern base of Rainier Mesa, just down hill from the E-Tunnel portal (Russell et al., 1996; Plate 3). The well site is located on an imbricate thrust sheet of carbonate rocks designated LCA3 in the base RM-SM hydrostratigraphic framework model (Figure 4-4 and Plate 2). The well penetrated a complex geologic section consisting of alternating intervals of carbonate and siliciclastic rocks before terminating in carbonate rocks (Table A-2, Appendix A). The base model designates the carbonate rocks at the bottom of Well ER-12-1 as LCA (Table A-3, Appendix A). However, the geologic complexities encountered in the well make interpretations difficult and uncertain, and may be indicative of more complex imbricate thrusting in the area. Water level measurements in the well may also indicate that the carbonate rocks at the bottom of Well ER-12-1 represent the hanging wall of an imbricate thrust and, thus, denote another, structurally lower occurrence of LCA3.

This alternative scenario models the carbonate rocks encountered at the bottom of Well ER-12-1 as part of another imbricate thrust slice of carbonate rocks, and designates these rocks as LCA3-1 to distinguish it from the structurally higher main LCA3 (Figure 5-5). The LCA3-1 is modeled as overlying the UCCU and, thus, the underlying LCA is considerably deeper beneath the eastern portion of Rainier Mesa in this alternative. The Mississippian siliciclastic rocks that occur between the LCA3 and LCA3-1 in the well are designated UCCU1 to distinguish them from the structurally lower UCCU. This alternative models the UCCU1 and the LCA3-1 as thin imbricate thrust slices of limited extent that form lens-shaped zones of imbrication at the base of the main LCA3 sheet (Figure 5-6). 
This page intentionally left blank. 


\section{Base Model}

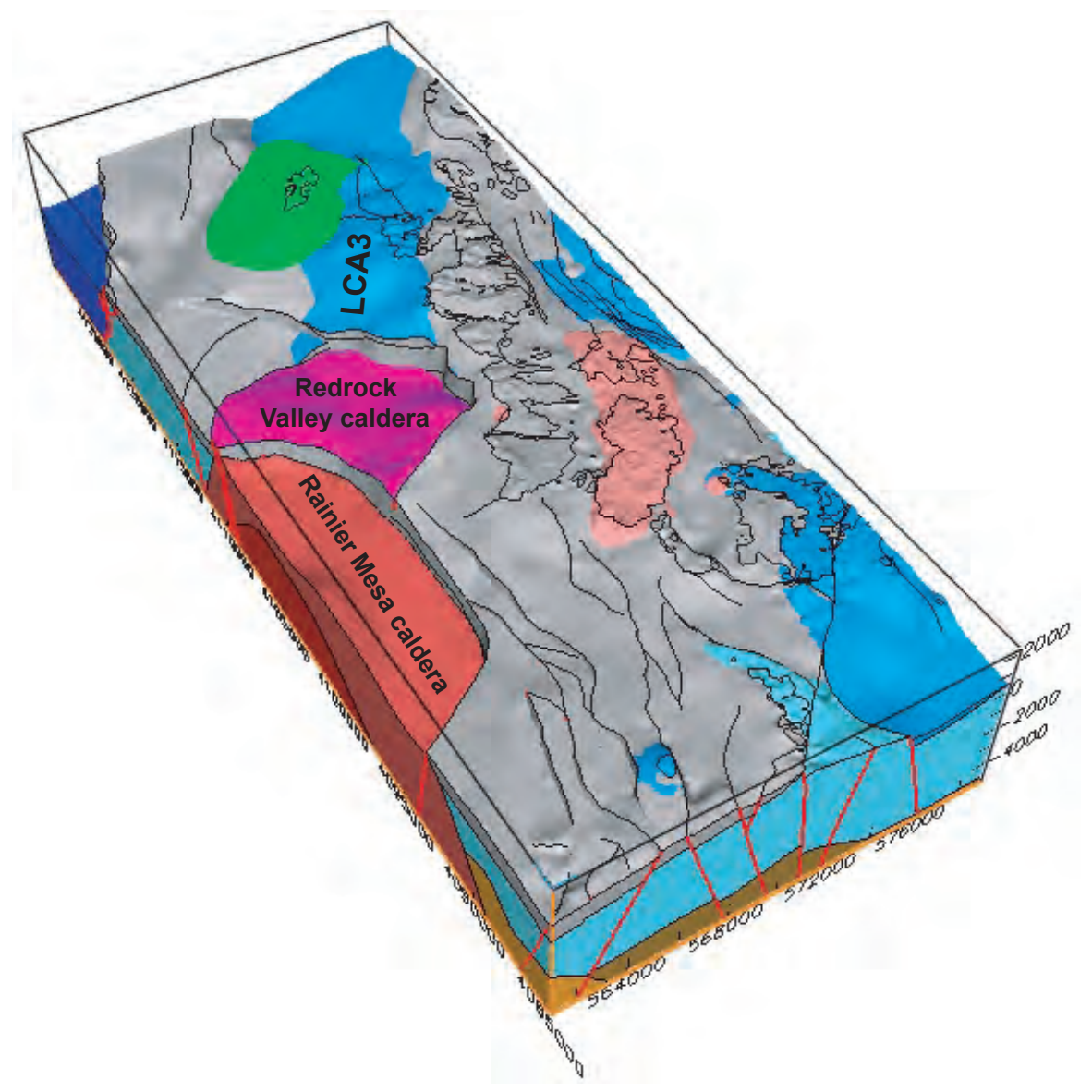

\section{Alternative Model}

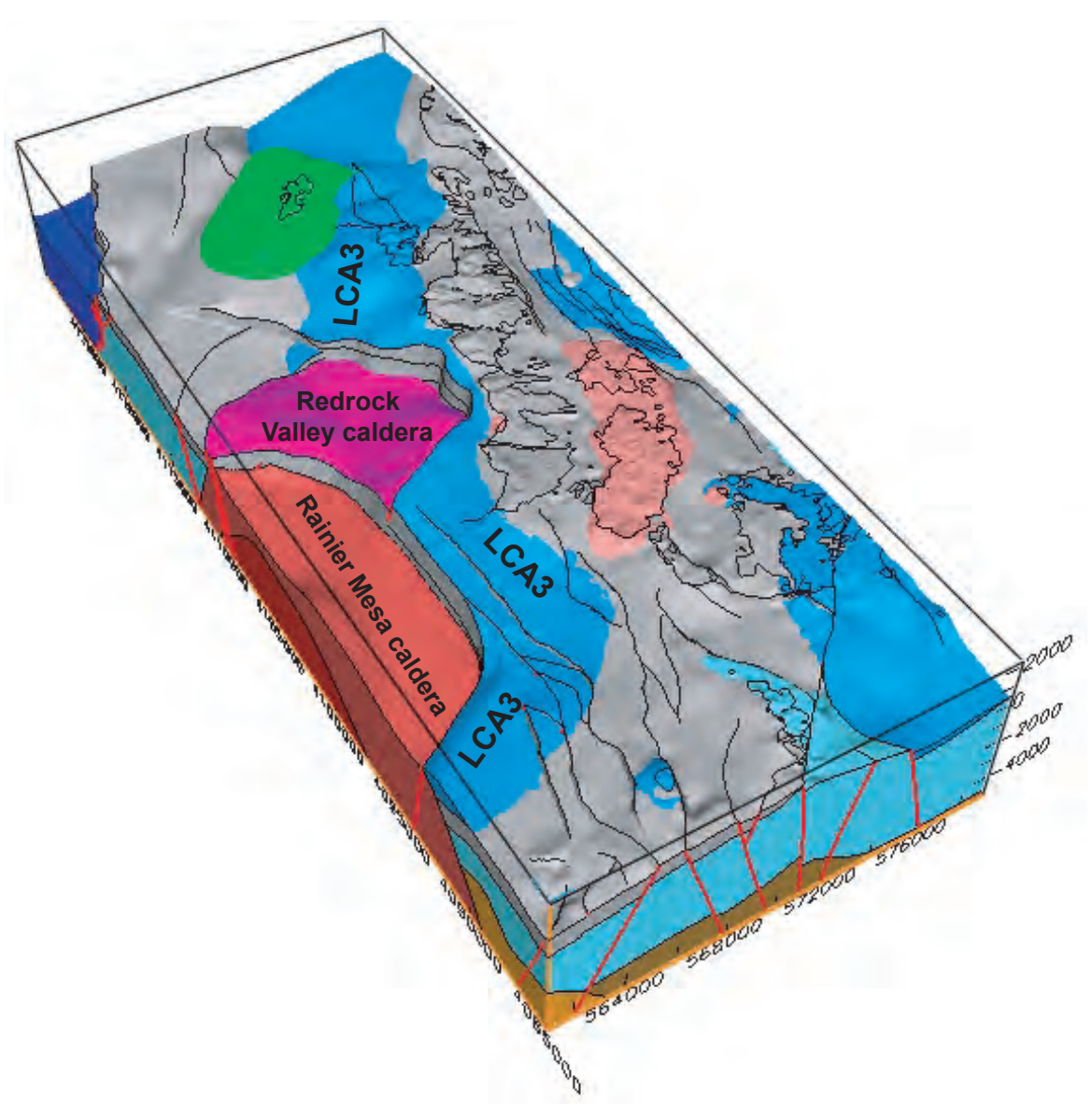

Figure 5-1

Comparison of the Base Model with the More Extensive LCA3 Alternative (Perspective views with alluvium, volcanic rocks, and LCCU1 removed) 

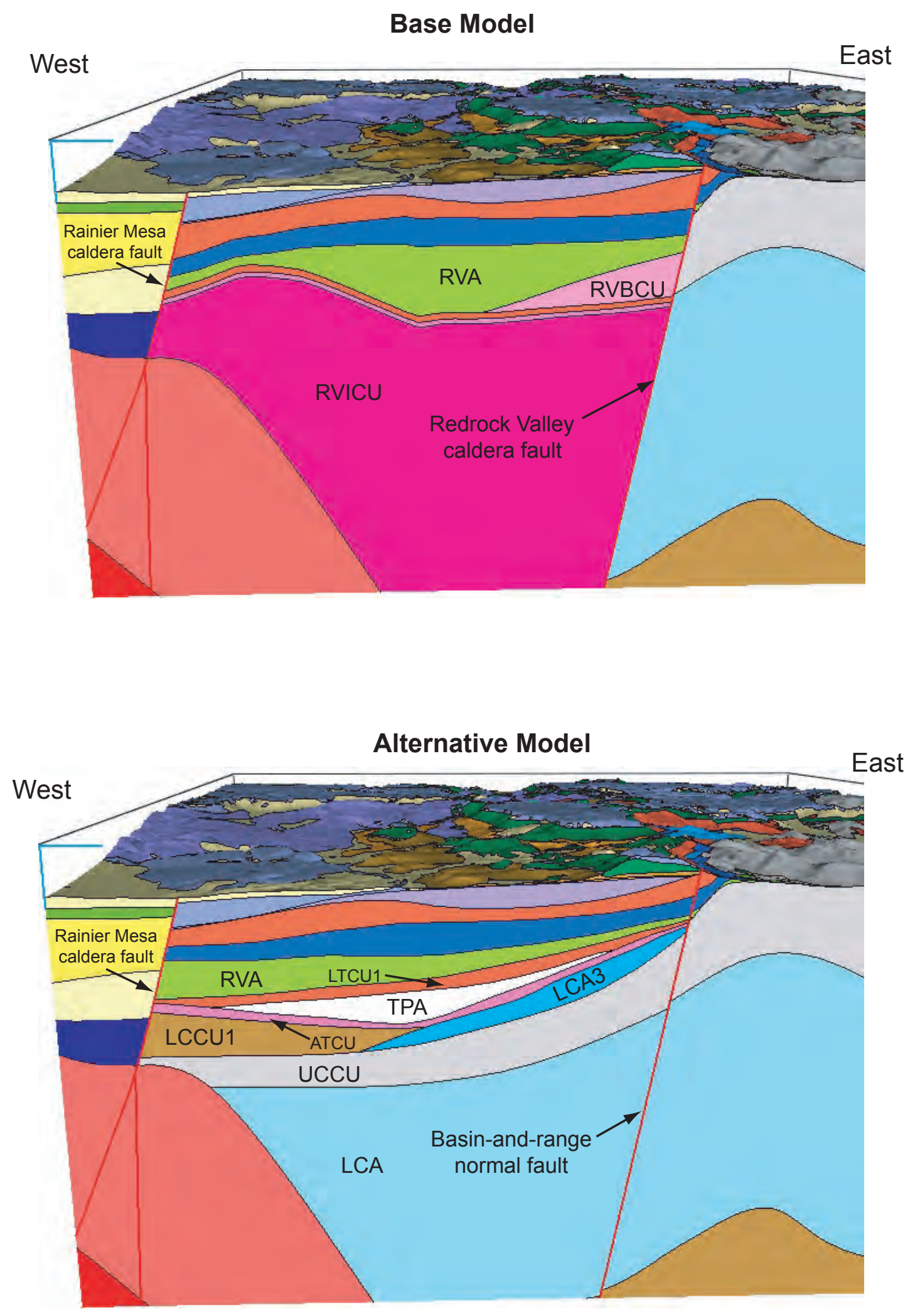

Figure 5-2

West-East Profiles Through the Base Model and the No Redrock Valley Caldera Alternative Model 


\section{Base Model}

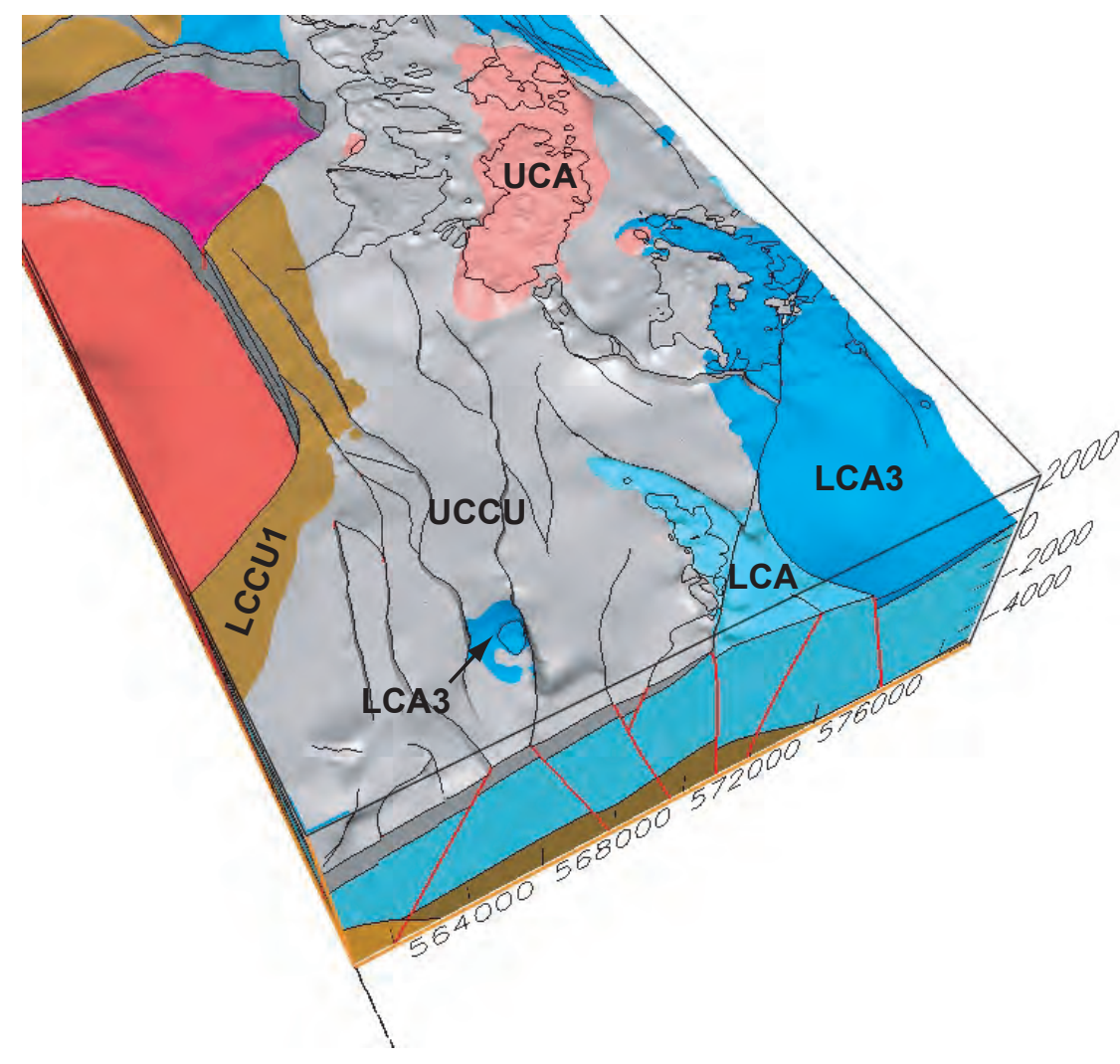

Alternative Model

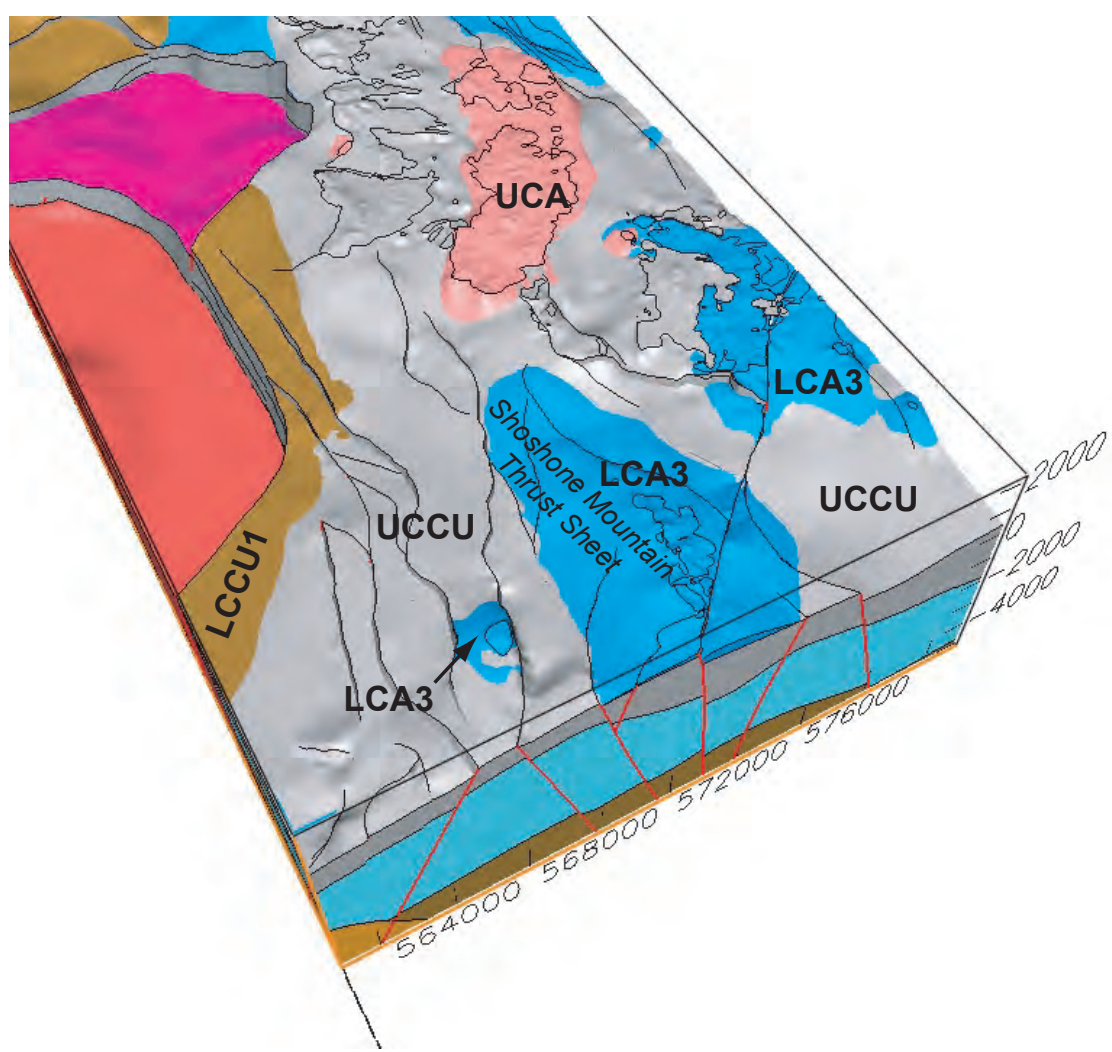

Figure 5-3

Comparison of the Base Model with the Shoshone Mountain Thrust Sheet Alternative (Perspective views of the southern portion of the model area with alluvium and volcanic rocks removed) 


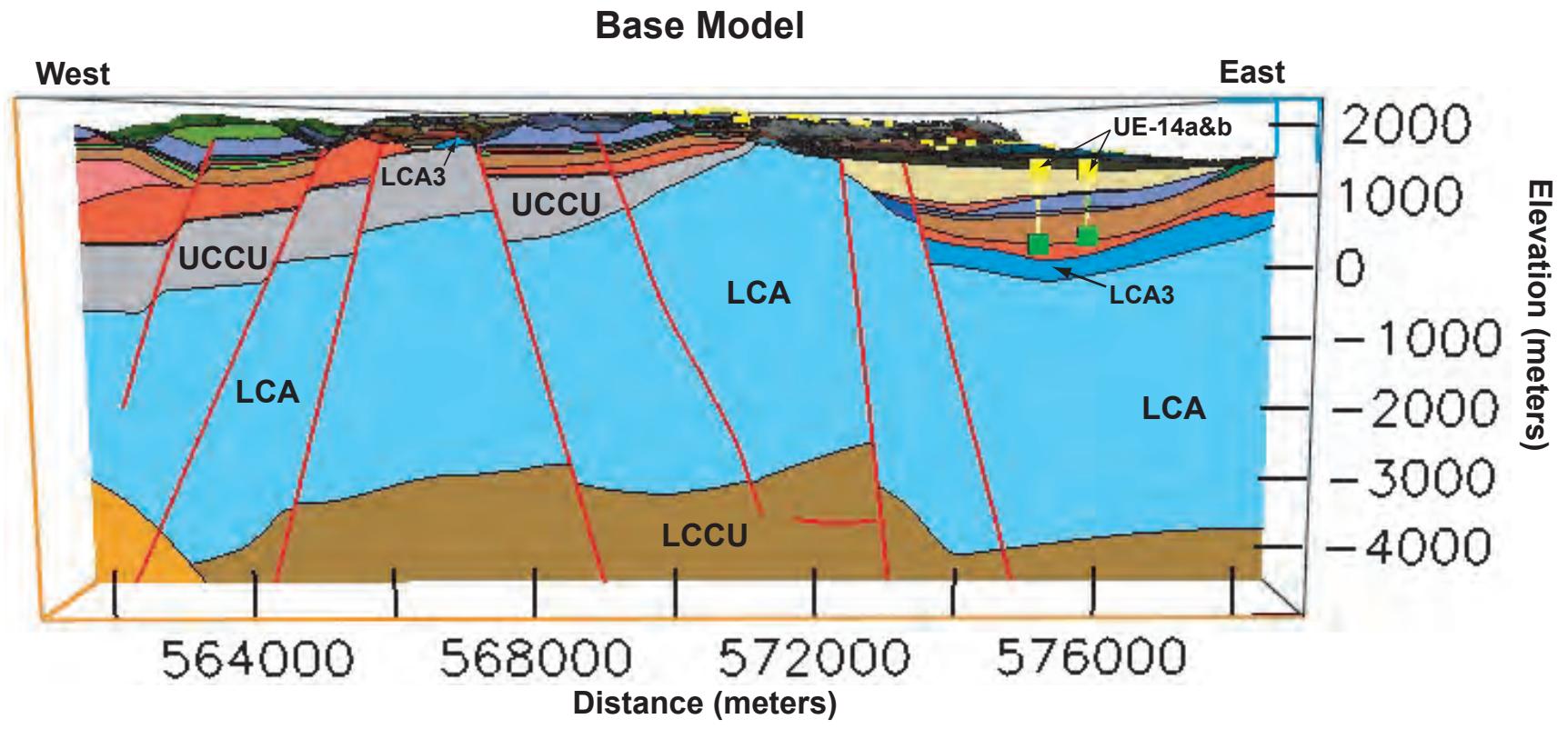

\section{Alternative Model}

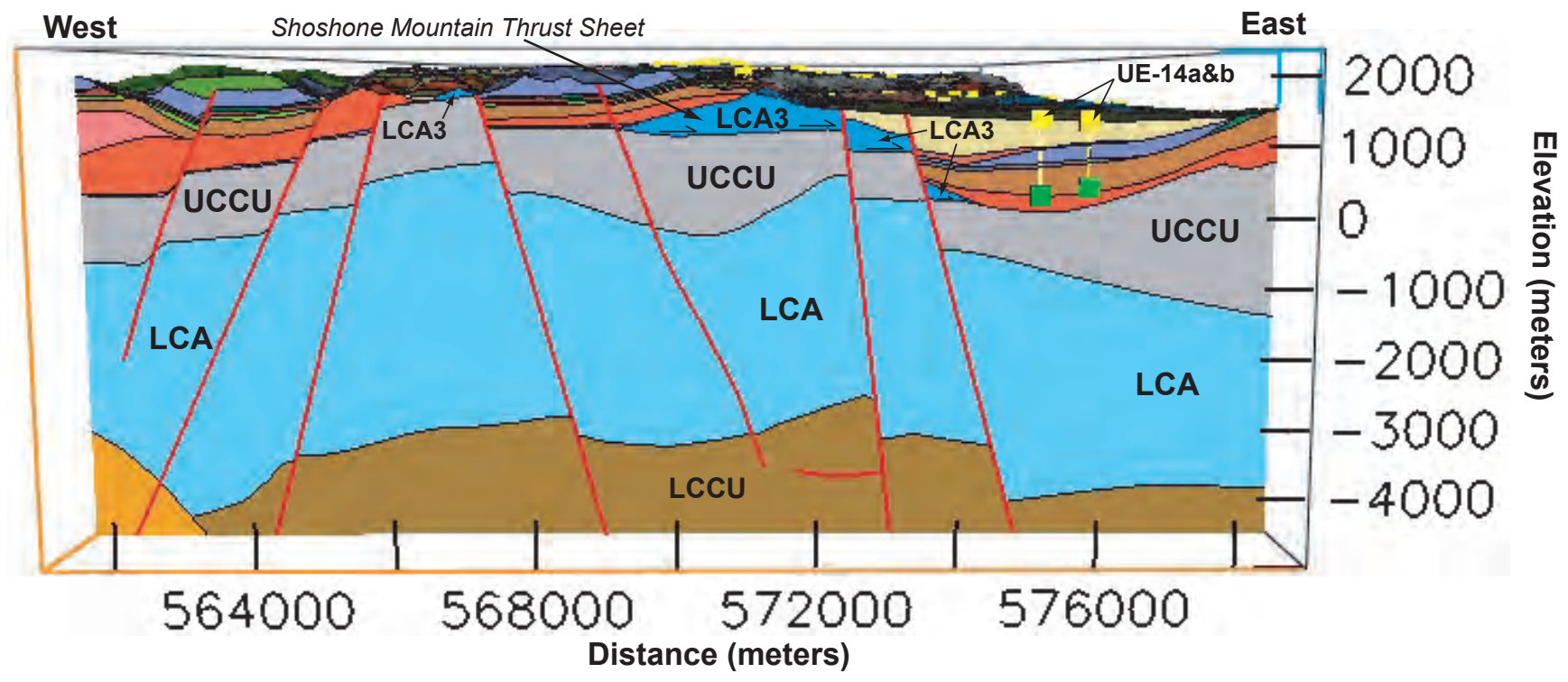

Figure 5-4

West - East Profiles Through the Base Model and the Shoshone Mountain Thrust Sheet Alternative 


\section{Base Model}

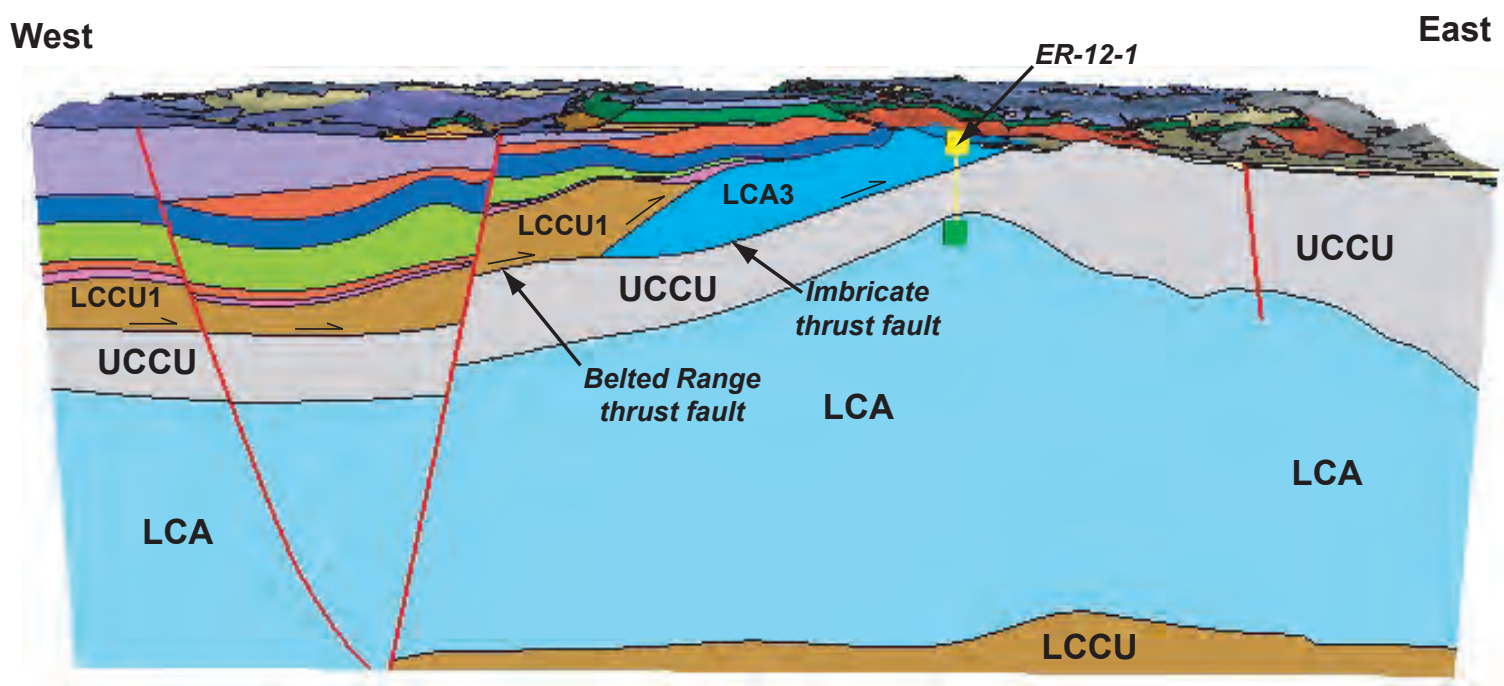

Alternative Model

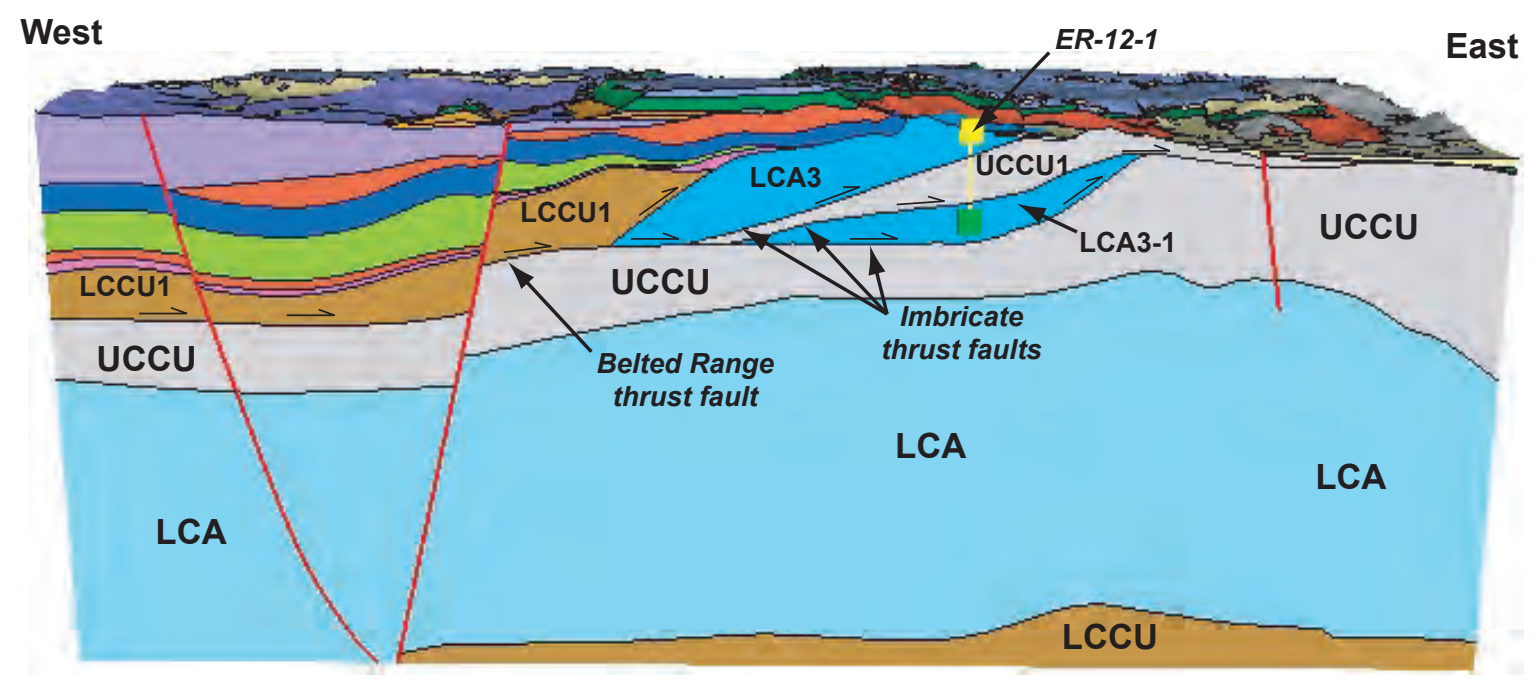

Figure 5-5

West-East Profiles Through the Base Model and the LCA3 at Bottom of ER-12-1 Alternative 


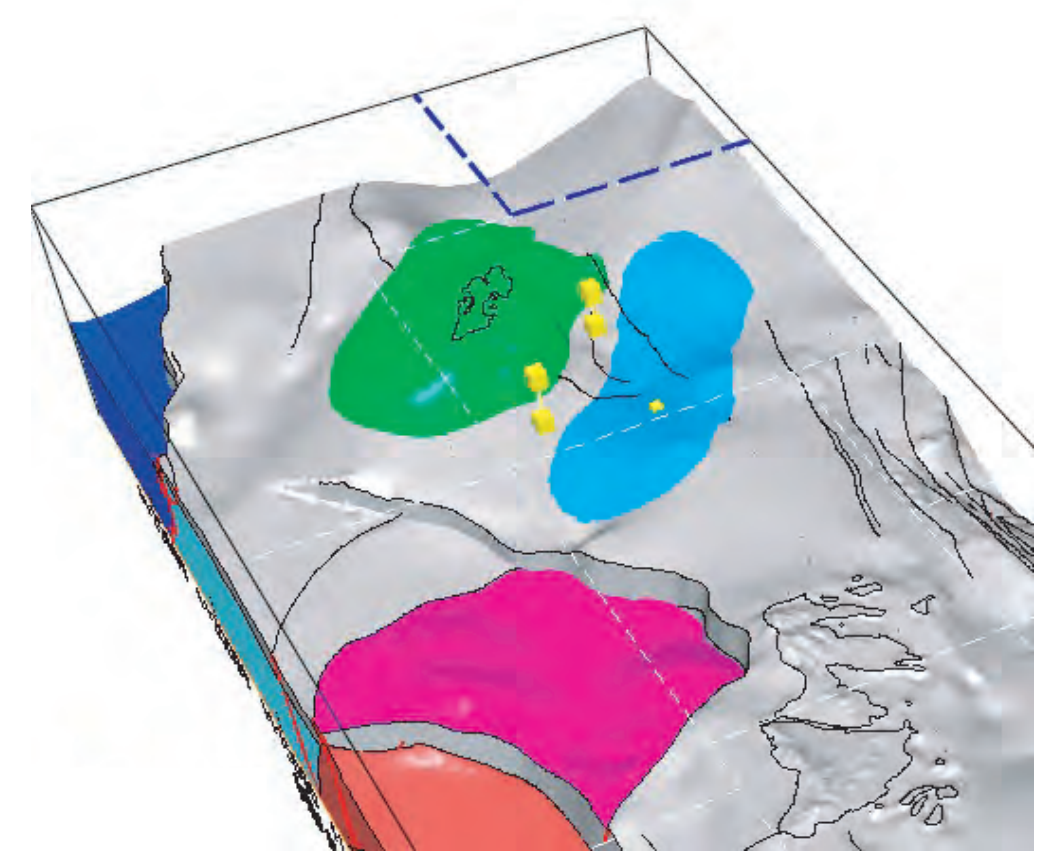

LCA3-1 Extent

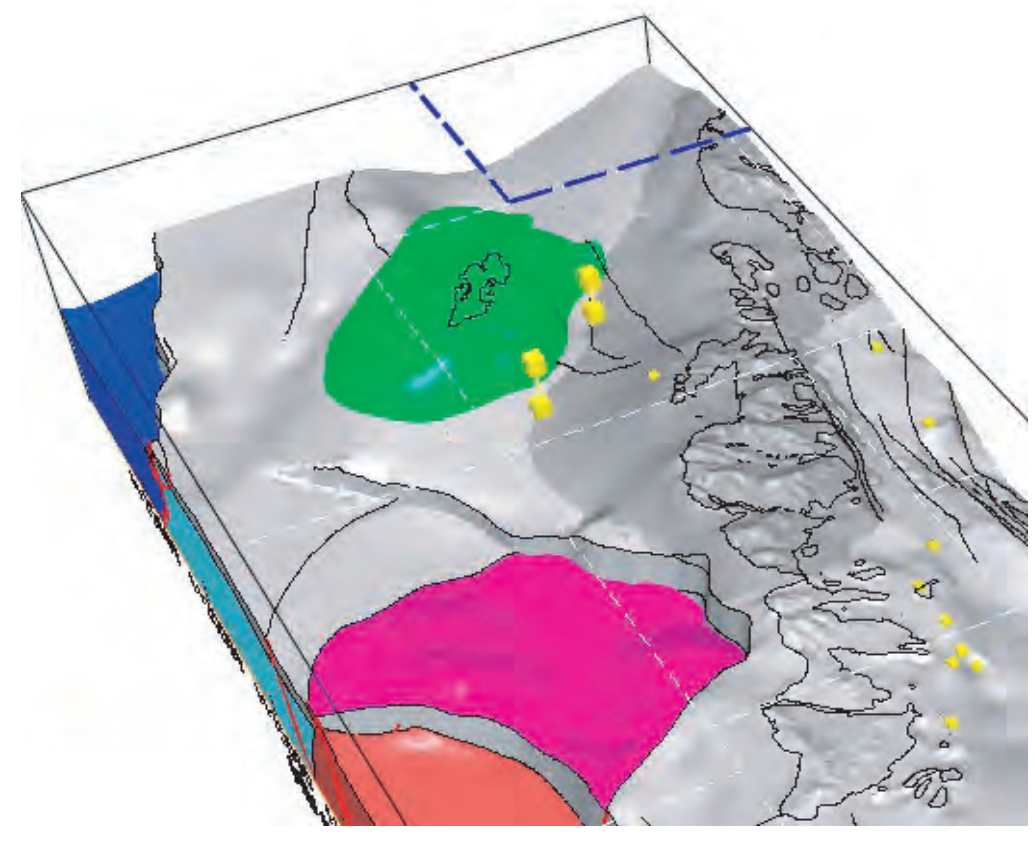

UCCU1 Extent

Figure 5-6

Block Model Views Showing Lateral Extents of the LCA3-1 and UCCU1

in the LCA3 at Bottom of ER-12-1 Alternative 


\subsection{SUMMARY}

The former testing areas at Rainier Mesa, Aqueduct Mesa (together referred to as "Rainier Mesa"), and Shoshone Mountain (collectively, CAU 99; Figure 1-1) were the site of 67 underground nuclear tests. Many of the tests on Rainier Mesa were conducted below a perched water table and all were conducted above the regional water table. At this point, there are questions regarding the availability of test-related contaminants for transport via the groundwater flow systems. Models are being developed by the UGTA sub-project of the NNSA/NSO Environmental Restoration Project to predict groundwater flow and contaminant transport from the source areas to groundwater discharge areas. The CAU models require a hydrostratigraphic framework that addresses the character and extent of geologic units in three dimensions. The development and description of this framework for the RM-SM area is documented in this report.

The general hydrogeologic framework for the NTS and vicinity established by USGS geoscientists in the early 1970s, has provided the foundation for most subsequent hydrogeologic studies at the NTS, including the RM-SM hydrostratigraphic model. The hydrostratigraphic framework for the RM-SM area documented in this report is a product of many field and analytical studies conducted over several years, supported by the UGTA project, in which the hydrogeologic understanding of the model area has become increasingly detailed and refined as a result of the contributions of many people and organizations associated with the NTS.

The hydrogeology of the NTS, including the RM-SM model area, is complex. The thick sections of volcanic rocks comprise a wide variety of lithologies that can range in hydraulic character from aquifer to aquitard. Mesozoic contractual tectonism has reshuffled portions of the regional confining and aquifer units. Basin-and-range faulting has acted to further complicate the area, placing the various lithologic units in juxtaposition, and blocking or enhancing the flow of groundwater in a variety of ways.

In this study, earlier hydrogeologic framework models were integrated with drill-hole data (stratigraphic, lithologic, and alteration data), data from several geophysical, geological, and hydrological studies, and a conceptual structural model to formulate a hydrostratigraphic classification system. Applying this updated understanding of RM-SM area hydrogeology, the authors organized the geologic units in the study area into 43 HSUs. The model incorporates 
35 Tertiary-age volcanic HSUs, including 16 aquifers, 12 confining units, 2 composite units, and 5 intrusive confining units. Other units include an alluvial aquifer and a Mesozoic-age granitic confining unit. The underlying pre-Tertiary rocks were divided into six HSUs, including three aquifers and three confining units.

The drill-hole database was then converted to a hydrostratigraphic database based on this hydrostratigraphic classification system and, along with geologic data from tunnel mapping and an enhanced conceptual structural model, provided the basis to construct cross sections and unitextent maps for each HSU. Three-dimensional surfaces were derived from these maps using the EarthVision ${ }^{\circledR}$ modeling software. The 3-D volumes defined by these surfaces will serve as inputs for the UGTA groundwater modeling process.

To construct this model, the raw data compiled by NSTec (and predecessor contractor BN) geologists, and interpretive products prepared by NSTec geologists (fault framework, cross sections, unit-extent maps, etc.) were input into EarthVision ${ }^{\circledR}$. Personnel of SNJV who are knowledgeable in the use of EarthVision ${ }^{\circledR}$ were responsible for building the digital 3-D model. The resultant model was reviewed and corrected as necessary by the authors, in an iterative fashion, to resolve structural problems that tend to develop as a result of sparse data and the computerized model-building process. The maps and cross sections provided in this document are selected presentations from the digital model and are meant only to generally illustrate the character of the HSUs (model layers). This framework will be transmitted electronically in the form of an EarthVision ${ }^{\circledR}$ model that is directly usable by the hydrologic and transport modelers.

The geologic complexity of the model area and sparse data for much of the region resulted in the incorporation of some non-unique interpretations into the base model. This made it necessary to address alternative interpretations for some of the major features in the model. Four of these alternatives were developed so they could be modeled in the same fashion as the base model, and can be used to assess the impacts of the alternative interpretations. 


\subsection{REFERENCES}

Allen, B. M., 1995. Preliminary Geologic Site Characterization of the LYNER Horizontal Drift Complex, Yucca Flat, NTS. Raytheon Services Nevada Report TSP:DGP:080:95, prepared for U.S. Department of Energy Nevada Operations Office, Las Vegas, NV.

Allen, B. A., S. L. Drellack, and M. J. Townsend, 1997. Surface Effects of Underground Nuclear Explosions. DOE/NV/11718--122. Bechtel Nevada, Las Vegas, NV.

App, F. N., 1981. "Progress in Seismic Exploration at Los Alamos." In: Jones, E., ed., Proceedings, Monterey Containment Symposium. Los Alamos National Laboratory. LA-9211-C, p. 37. Los Alamos, NM.

App, F. N., and N. Marusak, 1997. Tuff Pile I - A Justification for the Projection of Material Properties within a Portion of Los Alamos Test Areas 1, 3, 4, and 7, Nevada Test Site. LA-UR-97-1024. Los Alamos National Laboratory, Los Alamos, NM.

Asch, T. H., U.S. Geological Survey, 2005a. Written communication: Email dated July 29, 2005. Subject: "Preliminary 2-D Modeling Results for Rainier Mesa MT." Denver, CO.

Asch, T. H, U.S. Geological Survey, 2005b. Written communication: Email dated October 3, 2005. Subject: "Rainier Mesa MT Models." Denver, CO.

Asch, T. H., B. D. Rodriguez, J. A. Sampson, J. M. Williams, and M. Deszcz-Pan, 2006. Deep Resistivity Structure of Rainier Mesa - Shoshone Mountain, Nevada Test Site, Nevada. U.S. Geological Survey Open File Report 2006-1356, 49 pp.

Barnes, H., 1962. Stratigraphic Interpretation of Rocks Penetrated by UE15d Drill Hole. U.S. Geological Survey Technical Letter Yucca 1, Supplement 5, 8 pp. Denver, CO.

Barnes, H., F. N. Houser, and F. G. Poole, 1963. "Geologic Map of the Oak Spring Quadrangle, Nye County, Nevada.” U.S. Geological Survey Map GQ-214, scale 1:24,000. Washington, D.C.

Barnes, H., F. N. Houser, and F. G. Poole, 1968. Regional Thrust Fault System in Nevada Test Site and Vicinity. In: Eckel, E. B., ed., Nevada Test Site. Memoir 110, pp. 233-238. The Geological Society of America, Inc. Boulder, CO.

Bath, G. D., C. E. Jahren, J. G. Rosenbaum, and M. J. Baldwin, 1983. "Magnetic Investigations." In: Geologic and Geophysical Investigations of Climax Stock Intrusive, Nevada. U.S. Geological Survey Open-File Report 83-377, pp. 40-57. Denver, CO.

Bechtel Nevada, 2002a. A Hydrostratigraphic Model and Alternatives for the Groundwater Flow and Contaminant Transport Model of Corrective Action Units 101 and 102: Central and Western Pahute Mesa, Nye County, Nevada. DOE/NV/11718--706. Las Vegas, NV. 
Bechtel Nevada, 2002b. Nevada Test Site Orthophoto Site Atlas. DOE/NV/11718--604. Las Vegas, NV.

Bechtel Nevada, 2005. A Hydrostratigraphic Model and Alternatives for the Groundwater Flow and Contaminant Transport Model of Corrective Action Unit 98: Frenchman Flat, Clark, Lincoln, and Nye County, Nevada. DOE/NV/11718--1064. Las Vegas, NV.

Bechtel Nevada, 2006. A Hydrostratigraphic Model and Alternatives for the Groundwater Flow and Contaminant Transport Model of Corrective Action Unit 97: Yucca Flat-Climax Mine, Lincoln and Nye Counties, Nevada. DOE/NV/11718--1119. Las Vegas, NV.

Belcher, W. R., ed., 2004. Death Valley Regional Ground-Water Flow System, Nevada and California - Hydrogeologic Framework and Transient Ground-Water Flow Model. U.S. Geological Survey Scientific Investigations Report 2004-5205, 408 pp.

Blankennagel, R. K., and J. E. Weir, Jr., 1973. Geohydrology of the Eastern Part of Pahute Mesa, Nevada Test Site, Nye County, Nevada. U.S. Geological Survey Professional Paper 712-B, 35 pp. Washington, D.C.

BN, see Bechtel Nevada.

Burkhard, N. R., 1981. "NTS Seismic Reflection Data and the Problems Thereof." In: Proceedings, Monterey Containment Symposium, Monterey, California, August 26-28, 1981. LA-9211-C, v. 1, pp. 339-341. Los Alamos National Laboratory, Los Alamos, NM.

Burkhard, N. R., and R. D. McArthur, 1985. "Geologic and Geophysical Investigations of Mid Valley at the NTS." In: Olsen, C. W., ed., Proceedings, Third Symposium on the Containment of Underground Nuclear Explosions. Lawrence Livermore National Laboratory, CONF-850953, v. 2, pp. 72-84.

Byers, F. M., Jr., and W. L. Hawkins, 1981. Geology of Drill Hole UE18t and Area 18, Timber Mountain Caldera Moat, Nevada Test Site (with a section on Geophysical Logging by D. C. Muller). U.S. Geological Survey Open-File Report USGS-4474-31. Denver, CO.

Byers, F. M., Jr., W. J. Carr, and P. P. Orkild, 1989. "Volcanic Centers of Southwestern Nevada: Evolution of Understanding, 1960-1988." Journal of Geophysical Research, v. 94, n. 5, pp. 5,908-5,924.

Byers, F. M., Jr., W. J. Carr, P. P. Orkild, W. D. Quinlivan, and K. A. Sargent, 1976. Volcanic Suites and Related Cauldrons of the Timber Mountain-Oasis Valley Caldera Complex, Southern Nevada. U.S. Geological Survey Professional Paper 919, 70 pp. Washington, D.C.

Byers, F. M., Jr., C. L. Rogers, W. J. Carr, and S. J. Luft, 1966. Geologic Map of the Buckboard Mesa Quadrangle, Nye County, Nevada. U.S. Geological Survey Geologic Quadrangle Map GQ-552, scale 1:24,000. 
Carr, W. J., F. M. Byers, Jr., and E. C. Jenkins, 1981. Geology of Drill Hole UE18r, Timber Mountain Caldera, Nevada Test Site. U.S. Geological Survey Open File Report 474-313 (previously issued as U.S. Geological Survey Technical Letter: Special Studies-69, September 20, 1968). Denver, CO.

Carroll, R. D., 1983. "Seismic Velocity and Postshot Properties in and Near Chimneys." In: Proceedings, Monterey Containment Symposium, Monterey, California, August 26-28, 1981. LA-9211-C, v. 1, pp. 379-396. Los Alamos National Laboratory, Los Alamos, NM.

Carroll, R. D., 1986. Shear-Wave Velocity Measurements in Volcanic Tuff in Rainier Mesa Tunnels, Nevada Test Site, Nevada. U.S. Geological Survey Report 474-321, 24 pp.

Carroll, R. D., 1990. Electric Logging and Electrical Properties of Rocks in Rainier Mesa Area, Nevada Test Site, Nevada. U.S. Geological Survey Open-File Report 90-31, 90 pp.

Carroll, R. D., 1994. Measurement of Seismic P- and S-Wave Attenuation in Volcanic Tuff, Rainier Mesa Tunnels, Nevada Test Site. U.S. Geological Survey Report U.S. Geological Survey Open-File Report 94-618, 55 pp.

Carroll, R. D., and J. E. Kibler, 1983. Sourcebook of Locations of Geophysical Surveys in Tunnels and Horizontal Holes Including Results of Seismic Refraction Surveys, Rainier Mesa, Aqueduct Mesa, and Area 16, Nevada Test Site. U.S. Geological Survey Open-File Report 83-399, $85 \mathrm{p}$.

Cashman, P. H., and J. H. Trexler, Jr., 1991. "The Mississippian Antler Foreland and Continental Margin in Southern Nevada: The Eleana Formation Reinterpreted." In: Cooper, J. D., and C. H. Stevens, eds., Paleozoic Paleogeography of the Western United States - II: Pacific Section SEPM, v. 67, pp. 271-280.

Cashman, P. H., J. H. Trexler, and J. C. Cole, 2001. Geology of the Pre-Tertiary Rocks in the Eleana Range, Nevada Test Site, Southern Nevada. U.S. Geological Survey Open-File Report. Denver, CO.

Caskey, S. J., 1991. Mesozoic and Cenozoic Structural Geology of the CP Hills, Nevada Test Site, Nye County, Nevada; and Regional Implications. State of Nevada Agency for Nuclear Project/Nuclear Waste Project Office. Report Number NWPO-TR-018-91.

Caskey, S. J., and R. A. Schweickert, 1992. "Mesozoic Deformation in the Nevada Test Site and Vicinity: Implications for the Structural Framework of the Cordilleran Fold and Thrust Belt and Tertiary Extension North of Las Vegas." Tectonics, v. 11, no. 6, pp. 1314-1331.

Chapman, J. B., 1994. Classification of Groundwater at the Nevada Test Site. Desert Research Institute Report 45069 (DOE/NV/10384-28).

Christiansen, R. L., P. W. Lipman, W. J. Carr, F. M. Byers, Jr., P. P. Orkild, and K. A. Sargent, 1977. Timber Mountain - Oasis Valley Caldera Complex of Southern Nevada. Geological Society of America Bulletin, No. 88, pp. 943-959. 
Claassen, H. C., 1973. Water Quality and Physical Characteristics of Nevada Test Site WaterSupply Wells. U.S. Geological Survey Open-File Report USGS-474-158 (NTS-242).

Cole, J. C., U.S. Geological Survey, 1992. Written communication to S. L. Drellack, Raytheon Services Nevada, regarding thickness of Paleozoic units at the NTS. Denver, CO.

Cole, J. C., 1997. Major Structural Controls on the Distribution of Pre-Tertiary Rocks, Nevada Test Site Vicinity, Southern Nevada. U.S. Geological Survey Open-File Report 97-533, scale 1:100,000, 19 pp. Denver, CO.

Cole, J. C., U.S. Geological Survey, 2005. Written communication. Subject: Summary of Field Notes Regarding Pre-Tertiary Stratigraphy in the Shoshone-Mountain Area. Denver, CO.

Cole, J. C., and P. H. Cashman, 1997. "Geologic Map of the Mine Mountain Area, Nevada Test Site, Southern Nevada.” U.S. Geological Survey Open-File Report 97-697, scale 1:12,000, 8 pp. Denver CO.

Cole, J. C., and P. H. Cashman, 1999. Structural Relationships of Pre-Tertiary Rocks in the Nevada Test Site Region, Southern Nevada. U.S. Geological Survey Professional Paper 1607.

Cole, J. C., A. G. Harris, and R. R. Wahl, 1997. "Subcrop Geologic Map of Pre-Tertiary Rocks in the Yucca Flat and Northern Frenchman Flat Areas, Nevada Test Site, Southern Nevada." U.S. Geological Survey Open-File Report 97-678, scale 1:48,000, 24 pp. Denver, CO.

Colton, R. B., and E. J. McKay, 1966. "Geologic Map of the Yucca Flat Quadrangle, Nye and Lincoln Counties, Nevada.” U.S. Geological Survey Geologic Quadrangle Map GQ-582, scale 1:24,000. Washington, DC.

D'Agnese, F. A., C. C. Faunt, A. K. Turner, and M. C. Hill, 1997. Hydrogeologic Evaluation and Numerical Simulations of the Death Valley Regional Groundwater Flow System, Nevada and California. USGS Professional Paper 1607. U.S. Geological Survey, Denver CO.

Davis, R. E, 1962. Preliminary Report on the Geology of the U16a Tunnel, Nevada Test Site. U.S. Geological Survey Technical Letter: Marshmallow-4.

DOE, see U.S. Department of Energy.

Drellack, S. L., Jr., and P. H. Thompson, 1990. Selected Stratigraphic Data for Drill Holes in LANL Use Areas of Yucca Flat, NTS. DOE/NV/10322--39. Fenix \& Scisson, Inc., Las Vegas, NV.

Drellack, S. L., Jr., P. H. Thompson, and C. J. Rayburn, 1989. Geology of the U-1a.01 Horizontal Drift Complex, Southwestern Yucca Flat, Nevada Test Site. Fenix \& Scisson of Nevada Geologic Report DOE/NV/10322-37, 69 p. Las Vegas, NV.

Drellack, S. L., Jr., L. B. Prothro, K. E. Roberson, B. A. Schier, and E. H. Price, 1997. Analysis of Fractures in Volcanic Cores from Pahute Mesa, Nevada Test Site. DOE/NV/11718--160. Prepared by Bechtel Nevada, Las Vegas, NV. 
Fairer, G. M., D. R. Townsend, R. D. Carroll, M. J. Cunningham, D. C. Muller, D. L. Healey, and W. L. Ellis, 1979. U.S. Geological Survey Investigations in Connection with the MIGHTY EPIC Event, U12n.10 Tunnel, Nevada Test Site. U.S. Geological Survey Open-File Report USGS-474-228 (Area 12-44).

Faunt, C. C., 1998. Effects of Faulting on Groundwater Movement in the Death Valley Region, Nevada and California. U.S. Geological Survey Water Resources Investigations Report 95-4132. Denver, CO.

Faunt, C. C., W. R. Belcher, and F. A. D’Agnese, 1999. “Using Geologic Data for a ThreeDimensional Hydrogeologic Framework Model of the Death Valley Region." In: Slate, J. L., ed., Proceedings of Conference on Status of Geological Research and Mapping in Death Valley National Park, Las Vegas, NV, April 9-11, 1999. U.S. Geological Survey Open File Report OFR-99-153, pp. 59-60.

Federal Facility Agreement and Consent Order, 1996 as amended. Agreed to by the U.S. Department of Energy, the U.S. Department of Defense, and the state of Nevada. Las Vegas, NV.

Fenelon, J. M., 2005. Analysis of Ground-Water Levels and Associated Trends in Yucca Flat, Nevada Test Site, Nye County, Nevada, 1951-2003. U.S. Geological Survey Scientific Investigations Report 2005-5171. Denver, CO.

Ferguson, J. F., A. H. Cogbill, and R. G. Warren, 1994. "A Geophysical-Geological Transect of the Silent Canyon Caldera Complex, Pahute Mesa, Nevada.” Journal of Geophysical Research, v. 99, n. 33, pp. 4323-4339.

Fernald, A. T., F. M. Byers, and J. P. Ohl, 1975. Lithologic Logs and Stratigraphic Units of Drill Holes and Mined Shafts in Areas 1 and 6, Nevada Test Site. U.S. Geological Survey OpenFile Report 474-206, 61 pp. Denver, CO.

Fernald, A. T., G. S. Corchary, and W. P. Williams, 1968. "Surficial Geologic Map of Yucca Flat, Nye and Lincoln Counties, Nevada." U.S. Geological Survey Miscellaneous Investigations Map I-550, scale 1:48,000. Washington, D.C.

Fridrich, C. J., S. A. Minor, P. L. Ryder, and J. L. Slate, 1999. Geologic Map of the Oasis Valley Basin and Vicinity, Nye County, Nevada. U.S. Geological Survey Open-File Report 99-533B, scale 1:62,500.

FFACO, see Federal Facility Agreement and Consent Order.

Gibbons, A. B., E. N. Hinrichs, W. R. Hansen, and R. W. Lemke, 1963. "Geologic Map of the Rainier Mesa Quadrangle, Nye County, Nevada.” U.S. Geological Survey Map GQ-215, scale 1:24,000. Washington, D.C.

Gillespie, D., J. D. Donithon, and P. R. Seaber, 1996. NTS Water-Supply Wells.

DOE/NV/10845-56 (DRI Publication No. 45138). Desert Research Institute, Las Vegas, NV. 
Gonzales, J. L., and S. L. Drellack, 1999. Written communication. Subject: Addendum to the Descriptive Narrative for the Hydrogeologic Model of the Yucca Flat CAU: Northern Extension. Prepared for the U.S. Department of Energy by Bechtel Nevada, Las Vegas, NV.

Gonzales, J. L., S. L. Drellack, and M. J. Townsend, 1998. Written communication. Subject: Descriptive Narrative for the Hydrogeologic Model at the Yucca Flat Corrective Area Unit. An interim report. Bechtel Nevada, Las Vegas NV.

Grasso, D. N., 2001. GIS Surface Effects Archive of Underground Nuclear Detonations Conducted at Yucca Flat and Pahute Mesa, Nevada Test Site, Nevada. U.S. Geological Survey Open-File Report OFR-2001-272.

Grasso, D. N., 2003. Geologic Surface Effects of Underground Nuclear Testing, Buckboard Mesa, Climax Stock, Dome Mountain, Frenchman Flat, Rainier/Aqueduct Mesa, and Shoshone Mountain, NTS, Nevada. U.S. Geological Survey Open-File Report OFR-2003-125.

Grauch, V. J. S., D. A. Sawyer, C. J. Fridrich, and M. R. Hudson, 1997. Geophysical Interpretations West of and Within the Northwestern Part of the Nevada Test Site. U.S. Geological Survey Open-File Report 97-476. Denver, CO.

Hansen, D. J., P. D. Greger, C. A. Wills, and W. K. Ostler, 1997. Nevada Test Site Wetlands Assessment. DOE/NV/11718--124. Prepared for the U.S. Department of Energy by Bechtel Nevada, Las Vegas, NV.

Harrill, J. R., J. S. Gates, and J. M. Thomas, 1988. Major Groundwater Flow Systems in the Great Basin Region of Nevada, Utah and Adjacent States. Hydrological Investigation Atlas HA-694-C, scale 1:1,000,000. U.S. Geological Survey, Denver, CO.

Hasler, J. W., 1963. Interim Geological Investigations in the U12e.07 Tunnel, Nevada Test Site, Nye County, Nevada. U.S. Geological Survey Trace Element Investigation Report, TEI-834.

Hawkins, W. L., D. A. Trudeau, and T. M. Mihevc, 1989. "Hydrologic Testing in Exploratory Drill Hole UE4t, Yucca Flat, the Nevada Test Site.” In: Olsen, C. W., and J. A. Carter, eds., Proceedings, Fifth Symposium on Containment of Underground Nuclear Explosions, Santa Barbara, California, September 19-22, 1989. Lawrence Livermore National Laboratory, CONF-8909163, v. 2, pp. 141-159. Livermore, CA.

Healey, D. L., 1968. Application of Gravity Data to Geologic Problems at Nevada Test Site. In: Eckel, E. B., ed., Nevada Test Site. Memoir 110, pp. 147-156. The Geological Society of America, Inc. Boulder, CO.

Healey, D. L., R. N. Harris, D. A. Ponce, and H. W. Oliver, 1987. Complete Bouguer Gravity Map of the Nevada Test Site and Vicinity, Nevada. U.S. Geological Survey Open-File Report 87-506. Denver, CO. 
Hildenbrand, T. G., G. A. Phelps, and E. A. Mankinen, 2006. Inversion of Gravity Data to Define the Pre-Cenozoic Surface and Regional Structures Possibly Influencing Groundwater Flow in the Rainier Mesa Region, Nye County, Nevada. U.S. Geological Survey Open-File Report 2006-1299, 28 pp.

Hinrichs, E. N., R. D. Krushensky, and S. J. Luft, 1967. Geologic Map of the Ammonia Tanks Quadrangle, Nye County, Nevada. U.S. Geological Survey Geologic Quadrangle Map GQ-638, scale 1:24,000.

Hoover, D. B., W. F. Hanna, L. A. Anderson, V. J. Flanigan, and L. W. Pankratz, 1982. Geophysical Studies of the Syncline Ridge Area, Nevada Test Site, Nye County, Nevada. U.S. Geological Survey Open-File Report 82-145. Denver, CO

Hoover, D. L., WC Swadley, and A. J. Gordon, 1981. Correlation Characteristics of Surficial Deposits with a Description of Surficial Stratigraphy in the Nevada Test Site Region. U.S. Geological Survey Open-File Report 81-512. Denver, CO.

Houser, F. N., and F. G. Poole, 1960. "Preliminary Geologic Map of the Climax Stock and Vicinity, Nye County, Nevada.” U.S. Geological Survey Map I-328, scale 1:4,800. Washington, D,C.

Houser, F. N., R. E. Davis, and W. L. Emerick, 1961. Geologic Reconnaissance of Granitic Intrusive Masses at Gold Meadows, Tem Piute, and Trappman's Camp, Lincoln and Nye Counties, Nevada, and Comparison with the Climax Stock at the Nevada Test Site. U.S. Geological Survey Professional Paper TEI-793, 20 pp. Washington, D.C.

IT, see IT Corporation.

IT Corporation, 1996a. Regional Geologic Model Data Documentation Package (Phase I, Data Analysis Documentation, Volume I, Parts 1 and 2). ITLV/10972--181. Las Vegas, NV.

IT Corporation, 1996b. Potentiometric Data Task Documentation Package (Phase I, Data Analysis Documentation, Volume II). ITLV/10972--181. Las Vegas, NV.

IT Corporation, 1996c. Hydrologic Parameters Data Documentation Package (Phase I, Data Analysis Documentation, Volume IV). ITLV/10972--181. Las Vegas, NV.

IT Corporation, 1996d. Groundwater Flow Model Documentation Package (Phase 1, Data Analysis Documentation, Volume VI). ITLV/10972--181. Las Vegas, NV.

Jachens, R. C., U.S. Geological Survey, 1999. Written communication to S. L. Drellack, Bechtel Nevada, concerning the inferred subsurface distribution of Cretaceous granitic bodies along the north edge of Yucca Flat, Nevada Test Site. Menlo Park, CA.

Jachens, R. C., and B. C. Moring, 1990. Maps of Cenozoic Deposits and the Isostatic Residual Gravity Over Basement for Nevada. U.S. Geological Survey Open File Report 90-404, 15 p. 
Kirchoff-Stein, K. S., D. A. Ponce, and B. A. Chuchel, 1989. "Preliminary Aeromagnetic Map of the Nevada Test Site and Vicinity, Nevada." U.S. Geological Survey Open-File Report 89-446. Denver, CO.

Laczniak, R. J., J. C. Cole, D. A. Sawyer, and D. A. Trudeau, 1996. Summary of Hydrogeologic Controls on the Ground-water Flow at the Nevada Test Site, Nye County, Nevada.

U.S. Geological Survey Water-Resources Investigation Report 96-4109. Carson City, NV.

Lipman, P. W., 2000. Calderas. In: Haraldur, Sigurdsson, B. F. Houghton, S. R. McNutt, H. Rymer, and J. Stix, eds., Encyclopedia of Volcanoes, pp. 643-662. Academic Press, San Diego, CA.

Maldonado, F., 1977. Summary of the Geology and Physical Properties of the Climax Stock, Nevada Test Site. U.S. Geological Survey Open-File Report 77-356, 25 pp. Denver, CO.

Maldonado, F., D. C. Muller, and J. N. Morrison, 1979. Preliminary Geologic and Geophysical Data of the UE25a-3 Exploratory Drill Hole, Nevada Test Site, Nevada. U.S. Geological Survey Open-File Report USGS-1543-6.

Maldonado, F., S. G. Steel, and D. R. Townsend., 1979. Supplementary Lithologic Logs of Selected Vertical Drill Holes in Area 12, Nevada Test Site. U.S. Geological Survey Report USGS-474-261, 61 pp. Denver, CO.

Mankinen, E. A., T. G. Hildenbrand, G. L. Dixon, E. H. McKee, C. J. Fridrich, and R. J. Laczniak, 1999. Gravity and Magnetic Study of the Pahute Mesa and Oasis Valley Region, Nye County, Nevada. U.S. Geological Survey Open-File Report 99-303. Menlo Park, CA.

Maxey, G. B., 1974. Hydrostratigraphic Units. Journal of Hydrology, v. 2, pp. 124-129.

McArthur, R. D., and N. R. Burkhard, 1986. Geological and Geophysical Investigations of Mid Valley. Lawrence Livermore National Laboratory Report: UCID-20740, 91 pp.

McCafferty, A. E., and V. J. S. Grauch, 1997. Aeromagnetic and Gravity Anomaly Maps of the Southwestern Nevada Volcanic Field, Nevada and California. U.S. Geological Survey Geophysical Investigation Map GP-1015, scale 1:250,000.

McKeown, F. A., D. L. Healey, and C. H. Miller, 1976. “Geologic Map of the Yucca Lake Quadrangle, Nye County, Nevada.” U.S. Geological Survey, GQ-1327, scale 1:24,000. Washington, D.C.

Miller, D. R., 1970. Lithologic Logs and Stratigraphic Identification for Vertical Drill Holes in Area 12, Nevada Test Site. U.S. Geological Survey Administrative Report Area 12-27, 34 pp. Denver, CO.

Naeser, C. W., and F. Maldonado, 1981. Fission-Track Dating of the Climax and Gold Meadows Stocks, Nye County, Nevada. In: Short Contributions to Geochronology: U.S. Geological Survey Professional Paper 1199E, pp. 45-47. 
Nevada Bureau of Mines and Geology, 1996. County Digital Geologic Mapping Project- Final Report. Open-File Report 97-1, scale 1:250,000.

Noble, D. C., R. D. Krushensky, E. J. McKay, and J. R. Ege, 1967. “Geologic Map of the Dead Horse Flat Quadrangle, Nye County, Nevada.” U.S. Geological Survey Geologic Quadrangle Map GQ-614, scale 1:24,000.

Orkild, P. P., 1963. "Geologic Map of the Tippipah Spring Quadrangle, Nye County, Nevada." U.S. Geological Survey, Quadrangle Map GQ-213, scale 1:24,000. Washington, D.C.

Orkild, P. P., 1968. "Geologic Map of the Mine Mountain Quadrangle, Nye County, Nevada." U.S. Geological Survey, Quadrangle Map GQ-746, scale 1:24,000. Washington, D.C.

Orkild, P. P., 1983. "Geology of the Nevada Test Site." In: Proceedings, Monterey Containment Symposium, Monterey, California, August 26-28, 1981. LA-9211-C, v. 1, pp. 323-337. Los Alamos National Laboratory, Los Alamos, NM.

Orkild, P. P., and J. T. O’Connor, 1970. “Geologic Map of the Topopah Spring Quadrangle, Nye County, Nevada.” U.S. Geological Survey Geologic Quadrangle Map GQ-849, scale $1: 24,000$.

Orkild, P. P., M. J. Baldwin, and D. R. Townsend, 1983. “Geologic Investigations.” In: Geologic and Geophysical Investigations of Climax Stock Intrusive, Nevada. U.S. Geological Survey Open-File Report 83-377, pp. 1-24. Denver, CO.

Orkild, P. P., K. A. Sargent, and R. P. Snyder, 1969. "Geologic Map of Pahute Mesa, Nevada Test Site and Vicinity, Nye County, Nevada." U.S. Geological Survey Miscellaneous Geologic Investigations Series Map I-567, scale 1:48,000.

Pawloski, G. A., A. F. B. Tompson, C. J. Bruton, and M. Zavarin, eds., 2000. Evaluation of the Hydrologic Source Term from Underground Nuclear Tests in Frenchman Flat and the Nevada Test Site. Contributors: W. L. Bourcier, C. J. Bruton, S. F., Carle, B. K. Esser, A .B. Kersting, R. M. Maxwell, G. A. Pawloski, J. A. Rard, D. E. Shumaker, D. K. Smith, A. F. B. Tompson, and M. Zavarin. UCRL-ID-138007. Lawrence Livermore National Laboratory, Livermore, CA.

Phelps, G. A., R. C. Jachens, B. C. Moring, and C. W. Roberts, 2004. Modeling of the Climax Stock and Related Plutons Based on the Inversion of Magnetic Data, Southwest Nevada. U.S. Geological Survey Open-File Report OFR-2004-1345.

Ponce, D. A., 1999. Digital Aeromagnetic Map of the Nevada Test Site Area, Nye, Lincoln, and Clark Counties, Nevada and Inyo County, California. U.S. Geological Survey Open-File Report 99-55413, CD-ROM, scale 1:100,000.

Ponce, D. A., R. N. Harris, and H. W. Oliver, 1988. Isostatic Gravity Map of the Nevada Test Site and Vicinity, Nevada. U.S. Geological Survey Open-File Report 88-664. Denver, CO. 
Ponce, D. A., E. A. Mankinen, J. G. Davidson, R. L. Morin, and R. J. Blakely, 1999. Digital Isostatic Gravity Map of the Nevada Test Site Area, Nye, Lincoln, Clark Counties, Nevada and Inyo County, California. U.S. Geological Survey Open-File Report 99-554c, CD-ROM, scale 1:100,000.

Poole, F. G., F. N. Houser, and P. P. Orkild, 1961. Eleana Formation of Nevada Test Site and Vicinity, Nye County, Nevada. U.S. Geological Survey Professional Paper 424-D, pp. D-104 to D-111.

Prothro, L. B., 1998. Written communication. Subject: Analysis of Fractures in Cores from the Tuff Confining Unit beneath Yucca Flat, Nevada Test Site. Prepared for U.S. Department of Energy National Nuclear Security Administration Nevada Site Office by Bechtel Nevada, Las Vegas, NV.

Prothro, L. B., 2005. Mineralogic Zonation Within the Tuff Confining Unit, Yucca Flat, Nevada Test Site. DOE/NV/11718--995. Bechtel Nevada, Las Vegas, NV.

Prothro, L. B., 2006. Extensional Basin Formation and Tilt-Domain Reversal Associated with Reactivation of a Thrust Ramp, Yucca Flat, Nye County, Nevada. Geological Society of America Abstracts with Programs, vol. 37, no. 7, p. 211.

Prothro, L. B., and S. L. Drellack, Jr., 1997. Nature and Extent of Lava-Flow Aquifers Beneath Pahute Mesa, Nevada Test Site. Prepared for U.S. Department of Energy, National Nuclear Security Administration Nevada Site Office by Bechtel Nevada, Las Vegas, NV.

Rayburn, C. J., S. L. Drellack, Jr., and P. H. Thompson, 1989. "Occurrence, Distribution, and Measurement of Carbonate in the Alluvium of Southern Yucca Flat, Nevada Test Site.” In: Olsen, C. W., and J. A. Carter, eds., Proceedings, Fifth Symposium on the Containment of Underground Nuclear Explosions, Santa Barbara, California, September 19-22, 1989. Lawrence Livermore National Laboratory, CONF-8909163, v. 2, pp. 186-205.

Raytheon Services Nevada, 1990. "Nevada Test Site Drilling and Mining Summary." Available from Bechtel Nevada, Mercury, NV.

Reiner, S. R., 2002. Aquifer-Test Report of WW-4A, Area 6, Nevada Test Site. U.S. Geological Survey, Carson City, NV.

Reiner, S. R., G. L. Locke, and L. S. Robie. 1995. Ground-Water Data for the Nevada Test Site and Selected Other Areas in South-Central Nevada 1992-1993. U.S. Geological Survey Open-File Report 95-160.

Rogers, C. L., and D. C. Noble, 1969. "Geologic Map of the Oak Spring Butte Quadrangle, Nye County, Nevada." U.S. Geological Survey Map GQ-822, scale 1:24,000. Washington, D.C.

Rogers, A. M., G. M. Woulett, and P. A. Covington, 1977. Seismicity of the Pahute Mesa Area, Nevada Test Site, 8 October 1975 to 30 June 1976. U.S. Geological Survey Open-File Report USGS-474-184. 
Rogers, A. M., S. C. Harmsen, E. J. Corbett, K. Priestley, and D. dePolo, 1991. "The Seismicity of Nevada and Some Adjacent parts of the Great Basin.” In: Slemmons, D. B., E. R. Engdahl, M. D. Zoback, and D. D. Blackwell, eds., Neotectonics of North America. Geological Society of America, Decade Map Volume 1, pp. 153- 84. Boulder, CO.

Russell, C. E., D. Gillespie, J. C. Cole, S. L. Drellack, L. B. Prothro, P. H. Thompson, R. L. McCall, G. A. Pawloski, and R. Carlson, 1996. Completion Report for Well ER-12-1. DOE/NV/10845-36. Prepared for U.S. Department of Energy Nevada Operations Office, Las Vegas, NV.

Sargent, K. A., S. J. Luft, A. B. Gibbons, and D. L. Hoover, 1966. “Geologic Map of the Quartet Dome Quadrangle, Nye County, Nevada.” U.S. Geological Survey Map GQ-496, scale 1:24,000. Washington, D.C.

Sargent, K. A., and P. P. Orkild, 1973. "Geologic Map of the Wheelbarrow Peak-Rainier Mesa Area, Nye County, Nevada." U.S. Geological Survey Miscellaneous Geologic Investigations Map 1-754, scale 1:48,000. Washington, D.C.

Sawyer, D. A., and K. A. Sargent, 1989. Petrographic Evolution of Divergent Peralkaline Magmas from the Silent Canyon Caldera Complex, Southwestern Nevada Volcanic Field, Journal of Geophysical Research, v. 94, pp. 6,021-6,040.

Sawyer, D. A., R. J. Fleck, M. A. Lanphere, R. G. Warren, D. E. Broxton, and M. R. Hudson, 1994. "Episodic Caldera Volcanism in the Miocene Southwest Nevada Volcanic Field: Revised Stratigraphic Framework, ${ }^{40} \mathrm{Ar} /{ }^{39} \mathrm{Ar}$ Geochronology and Implications for Magmatism and Extension." Geological Society of America Bulletin, v. 106, pp. 1304-1318.

Seaber, P. R., 1988. "Hydrostratigraphic Units.” In: Back, W., J. R., Rosenshein, and P. R. Seaber, eds., Hydrogeology. The Geology of North America, Geological Society of America, v. O-2, pp. 9-14.

Slate, J. L., M. E. Berry, P. D. Rowley, C. J. Fridrich, K. S. Morgan, J. B. Workman, O. D. Young, G. L. Dixon, V. S. Williams, E. H. McKee, D. A. Ponce, T. G. Hildenbrand, WC Swadley, S. C. Lundstrom, E. B. Ekren, R. G. Warren, J. C. Cole, R. J. Fleck, M. A. Lanphere, D. A. Sawyer, S. A. Minor, D. J. Grunwald, R. J. Laczniak, C. M. Menges, J. C. Yount, and A. S. Jayko, 1999. Digital Geologic Map of the Map of the Nevada Test Site and Vicinity, Nye, Lincoln, and Clark Counties, Nevada and Inyo County, California. U.S. Geological Survey Open-File Report 99B554BA, scale 1:120,000.

SNJV, see Stoller-Navarro Joint Venture.

Snyder, R. P., 1977. Geology of the Gold Meadows Stock, Nevada Test Site. U.S. Geological Survey Report 474-179, 10 pp. Denver, CO.

Stewart, J. H., and J. E. Carlson, 1978. Geologic Map of Nevada, Scale 1:500,000. U.S. Geological Survey, Reston, VA. 
Stoller-Navarro Joint Venture, 2005a. Rainier Mesa-Shoshone Mountain Hydrogeologic Investigation Wells Drilling and Completion Criteria. S-N/99205--038. Las Vegas, NV.

Stoller-Navarro Joint Venture, 2005b. Underground Test Area Fracture Analysis Report for Yucca Flat Wells ER-2-1, ER-6-2\#1, ER-7-1, and ER-12-2. S-N/99205--040. Las Vegas, NV.

Stoller-Navarro Joint Venture, 2005c. Written communication. Subject: Fracture.05mbd and a Users' Guide to the Fracture Characterization Database for the Nevada Test Site and Vicinity. Revision 5, August. Las Vegas, NV.

Stoller-Navarro Joint Venture, 2006a. Analysis of Well ER-12-4 FY 2005 and FY 2006 Hydrologic Testing, Nevada Test Site, Nye County, Nevada. S-N/99205--083. Las Vegas, NV.

Stoller-Navarro Joint Venture, 2006b. Underground Test Area Fracture Analysis Report for Rainier Mesa Wells ER-12-3 and ER-12-4, and Shoshone Mountain Well ER-16-1, Nevada Test Site, Nevada. S-N/99205--085. Las Vegas, NV.

Sweetkind, D., R. P. Dickerson, R. J. Blakely, and P. D. Denning, 2001. Interpretive Geologic Cross Sections for the Death Valley Regional Flow System and Surrounding Areas, Nevada and California. U.S. Geologic Survey Miscellaneous Field Studies Map MF-2370.

Tompson, A. F. B., C. J. Bruton, and G. A. Pawloski, 1999. Evaluation of the Hydrologic Source Term from the Underground Nuclear Tests In Frenchman Flat and the Nevada Test Site: The CAMBRIC Test. UCRL-ID-132300. Lawrence Livermore National Laboratory, Livermore, CA.

Townsend, D. R., Peer Consultants, and M. J. Townsend, Bechtel Nevada, 2003. Written communication. Subject: Underground Test Area Geology Task to Construct a Database of Drill-Hole and Stratigraphic Information for the Rainier Mesa Area: Status Report for Work Conducted in Fiscal Year 2003. Prepared for Bechtel Nevada, September 30, 2003. Las Vegas, NV.

Townsend, D. R., Peer Consultants, and M. J. Townsend, Bechtel Nevada, 2004. Written communication. Subject: Underground Test Area Geology Task to Construct a Database of Drill-Hole and Stratigraphic Information for the Rainier Mesa Area: Status Report for Work Conducted in Fiscal Year 2004. Prepared for Bechtel Nevada, July 30, 2004. Las Vegas, NV.

Townsend, D. R., Peer Consultants, 2006. Personal communication to L. B. Prothro regarding faulting at Rainier Mesa.

Trexler, J. H., Jr., J. C. Cole, and P. H. Cashman, 1996. "Middle Devonian-Mississippian Stratigraphy on and near the Nevada Test Site: Implications for Hydrocarbon Potential" American Association of Petroleum Geologists Bulletin, v. 80, pp. 1736-1762.

U.S. Department of Energy, Nevada Operations Office, 1995a. Completion Report for Well ER-19-1. DOE/NV/11718--410. Las Vegas, NV. 
U.S. Department of Energy, Nevada Operations Office, 1995b. Completion Report for Well ER-3-2. DOE/NV--408. Prepared by IT Corporation, Las Vegas, NV.

U.S. Department of Energy, Nevada Operations Office, 1996. Final Environmental Impact Statement for the Nevada Test Site and Off-site Locations in the State of Nevada. DOE/EIS-0243. Las Vegas, NV.

U.S. Department of Energy, Nevada Operations Office, 1997. Regional Groundwater Flow and Tritium Transport Modeling and Risk Assessment of the Underground Test Area, Nevada Test Site, Nevada. DOE/NV--477. Las Vegas, NV.

U.S. Department of Energy, Nevada Operations Office, 2000. United States Nuclear Tests, July 1945 through September 1992. DOE/NV--209, Revision 15. Las Vegas, NV.

U.S. Department of Energy, 2003. Routine Radiological Environmental Monitoring Plan. DOE/NV/11718--804. Prepared by Bechtel Nevada, Las Vegas, NV.

U.S. Department of Energy, National Nuclear Security Administration Nevada Site Office, 2004. Completion Report for Well ER-12-2. DOE/NV/11718--846. Prepared by Bechtel Nevada, Las Vegas, NV.

U.S. Department of Energy, National Nuclear Security Administration Nevada Site Office, 2005. Well Completion Report for Well Cluster ER-5-3. DOE/NV/11718--1093. Prepared by Bechtel Nevada. Las Vegas, NV.

U.S. Department of Energy, National Nuclear Security Administration Nevada Site Office, 2006a. Completion Report for Well ER-12-3. DOE/NV/11718--1182. Prepared by Bechtel Nevada, Las Vegas, NV.

U.S. Department of Energy, National Nuclear Security Administration Nevada Site Office, 2006b. Completion Report for Well ER-12-4. DOE/NV--1128. Prepared by Bechtel Nevada, Las Vegas, NV.

U.S. Department of Energy, National Nuclear Security Administration Nevada Site Office, 2006c. Completion Report for Well ER-16-1. DOE/NV--1180. Prepared by National Security Technologies, LLC, Las Vegas, NV.

USGS, see U.S. Geological Survey.

U.S. Geological Survey Web site. USGS/DOE Nevada Site Page, USGS/USDOE Cooperative Studies in Nevada, Well-site data for U-12s. http://nevada.usgs.gov/doe_nv/sitepage_temp.cfm?site_id=371342116125102. Last accessed September 6, 2006.

Waddell, R. K., J. H. Robison, and R. K. Blankennagel, 1984. Hydrology of Yucca Mountain and Vicinity, Nevada-California Investigative Results through Mid-1983. U.S. Geological Survey Water-Resources Investigation Report 84-4267, 72 pp. Denver, CO. 
Wagoner, J. L., and H. L. McKague, 1984. Variation of Physical Properties of Alluvium in an Arid Basin. UCRL-90672. Lawrence Livermore National Laboratory, Livermore, CA.

Wagoner, J. L., and W. Richardson, 1986. Stratigraphic Contacts From Drill Holes at the Nevada Test Site. UCID-20790, 39 pp. Lawrence Livermore National Laboratory, Livermore, CA.

Walker, G. E., 1962. Ground Water in the Climax Stock, Nevada Test Site, Nye County, Nevada. U.S. Geological Survey Trace Elements Investigations Report TEI-813, 48 pp. Washington, D.C.

Warren, R. G., G. L. Cole, and D. Walther, 2000. A Structural Block Model for the ThreeDimensional Geology of the Southwestern Nevada Volcanic Field. LA-UR-00-5866. Los Alamos National Laboratory, Los Alamos, NM.

Warren, R. G., D. A. Sawyer, and H. R. Covington, 1989. Distinguishing Characteristics of Stratigraphic Units of Pahute Mesa, Attachment 2, Los Alamos National Laboratory informal technical report prepared for the DOE/NV Underground Test Area Project, July 26, 1989.

Warren, R. G., D. A. Sawyer, F. M. Byers, Jr., and J. C. Cole, 2003. A Petrographical, Geochemical and Geophysical Database and Framework for the Southwestern Nevada Volcanic Field. LA-UR-03-1503. Los Alamos National Laboratory, Los Alamos, NM.

Winograd, I. J., and W. Thordarson, 1975. Hydrogeologic and Hydrochemical Framework, South-Central Great Basin, Nevada-California, with Special Reference to the Nevada Test Site. U.S. Geological Survey Professional Paper 712-C, 126 pp. Washington, D.C.

Workman, J. B., C. Menges, W. R. Page, E. B. Ekren, P. P. Rowley, and G. L. Dixon, 2002 b. Tectonic Map of the Death Valley Groundwater Model Area, Nevada and California. U.S. Geologic Survey Miscellaneous Field Studies Map MF-2381-B, scale, 1:250,000.

Workman, J. B., C. Menges, W. R. Page, E. M. Taylor, E. B. Ekren, P. P. Rowley, G. L. Dixon, R. A. Thompson, and L. A. Wright, 2002a. Geologic Map of the Death Valley Groundwater Model Area, Nevada and California. U.S. Geological Survey Miscellaneous Map MF-2381-A. Scale 1:250,000.

Zavarin M., S. F. Carle, and R. M. Maxwell, 2004. Upscaling Radionuclide Retardation - Linking the Surface Complexation and Ion Exchange Mechanistic Approach to a Linear Kd Approach. Report on work performed for the UGTA program, Lawrence Livermore National Laboratory UCRL-TR-214713, Livermore, CA. 


\section{Distribution List}

$\underline{\text { Copies }}$

W. R. Wilborn

11 (4 paper, 7 CDs)

U.S. Department of Energy

National Nuclear Security Administration

Nevada Site Office

Environmental Restoration Division

P.O. Box 98518, M/S 505

Las Vegas, NV 89193-8518

U.S. Department of Energy

$1 \mathrm{CD}$ (uncontrolled)

National Nuclear Security Administration

Nevada Site Office

Technical Library

P.O. Box 98518, M/S 505

Las Vegas, NV 89193-8518

U.S. Department of Energy

2 CDs (uncontrolled)

National Nuclear Security Administration

Nevada Site Office

Public Reading Facility

c/o Nuclear Testing Archive

P.O. Box 98518, M/S 505

Las Vegas, NV 89193-8518

U.S. Department of Energy

$1 \mathrm{CD}$ (uncontrolled)

Office of Scientific and Technical Information

P.O. Box 62

Oak Ridge, Tennessee 37831-0062

Northern Nevada FFACO Public Reading Room

$1 \mathrm{CD}$ (uncontrolled)

c/o Nevada State Library and Archive

100 West Stuart Street

Carson City, NV 89701-4208

T. C. Beard

$1 \mathrm{CD}$

Stoller-Navarro Joint Venture

7710 W. Cheyenne, Bldg. 3, M/S 439

Las Vegas, NV 89129

N. M. Becker

2 (1 paper, $1 \mathrm{CD})$

Los Alamos National Laboratory

P.O. Box 1663, EES-6, M/S T-003

Los Alamos, NM 87545-1663 


\section{Distribution List}

\section{$\underline{\text { Copies }}$}

S. L. Drellack

2 (1 paper, $1 \mathrm{CD})$

National Security Technologies, LLC

P.O. Box 98521, NLV082

Las Vegas, NV 89193-8521

J. L. Gonzales

$1 \mathrm{CD}$

National Security Technologies, LLC

P.O. Box 98521, NLV082

Las Vegas, NV 89193-8521

J. P. McCord

2 (1 paper, $1 \mathrm{CD})$

Stoller-Navarro Joint Venture

7710 W. Cheyenne, Bldg. 3, M/S 439

Las Vegas, NV 89129

P. K. Ortego

$1 \mathrm{CD}$

National Security Technologies, LLC

P.O. Box 98521, NLV082

Las Vegas, NV 89193-8521

G. A. Pawloski

2 (1 paper, $1 \mathrm{CD})$

Lawrence Livermore National Laboratory

P.O. Box 808

Livermore, CA 94551-0808

G. A. Phelps

$1 \mathrm{CD}$

U.S. Geological Survey

345 Middlefield Road

Menlo Park, CA 94025

L. B. Prothro

2 (1 paper, $1 \mathrm{CD})$

National Security Technologies, LLC

P.O. Box 98521, NLV082

Las Vegas, NV 89193-8521

C. E. Russell

2 (1 paper, $1 \mathrm{CD})$

Desert Research Institute

755 East Flamingo Road

P.O. Box 19040

Las Vegas, NV 89119-7363 


\section{Distribution List}

\section{$\underline{\text { Copies }}$}

G. Ruskauff

$1 \mathrm{CD}$

Stoller-Navarro Joint Venture

7710 W. Cheyenne, Bldg. 3, M/S 439

Las Vegas, NV 89129

Stoller Navarro Central Files

2 (1 paper, $1 \mathrm{CD})$

Stoller-Navarro Joint Venture

7710 W. Cheyenne, Bldg. 3, M/S 439

Las Vegas, NV 89129

Environmental Management Information System

$1 \mathrm{CD}$

Stoller-Navarro Joint Venture

7710 W. Cheyenne, Bldg. 3, M/S 439

Las Vegas, NV 89129

B. K. Thompson

Water Resources, Nevada District

2 (1 paper, $1 \mathrm{CD})$

U.S. Geological Survey

160 N. Stephanie Street

Henderson, NV 89074

M. J. Townsend

2 (1 paper, $1 \mathrm{CD})$

National Security Technologies, LLC

P.O. Box 98521, NTS416

Las Vegas, NV 89193-8521 
This page intentionally left blank.

Dist-4 


\section{APPENDIX A}

Hydrostratigraphic Drill Hole Database for the Rainier Mesa-Shoshone Mountain Model Area 
Table A-1

Well Data for Selected Drill Holes within the Rainier Mesa-Shoshone Mountain Model Area

\begin{tabular}{|c|c|c|c|c|c|c|c|c|c|}
\hline Hole Name & $\begin{array}{c}\text { Associated } \\
\text { Tunnel } \\
\end{array}$ & $\begin{array}{c}\text { Year } \\
\text { Drilled }\end{array}$ & $\begin{array}{c}\text { Sample } \\
\text { Type }\end{array}$ & Orient. & NSP27-N (ft) & NSP27-E (ft) & $\begin{array}{l}\text { Diameter } \\
\text { at TD (in.) }\end{array}$ & $\begin{array}{c}\text { Collar } \\
\text { Elev. (ft) }\end{array}$ & TD (ft) \\
\hline UE1a & NONE & 1964 & $\overline{\text { CUT }}$ & $\mathrm{V}$ & 837,000 & 660,000 & 9.875 & 4303 & 957 \\
\hline UE1d & NONE & 1964 & CUT & $\mathrm{V}$ & 873,700 & 661,050 & 9.00 & 4296 & 857 \\
\hline UE1f & NONE & 1964 & CUT & $\mathrm{V}$ & 836,212 & 661,373 & 9.00 & 4277 & 703 \\
\hline UE1L & NONE & 1972 & CUT & $\mathrm{V}$ & 837,000 & 654,001 & 12.25 & 4,454 & 5,339 \\
\hline UE2ad & NONE & 1970 & CUT & $\mathrm{V}$ & 873,000 & 666,500 & 12.25 & 4413 & 1270 \\
\hline U2ca\#1 & NONE & 1965 & CUT & $\mathrm{V}$ & 870,198 & 653,250 & 9.875 & 4,871 & 1,473 \\
\hline UE2ce & NONE & 1977 & CUT & $\mathrm{V}$ & 871,100 & 654,900 & 12.25 & 4,764 & 1,650 \\
\hline U2cms & NONE & 1968 & EMP & $\mathrm{V}$ & 863,050 & 657,204 & 64.0 & 4,583 & 1,575 \\
\hline U2cn & NONE & 1969 & EMP & $\mathrm{V}$ & 863,650 & 657,120 & 64.0 & 4,589 & 1,548 \\
\hline UE2co & NONE & 1980 & CUT & $\mathrm{V}$ & 861,900 & 657,400 & 12.25 & 4,562 & 1,921 \\
\hline U2co & NONE & 1980 & EMP & $\mathrm{V}$ & 861,950 & 657,375 & 96 & 4,562 & 1,170 \\
\hline U2cp & NONE & 1981 & EMP & $\mathrm{V}$ & 861,114 & 658,554 & 96 & 4,510 & 1,250 \\
\hline U2cq & NONE & 1982 & EMP & $\mathrm{V}$ & 860,450 & 658,901 & 96 & 4,499 & 1,450 \\
\hline $\mathrm{U} 2 \mathrm{cr}$ & NONE & 1983 & EMP & $\mathrm{V}$ & 871,800 & 657,800 & 96 & 4,604 & 1,367 \\
\hline U2cs & NONE & 1984 & EMP & $\mathrm{V}$ & 864,600 & 658,794 & 96 & 4,526 & 1,500 \\
\hline U2ct & NONE & 1986 & EMP & $\mathrm{V}$ & 862115 & 658860 & 96 & 4509 & 1500 \\
\hline U2cu & NONE & 1987 & EMP & $\mathrm{V}$ & 866,200 & 658,794 & 96 & 4,526 & 1,515 \\
\hline UE2s & NONE & 1968 & CUT & $\mathrm{V}$ & 863,050 & 657,169 & 9.875 & 4,583 & 1,970 \\
\hline U4as & NONE & 1984 & EMP & $\mathrm{V}$ & 859,450 & 659,000 & 96 & 4,488 & 1,450 \\
\hline U4at & NONE & 1987 & EMP & $\mathrm{V}$ & 858,600 & 659,150 & 96 & 4,476 & 1,521 \\
\hline UE4ac & NONE & 1974 & CUT & $\mathrm{V}$ & 855,950 & 659,250 & 12.25 & 4,471 & 1,677 \\
\hline WW8 & NONE & 1963 & CUT & $\mathrm{V}$ & 879,468 & 609,999 & 7.625 & 5,695 & 5,499 \\
\hline ER-12-1 & NONE & 1992 & CUT & $\mathrm{V}$ & 886,640 & 640,540 & 12.25 & 5,818 & 3,588 \\
\hline ER-12-2 & NONE & 2003 & CUT & $\mathrm{V}$ & 881,865 & 658,543 & 12.25 & 4,705 & 6,869 \\
\hline ER-12-3 & N\&E & 2005 & CUT & $\mathrm{V}$ & $890,278.7$ & $631,811.0$ & 12.25 & $7,390.8$ & 4,908 \\
\hline ER-12-4 & $\mathrm{T}$ & 2005 & CUT & $\mathrm{V}$ & $899,282.8$ & $640,786.4$ & 12.25 & $6,883.7$ & 3,715 \\
\hline UE12e\#1 & $E$ & 1973 & C & $\mathrm{V}$ & 887,459 & 632,001 & 3.99 & 7,431 & 2,000 \\
\hline UE12e\#3 & $E$ & 1973 & C & $\mathrm{V}$ & 885,923 & 631,038 & 3.99 & $7,460.0$ & 2,199 \\
\hline UE12g.10\#1 & $\mathrm{G}$ & 1968 & $\mathrm{C}$ & $\mathrm{V}$ & $882,737.7$ & $631,725.6$ & 3.75 & $7,528.3$ & 1,522 \\
\hline UE12g.10\#2 & $G$ & 1968 & $\mathrm{C}$ & $\mathrm{V}$ & $883,410.6$ & $632,397.0$ & 3.75 & $7,576.9$ & 1,540 \\
\hline UE12g.10\#3 & $G$ & 1974 & $\mathrm{C}$ & $\mathrm{V}$ & $882,944.1$ & $633,034.3$ & 3.99 & $7,529.6$ & 1,425 \\
\hline UE12g.10\#4 & $\mathrm{G}$ & 1976 & $\mathrm{C}$ & $\mathrm{V}$ & $883,242.3$ & $632,378.8$ & 3.99 & $7,570.4$ & 576 \\
\hline UE12g.10\#5 & $G$ & 1976 & C & $\mathrm{V}$ & $883,237.4$ & $632,370.3$ & 3.99 & $7,571.4$ & 1,402 \\
\hline UE12g.10\#6 & $\mathrm{G}$ & 1977 & $\mathrm{C}$ & $\mathrm{V}$ & $882,870.2$ & $632,160.3$ & 3.99 & $7,554.9$ & 1,450 \\
\hline UE12n\#1 & $\mathrm{N}$ & 1973 & $\mathrm{C}$ & $\mathrm{V}$ & $892,866.8$ & $632,209.1$ & 3.99 & $7,321.4$ & $2,001.2$ \\
\hline
\end{tabular}


Table A-1

Well Data for Selected Drill Holes within the Rainier Mesa-Shoshone Mountain Model Area

\begin{tabular}{|c|c|c|c|c|c|c|c|c|c|}
\hline Hole Name & $\begin{array}{c}\text { Associated } \\
\text { Tunnel } \\
\end{array}$ & $\begin{array}{c}\text { Year } \\
\text { Drilled }\end{array}$ & $\begin{array}{c}\begin{array}{c}\text { Sample } \\
\text { Type }\end{array} \\
\end{array}$ & Orient. & NSP27-N (ft) & NSP27-E (ft) & $\begin{array}{l}\text { Diameter } \\
\text { at TD (in.) }\end{array}$ & $\begin{array}{c}\text { Collar } \\
\text { Elev. (ft) }\end{array}$ & TD (ft) \\
\hline UE12n\#2 & $\mathrm{N}$ & 1973 & $\mathrm{C}$ & $\mathrm{V}$ & 895,938 & 633,839 & 3.99 & 7,344 & 1,799 \\
\hline UE12n\#3 & $\mathrm{N}$ & 1973 & $\mathrm{C}$ & $\mathrm{V}$ & 896,075 & 632,559 & 3.99 & 7,479 & 1,409 \\
\hline UE12n\#4 & $\mathrm{N}$ & 1973 & $\mathrm{C}$ & $\mathrm{V}$ & 892,035 & 635,753 & 3.03 & 6,894 & 830 \\
\hline UE12n\#6 & $\mathrm{N}$ & 1973 & $\mathrm{C}$ & $\mathrm{V}$ & 891,000 & 631,250 & 3.99 & 7,420 & 2,317 \\
\hline UE12n\#8 & $\mathrm{N}$ & 1973 & $\mathrm{C}$ & $\mathrm{V}$ & 895,550 & 632,920 & 3.99 & 7,395 & 1,784 \\
\hline UE12n\#9 & $\mathrm{N}$ & 1975 & $\mathrm{C}$ & $\mathrm{V}$ & 895,600 & 632,309 & 3.99 & 7,383 & 1,550 \\
\hline UE12n\#10 & $\mathrm{N}$ & 1977 & $\mathrm{C}$ & $\mathrm{V}$ & 896,655 & 634,354 & 2.98 & 7,384 & 1,877 \\
\hline UE12n\#11 & $\mathrm{N}$ & 1978 & $\mathrm{C}$ & $\mathrm{V}$ & 896,074 & 634,582 & 3.875 & 7,309 & 1,882 \\
\hline UE12n\#12 & $\mathrm{N}$ & 1980 & $\mathrm{C}$ & $\mathrm{V}$ & 896,600 & 634,000 & 2.98 & $7,413.4$ & 1,733 \\
\hline UE12n\#13 & $\mathrm{N}$ & 1983 & $\mathrm{C}$ & $\mathrm{V}$ & $893,283.4$ & $630,750.5$ & 3.93 & $7,354.6$ & 1,086 \\
\hline UE12n\#14 & $\mathrm{N}$ & 1987 & $\mathrm{C}$ & $\mathrm{V}$ & $891,661.8$ & $633,255.7$ & 3.97 & $7,415.5$ & $1,737.6$ \\
\hline UE12n\#15 & $\mathrm{N}$ & 1987 & $\mathrm{C}$ & $\mathrm{V}$ & $894,759.1$ & 631,677 & 3.97 & $7,370.7$ & 585.0 \\
\hline UE12n\#15A & $\mathrm{N}$ & 1987 & $\mathrm{C}$ & $\mathrm{V}$ & $894,749.9$ & $631,678.7$ & 3.937 & $7,369.2$ & $1,933.8$ \\
\hline UE12n\#16 & $\mathrm{N}$ & 1989 & $\mathrm{C}$ & $\mathrm{V}$ & $895,989.5$ & $630,522.1$ & 3.937 & $7,527.4$ & $2,237.4$ \\
\hline UE12p & $\mathrm{P}$ & 1967 & C & $\mathrm{V}$ & 906,011 & 646,971 & 2.35 & 6,338 & 1,848 \\
\hline UE12p\#1 & $\mathrm{P}$ & 1969 & $\mathrm{C}$ & $\mathrm{V}$ & 906,432 & 644,827 & 2.35 & 6,477 & 2,165 \\
\hline UE12p\#2 & NONE & 1969 & $\mathrm{C}$ & $\mathrm{V}$ & 911,388 & 648,291 & 2.35 & 6,347 & 2,225 \\
\hline UE12p\#3 & NONE & 1970 & $\mathrm{C}$ & $\mathrm{V}$ & $907,719.0$ & 650,425 & 2.35 & 3,332 & 2,601 \\
\hline UE12p\#4 & $\mathrm{P}$ & 1986 & $\mathrm{C}$ & $\mathrm{V}$ & $904,748.1$ & $646,550.8$ & 3.03 & $6,396.0$ & $1,781.8$ \\
\hline UE12p\#5 & NONE & 1989 & $\mathrm{C}$ & $\mathrm{V}$ & $905,030.0$ & $644,100.4$ & 3.95 & $6,527.5$ & $1,302.5$ \\
\hline UE12p\#6 & $P$ & 1989 & C & $\mathrm{V}$ & $906,066.8$ & $647,775.8$ & 2.35 & $6,344.9$ & $2,282.9$ \\
\hline U12q & NONE & 1962 & EMP & $\mathrm{V}$ & $891,406.9$ & $627,321.5$ & 64 & $7,413.5$ & 2,144 \\
\hline U12r & NONE & 1962 & EMP & $\mathrm{V}$ & $895,401.0$ & $628,499.3$ & 60 & 7,514 & 2,520 \\
\hline U12s & NONE & 1965 & EMP & $\mathrm{V}$ & 902,407 & 631,260 & 52 & 6,794 & 1,596 \\
\hline U12b\#2 UCRL-2 & $\mathrm{B}$ & 1957 & $\mathrm{C}$ & $\mathrm{V}$ & 889,947 & 636,110 & 3.0 & 6,795 & 1,043 \\
\hline U12b\#3 UCRL-3 & $\mathrm{B}$ & 1957 & $\mathrm{C}$ & $\mathrm{V}$ & 890,617 & 634,913 & 3.0 & 7,495 & 1,074 \\
\hline U12b.07-1 & $\mathrm{B}$ & 1961 & PART C & $\mathrm{V}$ & 891,222 & 634,404 & 6.125 & 7,480 & 950 \\
\hline U12b.07-2 & $\mathrm{B} / \mathrm{N}$ & 1961 & PART C & $\mathrm{V}$ & $892,714.8$ & $634,195.4$ & 6.125 & $7,378.3$ & 2,720 \\
\hline $\mathrm{U} 12 \mathrm{e} \mathrm{CH} \# 3$ & $E$ & 1967 & CUT & $\mathrm{V}$ & 886,073 & 633,888 & 36 & 7,573 & 1,425 \\
\hline U12e.04\#32 & $E / G$ & 1961 & PART C & $\mathrm{V}$ & $884,688.5$ & $634,015.7$ & 3.0 & $7,559.7$ & 1,400 \\
\hline U12e.06-1 & $E$ & 1961 & PART C & $\mathrm{V}$ & 885,187 & $631,775.9$ & 6.125 & $7,573.1$ & 3,114 \\
\hline U12e.06 A & $E$ & 1960 & $\mathrm{C}$ & $\mathrm{V}$ & 885,979 & 633,873 & 6.125 & 6,164 & 1,000 \\
\hline U12e.06 B & $E$ & 1960 & C & $\mathrm{V}$ & 885,249 & 632,341 & 6.125 & 6,171 & 975 \\
\hline $\mathrm{U} 12 \mathrm{n} \# 1 \mathrm{CH}$ & $\mathrm{N}$ & 1967 & CUT & $\mathrm{V}$ & 893,730 & 635,423 & 26 & 7,289 & 1,221 \\
\hline U12n.02 \#1 & $\mathrm{N}$ & 1966 & CUT & $\mathrm{V}$ & 892,771 & 633,667 & 15 & 7,203 & 1,233 \\
\hline
\end{tabular}


Table A-1

Well Data for Selected Drill Holes within the Rainier Mesa-Shoshone Mountain Model Area

\begin{tabular}{|c|c|c|c|c|c|c|c|c|c|}
\hline Hole Name & $\begin{array}{c}\text { Associated } \\
\text { Tunnel } \\
\end{array}$ & $\begin{array}{c}\text { Year } \\
\text { Drilled } \\
\end{array}$ & $\begin{array}{c}\text { Sample } \\
\text { Type } \\
\end{array}$ & Orient. & NSP27-N (ft) & NSP27-E (ft) & $\begin{array}{l}\text { Diameter } \\
\text { at TD (in.) } \\
\end{array}$ & $\begin{array}{c}\text { Collar } \\
\text { Elev. (ft) }\end{array}$ & TD (ft) \\
\hline U12n.10 UG\#2 & $\mathrm{N}$ & 1975 & C & -38 & 895,332 & 632,583 & 3.9 & 6,074 & 451 \\
\hline U12n.10 UG\#3 & $\mathrm{N}$ & 1975 & $\mathrm{C}$ & -81 & 895,323 & 632,629 & 3.9 & 6,074 & 336.1 \\
\hline U12n.15 UG-1 & $\mathrm{N}$ & 1981 & C & -60 & 896,485 & 633,917 & 3.9 & 6,073 & 298.4 \\
\hline U12n.17 UG-1 & $\mathrm{N}$ & 1984 & $\mathrm{C}$ & $\mathrm{V}$ & $892,963.6$ & $634,295.2$ & 3.9 & $6,065.7$ & 685.5 \\
\hline U12t.04 RE-2 & $\mathrm{T}$ & 1984 & $\mathrm{C}$ & $\mathrm{V}$ & $899,514.2$ & $641,678.6$ & 3.9 & $5,621.8$ & 827.8 \\
\hline U12t.04 CH\#1 & $\mathrm{T}$ & 1982 & $\mathrm{C}$ & $\mathrm{V}$ & 899,876 & 641,542 & 36 & $6,795.9$ & 1,187 \\
\hline UE12t\#1 & $\mathrm{T}$ & 1967 & $\mathrm{C}$ & $\mathrm{V}$ & 898,949 & 642,521 & 2.35 & $6,762.4$ & 2,262 \\
\hline UE12t\#2 & $\mathrm{T}$ & 1969 & $\mathrm{C}$ & $\mathrm{V}$ & 897,406 & 640,740 & 3.94 & 7,008 & 1,684 \\
\hline UE12t\#3 & $\mathrm{T}$ & 1973 & C & $\mathrm{V}$ & 899,833 & 641,874 & 3.94 & 6,777 & 2,176 \\
\hline UE12t\#4 & $\mathrm{T}$ & 1973 & C & $\mathrm{V}$ & 898,930 & 640,839 & 3.99 & 6,920 & 2,290 \\
\hline UE12t\#5 & $\mathrm{T}$ & 1984 & $\mathrm{C}$ & $\mathrm{V}$ & 897,020 & 640,192 & 3.99 & 7,059 & 1,611 \\
\hline UE12t\#6 & NONE & 1988 & $\mathrm{C}$ & $\mathrm{V}$ & $901,402.2$ & $638,431.7$ & 3.94 & $6,907.0$ & $1,460.9$ \\
\hline UE12t\#7 & NONE & 1989 & $\mathrm{C}$ & $\mathrm{V}$ & $902,905.4$ & $641,162.7$ & 3.94 & $6,960.9$ & $1,691.9$ \\
\hline UE12t\#8 & NONE & 1989 & $\mathrm{C}$ & $\mathrm{V}$ & $904,027.5$ & $642,809.3$ & 3.94 & $6,724.9$ & 1,408 \\
\hline RM Exploratory \#1 & NONE & $1962 / 63$ & PART C & $\mathrm{V}$ & 892,097 & 629,404 & 6.125 & $7,361.0$ & 3,833 \\
\hline UE14a & NONE & 1983 & CUT & $\mathrm{V}$ & 794,100 & 652,500 & 12.25 & $4,339.0$ & 3,300 \\
\hline UE14b & NONE & 1984 & CUT & $\mathrm{V}$ & 794,100 & 650,111 & 12.25 & $4,353.0$ & 3,680 \\
\hline ER-16-1 & 16 & 2005 & CUT & $\mathrm{V}$ & $822,414.1$ & $635,354.3$ & 12.25 & $6,591.5$ & 4,005 \\
\hline UE16a \#1 & 16 & 1973 & $\mathrm{C}$ & $\mathrm{V}$ & $822,399.9$ & $635,400.6$ & 3.03 & $6,594.8$ & 1,197 \\
\hline UE16b & NONE & 1982 & $\mathrm{C}$ & $\mathrm{V}$ & 839,498 & 641,345 & 3.99 & 4,890 & 361 \\
\hline UE16c & NONE & 1976 & $\mathrm{C}$ & $\mathrm{V}$ & 844,958 & 644,557 & 3.99 & 4,726 & 144 \\
\hline UE16d & NONE & 1981 & $\mathrm{C}$ & $\mathrm{V}$ & 844,878 & 646,567 & 6.25 & 4,684 & 2,321 \\
\hline UE16f & NONE & 1977 & C & $\mathrm{V}$ & 832,355 & 648,843 & 8.75 & 4,625 & 1,479 \\
\hline HTH-1 & NONE & 1962 & CUT & $\mathrm{V}$ & 876,855 & 629,310 & 7.63 & 6,156 & 4,206 \\
\hline UE17a & NONE & 1976 & C & $\mathrm{V}$ & 846,138 & 645,991 & 6.25 & 4,697 & 1,214 \\
\hline UE17b & NONE & 1976 & C & $\mathrm{V}$ & 849,217 & 646,470 & 3.99 & 4,780 & 256.5 \\
\hline UE17c & NONE & 1976 & $\mathrm{C}$ & $\mathrm{V}$ & 857,444 & 650,047 & 3.99 & 4,835 & 586 \\
\hline UE17d & NONE & 1976 & C & $\mathrm{V}$ & 847,189 & 647,788 & 3.99 & 4,678 & 398 \\
\hline UE17e & NONE & 1977 & C & $\mathrm{V}$ & 853,205 & 646,448 & 3.94 & 4,934 & 3,000 \\
\hline ER-19-1 & NONE & 1993 & $\mathrm{C}$ & $\mathrm{V}$ & $884,236.8$ & $624,548.9$ & 15.00 & 6139.8 & 3,595 \\
\hline U19ac & NONE & 1980 & EMP & $\mathrm{V}$ & 921,600 & 605,100 & 96.0 & 7,038 & 2,300 \\
\hline U19an & NONE & 1985 & EMP & $\mathrm{V}$ & 928,413 & 604,488 & 120.0 & 6,978 & 2,150 \\
\hline U19ax & NONE & 1987 & EMP & $\mathrm{V}$ & 927,349 & 604,751 & 96.0 & 6,986 & 2,200 \\
\hline U19t & NONE & 1978 & EMP & $\mathrm{V}$ & 924,006 & 607,394 & 80.0 & 6,991 & 1,932 \\
\hline UE19b & NONE & 1964 & CUT & $\mathrm{V}$ & 933,798 & 606,828 & 9.88 & 6,802 & 2,330 \\
\hline
\end{tabular}


Table A-1

Well Data for Selected Drill Holes within the Rainier Mesa-Shoshone Mountain Model Area

\begin{tabular}{|c|c|c|c|c|c|c|c|c|c|}
\hline Hole Name & $\begin{array}{c}\text { Associated } \\
\text { Tunnel } \\
\end{array}$ & $\begin{array}{c}\text { Year } \\
\text { Drilled }\end{array}$ & $\begin{array}{c}\text { Sample } \\
\text { Type }\end{array}$ & Orient. & NSP27-N (ft) & NSP27-E (ft) & $\begin{array}{l}\text { Diameter } \\
\text { at TD (in.) }\end{array}$ & $\begin{array}{c}\text { Collar } \\
\text { Elev. (ft) }\end{array}$ & TD (ft) \\
\hline UE19b\#1 & NONE & 1966 & CUT & $\mathrm{V}$ & 933,700 & 606,835 & 9.88 & 6,802 & 4,500 \\
\hline UE19t & NONE & 1978 & CUT & $\mathrm{V}$ & 924,076 & 607,324 & 12.25 & 6,989 & 2,150 \\
\hline ER-30-1 & NONE & 1994 & CUT & $\mathrm{V}$ & 837,451 & 602,276 & 12.25 & 4,647 & 1,426 \\
\hline
\end{tabular}

\section{Explanation}

Sample Type

$\mathrm{C}=$ Core Hole

Part C $=$ Partial Core

Cut $=$ Drill Cuttings

EMP = Large Diameter Emplacement Hole; Cuttings

\section{Orientation}

$V=$ Vertical (or angle in degrees from horizontal) 
Table A-2

Geologic and Hydrostratigraphic Drill hole Database for the Rainier Mesa-Shoshone Mountain Model Area (vertical drill holes only)

\begin{tabular}{|c|c|c|c|c|c|c|c|c|c|}
\hline Hole Name & Strat $^{1}$ & Lith $^{2}$ & Major Alt. ${ }^{3}$ & $H_{G U^{4}}$ & $\mathrm{HSU}^{5}$ & \begin{tabular}{|c|}
$\begin{array}{c}\text { Depth Top } \\
\text { (ft) }\end{array}$ \\
\end{tabular} & $\begin{array}{c}\text { Depth } \\
\text { Top }^{6}(\mathrm{~m}) \\
\end{array}$ & \begin{tabular}{|c|}
$\begin{array}{c}\text { Elev. Top } \\
\\
(\mathrm{ft})\end{array}$ \\
\end{tabular} & \begin{tabular}{|c}
$\begin{array}{c}\text { Elev. Top } \\
(\mathrm{m})\end{array}$ \\
\end{tabular} \\
\hline UE1a & 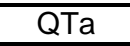 & $\mathrm{AL}$ & $\mathrm{nr}$ & AA & AA & 0 & 0.0 & $4,303.0$ & $1,311.6$ \\
\hline UE1a & Tlc & $\overline{\mathrm{COL}}$ & $\mathrm{nr}$ & AA & AA & 320 & 97.5 & $3,983.0$ & $1,214.0$ \\
\hline UE1a & $\mathrm{MDe}$ & QTZ & na & SCU & UCCU & 900 & 274.3 & $3,403.0$ & $1,037.2$ \\
\hline UE1d & QTa & $\mathrm{AL}$ & $\mathrm{nr}$ & $\mathrm{AA}$ & $\mathrm{AA}$ & 0 & 0.0 & $4,296.0$ & $1,309.4$ \\
\hline UE1d & Tlc & $\mathrm{COL}$ & $\mathrm{nr}$ & AA & AA & 430 & 131.1 & $3,866.0$ & $1,178.4$ \\
\hline UE1d & $\mathrm{nr}$ & BED & ZE & TCU & LTCU & 530 & 161.5 & $3,766.0$ & $1,147.9$ \\
\hline UE1d & Tlc & $\mathrm{COL}$ & $\overline{A R}$ & TCU & ATCU & 0 & 0.0 & $3,609.0$ & $1,100.0$ \\
\hline UE1d & $\mathrm{Pz}$ & LS & na & $\mathrm{CA}$ & LCA3 & 750 & 228.6 & $3,546.0$ & $1,080.8$ \\
\hline UE1d & $\mathrm{Oe}$ & QTZ & na & SCU & LCA3 & 820 & 249.9 & $3,476.0$ & $1,059.5$ \\
\hline UE1f & QTa & $\mathrm{AL}$ & $\mathrm{nr}$ & AA & AA & 0 & 0.0 & $4,277.0$ & $1,303.6$ \\
\hline UE1f & QTa & $\mathrm{COL}$ & $\mathrm{nr}$ & AA & AA & 300 & 91.4 & $3,977.0$ & $1,212.2$ \\
\hline UE1f & $\mathrm{nr}$ & TS/RWT & $\mathrm{nr}$ & VTA & TM-LVTA & 320 & 97.5 & $3,957.0$ & $1,206.1$ \\
\hline UE1f & $\mathrm{nr}$ & PWT & $\mathrm{GL}$ & VTA & TM-LVTA & 410 & 125.0 & $3,867.0$ & $1,178.7$ \\
\hline UE1f & $\mathrm{nr}$ & TS/RWT & $\mathrm{GL}$ & VTA & \begin{tabular}{|l|} 
TM-LVTA \\
\end{tabular} & 480 & 146.3 & $3,797.0$ & $1,157.3$ \\
\hline UE1f & $\mathrm{MDe}$ & QTZ/SLT & na & SCU & UCCU & 560 & 170.7 & $3,717.0$ & $1,132.9$ \\
\hline UE1f & MDe & QTZ & na & SCU & UCCU & 655 & 199.6 & $3,622.0$ & $1,104.0$ \\
\hline UE1L & QTa & $\mathrm{AL}$ & $\mathrm{nr}$ & AA & AA & 0 & 0.0 & $4,454.0$ & $1,357.6$ \\
\hline UE1L & $\mathrm{Mc}$ & $\mathrm{SH}$ & na & SCU & UCCU & 200 & 61.0 & $4,254.0$ & $1,296.6$ \\
\hline UE2ad & QTa & $\mathrm{AL}$ & $\mathrm{nr}$ & $\mathrm{AA}$ & AA & 0 & 0.0 & $4,448.2$ & $1,355.8$ \\
\hline UE2ad & $\mathrm{Tn}$ & TB & $\mathrm{GL}$ & VTA & TM-LVTA & 469 & 143.0 & $3,979.0$ & $1,212.8$ \\
\hline UE2ad & Cbk & DO & na & $\mathrm{CA}$ & LCA3 & 781 & 238.0 & $3,667.4$ & $1,117.8$ \\
\hline U2ca\#1 & QTa & $\mathrm{AL}$ & $\mathrm{nr}$ & AA & AA & 0 & 0.0 & $4,871.0$ & $1,484.7$ \\
\hline U2ca\#1 & pre-Tmr & BED & $\mathrm{GL}$ & VTA & TM-LVTA & 522 & 159.0 & $4,349.4$ & $1,325.7$ \\
\hline U2ca\#1 & Tbgb & BED & $\mathrm{GL}$ & VTA & TM-LVTA & 669 & 204.0 & $4,201.7$ & $1,280.7$ \\
\hline U2ca\#1 & $\mathrm{Tn}$ & BED & $\mathrm{GL}$ & VTA & TM-LVTA & 732 & 223.0 & $4,139.4$ & $1,261.7$ \\
\hline U2ca\#1 & $\mathrm{Tn}$ & BED & ZE & $\overline{\mathrm{TCU}}$ & LTCU & 820 & 250.0 & $4,050.8$ & $1,234.7$ \\
\hline U2ca\#1 & $\mathrm{Tn}$ & BED & ZE & TCU & ATCU & 1,365 & 416.1 & $3,506.0$ & $1,068.6$ \\
\hline U2ca\#1 & $\mathrm{Pz}$ & $\mathrm{DM}$ & na & $\mathrm{CA}$ & LCA3 & 1,421 & 433.0 & $3,450.4$ & $1,051.7$ \\
\hline UE2ce & QTa & $\mathrm{AL}$ & $\mathrm{nr}$ & AA & AA & 0 & 0.0 & $4,764.0$ & $1,452.1$ \\
\hline UE2ce & pre-Tmr & BED & $\mathrm{GL}$ & VTA & TM-LVTA & 384 & 117.0 & $4,380.2$ & $1,335.1$ \\
\hline UE2ce & Tbgb & BED & $\mathrm{GL}$ & VTA & TM-LVTA & 564 & 172.0 & $4,199.7$ & $1,280.1$ \\
\hline UE2ce & $\mathrm{Tn}$ & BED & $\mathrm{GL}$ & VTA & TM-LVTA & 659 & 201.0 & $4,104.6$ & $1,251.1$ \\
\hline UE2ce & Cbk & $\mathrm{DM}$ & na & $\mathrm{CA}$ & LCA3 & 1,106 & 337.0 & $3,658.4$ & $1,115.1$ \\
\hline U2ce & QTa & $\mathrm{AL}$ & $\mathrm{nr}$ & AA & AA & 0 & 0.0 & $4,764.0$ & $1,452.1$ \\
\hline U2ce & pre-Tmr & BED & $\mathrm{GL}$ & VTA & TM-LVTA & 384 & 117.0 & $4,380.1$ & $1,335.1$ \\
\hline U2ce & $\mathrm{Pz}$ & DM & na & $\mathrm{CA}$ & LCA3 & 1,132 & 345.0 & $3,632.1$ & $1,107.1$ \\
\hline $\mathrm{U} 2 \mathrm{cms}$ & QTa & $\mathrm{AL}$ & $\mathrm{nr}$ & AA & AA & 0 & 0.0 & $4,583.0$ & $1,396.9$ \\
\hline U2cms & $\mathrm{Tmr}$ & NWT & $\mathrm{GL}$ & VTA & TM-LVTA & 840 & 256.0 & $3,743.1$ & $1,140.9$ \\
\hline U2cms & pre-Tmr & BED & $\mathrm{GL}$ & VTA & \begin{tabular}{|l|} 
TM-LVTA \\
\end{tabular} & 1,001 & 305.0 & $3,582.3$ & $1,091.9$ \\
\hline $\mathrm{U} 2 \mathrm{cmS}$ & Tbg & BED & $\mathrm{GL}$ & VTA & TM-LVTA & 1,339 & 408.0 & $3,244.4$ & 988.9 \\
\hline $\mathrm{U} 2 \mathrm{cms}$ & $\mathrm{Tn}$ & BED & $\mathrm{GL}$ & VTA & TM-LVTA & 1,421 & 433.0 & $3,162.4$ & 963.9 \\
\hline U2cn & QTa & $\mathrm{AL}$ & $\mathrm{nr}$ & AA & AA & 0 & 0.0 & $4,589.0$ & $1,398.7$ \\
\hline U2cn & $\mathrm{Tmr}$ & WT & $\mathrm{GL}$ & WTA & \begin{tabular}{|l|} 
TM-WTA \\
\end{tabular} & 810 & 247.0 & $3,778.6$ & $1,151.7$ \\
\hline U2cn & $\mathrm{Tmr}$ & NWT & $\mathrm{GL}$ & VTA & TM-LVTA & 1,039 & 316.7 & $3,550.0$ & $1,082.0$ \\
\hline U2cn & Tbgb & BED & $\mathrm{GL}$ & VTA & TM-LVTA & 1,138 & 347.0 & $3,450.6$ & $1,051.7$ \\
\hline U2cn & $\mathrm{Tn}$ & BED & $\mathrm{GL}$ & VTA & \begin{tabular}{|l|} 
TM-LVTA \\
\end{tabular} & 1,224 & 373.0 & $3,365.3$ & $1,025.7$ \\
\hline U2cn & $\mathrm{Pz}$ & $\mathrm{DM}$ & na & $\mathrm{CA}$ & LCA3 & 1,391 & 424.0 & $3,197.9$ & 974.7 \\
\hline UE2co & QTa & $\mathrm{AL}$ & $\mathrm{nr}$ & AA & AA & 0 & 0.0 & $4,562.0$ & $1,390.5$ \\
\hline UE2co & Tmab & BED & $\mathrm{GL}$ & VTA & TM-UVTA & 696 & 212.0 & $3,866.5$ & $1,178.5$ \\
\hline UE2co & $\mathrm{Tmr}$ & WT & $\mathrm{GL}$ & VTA & TM-WVTA & 732 & 223.0 & $3,830.4$ & $1,167.5$ \\
\hline UE2co & pre-Tmr & BED & $\mathrm{GL}$ & VTA & TM-LVTA & 869 & 265.0 & $3,692.6$ & $1,146.8$ \\
\hline UE2co & Tw & BED & $\mathrm{GL}$ & VTA & \begin{tabular}{|l|} 
TM-LVTA \\
\end{tabular} & 1,018 & 310.3 & $3,544.0$ & $1,080.2$ \\
\hline UE2co & Tc & BED & $\mathrm{GL}$ & VTA & TM-LVTA & 1,074 & 327.4 & $3,487.9$ & $1,063.1$ \\
\hline UE2co & Tbgb & BED & $\mathrm{GL}$ & VTA & \begin{tabular}{|l|} 
TM-LVTA \\
\end{tabular} & 1,286 & 392.0 & $3,275.9$ & 998.5 \\
\hline UE2co & $\mathrm{Tn}$ & BED & $\mathrm{GL}$ & VTA & TM-LVTA & 1,319 & 402.0 & $3,243.1$ & 988.5 \\
\hline UE2co & Tub & BED & $\mathrm{GL}$ & VTA & TM-LVTA & 1,631 & 497.0 & $2,931.4$ & 893.5 \\
\hline
\end{tabular}


Table A-2

Geologic and Hydrostratigraphic Drill hole Database for the Rainier Mesa-Shoshone Mountain Model Area (vertical drill holes only)

\begin{tabular}{|c|c|c|c|c|c|c|c|c|c|}
\hline Hole Name & Strat $^{1}$ & Lith $^{2}$ & Major Alt. ${ }^{3}$ & $\mathrm{HGU}^{4}$ & $\mathrm{HSU}^{5}$ & \begin{tabular}{|c|}
$\begin{array}{c}\text { Depth Top } \\
6 \\
(\mathrm{ft})\end{array}$ \\
\end{tabular} & $\begin{array}{c}\text { Depth } \\
\operatorname{Top}^{6}(\mathrm{~m}) \\
\end{array}$ & \begin{tabular}{|c|}
$\begin{array}{c}\text { Elev. Top } \\
\end{array}$ \\
(ft)
\end{tabular} & \begin{tabular}{|c|}
$\begin{array}{c}\text { Elev. Top } \\
\text { (m) }\end{array}$ \\
\end{tabular} \\
\hline UE2co & Ton2 & BED & $\overline{\mathrm{GL}}$ & VTA & TM-LVTA & 1,650 & 503.0 & $2,911.7$ & 887.5 \\
\hline UE2co & To & BED & $\mathrm{AR}$ & TCU & ATCU & 1,764 & 537.6 & $2,798.2$ & 852.9 \\
\hline UE2co & $\mathrm{Pz}$ & $\mathrm{DM}$ & na & $\mathrm{CA}$ & LCA3 & 1,772 & 540.0 & $2,790.4$ & 850.5 \\
\hline U2co & QTa & $\mathrm{AL}$ & $\mathrm{nr}$ & AA & AA & 0 & 0.0 & $4,562.0$ & $1,390.5$ \\
\hline U2co & Tmab & BED & $\mathrm{GL}$ & VTA & TM-UVTA & 633 & 193.0 & $3,928.8$ & $1,197.5$ \\
\hline U2co & $\mathrm{Tmr}$ & VT & $\mathrm{GL}$ & WTA & TM-WTA & 656 & 200.0 & $3,905.8$ & $1,190.5$ \\
\hline U2co & $\mathrm{Tmr}$ & WTA & $\mathrm{GL}$ & WTA & TM-WTA & 679 & 207.0 & $3,882.9$ & $1,183.5$ \\
\hline U2co & $\mathrm{Tmr}$ & NWT & $\mathrm{GL}$ & VTA & TM-LVTA & 800 & 243.8 & $3,762.0$ & $1,146.7$ \\
\hline U2co & pre-Tmr & BED & $\mathrm{GL}$ & VTA & TM-LVTA & 873 & 266.0 & $3,689.3$ & $1,124.5$ \\
\hline U2co & Tw & BED & $\mathrm{GL}$ & VTA & TM-LVTA & 1,008 & 307.1 & $3,554.3$ & $1,083.4$ \\
\hline U2co & Tc & BED & $\mathrm{GL}$ & VTA & TM-LVTA & 1,079 & 328.9 & $3,482.9$ & $1,061.6$ \\
\hline U2cp & QTa & $\mathrm{AL}$ & $\mathrm{nr}$ & AA & $\mathrm{AA}$ & 0 & 0.0 & $4,510.0$ & $1,374.6$ \\
\hline U2cp & Tmab & BED & $\mathrm{GL}$ & VTA & TM-UVTA & 643 & 196.0 & $3,867.0$ & $1,178.6$ \\
\hline U2cp & $\mathrm{Tmr}$ & VT & $\mathrm{GL}$ & WTA & TM-WTA & 686 & 209.0 & $3,824.3$ & $1,165.6$ \\
\hline U2cp & $\mathrm{Tmr}$ & WT & DV & WTA & TM-WTA & 735 & 224.0 & $3,775.1$ & $1,150.6$ \\
\hline U2cp & Tmr & NWT & $\mathrm{GL}$ & VTA & TM-LVTA & 874 & 266.3 & $3,636.2$ & $1,108.3$ \\
\hline U2cp & pre-Tmr & BED & $\mathrm{GL}$ & VTA & TM-LVTA & 974 & 297.0 & $3,535.6$ & $1,077.6$ \\
\hline U2cq & QTa & $\mathrm{AL}$ & $\mathrm{nr}$ & AA & AA & 0 & 0.0 & $4,499.0$ & $1,371.3$ \\
\hline U2cq & Tma & NWT & $\mathrm{GL}$ & VTA & TM-UVTA & 522 & 159.0 & $3,977.4$ & $1,212.3$ \\
\hline U2cq & Tmab & BED & $\mathrm{GL}$ & VTA & TM-UVTA & 548 & 167.0 & $3,951.1$ & $1,204.3$ \\
\hline U2cq & $\mathrm{Tmr}$ & WT & $\mathrm{GL}$ & WTA & TM-WTA & 564 & 172.0 & $3,934.7$ & $1,199.3$ \\
\hline U2cq & $\mathrm{Tmr}$ & VT & $\mathrm{GL}$ & WTA & TM-WTA & 597 & 182.0 & $3,901.9$ & $1,189.3$ \\
\hline U2cq & Tmr & WT & DV & WTA & TM-WTA & 617 & 188.0 & $3,882.2$ & $1,183.3$ \\
\hline U2cq & Tmr & NWT & $\mathrm{GL}$ & VTA & TM-LVTA & 789 & 240.5 & $3,710.0$ & $1,130.8$ \\
\hline U2cq & pre-Tmr & BED & $\mathrm{GL}$ & VTA & TM-LVTA & 889 & 271.0 & $3,609.9$ & $1,100.3$ \\
\hline U2cq & Tw & BED & $\mathrm{GL}$ & VTA & TM-LVTA & 1,087 & 331.3 & $3,412.1$ & $1,040.0$ \\
\hline U2cq & Tc & BED & $\mathrm{GL}$ & VTA & TM-LVTA & 1,142 & 348.1 & $3,356.9$ & $1,023.2$ \\
\hline U2cq & Tbgb & NWT & $\mathrm{GL}$ & VTA & TM-LVTA & 1,339 & 408.0 & $3,160.4$ & 963.3 \\
\hline U2cq & $\mathrm{Tn}$ & BED & $\mathrm{GL}$ & VTA & TM-LVTA & 1,391 & 424.0 & $3,107.9$ & 947.3 \\
\hline $\mathrm{U} 2 \mathrm{cr}$ & QTa & $\mathrm{AL}$ & $\mathrm{nr}$ & AA & AA & 0 & 0.0 & $4,604.0$ & $1,403.3$ \\
\hline $\mathrm{U} 2 \mathrm{cr}$ & pre-Tmr & BED & $\mathrm{GL}$ & VTA & TM-LVTA & 312 & 95.0 & $4,292.3$ & $1,308.3$ \\
\hline $\mathrm{U} 2 \mathrm{cr}$ & Tbgb & BED & $\mathrm{GL}$ & VTA & TM-LVTA & 469 & 143.0 & $4,134.8$ & $1,260.3$ \\
\hline $\mathrm{U} 2 \mathrm{cr}$ & $\mathrm{Tn}$ & BED & $\mathrm{GL}$ & VTA & TM-LVTA & 571 & 174.0 & $4,033.1$ & $1,229.3$ \\
\hline $\mathrm{U} 2 \mathrm{cr}$ & Tub & BED & $\mathrm{GL}$ & VTA & TM-LVTA & 909 & 277.0 & $3,695.2$ & $1,126.3$ \\
\hline $\mathrm{U} 2 \mathrm{cr}$ & Ton2 & BED & $\mathrm{GL}$ & VTA & TM-LVTA & 971 & 296.0 & $3,632.9$ & $1,107.3$ \\
\hline $\mathrm{U} 2 \mathrm{cr}$ & Tlc & AA & $\mathrm{AR}$ & $\mathrm{TCU}$ & ATCU & 1,260 & 384.0 & $3,344.2$ & $1,019.3$ \\
\hline $\mathrm{U} 2 \mathrm{cr}$ & MDe & QZT/SH & na & $\mathrm{CCU}$ & UCCU & 1,309 & 399.0 & $3,294.9$ & $1,004.3$ \\
\hline U2cs & QTa & $\mathrm{AL}$ & $\mathrm{nr}$ & AA & AA & 0 & 0.0 & $4,525.9$ & $1,379.5$ \\
\hline U2cs & $\mathrm{Tmr}$ & NWT & $\mathrm{GL}$ & VTA & TM-LVTA & 650 & 198.0 & $3,876.3$ & $1,181.5$ \\
\hline U2cs & pre-Tmr & BED & $\mathrm{GL}$ & VTA & TM-LVTA & 728 & 222.0 & $3,797.6$ & $1,157.5$ \\
\hline U2cs & Tw & BED & $\mathrm{GL}$ & VTA & TM-LVTA & 799 & 243.5 & $3,727.0$ & $1,136.0$ \\
\hline U2cs & Tc & BED & GL & VTA & TM-LVTA & 851 & 259.4 & $3,674.9$ & $1,120.1$ \\
\hline U2cs & Tbgb & BED & $\mathrm{GL}$ & VTA & TM-LVTA & 1,063 & 324.0 & $3,462.9$ & $1,055.5$ \\
\hline U2cs & Tn & BED & $\mathrm{GL}$ & VTA & TM-LVTA & 1,099 & 335.0 & $3,426.8$ & $1,044.5$ \\
\hline U2cs & Tub & BED & $\mathrm{GL}$ & VTA & TM-LVTA & 1,421 & 433.0 & $3,105.3$ & 946.5 \\
\hline U2cs & Ton2 & BED & GL & VTA & TM-LVTA & 1,437 & 438.0 & $3,088.9$ & 941.5 \\
\hline U2ct & QTa & $\mathrm{AL}$ & $\mathrm{nr}$ & $\mathrm{AA}$ & $\mathrm{AA}$ & 0 & 0.0 & $4,509.0$ & $1,374.3$ \\
\hline U2ct & $\mathrm{Tmr}$ & NWT & $\mathrm{GL}$ & VTA & TM-LVTA & 892 & 271.9 & $3,617.0$ & $1,102.5$ \\
\hline U2ct & Tmrh & BED & $\mathrm{GL}$ & VTA & TM-LVTA & 938 & 285.9 & $3,571.0$ & $1,088.4$ \\
\hline U2ct & $\mathrm{Tp}$ & BED & $\mathrm{GL}$ & VTA & TM-LVTA & 979 & 298.4 & $3,530.0$ & $1,075.9$ \\
\hline U2ct & Th & BED & $\mathrm{GL}$ & VTA & TM-LVTA & 1,079 & 328.9 & $3,430.0$ & $1,045.5$ \\
\hline U2ct & Tw & BED & $\mathrm{GL}$ & VTA & TM-LVTA & 1,145 & 349.0 & $3,364.0$ & $1,025.3$ \\
\hline U2ct & $\mathrm{Tc}$ & BED & GL & VTA & TM-LVTA & 1,178 & 359.1 & $3,331.0$ & $1,015.3$ \\
\hline U2ct & Tbgb & BED & GL & VTA & TM-LVTA & 1,430 & 435.9 & $3,079.0$ & 938.5 \\
\hline U2ct & Tn & BED & $\mathrm{GL}$ & VTA & TM-LVTA & 1,480 & 451.1 & $3,029.0$ & 923.2 \\
\hline U2cu & QTa & $\mathrm{AL}$ & $\mathrm{nr}$ & AA & AA & 0 & 0.0 & $4,525.9$ & $1,379.5$ \\
\hline
\end{tabular}


Table A-2

Geologic and Hydrostratigraphic Drill hole Database for the Rainier Mesa-Shoshone Mountain Model Area (vertical drill holes only)

\begin{tabular}{|c|c|c|c|c|c|c|c|c|c|}
\hline Hole Name & Strat $^{1}$ & Lith $^{2}$ & Major Alt. ${ }^{3}$ & $\mathrm{HGU}^{4}$ & $H_{S U^{5}}$ & \begin{tabular}{|c|}
$\begin{array}{c}\text { Depth Top } \\
\text { (ft) }\end{array}$ \\
\end{tabular} & $\begin{array}{c}\text { Depth } \\
\text { Top }^{6}(\mathrm{~m}) \\
\end{array}$ & \begin{tabular}{|c|}
$\begin{array}{c}\text { Elev. Top } \\
\text { (ft) }\end{array}$ \\
\end{tabular} & $\begin{array}{c}\begin{array}{c}\text { Elev. Top } \\
\text { (m) }\end{array} \\
\end{array}$ \\
\hline U2cu & pre-Tmr & BED & 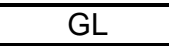 & VTA & TM-LVTA & 638 & 194.5 & $3,887.8$ & $1,185.0$ \\
\hline U2cu & Tw & BED & $\overline{G L}$ & VTA & TM-LVTA & 664 & 202.4 & $3,861.9$ & $1,177.1$ \\
\hline U2cu & Tc & BED & $\mathrm{GL}$ & VTA & TM-LVTA & 704 & 214.6 & $3,821.8$ & $1,164.9$ \\
\hline U2cu & Tbgb & BED & $\mathrm{GL}$ & VTA & TM-LVTA & 936 & 285.3 & $3,589.9$ & $1,094.2$ \\
\hline U2cu & $\mathrm{Tn}$ & BED & $\overline{G L}$ & VTA & TM-LVTA & 980 & 298.7 & $3,545.9$ & $1,080.8$ \\
\hline U2cu & Tub & BED & $\mathrm{GL}$ & VTA & TM-LVTA & 1,280 & 390.1 & $3,246.0$ & 989.4 \\
\hline U2cu & Ton2 & BED & $\mathrm{GL}$ & VTA & TM-LVTA & 1,305 & 397.8 & $3,220.8$ & 981.7 \\
\hline U4as & QTa & $\mathrm{AL}$ & $\mathrm{nr}$ & AA & AA & 0 & 0.0 & $4,487.9$ & $1,367.9$ \\
\hline U4as & Tma & WT & $\mathrm{GL}$ & VTA & TM-UVTA & 400 & 122.0 & $4,087.6$ & $1,245.9$ \\
\hline U4as & Tmab & BED & $\overline{G L}$ & VTA & TM-UVTA & 427 & 130.0 & $4,061.4$ & $1,237.9$ \\
\hline U4as & $\mathrm{Tmr}$ & WT & $\mathrm{GL}$ & WTA & TM-WTA & 449 & 137.0 & $4,038.4$ & $1,230.9$ \\
\hline U4as & $\mathrm{Tmr}$ & VT & DV & WTA & TM-WTA & 453 & 138.0 & $4,035.1$ & $1,229.9$ \\
\hline U4as & $\mathrm{Tmr}$ & WT & $\mathrm{GL}$ & WTA & TM-WTA & 472 & 144.0 & $4,015.5$ & $1,223.9$ \\
\hline U4as & $\mathrm{Tmr}$ & NWT & $\mathrm{GL}$ & VTA & TM-LVTA & 673 & 205.1 & $3,814.9$ & $1,162.8$ \\
\hline U4as & pre-Tmr & BED & $\mathrm{GL}$ & VTA & TM-LVTA & 787 & 240.0 & $3,700.5$ & $1,127.9$ \\
\hline U4as & Tw & BED & $\mathrm{GL}$ & VTA & TM-LVTA & 1,024 & 312.0 & $3,464.3$ & $1,055.9$ \\
\hline U4as & Tc & BED & $\mathrm{GL}$ & VTA & TM-LVTA & 1,066 & 325.0 & $3,421.6$ & $1,042.9$ \\
\hline U4as & Tbgb & BED & $\mathrm{GL}$ & VTA & TM-LVTA & 1,312 & 400.0 & $3,175.6$ & 967.9 \\
\hline U4as & $\mathrm{Tn}$ & BED & $\overline{G L}$ & VTA & TM-LVTA & 1,352 & 412.0 & $3,136.2$ & 955.9 \\
\hline U4at & QTa & $\mathrm{AL}$ & $\mathrm{nr}$ & $\mathrm{AA}$ & $\mathrm{AA}$ & 0 & 0.0 & $4,479.0$ & $1,365.2$ \\
\hline U4at & Tma & NWT & $\overline{G L}$ & VTA & TM-UVTA & 344 & 105.0 & $4,134.5$ & $1,260.2$ \\
\hline U4at & Tmab & BED & $\mathrm{GL}$ & VTA & TM-UVTA & 384 & 117.0 & $4,095.0$ & $1,248.2$ \\
\hline U4at & $\mathrm{Tmr}$ & WT & DV & WTA & TM-WTA & 407 & 124.0 & $4,072.2$ & $1,241.2$ \\
\hline U4at & $\mathrm{Tmr}$ & VT & $\mathrm{GL}$ & WTA & TM-WTA & 420 & 128.0 & $4,059.1$ & $1,237.2$ \\
\hline U4at & Tmr & WT & DV & WTA & TM-WTA & 433 & 132.0 & $4,045.9$ & $1,233.2$ \\
\hline U4at & $\mathrm{Tmr}$ & NWT & $\overline{G L}$ & VTA & TM-LVTA & 669 & 203.9 & $3,810.0$ & $1,161.3$ \\
\hline U4at & pre-Tmr & BED & $\mathrm{GL}$ & VTA & TM-LVTA & 751 & 229.0 & $3,727.7$ & $1,136.2$ \\
\hline U4at & Tw & BED & $\mathrm{GL}$ & VTA & TM-LVTA & 974 & 297.0 & $3,504.6$ & $1,068.2$ \\
\hline U4at & Tc & BED & $\mathrm{GL}$ & VTA & TM-LVTA & 1,056 & 322.0 & $3,422.6$ & $1,043.2$ \\
\hline U4at & Tbgb & BED & $\mathrm{GL}$ & VTA & TM-LVTA & 1,332 & 406.0 & $3,147.0$ & 959.2 \\
\hline U4at & $\mathrm{Tn}$ & BED & ZE & $\mathrm{TCU}$ & LTCU & 1,378 & 420.0 & $3,101.1$ & 945.2 \\
\hline UE2s & QTa & $\mathrm{AL}$ & $\mathrm{nr}$ & AA & AA & 0 & 0.0 & $4,583.0$ & $1,396.9$ \\
\hline UE2s & $\mathrm{Tmr}$ & NWT & $\overline{G L}$ & VTA & TM-LVTA & 840 & 256.0 & $3,743.1$ & $1,140.9$ \\
\hline UE2s & pre-Tmr & BED & $\mathrm{GL}$ & VTA & TM-LVTA & 1,001 & 305.0 & $3,582.3$ & $1,091.9$ \\
\hline UE2s & Tbg & BED & $\mathrm{GL}$ & VTA & TM-LVTA & 1,339 & 408.0 & $3,244.4$ & 988.9 \\
\hline UE2s & $\mathrm{Tn}$ & BED & $\mathrm{GL}$ & VTA & TM-LVTA & 1,421 & 433.0 & $3,162.4$ & 963.9 \\
\hline UE2s & $\mathrm{Pz}$ & DM & $\mathrm{N} / \mathrm{A}$ & $\mathrm{CA}$ & LCA3 & 1,736 & 529.0 & $2,847.4$ & 867.9 \\
\hline UE4ac & QTa & $\mathrm{AL}$ & $\mathrm{nr}$ & $\mathrm{AA}$ & AA & 0 & 0.0 & $4,471.0$ & $1,362.8$ \\
\hline UE4ac & $\mathrm{Tmr}$ & NWT & $\mathrm{GL}$ & VTA & TM-LVTA & 525 & 160.0 & $3,946.1$ & $1,202.8$ \\
\hline UE4ac & pre-Tmr & BED & $\mathrm{GL}$ & VTA & TM-LVTA & 705 & 215.0 & $3,765.6$ & $1,147.8$ \\
\hline UE4ac & Tw & BED & $\mathrm{GL}$ & VTA & TM-LVTA & 953 & 290.5 & $3,517.9$ & $1,072.3$ \\
\hline UE4ac & Tc & BED & $\mathrm{GL}$ & VTA & TM-LVTA & 997 & 303.9 & $3,474.0$ & $1,058.9$ \\
\hline UE4ac & Tbgb & BED & $\mathrm{GL}$ & VTA & TM-LVTA & 1,142 & 348.0 & $3,329.3$ & $1,014.8$ \\
\hline UE4ac & $\mathrm{Tn}$ & BED & $\mathrm{GL}$ & VTA & TM-LVTA & 1,175 & 358.0 & $3,296.5$ & $1,004.8$ \\
\hline UE4ac & To & BED & AR & TCU & ATCU & 1,422 & 433.4 & $3,049.1$ & 929.4 \\
\hline UE4ac & $\mathrm{Pz}$ & DM & na & $\mathrm{CA}$ & LCA3 & 1,565 & 477.0 & $2,906.0$ & 885.8 \\
\hline WW8 & Tmrr & DWT & GL, DV & WTA & TM-WTA & 0 & 0 & 5695 & $1,735.8$ \\
\hline WW8 & Trl & NWT & $\mathrm{ZC}$ & TCU & BRA & 152 & 46.3 & $5,543.0$ & $1,689.5$ \\
\hline WW8 & Tbq & LA & DV & LFA & BRA & 792 & 241.4 & $4,903.0$ & $1,494.4$ \\
\hline WW8 & Tbq & NWT & $Z C$ & TCU & BRA & 1128 & 343.8 & $4,567.0$ & $1,392.0$ \\
\hline WW8 & Tbq & LA & DV & LFA & BRA & 1276 & 388.9 & $4,419.0$ & $1,346.9$ \\
\hline WW8 & Tbq & MWT & DV & WTA & BRA & 1642 & 500.5 & $4,053.0$ & $1,235.4$ \\
\hline WW8 & Tbq & LA & DV & LFA & BRA & 1689 & 514.8 & $4,006.0$ & $1,221.0$ \\
\hline WW8 & Toy & BED & GL, ZE & VTA & OSBCU & 2010 & 612.6 & $3,685.0$ & $1,123.2$ \\
\hline WW8 & Toy & PWT & ZE & WTA & OSBCU & 2248 & 685.2 & $3,447.0$ & $1,050.6$ \\
\hline WW8 & Toy & BED & $\overline{Z E}$ & $\overline{T C U}$ & OSBCU & 2351 & 716.6 & $3,344.0$ & $1,019.3$ \\
\hline
\end{tabular}


Table A-2

Geologic and Hydrostratigraphic Drill hole Database for the Rainier Mesa-Shoshone Mountain Model Area (vertical drill holes only)

\begin{tabular}{|c|c|c|c|c|c|c|c|c|c|}
\hline Hole Name & Strat $^{1}$ & Lith $^{2}$ & Major Alt. ${ }^{3}$ & $H_{G}{ }^{4}$ & $\mathrm{HSU}^{5}$ & \begin{tabular}{|c|}
$\begin{array}{c}\text { Depth Top } \\
6 \\
(\mathrm{ft})\end{array}$ \\
\end{tabular} & $\begin{array}{c}\text { Depth } \\
\operatorname{Top}^{6}(\mathrm{~m}) \\
\end{array}$ & \begin{tabular}{|c|}
$\begin{array}{c}\text { Elev. Top } \\
\end{array}$ \\
(ft)
\end{tabular} & \begin{tabular}{|c|}
$\begin{array}{c}\text { Elev. Top } \\
\text { (m) }\end{array}$ \\
\end{tabular} \\
\hline WW8 & Tor & BED & $\overline{Z Z E}$ & TCU & OSBCU & 2500 & 762.0 & $3,195.0$ & 973.8 \\
\hline WW8 & Tor & MWT & DV & WTA & RVA & 2741 & 835.5 & $2,954.0$ & 900.4 \\
\hline WW8 & Tor & BED & ZE & TCU & RVA & 3721 & $1,134.2$ & $1,974.0$ & 601.7 \\
\hline WW8 & Tot & BED & ZE & TCU & RVA & 3800 & $1,158.2$ & $1,895.0$ & 577.6 \\
\hline WW8 & Tot & PWT & DV & WTA & RVA & 3888 & $1,185.1$ & $1,807.0$ & 550.8 \\
\hline WW8 & Tot & DWT & DV & WTA & RVA & 4073 & $1,241.5$ & $1,622.0$ & 494.4 \\
\hline WW8 & Tot & BED & ZE & TCU & LTCU1 & 5040 & $1,536.2$ & 655.0 & 199.6 \\
\hline WW8 & $T \ln$ & BED & $\mathrm{AR}$ & TCU & ATCU & 5280 & $1,609.3$ & 415.0 & 126.5 \\
\hline WW8 & $\mathrm{nr}$ & $\mathrm{nr}$ & $\mathrm{nr}$ & $\mathrm{nr}$ & ATCU & 5490 & $1,673.4$ & 205.0 & 62.5 \\
\hline ER-12-1 & QTa & $\mathrm{AL}$ & $\mathrm{nr}$ & AA & $\mathrm{AA}$ & 0 & 0.0 & $5,818.0$ & $1,773.3$ \\
\hline ER-12-1 & $\mathrm{Pz}$ & $\mathrm{DM}$ & na & $\mathrm{CA}$ & LCA3 & 28 & 8.5 & $5,790.0$ & $1,764.8$ \\
\hline ER-12-1 & $\mathrm{Mc}$ & $\mathrm{SH}$ & na & $\mathrm{SCU}$ & UCCU & 1,027 & 313.0 & $4,791.0$ & $1,460.3$ \\
\hline ER-12-1 & $\mathrm{Pz}$ & DM & na & $\mathrm{CA}$ & LCA & 2,870 & 874.8 & $2,948.0$ & 898.6 \\
\hline ER-12-2 & QTa & AA & $\mathrm{nr}$ & AA & AA & 0 & 0.0 & $4,705.3$ & $1,434.2$ \\
\hline ER-12-2 & Toy & NWT & ZE & TCU & OSBCU & 450 & 137.2 & $4,255.3$ & $1,297.0$ \\
\hline ER-12-2 & Ton1 & BED & ZE & TCU & OSBCU & 498 & 151.8 & $4,207.3$ & $1,282.4$ \\
\hline ER-12-2 & Tor & MWT & DV & WTA & RVA & 512 & 156.1 & $4,193.3$ & $1,278.1$ \\
\hline ER-12-2 & Tor & PWT & DV & WTA & RVA & 550 & 167.6 & $4,155.3$ & $1,266.5$ \\
\hline ER-12-2 & Tor & DWT & DV & WTA & RVA & 570 & 173.7 & $4,135.3$ & $1,260.4$ \\
\hline ER-12-2 & Tor & PWT & DV & WTA & RVA & 590 & 179.8 & $4,115.3$ & $1,254.3$ \\
\hline ER-12-2 & $\mathrm{Mc}$ & $\mathrm{SH}$ & na & $\mathrm{SCU}$ & $\mathrm{UCCU}$ & 610 & 185.9 & $4,095.3$ & $1,248.2$ \\
\hline ER-12-2 & $\mathrm{MDe}$ & SH/LS & na & $\mathrm{SCU}$ & UCCU & 1,560 & 475.5 & $3,145.3$ & 958.7 \\
\hline ER-12-2 & $\mathrm{MDe}$ & $\mathrm{SH}$ & na & $\mathrm{SCU}$ & UCCU & 1,890 & 576.1 & $2,815.3$ & 858.1 \\
\hline ER-12-2 & MDe & QTZ & na & $\mathrm{SCU}$ & UCCU & 2,530 & 771.1 & $2,175.3$ & 663.0 \\
\hline ER-12-2 & MDe & $\mathrm{SH}$ & na & $\mathrm{SCU}$ & $\mathrm{UCCU}$ & 3,508 & $1,069.2$ & $1,197.3$ & 364.9 \\
\hline ER-12-2 & $\mathrm{MDe}$ & QTZ & na & $\mathrm{SCU}$ & UCCU & 5,835 & $1,778.5$ & $-1,129.7$ & -344.3 \\
\hline ER-12-2 & MDe & SH/QTZ & na & $\mathrm{SCU}$ & UCCU & 6,150 & $1,874.5$ & $-1,444.7$ & -440.3 \\
\hline ER-12-2 & MDe & QTZ & na & $\mathrm{SCU}$ & UCCU & 6,546 & $1,995.2$ & $-1,840.7$ & -561.0 \\
\hline ER-12-3 & Tmrp & MWT & DV & WTA & TM-WTA & 0 & 0.0 & $7,390.8$ & $2,252.7$ \\
\hline ER-12-3 & Tmrp & PWT & DV & WTA & TM-WTA & 270 & 82.3 & $7,120.8$ & $2,170.4$ \\
\hline ER-12-3 & Tmrp & NWT & $\mathrm{GL}$ & VTA & TM-LVTA & 288 & 87.8 & $7,102.8$ & $2,164.9$ \\
\hline ER-12-3 & Tmrh & BED & $\mathrm{GL}$ & VTA & TM-LVTA & 346 & 105.5 & $7,044.8$ & $2,147.3$ \\
\hline ER-12-3 & $\mathrm{Tp}$ & BED & $\mathrm{GL}$ & VTA & TM-LVTA & 406 & 123.7 & $6,984.8$ & $2,129.0$ \\
\hline ER-12-3 & $\mathrm{Th}$ & BED & $\mathrm{GL}$ & VTA & TM-LVTA & 510 & 155.4 & $6,880.8$ & $2,097.3$ \\
\hline ER-12-3 & Tw & BED & $\mathrm{GL}$ & VTA & TM-LVTA & 611 & 186.2 & $6,779.8$ & $2,066.5$ \\
\hline ER-12-3 & Tc & BED & GL/AR & VTA & TM-LVTA & 636 & 193.9 & $6,754.8$ & $2,058.9$ \\
\hline ER-12-3 & $\mathrm{Tc}$ & BED/NWT & $\mathrm{GL}$ & VTA & TM-LVTA & 716 & 218.2 & $6,674.8$ & $2,034.5$ \\
\hline ER-12-3 & $\mathrm{Tc}$ & BED & ZE & TCU & UTCU1 & 955 & 291.1 & $6,435.8$ & $1,961.6$ \\
\hline ER-12-3 & Tbd & BED & ZE & $\mathrm{TCU}$ & UTCU1 & 1,040 & 317.0 & $6,350.8$ & $1,935.7$ \\
\hline ER-12-3 & Tbg & MWT/DWT & DV & WTA & BRA & 1,085 & 330.7 & $6,305.8$ & $1,922.0$ \\
\hline ER-12-3 & Tbg & BED & ZE & $\mathrm{TCU}$ & LTCU & 1,143 & 348.4 & $6,247.8$ & $1,904.3$ \\
\hline ER-12-3 & Tn4K & BED & ZE & TCU & LTCU & 1,250 & 381.0 & $6,140.8$ & $1,871.7$ \\
\hline ER-12-3 & Tn4J & BED & $\mathrm{ZE}$ & TCU & LTCU & 1,354 & 412.7 & $6,036.8$ & $1,840.0$ \\
\hline ER-12-3 & $\mathrm{Tn} 4 \mathrm{H}$ & BED & ZE & TCU & LTCU & 1,390 & 423.7 & $6,000.8$ & $1,829.0$ \\
\hline ER-12-3 & Tn4G & BED & ZE & $\mathrm{TCU}$ & LTCU & 1,438 & 438.3 & $5,952.8$ & $1,814.4$ \\
\hline ER-12-3 & Tn4AF & BED & ZE & TCU & LTCU & 1,450 & 442.0 & $5,940.8$ & $1,810.8$ \\
\hline ER-12-3 & Tn3D & BED & ZE & TCU & LTCU & 1,588 & 484.0 & $5,802.8$ & $1,768.7$ \\
\hline ER-12-3 & Tn3BC & BED & ZE & TCU & LTCU & 1,648 & 502.3 & $5,742.8$ & $1,750.4$ \\
\hline ER-12-3 & Tn3A & BED & ZE & TCU & LTCU & 1,728 & 526.7 & $5,662.8$ & $1,726.0$ \\
\hline ER-12-3 & Tub & NWT & ZE & $\mathrm{TCU}$ & LTCU & 1,791 & 545.9 & $5,599.8$ & $1,706.8$ \\
\hline ER-12-3 & Ton2 & BED & ZE & TCU & OSBCU & 1,809 & 551.4 & $5,581.8$ & $1,701.3$ \\
\hline ER-12-3 & Tot & NWT & ZE & $\mathrm{TCU}$ & OSBCU & 1,986 & 605.3 & $5,404.8$ & $1,647.4$ \\
\hline ER-12-3 & To & BED & ZE/AR & TCU & ATCU & 2,179 & 664.2 & $5,211.8$ & $1,588.6$ \\
\hline ER-12-3 & $\mathrm{Pz}$ & DM & $\mathrm{N} / \mathrm{A}$ & $\mathrm{CA}$ & LCA3 & 2,210 & 673.6 & $5,180.8$ & $1,579.1$ \\
\hline ER-12-3 & $\mathrm{Pz}$ & LS & $\mathrm{N} / \mathrm{A}$ & $\mathrm{CA}$ & LCA3 & 4,102 & $1,250.3$ & $3,288.8$ & $1,002.4$ \\
\hline ER-12-4 & Tmrp & MWT & DV & WTA & TM WTA & 0 & 0.0 & $6,883.7$ & $2,098.2$ \\
\hline
\end{tabular}


Table A-2

Geologic and Hydrostratigraphic Drill hole Database for the Rainier Mesa-Shoshone Mountain Model Area (vertical drill holes only)

\begin{tabular}{|c|c|c|c|c|c|c|c|c|c|}
\hline Hole Name & Strat $^{1}$ & Lith $^{2}$ & Major Alt. ${ }^{3}$ & $H G U^{4}$ & $\mathrm{HSU}^{5}$ & $\begin{array}{c}\text { Depth Top } \\
\text { (ft) }\end{array}$ & $\begin{array}{c}\text { Depth } \\
\operatorname{Top}^{6}(\mathrm{~m})\end{array}$ & \begin{tabular}{|c|}
$\begin{array}{c}\text { Elev. Top } \\
\end{array}$ \\
(ft)
\end{tabular} & \begin{tabular}{|c}
$\begin{array}{c}\text { Elev. Top } \\
\text { (m) }\end{array}$ \\
\end{tabular} \\
\hline ER-12-4 & Tmrp & PWT & $\overline{D D V / G L}$ & "WTA & TM WTA & 272 & 82.9 & $6,611.7$ & $2,015.2$ \\
\hline ER-12-4 & Tmrp & NWT & $\mathrm{GL}$ & VTA & TM LVTA & 296 & 90.2 & $6,587.7$ & $2,007.9$ \\
\hline ER-12-4 & Tmrh & BED & $\overline{G L}$ & VTA & TM LVTA & 348 & 106.1 & $6,535.7$ & $1,992.1$ \\
\hline ER-12-4 & $\mathrm{Tp}$ & BED & $\mathrm{GL}$ & VTA & TM LVTA & 394 & 120.1 & $6,489.7$ & $1,978.1$ \\
\hline ER-12-4 & Th & BED & $\mathrm{GL}$ & VTA & TM LVTA & 452 & 137.8 & $6,431.7$ & $1,960.4$ \\
\hline ER-12-4 & $\mathrm{Tc}$ & BED & GL/ZE & VTA & TM LVTA & 536 & 163.4 & $6,347.7$ & $1,934.8$ \\
\hline ER-12-4 & Tbd & BED & $\mathrm{GL}$ & VTA & TM LVTA & 632 & 192.6 & $6,251.7$ & $1,905.5$ \\
\hline ER-12-4 & Tbg & LHR & $\mathrm{GL}$ & VTA & TM LVTA & 720 & 219.5 & $6,163.7$ & $1,878.7$ \\
\hline ER-12-4 & Tbg & LHR & GL/SI & WTA & BRA & 730 & 222.5 & $6,153.7$ & $1,875.6$ \\
\hline ER-12-4 & $\overline{\mathrm{Tbg}}$ & DWT & DV & WTA & BRA & 768 & 234.1 & $6,115.7$ & $1,864.1$ \\
\hline ER-12-4 & Tbgb & BED & GL/ZE & VTA & LVTA1 & 810 & 246.9 & $6,073.7$ & $1,851.3$ \\
\hline ER-12-4 & Tbgb & BED & GL/ZE & VTA & LVTA1 & 848 & 258.5 & $6,035.7$ & $1,839.7$ \\
\hline ER-12-4 & Tn4k & BED & ZE & TCU & BRCU & 960 & 292.6 & $5,923.7$ & $1,805.5$ \\
\hline ER-12-4 & Tn4J & BED & ZE & TCU & BRCU & 1,080 & 329.2 & $5,803.7$ & $1,769.0$ \\
\hline ER-12-4 & Tn4g & BED & ZE & TCU & BRCU & 1,127 & 343.5 & $5,756.7$ & $1,754.6$ \\
\hline ER-12-4 & Tn4f & BED & ZE & TCU & BRCU & 1,152 & 351.1 & $5,731.7$ & $1,747.0$ \\
\hline ER-12-4 & Tn4abcde & BED & ZE & $\overline{T C U}$ & BRCU & 1,202 & 366.4 & $5,681.7$ & $1,731.8$ \\
\hline ER-12-4 & Tn3bcd & BED & ZE & TCU & BRCU & 1,325 & 403.9 & $5,558.7$ & $1,694.3$ \\
\hline ER-12-4 & Tn3A & BED & ZE/AR & TCU & BRCU & 1,447 & 441.0 & $5,436.7$ & $1,657.1$ \\
\hline ER-12-4 & Tub & NWT/PWT & ZE & TCU & BRCU & 1,488 & 453.5 & $5,395.7$ & $1,644.6$ \\
\hline ER-12-4 & Tub & BED & ZE & TCU & BRCU & 1,584 & 482.8 & $5,299.7$ & $1,615.3$ \\
\hline ER-12-4 & Ton2 & BED & ZE & TCU & OSBCU & 1,590 & 484.6 & $5,293.7$ & $1,613.5$ \\
\hline ER-12-4 & Toy & PWT & ZE & TCU & OSBCU & 1,690 & 515.1 & $5,193.7$ & $1,583.0$ \\
\hline ER-12-4 & Toy & NWT & ZE & TCU & OSBCU & 1,746 & 532.2 & $5,137.7$ & $1,566.0$ \\
\hline ER-12-4 & Ton1 & BED & ZE/AR & TCU & OSBCU & 1,891 & 576.4 & $4,992.7$ & $1,521.8$ \\
\hline ER-12-4 & To & BED & ZE & TCU & OSBCU & 2,060 & 627.9 & $4,823.7$ & $1,470.3$ \\
\hline ER-12-4 & Tlt & $\mathrm{PCL}$ & ZE/AR & TCU & ATCU & 2,212 & 674.2 & $4,671.7$ & $1,423.9$ \\
\hline ER-12-4 & Tlt & $\mathrm{PCL}$ & ZE/AR & TCU & ATCU & 2,240 & 682.8 & $4,643.7$ & $1,415.4$ \\
\hline ER-12-4 & $\mathrm{Pz}$ & $\mathrm{DM}$ & na & $\mathrm{CA}$ & LCA3 & 2,488 & 758.3 & $4,395.7$ & $1,339.8$ \\
\hline U12b.07-2 & $\mathrm{Tmr}$ & MWT/DWT & $\mathrm{nr}$ & WTA & TM-WTA & 0 & 0.0 & $7,378.3$ & $2,248.9$ \\
\hline U12b.07-2 & $\mathrm{Tmr}$ & PWT/NWT & $\mathrm{nr}$ & VTA & TM-LVTA & 250 & 76.2 & $7,128.3$ & $2,172.7$ \\
\hline U12b.07-2 & $\begin{array}{l}\text { pre-Tmr, } \\
\text { post-Tbg }\end{array}$ & BED/RWT & GL & VTA & TM-LVTA & 370 & 112.8 & $7,008.3$ & $2,136.1$ \\
\hline U12b.07-2 & Tbg & FB & $\mathrm{nr}$ & VTA & TM-LVTA & 900 & 274.3 & $6,478.3$ & $1,974.6$ \\
\hline U12b.07-2 & Tbgb & BED & GL? & VTA & TM-LVTA & 930 & 283.5 & $6,448.3$ & $1,965.4$ \\
\hline U12b.07-2 & Tn4 & BED/RWT & $Z C$ & TCU & LTCU & 1,035 & 315.5 & $6,343.3$ & $1,933.4$ \\
\hline U12b.07-2 & Tn3 & BED/RWT & ZC & $\mathrm{TCU}$ & LTCU & 1,475 & 449.6 & $5,903.3$ & $1,799.3$ \\
\hline U12b.07-2 & Tub & NWT/PWT & ZE & TCU & LTCU & 1,700 & 518.2 & $5,678.3$ & $1,730.7$ \\
\hline U12b.07-2 & Ton2 & BED/RWT & $Z C$ & $\mathrm{TCU}$ & OSBCU & 1,715 & 522.7 & $5,663.3$ & $1,726.2$ \\
\hline U12b.07-2 & Toy & NWT/PWT & ZE & $\mathrm{TCU}$ & OSBCU & 1,910 & 582.2 & $5,468.3$ & $1,666.7$ \\
\hline U12b.07-2 & Ton1 & BED/RWT & $Z C$ & TCU & OSBCU & 2,198 & 670.0 & $5,180.3$ & $1,578.9$ \\
\hline U12b.07-2 & Tor & PWT/DWT & DV & WTA & RVA & 2,313 & 705.0 & $5,065.3$ & $1,543.9$ \\
\hline U12b.07-2 & Ddl & DM & na & $\mathrm{CA}$ & LCA3 & 2,420 & 737.6 & $4,958.3$ & $1,511.3$ \\
\hline U12b.07-1 & $\mathrm{Tmr}$ & MWT/DWT & $\mathrm{nr}$ & WTA & TM-WTA & 0 & 0.0 & $7,480.0$ & $2,279.9$ \\
\hline U12b.07-1 & $\mathrm{Tmr}$ & PWT/NWT & $\mathrm{nr}$ & VTA & TM-LVTA & 210 & 64.0 & $7,270.0$ & $2,215.9$ \\
\hline U12b.07-1 & $\begin{array}{l}\text { pre-Tmr, } \\
\text { post-Tbg }\end{array}$ & BED/RWT & GL & VTA & TM-LVTA & 300 & 91.4 & $7,180.0$ & $2,188.5$ \\
\hline U12b.07-1 & Tbg & PWT/NWT & $\mathrm{nr}$ & VTA & TM-LVTA & 718 & 218.8 & $6,762.0$ & $2,061.1$ \\
\hline U12b.07-1 & Tbgb & BED & $Z C$ & $\mathrm{TCU}$ & LTCU & 820 & 249.9 & $6,660.0$ & $2,030.0$ \\
\hline U12b\#2/UCRL-2 & $\begin{array}{l}\text { pre-Tmr, } \\
\text { post-Tbg }\end{array}$ & BED/RWT & ZC & $\mathrm{TCU}$ & LTCU & 0 & 0.0 & 6,795 & $2,071.1$ \\
\hline U12b\#2/UCRL-2 & Tbgb & BED & $Z C$ & $\mathrm{TCU}$ & LTCU & 125 & 38.1 & $6,670.0$ & $2,033.0$ \\
\hline U12b\#2/UCRL-2 & Tn4 & BED/RWT & $Z C$ & $\mathrm{TCU}$ & LTCU & 243 & 74.1 & $6,552.0$ & $1,997.0$ \\
\hline U12b\#2/UCRL-2 & Tn3 & BED/RWT & $Z C$ & $\mathrm{TCU}$ & LTCU & 562 & 171.3 & $6,233.0$ & $1,899.8$ \\
\hline U12b\#2/UCRL-2 & Ton2 & BED/RWT & $Z C$ & $\mathrm{TCU}$ & OSBCU & 715 & 217.9 & $6,080.0$ & $1,853.2$ \\
\hline U12b\#2/UCRL-2 & To & NWT? & $Z C$ & $\mathrm{TCU}$ & OSBCU & 1,000 & 304.8 & $5,795.0$ & $1,766.3$ \\
\hline
\end{tabular}


Table A-2

Geologic and Hydrostratigraphic Drill hole Database for the Rainier Mesa-Shoshone Mountain Model Area (vertical drill holes only)

\begin{tabular}{|c|c|c|c|c|c|c|c|c|c|}
\hline Hole Name & Strat $^{1}$ & Lith $^{2}$ & Major Alt. ${ }^{3}$ & $\mathrm{HGU}^{4}$ & $\mathrm{HSU}^{5}$ & \begin{tabular}{|c}
$\begin{array}{c}\text { Depth Top } \\
\text { (ft) }\end{array}$ \\
\end{tabular} & $\begin{array}{c}\text { Depth } \\
\operatorname{Top}^{6}(\mathrm{~m}) \\
\end{array}$ & \begin{tabular}{|c|}
$\begin{array}{c}\text { Elev. } \text { Top }^{7} \\
\text { (ft) }\end{array}$ \\
\end{tabular} & $\begin{array}{c}\text { Elev. Top } \\
\text { (m) } \\
\end{array}$ \\
\hline U12b\#3/UCRL-3 & $\overline{\mathrm{Tmr}}$ & "MWT/DWT & $\overline{\mathrm{nr}}$ & WTA & TM-WTA & 0 & 0.0 & 7,495 & $2,284.5$ \\
\hline U12b\#3/UCRL-3 & $\mathrm{Tmr}$ & PWT/NWT & $\mathrm{nr}$ & VTA & TM-LVTA & 253 & 77.1 & $7,242.0$ & $2,207.4$ \\
\hline U12b\#3/UCRL-3 & $\begin{array}{l}\text { pre-Tmr, } \\
\text { post-Tbg }\end{array}$ & BED/RWT & GL & VTA & TM-LVTA & 272 & 82.9 & $7,223.0$ & $2,201.6$ \\
\hline U12b\#3/UCRL-3 & $\begin{array}{l}\text { pre-Tmr, } \\
\text { post-Tbg }\end{array}$ & BED/RWT & ZC & TCU & UTCU1 & 856 & 260.9 & $6,639.0$ & $2,023.6$ \\
\hline U12b\#3/UCRL-3 & Tbg & MWT? & & WTA & BRA & 990 & 301.8 & $6,505.0$ & $1,982.7$ \\
\hline U12b\#3/UCRL-3 & Tbgb & BED & ZC & TCU & LTCU & 1,061 & 323.4 & $6,434.0$ & $1,961.1$ \\
\hline UE12g.10\#1 & $\mathrm{Tmr}$ & MWT & $\mathrm{nr}$ & WTA & TM-WTA & 0 & 0.0 & $7,528.27$ & $2,294.6$ \\
\hline UE12g.10\#1 & $\mathrm{Tmr}$ & DWT & $\mathrm{nr}$ & WTA & TM-WTA & 185 & 56.4 & $7,343.3$ & $2,238.2$ \\
\hline UE12g.10\#1 & $\mathrm{Tmr}$ & PWT & $\mathrm{nr}$ & VTA & TM-LVTA & 385 & 117.3 & $7,143.3$ & $2,177.3$ \\
\hline UE12g.10\#1 & $\mathrm{Tmr}$ & NWT & $\mathrm{nr}$ & VTA & TM-LVTA & 425 & 129.5 & $7,103.3$ & $2,165.1$ \\
\hline UE12g.10\#1 & Tc & BED & $\mathrm{GL}$ & VTA & TM-LVTA & 495 & 150.9 & $7,033.3$ & $2,143.7$ \\
\hline UE12g.10\#1 & Tc & NWT & $\mathrm{nr}$ & VTA & TM-LVTA & 599 & 182.6 & $6,929.3$ & $2,112.0$ \\
\hline UE12g.10\#1 & $\begin{array}{l}\text { pre-Tmr, } \\
\text { post-Tc }\end{array}$ & BED/RWT & GL & VTA & TM-LVTA & 660 & 201.2 & $6,868.3$ & $2,093.4$ \\
\hline UE12g.10\#1 & Tcbs & NWT & $\mathrm{nr}$ & VTA & TM-LVTA & 988 & 301.1 & $6,540.3$ & $1,993.5$ \\
\hline UE12g.10\#1 & Tcbs & MWT & $\mathrm{nr}$ & WTA & SWA & 1,025 & 312.4 & $6,503.3$ & $1,982.2$ \\
\hline UE12g.10\#1 & Tct & BED & ZC & TCU & UTCU1 & 1,095 & 333.8 & $6,433.3$ & $1,960.9$ \\
\hline UE12g.10\#1 & Tbg & MWT & $\mathrm{nr}$ & WTA & BRA & 1,300 & 396.2 & $6,228.3$ & $1,898.4$ \\
\hline UE12g.10\#1 & $\overline{T b g}$ & DWT & $\mathrm{nr}$ & WTA & $\overline{B R A}$ & 1,330 & 405.4 & $6,198.3$ & $1,889.2$ \\
\hline UE12g.10\#1 & Tbgb & BED & $\mathrm{ZC}$ & TCU & LTCU & 1,370 & 417.6 & $6,158.3$ & $1,877.0$ \\
\hline UE12g.10\#1 & Tn4 & BED/RWT & $\mathrm{ZC}$ & TCU & LTCU & 1,437 & 438.0 & $6,091.3$ & $1,856.6$ \\
\hline UE12g.10\#2 & $\mathrm{Tmr}$ & MWT & $\mathrm{nr}$ & WTA & TM-WTA & 0 & 0.0 & $7,576.9$ & $2,309.4$ \\
\hline UE12g.10\#2 & $\mathrm{Tmr}$ & DWT & $\mathrm{nr}$ & WTA & TM-WTA & 190 & 57.9 & $7,386.9$ & $2,251.5$ \\
\hline UE12g.10\#2 & $\mathrm{Tmr}$ & PWT & $\mathrm{nr}$ & VTA & TM-LVTA & 350 & 106.7 & $7,226.9$ & $2,202.8$ \\
\hline UE12g.10\#2 & $\mathrm{Tmr}$ & NWT & $\mathrm{nr}$ & VTA & TM-LVTA & 390 & 118.9 & $7,186.9$ & $2,190.6$ \\
\hline UE12g.10\#2 & $\begin{array}{c}\text { pre-Tmr, } \\
\text { post-Tc }\end{array}$ & BED & GL & VTA & TM-LVTA & 465 & 141.7 & $7,111.9$ & $2,167.7$ \\
\hline UE12g.10\#2 & Tc & PWT & $\mathrm{nr}$ & VTA & TM-LVTA & 574 & 175.0 & $7,002.9$ & $2,134.5$ \\
\hline UE12g.10\#2 & $\mathrm{TC}$ & BED/RWT & $\mathrm{GL}$ & VTA & TM-LVTA & 615 & 187.5 & $6,961.9$ & $2,122.0$ \\
\hline UE12g.10\#2 & Tc & BED/RWT & ZC & $\mathrm{TCU}$ & UTCU2 & 926 & 282.2 & $6,650.9$ & $2,027.2$ \\
\hline UE12g.10\#2 & Tcbs & NWT/PWT & $\mathrm{nr}$ & TCU & UTCU2 & 992 & 302.4 & $6,584.9$ & $2,007.1$ \\
\hline UE12g.10\#2 & Tcbs & MWT & $\mathrm{nr}$ & WTA & SWA & 1,010 & 307.8 & $6,566.9$ & $2,001.6$ \\
\hline UE12g.10\#2 & Tct & BED & $\mathrm{ZC}$ & TCU & UTCU1 & 1,060 & 323.1 & $6,516.9$ & $1,986.4$ \\
\hline UE12g.10\#2 & Tbg & MWT & $\mathrm{nr}$ & WTA & BRA & 1,296 & 395.0 & $6,280.9$ & $1,914.4$ \\
\hline UE12g.10\#2 & Tbg & DWT & $\mathrm{nr}$ & WTA & BRA & 1,310 & 399.3 & $6,266.9$ & $1,910.2$ \\
\hline UE12g.10\#2 & Tbgb & BED & $\mathrm{ZC}$ & TCU & LTCU & 1,364 & 415.7 & $6,212.9$ & $1,893.7$ \\
\hline UE12g.10\#3 & $\mathrm{Tmr}$ & MWT & $\mathrm{nr}$ & WTA & TM-WTA & 0 & 0.0 & $7,529.6$ & $2,295.0$ \\
\hline UE12g.10\#3 & $\mathrm{Tmr}$ & DWT & $\mathrm{nr}$ & WTA & TM-WTA & 175 & 53.3 & $7,354.6$ & $2,241.7$ \\
\hline UE12g.10\#3 & $\mathrm{Tmr}$ & PWT & $\mathrm{nr}$ & VTA & TM-LVTA & 294 & 89.6 & $7,235.6$ & $2,205.4$ \\
\hline UE12g.10\#3 & $\begin{array}{l}\text { pre-Tmr, } \\
\text { post-Tc }\end{array}$ & BED & GL & VTA & TM-LVTA & 387 & 118.0 & $7,142.6$ & $2,177.1$ \\
\hline UE12g.10\#3 & Tc & NWT & $\mathrm{nr}$ & VTA & TM-LVTA & 507 & 154.5 & $7,022.6$ & $2,140.5$ \\
\hline UE12g.10\#3 & Tc & BED/RWT & $\mathrm{GL}$ & VTA & TM-LVTA & 545 & 166.1 & $6,984.6$ & $2,128.9$ \\
\hline UE12g.10\#3 & Tc & BED & $\mathrm{ZC}$ & TCU & UTCU2 & 911 & 277.7 & $6,618.6$ & $2,017.4$ \\
\hline UE12g.10\#3 & Tcbs & NWT/PWT & $\mathrm{nr}$ & TCU & UTCU2 & 931 & 283.8 & $6,598.6$ & $2,011.3$ \\
\hline UE12g.10\#3 & Tcbs & MWT & $\mathrm{nr}$ & WTA & SWA & 954 & 290.8 & $6,575.6$ & $2,004.3$ \\
\hline UE12g.10\#3 & Tcbs & NWT & $\mathrm{nr}$ & WTA & SWA & 959 & 292.3 & $6,570.6$ & $2,002.7$ \\
\hline UE12g.10\#3 & Tc & BED & ZC & TCU & UTCU1 & 967 & 294.7 & $6,562.6$ & $2,000.3$ \\
\hline UE12g.10\#3 & Tbg & MWT/DWT & $\mathrm{nr}$ & WTA & BRA & 1,171 & 356.9 & $6,358.6$ & $1,938.1$ \\
\hline UE12g.10\#3 & Tbg & PWT & $\mathrm{nr}$ & $\mathrm{TCU}$ & LTCU & 1,185 & 361.2 & $6,344.6$ & $1,933.8$ \\
\hline UE12g.10\#3 & Tbgb & BED & $\mathrm{ZC}$ & $\mathrm{TCU}$ & LTCU & 1,194 & 363.9 & $6,335.6$ & $1,931.1$ \\
\hline UE12g.10\#4 & $\mathrm{Tmr}$ & MWT & $\mathrm{nr}$ & WTA & TM-WTA & 0 & 0.0 & $7,570.4$ & $2,307.5$ \\
\hline UE12g.10\#4 & $\mathrm{Tmr}$ & DWT & $\mathrm{nr}$ & WTA & TM-WTA & 185 & 56.4 & $7,385.4$ & $2,251.1$ \\
\hline UE12g.10\#4 & $\mathrm{Tmr}$ & PWT & $\mathrm{nr}$ & VTA & TM-LVTA & 350 & 106.7 & $7,220.4$ & $2,200.8$ \\
\hline
\end{tabular}


Table A-2

Geologic and Hydrostratigraphic Drill hole Database for the Rainier Mesa-Shoshone Mountain Model Area (vertical drill holes only)

\begin{tabular}{|c|c|c|c|c|c|c|c|c|c|}
\hline Hole Name & Strat $^{1}$ & Lith $^{2}$ & Major Alt. ${ }^{3}$ & $H G U^{4}$ & $\mathrm{HSU}^{5}$ & $\begin{array}{c}\text { Depth Top } \\
\text { (ft) }\end{array}$ & $\begin{array}{c}\text { Depth } \\
\operatorname{Top}^{6}(\mathrm{~m})\end{array}$ & $\begin{array}{c}\text { Elev. Top }{ }^{7} \\
\text { (ft) }\end{array}$ & \begin{tabular}{|c}
$\begin{array}{c}\text { Elev. Top } \\
\text { (m) }\end{array}$ \\
\end{tabular} \\
\hline UE12g.10\#4 & $\mathrm{Tmr}$ & NWT & $\mathrm{nr}$ & VTA & TM-LVTA & 395 & 120.4 & $7,175.4$ & $2,187.1$ \\
\hline UE12g.10\#4 & $\begin{array}{l}\text { pre-Tmr, } \\
\text { post-Tbg }\end{array}$ & BED & GL & VTA & TM-LVTA & 470 & 143.3 & $7,100.4$ & $2,164.2$ \\
\hline UE12g.10\#5 & $\begin{array}{l}\text { pre-Tmr, } \\
\text { post-Tbg }\end{array}$ & BED/RWT & ZC & $\mathrm{TCU}$ & UTCU1 & nd & nd & nd & nd \\
\hline UE12g.10\#5 & Tbg & MWT & $\mathrm{nr}$ & WTA & BRA & 1,301 & 396.5 & $6,270.4$ & $1,911.2$ \\
\hline UE12g.10\#5 & Tbg & DWT & $\mathrm{nr}$ & WTA & BRA & 1,305 & 397.8 & $6,266.4$ & $1,910.0$ \\
\hline UE12g.10\#5 & $\mathrm{Tbg}$ & MWT/PWT & $\mathrm{nr}$ & WTA & BRA & 1,364 & 415.7 & $6,207.4$ & $1,892.0$ \\
\hline UE12g.10\#5 & Tbgb & BED & $Z C$ & TCU & LTCU & 1,369 & 417.3 & $6,202.4$ & $1,890.5$ \\
\hline UE12g.10\#6 & $\mathrm{Tmr}$ & MWT & $\mathrm{nr}$ & WTA & TM-WTA & 0 & 0.0 & $7,554.9$ & $2,302.7$ \\
\hline UE12g.10\#6 & $\mathrm{Tmr}$ & DWT & $\mathrm{nr}$ & WTA & TM-WTA & 180 & 54.9 & $7,374.9$ & $2,247.9$ \\
\hline UE12g.10\#6 & $\mathrm{Tmr}$ & PWT & $\mathrm{nr}$ & VTA & TM-LVTA & 380 & 115.8 & $7,174.9$ & $2,186.9$ \\
\hline UE12g.10\#6 & $\mathrm{Tmr}$ & NWT & $\mathrm{nr}$ & VTA & TM-LVTA & 420 & 128.0 & $7,134.9$ & $2,174.7$ \\
\hline UE12g.10\#6 & $\begin{array}{l}\text { pre-Tmr, } \\
\text { post-Tc }\end{array}$ & BED & $\mathrm{GL}$ & VTA & TM-LVTA & 475 & 144.8 & $7,079.9$ & $2,158.0$ \\
\hline UE12g.10\#6 & Tc & NWT & $\mathrm{nr}$ & VTA & TM-LVTA & 585 & 178.3 & $6,969.9$ & $2,124.4$ \\
\hline UE12g.10\#6 & Tc & BED/RWT & $\mathrm{GL}$ & VTA & TM-LVTA & 620 & 189.0 & $6,934.9$ & $2,113.8$ \\
\hline UE12g.10\#6 & Tc & BED/RWT & ZC & TCU & UTCU2 & 859 & 261.8 & $6,695.9$ & $2,040.9$ \\
\hline UE12g.10\#6 & Tc & BED/RWT & $\mathrm{GL}$ & VTA & UTCU2 & 890 & 271.3 & $6,664.9$ & $2,031.5$ \\
\hline UE12g.10\#6 & Tc & BED/RWT & $Z C$ & $\overline{T C U}$ & UTCU2 & 955 & 291.1 & $6,599.9$ & $2,011.6$ \\
\hline UE12g.10\#6 & Tcbs & NWT & ZE & TCU & UTCU2 & 997 & 303.9 & $6,557.9$ & $1,998.8$ \\
\hline UE12g.10\#6 & Tcbs & MWT & $\mathrm{nr}$ & WTA & SWA & 1,016 & 309.7 & $6,538.9$ & $1,993.1$ \\
\hline UE12g.10\#6 & Tc & BED/RWT & $Z C$ & TCU & UTCU1 & 1,088 & 331.6 & $6,466.9$ & $1,971.1$ \\
\hline UE12g.10\#6 & Tbg & MWT & $\mathrm{nr}$ & WTA & BRA & 1,295 & 394.7 & $6,259.9$ & $1,908.0$ \\
\hline UE12g.10\#6 & Tbg & DWT & $\mathrm{nr}$ & WTA & BRA & 1,300 & 396.2 & $6,254.9$ & $1,906.5$ \\
\hline UE12g.10\#6 & Tbgb & BED & $\mathrm{nr}$ & $\mathrm{TCU}$ & LTCU & 1,347 & 410.6 & $6,207.9$ & $1,892.2$ \\
\hline U12e CH\#3 & $\mathrm{Tmr}$ & MWT/DWT & $\mathrm{nr}$ & WTA & TM-WTA & 0 & 0.0 & $7,573.0$ & $2,308.3$ \\
\hline U12e $\mathrm{CH} \# 3$ & $\mathrm{Tmr}$ & PWT/NWT & $\mathrm{nr}$ & VTA & TM-LVTA & 340 & 103.6 & $7,233.0$ & $2,204.6$ \\
\hline U12e CH\#3 & Tc & BED/RWT & $\mathrm{GL}$ & VTA & TM-LVTA & 400 & 121.9 & $7,173.0$ & $2,186.3$ \\
\hline U12e CH\#3 & Tcbs & NWT & $\mathrm{nr}$ & VTA & TM-LVTA & 690 & 210.3 & $6,883.0$ & $2,097.9$ \\
\hline U12e CH\#3 & Tc & BED/RWT & $Z C$ & TCU & LTCU & 780 & 237.7 & $6,793.0$ & $2,070.5$ \\
\hline U12e $\mathrm{CH} \# 3$ & Tbg & PWT & ZE & $\mathrm{TCU}$ & LTCU & 1,090 & 332.2 & $6,483.0$ & $1,976.0$ \\
\hline $\mathrm{U12e} \mathrm{CH} \# 3$ & Tbgb & BED & $Z C$ & TCU & LTCU & 1,105 & 336.8 & $6,468.0$ & $1,971.4$ \\
\hline U12e $\mathrm{CH} \# 3$ & Tn4 & BED/RWT & $Z C$ & $\overline{T C U}$ & LTCU & 1,250 & 381.0 & $6,323.0$ & $1,927.3$ \\
\hline U12e.04-32 & nd & nd & nd & nd & nd & 0 & 0.0 & $7,559.7$ & $2,304.2$ \\
\hline U12e.04-32 & $\begin{array}{l}\text { pre-Tmr, } \\
\text { post-Tc }\end{array}$ & BED/RWT & GL & VTA & TM-LVTA & 600 & 182.9 & $6,959.70$ & $2,121.30$ \\
\hline U12e.04-32 & Tcbs & NWT & & VTA & TM-LVTA & 810 & 246.9 & $6,749.7$ & $2,057.3$ \\
\hline U12e.04-32 & Tc & BED/RWT & $\mathrm{GL}$ & VTA & TM-LVTA & 819 & 249.6 & $6,740.9$ & $2,054.6$ \\
\hline U12e.04-32 & Tc & BED/RWT & $Z C$ & TCU & LTCU & 865 & 263.7 & $6,694.7$ & $2,040.5$ \\
\hline U12e.04-32 & $\mathrm{Tbg}$ & NWT & ZE & TCU & LTCU & 1,010 & 307.8 & $6,549.7$ & $1,996.3$ \\
\hline U12e.04-32 & Tbgb & BED & $\mathrm{GL}$ & VTA & LTCU & 1,015 & 309.4 & $6,544.7$ & $1,994.8$ \\
\hline U12e.04-32 & Tbgb & BED & $Z C$ & TCU & LTCU & 1,054 & 321.3 & $6,505.7$ & $1,982.9$ \\
\hline U12e.04-32 & Tn4 & BED/RWT & ZC & $\mathrm{TCU}$ & LTCU & 1,085 & 330.7 & $6,474.7$ & $1,973.5$ \\
\hline U12e.06-1 & Tc & BED/RWT & $\mathrm{GL}$ & VTA & TM-LVTA & 970 & 295.7 & $6,603.1$ & $2,012.6$ \\
\hline U12e.06-1 & Tbgb & BED & $Z C$ & $\mathrm{TCU}$ & LTCU & 1,194 & 363.9 & $6,379.1$ & $1,944.3$ \\
\hline U12e.06-1 & Tn4-To & BED/RWT & $Z C$ & $\mathrm{TCU}$ & LTCU & 1,280 & 390.1 & $6,293.1$ & $1,918.1$ \\
\hline U12e.06-1 & $\mathrm{TI}$ & $\mathrm{PCL}$ & ZM & $\mathrm{TCU}$ & ATCU & 2,380 & 725.4 & $5,193.1$ & $1,582.9$ \\
\hline U12e.06-1 & Ddg & $\mathrm{DM}$ & na & $\mathrm{CA}$ & LCA3 & 2,415 & 736.1 & $5,158.1$ & $1,572.2$ \\
\hline U12e.06 A & Tn4 & BED/RWT & $Z C$ & $\mathrm{TCU}$ & LTCU & 0 & 0.0 & $6,164.0$ & $1,878.8$ \\
\hline U12e.06 A & Tn3 & BED/RWT & $Z C$ & $\mathrm{TCU}$ & LTCU & 107 & 32.6 & $6,057.0$ & $1,846.2$ \\
\hline U12e.06 A & Ton2 & BED/RWT & $Z C$ & $\mathrm{TCU}$ & OSBCU & 338 & 103.0 & $5,826.0$ & $1,775.8$ \\
\hline U12e.06 A & Ton1 & BED/RWT & $Z C$ & $\mathrm{TCU}$ & OSBCU & 532 & 162.2 & $5,632.0$ & $1,716.6$ \\
\hline U12e.06 A & $\mathrm{TI}$ & $\mathrm{PCL}$ & ZM? & $\mathrm{TCU}$ & ATCU & 942 & 287.1 & $5,222.0$ & $1,591.7$ \\
\hline U12e.06 A & Ddg & DM & na & $\mathrm{CA}$ & LCA3 & 972 & 296.3 & $5,192.0$ & $1,582.5$ \\
\hline U12e.06 B & Tn4 & BED/RWT & $Z C$ & $\mathrm{TCU}$ & LTCU & 0 & 0.0 & $6,171.0$ & $1,880.9$ \\
\hline U12e.06 B & Tn3 & BED/RWT & $Z C$ & TCU & LTCU & 138 & 42.1 & $6,033.0$ & $1,838.9$ \\
\hline
\end{tabular}


Table A-2

Geologic and Hydrostratigraphic Drill hole Database for the Rainier Mesa-Shoshone Mountain Model Area (vertical drill holes only)

\begin{tabular}{|c|c|c|c|c|c|c|c|c|c|}
\hline Hole Name & Strat $^{1}$ & Lith $^{2}$ & Major Alt. ${ }^{3}$ & $H G U^{4}$ & $\mathrm{HSU}^{5}$ & $\begin{array}{c}\text { Depth Top } \\
\text { (ft) }\end{array}$ & $\begin{array}{c}\text { Depth } \\
\operatorname{Top}^{6}(\mathrm{~m})\end{array}$ & $\begin{array}{c}\text { Elev. Top }{ }^{7} \\
\text { (ft) }\end{array}$ & \begin{tabular}{|c}
$\begin{array}{c}\text { Elev. Top } \\
\text { (m) }\end{array}$ \\
\end{tabular} \\
\hline U12e.06 B & Ton2 & BED/RWT & $Z C$ & $\mathrm{TCU}$ & OSBCU & 390 & 118.9 & $5,781.0$ & $1,762.0$ \\
\hline U12e.06 B & Ton1 & BED/RWT & $Z C$ & $\mathrm{TCU}$ & OSBCU & 571 & 174.0 & $5,600.0$ & $1,706.9$ \\
\hline U12e.06 B & $\mathrm{TI}$ & $\mathrm{PCL}$ & ZM? & $\mathrm{TCU}$ & ATCU & 945 & 288.0 & $5,226.0$ & $1,592.9$ \\
\hline U12e.06 B & Ddg & DM & na & $\mathrm{CA}$ & LCA3 & 959 & 292.3 & $5,212.0$ & $1,588.6$ \\
\hline UE12n\#1 & $\mathrm{Tmr}$ & MWT & $\mathrm{nr}$ & WTA & TM-WTA & 0 & 0.0 & $7,321.4$ & $2,231.6$ \\
\hline UE12n\#1 & $\mathrm{Tmr}$ & DWT & $\mathrm{nr}$ & WTA & TM-WTA & 60 & 18.3 & $7,261.4$ & $2,213.3$ \\
\hline UE12n\#1 & $\mathrm{Tmr}$ & PWT & $\mathrm{nr}$ & VTA & TM-LVTA & 200 & 61.0 & $7,121.4$ & $2,170.6$ \\
\hline UE12n\#1 & $\mathrm{Tmr}$ & NWT & $\mathrm{nr}$ & VTA & TM-LVTA & 250 & 76.2 & $7,071.4$ & $2,155.4$ \\
\hline UE12n\#1 & Tmrh & BED & $\mathrm{GL}$ & VTA & TM-LVTA & 306 & 93.3 & $7,015.4$ & $2,138.3$ \\
\hline UE12n\#1 & Tpc & NWT & $\mathrm{nr}$ & VTA & TM-LVTA & 432 & 131.7 & $6,889.4$ & $2,099.9$ \\
\hline UE12n\#1 & $\mathrm{Tp} / \mathrm{Tc}$ & BED/RWT & $\mathrm{GL}$ & VTA & TM-LVTA & 466 & 142.0 & $6,855.4$ & $2,089.5$ \\
\hline UE12n\#1 & Tbg & PWT & $\mathrm{nr}$ & VTA & TM-LVTA & 1,050 & 320.0 & $6,271.4$ & $1,911.5$ \\
\hline UE12n\#1 & Tbg & DWT/FB & $\mathrm{nr}$ & WTA & BRA & 1,060 & 323.1 & $6,261.4$ & $1,908.5$ \\
\hline UE12n\#1 & Tbg & NWT & $\mathrm{nr}$ & VTA & LVTA1 & 1,106 & 337.1 & $6,215.4$ & $1,894.5$ \\
\hline UE12n\#1 & Tbgb & BED & $\mathrm{GL}$ & VTA & LVTA1 & 1,111 & 338.6 & $6,210.4$ & $1,892.9$ \\
\hline UE12n\#1 & Tn4 & BED & $\mathrm{GL}$ & VTA & LVTA1 & 1,201 & 366.1 & $6,120.4$ & $1,865.5$ \\
\hline UE12n\#1 & Tn4 & BED & $Z C$ & $\mathrm{TCU}$ & LTCU & 1,239 & 377.6 & $6,082.4$ & $1,853.9$ \\
\hline UE12n\#1 & Tn3 & BED/RWT & $Z C$ & TCU & LTCU & 1,612 & 491.3 & $5,709.4$ & $1,740.2$ \\
\hline UE12n\#1 & Tub & NWT & ZE & $\mathrm{TCU}$ & LTCU & 1,831 & 558.1 & $5,490.4$ & $1,673.5$ \\
\hline UE12n\#1 & Ton2 & BED/RWT & $\mathrm{ZC}$ & $\mathrm{TCU}$ & OSBCU & 1,878 & 572.4 & $5,443.4$ & $1,659.1$ \\
\hline UE12n\#2 & $\mathrm{Tmr}$ & MWT/DWT & $\mathrm{nr}$ & WTA & TM-WTA & 0 & 0.0 & $7,344.0$ & $2,238.5$ \\
\hline UE12n\#2 & $\mathrm{Tmr}$ & PWT/NWT & $\mathrm{nr}$ & VTA & TM-LVTA & 50 & 15.2 & $7,294.0$ & $2,223.2$ \\
\hline UE12n\#2 & $\begin{array}{l}\text { pre-Tmr, } \\
\text { post-Tbg }\end{array}$ & BED/RWT & GL & VTA & TM-LVTA & 150 & 45.7 & $7,194.0$ & $2,192.7$ \\
\hline UE12n\#2 & Tbgb & BED & $\mathrm{GL}$ & VTA & TM-LVTA & 710 & 216.4 & $6,634.0$ & $2,022.0$ \\
\hline UE12n\#2 & Tn4 & BED/RWT & $Z C$ & $\mathrm{TCU}$ & LTCU & 810 & 246.9 & $6,534.0$ & $1,991.6$ \\
\hline UE12n\#2 & Tn3 & BED/RWT & $Z C$ & $\mathrm{TCU}$ & LTCU & 1,221 & 372.2 & $6,123.0$ & $1,866.3$ \\
\hline UE12n\#2 & Tub & PWT/NWT & $\mathrm{nr}$ & $\mathrm{TCU}$ & LTCU & 1,362 & 415.1 & $5,982.0$ & $1,823.3$ \\
\hline UE12n\#2 & Ton2 & BED/RWT & ZC & $\mathrm{TCU}$ & OSBCU & 1,385 & 422.1 & $5,959.0$ & $1,816.3$ \\
\hline UE12n\#2 & Toy & PWT/NWT & $\mathrm{nr}$ & $\mathrm{TCU}$ & OSBCU & 1,569 & 478.2 & $5,775.0$ & $1,760.2$ \\
\hline UE12n\#2 & Ton1 & RWT & $Z C$ & $\mathrm{TCU}$ & OSBCU & 1,585 & 483.1 & $5,759.0$ & $1,755.3$ \\
\hline UE12n\#2 & To & PWT & $\mathrm{nr}$ & $\mathrm{TCU}$ & OSBCU & 1,613 & 491.6 & $5,731.0$ & $1,746.8$ \\
\hline UE12n\#2 & $\mathrm{TI}$ & $\mathrm{PCL}$ & $\mathrm{ZC} / \mathrm{ZM}$ & $\mathrm{TCU}$ & ATCU & 1,639 & 499.6 & $5,705.0$ & $1,738.9$ \\
\hline UE12n\#2 & $\mathrm{pCs}$ & $\overline{Q T Z}$ & na & $\mathrm{CCU}$ & LCCU1 & 1,772 & 540.1 & $5,572.0$ & $1,698.3$ \\
\hline UE12n\#3 & $\mathrm{Tmr}$ & MWT/DWT & $\mathrm{nr}$ & WTA & TM-WTA & 0 & 0.0 & $7,479.0$ & $2,279.6$ \\
\hline UE12n\#3 & $\mathrm{Tmr}$ & NWT & $\mathrm{nr}$ & VTA & TM-LVTA & 50 & 15.2 & $7,429.0$ & $2,264.4$ \\
\hline UE12n\#3 & $\mathrm{Tp}$ & BED/RWT & $\mathrm{GL}$ & VTA & TM-LVTA & 136 & 41.5 & $7,343.0$ & $2,238.1$ \\
\hline UE12n\#3 & Tbgb & BED & $\mathrm{GL}$ & VTA & TM-LVTA & 641 & 195.4 & $6,838.0$ & $2,084.2$ \\
\hline UE12n\#3 & Tn4 & BED & $\mathrm{GL}$ & VTA & TM-LVTA & 789 & 240.5 & $6,690.0$ & $2,039.1$ \\
\hline UE12n\#3 & Tn4 & BED/RWT & $Z C$ & $\mathrm{TCU}$ & LTCU & 825 & 251.5 & $6,654.0$ & $2,028.1$ \\
\hline UE12n\#3 & Tn3 & BED/RWT & $Z C$ & $\mathrm{TCU}$ & LTCU & 1,117 & 340.5 & $6,362.0$ & $1,939.1$ \\
\hline UE12n\#3 & Tub & NWT & $\mathrm{ZC}$ & $\mathrm{TCU}$ & LTCU & 1,207 & 367.9 & $6,272.0$ & $1,911.7$ \\
\hline UE12n\#3 & Ton2 & BED/RWT & $\mathrm{ZC}$ & $\mathrm{TCU}$ & OSBCU & 1,220 & 371.9 & $6,259.0$ & $1,907.7$ \\
\hline UE12n\#3 & $\mathrm{TI}$ & $\mathrm{PCL}$ & $Z C$ & $\mathrm{TCU}$ & ATCU & 1,395 & 425.2 & $6,084.0$ & $1,854.4$ \\
\hline UE12n\#3 & $\mathrm{pCs}$ & QTZ & na & $\mathrm{CCU}$ & LCCU1 & 1,397 & 425.8 & $6,082.0$ & $1,853.8$ \\
\hline Ue12n\#4 & $\begin{array}{l}\text { pre-Tmr, } \\
\text { post-Tbg }\end{array}$ & BED/RWT & GL & VTA & TM-LVTA & 0 & 0.0 & $6,894.0$ & $2,101.3$ \\
\hline Ue12n\#4 & Tbgb & BED & $\mathrm{GL}$ & VTA & TM-LVTA & 125 & 38.1 & $6,769.0$ & $2,063.2$ \\
\hline Ue12n\#4 & Tbgb & BED & $Z C$ & $\mathrm{TCU}$ & LTCU & 200 & 61.0 & $6,694.0$ & $2,040.3$ \\
\hline Ue12n\#4 & Tn4 & BED/RWT & $\mathrm{ZC}$ & $\mathrm{TCU}$ & LTCU & 218 & 66.4 & $6,676.0$ & $2,034.8$ \\
\hline Ue12n\#4 & Tn3 & BED/RWT & $\mathrm{ZC}$ & $\mathrm{TCU}$ & LTCU & 624 & 190.2 & $6,270.0$ & $1,911.1$ \\
\hline Ue12n\#4 & Tub & NWT & ZE & $\mathrm{TCU}$ & LTCU & 780 & 237.7 & $6,114.0$ & $1,863.5$ \\
\hline Ue12n\#4 & Ton2 & BED/RWT & $\mathrm{ZC}$ & $\mathrm{TCU}$ & OSBCU & 787 & 239.9 & $6,107.0$ & $1,861.4$ \\
\hline UE12n\#6 & $\mathrm{Tmr}$ & MWT/DWT & $\mathrm{nr}$ & WTA & TM-WTA & 0 & 0.0 & $7,420.0$ & $2,261.6$ \\
\hline UE12n\#6 & $\mathrm{Tmr}$ & PWT & $\mathrm{nr}$ & VTA & TM-LVTA & 263 & 80.2 & $7,157.0$ & $2,181.5$ \\
\hline UE12n\#6 & $\mathrm{Tmr}$ & NWT & $\mathrm{nr}$ & VTA & TM-LVTA & 335 & 102.1 & $7,085.0$ & $2,159.5$ \\
\hline UE12n\#6 & Tmrh & BED & $\mathrm{nr}$ & VTA & TM-LVTA & 412 & 125.6 & $7,008.0$ & $2,136.0$ \\
\hline
\end{tabular}


Table A-2

Geologic and Hydrostratigraphic Drill hole Database for the Rainier Mesa-Shoshone Mountain Model Area (vertical drill holes only)

\begin{tabular}{|c|c|c|c|c|c|c|c|c|c|}
\hline Hole Name & Strat $^{1}$ & Lith $^{2}$ & Major Alt. ${ }^{3}$ & $H G U^{4}$ & $\mathrm{HSU}^{5}$ & $\begin{array}{c}\text { Depth Top } \\
\text { (ft) }\end{array}$ & $\begin{array}{c}\text { Depth } \\
\operatorname{Top}^{6}(\mathrm{~m})\end{array}$ & $\begin{array}{c}\text { Elev. Top }{ }^{7} \\
\text { (ft) }\end{array}$ & \begin{tabular}{|c}
$\begin{array}{c}\text { Elev. Top } \\
\text { (m) }\end{array}$ \\
\end{tabular} \\
\hline UE12n\#6 & Tpc & NWT & $\mathrm{nr}$ & VTA & TM-LVTA & 465 & 141.7 & $6,955.0$ & $2,119.9$ \\
\hline UE12n\#6 & $\mathrm{Tp} / \mathrm{Tc}$ & BED/RWT & $\mathrm{GL}$ & VTA & TM-LVTA & 472 & 143.9 & $6,948.0$ & $2,117.8$ \\
\hline UE12n\#6 & Tcbs & NWT/PWT & ZE & $\mathrm{TCU}$ & UTCU1 & 904 & 275.5 & $6,516.0$ & $1,986.1$ \\
\hline UE12n\#6 & Tc & BED/RWT & ZC & $\mathrm{TCU}$ & UTCU1 & 951 & 289.9 & $6,469.0$ & $1,971.8$ \\
\hline UE12n\#6 & Tbg & PWT & $\mathrm{nr}$ & $\mathrm{TCU}$ & UTCU1 & 1,220 & 371.9 & $6,200.0$ & $1,889.8$ \\
\hline UE12n\#6 & Tbg & DWT & $\mathrm{nr}$ & WTA & BRA & 1,225 & 373.4 & $6,195.0$ & $1,888.2$ \\
\hline UE12n\#6 & Tbgb & PWT/NWT & $\mathrm{nr}$ & $\mathrm{TCU}$ & LTCU & 1,317 & 401.4 & $6,103.0$ & $1,860.2$ \\
\hline UE12n\#6 & Tbgb & BED & $Z C$ & TCU & LTCU & 1,327 & 404.5 & $6,093.0$ & $1,857.1$ \\
\hline UE12n\#6 & Tn4 & BED/RWT & $Z C$ & $\mathrm{TCU}$ & LTCU & 1,410 & 429.8 & $6,010.0$ & $1,831.8$ \\
\hline UE12n\#6 & Tn3 & BED/RWT & $Z C$ & $\mathrm{TCU}$ & LTCU & 1,721 & 524.6 & $5,699.0$ & $1,737.1$ \\
\hline UE12n\#6 & Tub & NWT & ZE & TCU & LTCU & 1,922 & 585.8 & $5,498.0$ & $1,675.8$ \\
\hline UE12n\#6 & Ton2 & BED/RWT & ZC & $\mathrm{TCU}$ & OSBCU & 1,935 & 589.8 & $5,485.0$ & $1,671.8$ \\
\hline UE12n\#6 & Toy & NWT & ZE & $\mathrm{TCU}$ & OSBCU & 2,122 & 646.8 & $5,298.0$ & $1,614.8$ \\
\hline UE12n\#8 & $\mathrm{Tmr}$ & MWT/DWT & $\mathrm{nr}$ & WTA & TM-WTA & 0 & 0.0 & $7,395.0$ & $2,254.0$ \\
\hline UE12n\#8 & Tmr & PWT/NWT & $\mathrm{nr}$ & VTA & TM-LVTA & 50 & 15.2 & $7,345.0$ & $2,238.8$ \\
\hline UE12n\#8 & $\begin{array}{l}\text { pre-Tmr, } \\
\text { post-Tbg }\end{array}$ & BED/RWT & GL & VTA & TM-LVTA & 140 & 42.7 & $7,255.0$ & $2,211.3$ \\
\hline UE12n\#8 & Tbgb & BED & $\mathrm{GL}$ & VTA & TM-LVTA & 739 & 225.2 & $6,656.0$ & $2,028.7$ \\
\hline UE12n\#8 & Tbgb & BED & ZC & TCU & LTCU & 850 & 259.1 & $6,545.0$ & $1,994.9$ \\
\hline UE12n\#8 & Tn4 & BED/RWT & $Z C$ & $\mathrm{TCU}$ & LTCU & 860 & 262.1 & $6,535.0$ & $1,991.9$ \\
\hline UE12n\#8 & Tn3 & BED/RWT & $Z C$ & $\mathrm{TCU}$ & LTCU & 1,220 & 371.9 & $6,175.0$ & $1,882.1$ \\
\hline UE12n\#8 & Tub & NWT & ZE & $\mathrm{TCU}$ & LTCU & 1,337 & 407.5 & $6,058.0$ & $1,846.5$ \\
\hline UE12n\#8 & Ton2 & BED/RWT & $Z C$ & TCU & OSBCU & 1,363 & 415.4 & $6,032.0$ & $1,838.6$ \\
\hline UE12n\#8 & To & NWT/PWT & $\mathrm{nr}$ & $\mathrm{TCU}$ & OSBCU & 1,523 & 464.2 & $5,872.0$ & $1,789.8$ \\
\hline UE12n\#8 & To & BED/RWT & $Z C$ & $\mathrm{TCU}$ & OSBCU & 1,582 & 482.2 & $5,813.0$ & $1,771.8$ \\
\hline UE12n\#8 & $\mathrm{Tl}$ & $\mathrm{PCL}$ & $Z C$ & $\mathrm{TCU}$ & ATCU & 1,604 & 488.9 & $5,791.0$ & $1,765.1$ \\
\hline UE12n\#8 & $\mathrm{pCs}$ & QTZ/SLT & na & $\mathrm{CCU}$ & LCCU1 & 1,609 & 490.4 & $5,786.0$ & $1,763.6$ \\
\hline UE12n\#10 & $\mathrm{Tmr}$ & MWT/DWT & $\mathrm{nr}$ & WTA & TM-WTA & 0 & 0.0 & $7,384.0$ & $2,250.6$ \\
\hline UE12n\#10 & $\mathrm{Tmr}$ & MWT & $\mathrm{nr}$ & WTA & TM-WTA & 50 & 15.2 & $7,334.0$ & $2,235.4$ \\
\hline UE12n\#10 & $\mathrm{Tmr}$ & PWT/NWT & $\mathrm{nr}$ & VTA & TM-LVTA & 85 & 25.9 & $7,299.0$ & $2,224.7$ \\
\hline UE12n\#10 & $\begin{array}{l}\text { pre-Tmr, } \\
\text { post-Tbg }\end{array}$ & BED/RWT & $\mathrm{nr}$ & VTA & TM-LVTA & 148 & 45.1 & $7,236.0$ & $2,205.5$ \\
\hline UE12n\#10 & Tbgb & BED & $\mathrm{GL}$ & VTA & TM-LVTA & 735 & 224.0 & $6,649.0$ & $2,026.6$ \\
\hline UE12n\#10 & Tn4 & BED & $\mathrm{GL}$ & VTA & TM-LVTA & 841 & 256.3 & $6,543.0$ & $1,994.3$ \\
\hline UE12n\#10 & Tn4 & BED/RWT & $Z C$ & $\mathrm{TCU}$ & LTCU & 854 & 260.3 & $6,530.0$ & $1,990.3$ \\
\hline UE12n\#10 & Tn3 & BED/RWT & $Z C$ & $\mathrm{TCU}$ & LTCU & 1,273 & 388.0 & $6,111.0$ & $1,862.6$ \\
\hline UE12n\#10 & Tub & NWT & ZE & $\mathrm{TCU}$ & LTCU & 1,475 & 449.6 & $5,909.0$ & $1,801.1$ \\
\hline UE12n\#10 & Ton2 & BED/RWT & $Z C$ & $\mathrm{TCU}$ & OSBCU & 1,507 & 459.3 & $5,877.0$ & $1,791.3$ \\
\hline UE12n\#10 & Ton1 & RWT & $Z C$ & TCU & OSBCU & 1,560 & 475.5 & $5,824.0$ & $1,775.2$ \\
\hline UE12n\#10 & To & BED/RWT & $Z C$ & $\mathrm{TCU}$ & OSBCU & 1,653 & 503.8 & $5,731.0$ & $1,746.8$ \\
\hline UE12n\#10 & $\mathrm{Tcr}$ & $\mathrm{PCL}$ & ZC/ZM & $\mathrm{TCU}$ & ATCU & 1,699 & 517.9 & $5,685.0$ & $1,732.8$ \\
\hline UE12n\#10 & $\mathrm{Kgm}$ & IN & na & GCU & MGCU & 1,785 & 544.1 & $5,599.0$ & $1,706.6$ \\
\hline UE12n\#10 & $\mathrm{pCs}$ & $\mathrm{SCH} / \mathrm{QTZ}$ & na & $\mathrm{CCU}$ & LCCU1 & 1,813 & 552.6 & $5,571.0$ & $1,698.0$ \\
\hline UE12n\#9 & $\mathrm{Tmr}$ & MWT/DWT & $\mathrm{nr}$ & WTA & TM-WTA & 0 & 0.0 & $7,383.0$ & $2,250.3$ \\
\hline UE12n\#9 & $\mathrm{Tmr}$ & PWT/NWT & $\mathrm{nr}$ & VTA & TM-LVTA & 65 & 19.8 & $7,318.0$ & $2,230.5$ \\
\hline UE12n\#9 & Tmrh & BED & $\mathrm{GL}$ & VTA & TM-LVTA & 134 & 40.8 & $7,249.0$ & $2,209.5$ \\
\hline UE12n\#9 & Tрс? & NWT & $\mathrm{nr}$ & VTA & TM-LVTA & 218 & 66.4 & $7,165.0$ & $2,183.9$ \\
\hline UE12n\#9 & $\begin{array}{c}\mathrm{Tp} / \\
\text { post-Tbg }\end{array}$ & BED/RWT & $\mathrm{nr}$ & VTA & TM-LVTA & 222 & 67.7 & $7,161.0$ & $2,182.7$ \\
\hline UE12n\#9 & Tbgb & BED & GL & VTA & TM-LVTA & 683 & 208.2 & $6,700.0$ & $2,042.2$ \\
\hline UE12n\#9 & Tn4 & BED & $\mathrm{GL}$ & VTA & TM-LVTA & 785 & 239.3 & $6,598.0$ & $2,011.1$ \\
\hline UE12n\#9 & Tn4 & BED/RWT & $Z C$ & $\mathrm{TCU}$ & LTCU & 850 & 259.1 & $6,533.0$ & $1,991.3$ \\
\hline UE12n\#9 & Tn3 & BED/RWT & $Z C$ & $\mathrm{TCU}$ & LTCU & 1,150 & 350.5 & $6,233.0$ & $1,899.8$ \\
\hline UE12n\#9 & Tub & NWT & ZE & $\mathrm{TCU}$ & LTCU & 1,258 & 383.4 & $6,125.0$ & $1,866.9$ \\
\hline UE12n\#9 & Ton2 & BED/RWT & $Z C$ & $\mathrm{TCU}$ & OSBCU & 1,269 & 386.8 & $6,114.0$ & $1,863.5$ \\
\hline UE12n\#9 & To & BED/RWT & $Z C$ & TCU & OSBCU & 1,414 & 431.0 & $5,969.0$ & $1,819.4$ \\
\hline
\end{tabular}


Table A-2

Geologic and Hydrostratigraphic Drill hole Database for the Rainier Mesa-Shoshone Mountain Model Area (vertical drill holes only)

\begin{tabular}{|c|c|c|c|c|c|c|c|c|c|}
\hline Hole Name & Strat $^{1}$ & Lith $^{2}$ & Major Alt. ${ }^{3}$ & $H_{G}{ }^{4}$ & $\mathrm{HSU}^{5}$ & \begin{tabular}{|c|}
$\begin{array}{c}\text { Depth Top } \\
6 \\
(\mathrm{ft})\end{array}$ \\
\end{tabular} & $\begin{array}{c}\text { Depth } \\
\operatorname{Top}^{6}(\mathrm{~m}) \\
\end{array}$ & \begin{tabular}{|c|}
$\begin{array}{c}\text { Elev. Top } \\
\end{array}$ \\
(ft)
\end{tabular} & \begin{tabular}{|c|}
$\begin{array}{c}\text { Elev. Top } \\
\text { (m) }\end{array}$ \\
\end{tabular} \\
\hline UE12n\#9 & $\overline{\mathrm{Tl}}$ & 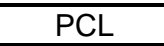 & ZC/ZM & TCU & 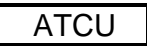 & 1,434 & 437.1 & $5,949.0$ & $1,813.3$ \\
\hline UE12n\#9 & $\mathrm{pCwc}$ & $\mathrm{SCH} / \mathrm{QTZ}$ & na & $\mathrm{CCU}$ & LCCU1 & 1,455 & 443.5 & $5,928.0$ & $1,806.9$ \\
\hline UE12n\#9 & $\mathrm{pCs}$ & QTZ & na & $\mathrm{CCU}$ & LCCU1 & 1,495 & 455.7 & $5,888.0$ & $1,794.7$ \\
\hline UE12n\#11 & $\mathrm{Tmr}$ & MWT/DWT & $\mathrm{nr}$ & WTA & TM-WTA & 0 & 0.0 & $7,309.0$ & $2,227.8$ \\
\hline UE12n\#11 & Tmr & PWT/NWT & $\mathrm{nr}$ & VTA & TM-LVTA & 60 & 18.3 & $7,249.0$ & $2,209.5$ \\
\hline UE12n\#11 & $\begin{array}{l}\text { pre-Tmr, } \\
\text { post-Tbg }\end{array}$ & BED & GL & VTA & TM-LVTA & 131 & 39.9 & $7,178.0$ & $2,187.9$ \\
\hline UE12n\#11 & Tbg? & NWT & $\mathrm{nr}$ & VTA & TM-LVTA & 762 & 232.3 & $6,547.0$ & $1,995.5$ \\
\hline UE12n\#11 & Tbgb & BED & $\mathrm{GL}$ & VTA & TM-LVTA & 783 & 238.7 & $6,526.0$ & $1,989.1$ \\
\hline UE12n\#11 & Tn4 & BED & $\mathrm{GL}$ & VTA & TM-LVTA & 870 & 265.2 & $6,439.0$ & $1,962.6$ \\
\hline UE12n\#11 & Tn4 & BED/RWT & $Z C$ & TCU & LTCU & 946 & 288.3 & $6,363.0$ & $1,939.4$ \\
\hline UE12n\#11 & Tn3 & BED/RWT & $Z C$ & TCU & LTCU & 1,335 & 406.9 & $5,974.0$ & $1,820.9$ \\
\hline UE12n\#11 & Tub & NWT & $\mathrm{ZE}$ & TCU & LTCU & 1,424 & 434.0 & $5,885.0$ & $1,793.7$ \\
\hline UE12n\#11 & Ton2 & BED/RWT & $Z C$ & TCU & OSBCU & 1,453 & 442.9 & $5,856.0$ & $1,784.9$ \\
\hline UE12n\#11 & Toy & NWT & $\mathrm{nr}$ & TCU & OSBCU & 1,607 & 489.8 & $5,702.0$ & $1,738.0$ \\
\hline UE12n\#11 & To & BED/RWT & ZC & TCU & OSBCU & 1,661 & 506.3 & $5,648.0$ & $1,721.5$ \\
\hline UE12n\#11 & $\mathrm{Tl}$ & $\mathrm{PCL}$ & ZC/ZM & TCU & ATCU & 1,702 & 518.8 & $5,607.0$ & $1,709.0$ \\
\hline UE12n\#12 & $\mathrm{Tmr}$ & MWT/DWT & $\mathrm{nr}$ & WTA & TM-WTA & 0 & 0.0 & $7,413.4$ & $2,259.6$ \\
\hline UE12n\#12 & $\mathrm{Tmr}$ & PWT/NWT & $\mathrm{nr}$ & VTA & TM-LVTA & 90 & 27.4 & $7,323.4$ & $2,232.2$ \\
\hline UE12n\#12 & $\begin{array}{l}\text { pre-Tmr, } \\
\text { post-Tbg }\end{array}$ & BED/RWT & GL & VTA & TM-LVTA & 180 & 54.9 & $7,233.4$ & $2,204.7$ \\
\hline UE12n\#12 & Tbgb & BED & $\mathrm{GL}$ & VTA & TM-LVTA & 710 & 216.4 & $6,703.4$ & $2,043.2$ \\
\hline UE12n\#12 & Tn4 & BED/RWT & $Z C$ & TCU & LTCU & 800 & 243.8 & $6,613.4$ & $2,015.8$ \\
\hline UE12n\#12 & Tn3 & BED/RWT & ZC & TCU & LTCU & 1,196 & 364.5 & $6,217.4$ & $1,895.1$ \\
\hline UE12n\#12 & Tub & NWT & ZE & TCU & LTCU & 1,350 & 411.5 & $6,063.4$ & $1,848.1$ \\
\hline UE12n\#12 & Ton2 & BED/RWT & $Z C$ & TCU & OSBCU & 1,365 & 416.1 & $6,048.4$ & $1,843.6$ \\
\hline UE12n\#12 & To & BED/RWT & $Z C$ & TCU & OSBCU & 1,550 & 472.4 & $5,863.4$ & $1,787.2$ \\
\hline UE12n\#12 & $\mathrm{TI}$ & $\mathrm{PCL}$ & $Z C$ & TCU & ATCU & 1,691 & 515.4 & $5,722.4$ & $1,744.2$ \\
\hline UE12n\#13 & $\mathrm{Tmr}$ & MWT/DWT & $\mathrm{nr}$ & WTA & TM-WTA & 0 & 0.0 & $7,354.6$ & $2,241.7$ \\
\hline UE12n\#13 & $\mathrm{Tmr}$ & PWT/NWT & $\mathrm{nr}$ & VTA & TM-LVTA & 215 & 65.5 & $7,139.6$ & $2,176.2$ \\
\hline UE12n\#13 & Tmrh & BED & $\mathrm{GL}$ & VTA & TM-LVTA & 288 & 87.8 & $7,066.6$ & $2,153.9$ \\
\hline UE12n\#13 & $\mathrm{Tpc}$ & NWT & $\mathrm{nr}$ & VTA & TM-LVTA & 425 & 129.5 & $6,929.6$ & $2,112.1$ \\
\hline UE12n\#13 & $\mathrm{Tp} / \mathrm{Tc}$ & BED/RWT & $\mathrm{GL}$ & VTA & TM-LVTA & 440 & 134.1 & $6,914.6$ & $2,107.6$ \\
\hline UE12n\#13 & $\mathrm{Tcb}$ & NWT & ZE & TCU & TM-LVTA & 841 & 256.3 & $6,513.6$ & $1,985.3$ \\
\hline UE12n\#13 & Tc & BED & $\mathrm{GL}$ & VTA & TM-LVTA & 856 & 260.9 & $6,498.6$ & $1,980.8$ \\
\hline UE12n\#13 & Tbg & NWT/PWT & $\mathrm{nr}$ & VTA & TM-LVTA & 1,051 & 320.3 & $6,303.6$ & $1,921.3$ \\
\hline UE12n\#14 & $\mathrm{Tmr}$ & MWT/DWT & $\mathrm{nr}$ & WTA & TM-WTA & 0 & 0.0 & $7,415.5$ & $2,260.2$ \\
\hline UE12n\#14 & $\mathrm{Tmr}$ & PWT/NWT & $\mathrm{nr}$ & VTA & TM-LVTA & 250 & 76.2 & $7,165.5$ & $2,184.0$ \\
\hline UE12n\#14 & $\begin{array}{l}\text { pre-Tmr, } \\
\text { post-Tbg }\end{array}$ & BED & GL & VTA & TM-LVTA & 368 & 112.2 & $7,047.5$ & 2,148.1 \\
\hline UE12n\#14 & Tpc & NWT & $\mathrm{nr}$ & VTA & TM-LVTA & 451 & 137.5 & $6,964.5$ & $2,122.8$ \\
\hline UE12n\#14 & $\mathrm{Tp} / \mathrm{Tc}$ & BED/RWT & $\mathrm{GL}$ & VTA & TM-LVTA & 465 & 141.7 & $6,950.5$ & $2,118.5$ \\
\hline UE12n\#14 & $\mathrm{Tcb}$ & NWT & $\mathrm{nr}$ & VTA & TM-LVTA & 788 & 240.2 & $6,627.5$ & $2,020.1$ \\
\hline UE12n\#14 & Tc & BED & $\mathrm{GL}$ & VTA & TM-LVTA & 803 & 244.8 & $6,612.5$ & $2,015.5$ \\
\hline UE12n\#14 & Tbg & NWT & $\mathrm{nr}$ & VTA & TM-LVTA & 978 & 298.1 & $6,437.5$ & $1,962.1$ \\
\hline UE12n\#14 & Tbg & $\mathrm{FB}$ & $\mathrm{nr}$ & VTA & TM-LVTA & 989 & 301.4 & $6,426.5$ & $1,958.8$ \\
\hline UE12n\#14 & Tbgb & BED & $\mathrm{GL}$ & VTA & TM-LVTA & 1,004 & 306.0 & $6,411.5$ & $1,954.2$ \\
\hline UE12n\#14 & Tn4 & BED/RWT & $Z C$ & TCU & LTCU & 1,086 & 331.0 & $6,329.5$ & $1,929.2$ \\
\hline UE12n\#14 & Tn3 & BED/RWT & $Z C$ & TCU & LTCU & 1,515 & 461.8 & $5,900.5$ & $1,798.5$ \\
\hline UE12n\#14 & Tub & NWT & ZE & $\mathrm{TCU}$ & LTCU & 1,667 & 508.1 & $5,748.5$ & $1,752.1$ \\
\hline UE12n\#14 & Ton2 & BED/RWT & $Z C$ & $\mathrm{TCU}$ & OSBCU & 1,681 & 512.4 & $5,734.5$ & $1,747.9$ \\
\hline UE12n\#15 & $\mathrm{Tmr}$ & MWT/DWT & $\mathrm{nr}$ & WTA & TM-WTA & 0 & 0.0 & $7,370.7$ & $2,246.6$ \\
\hline UE12n\#15 & $\mathrm{Tmr}$ & PWT/NWT & $\mathrm{nr}$ & VTA & TM-LVTA & 100 & 30.5 & $7,270.7$ & $2,216.1$ \\
\hline UE12n\#15 & $\begin{array}{l}\text { pre-Tmr, } \\
\text { post-Tbg }\end{array}$ & BED & GL & VTA & TM-LVTA & 173 & 52.7 & $7,197.7$ & 2,193.9 \\
\hline UE12n\#15 & $\mathrm{Tpc}$ & NWT & $\mathrm{nr}$ & VTA & TM-LVTA & 291 & 88.7 & $7,079.7$ & $2,157.9$ \\
\hline
\end{tabular}


Table A-2

Geologic and Hydrostratigraphic Drill hole Database for the Rainier Mesa-Shoshone Mountain Model Area (vertical drill holes only)

\begin{tabular}{|c|c|c|c|c|c|c|c|c|c|}
\hline Hole Name & Strat $^{1}$ & Lith $^{2}$ & Major Alt. ${ }^{3}$ & $H G U^{4}$ & $\mathrm{HSU}^{5}$ & \begin{tabular}{|c|}
$\begin{array}{c}\text { Depth Top } \\
6 \\
(\mathrm{ft})\end{array}$ \\
\end{tabular} & $\begin{array}{c}\text { Depth } \\
\operatorname{Top}^{6}(\mathrm{~m}) \\
\end{array}$ & $\begin{array}{c}\text { Elev. Top }{ }^{7} \\
\text { (ft) }\end{array}$ & \begin{tabular}{|c|}
$\begin{array}{c}\text { Elev. Top } \\
\text { (m) }\end{array}$ \\
\end{tabular} \\
\hline UE12n\#15 & $\mathrm{Tp} / \mathrm{Tc}$ & BED/RWT & $\mathrm{GL}$ & VTA & TM-LVTA & 298 & 90.8 & $7,072.7$ & $2,155.8$ \\
\hline UE12n\#15A & nd & nd & nd & nd & nd & 0 & 0.0 & $7,356.0$ & $2,242.1$ \\
\hline UE12n\#15A & $\mathrm{Tp} / \mathrm{Tc}$ & BED & $\mathrm{GL}$ & VTA & TM-LVTA & 700 & 213.4 & $6,655.8$ & $2,028.7$ \\
\hline UE12n\#15A & Tbg & NWT & $\mathrm{nr}$ & VTA & TM-LVTA & 912 & 278.0 & $6,443.9$ & $1,964.1$ \\
\hline UE12n\#15A & Tbgb & BED & $\mathrm{GL}$ & VTA & TM-LVTA & 959 & 292.3 & $6,397.0$ & $1,949.8$ \\
\hline UE12n\#15A & Tn4 & BED/RWT & $Z C$ & TCU & LTCU & 1,038 & 316.4 & $6,317.9$ & $1,925.7$ \\
\hline UE12n\#15A & Tn3 & BED/RWT & $Z C$ & TCU & LTCU & 1,448 & 441.4 & $5,907.8$ & $1,800.7$ \\
\hline UE12n\#15A & Tub & NWT & ZE & $\mathrm{TCU}$ & LTCU & 1,654 & 504.1 & $5,702.1$ & $1,738.0$ \\
\hline UE12n\#15A & Ton2 & BED/RWT & $Z C$ & TCU & OSBCU & 1,673 & 509.9 & $5,683.1$ & $1,732.2$ \\
\hline UE12n\#15A & To & BED/NWT & $Z C$ & TCU & OSBCU & 1,786 & 544.4 & $5,569.9$ & $1,697.7$ \\
\hline UE12n\#15A & $\mathrm{TI}$ & $\mathrm{PCL}$ & $\mathrm{ZM} / \mathrm{ZC}$ & $\mathrm{TCU}$ & ATCU & 1,844 & 562.1 & $5,511.8$ & $1,680.0$ \\
\hline UE12n\#15A & Kgm & IN & na & GCU & MGCU & 1,875 & 571.5 & $5,481.0$ & $1,670.6$ \\
\hline UE12n\#16 & $\mathrm{Tmr}$ & DWT/MWT & $\mathrm{nr}$ & WTA & TM-WTA & 0 & 0.0 & $7,527.40$ & $2,294.4$ \\
\hline UE12n\#16 & Tmrh & BED & $\overline{G L}$ & VTA & TM-LVTA & 110 & 33.5 & $7,417.4$ & $2,260.8$ \\
\hline UE12n\#16 & $\mathrm{Tpc}$ & NWT & $\mathrm{nr}$ & VTA & TM-LVTA & 224 & 68.3 & $7,303.4$ & $2,226.1$ \\
\hline UE12n\#16 & $\begin{array}{l}\text { pre-Tmr, } \\
\text { post-Tbg }\end{array}$ & BED/RWT & GL & VTA & TM-LVTA & 230 & 70.1 & $7,297.4$ & $2,224.2$ \\
\hline UE12n\#16 & Tbgb & BED & $\mathrm{GL}$ & VTA & TM-LVTA & 914 & 278.6 & $6,613.4$ & $2,015.8$ \\
\hline UE12n\#16 & Tn4 & BED & $\mathrm{GL}$ & VTA & TM-LVTA & 1,025 & 312.4 & $6,502.4$ & $1,981.9$ \\
\hline UE12n\#16 & Tn4 & BED/RWT & ZC & TCU & LTCU & 1,057 & 322.2 & $6,470.4$ & $1,972.2$ \\
\hline UE12n\#16 & Tn3 & BED/RWT & ZC & TCU & LTCU & 1,451 & 442.3 & $6,076.4$ & $1,852.1$ \\
\hline UE12n\#16 & Tub & NWT & ZE & $\mathrm{TCU}$ & LTCU & 1,715 & 522.7 & $5,812.4$ & $1,771.6$ \\
\hline UE12n\#16 & Ton2 & BED/RWT & $\mathrm{ZC}$ & TCU & OSBCU & 1,745 & 531.9 & $5,782.4$ & $1,762.5$ \\
\hline UE12n\#16 & To & BED/RWT & ZC & TCU & ATCU & 1,956 & 596.2 & $5,571.4$ & $1,698.2$ \\
\hline U12q & $\mathrm{Tmr}$ & MWT/DWT & $\mathrm{nr}$ & WTA & TM-WTA & 0 & 0.0 & $7,413.5$ & $2,259.6$ \\
\hline U12q & $\mathrm{Tmr}$ & MWT/NWT & $\mathrm{nr}$ & VTA & TM-LVTA & 180 & 54.9 & $7,233.5$ & $2,204.8$ \\
\hline U12q & $\begin{array}{l}\text { pre-Tmr, } \\
\text { post-Tbg }\end{array}$ & BED/RWT & GL & VTA & TM-LVTA & 240 & 73.2 & $7,173.5$ & $2,186.5$ \\
\hline U12q & Tbg & PWT & $\mathrm{nr}$ & VTA & TM-LVTA & 1,120 & 341.4 & $6,293.5$ & $1,918.3$ \\
\hline U12q & Tbgb & BED & ZC? & TCU & LTCU & 1,190 & 362.7 & $6,223.5$ & $1,896.9$ \\
\hline U12q & Tn4 & BED/RWT & $\mathrm{ZC}$ & TCU & LTCU & 1,200 & 365.8 & $6,213.5$ & $1,893.9$ \\
\hline U12q & Tn3 & BED/RWT & $\mathrm{ZC}$ & $\mathrm{TCU}$ & LTCU & 1,945 & 592.8 & $5,468.5$ & $1,666.8$ \\
\hline U12q & Tub? & PWT? & $\mathrm{nr}$ & $\mathrm{TCU}$ & LTCU & 2,040 & 621.8 & $5,373.5$ & $1,637.8$ \\
\hline U12q & Ton2? & BED/RWT & $Z C$ & TCU & OSBCU & 2,060 & 627.9 & $5,353.5$ & $1,631.7$ \\
\hline $\mathrm{U} 12 \mathrm{r}$ & $\mathrm{Tmr}$ & MWT/DWT & $\mathrm{nr}$ & WTA & TM-WTA & 0 & 0.0 & $7,514.0$ & $2,290.3$ \\
\hline U12r & $\begin{array}{l}\text { pre-Tmr, } \\
\text { post-Tbg }\end{array}$ & BED/RWT & GL & VTA & TM-LVTA & 120 & 36.6 & $7,394.0$ & $2,253.7$ \\
\hline $\mathrm{U} 12 \mathrm{r}$ & Tbg & MWT & $\mathrm{nr}$ & WTA & BRA & 1,200 & 365.8 & $6,314.0$ & $1,924.5$ \\
\hline $\mathrm{U} 12 \mathrm{r}$ & Tbgb & BED & $\mathrm{GL}$ & VTA & LVTA1 & 1,220 & 371.9 & $6,294.0$ & $1,918.4$ \\
\hline $\mathrm{U} 12 \mathrm{r}$ & Tn4 & BED/RWT & $\mathrm{GL}$ & VTA & LVTA1 & 1,350 & 411.5 & $6,164.0$ & $1,878.8$ \\
\hline $\mathrm{U} 12 \mathrm{r}$ & Tn4 & BED/RWT & $Z C$ & $\mathrm{TCU}$ & LTCU & 1,430 & 435.9 & $6,084.0$ & $1,854.4$ \\
\hline $\mathrm{U} 12 \mathrm{r}$ & Tn3/Ton2 & BED/RWT & $Z C$ & $\mathrm{TCU}$ & LTCU & 1,700 & 518.2 & $5,814.0$ & $1,772.1$ \\
\hline $\mathrm{U} 12 \mathrm{r}$ & To & BED/RWT & $Z C$ & $\mathrm{TCU}$ & OSBCU & 1,945 & 592.8 & $5,569.0$ & $1,697.4$ \\
\hline $\mathrm{U} 12 \mathrm{r}$ & $\mathrm{TI}$ & $\mathrm{PCL}$ & $\mathrm{AR}$ & $\mathrm{TCU}$ & ATCU & 1,980 & 603.5 & $5,534.0$ & $1,686.8$ \\
\hline $\mathrm{U} 12 \mathrm{r}$ & $\mathrm{Kgm}$ & QTZ MONZ & na & GCU & MGCU & 2,030 & 618.7 & $5,484.0$ & $1,671.5$ \\
\hline U12s & $\mathrm{Kgm}$ & QTZ MONZ & na & GCU & MGCU & 0 & 0.0 & $6,794.0$ & $2,070.8$ \\
\hline U12t.04 CH\#1 & $\mathrm{Tmr}$ & MWT/DWT & $\mathrm{nr}$ & WTA & TM-WTA & 0 & 0.0 & $6,795.9$ & $2,071.4$ \\
\hline U12t.04 CH\#1 & $\mathrm{Tmr}$ & PWT/NWT & $\mathrm{nr}$ & VTA & TM-LVTA & 300 & 91.4 & $6,495.9$ & $1,980.0$ \\
\hline U12t.04 CH\#1 & $\begin{array}{l}\text { pre-Tmr, } \\
\text { post-Tbg }\end{array}$ & BED/RWT & GL & VTA & TM-LVTA & 375 & 114.3 & $6,420.9$ & $1,957.1$ \\
\hline U12t.04 CH\#1 & Tbg & PWT/DWT & $\mathrm{nr}$ & WTA & BRA & 680 & 207.3 & $6,115.9$ & $1,864.1$ \\
\hline U12t.04 CH\#1 & Tbgb & BED & $\mathrm{GL}$ & VTA & LVTA1 & 718 & 218.8 & $6,077.9$ & $1,852.5$ \\
\hline U12t.04 CH\#1 & Tbgb & BED & $Z C$ & $\mathrm{TCU}$ & BRCU & 870 & 265.2 & $5,925.9$ & $1,806.2$ \\
\hline U12t.04 CH\#1 & Tn4 & BED/RWT & ZC & $\mathrm{TCU}$ & BRCU & 895 & 272.8 & $5,900.9$ & $1,798.6$ \\
\hline
\end{tabular}


Table A-2

Geologic and Hydrostratigraphic Drill hole Database for the Rainier Mesa-Shoshone Mountain Model Area (vertical drill holes only)

\begin{tabular}{|c|c|c|c|c|c|c|c|c|c|}
\hline Hole Name & Strat $^{1}$ & Lith $^{2}$ & Major Alt. ${ }^{3}$ & $\mathrm{HGU}^{4}$ & $\mathrm{HSU}^{5}$ & \begin{tabular}{|c|}
$\begin{array}{c}\text { Depth Top } \\
6 \\
(\mathrm{ft})\end{array}$ \\
\end{tabular} & $\begin{array}{c}\text { Depth } \\
\operatorname{Top}^{6}(\mathrm{~m}) \\
\end{array}$ & $\begin{array}{c}\text { Elev. Top }{ }^{7} \\
\text { (ft) }\end{array}$ & \begin{tabular}{|c|}
$\begin{array}{c}\text { Elev. Top } \\
\text { (m) }\end{array}$ \\
\end{tabular} \\
\hline U12t.04 RE\#2 & $\overline{T \text { Tn4 }}$ & "BED/RWT & ZC & TCU & 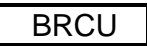 & 0 & 0.0 & $5,621.8$ & $1,713.5$ \\
\hline U12t.04 RE\#2 & Tn3 & BED/RWT & ZC & TCU & BRCU & 118 & 36.0 & $5,503.8$ & $1,677.6$ \\
\hline U12t.04 RE\#2 & Tub & PWT & $\mathrm{nr}$ & TCU & BRCU & 292 & 89.0 & $5,329.8$ & $1,624.5$ \\
\hline U12t.04 RE\#2 & Tub & DWT & $\mathrm{nr}$ & WTA & TUBA & 308 & 93.9 & $5,313.8$ & $1,619.7$ \\
\hline U12t.04 RE\#2 & Tub? & NWT & $Z C$ & TCU & OSBCU & 354 & 107.9 & $5,267.8$ & $1,605.6$ \\
\hline U12t.04 RE\#2 & Ton2 & BED/RWT & $Z C$ & $\mathrm{TCU}$ & OSBCU & 420 & 128.0 & $5,201.8$ & $1,585.5$ \\
\hline U12t.04 RE\#2 & Toy & NWT/PWT & $\mathrm{ZC} / \mathrm{ZM}$ & TCU & OSBCU & 506 & 154.2 & $5,115.8$ & $1,559.3$ \\
\hline U12t.04 RE\#2 & To & RWT & ZC & $\mathrm{TCU}$ & OSBCU & 746 & 227.4 & $4,875.8$ & $1,486.2$ \\
\hline UE12t\#1 & Tmr & MWT & $\mathrm{nr}$ & WTA & TM-WTA & 0 & 0.0 & $6,762.4$ & $2,061.2$ \\
\hline UE12t\#1 & $\mathrm{Tmr}$ & DWT & $\mathrm{nr}$ & WTA & TM-WTA & 50 & 15.2 & $6,712.4$ & $2,045.9$ \\
\hline UE12t\#1 & $\mathrm{Tmr}$ & PWT/NWT & $\mathrm{nr}$ & VTA & TM-LVTA & 310 & 94.5 & $6,452.4$ & $1,966.7$ \\
\hline UE12t\#1 & $\begin{array}{l}\text { pre-Tmr, } \\
\text { post-Tbg }\end{array}$ & BED/RWT & GL & VTA & TM-LVTA & 369 & 112.5 & $6,393.4$ & $1,948.7$ \\
\hline UE12t\#1 & Tbg & NWT/PWT & $\mathrm{nr}$ & VTA & TM-LVTA & 715 & 217.9 & $6,047.4$ & $1,843.2$ \\
\hline UE12t\#1 & Tbg & DWT/VIT & $\mathrm{nr}$ & WTA & BRA & 720 & 219.5 & $6,042.4$ & $1,841.7$ \\
\hline UE12t\#1 & Tbgb & BED & $\mathrm{GL}$ & VTA & LVTA1 & 739 & 225.2 & $6,023.4$ & $1,835.9$ \\
\hline UE12t\#1 & Tbgb & BED & ZC & TCU & BRCU & 880 & 268.2 & $5,882.4$ & $1,793.0$ \\
\hline UE12t\#1 & Tn4 & BED/RWT & $Z C$ & $\mathrm{TCU}$ & BRCU & 902 & 274.9 & $5,860.4$ & $1,786.2$ \\
\hline UE12t\#1 & Tn3 & BED/RWT & ZC & $\mathrm{TCU}$ & BRCU & 1,251 & 381.3 & $5,511.4$ & $1,679.9$ \\
\hline UE12t\#1 & Tub & NWT/PWT & ZE & $\mathrm{TCU}$ & BRCU & 1,428 & 435.3 & $5,334.4$ & $1,625.9$ \\
\hline UE12t\#1 & Tub & DWT & $\mathrm{nr}$ & WTA & TUBA & 1,457 & 444.1 & $5,305.4$ & $1,617.1$ \\
\hline UE12t\#1 & Tub & NWT & ZE & TCU & OSBCU & 1,493 & 455.1 & $5,269.4$ & $1,606.1$ \\
\hline UE12t\#1 & Ton2 & RWT & $Z C$ & $\mathrm{TCU}$ & OSBCU & 1,524 & 464.5 & $5,238.4$ & $1,596.7$ \\
\hline UE12t\#1 & Toy & NWT/PWT & ZE & TCU & OSBCU & 1,638 & 499.3 & $5,124.4$ & $1,561.9$ \\
\hline UE12t\#1 & To & BED/RWT & ZC & $\mathrm{TCU}$ & OSBCU & 1,883 & 573.9 & $4,879.4$ & $1,487.2$ \\
\hline UE12t\#1 & To & PWT & ZE & $\mathrm{TCU}$ & OSBCU & 2,053 & 625.8 & $4,709.4$ & $1,435.4$ \\
\hline UE12t\#1 & To & BED/RWT & $Z C$ & $\mathrm{TCU}$ & OSBCU & 2,116 & 645.0 & $4,646.4$ & $1,416.2$ \\
\hline UE12t\#1 & $\mathrm{TI}$ & $\mathrm{PCL}$ & ZM & $\mathrm{TCU}$ & ATCU & 2,190 & 667.5 & $4,572.4$ & $1,393.7$ \\
\hline UE12t\#1 & $\mathrm{Pz}$ & $\mathrm{DM}$ & $\mathrm{nr}$ & $\mathrm{CA}$ & LCA3 & 2,199 & 670.3 & $4,563.4$ & $1,390.9$ \\
\hline UE12t\#2 & $\mathrm{Tmr}$ & MWT/DWT & $\mathrm{nr}$ & WTA & TM-WTA & 0 & 0.0 & $7,008.0$ & $2,136.0$ \\
\hline UE12t\#2 & $\begin{array}{l}\text { pre-Tmr, } \\
\text { post-Tbg }\end{array}$ & BED/RWT & GL & VTA & TM-LVTA & 198 & 60.4 & $6,810.0$ & $2,075.7$ \\
\hline UE12t\#2 & Tbg? & NWT/RWT & $\mathrm{GL}$ & VTA & TM-LVTA & 561 & 171.0 & $6,447.0$ & $1,965.0$ \\
\hline UE12t\#2 & Tn4 & BED & $\mathrm{GL}$ & VTA & TM-LVTA & 606 & 184.7 & $6,402.0$ & $1,951.3$ \\
\hline UE12t\#2 & Tn4 & BED/RWT & ZC & TCU & LTCU & 649 & 197.8 & $6,359.0$ & $1,938.2$ \\
\hline UE12t\#2 & Tn3 & BED/RWT & $Z C$ & $\mathrm{TCU}$ & LTCU & 1,127 & 343.5 & $5,881.0$ & $1,792.5$ \\
\hline UE12t\#2 & Tub & NWT & ZE & TCU & LTCU & 1,302 & 396.8 & $5,706.0$ & $1,739.2$ \\
\hline UE12t\#2 & Ton2 & BED/RWT & $Z C$ & TCU & OSBCU & 1,312 & 399.9 & $5,696.0$ & $1,736.1$ \\
\hline UE12t\#2 & Ton1 & BED/RWT & ZC & TCU & OSBCU & 1,507 & 459.3 & $5,501.0$ & $1,676.7$ \\
\hline UE12t\#2 & $\mathrm{TI}$ & $\mathrm{PCL}$ & $\mathrm{nr}$ & $\mathrm{TCU}$ & ATCU & 1,665 & 507.5 & $5,343.0$ & $1,628.5$ \\
\hline UE12t\#2 & $\mathrm{Pz}$ & LS & na & $\mathrm{CA}$ & LCA3 & 1,666 & 507.8 & $5,342.0$ & $1,628.2$ \\
\hline UE12t\#4 & $\mathrm{Tmr}$ & MWT/DWT & $\mathrm{nr}$ & WTA & TM-WTA & 0 & 0.0 & $6,920.0$ & $2,109.2$ \\
\hline UE12t\#4 & $\mathrm{Tmr}$ & PWT/NWT & $\mathrm{nr}$ & VTA & TM-LVTA & 284 & 86.6 & $6,636.0$ & $2,022.7$ \\
\hline UE12t\#4 & $\begin{array}{l}\text { pre-Tmr, } \\
\text { post-Tbg }\end{array}$ & BED/RWT & GL & VTA & TM-LVTA & 353 & 107.6 & $6,567.0$ & $2,001.6$ \\
\hline UE12t\#4 & Tbg & $\mathrm{FB}$ & $\mathrm{nr}$ & VTA & TM-LVTA & 750 & 228.6 & $6,170.0$ & $1,880.6$ \\
\hline UE12t\#4 & Tbg & DWT & $\mathrm{nr}$ & WTA & BRA & 780 & 237.7 & $6,140.0$ & $1,871.5$ \\
\hline UE12t\#4 & Tbgb & BED & $\mathrm{GL}$ & VTA & LVTA1 & 825 & 251.5 & $6,095.0$ & $1,857.8$ \\
\hline UE12t\#4 & Tn4 & BED & GL & VTA & LVTA1 & 925 & 281.9 & $5,995.0$ & $1,827.3$ \\
\hline UE12t\#4 & Tn4 & BED/RWT & $Z C$ & TCU & BRCU & 965 & 294.1 & $5,955.0$ & $1,815.1$ \\
\hline UE12t\#4 & Tn3 & BED/RWT & ZC & $\mathrm{TCU}$ & BRCU & 1,331 & 405.7 & $5,589.0$ & $1,703.5$ \\
\hline UE12t\#4 & Tub & PWT/DWT & $\mathrm{nr}$ & & TUBA & 1,527 & 465.4 & $5,393.0$ & $1,643.8$ \\
\hline UE12t\#4 & Tub & BED & ZC & $\mathrm{TCU}$ & OSBCU & 1,607 & 489.8 & $5,313.0$ & $1,619.4$ \\
\hline UE12t\#4 & Ton2 & BED/RWT & ZC & $\mathrm{TCU}$ & OSBCU & 1,643 & 500.8 & $5,277.0$ & $1,608.4$ \\
\hline UE12t\#4 & Toy & NWT/PWT & ZC & $\mathrm{TCU}$ & OSBCU & 1,725 & 525.8 & $5,195.0$ & $1,583.4$ \\
\hline UE12t\#4 & To & RWT/NWT? & ZC & TCU & OSBCU & 1,918 & 584.6 & $5,002.0$ & $1,524.6$ \\
\hline
\end{tabular}


Table A-2

Geologic and Hydrostratigraphic Drill hole Database for the Rainier Mesa-Shoshone Mountain Model Area (vertical drill holes only)

\begin{tabular}{|c|c|c|c|c|c|c|c|c|c|}
\hline Hole Name & Strat $^{1}$ & Lith $^{2}$ & Major Alt. ${ }^{3}$ & $H_{G U^{4}}$ & $\mathrm{HSU}^{5}$ & $\begin{array}{c}\text { Depth Top } \\
\text { (ft) }\end{array}$ & $\begin{array}{c}\text { Depth } \\
\operatorname{Top}^{6}(\mathrm{~m})\end{array}$ & $\begin{array}{c}\text { Elev. Top } \\
\text { (ft) }\end{array}$ & \begin{tabular}{|c}
$\begin{array}{c}\text { Elev. Top } \\
\text { (m) }\end{array}$ \\
\end{tabular} \\
\hline UE12t\#4 & $\overline{\mathrm{TI}}$ & $\overline{P \mathrm{PCL}}$ & $\overline{Z Z C / Z M}$ & $\overline{\mathrm{TCU}}$ & 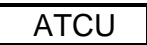 & 2,269 & 691.6 & $4,651.0$ & $1,417.6$ \\
\hline UE12t\#3 & $\mathrm{Tmr}$ & MWT/DWT & $\mathrm{nr}$ & WTA & TM-WTA & 0 & 0.0 & $6,777.0$ & $2,065.6$ \\
\hline UE12t\#3 & $\mathrm{Tmr}$ & PWT/NWT & $\mathrm{nr}$ & VTA & TM-LVTA & 320 & 97.5 & $6,457.0$ & $1,968.1$ \\
\hline UE12t\#3 & $\begin{array}{l}\text { pre-Tmr, } \\
\text { post-Tbg }\end{array}$ & BED/RWT & GL & VTA & TM-LVTA & 408 & 124.4 & $6,369.0$ & $1,941.3$ \\
\hline UE12t\#3 & Tbg & NWT/RWT & $\mathrm{GL}$ & VTA & TM-LVTA & 696 & 212.1 & $6,081.0$ & $1,853.5$ \\
\hline UE12t\#3 & $\overline{\mathrm{Tbg}}$ & NWT/PWT & $\mathrm{nr}$ & VTA & TM-LVTA & 725 & 221.0 & $6,052.0$ & $1,844.6$ \\
\hline UE12t\#3 & $\mathrm{Tbg}$ & DWT/VIT & $\mathrm{nr}$ & WTA & BRA & 752 & 229.2 & $6,025.0$ & $1,836.4$ \\
\hline UE12t\#3 & Tbgb & BED & $\overline{G L}$ & VTA & LVTA1 & 778 & 237.1 & $5,999.0$ & $1,828.5$ \\
\hline UE12t\#3 & $\overline{\mathrm{Tn} 4}$ & BED & $\overline{G L}$ & VTA & LVTA1 & 880 & 268.2 & $5,897.0$ & $1,797.4$ \\
\hline UE12t\#3 & Tn4 & BED/RWT & $\overline{Z C}$ & $\overline{\mathrm{TCU}}$ & BRCU & 918 & 279.8 & $5,859.0$ & $1,785.8$ \\
\hline UE12t\#3 & Tn3 & BED/RWT & ZC & TCU & BRCU & 1,285 & 391.7 & $5,492.0$ & $1,674.0$ \\
\hline UE12t\#3 & Tub & NWT/PWT & ZE & $\overline{\mathrm{TCU}}$ & BRCU & 1,426 & 434.6 & $5,351.0$ & $1,631.0$ \\
\hline UE12t\#3 & Tub & DWT/PWT & $\mathrm{nr}$ & WTA & TUBA & 1,457 & 444.1 & $5,320.0$ & $1,621.5$ \\
\hline UE12t\#3 & Tub? & BED & ZC & TCU & OSBCU & 1,490 & 454.2 & $5,287.0$ & $1,611.5$ \\
\hline UE12t\#3 & Ton2 & BED/RWT & $\overline{Z C}$ & $\overline{\mathrm{TCU}}$ & OSBCU & 1,531 & 466.6 & $5,246.0$ & $1,599.0$ \\
\hline UE12t\#3 & Toy & NWT/PWT & $\mathrm{nr}$ & $\overline{\mathrm{TCU}}$ & OSBCU & 1,682 & 512.7 & $5,095.0$ & $1,553.0$ \\
\hline UE12t\#3 & Ton1 & BED/RWT & $\overline{Z C}$ & $\overline{\mathrm{TCU}}$ & OSBCU & 1,906 & 580.9 & $4,871.0$ & $1,484.7$ \\
\hline UE12t\#3 & To & NWT/PWT & $\mathrm{nr}$ & TCU & OSBCU & 1,989 & 606.2 & $4,788.0$ & $1,459.4$ \\
\hline UE12t\#3 & $\mathrm{TI}$ & $\overline{P C L}$ & $Z C$ & TCU & ATCU & 2,083 & 634.9 & $4,694.0$ & $1,430.7$ \\
\hline UE12t\#5 & $\mathrm{Tmr}$ & MWT/DWT & $\mathrm{nr}$ & WTA & TM-WTA & 0 & 0.0 & $7,059.0$ & $2,151.6$ \\
\hline UE12t\#5 & $\mathrm{Tmr}$ & PWT/NWT & $\mathrm{nr}$ & VTA & TM-LVTA & 150 & 45.7 & $6,909.0$ & $2,105.9$ \\
\hline UE12t\#5 & $\begin{array}{l}\text { pre-Tmr, } \\
\text { post-Tbg }\end{array}$ & BED/RWT & GL & VTA & TM-LVTA & 200 & 61.0 & $6,859.0$ & $2,090.6$ \\
\hline UE12t\#5 & $\begin{array}{l}\text { pre-Tmr, } \\
\text { post-Tbg }\end{array}$ & BED/RWT & ZC & TCU & TM-LVTA & 425 & 129.5 & $6,634.0$ & $2,022.0$ \\
\hline UE12t\#5 & $\begin{array}{l}\text { pre-Tmr, } \\
\text { post-Tbg }\end{array}$ & BED & GL & VTA & TM-LVTA & 450 & 137.2 & $6,609.0$ & $2,014.4$ \\
\hline UE12t\#5 & $\begin{array}{l}\text { pre-Tmr, } \\
\text { post-Tbg }\end{array}$ & BED & ZC & TCU & TM-LVTA & 475 & 144.8 & $6,584.0$ & $2,006.8$ \\
\hline UE12t\#5 & Tbg? & RWT/NWT & ZC & TCU & TM-LVTA & 499 & 152.1 & $6,560.0$ & $1,999.5$ \\
\hline UE12t\#5 & Tbgb & BED & $\mathrm{GL}$ & VTA & TM-LVTA & 512 & 156.1 & $6,547.0$ & $1,995.5$ \\
\hline UE12t\#5 & Tbgb & BED & $Z C$ & TCU & LTCU & 545 & 166.1 & $6,514.0$ & $1,985.5$ \\
\hline UE12t\#5 & Tn4 & BED/RWT & ZC & TCU & LTCU & 600 & 182.9 & $6,459.0$ & $1,968.7$ \\
\hline UE12t\#5 & Tn3 & BED/RWT & $Z C$ & $\overline{\mathrm{TCU}}$ & LTCU & 1,085 & 330.7 & $5,974.0$ & $1,820.9$ \\
\hline UE12t\#5 & Tub? & BED & $Z C$ & TCU & LTCU & 1,234 & 376.1 & $5,825.0$ & $1,775.5$ \\
\hline UE12t\#5 & Ton2 & BED/RWT & $\overline{Z C}$ & $\overline{\mathrm{TCU}}$ & OSBCU & 1,285 & 391.7 & $5,774.0$ & $1,759.9$ \\
\hline UE12t\#5 & To & BED/RWT & ZC & TCU & OSBCU & 1,345 & 410.0 & $5,714.0$ & $1,741.6$ \\
\hline UE12t\#5 & $\mathrm{TI}$ & $\overline{P C L}$ & $Z C$ & $\overline{\mathrm{TCU}}$ & ATCU & 1,500 & 457.2 & $5,559.0$ & $1,694.4$ \\
\hline UE12t\#5 & $\mathrm{Pz}$ & DM/QTZ & na & $\mathrm{CA}$ & LCA3 & 1,511 & 460.6 & $5,548.0$ & $1,691.0$ \\
\hline UE12t\#6 & Tn3 & BED/RWT & $Z C$ & TCU & LTCU & 660 & 201.2 & $6,247.0$ & $1,904.1$ \\
\hline UE12t\#6 & Tub & FB? & ZE & TCU & LTCU & 870 & 265.2 & $5,377.0$ & $1,638.9$ \\
\hline UE12t\#6 & Ton2 & BED/RWT & $Z C$ & TCU & OSBCU & 883 & 269.1 & $6,024.0$ & $1,836.1$ \\
\hline UE12t\#6 & To & BED/RWT & $\mathrm{ZC}$ & TCU & OSBCU & 1,070 & 326.1 & $5,837.0$ & $1,779.1$ \\
\hline UE12t\#6 & To & NWT & $\mathrm{nr}$ & TCU & OSBCU & 1,163 & 354.5 & $5,744.0$ & $1,750.8$ \\
\hline UE12t\#6 & To & BED/RWT & $Z C$ & TCU & OSBCU & 1,203 & 366.7 & $5,704.0$ & $1,738.6$ \\
\hline UE12t\#6 & To & NWT? & ZM & TCU & OSBCU & 1,317 & 401.4 & $5,590.0$ & $1,703.8$ \\
\hline UE12t\#6 & CpC? & $\mathrm{SCH} / \mathrm{QTZ}$ & na & $\mathrm{CCU}$ & LCCU1 & 1,397 & 425.8 & $5,510.0$ & $1,679.5$ \\
\hline UE12t\#7 & $\mathrm{Tmr}$ & PWT/MWT & $\mathrm{nr}$ & WTA & TM-WTA & 0 & 0.0 & $6,960.9$ & $2,121.7$ \\
\hline UE12t\#7 & $\mathrm{Tmr}$ & DWT & $\mathrm{nr}$ & WTA & TM-WTA & 50 & 15.2 & $6,910.9$ & $2,106.4$ \\
\hline UE12t\#7 & $\mathrm{Tmr}$ & MWT/NWT & $\mathrm{nr}$ & VTA & TM-LVTA & 150 & 45.7 & $6,810.9$ & $2,076.0$ \\
\hline UE12t\#7 & $\begin{array}{l}\text { pre-Tmr, } \\
\text { post-Tbg }\end{array}$ & BED & GL & VTA & TM-LVTA & 206 & 62.8 & $6,754.9$ & $2,058.9$ \\
\hline UE12t\#7 & Tbgb & BED & $\mathrm{GL}$ & VTA & TM-LVTA & 483 & 147.2 & $6,477.9$ & $1,974.5$ \\
\hline UE12t\#7 & Tn4 & BED & $\mathrm{GL}$ & VTA & TM-LVTA & 560 & 170.7 & $6,400.9$ & $1,951.0$ \\
\hline UE12t\#7 & Tn4 & BED/RWT & $Z C$ & $\overline{\mathrm{TCU}}$ & LTCU & 697 & 212.4 & $6,263.9$ & $1,909.2$ \\
\hline
\end{tabular}


Table A-2

Geologic and Hydrostratigraphic Drill hole Database for the Rainier Mesa-Shoshone Mountain Model Area (vertical drill holes only)

\begin{tabular}{|c|c|c|c|c|c|c|c|c|c|}
\hline Hole Name & Strat $^{1}$ & Lith $^{2}$ & Major Alt. ${ }^{3}$ & $\mathrm{HGU}^{4}$ & $\mathrm{HSU}^{5}$ & \begin{tabular}{|c|}
$\begin{array}{c}\text { Depth Top } \\
6 \\
(\mathrm{ft})\end{array}$ \\
\end{tabular} & $\begin{array}{c}\text { Depth } \\
\operatorname{Top}^{6}(\mathrm{~m}) \\
\end{array}$ & $\begin{array}{c}\begin{array}{c}\text { Elev. Top } \\
\\
\text { (ft) }\end{array} \\
\end{array}$ & $\begin{array}{c}\text { Elev. Top } \\
\text { (m) } \\
\end{array}$ \\
\hline UE12t\#7 & $\overline{T \text { Tn3 }}$ & BED/RWT & ZC & TCU & LTCU & 853 & 260.0 & $6,107.9$ & $1,861.7$ \\
\hline UE12t\#7 & Tub & NWT/FB & ZE & TCU & LTCU & 1,028 & 313.3 & $5,932.9$ & $1,808.3$ \\
\hline UE12t\#7 & Ton2 & BED/RWT & $Z C$ & $\overline{\mathrm{TCU}}$ & OSBCU & 1,080 & 329.2 & $5,880.9$ & $1,792.5$ \\
\hline UE12t\#7 & Toy & NWT & ZE & TCU & OSBCU & 1,307 & 398.4 & $5,653.9$ & $1,723.3$ \\
\hline UE12t\#7 & Ton1 & RWT & $Z C$ & $\overline{T C U}$ & OSBCU & 1,393 & 424.6 & $5,567.9$ & $1,697.1$ \\
\hline UE12t\#7 & To & NWT & ZM & $\mathrm{TCU}$ & OSBCU & 1,454 & 443.2 & $5,506.9$ & $1,678.5$ \\
\hline UE12t\#7 & $\mathrm{TI}$ & $\mathrm{PCL}$ & ZM & $\overline{T C U}$ & ATCU & 1,497 & 456.3 & $5,463.9$ & $1,665.4$ \\
\hline UE12t\#7 & CpC? & SLT & na & $\mathrm{CCU}$ & LCCU1 & 1,574 & 479.8 & $5,386.9$ & $1,641.9$ \\
\hline UE12t\#8 & $\mathrm{Tmr}$ & PWT/MWT & $\mathrm{nr}$ & WTA & TM-WTA & 0 & 0.0 & $6,724.9$ & $2,049.7$ \\
\hline UE12t\#8 & $\mathrm{Tmr}$ & DWT & $\mathrm{nr}$ & WTA & TM-WTA & 50 & 15.2 & $6,674.9$ & $2,034.5$ \\
\hline UE12t\#8 & $\mathrm{Tmr}$ & MWT/NWT & $\mathrm{nr}$ & VTA & TM-LVTA & 150 & 45.7 & $6,574.9$ & $2,004.0$ \\
\hline UE12t\#8 & $\begin{array}{l}\text { pre-Tmr, } \\
\text { post-Tbg }\end{array}$ & BED & GL & VTA & TM-LVTA & 249 & 75.9 & $6,475.9$ & $1,973.8$ \\
\hline UE12t\#8 & Tbg? & BED & ZM & $\mathrm{TCU}$ & TM-LVTA & 422 & 128.6 & $6,302.9$ & $1,921.1$ \\
\hline UE12t\#8 & Tbgb & BED & $\mathrm{GL}$ & VTA & TM-LVTA & 445 & 135.6 & $6,279.9$ & $1,914.1$ \\
\hline UE12t\#8 & Tn4 & BED & $\mathrm{GL}$ & VTA & TM-LVTA & 545 & 166.1 & $6,179.9$ & $1,883.6$ \\
\hline UE12t\#8 & Tn4 & BED/RWT & ZC & TCU & LTCU & 814 & 248.1 & $5,910.9$ & $1,801.6$ \\
\hline UE12t\#8 & Tn3 & BED/RWT & $\mathrm{ZC}$ & $\mathrm{TCU}$ & LTCU & 948 & 289.0 & $5,776.9$ & $1,760.8$ \\
\hline UE12t\#8 & Tub & BED & $Z C$ & $\overline{T C U}$ & LTCU & 1,093 & 333.1 & $5,631.9$ & $1,716.6$ \\
\hline UE12t\#8 & Ton2 & BED/RWT & ZC & TCU & OSBCU & 1,106 & 337.1 & $5,618.9$ & $1,712.6$ \\
\hline UE12t\#8 & To & BED/RWT & $Z C$ & $\overline{T C U}$ & OSBCU & 1,255 & 382.5 & $5,469.9$ & $1,667.2$ \\
\hline UE12t\#8 & $\mathrm{TI}$ & $\mathrm{PCL}$ & ZM & TCU & ATCU & 1,365 & 416.1 & $5,359.9$ & $1,633.7$ \\
\hline UE12t\#8 & CpC? & SLT & na & $\mathrm{CCU}$ & LCCU1 & 1,374 & 418.8 & $5,350.9$ & $1,630.9$ \\
\hline UE12 $p$ & Tma & PWT/NWT & $\mathrm{nr}$ & VTA & TM-WTA & 0 & 0.0 & 6,338 & $1,931.8$ \\
\hline UE12 $p$ & $\mathrm{Tmr}$ & PWT/MWT & $\mathrm{nr}$ & VTA & TM-WTA & 45 & 13.7 & $6,293.0$ & $1,918.1$ \\
\hline UE12p & $\mathrm{Tmr}$ & DWT & $\mathrm{nr}$ & WTA & TM-WTA & 100 & 30.5 & $6,238.0$ & $1,901.3$ \\
\hline UE12 $p$ & $\mathrm{Tmr}$ & PWT/NWT & $\mathrm{nr}$ & VTA & TM-LVTA & 400 & 121.9 & $5,938.0$ & $1,809.9$ \\
\hline UE12p & $\begin{array}{l}\text { pre-Tmr, } \\
\text { post-Tbg }\end{array}$ & BED/RWT & GL & VTA & TM-LVTA & 503 & 153.3 & $5,835.0$ & $1,778.5$ \\
\hline UE12p & $\begin{array}{l}\text { pre-Tmr, } \\
\text { post-Tbg }\end{array}$ & BED/RWT & ZC & TCU & UTCU1 & 747 & 227.7 & $5,591.0$ & $1,704.1$ \\
\hline UE12p & Tbg & NWT/PWT & $\mathrm{nr}$ & TCU & UTCU1 & 1,206 & 367.6 & $5,132.0$ & $1,564.2$ \\
\hline UE12p & Tbg & MWT/DWT & $\mathrm{nr}$ & WTA & BRA & 1,250 & 381.0 & $5,088.0$ & $1,550.8$ \\
\hline UE12p & Tbg & PWT/NWT & $\mathrm{nr}$ & TCU & BRCU & 1,280 & 390.1 & $5,058.0$ & $1,541.7$ \\
\hline UE12p & Tbgb & BED & $\mathrm{nr}$ & TCU & BRCU & 1,359 & 414.2 & $4,979.0$ & $1,517.6$ \\
\hline UE12p & Tn4 & BED/RWT & ZC & $\mathrm{TCU}$ & BRCU & 1,430 & 435.9 & $4,908.0$ & $1,496.0$ \\
\hline UE12p & Tn3 & BED & $\mathrm{ZC}$ & TCU & BRCU & 1,628 & 496.2 & $4,710.0$ & $1,435.6$ \\
\hline UE12p & Tub & PWT/MWT & $\mathrm{nr}$ & WTA & TUBA & 1,764 & 537.7 & $4,574.0$ & $1,394.2$ \\
\hline UE12p & pre-T & $\mathrm{DM}$ & na & $\mathrm{CA}$ & LCA3 & 1,817 & 553.8 & $4,521.0$ & $1,378.0$ \\
\hline UE12p\#1 & Tmr & PWT/MWT & $\mathrm{nr}$ & VTA & TM-WTA & 0 & 0.0 & 6,477 & $1,974.2$ \\
\hline UE12p\#1 & $\mathrm{Tmr}$ & DWT & $\mathrm{nr}$ & WTA & TM-WTA & 75 & 22.9 & $6,402.0$ & $1,951.3$ \\
\hline UE12p\#1 & $\mathrm{Tmr}$ & PWT/NWT & $\mathrm{nr}$ & VTA & TM-LVTA & 275 & 83.8 & $6,202.0$ & $1,890.4$ \\
\hline UE12p\#1 & $\begin{array}{l}\text { pre-Tmr, } \\
\text { post-Tbg }\end{array}$ & BED/RWT & GL & VTA & TM-LVTA & 419 & 127.7 & $6,058.0$ & $1,846.5$ \\
\hline UE12p\#1 & $\begin{array}{l}\text { pre-Tmr, } \\
\text { post-Tbg }\end{array}$ & BED/RWT & ZC & TCU & UTCU1 & 864 & 263.3 & $5,613.0$ & $1,710.8$ \\
\hline UE12p\#1 & Tbg & PWT & $\mathrm{nr}$ & $\mathrm{TCU}$ & UTCU1 & 1,205 & 367.3 & $5,272.0$ & $1,606.9$ \\
\hline UE12p\#1 & Tbg & MWT/DWT & $\mathrm{nr}$ & WTA & BRA & 1,215 & 370.3 & $5,262.0$ & $1,603.9$ \\
\hline UE12p\#1 & Tbgb & BED & $\mathrm{ZC}$ & $\mathrm{TCU}$ & BRCU & 1,449 & 441.7 & $5,028.0$ & $1,532.5$ \\
\hline UE12p\#1 & Tn4 & BED/RWT & ZC & $\mathrm{TCU}$ & $\mathrm{BRCU}$ & 1,553 & 473.4 & $4,924.0$ & $1,500.8$ \\
\hline UE12p\#1 & Tn3 & BED/RWT & ZC & TCU & BRCU & 1,704 & 519.4 & $4,773.0$ & $1,454.8$ \\
\hline
\end{tabular}


Table A-2

Geologic and Hydrostratigraphic Drill hole Database for the Rainier Mesa-Shoshone Mountain Model Area (vertical drill holes only)

\begin{tabular}{|c|c|c|c|c|c|c|c|c|c|}
\hline Hole Name & Strat $^{1}$ & Lith $^{2}$ & Major Alt. ${ }^{3}$ & $\mathrm{HGU}^{4}$ & $\mathrm{HSU}^{5}$ & \begin{tabular}{|c|}
$\begin{array}{c}\text { Depth Top } \\
\text { (ft) }\end{array}$ \\
\end{tabular} & $\begin{array}{c}\text { Depth } \\
\text { Top }^{6}(\mathrm{~m}) \\
\end{array}$ & \begin{tabular}{|c|}
$\begin{array}{c}\text { Elev. Top } \\
\text { (ft) }\end{array}$ \\
\end{tabular} & $\begin{array}{c}\begin{array}{c}\text { Elev. Top } \\
\text { (m) }\end{array} \\
\end{array}$ \\
\hline UE12p\#1 & To & BED/RWT & ZC & TCU & OSBCU & 1,830 & 557.8 & $4,647.0$ & $1,416.4$ \\
\hline UE12p\#1 & KGM & IN & na & $\mathrm{ICU}$ & MGCU & 1,977 & 602.6 & $4,500.0$ & $1,371.6$ \\
\hline UE12p\#1 & pCS & QTZ & na & $\mathrm{CCU}$ & LCCU1 & 2,130 & 649.2 & $4,347.0$ & $1,325.0$ \\
\hline UE12p\#2 & $\mathrm{Tmr}$ & PWT/MWT & $\mathrm{nr}$ & VTA & TM-WTA & 0 & 0.0 & 6,347 & $1,934.6$ \\
\hline UE12p\#2 & Tmr & DWT & $\mathrm{nr}$ & WTA & \begin{tabular}{|l|} 
TM-WTA \\
\end{tabular} & 60 & 18.3 & $6,287.0$ & $1,916.3$ \\
\hline UE12p\#2 & $\mathrm{Tmr}$ & PWT/NWT & $\mathrm{nr}$ & VTA & TM-LVTA & 350 & 106.7 & $5,997.0$ & $1,827.9$ \\
\hline UE12p\#2 & $\begin{array}{l}\text { pre-Tmr, } \\
\text { post-Tbg }\end{array}$ & BED & GL & VTA & TM-LVTA & 459 & 139.9 & $5,888.0$ & $1,794.7$ \\
\hline UE12p\#2 & $\begin{array}{l}\text { pre-Tmr, } \\
\text { post-Tbg }\end{array}$ & BED/RWT & ZC & TCU & UTCU1 & 681 & 207.6 & $5,666.0$ & $1,727.0$ \\
\hline UE12p\#2 & Tbg & NWT/PWT & $\mathrm{nr}$ & $\mathrm{TCU}$ & UTCU1 & 1,353 & 412.4 & $4,994.0$ & $1,522.2$ \\
\hline UE12p\#2 & Tbg & MWT/DWT & $\mathrm{nr}$ & WTA & BRA & 1,406 & 428.5 & $4,941.0$ & $1,506.0$ \\
\hline UE12p\#2 & Tbg & PWT & $\mathrm{nr}$ & $\mathrm{TCU}$ & LTCU & 1,605 & 489.2 & $4,742.0$ & $1,445.4$ \\
\hline UE12p\#2 & Tbgb & BED & $Z C$ & $\mathrm{TCU}$ & LTCU & 1,728 & 526.7 & $4,619.0$ & $1,407.9$ \\
\hline UE12p\#2 & Tn4 & BED/RWT & ZC & TCU & LTCU & 1,778 & 541.9 & $4,569.0$ & $1,392.6$ \\
\hline UE12p\#2 & Tn3 & BED/RWT & ZC & TCU & LTCU & 1,960 & 597.4 & $4,387.0$ & $1,337.2$ \\
\hline UE12p\#2 & Tub & NWT & ZE & $\mathrm{TCU}$ & LTCU & 2,155 & 656.8 & $4,192.0$ & $1,277.7$ \\
\hline UE12p\#2 & To & BED/RWT & $\mathrm{ZC}$ & TCU & OSBCU & 2,173 & 662.3 & $4,174.0$ & $1,272.2$ \\
\hline UE12p\#3 & Tma & PWT/NWT & $\mathrm{nr}$ & VTA & TM-WTA & 0 & 0.0 & 6,332 & $1,930.0$ \\
\hline UE12p\#3 & $\mathrm{Tmr}$ & PWT/MWT & $\mathrm{nr}$ & VTA & TM-WTA & 75 & 22.9 & $6,257.0$ & $1,907.1$ \\
\hline UE12p\#3 & $\mathrm{Tmr}$ & DWT & $\mathrm{nr}$ & WTA & \begin{tabular}{|l|} 
TM-WTA \\
\end{tabular} & 170 & 51.8 & $6,162.0$ & $1,878.2$ \\
\hline UE12p\#3 & $\mathrm{Tmr}$ & PWT/NWT & $\mathrm{nr}$ & VTA & TM-LVTA & 455 & 138.7 & $5,877.0$ & $1,791.3$ \\
\hline UE12p\#3 & $\begin{array}{l}\text { pre-Tmr, } \\
\text { post-Tbg }\end{array}$ & BED & $\mathrm{GL}$ & VTA & TM-LVTA & 529 & 161.2 & $5,803.0$ & $1,768.8$ \\
\hline UE12p\#3 & $\begin{array}{l}\text { pre-Tmr, } \\
\text { post-Tbg }\end{array}$ & BED/RWT & ZC & TCU & UTCU1 & 929 & 283.2 & $5,403.0$ & $1,646.8$ \\
\hline UE12p\#3 & Tbg & NWT/PWT & $\mathrm{nr}$ & TCU & UTCU1 & 1,464 & 446.2 & $4,868.0$ & $1,483.8$ \\
\hline UE12p\#3 & Tbg & DWT & $\mathrm{nr}$ & WTA & BRA & 1,505 & 458.7 & $4,827.0$ & $1,471.3$ \\
\hline UE12p\#3 & Tbg & NWT & $\mathrm{nr}$ & TCU & BRCU & 1,750 & 533.4 & $4,582.0$ & $1,396.6$ \\
\hline UE12p\#3 & Tbgb & BED & $Z C$ & TCU & BRCU & 1,769 & 539.2 & $4,563.0$ & $1,390.8$ \\
\hline UE12p\#3 & Tn4 & BED/RWT & $\mathrm{ZC}$ & $\mathrm{TCU}$ & BRCU & 1,818 & 554.1 & $4,514.0$ & $1,375.9$ \\
\hline UE12p\#3 & Tn3 & BED/RWT & $\mathrm{ZC}$ & $\mathrm{TCU}$ & BRCU & 2,156 & 657.1 & $4,176.0$ & $1,272.8$ \\
\hline UE12p\#3 & $\mathrm{Tn}$ & BED/RWT & ZC & $\mathrm{TCU}$ & BRCU & 2,286 & 696.8 & $4,046.0$ & $1,233.2$ \\
\hline UE12p\#3 & Tub & DWT & $\mathrm{nr}$ & WTA & TUBA & 2,456 & 748.6 & $3,876.0$ & $1,181.4$ \\
\hline UE12p\#3 & Tub & PWT/NWT & $\mathrm{nr}$ & TCU & OSBCU & 2,535 & 772.7 & $3,797.0$ & $1,157.3$ \\
\hline UE12p\#3 & To & BED/RWT & $\mathrm{nr}$ & $\mathrm{TCU}$ & OSBCU & 2,581 & 786.7 & $3,751.0$ & $1,143.3$ \\
\hline UE12p\#3 & To & NWT & $\mathrm{nr}$ & $\mathrm{TCU}$ & OSBCU & 2,589 & 789.1 & $3,743.0$ & $1,140.9$ \\
\hline UE12p\#4 & Tma & PWT/NWT & $\mathrm{nr}$ & VTA & TM-WTA & 0 & 0.0 & $6,396.0$ & $1,949.5$ \\
\hline UE12p\#4 & Tma & BED & $\mathrm{GL}$ & VTA & \begin{tabular}{|l|} 
TM-WTA \\
\end{tabular} & 35 & 10.7 & $6,361.0$ & $1,938.8$ \\
\hline UE12p\#4 & $\mathrm{Tmr}$ & NWT/PWT & $\mathrm{nr}$ & VTA & TM-WTA & 67 & 20.4 & $6,329.0$ & $1,929.1$ \\
\hline UE12p\#4 & Tmr & MWT/DWT & $\mathrm{nr}$ & WTA & TM-WTA & 145 & 44.2 & $6,251.0$ & $1,905.3$ \\
\hline UE12p\#4 & $\mathrm{Tmr}$ & NWT/PWT & $\mathrm{nr}$ & VTA & TM-LVTA & 395 & 120.4 & $6,001.0$ & $1,829.1$ \\
\hline UE12p\#4 & $\begin{array}{l}\text { pre-Tmr, } \\
\text { post-Tbg }\end{array}$ & BED/RWT & GL & VTA & TM-LVTA & 548 & 167.0 & $5,848.0$ & $1,782.5$ \\
\hline UE12p\#4 & $\begin{array}{l}\text { pre-Tmr, } \\
\text { post-Tbg }\end{array}$ & BED/RWT & ZC & TCU & UTCU1 & 812 & 247.5 & $5,584.0$ & $1,702.0$ \\
\hline UE12p\#4 & Tbg & NWT/PWT & $\mathrm{nr}$ & $\mathrm{TCU}$ & UTCU1 & 1,222 & 372.5 & $5,174.0$ & $1,577.0$ \\
\hline
\end{tabular}


Table A-2

Geologic and Hydrostratigraphic Drill hole Database for the Rainier Mesa-Shoshone Mountain Model Area (vertical drill holes only)

\begin{tabular}{|c|c|c|c|c|c|c|c|c|c|}
\hline Hole Name & Strat $^{1}$ & Lith $^{2}$ & Major Alt. ${ }^{3}$ & $\mathrm{HGU}^{4}$ & $\mathrm{HSU}^{5}$ & \begin{tabular}{|c|}
$\begin{array}{c}\text { Depth Top } \\
6 \\
(\mathrm{ft})\end{array}$ \\
\end{tabular} & $\begin{array}{c}\text { Depth } \\
\operatorname{Top}^{6}(\mathrm{~m}) \\
\end{array}$ & $\begin{array}{c}\text { Elev. Top }{ }^{7} \\
\text { (ft) }\end{array}$ & \begin{tabular}{|c|}
$\begin{array}{c}\text { Elev. Top } \\
\text { (m) }\end{array}$ \\
\end{tabular} \\
\hline UE12p\#4 & Tbg & MWT/DWT & $\mathrm{nr}$ & WTA & BRA & 1,240 & 378.0 & $5,156.0$ & $1,571.6$ \\
\hline UE12p\#4 & Tbgb & BED & ZC & TCU & LTCU & 1,378 & 420.0 & $5,018.0$ & $1,529.5$ \\
\hline UE12p\#4 & Tn4 & BED/RWT & ZC & TCU & LTCU & 1,457 & 444.1 & $4,939.0$ & $1,505.4$ \\
\hline UE12p\#4 & Tn3 & BED/RWT & ZC & TCU & LTCU & 1,649 & 502.6 & $4,747.0$ & $1,446.9$ \\
\hline UE12p\#4 & Tub & NWT & $\mathrm{nr}$ & TCU & LTCU & 1,716 & 523.0 & $4,680.0$ & $1,426.5$ \\
\hline UE12p\#4 & Ton2 & BED/RWT & $\mathrm{ZC} / \mathrm{ZM}$ & $\mathrm{TCU}$ & OSBCU & 1,719 & 524.0 & $4,677.0$ & $1,425.6$ \\
\hline UE12p\#4 & pre-T & DM & na & LCA3 & LCA3 & 1,774 & 540.7 & $4,622.0$ & $1,408.8$ \\
\hline UE12p\#5 & $\mathrm{Tmr}$ & MWT/DWT & $\mathrm{nr}$ & WTA & TM-WTA & 0 & 0.0 & $6,527.45$ & 1,989.6 \\
\hline UE12p\#5 & Tmr & PWT/NWT & $\mathrm{nr}$ & VTA & TM-LVTA & 250 & 76.2 & $6,277.5$ & $1,913.4$ \\
\hline UE12p\#5 & $\begin{array}{l}\text { pre-Tmr, } \\
\text { post-Tbg }\end{array}$ & BED/RWT & GL & VTA & TM-LVTA & 390 & 118.9 & $6,137.5$ & $1,870.7$ \\
\hline UE12p\#5 & Tbg & BED/RWT & $\mathrm{ZC}$ & $\mathrm{TCU}$ & TM-LVTA & 881 & 268.5 & $5,646.5$ & $1,721.0$ \\
\hline UE12p\#5 & Tbgb & BED/RWT & $\mathrm{GL}$ & VTA & TM-LVTA & 893 & 272.2 & $5,634.5$ & $1,717.4$ \\
\hline UE12p\#5 & Tn4 & BED/RWT & $\mathrm{ZC}$ & $\mathrm{TCU}$ & LTCU & 931 & 283.8 & $5,596.5$ & $1,705.8$ \\
\hline UE12p\#5 & Tn3 & BED/RWT & $\mathrm{ZC}$ & TCU & LTCU & 1,224 & 373.1 & $5,303.5$ & $1,616.5$ \\
\hline UE12p\#5 & To & NWT & $\mathrm{nr}$ & TCU & OSBCU & 1,262 & 384.7 & $5,265.5$ & $1,604.9$ \\
\hline UE12p\#5 & To & RWT & $Z C$ & TCU & OSBCU & 1,281 & 390.4 & $5,246.5$ & $1,599.1$ \\
\hline UE12p\#5 & $\mathrm{TI}$ & $\mathrm{PCL}$ & ZM & TCU & ATCU & 1,295 & 394.7 & $5,232.5$ & $1,594.9$ \\
\hline UE12p\#5 & pre-T & LS & na & $\mathrm{CA}$ & LCA3 & 1,300 & 396.2 & $5,227.5$ & $1,593.3$ \\
\hline UE12p\#6 & Tma & PWT & $\mathrm{nr}$ & VTA & \begin{tabular}{|l|} 
TM-WTA \\
\end{tabular} & 0 & 0.0 & $6,344.89$ & $1,933.9$ \\
\hline UE12p\#6 & $\mathrm{Tmr}$ & PWT/MWT & $\mathrm{nr}$ & VTA & TM-WTA & 50 & 15.2 & $6,294.9$ & $1,918.7$ \\
\hline UE12p\#6 & $\mathrm{Tmr}$ & DWT & $\mathrm{nr}$ & WTA & TM-WTA & 150 & 45.7 & $6,194.9$ & $1,888.2$ \\
\hline UE12p\#6 & $\mathrm{Tmr}$ & $\mathrm{PWT/NWT}$ & $\mathrm{nr}$ & VTA & TM-LVTA & 450 & 137.2 & $5,894.9$ & $1,796.8$ \\
\hline UE12p\#6 & $\begin{array}{l}\text { pre-Tmr, } \\
\text { post-Tbg }\end{array}$ & BED & GL & VTA & TM-LVTA & 555 & 169.2 & $5,789.9$ & $1,764.8$ \\
\hline UE12p\#6 & $\begin{array}{l}\text { pre-Tmr, } \\
\text { post-Tbg }\end{array}$ & BED & ZC & TCU & UTCU1 & 800 & 243.8 & $5,544.9$ & $1,690.1$ \\
\hline UE12p\#6 & Tbg & NWT/PWT & $\mathrm{nr}$ & $\mathrm{TCU}$ & UTCU1 & 1,341 & 408.7 & $5,003.9$ & $1,525.2$ \\
\hline UE12p\#6 & Tbg & DWT & $\mathrm{nr}$ & WTA & BRA & 1,375 & 419.1 & $4,969.9$ & $1,514.8$ \\
\hline UE12p\#6 & Tbg & MWT/PWT & $\mathrm{nr}$ & TCU & BRCU & 1,475 & 449.6 & $4,869.9$ & $1,484.3$ \\
\hline UE12p\#6 & Tbgb & BED & $Z C$ & TCU & BRCU & 1,561 & 475.8 & $4,783.9$ & $1,458.1$ \\
\hline UE12p\#6 & Tn4 & BED/RWT & $\mathrm{ZC}$ & $\mathrm{TCU}$ & BRCU & 1,681 & 512.4 & $4,663.9$ & $1,421.6$ \\
\hline UE12p\#6 & Tn3 & BED/RWT & ZC & $\mathrm{TCU}$ & BRCU & 1,871 & 570.3 & $4,473.9$ & 1,363.6 \\
\hline UE12p\#6 & Tub & PWT/MWT & $\mathrm{nr}$ & WTA & TUBA & 2,005 & 611.1 & $4,339.9$ & $1,322.8$ \\
\hline UE12p\#6 & Tub & DWT & $\mathrm{nr}$ & WTA & TUBA & 2,075 & 632.5 & $4,269.9$ & $1,301.5$ \\
\hline UE12p\#6 & Tub & $\mathrm{FB}$ & ZM & $\mathrm{TCU}$ & OSBCU & 2,223 & 677.6 & $4,121.9$ & $1,256.4$ \\
\hline UE12p\#6 & Tub & BED & $Z C$ & TCU & OSBCU & 2,232 & 680.3 & $4,112.9$ & $1,253.6$ \\
\hline UE12p\#6 & To & BED/RWT & ZC & TCU & OSBCU & 2,263 & 689.8 & $4,081.9$ & $1,244.2$ \\
\hline UE12e\#1 & $\mathrm{Tmr}$ & DWT/NWT & $\mathrm{nr}$ & WTA & TM-WTA & 0 & 0.0 & 7,431 & $2,265.0$ \\
\hline UE12e\#1 & Tmh & BED & $\mathrm{GL}$ & VTA & TM-LVTA & 344 & 104.9 & $7,087.0$ & $2,160.1$ \\
\hline UE12e\#1 & Tpc & NWT & $\mathrm{nr}$ & VTA & TM-LVTA & 443 & 135.0 & $6,988.0$ & $2,129.9$ \\
\hline UE12e\#1 & $\begin{array}{l}\text { pre-Tmr, } \\
\text { post-Tbg }\end{array}$ & BED/RWT & GL & VTA & TM-LVTA & 491 & 149.7 & $6,940.0$ & $2,115.3$ \\
\hline UE12e\#1 & $\begin{array}{l}\text { pre-Tmr, } \\
\text { post-Tbg }\end{array}$ & BED/RWT & ZC & TCU & UTCU1 & 770 & 234.7 & $6,661.0$ & $2,030.3$ \\
\hline UE12e\#1 & $\mathrm{Tcb}$ & NWT & $Z C$ & TCU & UTCU1 & 819 & 249.6 & $6,612.0$ & $2,015.3$ \\
\hline UE12e\#1 & Tc & BED/RWT & ZC & TCU & UTCU1 & 827 & 252.1 & $6,604.0$ & $2,012.9$ \\
\hline UE12e\#1 & Tbg & MWT/DWT & $\mathrm{nr}$ & WTA & BRA & 1,048 & 319.4 & $6,383.0$ & $1,945.5$ \\
\hline UE12e\#1 & Tbg & MWT/PWT & $\mathrm{nr}$ & WTA & BRA & 1,055 & 321.6 & $6,376.0$ & $1,943.4$ \\
\hline
\end{tabular}


Table A-2

Geologic and Hydrostratigraphic Drill hole Database for the Rainier Mesa-Shoshone Mountain Model Area (vertical drill holes only)

\begin{tabular}{|c|c|c|c|c|c|c|c|c|c|}
\hline Hole Name & Strat $^{1}$ & Lith $^{2}$ & Major Alt. $^{3}$ & $H_{G}{ }^{4}$ & $\mathrm{HSU}^{5}$ & \begin{tabular}{|c|}
$\begin{array}{c}\text { Depth Top } \\
\text { (ft) }\end{array}$ \\
\end{tabular} & $\begin{array}{c}\text { Depth } \\
\operatorname{Top}^{6}(\mathrm{~m}) \\
\end{array}$ & \begin{tabular}{|c}
$\begin{array}{c}\text { Elev. Top } \\
\text { (ft) }\end{array}$ \\
\end{tabular} & \begin{tabular}{|c}
$\begin{array}{c}\text { Elev. Top } \\
\text { (m) }\end{array}$ \\
\end{tabular} \\
\hline UE12e\#1 & Tbgb & BED & $\mathrm{ZC}$ & $\overline{\mathrm{TCU}}$ & $\overline{\text { LTCU }}$ & 1,063 & 324.0 & $6,368.0$ & $1,941.0$ \\
\hline UE12e\#1 & Tn4 & BED/RWT & $Z C$ & $\mathrm{TCU}$ & LTCU & 1,139 & 347.2 & $6,292.0$ & $1,917.8$ \\
\hline UE12e\#1 & Tn3 & BED/RWT & ZC & TCU & LTCU & 1,503 & 458.1 & $5,928.0$ & $1,806.9$ \\
\hline UE12e\#1 & Tub & NWT & ZC & TCU & LTCU & 1,729 & 527.0 & $5,702.0$ & $1,738.0$ \\
\hline UE12e\#1 & Ton2 & BED/RWT & ZC & TCU & OSBCU & 1,750 & 533.4 & $5,681.0$ & $1,731.6$ \\
\hline UE12e\#1 & Toy & DWT & $\mathrm{nr}$ & WTA & OSBCU & 1,879 & 572.7 & $5,552.0$ & $1,692.2$ \\
\hline UE12e\#1 & Ton1 & BED/RWT & $\overline{Z C}$ & $\overline{\mathrm{TCU}}$ & OSBCU & 1,884 & 574.2 & $5,547.0$ & $1,690.7$ \\
\hline UE12e\#1 & To & NWT & ZC & TCU & OSBCU & 1,983 & 604.4 & $5,448.0$ & $1,660.6$ \\
\hline UE12e\#1 & Ton1 & BED/RWT & ZC & TCU & OSBCU & 1,991 & 606.9 & $5,440.0$ & $1,658.1$ \\
\hline UE12e\#3 & Tmr & DWT/PWT & $\mathrm{nr}$ & WTA & TM-WTA & 0 & 0.0 & $7,460.0$ & $2,273.8$ \\
\hline UE12e\#3 & Tmr & PWT/NWT & $\mathrm{nr}$ & VTA & TM-LVTA & 300 & 91.4 & $7,160.0$ & $2,182.4$ \\
\hline UE12e\#3 & Tmrh & BED & $\mathrm{GL}$ & VTA & TM-LVTA & 403 & 122.8 & $7,057.0$ & $2,151.0$ \\
\hline UE12e\#3 & Tpc & NWT & $\mathrm{nr}$ & VTA & TM-LVTA & 482 & 146.9 & $6,978.0$ & $2,126.9$ \\
\hline UE12e\#3 & $\begin{array}{l}\text { pre-Tmr, } \\
\text { post-Tc }\end{array}$ & BED/RWT & GL & VTA & TM-LVTA & 555 & 169.2 & $6,905.0$ & $2,104.6$ \\
\hline UE12e\#3 & $\mathrm{Tcb}$ & NWT & $\overline{G L}$ & VTA & TM-LVTA & 865 & 263.7 & $6,595.0$ & $2,010.2$ \\
\hline UE12e\#3 & Tc & BED/RWT & ZC & TCU & LTCU & 897 & 273.4 & $6,563.0$ & $2,000.4$ \\
\hline UE12e\#3 & Tbg & PWT/NWT & $\mathrm{nr}$ & TCU & LTCU & 1,083 & 330.1 & $6,377.0$ & $1,943.7$ \\
\hline UE12e\#3 & Tbgb & BED & $Z C$ & $\overline{T C U}$ & LTCU & 1,095 & 333.8 & $6,365.0$ & $1,940.1$ \\
\hline UE12e\#3 & Tn4 & BED/RWT & ZC & TCU & LTCU & 1,177 & 358.7 & $6,283.0$ & $1,915.1$ \\
\hline UE12e\#3 & Tn3 & BED/RWT & ZC & TCU & LTCU & 1,596 & 486.5 & $5,864.0$ & $1,787.3$ \\
\hline UE12e\#3 & Tub & NWT & $Z C$ & $\mathrm{TCU}$ & LTCU & 1,782 & 543.2 & $5,678.0$ & $1,730.7$ \\
\hline UE12e\#3 & Ton2 & BED/RWT & ZC & TCU & OSBCU & 1,801 & 548.9 & $5,659.0$ & $1,724.9$ \\
\hline UE12e\#3 & Toy & NWT & $\mathrm{ZC}$ & $\overline{T C U}$ & OSBCU & 1,961 & 597.7 & $5,499.0$ & $1,676.1$ \\
\hline UE12e\#3 & Ton1 & BED/RWT & ZC & TCU & OSBCU & 1,979 & 603.2 & $5,481.0$ & $1,670.6$ \\
\hline UE12e\#3 & To & NWT & $Z C$ & $\mathrm{TCU}$ & OSBCU & 2,030 & 618.7 & $5,430.0$ & $1,655.1$ \\
\hline UE12e\#3 & Ton1 & BED/RWT & ZC & TCU & OSBCU & 2,107 & 642.2 & $5,353.0$ & $1,631.6$ \\
\hline U12n.15 UG-1 & Tn3 & BED & ZC & $\mathrm{TCU}$ & LTCU & 0 & 0.0 & $6,073.0$ & $1,851.1$ \\
\hline (non-vertical hole) & Tub & BED & ZC & TCU & LTCU & 10 & 3.0 & $6,063.0$ & $1,848.0$ \\
\hline U12n.15 UG-1 & Ton2 & BED/RWT & $Z C$ & $\mathrm{TCU}$ & OSBCU & 24 & 7.3 & $6,049.0$ & $1,843.7$ \\
\hline (non-vertical hole) & To & BED/RWT & ZC & TCU & osBCU & 197 & 60.0 & $5,876.0$ & $1,791.0$ \\
\hline U12n.15 UG-1 & $\mathrm{TI}$ & $\mathrm{PCL}$ & $Z C$ & $\mathrm{TCU}$ & ATCU & 257 & 78.3 & $5,816.0$ & $1,772.7$ \\
\hline (non-vertical hole) & $\mathrm{pCCw}$ & $\mathrm{SCH} / \mathrm{QTZ}$ & na & $\mathrm{CU}$ & LCCU1 & 277 & 84.4 & $5,796.0$ & $1,766.6$ \\
\hline U12n.17 UG-1 & Tn3 & BED/RWT & $Z C$ & $\mathrm{TCU}$ & LTCU & 0 & 0.0 & $6,065.7$ & $1,848.8$ \\
\hline (non-vertical hole) & Tn3 & BED/RWT & zC & TCU & LTCU & 165 & 50.3 & $5,900.7$ & $1,798.5$ \\
\hline U12n.17 UG-1 & To & BED & $\overline{Z C}$ & TCU & OSBCU & 407 & 124.1 & $5,658.7$ & $1,724.8$ \\
\hline (non-vertical hole) & Ton2 & BED/RWT & ZC & TCU & OSBCU & 413 & 125.9 & $5,652.7$ & $1,722.9$ \\
\hline U12n.17 UG-1 & Toy & NWT & $\overline{Z E}$ & $\overline{\mathrm{TCU}}$ & OSBCU & 631 & 192.3 & $5,434.7$ & $1,656.5$ \\
\hline U12n.10 UG\#2 & nd & nd & nd & nd & nd & 0 & 0.0 & $6,074.0$ & $1,851.4$ \\
\hline U12n.10 UG\#2 & Tn3 & BED/RWT & $\mathrm{ZC}$ & $\mathrm{TCU}$ & LTCU & 0 & 0.0 & nd & nd \\
\hline (non-vertical hole) & Tub & BED/NWT & ZC & TCU & LTCU & 67 & 20.4 & $6,007.0$ & $1,830.9$ \\
\hline U12n.10 UG\#2 & Ton2 & BED/RWT & ZC & TCU & OSBCU & 83 & 25.3 & $5,991.0$ & $1,826.1$ \\
\hline (non-vertical hole) & $\mathrm{TI}$ & PCL & ZC & TCU & ATCU & 316 & 96.3 & $5,758.0$ & $1,755.0$ \\
\hline
\end{tabular}


Table A-2

Geologic and Hydrostratigraphic Drill hole Database for the Rainier Mesa-Shoshone Mountain Model Area (vertical drill holes only)

\begin{tabular}{|c|c|c|c|c|c|c|c|c|c|}
\hline Hole Name & Strat $^{1}$ & Lith $^{2}$ & Major Alt. ${ }^{3}$ & $\mathrm{HGU}^{4}$ & $\mathrm{HSU}^{5}$ & \begin{tabular}{|c|}
$\begin{array}{c}\text { Depth Top } \\
\text { (ft) }\end{array}$ \\
\end{tabular} & $\begin{array}{c}\text { Depth } \\
\operatorname{Top}^{6}(\mathrm{~m}) \\
\end{array}$ & \begin{tabular}{|c}
$\begin{array}{c}\text { Elev. Top } \\
\text { (ft) }\end{array}$ \\
\end{tabular} & $\begin{array}{c}\begin{array}{c}\text { Elev. Top } \\
\text { (m) }\end{array} \\
\end{array}$ \\
\hline U12n.10 UG\#2 & $\overline{p \mathrm{pCCw}}$ & "SCH/QTZ & na & $\overline{\mathrm{CUU}}$ & LCCU1 & 319 & 97.2 & $5,755.0$ & $1,754.1$ \\
\hline U12n.10 UG\#3 & nd & nd & nd & nd & nd & 0 & 0.0 & $6,074.0$ & $1,851.4$ \\
\hline U12n.10 UG\#3 & Tn3 & BED/RWT & ZC & TCU & LTCU & 0 & 0.0 & nd & nd \\
\hline (non-vertical hole) & Tub & BED/NWT & ZC & TCU & LTCU & 60 & 18.3 & $6,014.0$ & $1,833.1$ \\
\hline U12n.10 UG\#3 & Ton2 & BED/RWT & $\mathrm{ZC}$ & $\mathrm{TCU}$ & OSBCU & 71 & 21.6 & $6,003.0$ & $1,829.7$ \\
\hline (non-vertical hole) & $\mathrm{Tl}$ & PCL & ZC & TCU & ATCU & 298 & 90.8 & $5,776.0$ & $1,760.5$ \\
\hline U12n.10 UG\#3 & $\mathrm{pCs}$ & QTZ & na & $\mathrm{CU}$ & LCCU1 & 308 & 93.9 & $5,766.0$ & $1,757.5$ \\
\hline $\mathrm{U} 12 \mathrm{n} \# 1 \mathrm{CH}$ & $\mathrm{Tmr}$ & DWT/MWT & $\mathrm{nr}$ & WTA & TM-WTA & 0 & 0.0 & $7,289.0$ & $2,221.7$ \\
\hline $\mathrm{U} 12 \mathrm{n} \# 1 \mathrm{CH}$ & $\mathrm{Tmr}$ & PWT/NWT & $\mathrm{nr}$ & VTA & TM-LVTA & 200 & 61.0 & $7,089.0$ & $2,160.7$ \\
\hline U12n\#1CH & $\begin{array}{l}\text { pre-Tmr, } \\
\text { post-Tbg }\end{array}$ & BED/RWT & GL & VTA & TM-LVTA & 270 & 82.3 & $7,019.0$ & $2,139.4$ \\
\hline $\mathrm{U} 12 \mathrm{n} \# 1 \mathrm{CH}$ & $\mathrm{Tbg}$ & NWT & $\mathrm{GL}$ & VTA & TM-LVTA & 850 & 259.1 & $6,439.0$ & $1,962.6$ \\
\hline $\mathrm{U} 12 \mathrm{n} \# 1 \mathrm{CH}$ & Tbgb & BED & $\overline{G L}$ & VTA & TM-LVTA & 870 & 265.2 & $6,419.0$ & $1,956.5$ \\
\hline $\mathrm{U} 12 \mathrm{n} \# 1 \mathrm{CH}$ & Tn4 & BED/RWT & ZC & TCU & LTCU & 1,030 & 313.9 & $6,259.0$ & $1,907.7$ \\
\hline U12n.02\#1 & $\mathrm{Tmr}$ & DWT/MWT & $\mathrm{nr}$ & WTA & TM-WTA & 0 & 0.0 & $7,203.0$ & $2,195.5$ \\
\hline U12n.02\#1 & Tmr & PWT/NWT & $\mathrm{nr}$ & VTA & TM-LVTA & 240 & 73.2 & $6,963.0$ & $2,122.3$ \\
\hline U12n.02\#1 & $\begin{array}{l}\text { pre-Tmr, } \\
\text { post-Tbg }\end{array}$ & BED/RWT & GL & VTA & TM-LVTA & 290 & 88.4 & $6,913.0$ & $2,107.1$ \\
\hline U12n.02\#1 & Tbg & NWT & ZC & $\mathrm{TCU}$ & LTCU & 910 & 277.4 & $6,293.0$ & $1,918.1$ \\
\hline U12n.02\#1 & Tbgb & BED & ZC & TCU & LTCU & 930 & 283.5 & $6,273.0$ & $1,912.0$ \\
\hline U12n.02\#1 & Tn4 & BED/RWT & ZC & TCU & LTCU & 1,020 & 310.9 & $6,183.0$ & $1,884.6$ \\
\hline $\begin{array}{l}\text { RM Exploratory } \\
\# 1\end{array}$ & $\mathrm{TI}$ & PCL & ZM & TCU & ATCU & 3,637 & $1,108.6$ & $3,724.0$ & $1,135.1$ \\
\hline $\begin{array}{l}\text { RM Exploratory } \\
\# 1\end{array}$ & Cwc & QZT/SCH & na & $\mathrm{CCU}$ & LCCU1 & 3,687 & $1,123.8$ & $3,674.0$ & $1,119.8$ \\
\hline UE-14a & QTa & $\mathrm{AL}$ & $\mathrm{nr}$ & AA & AA & 0 & 0.0 & $4,339.0$ & $1,322.5$ \\
\hline UE-14a & $\mathrm{Ttt}$ & BED & $\mathrm{nr}$ & VTA & AA & 860 & 262.1 & $3,479.0$ & $1,060.4$ \\
\hline UE-14a & QTa & $\mathrm{AL}$ & $\mathrm{nr}$ & $\mathrm{AA}$ & AA & 896 & 273.1 & $3,443.0$ & $1,049.4$ \\
\hline UE-14a & Tma & PWT & $\mathrm{GL}$ & VTA & TM-UVTA & 1,063 & 324.0 & $3,276.0$ & 998.5 \\
\hline UE-14a & Tma & MWT & DV & WTA & TM-WTA & 1,158 & 353.0 & $3,181.0$ & 969.6 \\
\hline UE-14a & Tmab & BED & AT,ZE & VTA & TM-WTA & 1,306 & 398.1 & $3,033.0$ & 924.5 \\
\hline UE-14a & Tmr & PWT & $\mathrm{nr}$ & WTA & TM-WTA & 1,348 & 410.9 & $2,991.0$ & 911.7 \\
\hline UE-14a & $\mathrm{Tmr}$ & MWT & DV & WTA & TM-WTA & 1,552 & 473.0 & $2,787.0$ & 849.5 \\
\hline UE-14a & $\mathrm{Tmr}$ & NWT & ZE & TCU & UTCU & 1,886 & 574.9 & $2,453.0$ & 747.7 \\
\hline UE-14a & $\mathrm{Tp}$ & BED & $\mathrm{AR}, \mathrm{ZE}, \mathrm{CC}$ & TCU & UTCU & 2,021 & 616.0 & $2,318.0$ & 706.5 \\
\hline UE-14a & Tpc & PWT & ZE,SI & TCU & UTCU & 2,057 & 627.0 & $2,282.0$ & 695.6 \\
\hline UE-14a & Tpc & PWT/DWT & DV & WTA & TCA & 2,103 & 641.0 & $2,236.0$ & 681.5 \\
\hline UE-14a & Tpt & WT & $\mathrm{DV}, \mathrm{SI}$ & WTA & TSA & 2,431 & 741.0 & $1,908.0$ & 581.6 \\
\hline UE-14a & Tpt & MWT & $\mathrm{VP}, \mathrm{DV}, \mathrm{SI}$ & WTA & TSA & 2,510 & 765.0 & $1,829.0$ & 557.5 \\
\hline UE-14b & QTa & $\mathrm{AL}$ & $\mathrm{nr}$ & AA & AA & 0 & 0.0 & $4,353.0$ & $1,326.8$ \\
\hline UE-14b & $\mathrm{Ttt}$ & BED & GL,AR & VTA & AA & 1,201 & 366.0 & $3,152.2$ & 960.8 \\
\hline UE-14b & QTa & $\mathrm{AL}$ & $\mathrm{nr}$ & AA & AA & 1,221 & 372.0 & $3,132.5$ & 954.8 \\
\hline UE-14b & Tma & PWT & GL,ZE,AR & VTA & TM-UVTA & 1,339 & 408.0 & $3,014.4$ & 918.8 \\
\hline UE-14b & Tma & MWT & GL,ZE,AR & WTA & TM-WTA & 1,421 & 433.1 & $2,932.0$ & 893.7 \\
\hline UE-14b & Tmab & BED & $\mathrm{AR}, \mathrm{ZE}$ & VTA & TM-WTA & 1,591 & 485.0 & $2,761.7$ & 841.8 \\
\hline UE-14b & $\mathrm{Tmr}$ & PWT & ZE & WTA & TM-WTA & 1,624 & 495.0 & $2,728.9$ & 831.8 \\
\hline UE-14b & $\mathrm{Tmr}$ & MWT & DV & WTA & TM-WTA & 1,824 & 556.0 & $2,528.9$ & 770.8 \\
\hline UE-14b & Tmr & NWT & ZE & TCU & UTCU & 2,139 & 652.0 & $2,213.8$ & 674.8 \\
\hline UE-14b & $\mathrm{Tp}$ & BED & $\mathrm{AR}, \mathrm{ZE}, \mathrm{CC}$ & TCU & UTCU & 2,264 & 690.0 & $2,089.1$ & 636.8 \\
\hline UE-14b & Tpc & PWT & ZE,SI & TCU & UTCU & 2,300 & 701.0 & $2,053.0$ & 625.8 \\
\hline UE-14b & Tpc & DWT & $\mathrm{DV}, \mathrm{SI}$ & WTA & TCA & 2,346 & 715.0 & $2,007.1$ & 611.8 \\
\hline UE-14b & Tpt & MWT & DV & WTA & TSA & 2,622 & 799.0 & $1,731.5$ & 527.8 \\
\hline
\end{tabular}


Table A-2

Geologic and Hydrostratigraphic Drill hole Database for the Rainier Mesa-Shoshone Mountain Model Area (vertical drill holes only)

\begin{tabular}{|c|c|c|c|c|c|c|c|c|c|}
\hline Hole Name & Strat $^{1}$ & Lith $^{2}$ & Major Alt. ${ }^{3}$ & $H G U^{4}$ & $\mathrm{HSU}^{5}$ & $\begin{array}{c}\text { Depth Top } \\
\text { (ft) }\end{array}$ & $\begin{array}{c}\text { Depth } \\
\operatorname{Top}^{6}(\mathrm{~m})\end{array}$ & \begin{tabular}{|c|}
$\begin{array}{c}\text { Elev. Top } \\
\end{array}$ \\
(ft)
\end{tabular} & \begin{tabular}{|c}
$\begin{array}{c}\text { Elev. Top } \\
\text { (m) }\end{array}$ \\
\end{tabular} \\
\hline UE-14b & 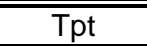 & VT & 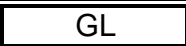 & "WTA & 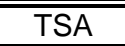 & 2,654 & 809.0 & $1,698.7$ & 517.8 \\
\hline UE-14b & Tpt & MWT & $\mathrm{DV}, \mathrm{SI}$ & WTA & $\overline{T S A}$ & 2,668 & 813.1 & $1,685.5$ & 513.7 \\
\hline UE-14b & Tpt & $\mathrm{VT}$ & $\mathrm{GL}$ & WTA & $\overline{T S A}$ & 3,580 & $1,091.1$ & 773.4 & 235.7 \\
\hline ER-16-1 & Tpc & DWT & DV & WTA & TCA & 0 & 0.0 & $6,591.5$ & $2,009.1$ \\
\hline ER-16-1 & Tpc & BED & $\mathrm{GL}$ & VTA & PVTA & 50 & 15.2 & $6,541.5$ & $1,993.8$ \\
\hline ER-16-1 & Tpt & DWT & DV & WTA & TSA & 156 & 47.5 & $6,435.5$ & $1,961.5$ \\
\hline ER-16-1 & Tpt & NWT & $\mathrm{GL}$ & VTA & LVTA & 336 & 102.4 & $6,255.5$ & $1,906.7$ \\
\hline ER-16-1 & Tc & BED & $\mathrm{GL}$ & VTA & LVTA & 356 & 108.5 & $6,235.5$ & $1,900.6$ \\
\hline ER-16-1 & Tcbs & NWT & $\mathrm{GL}$ & VTA & LVTA & 530 & 161.5 & $6,061.5$ & $1,847.5$ \\
\hline ER-16-1 & Tc & BED & $\overline{G L}$ & VTA & LVTA & 670 & 204.2 & $5,921.5$ & $1,804.9$ \\
\hline ER-16-1 & Tc & BED & ZE & TCU & LTCU & 776 & 236.5 & $5,815.5$ & $1,772.6$ \\
\hline ER-16-1 & Trl & NWT/PWT & DVIZE & TCU & LTCU & 818 & 249.3 & $5,773.5$ & $1,759.8$ \\
\hline ER-16-1 & Tn3\&4 & BED & $\mathrm{ZE}$ & $\mathrm{TCU}$ & LTCU & 1,085 & 330.7 & $5,506.5$ & $1,678.4$ \\
\hline ER-16-1 & Tub & NWT/PWT & ZE/DV & TCU & LTCU & 1,266 & 385.9 & $5,325.5$ & $1,623.2$ \\
\hline ER-16-1 & Tub & BED & ZE & TCU & LTCU & 1,380 & 420.6 & $5,211.5$ & $1,588.5$ \\
\hline ER-16-1 & Tub & NWT/PWT & ZE/DV & $\mathrm{TCU}$ & LTCU & 1,493 & 455.1 & $5,098.5$ & $1,554.0$ \\
\hline ER-16-1 & Ton2/Toy & NWT/PWT & ZE/DV & TCU & OSBCU & 1,602 & 488.3 & $4,989.5$ & $1,520.8$ \\
\hline ER-16-1 & Ton1 & BED & ZE & $\mathrm{TCU}$ & OSBCU & 1,750 & 533.4 & $4,841.5$ & $1,475.7$ \\
\hline ER-16-1 & Tor & PWT & DV & WTA & RVA & 1,900 & 579.1 & $4,691.5$ & $1,430.0$ \\
\hline ER-16-1 & TIt & $\mathrm{PCL}$ & $\mathrm{AR}$ & $\mathrm{TCU}$ & ATCU & 1,977 & 602.6 & $4,614.5$ & $1,406.5$ \\
\hline ER-16-1 & TIC & $\overline{P C L}$ & AR & $\overline{T C U}$ & ATCU & 2,006 & 611.4 & $4,585.5$ & $1,397.7$ \\
\hline ER-16-1 & Mc & $\mathrm{SH}$ & na & $\mathrm{CCU}$ & UCCU & 2,122 & 646.8 & $4,469.5$ & $1,362.3$ \\
\hline ER-16-1 & $\mathrm{Dg}$ & $\overline{Q T Z}$ & na & $\mathrm{CCU}$ & $\mathrm{LCA}$ & 3,516 & $1,071.7$ & $3,075.5$ & 937.4 \\
\hline ER-16-1 & $\mathrm{Dg}$ & $\mathrm{DM}$ & na & $\mathrm{CA}$ & LCA & 3,566 & $1,086.9$ & $3,025.5$ & 922.2 \\
\hline ER-16-1 & $\mathrm{Dg}$ & LS & na & $\mathrm{CA}$ & LCA & 3,716 & $1,132.6$ & $2,875.5$ & 876.5 \\
\hline ER-16-1 & $\mathrm{Dg}$ & $\overline{D M}$ & na & $\mathrm{CA}$ & LCA & 3,798 & $1,157.6$ & $2,793.5$ & 851.5 \\
\hline UE16a\#1 & Tpc & DWT & $\mathrm{nr}$ & WTA & TCA & 0 & 0.0 & $6,594.8$ & $2,010.1$ \\
\hline UE16a\#1 & $\mathrm{Tp}$ & BED/RWT & GL & VTA & PVTA & ND1 & ND1 & ND1 & ND1 \\
\hline UE16a\#1 & Tpt & DWT & $\overline{G L}$ & WTA & TSA & 205 & 62.5 & $6,389.8$ & $1,947.6$ \\
\hline UE16a\#1 & Th/Tw & BED/RWT & $\mathrm{GL}$ & VTA & LVTA & 392 & 119.5 & $6,202.8$ & $1,890.6$ \\
\hline UE16a\#1 & $\mathrm{Tcb}$ & PWT & $Z C$ & TCU & LTCU & 811 & 247.2 & $5,783.8$ & $1,762.9$ \\
\hline UE16a\#1 & Tc & BED & $Z C$ & TCU & LTCU & 1,068 & 325.5 & $5,526.8$ & $1,684.6$ \\
\hline UE16b & QTa & $\mathrm{AL}$ & na & $\mathrm{AA}$ & $\mathrm{AA}$ & 0 & 0.0 & $4,890.1$ & $1,490.5$ \\
\hline UE16b & Mc & $\mathrm{SH}$ & na & $\mathrm{CCU}$ & UCCU & 317 & 96.6 & $4,573.2$ & $1,393.9$ \\
\hline UE16c & QTa & $\mathrm{AL}$ & na & AA & $\mathrm{AA}$ & 0 & 0.0 & $4,726.0$ & $1,440.5$ \\
\hline UE16c & $\mathrm{Mc}$ & $\mathrm{SH}$ & na & $\mathrm{CCU}$ & UCCU & 120 & 36.6 & $4,606.0$ & $1,403.9$ \\
\hline UE16d & QTa & $\mathrm{AL}$ & na & AA & AA & 0 & 0.0 & $4,684.1$ & $1,427.7$ \\
\hline UE16d & $\mathrm{PPt}$ & LS & na & $\mathrm{CA}$ & UCA & 80 & 24.4 & $4,604.0$ & $1,403.3$ \\
\hline UE16d & $\mathrm{Mc}$ & $\mathrm{SH}$ & na & $\mathrm{CCU}$ & UCCU & 1,487 & 453.2 & $3,197.2$ & 974.5 \\
\hline UE16f & QTa & $\mathrm{AL}$ & na & AA & AA & 0 & 0.0 & $4,651.9$ & $1,417.9$ \\
\hline UE16f & Mc & $\mathrm{SH}$ & na & $\mathrm{CCU}$ & UCCU & 79 & 24.0 & $4,573.2$ & $1,393.9$ \\
\hline $\mathrm{HTH}-1$ & QTa & $\mathrm{AL}$ & $\mathrm{nr}$ & AA & $\mathrm{AA}$ & 0 & 0.0 & $6,156.0$ & $1,876.3$ \\
\hline $\mathrm{HTH}-1$ & Tbgr & DWT & $\mathrm{nr}$ & WTA & BRA & 70 & 21.3 & $6,086.0$ & $1,855.0$ \\
\hline $\mathrm{HTH}-1$ & Tbgp & DWT & $\mathrm{nr}$ & WTA & BRA & 142 & 43.3 & $6,014.0$ & $1,833.1$ \\
\hline $\mathrm{HTH}-1$ & Tbgb & BED & $\mathrm{nr}$ & $\mathrm{nr}$ & LTCU & 225 & 68.6 & $5,931.0$ & $1,807.8$ \\
\hline $\mathrm{HTH}-1$ & $\mathrm{Tn}$ & BED & $\mathrm{nr}$ & $\mathrm{nr}$ & LTCU & 315 & 96.0 & $5,841.0$ & $1,780.3$ \\
\hline $\mathrm{HTH}-1$ & Tub & MWT & $\mathrm{nr}$ & WTA & TUBA & 1,319 & 402.0 & $4,837.0$ & $1,474.3$ \\
\hline $\mathrm{HTH}-1$ & Toy & BED & $\mathrm{nr}$ & $\mathrm{nr}$ & OSBCU & 1,472 & 448.7 & $4,684.0$ & $1,427.7$ \\
\hline $\mathrm{HTH}-1$ & Tor & PWT & $\mathrm{nr}$ & WTA & RVA & 1,790 & 545.6 & $4,366.0$ & $1,330.8$ \\
\hline $\mathrm{HTH}-1$ & Tor & MWT & DV & WTA & RVA & 1,898 & 578.5 & $4,258.0$ & $1,297.8$ \\
\hline $\mathrm{HTH}-1$ & Tor & PWT & $\mathrm{nr}$ & WTA & RVA & 2,496 & 760.8 & $3,660.0$ & $1,115.6$ \\
\hline $\mathrm{HTH}-1$ & Tot & BED & $\mathrm{QC}, \mathrm{ZA}$ & $\mathrm{TCU}$ & LTCU1 & 2,599 & 792.2 & $3,557.0$ & $1,084.2$ \\
\hline $\mathrm{HTH}-1$ & Tot & NWT & $\mathrm{ZA}, \mathrm{QC}$ & TCU & LTCU1 & 2,750 & 838.2 & $3,406.0$ & $1,038.1$ \\
\hline $\mathrm{HTH}-1$ & Tot & BED & $\mathrm{AR}, \mathrm{CC}, \mathrm{QC}$ & TCU & ATCU & 3,534 & $1,077.2$ & $2,622.0$ & 799.2 \\
\hline
\end{tabular}


Table A-2

Geologic and Hydrostratigraphic Drill hole Database for the Rainier Mesa-Shoshone Mountain Model Area (vertical drill holes only)

\begin{tabular}{|c|c|c|c|c|c|c|c|c|c|}
\hline Hole Name & Strat $^{1}$ & Lith $^{2}$ & Major Alt. ${ }^{3}$ & $\mathrm{HGU}^{4}$ & $\mathrm{HSU}^{5}$ & \begin{tabular}{|c|}
$\begin{array}{c}\text { Depth Top } \\
6 \\
(\mathrm{ft})\end{array}$ \\
\end{tabular} & $\begin{array}{c}\text { Depth } \\
\operatorname{Top}^{6}(\mathrm{~m}) \\
\end{array}$ & $\begin{array}{c}\text { Elev. Top }{ }^{7} \\
\text { (ft) }\end{array}$ & \begin{tabular}{|c|}
$\begin{array}{c}\text { Elev. Top } \\
\text { (m) }\end{array}$ \\
\end{tabular} \\
\hline HTH-1 & $\overline{\mathrm{TI}}$ & 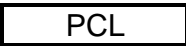 & $\mathrm{nr}$ & TCU & 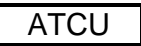 & 3,700 & $1,127.8$ & $2,456.0$ & 748.6 \\
\hline $\mathrm{HTH}-1$ & DSsl & DM & na & $\mathrm{CA}$ & LCA3 & 3,731 & $1,137.2$ & $2,425.0$ & 739.1 \\
\hline UE17a & QTa & $\mathrm{AL}$ & na & AA & AA & 0 & 0.0 & $4,696.9$ & $1,431.6$ \\
\hline UE17a & $\mathrm{PPt}$ & LS & na & $\mathrm{CA}$ & UCA & 73 & 22.3 & $4,623.7$ & $1,409.3$ \\
\hline UE17a & $\mathrm{Mc}$ & $\mathrm{SH}$ & na & $\mathrm{CCU}$ & $\mathrm{UCCU}$ & 473 & 144.1 & $4,150.9$ & $1,265.2$ \\
\hline UE17b & QTa & $\mathrm{AL}$ & na & $\mathrm{AA}$ & $\mathrm{AA}$ & 0 & 0.0 & $4,779.9$ & $1,456.9$ \\
\hline UE17b & $\mathrm{Mc}$ & $\mathrm{SH}$ & na & $\mathrm{CCU}$ & UCCU & 220 & 67.1 & $4,559.7$ & $1,389.8$ \\
\hline UE17c & QTa & $\mathrm{AL}$ & na & $\mathrm{AA}$ & $\mathrm{AA}$ & 0 & 0.0 & $4,835.0$ & $1,473.7$ \\
\hline UE17c & $\mathrm{Mc}$ & $\mathrm{SH}$ & na & $\mathrm{CCU}$ & $\mathrm{UCCU}$ & 570 & 173.7 & $4,265.1$ & $1,300.0$ \\
\hline UE17d & QTa & $\mathrm{AL}$ & na & $\mathrm{AA}$ & AA & 0 & 0.0 & $4,678.1$ & $1,425.9$ \\
\hline UE17d & $\mathrm{PPt}$ & LS & na & $\mathrm{CA}$ & UCA & 230 & 70.1 & $4,448.2$ & $1,355.8$ \\
\hline UE17e & $\mathrm{Mc}$ & $\mathrm{SH}$ & na & $\mathrm{CCU}$ & $\mathrm{UCCU}$ & 0 & 0.0 & $4,934.1$ & $1,503.9$ \\
\hline ER-19-1 & Tbgr & NWT-MWT & $\mathrm{DV}, \mathrm{ZE}$ & WTA & BRA & 0 & 0.0 & $6,140.0$ & $1,871.5$ \\
\hline ER-19-1 & Tbgr & DWT & DV & WTA & BRA & 25 & 7.6 & $6,115.0$ & $1,863.9$ \\
\hline ER-19-1 & Tbgp & MWT & $\mathrm{KF}, \mathrm{ZE}$ & WTA & BRA & 144 & 43.9 & $5,996.0$ & $1,827.6$ \\
\hline ER-19-1 & Tbgp & NWT & ZE & $\mathrm{TCU}$ & BRA & 170 & 51.8 & $5,970.0$ & $1,819.7$ \\
\hline ER-19-1 & Tbgb & BED & ZE, QZ & $\mathrm{TCU}$ & BRA & 205 & 62.5 & $5,935.0$ & $1,809.0$ \\
\hline ER-19-1 & Tn4K & BED & ZE, OP & TCU & LTCU & 360 & 109.7 & $5,780.0$ & $1,761.7$ \\
\hline ER-19-1 & Tn4J & BED & ZE & TCU & LTCU & 394 & 120.1 & $5,746.0$ & $1,751.4$ \\
\hline ER-19-1 & Tn4AF & BED & ZE & TCU & LTCU & 472 & 143.9 & $5,668.0$ & $1,727.6$ \\
\hline ER-19-1 & Tn4AF & BED & ZE, OP & TCU & LTCU & 781 & 238.0 & $5,359.0$ & $1,633.4$ \\
\hline ER-19-1 & Tn4AF & BED & ZE & TCU & LTCU & 876 & 267.0 & $5,264.0$ & $1,604.5$ \\
\hline ER-19-1 & Tn3D & BED & ZE & TCU & LTCU & 906 & 276.1 & $5,234.0$ & $1,595.3$ \\
\hline ER-19-1 & Ton2 & BED & ZE & $\mathrm{TCU}$ & OSBCU & 986 & 300.5 & $5,154.0$ & $1,570.9$ \\
\hline ER-19-1 & Ton2 & NWT & ZE & TCU & OSBCU & 1,111 & 338.6 & $5,029.0$ & $1,532.8$ \\
\hline ER-19-1 & Ton2 & BED & ZE, QZ & TCU & OSBCU & 1,336 & 407.2 & $4,804.0$ & $1,464.3$ \\
\hline ER-19-1 & Tor & BED & ZE & $\mathrm{TCU}$ & OSBCU & 1,567 & 477.6 & $4,573.0$ & $1,393.9$ \\
\hline ER-19-1 & Tor & NWT & ZE, QZ & TCU & OSBCU & 1,665 & 507.5 & $4,475.0$ & $1,364.0$ \\
\hline ER-19-1 & Tor & BED & ZE & TCU & OSBCU & 1,736 & 529.1 & $4,404.0$ & $1,342.3$ \\
\hline ER-19-1 & Tor & PWT & ZE & WTA & RVA & 1,813 & 552.6 & $4,327.0$ & $1,318.9$ \\
\hline ER-19-1 & Tor & MWT & DV & WTA & RVA & 1,862 & 567.5 & $4,278.0$ & $1,303.9$ \\
\hline ER-19-1 & Tor & DWT & DV & WTA & RVA & 1,931 & 588.6 & $4,209.0$ & $1,282.9$ \\
\hline ER-19-1 & Tor & PWT-MWT & ZE & WTA & RVA & 1,966 & 599.2 & $4,174.0$ & $1,272.2$ \\
\hline ER-19-1 & Tor & MWT-DWT & DV & WTA & RVA & 2,030 & 618.7 & $4,110.0$ & $1,252.7$ \\
\hline ER-19-1 & Tor & NWT & $\mathrm{KF}, \mathrm{ZE}$ & TCU & RVA & 2,474 & 754.1 & $3,666.0$ & $1,117.4$ \\
\hline ER-19-1 & Tot & PWT-MWT & $\mathrm{KF}, \mathrm{ZE}, \mathrm{AR}$ & WTA & RVA & 2,530 & 771.1 & $3,610.0$ & $1,100.3$ \\
\hline ER-19-1 & Toh & NWT & $\mathrm{QZ}, \mathrm{AR}, \mathrm{KF}$ & $\mathrm{TCU}$ & ATCU & 2,710 & 826.0 & $3,430.0$ & $1,045.5$ \\
\hline ER-19-1 & $\mathrm{CZw}$ & SLT/QTZ/SS & na & $\mathrm{SCU}$ & LCCU1 & 2,862 & 872.3 & $3,278.0$ & 999.1 \\
\hline ER-19-1 & $\mathrm{CZw}$ & SLT & na & SCU & LCCU1 & 3,093 & 942.7 & $3,047.0$ & 928.7 \\
\hline U-19ac & Tma & $\mathrm{nr}$ & $\mathrm{nr}$ & VTA & TM WTA & 0 & 0.0 & $7,038.0$ & $2,145.2$ \\
\hline U-19ac & Tmap & PWT & VP & WTA & TM WTA & 60 & 18.3 & $6,978.0$ & $2,126.9$ \\
\hline U-19ac & Tmap & PWT & DV & WTA & TM WTA & 140 & 42.7 & $6,898.0$ & $2,102.5$ \\
\hline U-19ac & Tmab & NWT & $\mathrm{GL}$ & VTA & TM WTA & 200 & 61.0 & $6,838.0$ & $2,084.2$ \\
\hline U-19ac & Tmrb & BED & $\mathrm{GL}$ & VTA & TM WTA & 216 & 65.8 & $6,822.0$ & $2,079.3$ \\
\hline U-19ac & Tmrr & NWT & $\mathrm{GL}$ & VTA & TM WTA & 233 & 71.0 & $6,805.0$ & $2,074.2$ \\
\hline U-19ac & Tmrr & PWT & GL, DV & WTA & TM WTA & 241 & 73.5 & $6,797.0$ & $2,071.7$ \\
\hline U-19ac & Tmrr & PWT & DV & WTA & TM WTA & 262 & 79.9 & $6,776.0$ & $2,065.3$ \\
\hline U-19ac & Tmrr & PWT & VP & WTA & TM WTA & 296 & 90.2 & $6,742.0$ & $2,055.0$ \\
\hline U-19ac & Tmrr & VT & $\mathrm{GL}$ & WTA & TM WTA & 325 & 99.1 & $6,713.0$ & $2,046.1$ \\
\hline U-19ac & Tmrr & MWT & DV & WTA & TM WTA & 355 & 108.2 & $6,683.0$ & $2,037.0$ \\
\hline U-19ac & Tmrp & DWT & DV & WTA & TM WTA & 403 & 122.8 & $6,635.0$ & $2,022.3$ \\
\hline U-19ac & Tmrp & MWT & DV & WTA & TM WTA & 450 & 137.2 & $6,588.0$ & $2,008.0$ \\
\hline U-19ac & Tmrp & DWT & DV & WTA & TM WTA & 1,110 & 338.3 & $5,928.0$ & $1,806.9$ \\
\hline U-19ac & Tmrp & VT & DV & WTA & TM WTA & 1,236 & 376.7 & $5,802.0$ & $1,768.4$ \\
\hline U-19ac & Tmrp & PWT & $\mathrm{GL}$ & WTA & TM WTA & 1,260 & 384.0 & $5,778.0$ & $1,761.1$ \\
\hline U-19ac & Tmrp & NWT & $\mathrm{GL}$ & VTA & TM WTA & 1,280 & 390.1 & $5,758.0$ & $1,755.0$ \\
\hline
\end{tabular}


Table A-2

Geologic and Hydrostratigraphic Drill hole Database for the Rainier Mesa-Shoshone Mountain Model Area (vertical drill holes only)

\begin{tabular}{|c|c|c|c|c|c|c|c|c|c|}
\hline Hole Name & Strat $^{1}$ & Lith $^{2}$ & Major Alt. ${ }^{3}$ & $\mathrm{HGU}^{4}$ & $\mathrm{HSU}^{5}$ & \begin{tabular}{|c|}
$\begin{array}{c}\text { Depth Top } \\
6 \\
(\mathrm{ft})\end{array}$ \\
\end{tabular} & $\begin{array}{c}\text { Depth } \\
\operatorname{Top}^{6}(\mathrm{~m}) \\
\end{array}$ & $\begin{array}{c}\text { Elev. Top } \\
\text { (ft) } \\
\end{array}$ & \begin{tabular}{|c|}
$\begin{array}{c}\text { Elev. Top } \\
\text { (m) }\end{array}$ \\
\end{tabular} \\
\hline U-19ac & Tmrh & RWT & $\overline{\mathrm{GL}}$ & VTA & PVTA & 1,342 & 409.0 & $5,696.0$ & $1,736.1$ \\
\hline U-19ac & Tmt & $\mathrm{BS}$ & $\mathrm{nr}$ & LFA & PVTA & 1,397 & 425.8 & $5,641.0$ & $1,719.4$ \\
\hline U-19ac & Tpcm & PWT & $\mathrm{nr}$ & WTA & PVTA & 1,445 & 440.4 & $5,593.0$ & $1,704.7$ \\
\hline U-19ac & Tpe & NWT & $\mathrm{GL}$ & VTA & PVTA & 1,470 & 448.1 & $5,568.0$ & $1,697.1$ \\
\hline U-19ac & Thp & NWT & $\mathrm{GL}$ & VTA & CHVTA & 1,520 & 463.3 & $5,518.0$ & $1,681.9$ \\
\hline U-19ac & Thp & NWT & $\mathrm{ZC}$ & TCU & CHVTA & 1,687 & 514.2 & $5,351.0$ & $1,631.0$ \\
\hline U-19ac & Tcpk & $\mathrm{LA}$ & $\mathrm{GL}$ & LFA & $\mathrm{KA}$ & 1,747 & 532.5 & $5,291.0$ & $1,612.7$ \\
\hline U-19ac & Tcpk & FB & DV & LFA & $\mathrm{KA}$ & 1,815 & 553.2 & $5,223.0$ & $1,592.0$ \\
\hline U-19ac & Tcpk & LA & DV & LFA & $\mathrm{KA}$ & 1,838 & 560.2 & $5,200.0$ & $1,585.0$ \\
\hline U-19ac & Tcpk & LA & GL, DV & LFA & $\mathrm{KA}$ & 2,280 & 694.9 & $4,758.0$ & $1,450.2$ \\
\hline U-19an & Tmar & $\mathrm{nr}$ & $\mathrm{nr}$ & $\mathrm{nr}$ & TM WTA & 0 & 0.0 & 6978 & $2,126.9$ \\
\hline U-19an & Tmar & PWT & VP & WTA & TM WTA & 30 & 9.1 & 6948 & $2,117.8$ \\
\hline U-19an & Tmar & MWT & DV & WTA & TM WTA & 56 & 17.1 & 6922 & $2,109.8$ \\
\hline U-19an & Tmap & MWT & DV & WTA & TM WTA & 129 & 39.3 & 6849 & $2,087.6$ \\
\hline U-19an & Tmap & DWT & DV & WTA & TM WTA & 175 & 53.3 & 6803 & $2,073.6$ \\
\hline U-19an & Tmap & MWT & DV & WTA & TM WTA & 192 & 58.5 & 6786 & $2,068.4$ \\
\hline U-19an & Tmap & PWT & $\mathrm{GL}$ & WTA & TM WTA & 203 & 61.9 & 6775 & $2,065.0$ \\
\hline U-19an & Tmrb & NWT & $\mathrm{GL}$ & VTA & TM WTA & 212 & 64.6 & 6766 & $2,062.3$ \\
\hline U-19an & Tmrr & NWT & $\mathrm{GL}$ & VTA & TM WTA & 220 & 67.1 & 6758 & $2,059.8$ \\
\hline U-19an & Tmrr & PWT & $\mathrm{GL}$ & WTA & TM WTA & 238 & 72.5 & 6740 & $2,054.4$ \\
\hline U-19an & Tmrr & PWT & VP & WTA & TM WTA & 262 & 79.9 & 6716 & $2,047.0$ \\
\hline U-19an & Tmrr & MWT & DV & WTA & TM WTA & 300 & 91.4 & 6678 & $2,035.5$ \\
\hline U-19an & Tmrr & DWT & DV & WTA & TM WTA & 311 & 94.8 & 6667 & $2,032.1$ \\
\hline U-19an & Tmrr & MWT & DV & WTA & TM WTA & 331 & 100.9 & 6647 & $2,026.0$ \\
\hline U-19an & Tmrp & MWT & DV & WTA & TM WTA & 346 & 105.5 & 6632 & $2,021.4$ \\
\hline U-19an & Tmrp & DWT & DV & WTA & TM WTA & 380 & 115.8 & 6598 & $2,011.1$ \\
\hline U-19an & Tmrp & MWT & DV & WTA & TM WTA & 440 & 134.1 & 6538 & $1,992.8$ \\
\hline U-19an & Tmrp & VT & $\mathrm{GL}$ & WTA & TM WTA & 1065.4 & 324.7 & 5912.6 & $1,802.2$ \\
\hline U-19an & Tmrp & MWT & $\mathrm{GL}$ & WTA & TM WTA & 1101.4 & 335.7 & 5876.6 & $1,791.2$ \\
\hline U-19an & Tmrp & PWT & $\mathrm{GL}$ & WTA & TM WTA & 1120 & 341.4 & 5858 & $1,785.5$ \\
\hline U-19an & Tmrp & NWT & $\mathrm{GL}$ & VTA & TM WTA & 1170 & 356.6 & 5808 & $1,770.3$ \\
\hline U-19an & Tpr & BED & $\mathrm{GL}$ & VTA & PVTA & 1226.7 & 373.9 & 5751.3 & $1,753.0$ \\
\hline U-19an & Thp & NWT & $\mathrm{GL}$ & VTA & CHVTA & 1242.1 & 378.6 & 5735.9 & $1,748.3$ \\
\hline U-19an & Thp & $\mathrm{PL}$ & $\mathrm{GL}$ & LFA & CHVTA & 1296 & 395.0 & 5682 & $1,731.9$ \\
\hline U-19an & Thp & NWT & $\mathrm{GL}$ & VTA & CHVTA & 1314 & 400.5 & 5664 & $1,726.4$ \\
\hline U-19an & Thp & NWT & $Z C$ & TCU & CHVTA & 1370 & 417.6 & 5608 & $1,709.3$ \\
\hline U-19an & Thp & NWT & $\mathrm{GL}$ & VTA & CHVTA & 1390.2 & 423.7 & 5587.8 & $1,703.2$ \\
\hline U-19an & Thp & BED & GL & VTA & CHVTA & 1417.1 & 431.9 & 5560.9 & $1,695.0$ \\
\hline U-19an & Tcu & BED & $\mathrm{GL}$ & VTA & CHVTA & 1433 & 436.8 & 5545 & $1,690.1$ \\
\hline U-19an & Tcu & NWT & ZC & TCU & CHVTA & 1436 & 437.7 & 5542 & $1,689.2$ \\
\hline U-19an & Tcu & BED & ZC & TCU & CHVTA & 1448.7 & 441.6 & 5529.3 & $1,685.3$ \\
\hline U-19an & Tcu & NWT & GL & VTA & CHVTA & 1460 & 445.0 & 5518 & $1,681.9$ \\
\hline U-19an & Tcj & NWT & $\mathrm{GL}$ & VTA & CHVTA & 1470 & 448.1 & 5508 & $1,678.8$ \\
\hline U-19an & Tcpk & LA & ZC & LFA & $\mathrm{KA}$ & 1478 & 450.5 & 5500 & $1,676.4$ \\
\hline U-19an & Tcpk & LA & $\mathrm{GL}$ & LFA & $\mathrm{KA}$ & 1540 & 469.4 & 5438 & $1,657.5$ \\
\hline U-19an & Tcpk & LA & DV & LFA & $\mathrm{KA}$ & 1611.7 & 491.2 & 5366.3 & $1,635.6$ \\
\hline U-19an & Tcpk & LA & $\mathrm{GL}$ & LFA & $\mathrm{KA}$ & 2046.1 & 623.7 & 4931.9 & $1,503.2$ \\
\hline U-19an & Tcpk & $\mathrm{PL}$ & ZC & TCU & $\mathrm{KA}$ & 2078 & 633.4 & 4900 & $1,493.5$ \\
\hline U-19an & Tcblr & NWT & ZE & TCU & $\mathrm{BFCU}$ & 2100 & 640.1 & 4878 & $1,486.8$ \\
\hline U-19an & Tcblp & NWT & ZE & TCU & BFCU & 2140 & 652.3 & 4838 & $1,474.6$ \\
\hline U-19ax & Tma & $\mathrm{nr}$ & $\mathrm{nr}$ & $\mathrm{nr}$ & TM WTA & 0 & 0.0 & 6986 & $2,129.3$ \\
\hline U-19ax & Tmap & PWT & VP & WTA & TM WTA & 80 & 24.4 & 6906 & $2,104.9$ \\
\hline U-19ax & Tmap & MWT & DV & WTA & TM WTA & 166 & 50.6 & 6820 & $2,078.7$ \\
\hline U-19ax & Tmap & PWT & GL & WTA & TM WTA & 195 & 59.4 & 6791 & $2,069.9$ \\
\hline U-19ax & Tmab & BED & $\mathrm{GL}$ & VTA & TM WTA & 204 & 62.2 & 6782 & $2,067.2$ \\
\hline U-19ax & Tmrr & PWT & $\mathrm{GL}$ & WTA & TM WTA & 228 & 69.5 & 6758 & $2,059.8$ \\
\hline
\end{tabular}


Table A-2

Geologic and Hydrostratigraphic Drill hole Database for the Rainier Mesa-Shoshone Mountain Model Area (vertical drill holes only)

\begin{tabular}{|c|c|c|c|c|c|c|c|c|c|}
\hline Hole Name & Strat $^{1}$ & Lith $^{2}$ & Major Alt. ${ }^{3}$ & $\mathrm{HGU}^{4}$ & $\mathrm{HSU}^{5}$ & \begin{tabular}{|c|}
$\begin{array}{c}\text { Depth Top } \\
6 \\
(\mathrm{ft})\end{array}$ \\
\end{tabular} & $\begin{array}{c}\text { Depth } \\
\operatorname{Top}^{6}(\mathrm{~m}) \\
\end{array}$ & \begin{tabular}{|c|}
$\begin{array}{c}\text { Elev. Top } \\
\end{array}$ \\
(ft)
\end{tabular} & \begin{tabular}{|c|}
$\begin{array}{c}\text { Elev. Top } \\
\text { (m) }\end{array}$ \\
\end{tabular} \\
\hline U-19ax & Tmrr & PWT & VP & WTA & TM WTA & 236 & 71.9 & 6750 & $2,057.4$ \\
\hline U-19ax & Tmrr & MWT & DV & WTA & TM WTA & 305 & 93.0 & 6681 & $2,036.4$ \\
\hline U-19ax & Tmrr & VT & DV & WTA & TM WTA & 320 & 97.5 & 6666 & $2,031.8$ \\
\hline U-19ax & Tmrr & MWT & DV & WTA & TM WTA & 330 & 100.6 & 6656 & $2,028.7$ \\
\hline U-19ax & Tmrp & MWT & DV & WTA & TM WTA & 342 & 104.2 & 6644 & $2,025.1$ \\
\hline U-19ax & Tmrp & VT & $\mathrm{GL}$ & WTA & TM WTA & 1081 & 329.5 & 5905 & $1,799.8$ \\
\hline U-19ax & Tmrp & MWT & $\mathrm{GL}$ & WTA & TM WTA & 1124 & 342.6 & 5862 & $1,786.7$ \\
\hline U-19ax & Tmrp & PWT & $\mathrm{GL}$ & WTA & TM WTA & 1156 & 352.3 & 5830 & $1,777.0$ \\
\hline U-19ax & Tmrp & NWT & $\mathrm{GL}$ & VTA & TM WTA & 1198 & 365.2 & 5788 & $1,764.2$ \\
\hline U-19ax & Tmrh & NWT & $\overline{G L}$ & VTA & PVTA & 1232 & 375.5 & 5754 & $1,753.8$ \\
\hline U-19ax & Thp & NWT & $\mathrm{GL}$ & VTA & CHVTA & 1265 & 385.6 & 5721 & $1,743.8$ \\
\hline U-19ax & Tcj & NWT & $\overline{G L}$ & VTA & CHVTA & 1475 & 449.6 & 5511 & $1,679.8$ \\
\hline U-19ax & Tcpk & $\mathrm{PL}$ & $Z C$ & TCU & $\mathrm{KA}$ & 1516 & 462.1 & 5470 & $1,667.3$ \\
\hline U-19ax & Tcpk & LA & GL, ZE & LFA & $\mathrm{KA}$ & 1574 & 479.8 & 5412 & $1,649.6$ \\
\hline U-19ax & Tcpk & LA & DV & LFA & $\mathrm{KA}$ & 1680 & 512.1 & 5306 & $1,617.3$ \\
\hline U-19ax & Tcpk & LA & $\mathrm{GL}$ & LFA & $\mathrm{KA}$ & 2054 & 626.1 & 4932 & $1,503.3$ \\
\hline U-19ax & Tcpk & LA & $Z C$ & LFA & $\mathrm{KA}$ & 2083 & 634.9 & 4903 & $1,494.4$ \\
\hline U-19ax & Tcblp & NWT & $A B$ & $\mathrm{TCU}$ & BFCU & 2118 & 645.6 & 4868 & $1,483.8$ \\
\hline U-19ax & Tcbx & TB & DV & WTA & BFCU & 2190 & 667.5 & 4796 & $1,461.8$ \\
\hline $\mathrm{U}-19 \mathrm{t}$ & Tma & $\mathrm{nr}$ & $\mathrm{nr}$ & $\mathrm{nr}$ & TM WTA & 0 & 0.0 & $6,991.0$ & $2,130.9$ \\
\hline $\mathrm{U}-19 \mathrm{t}$ & Tmap & DWT & DV & WTA & TM WTA & 70 & 21.3 & $6,921.0$ & $2,109.5$ \\
\hline $\mathrm{U}-19 \mathrm{t}$ & Tmab & NWT & $\mathrm{GL}$ & VTA & TM WTA & 197 & 60.0 & $6,794.0$ & $2,070.8$ \\
\hline $\mathrm{U}-19 \mathrm{t}$ & Tmrb & NWT & $\mathrm{GL}$ & VTA & TM WTA & 210 & 64.0 & $6,781.0$ & $2,066.8$ \\
\hline $\mathrm{U}-19 \mathrm{t}$ & Tmrb & BED & $\mathrm{GL}$ & VTA & TM WTA & 231 & 70.4 & $6,760.0$ & $2,060.4$ \\
\hline $\mathrm{U}-19 \mathrm{t}$ & Tmrr & NWT & $\mathrm{GL}$ & VTA & TM WTA & 239 & 72.8 & $6,752.0$ & $2,058.0$ \\
\hline $\mathrm{U}-19 \mathrm{t}$ & Tmrr & PWT & GL, ZE & WTA & TM WTA & 250 & 76.2 & $6,741.0$ & $2,054.7$ \\
\hline $\mathrm{U}-19 \mathrm{t}$ & Tmrr & MWT & DV & WTA & TM WTA & 270 & 82.3 & $6,721.0$ & $2,048.6$ \\
\hline $\mathrm{U}-19 \mathrm{t}$ & Tmrr & DWT & DV & WTA & TM WTA & 308 & 93.9 & $6,683.0$ & $2,037.0$ \\
\hline $\mathrm{U}-19 \mathrm{t}$ & Tmrr & VT & DV & WTA & TM WTA & 320 & 97.5 & $6,671.0$ & $2,033.3$ \\
\hline $\mathrm{U}-19 \mathrm{t}$ & Tmrr & DWT & DV & WTA & TM WTA & 340 & 103.6 & $6,651.0$ & $2,027.2$ \\
\hline $\mathrm{U}-19 \mathrm{t}$ & Tmrr & MWT & DV & WTA & TM WTA & 352 & 107.3 & $6,639.0$ & $2,023.6$ \\
\hline $\mathrm{U}-19 \mathrm{t}$ & Tmrp & DWT & DV & WTA & TM WTA & 397 & 121.0 & $6,594.0$ & $2,009.9$ \\
\hline $\mathrm{U}-19 \mathrm{t}$ & Tmrp & MWT & DV & WTA & TM WTA & 464 & 141.4 & $6,527.0$ & $1,989.4$ \\
\hline $\mathrm{U}-19 \mathrm{t}$ & Tmrp & DWT & DV & WTA & TM WTA & 1,070 & 326.1 & $5,921.0$ & $1,804.7$ \\
\hline $\mathrm{U}-19 \mathrm{t}$ & Tmrp & VT & $\mathrm{GL}$ & WTA & TM WTA & 1,195 & 364.2 & $5,796.0$ & $1,766.6$ \\
\hline $\mathrm{U}-19 \mathrm{t}$ & Tmrp & MWT & $\mathrm{GL}$ & WTA & TM WTA & 1,218 & 371.2 & $5,773.0$ & $1,759.6$ \\
\hline $\mathrm{U}-19 \mathrm{t}$ & Tmrp & PWT & $\mathrm{GL}$ & WTA & TM WTA & 1,230 & 374.9 & $5,761.0$ & $1,756.0$ \\
\hline $\mathrm{U}-19 \mathrm{t}$ & Tmrp & NWT & $\mathrm{GL}$ & VTA & TM WTA & 1,269 & 386.8 & $5,722.0$ & $1,744.1$ \\
\hline $\mathrm{U}-19 \mathrm{t}$ & Tmrh & RWT & $Z C$ & $\mathrm{TCU}$ & PVTA & 1,316 & 401.1 & $5,675.0$ & $1,729.7$ \\
\hline $\mathrm{U}-19 \mathrm{t}$ & Tmrh & RWT & GL, ZE & VTA & PVTA & 1,320 & 402.3 & $5,671.0$ & $1,728.5$ \\
\hline U-19t & Tmrh & RWT & $\mathrm{ZC}$ & TCU & PVTA & 1,330 & 405.4 & $5,661.0$ & $1,725.5$ \\
\hline $\mathrm{U}-19 \mathrm{t}$ & Tmrh & RWT & $\mathrm{GL}$ & VTA & PVTA & 1,340 & 408.4 & $5,651.0$ & $1,722.4$ \\
\hline $\mathrm{U}-19 \mathrm{t}$ & Tpe & NWT & $\mathrm{GL}$ & VTA & PVTA & 1,366 & 416.4 & $5,625.0$ & $1,714.5$ \\
\hline $\mathrm{U}-19 \mathrm{t}$ & Thp & NWT & $\mathrm{GL}$ & VTA & CHVTA & 1,412 & 430.4 & $5,579.0$ & $1,700.5$ \\
\hline U-19t & Tcu & BED & $Z C$ & $\mathrm{TCU}$ & CHVTA & 1,500 & 457.2 & $5,491.0$ & $1,673.7$ \\
\hline $\mathrm{U}-19 \mathrm{t}$ & Tcu & NWT & $Z C$ & $\mathrm{TCU}$ & CHVTA & 1,510 & 460.2 & $5,481.0$ & $1,670.6$ \\
\hline $\mathrm{U}-19 \mathrm{t}$ & Tcpk & $\mathrm{PL}$ & $Z C$ & $\mathrm{TCU}$ & $\mathrm{KA}$ & 1,530 & 466.3 & $5,461.0$ & $1,664.5$ \\
\hline $\mathrm{U}-19 \mathrm{t}$ & Tcpk & LA & $\mathrm{GL}$ & LFA & $\mathrm{KA}$ & 1,650 & 502.9 & $5,341.0$ & $1,627.9$ \\
\hline $\mathrm{U}-19 \mathrm{t}$ & Tcpk & FB & $\overline{G L}$ & LFA & $\mathrm{KA}$ & 1,688 & 514.5 & $5,303.0$ & $1,616.4$ \\
\hline $\mathrm{U}-19 \mathrm{t}$ & Tcpk & LA & DV & LFA & $\mathrm{KA}$ & 1,710 & 521.2 & $5,281.0$ & $1,609.6$ \\
\hline $\mathrm{U}-19 \mathrm{t}$ & Tcpk & FB & DV & LFA & $\mathrm{KA}$ & 1,890 & 576.1 & $5,101.0$ & $1,554.8$ \\
\hline UE-19b & Ttp & $\mathrm{nr}$ & $\mathrm{nr}$ & VTA & TM WTA & 0 & 0.0 & $6,802.0$ & $2,073.2$ \\
\hline UE-19b & Ttp & PWT & $\mathrm{nr}$ & WTA & TM WTA & 30 & 9.1 & $6,772.0$ & $2,064.1$ \\
\hline UE-19b & Ttp & BED & $\mathrm{nr}$ & VTA & TM WTA & 40 & 12.2 & $6,762.0$ & $2,061.1$ \\
\hline UE-19b & Tmar & PWT & $\mathrm{nr}$ & WTA & TM WTA & 78 & 23.8 & $6,724.0$ & $2,049.5$ \\
\hline UE-19b & Tmap & PWT & $\mathrm{nr}$ & WTA & TM WTA & 170 & 51.8 & $6,632.0$ & $2,021.4$ \\
\hline
\end{tabular}


Table A-2

Geologic and Hydrostratigraphic Drill hole Database for the Rainier Mesa-Shoshone Mountain Model Area (vertical drill holes only)

\begin{tabular}{|c|c|c|c|c|c|c|c|c|c|}
\hline Hole Name & Strat $^{1}$ & Lith $^{2}$ & Major Alt. ${ }^{3}$ & $\mathrm{HGU}^{4}$ & $\mathrm{HSU}^{5}$ & \begin{tabular}{|c|}
$\begin{array}{c}\text { Depth Top } \\
6 \\
(\mathrm{ft})\end{array}$ \\
\end{tabular} & $\begin{array}{c}\text { Depth } \\
\operatorname{Top}^{6}(\mathrm{~m}) \\
\end{array}$ & $\begin{array}{c}\text { Elev. Top }{ }^{7} \\
\text { (ft) }\end{array}$ & \begin{tabular}{|c|}
$\begin{array}{c}\text { Elev. Top } \\
\text { (m) }\end{array}$ \\
\end{tabular} \\
\hline UE-19b & Tmap & 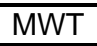 & $\mathrm{nr}$ & WTA & TM WTA & 210 & 64.0 & $6,592.0$ & $2,009.2$ \\
\hline UE-19b & Tmap & PWT & $\mathrm{nr}$ & WTA & TM WTA & 300 & 91.4 & $6,502.0$ & $1,981.8$ \\
\hline UE-19b & Tmrr & MWT & $\mathrm{nr}$ & WTA & TM WTA & 400 & 121.9 & $6,402.0$ & $1,951.3$ \\
\hline UE-19b & Tmrp & DWT & $\mathrm{nr}$ & WTA & TM WTA & 470 & 143.3 & $6,332.0$ & $1,930.0$ \\
\hline UE-19b & Tyb & $\mathrm{BD}$ & $\mathrm{nr}$ & $\mathrm{ICU}$ & TM WTA & 893 & 272.2 & $5,909.0$ & $1,801.1$ \\
\hline UE-19b & Tmrp & DWT & $\mathrm{nr}$ & WTA & TM WTA & 900 & 274.3 & $5,902.0$ & $1,798.9$ \\
\hline UE-19b & Tmrp & NWT & $\mathrm{nr}$ & VTA & TM WTA & 1,090 & 332.2 & $5,712.0$ & $1,741.0$ \\
\hline UE-19b & Thp & NWT & $\mathrm{nr}$ & VTA & CHVTA & 1,110 & 338.3 & $5,692.0$ & $1,734.9$ \\
\hline UE-19b & Thp & BED & $\mathrm{nr}$ & VTA & CHVTA & 1,154 & 351.7 & $5,648.0$ & $1,721.5$ \\
\hline UE-19b & Tcu & BED & $\mathrm{nr}$ & VTA & CHVTA & 1,312 & 399.9 & $5,490.0$ & $1,673.4$ \\
\hline UE-19b & Tcpk & BED & $\mathrm{nr}$ & VTA & CHVTA & 1,380 & 420.6 & $5,422.0$ & $1,652.6$ \\
\hline UE-19b & Tcpk & LA & $\mathrm{nr}$ & LFA & $\mathrm{KA}$ & 1,460 & 445.0 & $5,342.0$ & $1,628.2$ \\
\hline UE-19b & Tbdl & BED & $\mathrm{nr}$ & $\mathrm{nr}$ & BRA & 1,610 & 490.7 & $5,192.0$ & $1,582.5$ \\
\hline UE-19b & Tbdl & $\mathrm{LA}$ & $\mathrm{nr}$ & LFA & BRA & 1,745 & 531.9 & $5,057.0$ & $1,541.4$ \\
\hline UE-19b & $\mathrm{nr}$ & $\mathrm{nr}$ & $\mathrm{nr}$ & $\mathrm{nr}$ & BRA & 2,300 & 701.0 & $4,502.0$ & $1,372.2$ \\
\hline UE-19b \#1 & $\mathrm{nr}$ & $\mathrm{nr}$ & $\mathrm{nr}$ & VTA & $\mathrm{nr}$ & 0 & 0.0 & $6,802.0$ & $2,073.2$ \\
\hline UE-19b \#1 & $\mathrm{nr}$ & $\mathrm{nr}$ & $\mathrm{nr}$ & $\mathrm{nr}$ & $\mathrm{nr}$ & 1,610 & 490.7 & $5,192.0$ & $1,582.5$ \\
\hline UE-19b \#1 & $\mathrm{nr}$ & $\mathrm{nr}$ & $\mathrm{nr}$ & $\mathrm{nr}$ & BRA & 1,611 & 491.0 & $5,191.0$ & $1,582.2$ \\
\hline UE-19b \#1 & Tbdl & LA & $\mathrm{nr}$ & LFA & BRA & 2,300 & 701.0 & $4,502.0$ & $1,372.2$ \\
\hline UE-19b \#1 & Tbdl & MWT & $\mathrm{nr}$ & WTA & BRA & 3,520 & $1,072.9$ & $3,282.0$ & $1,000.4$ \\
\hline UE-19b \#1 & Tbdk & MWT & $\mathrm{nr}$ & WTA & BRA & 3,850 & $1,173.5$ & $2,952.0$ & 899.8 \\
\hline UE-19b \#1 & Tbds & LA & $\mathrm{nr}$ & LFA & BRA & 3,926 & $1,196.6$ & $2,876.0$ & 876.6 \\
\hline UE-19t & Tma & $\mathrm{nr}$ & $\mathrm{nr}$ & $\mathrm{nr}$ & TM WTA & 0 & 0.0 & $6,989.0$ & $2,130.2$ \\
\hline UE-19t & Tmap & MWT & VP & WTA & TM WTA & 80 & 24.4 & $6,909.0$ & $2,105.9$ \\
\hline UE-19t & Tmap & MWT & DV & WTA & TM WTA & 153 & 46.6 & $6,836.0$ & $2,083.6$ \\
\hline UE-19t & Tmab & NWT & $\mathrm{GL}$ & VTA & TM WTA & 198 & 60.4 & $6,791.0$ & $2,069.9$ \\
\hline UE-19t & Tmrb & NWT & $\mathrm{GL}$ & VTA & TM WTA & 209 & 63.7 & $6,780.0$ & $2,066.5$ \\
\hline UE-19t & Tmrr & PWT & $\mathrm{GL}$ & WTA & TM WTA & 245 & 74.7 & $6,744.0$ & $2,055.6$ \\
\hline UE-19t & Tmrr & MWT & DV & WTA & TM WTA & 269 & 82.0 & $6,720.0$ & $2,048.3$ \\
\hline UE-19t & Tmrr & VT & $\mathrm{GL}$ & WTA & TM WTA & 317 & 96.6 & $6,672.0$ & $2,033.6$ \\
\hline UE-19t & Tmrr & DWT & DV & WTA & TM WTA & 340 & 103.6 & $6,649.0$ & $2,026.6$ \\
\hline UE-19t & Tmrr & MWT & DV & WTA & TM WTA & 348 & 106.1 & $6,641.0$ & $2,024.2$ \\
\hline UE-19t & Tmrp & DWT & DV & WTA & TM WTA & 394 & 120.1 & $6,595.0$ & $2,010.2$ \\
\hline UE-19t & Tmrp & MWT & DV & WTA & TM WTA & 460 & 140.2 & $6,529.0$ & $1,990.0$ \\
\hline UE-19t & Tmrp & DWT & DV & WTA & TM WTA & 1,067 & 325.2 & $5,922.0$ & $1,805.0$ \\
\hline UE-19t & Tmrp & VT & $\mathrm{GL}$ & WTA & TM WTA & 1,193 & 363.6 & $5,796.0$ & $1,766.6$ \\
\hline UE-19t & Tmrp & DWT & $\mathrm{GL}$ & WTA & TM WTA & 1,215 & 370.3 & $5,774.0$ & $1,759.9$ \\
\hline UE-19t & Tmrp & PWT & $\mathrm{GL}$ & WTA & TM WTA & 1,221 & 372.2 & $5,768.0$ & $1,758.1$ \\
\hline UE-19t & Tmrp & NWT & GL & VTA & TM WTA & 1,250 & 381.0 & $5,739.0$ & $1,749.2$ \\
\hline UE-19t & Tmrh & NWT & $\mathrm{GL}$ & VTA & PVTA & 1,330 & 405.4 & $5,659.0$ & $1,724.9$ \\
\hline UE-19t & Tpe & NWT & $\mathrm{GL}$ & VTA & PVTA & 1,369 & 417.3 & $5,620.0$ & $1,713.0$ \\
\hline UE-19t & Thp & NWT & GL & VTA & CHVTA & 1,399 & 426.4 & $5,590.0$ & $1,703.8$ \\
\hline UE-19t & Tcu & BED & GL, ZE & VTA & CHVTA & 1,448 & 441.4 & $5,541.0$ & $1,688.9$ \\
\hline UE-19t & Tcpk & $\mathrm{PL}$ & ZC & TCU & $\mathrm{KA}$ & 1,515 & 461.8 & $5,474.0$ & $1,668.5$ \\
\hline UE-19t & Tcpk & $\mathrm{LA}$ & GL, ZE & LFA & $\mathrm{KA}$ & 1,561 & 475.8 & $5,428.0$ & $1,654.5$ \\
\hline UE-19t & Tcpk & $\mathrm{FB}$ & GL, ZE & LFA & $\mathrm{KA}$ & 1,620 & 493.8 & $5,369.0$ & $1,636.5$ \\
\hline UE-19t & Tcpk & $\mathrm{LA}$ & $\mathrm{GL}$ & LFA & $\mathrm{KA}$ & 1,680 & 512.1 & $5,309.0$ & $1,618.2$ \\
\hline UE-19t & Tcpk & $\mathrm{LA}$ & DV & LFA & $\mathrm{KA}$ & 1,700 & 518.3 & $5,288.7$ & $1,612.0$ \\
\hline ER-30-1 & QTa & $\mathrm{AL}$ & $\mathrm{GL}, \mathrm{ZE}, \mathrm{CC}$ & $\mathrm{AA}$ & AA & 0 & 0.0 & 4647.4 & $1,416.5$ \\
\hline ER-30-1 & Tgm & $\mathrm{AL}$ & GL, ZE & AA & AA & 25 & 7.6 & $4,622.4$ & $1,408.9$ \\
\hline ER-30-1 & Tgm & BED & GL, ZE & VTA & AA & 155 & 47.2 & $4,492.4$ & $1,369.3$ \\
\hline ER-30-1 & Tgm & NWT & $Z C$ & TCU & AA & 225 & 68.6 & $4,422.4$ & $1,347.9$ \\
\hline ER-30-1 & Tfdb & $\mathrm{BS}$ & $\mathrm{AR}$ & LFA & $\mathrm{FCCM}$ & 382 & 116.4 & $4,265.4$ & $1,300.1$ \\
\hline ER-30-1 & Tfdb & $\mathrm{BS}$ & $\mathrm{PI}, \mathrm{AR}$ & LFA & FCCM & 410 & 125.0 & $4,237.4$ & $1,291.6$ \\
\hline ER-30-1 & $\mathrm{Tg}$ & NWT & ZC, CC & $\mathrm{TCU}$ & FCCM & 714 & 217.6 & $3,933.4$ & $1,198.9$ \\
\hline ER-30-1 & Tfbw & NWT & ZC, QC & $\mathrm{TCU}$ & FCCM & 790 & 240.8 & $3,857.4$ & $1,175.7$ \\
\hline
\end{tabular}


Table A-2

Geologic and Hydrostratigraphic Drill hole Database for the Rainier Mesa-Shoshone Mountain Model Area (vertical drill holes only)

\begin{tabular}{|c|c|c|c|c|c|c|c|c|c|}
\hline Hole Name & Strat $^{1}$ & Lith $^{2}$ & Major Alt. ${ }^{3}$ & $H G U^{4}$ & $\mathrm{HSU}^{5}$ & \begin{tabular}{|c|}
$\begin{array}{c}\text { Depth Top } \\
\text { (ft) }\end{array}$ \\
\end{tabular} & $\begin{array}{c}\text { Depth } \\
\operatorname{Top}^{6}(\mathrm{~m})\end{array}$ & \begin{tabular}{|c|}
$\begin{array}{c}\text { Elev. Top } \\
\end{array}$ \\
(ft)
\end{tabular} & \begin{tabular}{|c}
$\begin{array}{c}\text { Elev. Top } \\
\text { (m) }\end{array}$ \\
\end{tabular} \\
\hline ER-30-1 & $\overline{T \text { Tfbw }}$ & BED & $\overline{Z Z E}, \mathrm{QC}$ & $\overline{\mathrm{TCU}}$ & FCCM & 822 & 250.5 & $3,825.4$ & $1,166.0$ \\
\hline ER-30-1 & Tfbb & BS & $\mathrm{MP}, \mathrm{CH}$ & LFA & FCCM & 950 & 289.6 & $3,697.4$ & $1,127.0$ \\
\hline ER-30-1 & Tmar & MWT & $\mathrm{DV}, \mathrm{AR}$ & WTA & TMCM & 1198 & 365.2 & $3,449.4$ & $1,051.4$ \\
\hline \multicolumn{10}{|c|}{ EXPLANATION } \\
\hline \multicolumn{10}{|c|}{ na = not applicable } \\
\hline \multicolumn{10}{|c|}{ nd = unit not defined, borehole spudded in a lower stratigraphic unit (e.g., at tunnel level) } \\
\hline \multicolumn{10}{|c|}{ nr = not reported or unknown } \\
\hline & & & & & & & & & \\
\hline \multicolumn{10}{|c|}{1 Strat = Stratigraphic unit. See Tables 4-1 and 4-2 in the main body of this report for abbreviations } \\
\hline \multicolumn{10}{|c|}{ Stratigraphic assignments, lithology, and major alteration compiled from Warren et al. (2001) and well-specific } \\
\hline \multicolumn{10}{|c|}{ completion reports (see Section 8.0 of main body of this report). } \\
\hline & & & & & & & & & \\
\hline \multicolumn{10}{|c|}{2 Lith = Lithology } \\
\hline & \multicolumn{2}{|c|}{$\mathrm{AL}=$ alluvium } & & & \multicolumn{2}{|c|}{ NWT = nonwelded tuff } & & & \\
\hline & \multicolumn{2}{|c|}{$\mathrm{BD}=$ basaltic dike } & & & \multicolumn{2}{|c|}{$\mathrm{PCL}=$ paleocolluvium } & & & \\
\hline & \multicolumn{2}{|l|}{ BS = basalt } & & & \multicolumn{3}{|c|}{$\mathrm{PL}=$ pumiceous (frothy) lava } & & \\
\hline & \multicolumn{2}{|c|}{ BED = bedded tuff } & & & \multicolumn{3}{|c|}{ PWT = partially welded tuff } & & \\
\hline & \multicolumn{2}{|c|}{ COL = colluvium } & & & \multicolumn{3}{|c|}{$\mathrm{QTZ}=$ quartzite or sandstone } & & \\
\hline & \multicolumn{2}{|c|}{$\mathrm{DM}=$ dolomite } & & & \multicolumn{2}{|c|}{ RWT = reworked tuff } & & & \\
\hline & DWT $=$ den & y welde & & & $\mathrm{SCH}=\mathrm{SC}$ & ist & & & \\
\hline & FB $=$ flow $b$ & cia & & & $\mathrm{SH}=\mathrm{sha}$ & & & & \\
\hline & GN = grani & & & & SLT = silt & tone & & & \\
\hline & IN = intrusi & & & & TS $=$ tuffa & ceous sandsto & & & \\
\hline & ITL = intern & iate to $t$ & nytic lava & & TUF = tuf & & & & \\
\hline & $\mathrm{LA}=$ lava & & & & TB = tuff & reccia & & & \\
\hline & LHR = laha & & & & VT = vitro & hyric tuff & & & \\
\hline & LS = limest & & & & WT = wel & led tuff & & & \\
\hline & MWT $=\mathrm{mo}$ & ately we & d tuff & & & & & & \\
\hline & & & & & & & & & \\
\hline 3 Major Alt & & & & & & & & & \\
\hline & $A B=$ albitic & & & & $\mathrm{PI}=$ pilota & xitic (holocryst & alline) & & \\
\hline & $\mathrm{AR}=$ argilli & & & & PY = pyrit & & & & \\
\hline & $\mathrm{CC}=$ calcit & & & & $\mathrm{QC}=$ silic & c (chalcedony) & & & \\
\hline & $\mathrm{CH}=$ chlori & & & & $\mathrm{QF}=$ qua & tzo-feldspathic & & & \\
\hline & $\mathrm{DM}=$ dolon & & & & $\mathrm{QZ}=$ silic & & & & \\
\hline & DV = devitr & & & & SE $=$ seri & te (holocrystal & line) & & \\
\hline & $\mathrm{FL}=$ fluoriti & & & & $\mathrm{nr}=\mathrm{nrnol}$ & & & & \\
\hline & $G L=$ vitric & & & & $\mathrm{VP}=$ devi & rified (vapor pl & nase) & & \\
\hline & KA = kaolin & & & & $Z A=$ zeol & tic (analcime) & & & \\
\hline & $\mathrm{KF}=$ potas & & & & $Z C=\mathrm{zeol}$ & tic (clinoptilolite & & & \\
\hline & $\mathrm{MP}=$ micro & rphyritic & locrystalline) & & ZE $=$ zeol & & & & \\
\hline & OP = opalli & & & & $\mathrm{ZM}=\mathrm{zeo}$ & tic (mordenite) & & & \\
\hline & & & & & & & & & \\
\hline & & & & & & & & & \\
\hline $\begin{array}{l}4 \mathrm{HGU}=\mathrm{Hy} \\
5 \mathrm{HSU}=\mathrm{Hy}\end{array}$ & ologic unit. & $\frac{\mathrm{e} \text { Table }}{\text { See } T a}$ & in the main b & dy of th & $\frac{s \text { report fol }}{\text { this repor }}$ & $\begin{array}{l}\text { abbreviatıons. } \\
\text { for abbreviatic }\end{array}$ & ons. & & \\
\hline 6 Depth To & stance from & ound su & e to top of uni & & & & & & \\
\hline 7 Elev. Top & vation (abov & nean se & vel) of unit top & & & & & & \\
\hline
\end{tabular}


Table A-3

Hydrostratigraphic Data for Selected Drill Holes in the Rainier Mesa-Shoshone Mountain CAU Model Area (meters, elevation)

\begin{tabular}{|c|c|c|c|c|c|c|c|c|c|c|c|c|c|}
\hline WELL_ID & NORTHING & EASTING $^{1}$ & $\mathrm{GND} \mathrm{EL}^{2}, \mathrm{ft}$ & GND EL ${ }^{2}, \mathrm{~m}$ & 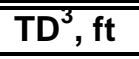 & $\bar{T} \mathrm{TD} \mathrm{EL}^{4}, \mathrm{ft}$ & 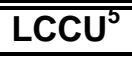 & LCA & UCCU & LCCU1 & LCA3 & MGCU & 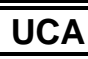 \\
\hline UE1a & $837,000.0$ & $660,000.0$ & $4,303.0$ & 1,311.6 & 957.0 & $3,346.0$ & NDE & NDE & 1037.2 & NP & $\mathrm{NP}$ & NDE & NP \\
\hline UE1f & $36,212.0$ & $661,373.0$ & $4,277.0$ & 1,303.6 & 703.0 & $3,574.0$ & NDE & NDE & 1132.9 & $\mathrm{NP}$ & $\mathrm{NP}$ & NDE & NP \\
\hline UE2ad & $867,000.0$ & $661,001.0$ & $4,448.0$ & $1,355.8$ & 866.0 & $3,582.0$ & NDE & NDE & NDE & NDE & 1117.7 & $\mathrm{NDE}$ & NP \\
\hline U2ca\#1 & $870,198.0$ & $653,250.0$ & $4,871.0$ & $1,484.7$ & $1,473.0$ & $3,398.0$ & NDE & NDE & NDE & NDE & 1051.7 & NDE & NP \\
\hline U2ce & $871,699.0$ & $654,901.0$ & $4,764.1$ & $1,452.1$ & $1,206.0$ & $3,558.1$ & NDE & NDE & NDE & NDE & 1107.1 & JDE & NP \\
\hline UE2ce & $871,100.0$ & $654,900.0$ & $4,764.0$ & $1,452.1$ & $1,650.0$ & $3,114.0$ & NDE & NDE & NDE & NDE & 1115.1 & NDE & NP \\
\hline UE2co & $861,900.0$ & $657,400.0$ & $4,562.0$ & $1,390.5$ & $1,921.0$ & $2,641.0$ & NDE & NDE & $\overline{N D E}$ & NDE & 850.5 & $\overline{\mathrm{NDE}}$ & $\overline{N P}$ \\
\hline U2co & 0.0 & $657,375.0$ & $4,562.0$ & $1,390.5$ & $1,170.0$ & $3,392.0$ & NDE & NDE & NDE & NDE & NDE & $\mathrm{DEE}$ & NDE \\
\hline U2cp & $861,114.0$ & $658,554.0$ & $4,510.0$ & $1,374.6$ & $1,250.0$ & $3,260.0$ & NDE & NDE & NDE & NDE & NDE & NDE & NDE \\
\hline $\mathrm{U} 2 \mathrm{cq}$ & $860,450.0$ & $658,901.0$ & 4,499.0 & 1,371.3 & $1,450.0$ & $3,049.0$ & NDE & NDE & NDE & NDE & NDE & NDE & NDE \\
\hline U2cr & $871,800.0$ & $657,800.0$ & $4,604.0$ & 1,403.3 & $1,367.0$ & $3,237.0$ & NDE & NDE & 1004.3 & $\mathrm{NP}$ & $\mathrm{NP}$ & NDE & NP \\
\hline U2cs & $864,600.0$ & $658,794.0$ & $4,526.0$ & $1,379.5$ & $1,500.0$ & $3,026.0$ & NDE & NDE & NDE & NDE & NDE & NDE & NDE \\
\hline U4at & $858,600.0$ & $659,150.0$ & $4,476.0$ & $1,364.3$ & $1,521.0$ & $2,955.0$ & NDE & NDE & $\mathrm{NDE}$ & NDE & NDE & NDE & NDE \\
\hline UE4ac & $855,950.0$ & $659,250.0$ & $4,471.0$ & $1,362.8$ & $1,677.0$ & $2,794.0$ & NDE & NDE & NDE & NDE & 885.8 & $\mathrm{NDE}$ & NP \\
\hline WW8 & $879,468.0$ & $609,999.0$ & 5,695.0 & 1,735.8 & $5,499.0$ & 196.0 & NDE & NDE & NDE & NDE & NDE & NDE & NDE \\
\hline Effinger 1 & $888,562.0$ & $650,404.0$ & $5,152.0$ & 1,570.3 & 180.0 & 4,972.0 & NDE & NDE & NDE & NDE & NDE & NDE & NDE \\
\hline ER-12-1 & $886,640.0$ & $640,540.0$ & $5,818.0$ & $1,773.3$ & $3,588.0$ & $2,230.0$ & NDE & 898.8 & 1460.6 & $\overline{N P}$ & 1765.1 & NDE & $\overline{N P}$ \\
\hline ER-12-2 & $881,865.4$ & $658,542.7$ & $4,705.3$ & $1,434.2$ & $6,883.0$ & $-2,177.7$ & NDE & NDE & 1248.2 & $\mathrm{NP}$ & $\mathrm{NP}$ & NDE & NP \\
\hline ER-12-3 & $890,278.7$ & $631,811.0$ & 7,390.8 & 2,252.7 & $4,908.0$ & $2,482.8$ & NDE & NDE & NDE & NDE & 1579.1 & NDE & NP \\
\hline ER-12-4 & $899,282.8$ & $640,786.4$ & 6,883.7 & $2,098.2$ & $3,715.0$ & $3,168.7$ & NDE & NDE & NDE & NDE & 1339.6 & NDE & NP \\
\hline UE12e\#1 & $887,459.0$ & $632,001.0$ & $7,431.0$ & $2,265.0$ & $2,000.0$ & $5,431.0$ & NDE & NDE & NDE & NDE & NDE & NDE & NDE \\
\hline UE12e\#3 & $885,923.0$ & $631,038.0$ & $7,460.0$ & 2,273.8 & $2,199.0$ & $5,261.0$ & NDE & NDE & NDE & NDE & NDE & NDE & NDE \\
\hline UE12g.10\#1 & $882,737.7$ & $631,725.6$ & $7,528.3$ & $2,294.6$ & $1,522.0$ & $6,006.3$ & NDE & NDE & NDE & NDE & NDE & NDE & NDE \\
\hline UE12g.10\#2 & $883,410.6$ & $632,397.0$ & 7,576.9 & $2,309.4$ & $1,540.0$ & 6,036.9 & NDE & NDE & NDE & NDE & NDE & NDE & NDE \\
\hline UE12g.10\#3 & $882,944.1$ & $633,034.3$ & $7,529.6$ & $2,295.0$ & $1,425.0$ & 6,104.6 & NDE & NDE & NDE & NDE & NDE & NDE & NDE \\
\hline
\end{tabular}


Table A-3

Hydrostratigraphic Data for Selected Drill Holes in the Rainier Mesa-Shoshone Mountain CAU Model Area (meters, elevation)

\begin{tabular}{|c|c|c|c|c|c|c|c|c|c|c|c|c|c|c|}
\hline WELL_ID & ATCU & LTCU1 & RVA & OSBCU & LTCU & TUBA & BRCU & LVTA1 & BRA & UTCU1 & BFCU & SWA & UTCU2 & $\mathrm{KA}$ \\
\hline UE1a & $\overline{\mathrm{NP}}$ & $\overline{\mathrm{NP}}$ & $\overline{\mathrm{NP}}$ & $\overline{\mathrm{NP}}$ & $\overline{\mathrm{NP}}$ & $\overline{\mathrm{NP}}$ & $\overline{\mathrm{NP}}$ & $\overline{\mathrm{NP}}$ & $\overline{\mathrm{NP}}$ & $\overline{\mathrm{NP}}$ & $\overline{\mathrm{ND}}$ & $\overline{\mathrm{NP}}$ & $\overline{\mathrm{NP}}$ & ND \\
\hline UE1d & 1100.0 & NP & NP & NP & 1147.9 & $\mathrm{NP}$ & NP & NP & NP & $\mathrm{NP}$ & ND & NP & NP & ND \\
\hline UE1f & NP & NP & NP & NP & NP & NP & NP & NP & NP & NP & ND & NP & NP & ND \\
\hline UE1L & NP & NP & NP & NP & NP & NP & NP & NP & NP & NP & ND & ND & ND & ND \\
\hline UE2ad & 1120.5 & NP & NP & NP & NP & NP & NP & NP & NP & NP & ND & NP & NP & ND \\
\hline U2ca\#1 & 1068.6 & NP & NP & NP & 1234.7 & NP & $\mathrm{NP}$ & NP & NP & $\mathrm{NP}$ & ND & ND & ND & ND \\
\hline U2ce & NP & NP & NP & NP & NP & NP & $\mathrm{NP}$ & NP & NP & $\mathrm{NP}$ & ND & ND & ND & ND \\
\hline UE2ce & NP & NP & NP & NP & NP & $\mathrm{NP}$ & NP & NP & NP & $\mathrm{NP}$ & ND & ND & ND & ND \\
\hline U2 $\mathrm{cms}$ & NDE & NDE & NDE & NDE & NDE & NDE & NDE & NDE & NDE & NDE & NDE & NDE & NDE & NDE \\
\hline U2cn & NP & NP & NP & NP & NP & NP & $\mathrm{NP}$ & $\mathrm{NP}$ & NP & $\mathrm{NP}$ & ND & ND & ND & ND \\
\hline UE2co & 852.9 & NP & NP & NP & NP & NP & NP & NP & $\mathrm{NP}$ & $\mathrm{NP}$ & ND & ND & ND & ND \\
\hline U2co & NDE & NDE & NDE & NDE & NDE & NDE & NDE & NDE & NDE & NDE & NDE & NDE & NDE & NDE \\
\hline U2cp & NDE & NDE & NDE & NDE & NDE & NDE & NDE & NDE & NDE & NDE & NDE & NDE & NDE & NDE \\
\hline U2cq & NDE & NDE & NDE & NDE & NDE & NDE & NDE & NDE & NDE & NDE & NDE & NDE & NDE & $\mathrm{NDE}$ \\
\hline U2cr & 1019.3 & $\mathrm{NP}$ & $\mathrm{NP}$ & NP & NP & NP & NP & NP & NP & NP & ND & ND & ND & ND \\
\hline U2cs & NDE & NDE & NDE & NDE & NDE & NDE & NDE & NDE & NDE & NDE & NDE & NDE & NDE & NDE \\
\hline U2ct & NDE & NDE & NDE & NDE & NDE & NDE & NDE & NDE & NDE & NDE & NDE & NDE & NDE & NDE \\
\hline U2cu & NDE & NDE & NDE & NDE & NDE & NDE & NDE & NDE & NDE & NDE & NDE & NDE & NDE & NDE \\
\hline UE2s & NP & NP & NP & NP & NP & NP & NDE & NDE & NDE & NDE & NDE & NDE & NDE & NDE \\
\hline U4as & $\overline{N D E}$ & $\overline{N D E}$ & $\overline{N D E}$ & NDE & $\overline{N D E}$ & NDE & $\overline{N D E}$ & NDE & NDE & $\overline{N D E}$ & $\overline{N D E}$ & NDE & $\overline{N D E}$ & $\mathrm{NDE}$ \\
\hline U4at & NDE & NDE & NDE & NDE & 945.2 & NP & NP & NP & NP & NP & ND & ND & ND & ND \\
\hline UE4ac & 929.4 & NP & NP & NP & NP & NP & NP & NP & NP & NP & ND & ND & ND & ND \\
\hline WW8 & 126.5 & 199.6 & 900.4 & 1123.2 & ND & $\mathrm{NP}$ & ND & NP & 1689.5 & NP & ND & NP & NP & ND \\
\hline Effinger 1 & NDE & NDE & NDE & NDE & NDE & NDE & NDE & NDE & NDE & NDE & NDE & NDE & NDE & NDE \\
\hline ER-12-1 & $\mathrm{NP}$ & NP & NP & NP & NP & $\mathrm{NP}$ & $\mathrm{NP}$ & NP & NP & $\mathrm{NP}$ & ND & NP & NP & ND \\
\hline ER-12-2 & ND & ND & 1278.1 & 1297.0 & NP & NP & $\mathrm{NP}$ & NP & $\mathrm{NP}$ & NP & ND & NP & NP & ND \\
\hline ER-12-3 & 1588.6 & NP & NP & 1701.3 & 1904.3 & NP & NP & NP & 1922.0 & 1961.6 & ND & NP & NP & ND \\
\hline ER-12-4 & 1423.9 & NP & NP & 1613.3 & 1644.4 & NP & 1805.3 & 1851.1 & 1875.4 & NP & ND & NP & NP & ND \\
\hline UE12e\#1 & NDE & NDE & NDE & 1731.6 & 1941.0 & $\mathrm{NP}$ & NP & NP & 1945.5 & 2030.3 & ND & NP & NP & ND \\
\hline UE12e\#3 & NDE & NDE & NDE & 1724.9 & 2000.4 & $\mathrm{NP}$ & NP & NP & NP & NP & ND & NP & NP & ND \\
\hline UE12g.10\#1 & NDE & NDE & NDE & NDE & 1877.0 & $\mathrm{NP}$ & NP & NP & 1898.4 & 1960.9 & ND & 1982.2 & NP & ND \\
\hline UE12g.10\#2 & NDE & NDE & NDE & NDE & 1893.7 & NP & NP & NP & 1914.4 & 1986.4 & ND & 2001.6 & 2027.2 & ND \\
\hline UE12g.10\#3 & NDE & NDE & NDE & NDE & 1893.7 & NP & NP & NP & 1914.4 & 1986.4 & $\mathrm{ND}$ & 2001.6 & 2027.2 & ND \\
\hline UE12g.10\#4 & NDE & NDE & NDE & NDE & NDE & NDE & NDE & NDE & NDE & NDE & ND & NDE & NDE & NDE \\
\hline UE12g.10\#5 & NDE & NDE & NDE & NDE & 1890.5 & NP & NP & NP & 1911.2 & ND2 & ND & NP & NP & ND \\
\hline UE12g.10\#6 & NDE & NDE & NDE & NDE & 1892.2 & NDE & NDE & NDE & 1908.0 & 1971.1 & ND & 1993.1 & 2040.9 & ND \\
\hline UE12n\#1 & NDE & NDE & NDE & 1659.1 & 1853.9 & NP & NP & 1894.5 & 1908.5 & NP & ND & NP & NP & ND \\
\hline
\end{tabular}


Table A-3

Hydrostratigraphic Data for Selected Drill Holes in the Rainier Mesa-Shoshone Mountain CAU Model Area (meters, elevation)

\begin{tabular}{|c|c|c|c|c|c|c|c|c|c|c|c|c|}
\hline WELL_ID & CHVTA & LVTA & TSA & UTCU & PVTA & TCA & TMLVTA & TMWTA & TMUVTA & TMCM & FCCM & AA \\
\hline UE1a & $\overline{\mathrm{NDD}}$ & $\overline{\mathrm{NPP}}$ & $\overline{\mathrm{NP}}$ & 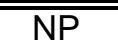 & $\overline{\mathrm{NP}}$ & $\overline{\mathrm{NP}}$ & 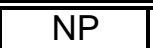 & $\overline{\mathrm{NP}}$ & 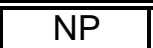 & 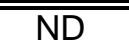 & $\overline{\mathrm{ND}}$ & $\overline{1311.6}$ \\
\hline UE1d & $\overline{N D}$ & $\mathrm{NP}$ & NP & NP & NP & $\overline{N P}$ & NP & $\mathrm{NP}$ & $\mathrm{NP}$ & ND & $\overline{N D}$ & 1309.4 \\
\hline UE1f & ND & NP & $\mathrm{NP}$ & $\mathrm{NP}$ & NP & $\mathrm{NP}$ & 1206.1 & NP & $\mathrm{NP}$ & ND & ND & 1303.6 \\
\hline UE1L & $\overline{N D}$ & NP & NP & NP & NP & $\overline{N P}$ & NP & NP & NP & ND & $\overline{N D}$ & 1358.5 \\
\hline UE2ad & ND & NP & NP & NP & NP & NP & 1213.0 & NP & $\mathrm{NP}$ & ND & ND & 1355.8 \\
\hline U2ca\#1 & ND & $\mathrm{NP}$ & $\mathrm{NP}$ & $\mathrm{NP}$ & $\mathrm{NP}$ & $\mathrm{NP}$ & 1325.7 & $\mathrm{NP}$ & $\mathrm{NP}$ & ND & ND & 1484.7 \\
\hline U2ce & ND & NP & $\mathrm{NP}$ & $\mathrm{NP}$ & NP & NP & 1335.1 & NP & $\mathrm{NP}$ & ND & ND & 1452.1 \\
\hline UE2ce & $\overline{N D}$ & NP & NP & NP & NP & NP & 1335.1 & NP & $\mathrm{NP}$ & ND & $\overline{N D}$ & 1452.1 \\
\hline U2cms & NDE & $\overline{N D E}$ & $\mathrm{NDE}$ & $\mathrm{NDE}$ & $\overline{N D E}$ & NDE & 1140.9 & NP & NP & ND & ND & 1396.9 \\
\hline U2cn & ND & NP & NP & NP & NP & NP & 1082.0 & 1151.7 & NP & ND & ND & 1398.7 \\
\hline UE2co & ND & NP & NP & NP & NP & NP & 1178.5 & NP & NP & ND & ND & 1390.5 \\
\hline U2co & NDE & NDE & NDE & NDE & NDE & NDE & 1146.7 & 1190.5 & 1197.5 & ND & ND & 1390.5 \\
\hline U2cp & NDE & NDE & NDE & NDE & NDE & NDE & 1108.3 & 1165.6 & 1178.6 & ND & ND & 1374.6 \\
\hline U2cq & NDE & NDE & $\mathrm{NDE}$ & NDE & $\overline{N D E}$ & NDE & 1130.8 & 1199.3 & 1212.3 & ND & $\overline{N D}$ & 1371.3 \\
\hline U2cr & ND & NP & $\mathrm{NP}$ & NP & NP & $\mathrm{NP}$ & 1308.3 & NP & $\mathrm{NP}$ & ND & ND & 1403.3 \\
\hline U2cs & NDE & $\overline{N D E}$ & NDE & NDE & $\overline{N D E}$ & NDE & 1181.5 & NP & NP & ND & ND & 1379.5 \\
\hline U2ct & NDE & NDE & NDE & NDE & NDE & NDE & 1102.5 & NP & NP & ND & ND & 1374.3 \\
\hline U2cu & NDE & NDE & NDE & NDE & NDE & NDE & 1185.0 & NP & NP & ND & ND & 1379.5 \\
\hline UE2s & NDE & NDE & NDE & NDE & NDE & NDE & 1140.9 & $\mathrm{NP}$ & $\mathrm{NP}$ & ND & ND & 1396.9 \\
\hline U4as & NDE & $\overline{N D E}$ & NDE & NDE & $\overline{N D E}$ & NDE & 1162.8 & 1230.9 & 1245.9 & $\overline{N D}$ & $\overline{N D}$ & 1367.9 \\
\hline U4at & ND & NP & NP & NP & $\mathrm{NP}$ & NP & 1161.3 & 1241.2 & 1260.2 & ND & ND & 1364.3 \\
\hline UE4ac & ND & NP & NP & NP & NP & NP & 1202.8 & NP & NP & ND & ND & 1362.8 \\
\hline WW8 & ND & NP & NP & NP & NP & NP & ND & 1735.8 & ND & ND & ND & NP \\
\hline Effinger 1 & NDE & NDE & $\mathrm{NDE}$ & NDE & NDE & NDE & NDE & NDE & NDE & ND & ND & 1570.3 \\
\hline ER-12-1 & ND & NP & NP & NP & NP & $\overline{N P}$ & NP & NP & NP & ND & $\overline{N D}$ & 1773.3 \\
\hline ER-12-2 & ND & $\mathrm{NP}$ & NP & NP & $\mathrm{NP}$ & NP & $\mathrm{NP}$ & NP & NP & ND & ND & 1434.2 \\
\hline ER-12-3 & ND & NP & NP & NP & NP & NP & 2164.9 & 2252.7 & ND & ND & ND & NP \\
\hline ER-12-4 & ND & NP & $\mathrm{NP}$ & NP & NP & NP & 2007.7 & 2097.9 & ND & ND & ND & 2098.2 \\
\hline UE12e\#1 & ND & NP & NP & NP & NP & NP & 2160.1 & 2265.0 & ND & ND & ND & NP \\
\hline UE12e\#3 & ND & NP & NP & NP & NP & NP & 2182.4 & 2273.8 & ND & ND & ND & NP \\
\hline UE12g.10\#1 & ND & NP & NP & NP & NP & NP & 2177.3 & 2294.6 & ND & ND & ND & NP \\
\hline UE12g.10\#2 & ND & NP & NP & NP & NP & NP & 2202.8 & 2309.4 & ND & ND & ND & NP \\
\hline UE12g.10\#3 & ND & NP & NP & NP & NP & NP & 2205.4 & 2295.0 & ND & ND & ND & NP \\
\hline UE12g.10\#4 & NDE & NDE & NDE & NDE & NDE & $\mathrm{NDE}$ & 2200.8 & 2307.5 & ND & ND & ND & NP \\
\hline UE12g.10\#5 & ND & NP & NP & NP & NP & NP & NP & NP & ND & ND & ND & $\mathrm{NP}$ \\
\hline UE12g.10\#6 & ND & NP & NP & NP & NP & NP & 2186.9 & 2302.7 & ND & ND & ND & NP \\
\hline UE12n\#1 & ND & NP & NP & NP & NP & NP & 2170.6 & 2231.6 & ND & ND & ND & NP \\
\hline
\end{tabular}


Table A-3

Hydrostratigraphic Data for Selected Drill Holes in the Rainier Mesa-Shoshone Mountain CAU Model Area (meters, elevation)

\begin{tabular}{|c|c|c|c|c|c|c|c|c|c|c|c|c|c|}
\hline WELL_ID & NORTHING & EASTING $^{1}$ & $\mathrm{GND} \mathrm{EL}^{2}, \mathrm{ft}$ & GND EL ${ }^{2}, \mathrm{~m}$ & 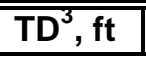 & $\bar{T} \mathrm{TD} \mathrm{EL}^{4}, \mathrm{ft}$ & 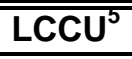 & LCA & UCCU & LCCU1 & LCA3 & MGCU & 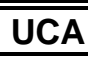 \\
\hline UE12n\#2 & $895,938.0$ & $633,839.0$ & 7,344.0 & 2,238.5 & 1,799.0 & 5,545.0 & NDE & NDE & NDE & 1698.3 & $\mathrm{NP}$ & NDE & NP \\
\hline UE12n\#4 & $892,035.0$ & $635,753.0$ & $6,894.0$ & \begin{tabular}{|l|}
$2,101.3$ \\
\end{tabular} & 830.0 & $6,064.0$ & NDE & NDE & NDE & NDE & NDE & NDE & NDE \\
\hline UE12n\#8 & $895,550.0$ & $632,920.0$ & $7,395.0$ & $2,254.0$ & $1,784.0$ & $5,611.0$ & NDE & NDE & NDE & 1763.6 & NP & $\mathrm{JDE}$ & NP \\
\hline UE12n\#9 & $895,600.0$ & $632,309.0$ & 7,383.0 & $2,250.3$ & $1,550.0$ & 5,833.0 & NDE & NDE & NDE & 1806.9 & $\mathrm{NP}$ & NDE & NP \\
\hline UE12n\#10 & $896,655.0$ & $634,354.0$ & 7,384.0 & $2,250.6$ & $1,877.0$ & 5,507.0 & NP & $\mathrm{NP}$ & $\mathrm{NP}$ & 1698.0 & $\mathrm{NP}$ & 1706.6 & NP \\
\hline UE12n\#11 & $896,074.0$ & $634,582.0$ & 7,309.0 & $2,227.8$ & $1,882.0$ & 5,427.0 & NDE & NDE & NDE & NDE & NDE & NDE & NDE \\
\hline UE12n\#13 & $893,283.4$ & $630,750.5$ & $7,354.6$ & $2,241.7$ & $1,086.0$ & 6,268.6 & NDE & NDE & NDE & NDE & NDE & $\mathrm{DE}$ & NDE \\
\hline UE12n\#14 & $891,661.8$ & $633,255.7$ & $7,415.5$ & $2,260.2$ & $1,737.6$ & 5,677.9 & NDE & NDE & NDE & NDE & NDE & NDE & NDE \\
\hline UE12n\#15 & $894,759.1$ & $631,677.0$ & $7,370.7$ & 2,246.6 & 585.0 & 6,785.7 & NDE & NDE & NDE & NDE & NDE & NDE & NDE \\
\hline UE12n\#15A & $894,749.9$ & $631,678.7$ & $7,369.2$ & $2,246.1$ & $1,933.8$ & $5,435.4$ & $\mathrm{NP}$ & NP & $\mathrm{NP}$ & $\mathrm{NP}$ & $\mathrm{NP}$ & 1674.6 & NP \\
\hline UE12n\#16 & $895,989.5$ & $630,522.1$ & 7,527.4 & $2,294.4$ & $2,237.4$ & $5,290.0$ & NDE & NDE & NDE & NDE & NDE & NDE & NDE \\
\hline UE12p & 1.0 & $646,971.0$ & 6,338.0 & 1,931.8 & $1,848.0$ & 4,490.0 & NDE & NDE & NDE & NDE & 1378.0 & NDE & NP \\
\hline UE12p\#1 & $906,432.0$ & $644,827.0$ & $6,477.0$ & \begin{tabular}{|l|}
$1,974.2$ \\
\end{tabular} & $2,165.0$ & 4,312.0 & $\mathrm{NP}$ & NP & $\mathrm{NP}$ & $\mathrm{NP}$ & $\mathrm{NP}$ & 1371.6 & NP \\
\hline UE12p\#6 & $906,066.8$ & $647,775.8$ & 6,344.9 & $1,933.9$ & $2,282.9$ & $4,062.0$ & NDE & NDE & NDE & NDE & NDE & NDE & NDE \\
\hline U12q & 06.9 & $627,321.5$ & $7,413.5$ & $2,259.6$ & $2,144.0$ & $5,269.5$ & NDE & NDE & NDE & NDE & NDE & NDE & NDE \\
\hline $\mathrm{U} 12 \mathrm{r}$ & $895,401.0$ & $628,499.3$ & $7,514.0$ & $2,290.3$ & $2,520.0$ & $4,994.0$ & NP & $\mathrm{NP}$ & $\mathrm{NP}$ & NP & NP & 1671.5 & NP \\
\hline U12s & $902,407.0$ & $631,260.0$ & $6,794.0$ & $2,070.8$ & $1,596.0$ & $5,198.0$ & NP & $\mathrm{NP}$ & NP & $\mathrm{NP}$ & $\mathrm{NP}$ & 2070.8 & NP \\
\hline U12b\#2 UCRL- & $889,947.0$ & $636,110.0$ & $6,795.0$ & $2,071.1$ & $1,043.0$ & $5,752.0$ & NDE & NDE & NDE & NDE & NDE & NDE & NDE \\
\hline U12b\#3 UCRL- & $890,617.0$ & $634,913.0$ & $7,495.0$ & $2,284.5$ & $1,074.0$ & $6,421.0$ & NDE & NDE & NDE & $\mathrm{NDE}$ & NDE & NDE & NDE \\
\hline U12b.07-1 & $891,222.0$ & $634,404.0$ & $7,480.0$ & $2,279.9$ & 950.0 & $6,530.0$ & NDE & NDE & NDE & NDE & NDE & NDE & NDE \\
\hline U12b.07-2 & $892,714.8$ & $634,195.4$ & $7,378.3$ & $2,248.9$ & $2,720.0$ & $4,658.3$ & NDE & NDE & NDE & NDE & 1511.3 & NDE & NP \\
\hline $\mathrm{U} 12 \mathrm{e} \mathrm{CH} \# 3$ & $886,073.0$ & $633,888.0$ & $7,573.0$ & $2,308.3$ & $1,425.0$ & 6,148.0 & NDE & NDE & NDE & NDE & NDE & NDE & NDE \\
\hline U12e.04\#32 & $884,688.5$ & $634,015.7$ & $7,559.7$ & $2,304.2$ & $1,400.0$ & $6,159.7$ & NDE & NDE & NDE & NDE & NDE & NDE & NDE \\
\hline U12e.06-1 & $885,037.6$ & $631,775.9$ & $7,573.1$ & $2,308.3$ & $3,114.0$ & $4,459.1$ & NDE & NDE & NDE & NDE & 1572.2 & $\mathrm{NDE}$ & NP \\
\hline U12e.06 A & $885,979.0$ & $633,873.0$ & $6,164.0$ & $1,878.8$ & $1,000.0$ & $5,164.0$ & NDE & NDE & NDE & $\mathrm{NDE}$ & 1582.5 & $\mathrm{NDE}$ & NP \\
\hline U12e.06 B & $885,249.0$ & $632,341.0$ & 6,171.0 & $1,880.9$ & 975.0 & 5,196.0 & NDE & NDE & NDE & NDE & 1588.6 & NDE & NP \\
\hline
\end{tabular}


Table A-3

Hydrostratigraphic Data for Selected Drill Holes in the Rainier Mesa-Shoshone Mountain CAU Model Area (meters, elevation)

\begin{tabular}{|c|c|c|c|c|c|c|c|c|c|c|c|c|c|c|}
\hline WELL_ID & ATCU & LTCU1 & RVA & OSBCU & LTCU & TUBA & BRCU & LVTA1 & BRA & UTCU1 & BFCU & SWA & UTCU2 & $\mathrm{KA}$ \\
\hline UE12n\#2 & 1738.9 & $\overline{\mathrm{NP}}$ & $\overline{\mathrm{NP}}$ & 1816.3 & 1991.6 & $\overline{\mathrm{NP}}$ & $\overline{\mathrm{NP}}$ & $\overline{\mathrm{NP}}$ & $\overline{\mathrm{NP}}$ & $\overline{\mathrm{NP}}$ & $\overline{\mathrm{ND}}$ & $\overline{\mathrm{NP}}$ & $\overline{\mathrm{NP}}$ & $\overline{\mathrm{ND}}$ \\
\hline UE12n\#3 & 1854.4 & NP & NP & 1907.7 & 2028.1 & $\mathrm{NP}$ & NP & NP & NP & $\mathrm{NP}$ & ND & NP & NP & ND \\
\hline UE12n\#4 & NDE & NDE & NDE & 1861.4 & 2040.3 & NP & NP & NP & NP & NP & ND & NP & NP & ND \\
\hline UE12n\#6 & NDE & NDE & NDE & 1671.8 & 1860.2 & NP & NP & NP & 1888.2 & 1986.1 & ND & NP & NP & ND \\
\hline UE12n\#8 & 1765.1 & NP & NP & 1838.6 & 1994.9 & $\mathrm{NP}$ & NP & NP & $\mathrm{NP}$ & NP & ND & $\mathrm{NP}$ & NP & ND \\
\hline UE12n\#9 & 1813.3 & NP & NP & 1863.5 & 1991.3 & NP & NP & NP & NP & NP & $\overline{N D}$ & NP & NP & ND \\
\hline UE12n\#10 & 1732.8 & NP & NP & 1791.3 & 1990.3 & NP & NP & NP & NP & NP & ND & NP & NP & ND \\
\hline UE12n\#11 & 1709.0 & NP & NP & 1784.9 & 1939.4 & NP & $\mathrm{NP}$ & NP & NP & $\mathrm{NP}$ & ND & NP & NP & ND \\
\hline UE12n\#12 & 1744.2 & NP & NP & 1843.4 & 2015.8 & $\mathrm{NP}$ & $\mathrm{NP}$ & NP & $\mathrm{NP}$ & $\mathrm{NP}$ & ND & $\mathrm{NP}$ & NP & ND \\
\hline UE12n\#13 & NDE & NDE & NDE & NDE & NDE & NDE & NDE & NDE & NDE & NDE & NDE & NDE & NDE & $\mathrm{NDE}$ \\
\hline UE12n\#14 & NDE & NDE & $\overline{N D E}$ & 1747.9 & 1929.2 & $\mathrm{NP}$ & NP & $\mathrm{NP}$ & $\mathrm{NP}$ & $\mathrm{NP}$ & ND & NP & NP & ND \\
\hline UE12n\#15 & NDE & NDE & NDE & NDE & NDE & NDE & NDE & NDE & NDE & NDE & NDE & NDE & NDE & $\mathrm{NDE}$ \\
\hline UE12n\#15A & 1684.1 & NP & NP & 1736.2 & 1929.7 & $\mathrm{NP}$ & NP & $\mathrm{NP}$ & $\mathrm{NP}$ & NP & ND & $\mathrm{NP}$ & NP & ND \\
\hline UE12n\#16 & NDE & NDE & NDE & 1762.5 & 1972.2 & $\mathrm{NP}$ & NP & NP & $\mathrm{NP}$ & NP & ND & NP & NP & ND \\
\hline UE12p & NP & NP & NP & NP & NP & 1394.2 & 1541.7 & NP & 1550.8 & 1704.1 & ND & NP & NP & ND \\
\hline UE12p\#1 & NP & NP & NP & 1416.4 & 1532.5 & NP & NP & NP & 1603.9 & 1710.8 & $\mathrm{ND}$ & NP & NP & ND \\
\hline UE12p\#2 & NDE & NDE & NDE & 1272.2 & 1445.5 & NP & NP & NP & 1506.0 & $\mathrm{NP}$ & ND & NP & NP & ND \\
\hline UE12p\#3 & NDE & NDE & $\overline{N D E}$ & 1157.3 & NP & 1181.4 & 1396.6 & NP & 1471.3 & 1646.8 & ND & NP & NP & ND \\
\hline UE12p\#4 & NP & NP & NP & 1425.6 & 1529.5 & NP & NP & NP & 1571.6 & 1702.0 & ND & NP & NP & ND \\
\hline UE12p\#5 & 1594.9 & NP & NP & 1604.9 & 1705.8 & NP & NP & NP & NP & NP & ND & NP & NP & ND \\
\hline UE12p\#6 & NDE & NDE & NDE & 1256.4 & NP & 1322.8 & 1484.3 & NP & 1514.8 & 1690.1 & ND & NP & NP & ND \\
\hline U12q & NDE & NDE & NDE & 1631.7 & 1896.9 & NP & NP & NP & NP & NP & ND & NP & NP & ND \\
\hline U12r & 1686.8 & NP & NP & 1697.4 & 1854.4 & NP & NP & 1918.4 & 1924.5 & NP & ND & NP & NP & ND \\
\hline U12s & NP & NP & NP & NP & NP & NP & $\mathrm{NP}$ & NP & NP & NP & ND & NP & NP & NP \\
\hline U12b\#2 UCRL- & NDE & NDE & NDE & 1853.2 & 2071.1 & ND2 & ND2 & ND2 & ND2 & ND2 & ND2 & ND2 & ND2 & ND2 \\
\hline U12b\#3 UCRL- & NDE & NDE & NDE & NDE & 1961.1 & NP & NP & NP & 1982.7 & 2023.6 & ND & NP & NP & ND \\
\hline U12b.07-1 & NDE & NDE & NDE & NDE & 2030.0 & NP & NP & NP & NP & NP & ND & NP & NP & ND \\
\hline U12b.07-2 & NP & NP & 1543.9 & 1726.2 & 1933.4 & NP & NP & NP & NP & NP & ND & NP & NP & ND \\
\hline U12e $\mathrm{CH}$ 3 & NDE & NDE & NDE & NDE & 2070.5 & NP & NP & NP & $\mathrm{NP}$ & NP & ND & NP & NP & ND \\
\hline U12e.04\#32 & NDE & NDE & NDE & NDE & 2040.5 & $\mathrm{NP}$ & NP & NP & NP & NP & ND & NP & NP & ND \\
\hline U12e.06-1 & 1582.9 & NP & NP & NP & 1944.3 & NP & NP & NP & NP & NP & ND & NP & NP & ND \\
\hline U12e.06 A & 1591.7 & NP & NP & 1775.8 & 1878.8 & NP & NP & NP & $\mathrm{NP}$ & NP & ND & NP & NP & ND \\
\hline U12e.06 B & 1592.9 & NP & NP & 1762.0 & 1880.9 & NP & NP & NP & NP & NP & ND & NP & NP & ND \\
\hline $\mathrm{U12n \# 1 \textrm {CH }}$ & NDE & NDE & NDE & NDE & 1907.7 & NP & NP & NP & $\mathrm{NP}$ & NP & ND & NP & NP & ND \\
\hline U12n.02 \#1 & NDE & NDE & NDE & NDE & 1918.1 & $\mathrm{NP}$ & NP & NP & $\mathrm{NP}$ & NP & ND & NP & NP & ND \\
\hline U12n.10 UG\#2 & 1755.0 & NP & NP & 1826.1 & ND2 & ND2 & ND2 & ND2 & ND2 & ND2 & ND2 & ND2 & ND2 & ND2 \\
\hline U12n.10 UG\#3 & 1760.5 & NP & NP & 1826.1 & ND2 & ND2 & ND2 & ND2 & ND2 & ND2 & ND2 & ND2 & ND2 & ND2 \\
\hline
\end{tabular}


Table A-3

Hydrostratigraphic Data for Selected Drill Holes in the Rainier Mesa-Shoshone Mountain CAU Model Area (meters, elevation)

\begin{tabular}{|c|c|c|c|c|c|c|c|c|c|c|c|c|}
\hline WELL_ID & CHVTA & LVTA & TSA & UTCU & PVTA & TCA & TMLVTA & \begin{tabular}{|l|} 
TMWTA \\
\end{tabular} & TMUVTA & TMCM & FCCM & $\overline{A A}$ \\
\hline UE12n\#2 & $\overline{N D}$ & NP & $\overline{\mathrm{NP}}$ & $\mathrm{NP}$ & $\overline{\mathrm{NP}}$ & $\mathrm{NP}$ & 2223.2 & 2238.5 & $\overline{N D}$ & $\overline{N D}$ & ND & NP \\
\hline UE12n\#3 & ND & NP & NP & NP & NP & NP & 2264.4 & 2279.6 & ND & ND & ND & NP \\
\hline UE12n\#4 & ND & NP & NP & NP & NP & NP & 2101.3 & NP & ND & ND & ND & NP \\
\hline UE12n\#6 & ND & NP & $\mathrm{NP}$ & 1986.1 & NP & $\mathrm{NP}$ & 2181.5 & 2261.6 & ND & ND & ND & NP \\
\hline UE12n\#8 & ND & NP & NP & NP & NP & NP & 2238.8 & 2254.0 & ND & ND & ND & NP \\
\hline UE12n\#9 & ND & NP & NP & $\mathrm{NP}$ & NP & $\mathrm{NP}$ & 2230.5 & 2250.3 & ND & ND & ND & $\mathrm{NP}$ \\
\hline UE12n\#10 & ND & NP & NP & $\mathrm{NP}$ & NP & $\mathrm{NP}$ & 2224.7 & 2250.6 & ND & ND & ND & NP \\
\hline UE12n\#11 & ND & NP & NP & NP & NP & NP & 2209.5 & 2227.8 & ND & ND & ND & NP \\
\hline UE12n\#12 & ND & NP & NP & NP & $\mathrm{NP}$ & $\mathrm{NP}$ & 2232.2 & 2259.6 & ND & $\mathrm{ND}$ & ND & $\mathrm{NP}$ \\
\hline UE12n\#13 & NDE & NDE & NDE & NDE & NDE & NDE & 2176.2 & 2241.7 & ND & ND & ND & NP \\
\hline UE12n\#14 & ND & NP & NP & NP & NP & NP & 2184.0 & 2260.2 & ND & ND & ND & NP \\
\hline UE12n\#15 & NDE & NDE & NDE & NDE & $\overline{N D E}$ & NDE & 2216.1 & 2246.6 & $\overline{N D}$ & ND & $\overline{N D}$ & NP \\
\hline UE12n\#15A & ND & NP & NP & NP & NP & $\mathrm{NP}$ & 2216.1 & 2246.6 & ND & ND & ND & NP \\
\hline UE12n\#16 & ND & NP & NP & NP & NP & NP & 2260.8 & 2294.4 & ND & ND & ND & NP \\
\hline UE12p & ND & NP & NP & NP & NP & NP & 1809.9 & 1931.8 & ND & ND & ND & NP \\
\hline UE12p\#1 & ND & NP & NP & NP & NP & NP & 1890.4 & 1974.2 & ND & ND & ND & NP \\
\hline UE12p\#2 & ND & NP & NP & $\mathrm{NP}$ & NP & NP & 1827.9 & 1934.6 & ND & ND & ND & NP \\
\hline UE12p\#3 & ND & NP & NP & NP & NP & $\mathrm{NP}$ & 1791.3 & 1930.0 & ND & ND & ND & NP \\
\hline UE12p\#4 & ND & NP & NP & NP & NP & $\mathrm{NP}$ & 1829.1 & 1949.5 & ND & ND & ND & NP \\
\hline UE12p\#5 & ND & NP & NP & NP & NP & NP & 1913.4 & 1989.6 & ND & ND & ND & NP \\
\hline UE12p\#6 & ND & NP & NP & NP & NP & NP & 1796.8 & 1933.9 & ND & ND & ND & NP \\
\hline U12q & ND & NP & NP & NP & NP & NP & 2204.8 & 2259.6 & ND & ND & ND & NP \\
\hline $\mathrm{U} 12 \mathrm{r}$ & ND & NP & NP & NP & NP & NP & 2253.7 & 2290.3 & ND & ND & ND & NP \\
\hline U12s & NP & $\mathrm{NP}$ & NP & NP & $\mathrm{NP}$ & $\mathrm{NP}$ & $\mathrm{NP}$ & $\mathrm{NP}$ & NP & ND & ND & NP \\
\hline U12b\#2 UCRL-1 & ND2 & ND2 & ND2 & ND2 & ND2 & ND2 & ND2 & ND2 & ND2 & ND & ND & ND2 \\
\hline U12b\#3 UCRL-1 & ND & NP & NP & NP & NP & NP & 2207.4 & 2284.5 & NP & ND & ND & NP \\
\hline U12b.07-1 & ND & NP & NP & NP & NP & NP & 2215.9 & 2279.9 & NP & ND & ND & NP \\
\hline U12b.07-2 & ND & NP & NP & NP & NP & NP & 2172.7 & 2248.9 & NP & ND & ND & NP \\
\hline $\mathrm{U} 12 \mathrm{e} \mathrm{CH}$ 3 & ND & NP & NP & NP & NP & NP & 2204.6 & 2308.3 & NP & $\mathrm{ND}$ & ND & $\mathrm{NP}$ \\
\hline U12e.04\#32 & ND & NP & NP & NP & NP & NP & 2121.3 & NP & NP & ND & ND & NP \\
\hline U12e.06-1 & ND & NP & NP & NP & NP & $\mathrm{NP}$ & 2012.6 & NP & $\mathrm{NP}$ & ND & ND & NP \\
\hline U12e.06 A & ND & NP & NP & NP & NP & NP & NP & NP & NP & ND & ND & NP \\
\hline U12e.06 B & ND & NP & NP & NP & NP & NP & NP & NP & NP & ND & ND & NP \\
\hline $\mathrm{U} 12 \mathrm{n} \# 1 \mathrm{CH}$ & ND & NP & NP & NP & NP & NP & 2160.7 & 2221.7 & NP & ND & ND & NP \\
\hline U12n.02 \#1 & ND & NP & NP & NP & NP & NP & 2122.3 & 2195.5 & NP & ND & ND & NP \\
\hline U12n.10 UG\#2 & ND2 & ND2 & ND2 & ND2 & ND2 & ND2 & ND2 & ND2 & ND2 & ND & ND & ND2 \\
\hline U12n.10 UG\#3 & ND2 & ND2 & ND2 & ND2 & ND2 & ND2 & ND2 & ND2 & ND2 & ND & ND & ND2 \\
\hline
\end{tabular}

6 of 10 
Table A-3

Hydrostratigraphic Data for Selected Drill Holes in the Rainier Mesa-Shoshone Mountain CAU Model Area (meters, elevation)

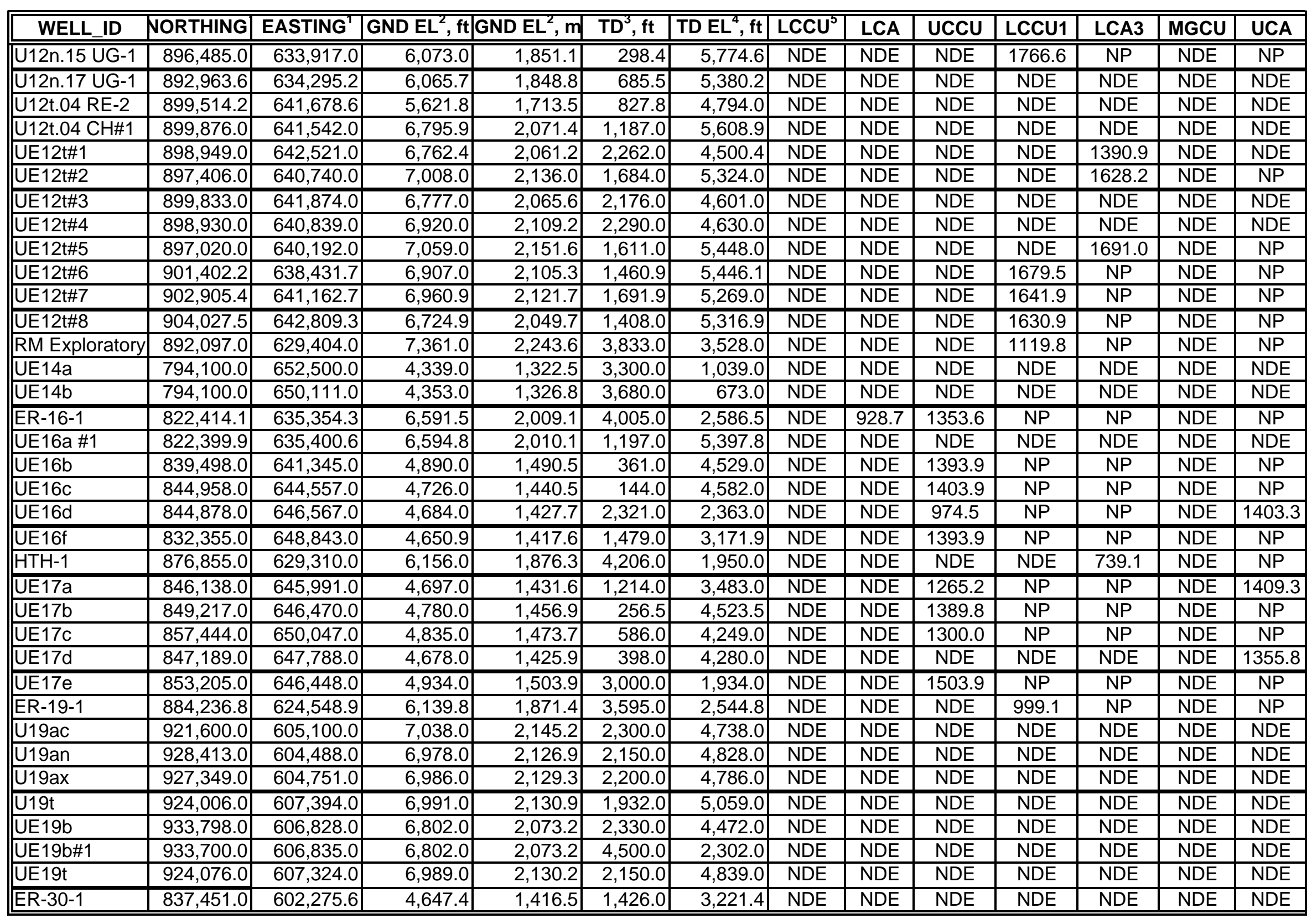


Table A-3

Hydrostratigraphic Data for Selected Drill Holes in the Rainier Mesa-Shoshone Mountain CAU Model Area (meters, elevation)

\begin{tabular}{|c|c|c|c|c|c|c|c|c|c|c|c|c|c|c|}
\hline WELL_ID & ATCU & LTCU1 & RVA & OSBCU & LTCU & TUBA & BRCU & LVTA1 & BRA & UTCU1 & BFCU & SWA & UTCU2 & $\mathrm{KA}$ \\
\hline U12n.15 UG-1 & 1772.7 & NP & NP & 1843.7 & 1851.1 & ND2 & ND2 & ND2 & ND2 & ND2 & ND2 & ND2 & ND2 & ND2 \\
\hline U12n.17 UG-1 & NDE & NDE & NDE & 1724.8 & 1848.8 & ND2 & ND2 & ND2 & ND2 & ND2 & ND2 & ND2 & ND2 & ND2 \\
\hline U12t.04 RE-2 & NDE & NDE & NDE & 1605.6 & NP & 1619.7 & ND2 & ND2 & ND2 & ND2 & ND2 & ND2 & ND2 & ND \\
\hline U12t.04 CH\#1 & NDE & NDE & NDE & NDE & NDE & NDE & 1806.2 & 1852.5 & 1864.1 & NP & ND & NP & NP & ND \\
\hline UE12t\#1 & 1393.7 & NDE & $\mathrm{NDE}$ & 1606.1 & NP & 1617.1 & 1859.3 & 1902.3 & 1908.0 & NP & $\mathrm{ND}$ & NP & NP & ND \\
\hline UE12t\#2 & 1628.5 & NP & NP & 1736.1 & 1938.2 & NP & NP & NP & NP & NP & ND & NP & NP & ND \\
\hline UE12t\#3 & 1430.7 & NP & NP & 1611.5 & NP & 1621.5 & 1785.8 & 1828.5 & 1836.4 & NP & ND & NP & NP & ND \\
\hline UE12t\#4 & 1417.6 & NP & NP & 1619.4 & NP & 1643.8 & 1815.1 & 1857.8 & 1871.5 & NP & ND & NP & NP & ND \\
\hline UE12t\#5 & 1694.4 & NP & NP & 1759.9 & 1985.5 & NP & NP & NP & NP & NP & ND & NP & NP & ND \\
\hline UE12t\#6 & NP & NP & NP & 1836.1 & 1904.1 & ND1 & ND1 & ND1 & ND1 & ND1 & $\mathrm{ND}$ & ND1 & ND1 & ND1 \\
\hline UE12t\#7 & 1665.4 & NP & NP & 1792.5 & 1909.2 & NP & NP & NP & NP & NP & ND & NP & NP & ND \\
\hline UE12t\#8 & 1633.7 & NP & NP & NP & 1801.6 & NP & NP & NP & NP & NP & ND & NP & NP & ND \\
\hline RM Exploratory & 1135.1 & NP & NP & NP & 1918.1 & ND1 & ND1 & ND1 & ND1 & ND1 & ND1 & ND1 & ND1 & ND1 \\
\hline UE14a & NDE & NDE & NDE & NDE & NDE & NDE & NDE & NDE & NDE & NDE & ND & NDE & NDE & $\mathrm{NDE}$ \\
\hline UE14b & NDE & NDE & NDE & NDE & NDE & NDE & NDE & NDE & NDE & NDE & NDE & NDE & NDE & NDE \\
\hline ER-16-1 & 1406.5 & NP & 1430.0 & 1520.8 & 1772.6 & NP & NP & NP & NP & NP & ND & NP & NP & ND \\
\hline UE16a \#1 & $\mathrm{NDE}$ & NDE & NDE & NDE & 1762.9 & NP & NP & NP & NP & NP & ND & NP & NP & ND \\
\hline UE16b & NP & NP & NP & NP & NP & NP & NP & NP & NP & NP & ND & NP & NP & ND \\
\hline UE16c & NP & NP & NP & NP & NP & NP & NP & NP & NP & NP & ND & NP & NP & ND \\
\hline UE16d & NP & NP & NP & NP & NP & NP & NP & NP & NP & NP & ND & NP & NP & ND \\
\hline UE16f & NP & NP & NP & NP & NP & NP & NP & NP & NP & NP & ND & NP & NP & ND \\
\hline $\mathrm{HTH}-1$ & 799.2 & 1084.2 & 1330.8 & 1427.7 & 1807.8 & 1474.3 & NP & NP & 1855.0 & NP & NP & NP & NP & NP \\
\hline UE17a & $\mathrm{NP}$ & NP & NP & NP & NP & NP & NP & NP & $\mathrm{NP}$ & NP & ND & NP & NP & ND \\
\hline UE17b & NP & NP & NP & NP & NP & NP & NP & NP & NP & NP & ND & NP & NP & ND \\
\hline UE17c & $\mathrm{NP}$ & NP & NP & $\mathrm{NP}$ & NP & $\mathrm{NP}$ & NP & NP & $\mathrm{NP}$ & $\mathrm{NP}$ & ND & $\mathrm{NP}$ & NP & ND \\
\hline UE17d & NP & NP & NP & NP & NP & NP & NP & NP & NP & NP & ND & NP & NP & ND \\
\hline UE17e & NP & NP & NP & NP & NP & NP & NP & NP & NP & NP & ND & NP & NP & ND \\
\hline ER-19-1 & 1045.5 & ND & 1318.9 & 1570.9 & 1761.7 & ND & ND & ND & 1871.5 & NP & NP & NP & NP & NP \\
\hline U19ac & NDE & NDE & NDE & NDE & NDE & NDE & NDE & NDE & NDE & NDE & NDE & NDE & NDE & 1612.7 \\
\hline U19an & NDE & NDE & NDE & NDE & NDE & NDE & NDE & NDE & NDE & NDE & 1486.8 & ND & ND & 1676.4 \\
\hline U19ax & NDE & NDE & NDE & NDE & NDE & NDE & NDE & NDE & NDE & NDE & 1483.8 & ND & ND & 1667.3 \\
\hline U19t & NDE & NDE & NDE & NDE & NDE & NDE & NDE & NDE & NDE & NDE & NDE & NDE & NDE & 1664.5 \\
\hline UE19b & NDE & NDE & NDE & NDE & NDE & NDE & NDE & NDE & 1582.5 & NP & NP & ND & ND & 1628.2 \\
\hline UE19b\#1 & NDE & NDE & NDE & NDE & NDE & NDE & NDE & NDE & 1582.5 & ND1 & ND1 & ND1 & ND1 & ND1 \\
\hline UE19t & NDE & NDE & $\overline{N D E}$ & NDE & $\overline{N D E}$ & NDE & NDE & NDE & NDE & NDE & $\overline{N D E}$ & $\mathrm{NDE}$ & NDE & 1668.5 \\
\hline ER-30-1 & NDE & NDE & NDE & NDE & NDE & NDE & NDE & NDE & NDE & NDE & NDE & $\mathrm{NDE}$ & NDE & NDE \\
\hline
\end{tabular}


Table A-3

Hydrostratigraphic Data for Selected Drill Holes in the Rainier Mesa-Shoshone Mountain CAU Model Area (meters, elevation)

\begin{tabular}{|c|c|c|c|c|c|c|c|c|c|c|c|c|}
\hline WELL_ID & CHVTA & LVTA & TSA & UTCU & PVTA & TCA & TMLVTA & TMWTA & TMUVTA & TMCM & FCCM & $\mathrm{AA}$ \\
\hline U12n.15 UG-1 & ND2 & ND2 & ND2 & ND2 & ND2 & ND2 & ND2 & ND2 & ND2 & ND & ND & ND2 \\
\hline U12n.17 UG-1 & ND2 & ND2 & ND2 & ND2 & ND2 & ND2 & ND2 & ND2 & ND2 & ND & ND & ND2 \\
\hline U12t.04 RE-2 & ND & ND2 & ND2 & ND2 & ND2 & ND2 & ND2 & ND2 & ND & ND & ND & NP \\
\hline U12t.04 CH\#1 & ND & NP & NP & NP & NP & $\mathrm{NP}$ & 1980.0 & 2071.4 & ND & ND & ND & $\mathrm{NP}$ \\
\hline UE12t\#1 & ND & NP & NP & NP & NP & NP & 1966.7 & 2161.2 & ND & ND & ND & NP \\
\hline UE12t\#2 & ND & NP & NP & NP & NP & NP & 2075.7 & 2136.0 & ND & ND & ND & NP \\
\hline UE12t\#3 & ND & NP & NP & NP & NP & NP & 1968.1 & 2065.6 & ND & ND & ND & NP \\
\hline UE12t\#4 & ND & NP & NP & NP & NP & NP & 2022.7 & 2109.2 & ND & ND & ND & NP \\
\hline UE12t\#5 & ND & NP & NP & NP & NP & NP & 2105.9 & 2151.6 & ND & ND & ND & NP \\
\hline UE12t\#6 & ND1 & ND1 & ND1 & ND1 & ND1 & ND1 & ND1 & ND1 & $\mathrm{ND}$ & ND & ND & ND1 \\
\hline UE12t\#7 & ND & NP & NP & NP & NP & NP & 2076.0 & 2121.7 & ND & ND & ND & NP \\
\hline UE12t\#8 & ND & NP & NP & NP & NP & NP & 2004.0 & 2049.7 & ND & ND & ND & $\mathrm{NP}$ \\
\hline RM Exploratory & ND1 & ND1 & ND1 & ND1 & ND1 & ND1 & ND1 & ND1 & ND & ND & ND & ND1 \\
\hline UE14a & NDE & $\mathrm{NDE}$ & 581.6 & 747.7 & NP & 681.5 & NP & 969.6 & 998.5 & ND & ND & 1322.5 \\
\hline UE14b & NDE & NDE & 527.8 & 674.8 & NP & 611.8 & NP & 893.7 & 918.8 & ND & ND & 1326.8 \\
\hline ER-16-1 & ND & 1906.7 & 1961.5 & NP & 1993.8 & 2009.1 & NP & NP & NP & ND & ND & NP \\
\hline UE16a \#1 & ND & 1890.7 & 1947.6 & NP & ND1 & 2010.1 & NP & NP & NP & ND & ND & NP \\
\hline UE16b & ND & NP & NP & NP & NP & NP & NP & NP & NP & ND & ND & 1490.5 \\
\hline UE16c & ND & NP & NP & NP & NP & NP & NP & NP & NP & ND & ND & 1440.5 \\
\hline UE16d & ND & NP & NP & NP & NP & NP & NP & NP & NP & ND & ND & 1427.7 \\
\hline UE16f & ND & NP & NP & NP & NP & NP & NP & NP & NP & ND & ND & 1417.6 \\
\hline $\mathrm{HTH}-1$ & NP & ND & NP & ND & NP & NP & ND & ND & ND & ND & ND & 1876.3 \\
\hline UE17a & ND & NP & NP & NP & NP & NP & NP & NP & NP & ND & ND & 1431.6 \\
\hline UE17b & ND & NP & NP & NP & NP & NP & NP & NP & NP & ND & ND & 1456.9 \\
\hline UE17c & ND & NP & NP & NP & NP & NP & NP & NP & $\mathrm{NP}$ & ND & ND & 1473.7 \\
\hline UE17d & ND & NP & NP & NP & NP & NP & NP & NP & NP & ND & ND & 1425.9 \\
\hline UE17e & ND & NP & NP & NP & NP & NP & NP & NP & NP & ND & ND & NP \\
\hline ER-19-1 & NP & ND & NP & ND & NP & NP & NP & NP & NP & ND & ND & NP \\
\hline U19ac & 1681.9 & ND & NP & ND & 1736.1 & NP & ND & 2145.2 & ND & ND & ND & NP \\
\hline U19an & 1748.3 & ND & NP & ND & 1753.0 & NP & ND & 2126.9 & ND & ND & ND & NP \\
\hline U19ax & 1743.8 & ND & NP & ND & 1753.8 & NP & ND & 2129.3 & ND & ND & ND & NP \\
\hline U19t & 1700.5 & ND & NP & ND & 1729.7 & NP & ND & 2130.9 & ND & ND & ND & NP \\
\hline UE19b & 1734.9 & ND & NP & ND & NP & NP & ND & 2073.2 & ND & ND & ND & NP \\
\hline UE19b\#1 & ND1 & ND1 & ND1 & ND1 & ND1 & ND1 & ND1 & ND1 & ND1 & ND & ND & ND1 \\
\hline UE19t & 1703.8 & ND & NP & ND & 1724.9 & NP & ND & 2130.2 & ND & ND & ND & NP \\
\hline ER-30-1 & NDE & NDE & NDE & NDE & NDE & NDE & ND & ND & ND & 1051.3 & 1300.0 & 1416.5 \\
\hline
\end{tabular}


Table A-3

Hydrostratigraphic Data for Selected Drill Holes in the Rainier Mesa-Shoshone Mountain CAU Model Area (meters, elevation)

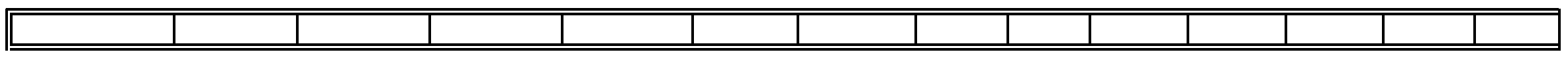

\section{EXPLANATION}

${ }^{1}$ Northings and Eastings as Central NV State Planar coordinates, in feet; NAD 27.

${ }^{2}$ GND EL-Ground (surface) elevation in feet (ft) or meters (m)

${ }^{3} \mathrm{TD}$, ft-Total depth of borehole in feet (ft)

${ }^{4}$ TD EL, ft- Elevation at total depth in feet ( $\mathrm{ft}$ )

${ }^{5}$ All hydrogeologic tops presented in meters elevation.

\section{Qualifiers}

NDE - Borehole not deep enough.

$\mathrm{NP}$ - Unit not present in drill hole.

FO - Unit faulted out.

ND - Unit not differentiated in local area (i.e. HSU defined for adjacent model).

ND1 - Unit not defined in borehole (i.e. missing or poor information).

ND2 - Unit not defined, borehole spudded in a lower stratgraphic unit (i.e.at tunnel level).

\section{Hydrostratigraphic Units}

LCCU = lower clastic confining unit

LCA = lower carbonate aquifer

$\mathrm{UCCU}=$ upper clastic confining unit

$\mathrm{UCA}=$ upper carbonate aquifer

LCA3 $=$ lower carbonate aquifer

LCCU1 = lower clastic confining unit 1-thrust plate

MGCU = Mesozoic granite confining unit

ATCU $=$ argillic tuff confining unit

LTCU1 = lower tuff confining unit 1

RVA = Redrock Valley aquifer

OSBCU = Oak Spring Butte confining unit

LTCU = lower tuff confining unit

TUBA = Tub Spring aquifer

Pre-Tbg LFA = Pre- Grouse Canyon lava-flow aquifer

BRCU = Belted Range confining unit

LVTA1 = lower vitric tuff aquifer 1

BRA = Belted Range aquifer
UTCU1 = upper tuff confining unit 1

$\mathrm{BFCU}=$ Bullfrog confining unit

SWA $=$ Stockade Wash aquifer

UTCU2 = upper tuff confining unit 2

$\mathrm{KA}=$ Kearsarge aquifer

CHVTA = Calico Hills vitric tuff aquifer

LVTA = lower vitric tuff aquifer

TSA = Topopah Spring aquifer

PVTA = Paintbrush vitric tuff aquifer

TCA = Tiva Canyon aquifer

TM-LVTA = Timber Mountain lower vitric tuff aquifer

TM-WTA $=$ Timber Mountain welded tuff aquifer

TM-UVTA = Timber Mountain upper vitric tuff aquifer

TMCM = Timber Mountain composite unit

FCCM = Fortymile Canyon composite unit

$A A=$ alluvial aquifer 


\title{
APPENDIX B
}

\section{Graphical Presentations for Selected UGTA Wells in the Rainier Mesa-Shoshone Mountain Model Area Showing Stratigraphy, Lithology, Alteration, and Hydrogeologic Units}

\author{
B-1 Well ER-12-1 (Russell et al., 1996) \\ B-2 Well ER-12-2 (DOE, 2004) \\ B-3 Well ER-12-3 (DOE, 2006a) \\ B-4 Well ER-12-4 (DOE, 2006b) \\ B-5 Well ER-16-1 (DOE, 2006c) \\ B-6 Well ER-19-1 (DOE, 1995a)
}




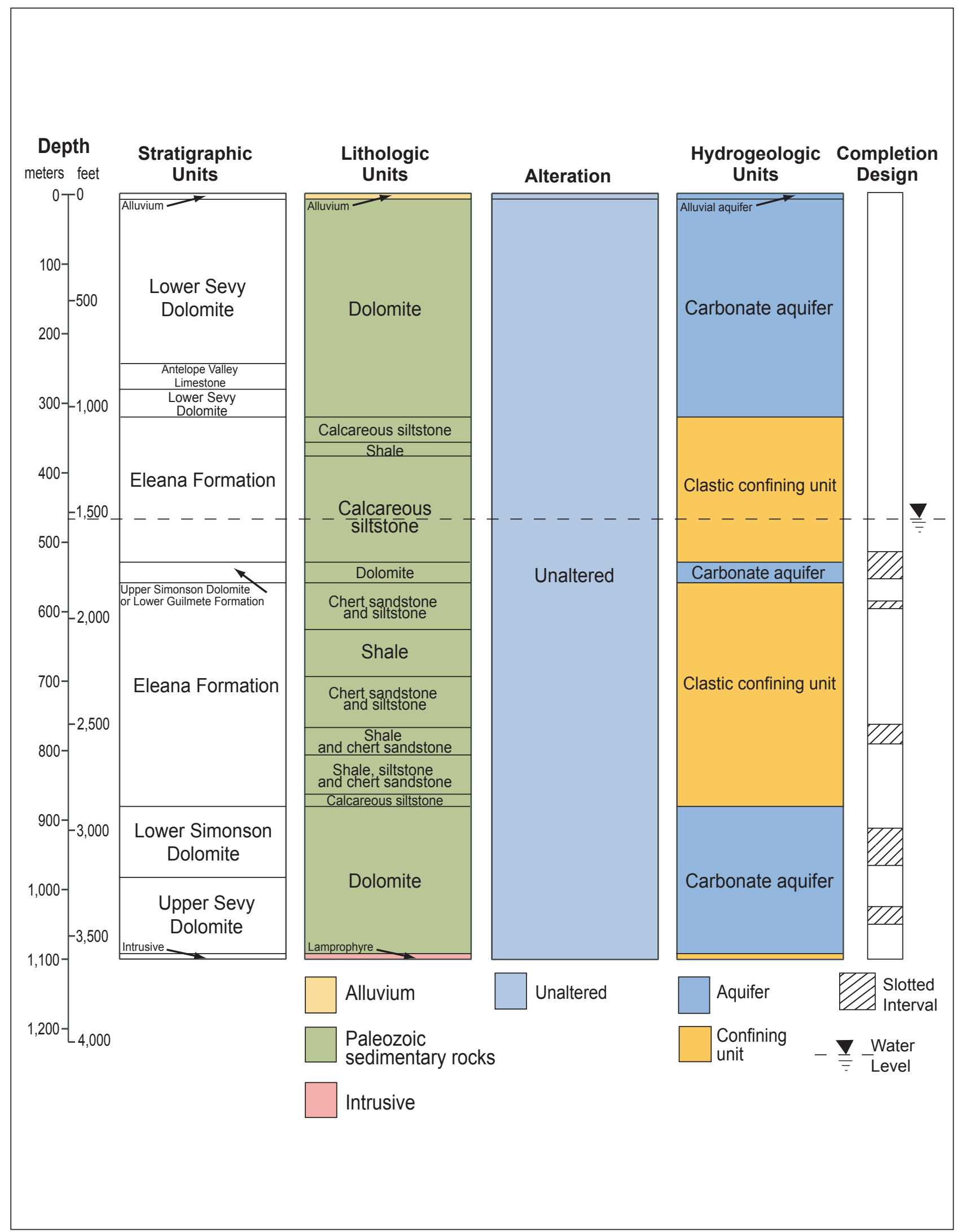

Figure B-1

Graphical Presentation Showing Stratigraphy, Lithology, Alteration, and Hydrogeologic Units for UGTA Well ER-12-1 


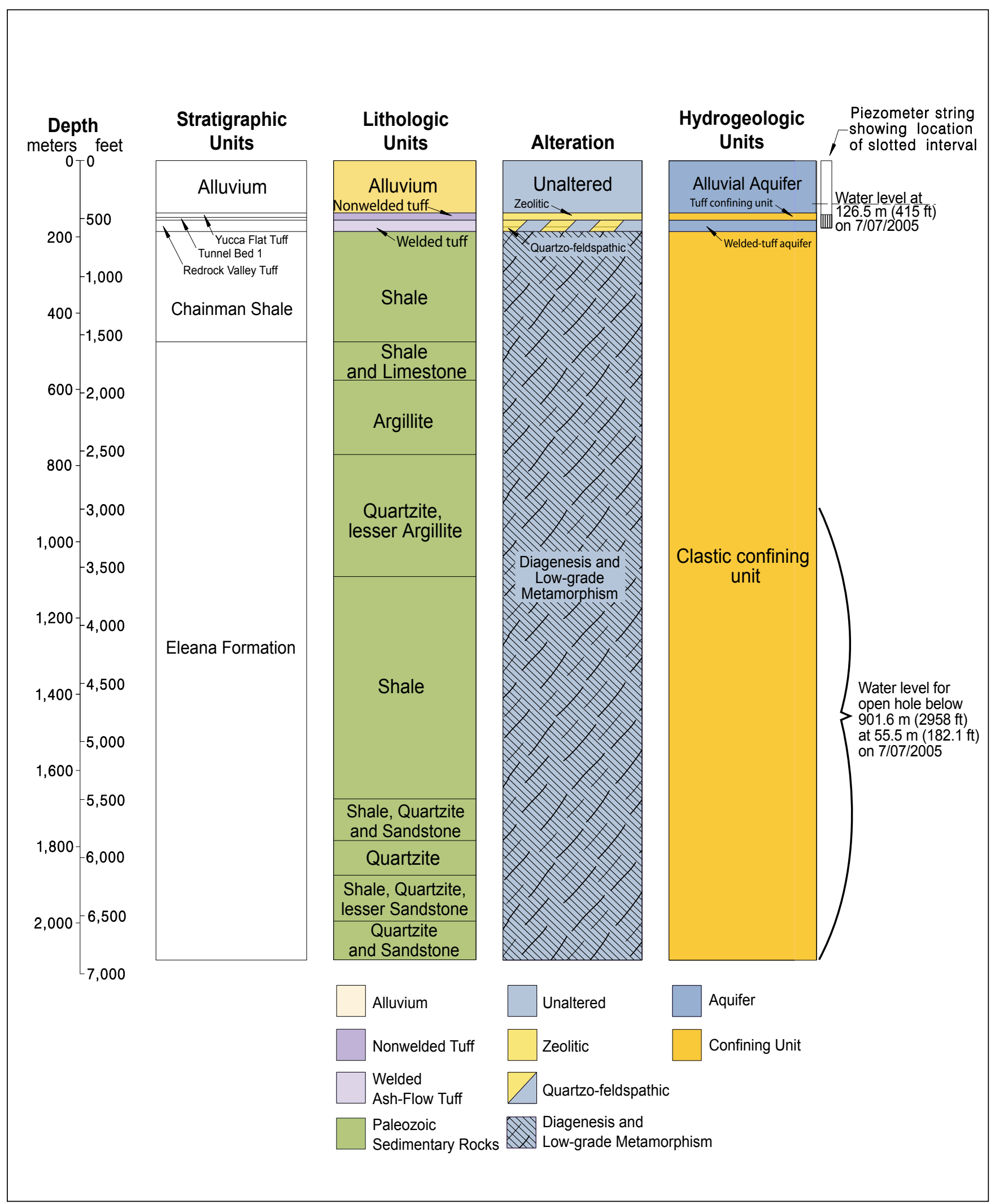

Figure B-2

Graphical Presentation Showing Stratigraphy, Lithology, Alteration, and Hydrogeolgic Units for UGTA Well ER-12-2 


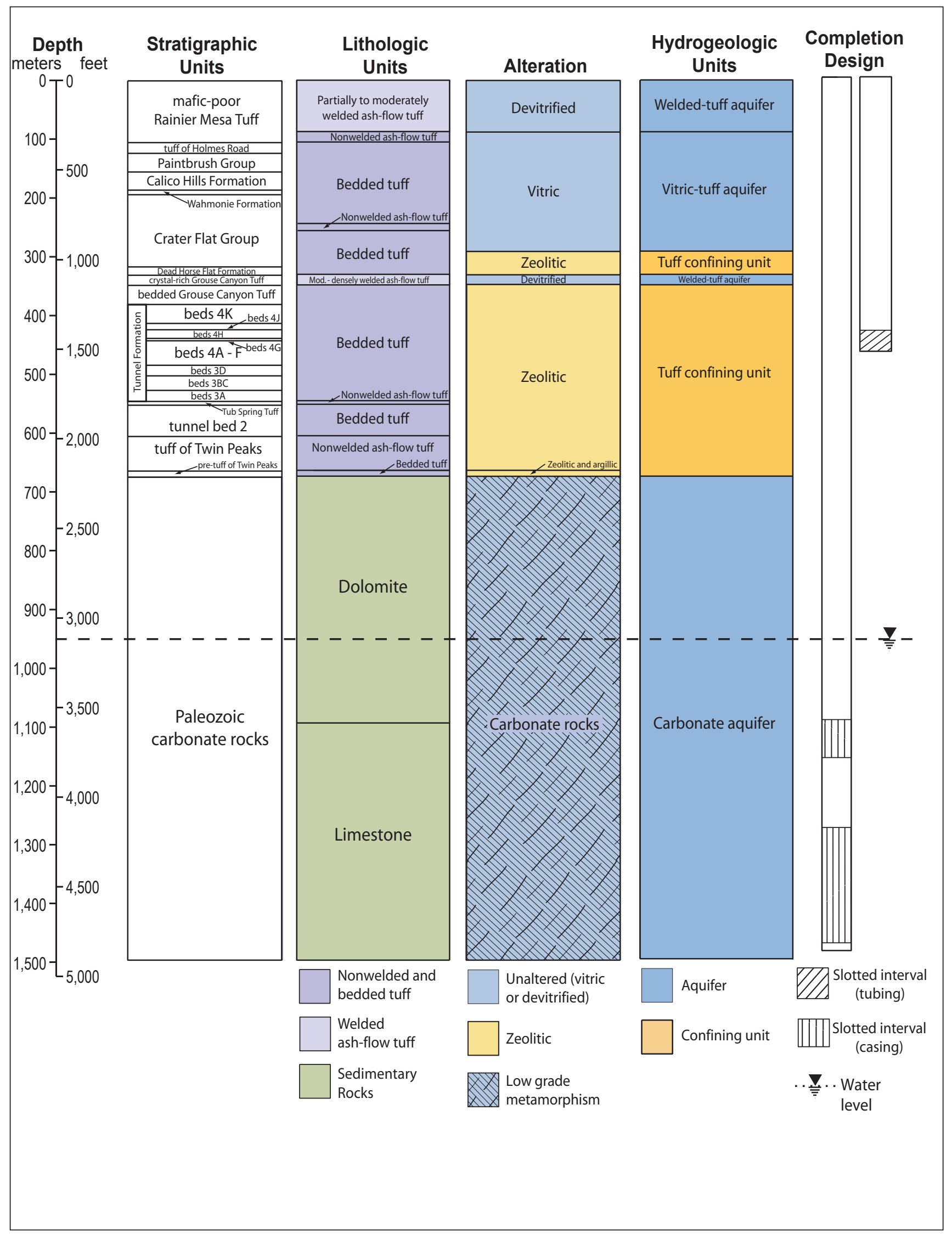

Figure B-3

Graphical Presentation Showing Stratigraphy, Lithology, Alteration, and Hydrogeologic Units for UGTA Well ER-12-3 


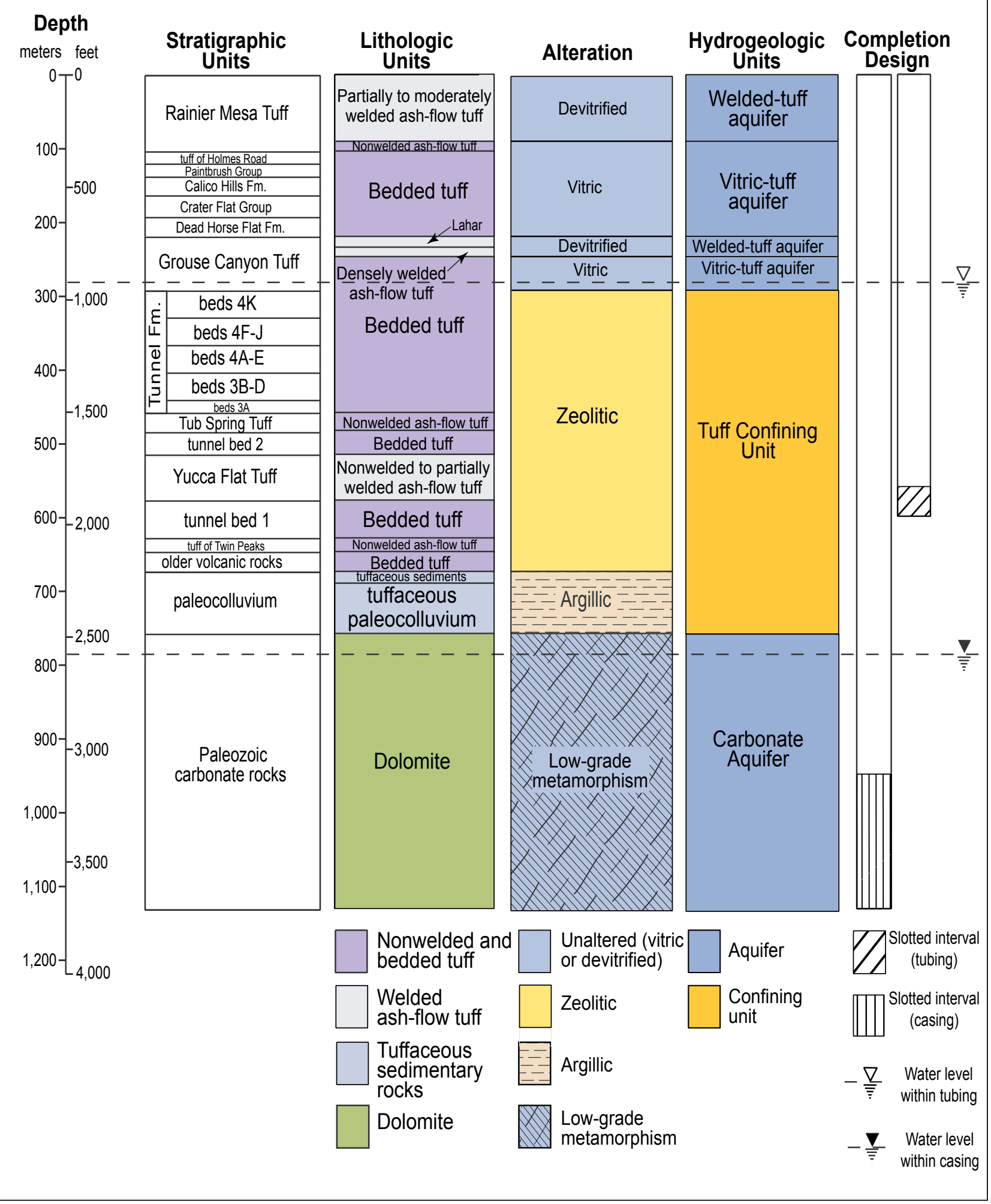

Figure B-4

Graphical Presentation Showing Stratigraphy, Lithology, Alteration, and Hydrogeologic Units for UGTA Well ER-12-4 


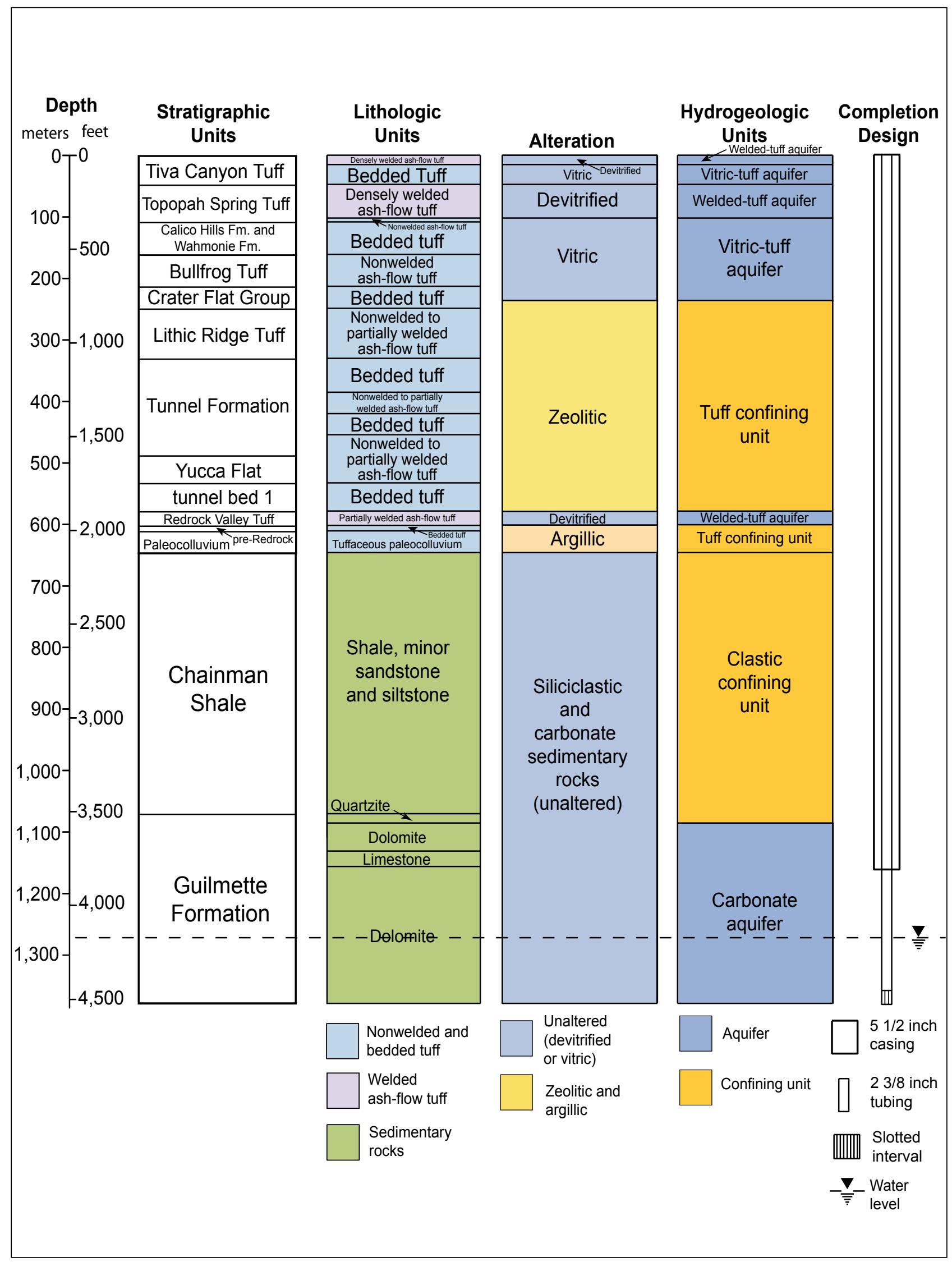

Figure B-5

Graphical Presentation Showing Stratigraphy, Lithology, Alteration, and Hydrogeologic Units for UGTA Well ER-16-1 


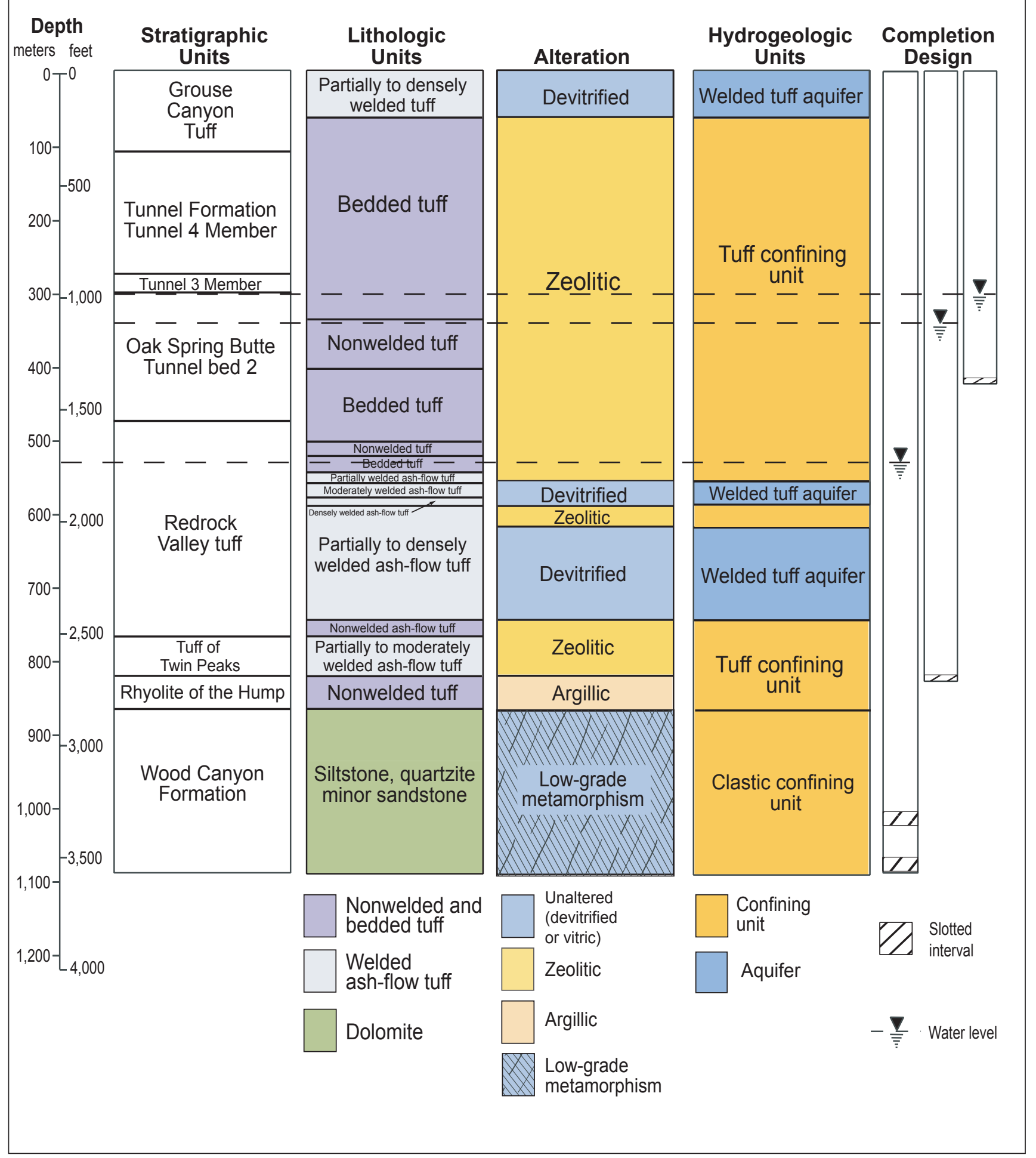

Figure B-6

Graphical Presentation Showing Stratigraphy, Lithology, Alteration, and Hydrogeologic Units for UGTA Well ER-19-1 


\section{APPENDIX C}

Hydrostratigraphic Profiles through the Rainier Mesa-Shoshone Mountain Base Model 


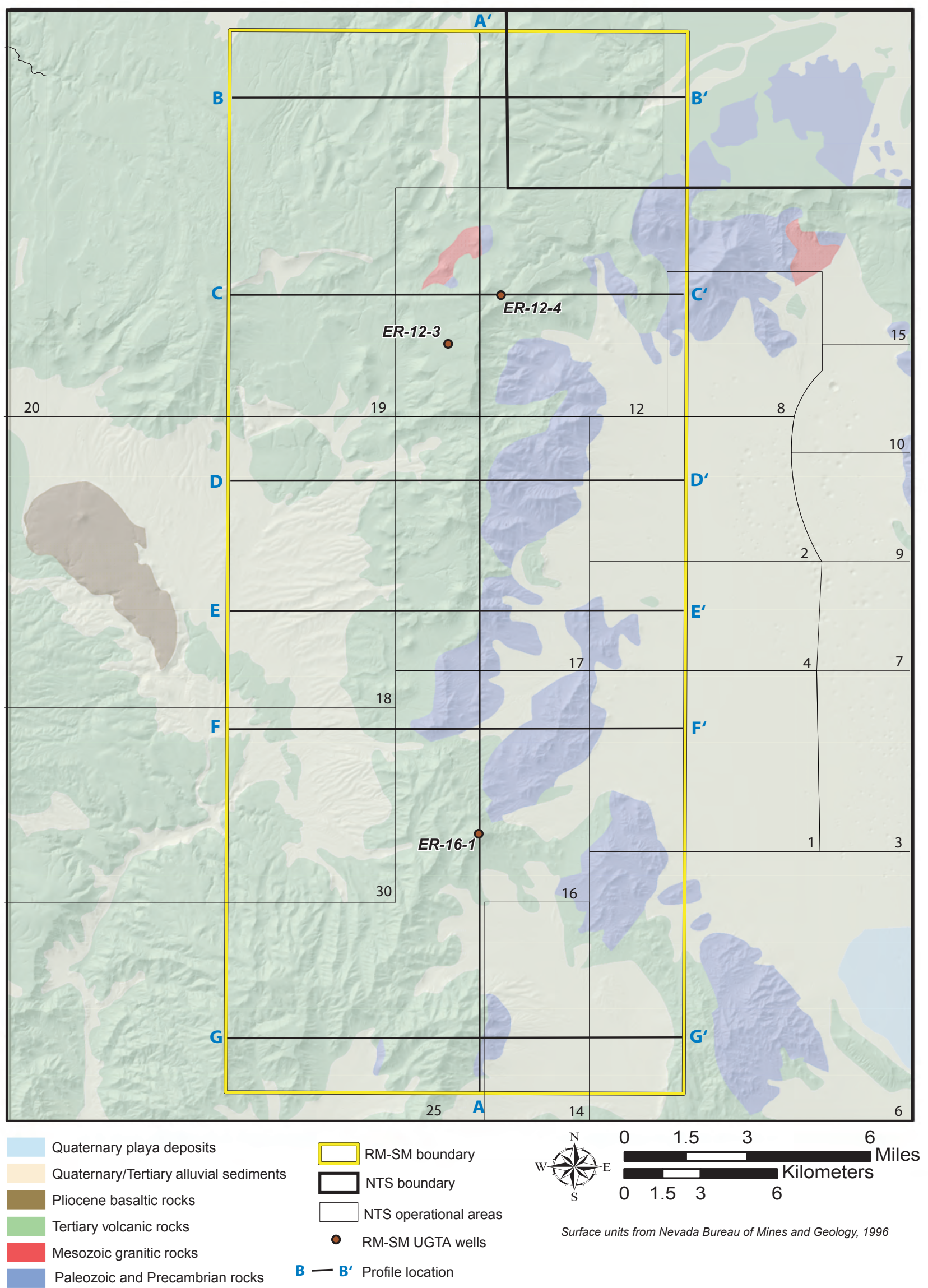

Figure C-1

Locations of Hydrostratigraphic Profiles through the RM-SM Base Model 


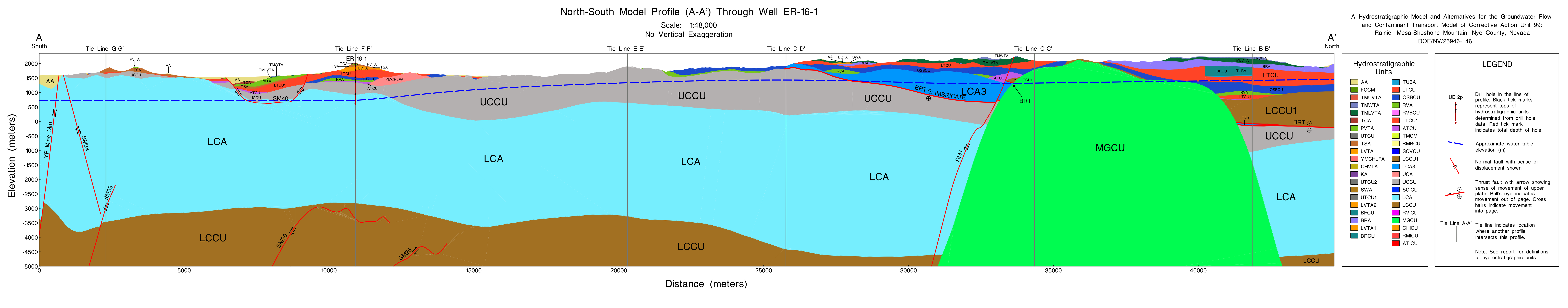


West-East Model Profile (B-B') through the Northern Portion of the Model Area at Drill Hole UE-19t Scale: $1: 48,000$

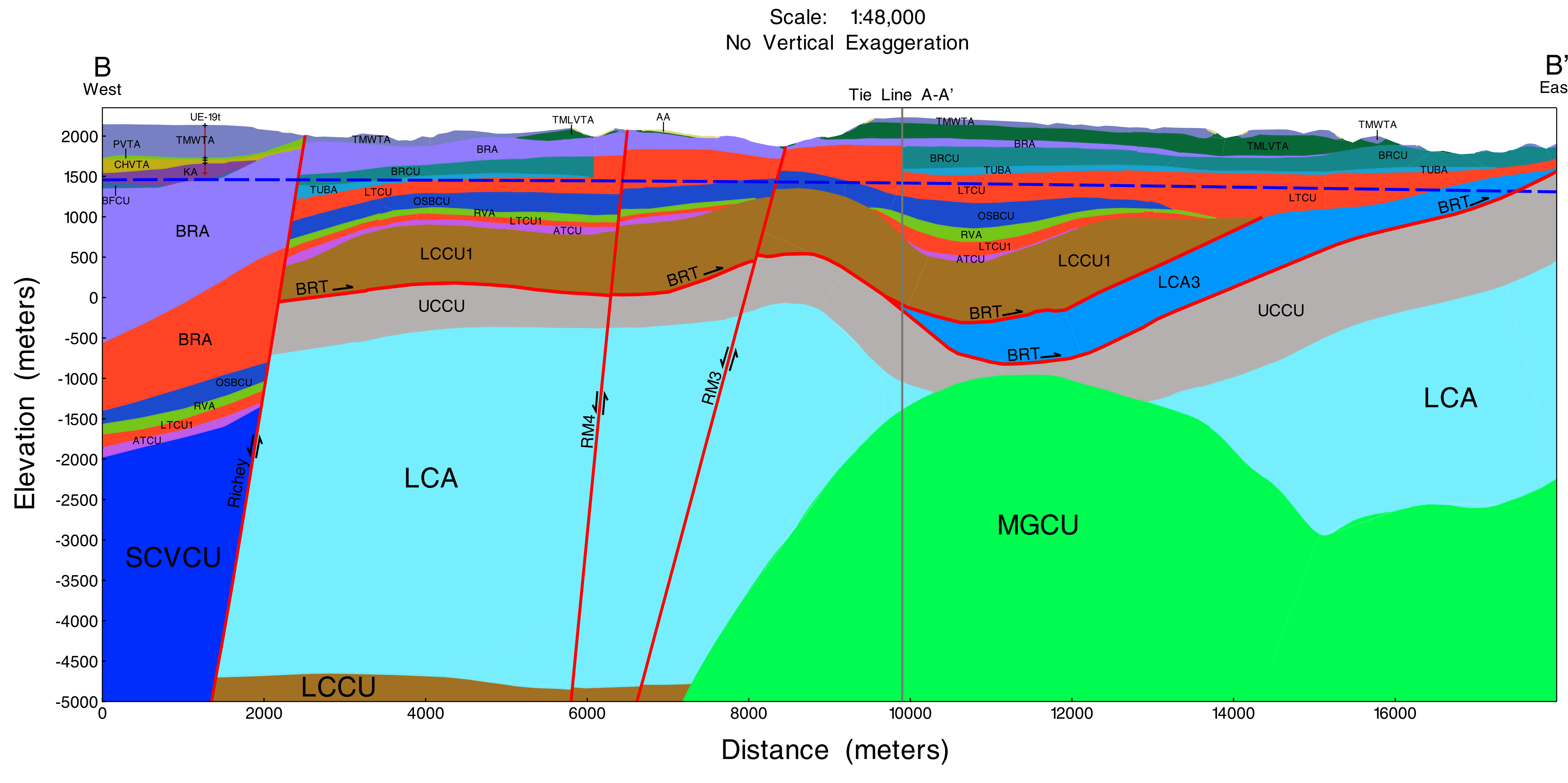

A Hydrostratigraphic Model and Alternatives for the Groundwater Flow and Contaminant Transport Model of Corrective Action Unit 99:
Rainier Mesa-Shoshone Mountain, Nye County, Nevada

B DOE/NV/25946-146
Hydrostratigraphic

$\square_{\text {AA }}^{\text {A }} \square_{\text {TUBA }}^{\text {TUM }}$

$\square$ TMUVTA $\square$ OSBCU

\begin{tabular}{l} 
TMLVTA \\
\hline RVBCu
\end{tabular}

$\begin{array}{ll}\text { TCA } & \square \text { LTCU1 } \\ \text { PVTA } & \text { ATCU }\end{array}$

$\square$ TMCM

$\square$ ISA $\square$ RMBACU

CHVTA LCA3

$\square$ UCA

swa $\square$ scicu

LCA

BFCu RVICU

LVTA1 $\square$ CHICU

$\square$ brau $\square$ RMicu

ATICU
LEGEND

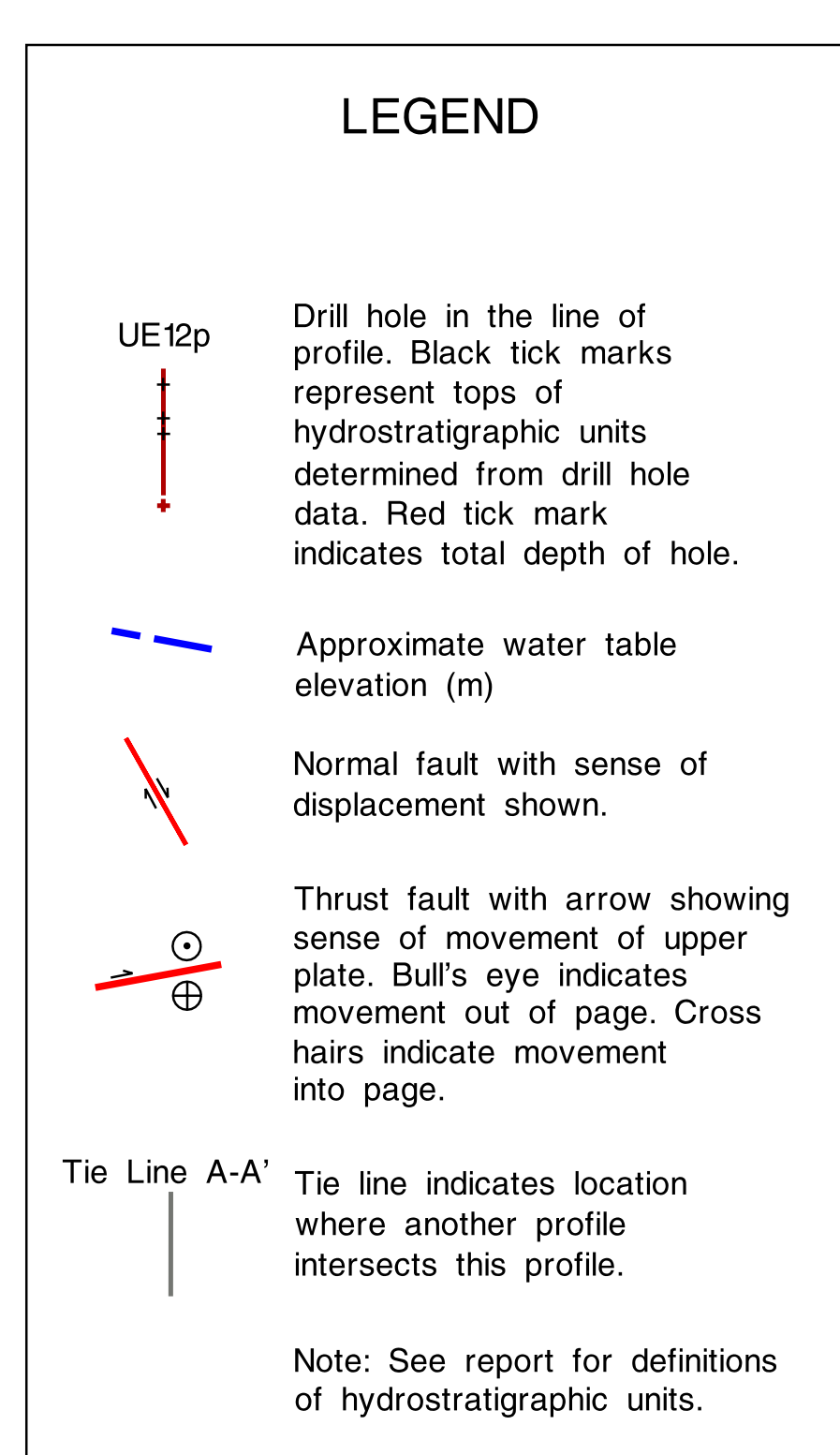


West-East Model Profile (C-C') through Aqueduct Mesa at Well ER-12-4 Scale: $1: 48,000$

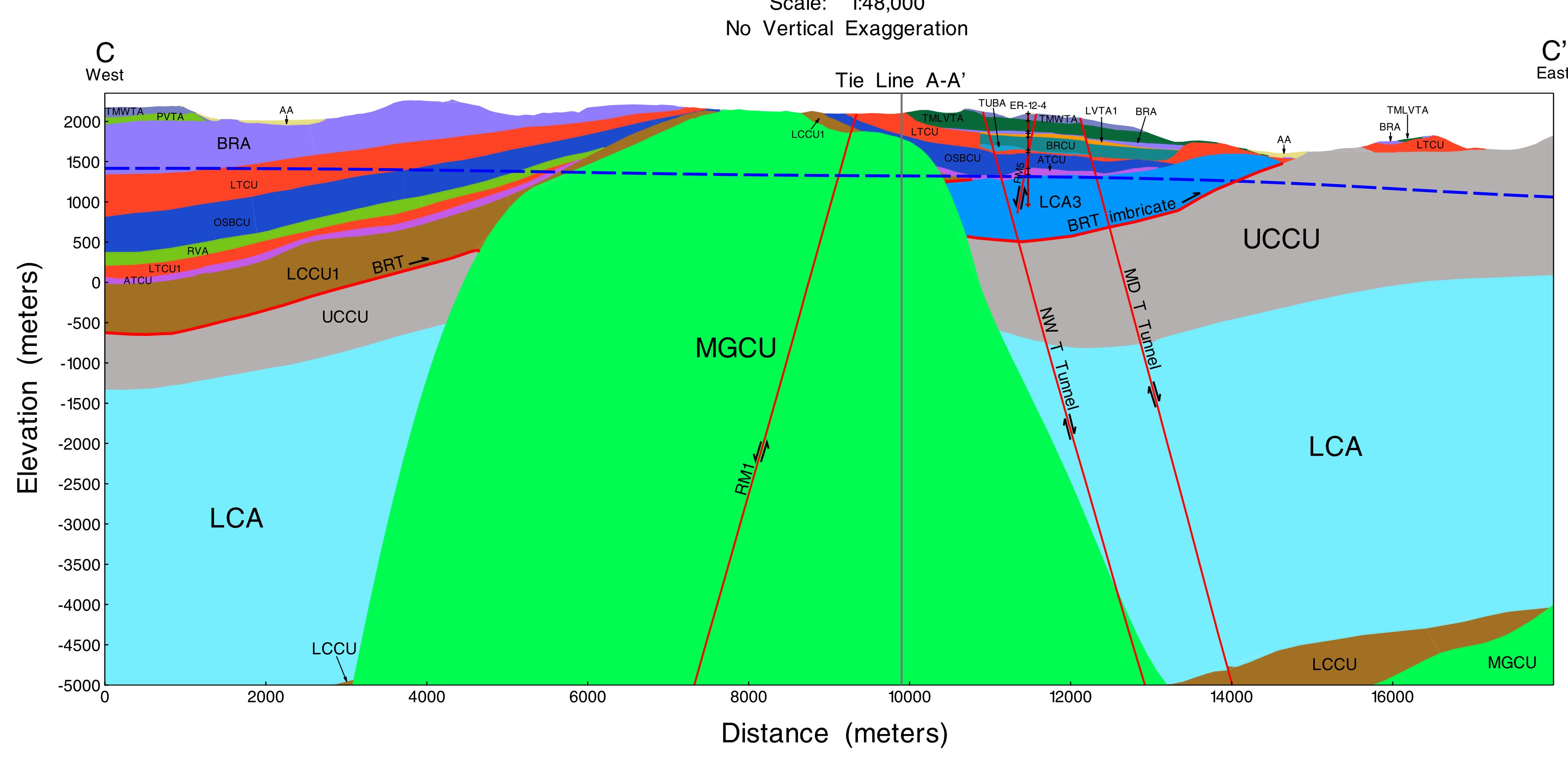

A Hydrostratigraphic Model and Alternatives for the Groundwater Flow

and Contaminant Transport Model of Corrective Action Unit 99:

$\underset{\text { East }}{C^{\prime}}$

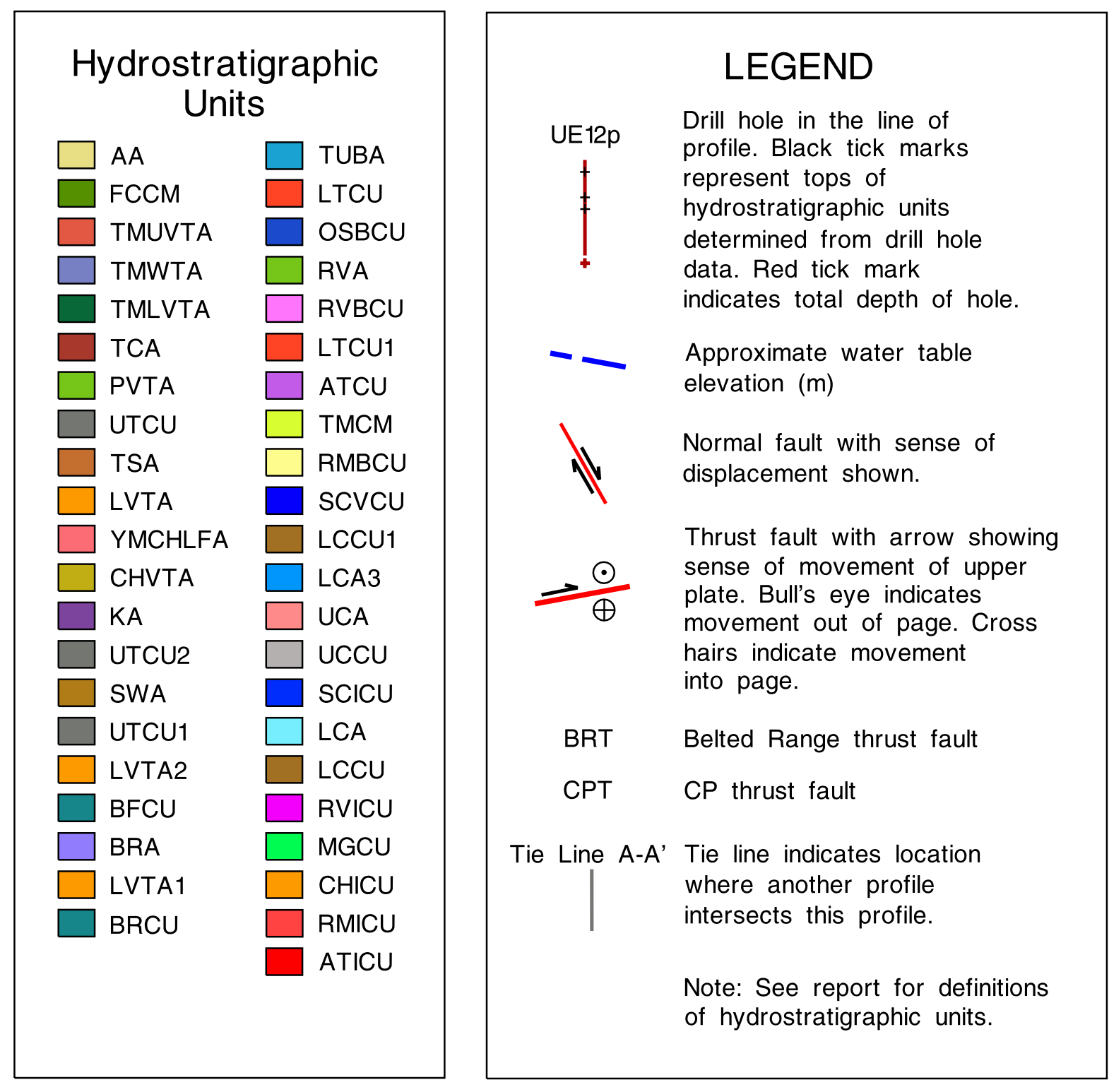


West-East Model Profile (D-D') through the Redrock Valley Caldera at Drill Hole UE-2ce Scale: $1: 48,000$ No Vertical Exaggeration

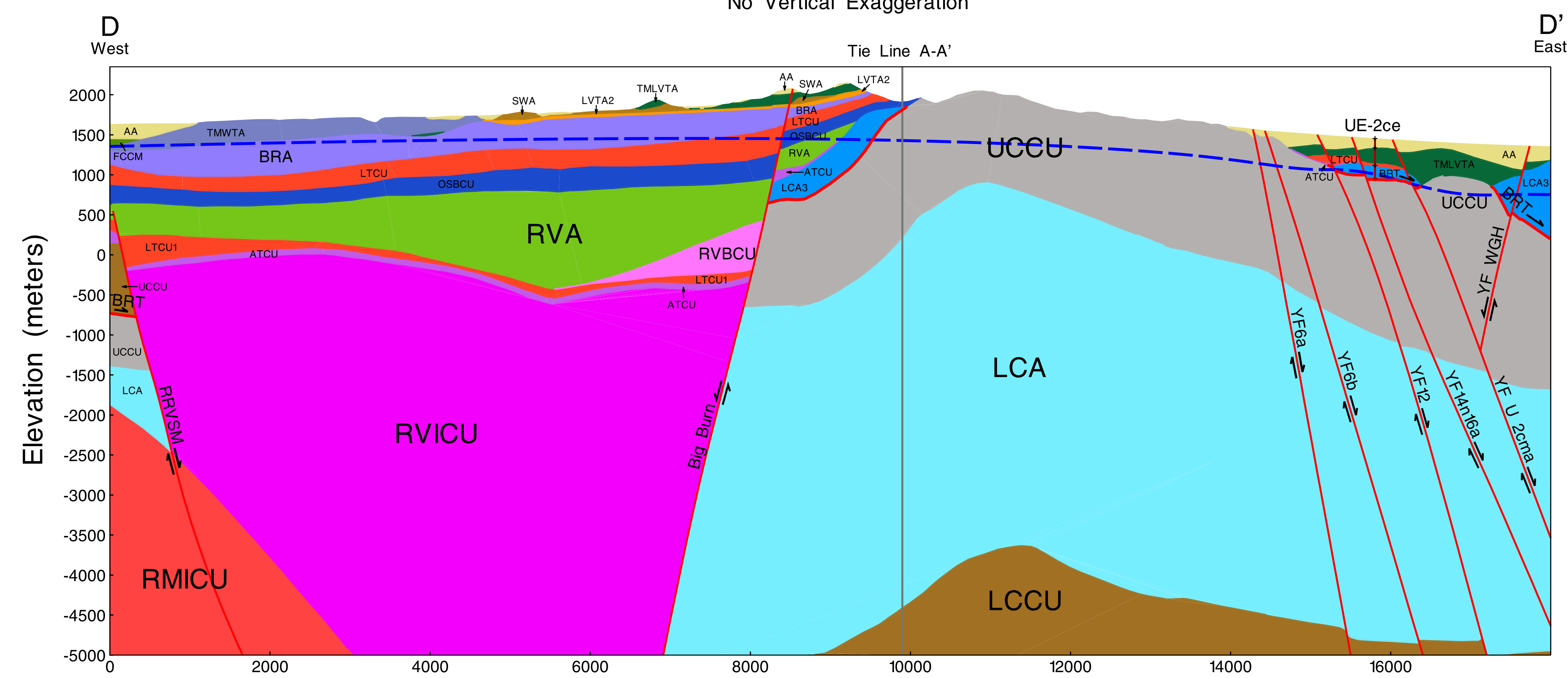

Distance (meters)
A Hydrostratigraphic Model and Alternatives for the Groundwater Flow and Contaminant Transport Model of Corrective Action Unit 99: Rainier Mesa-Shoshone Mountain, Nye County, Nevada $D^{\prime}$
East

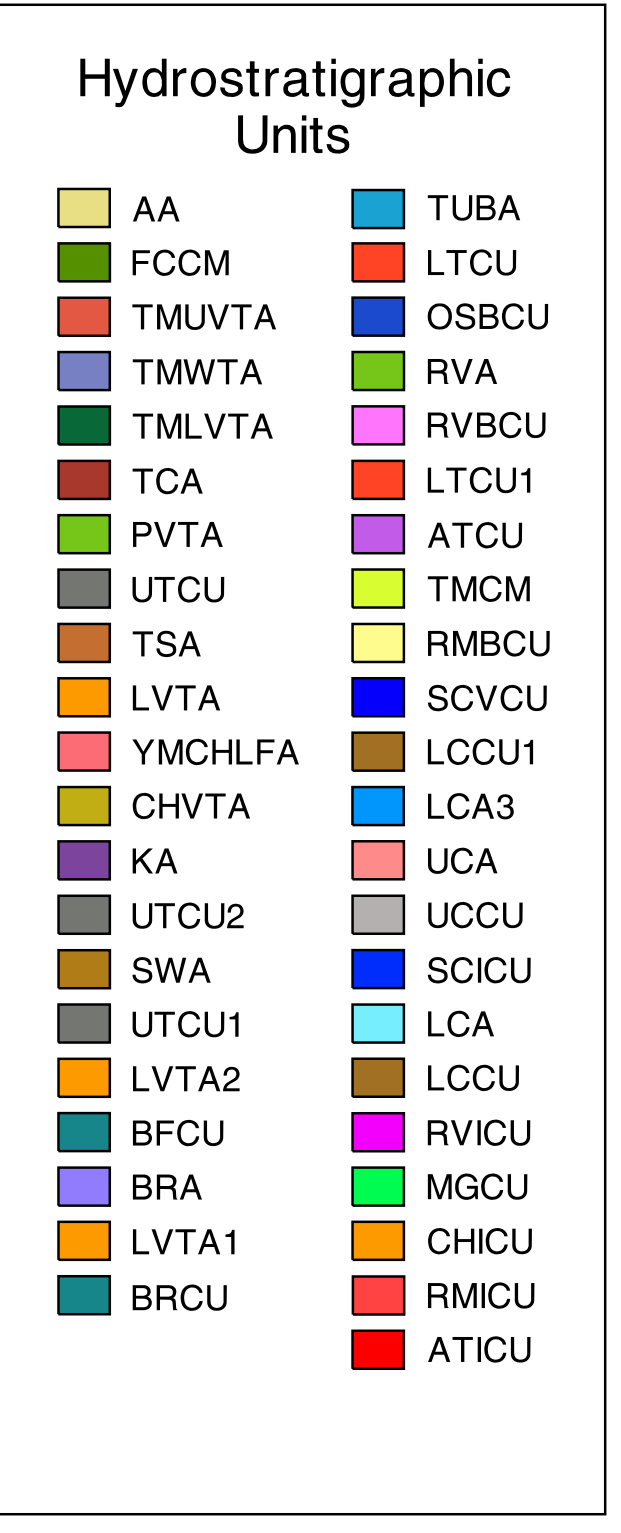

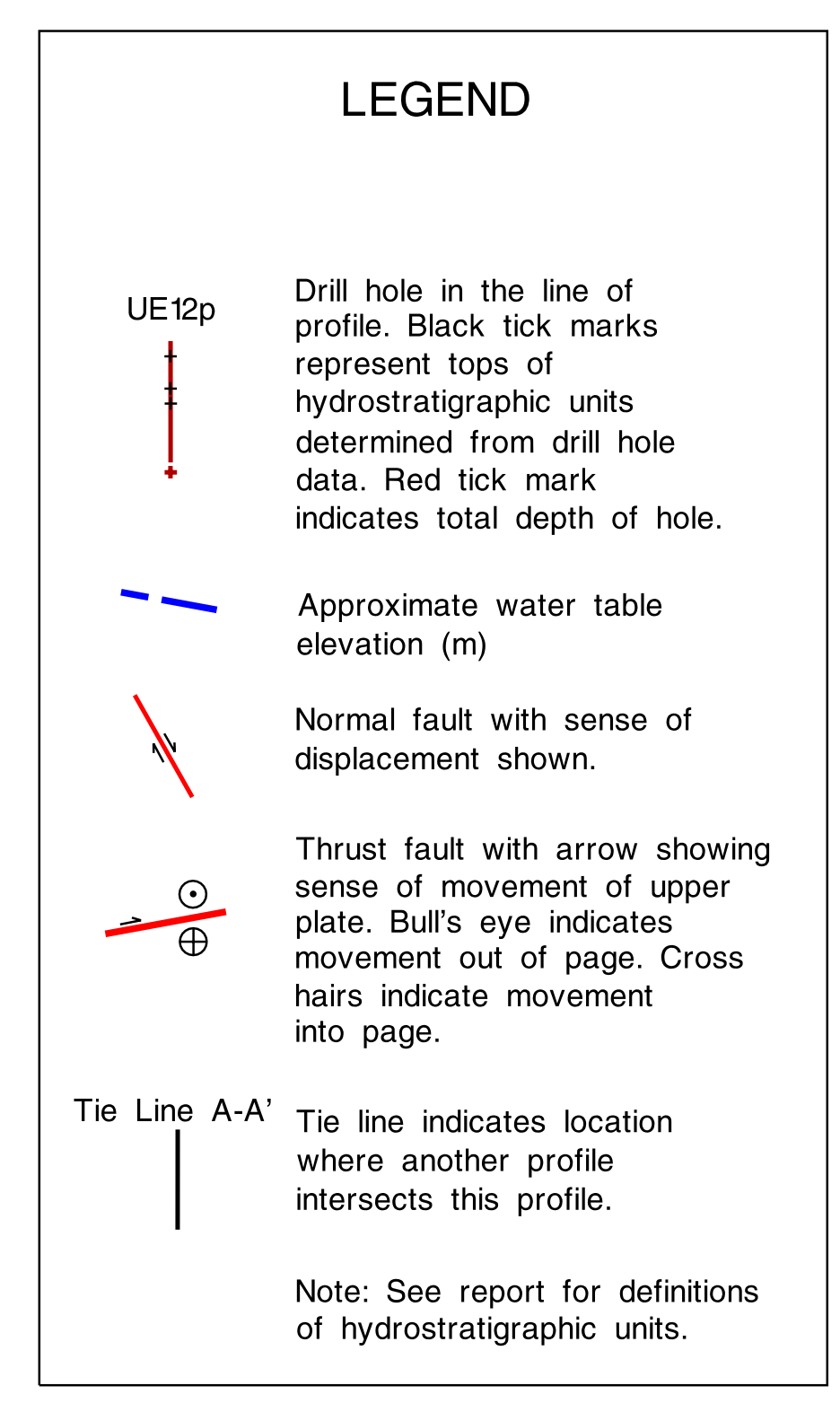


West-East Model Profile (E-E') through the Central Portion of the Model Area at Drill Hole UE-17e

Scale: $1: 48,000$

No Vertical Exaggeration

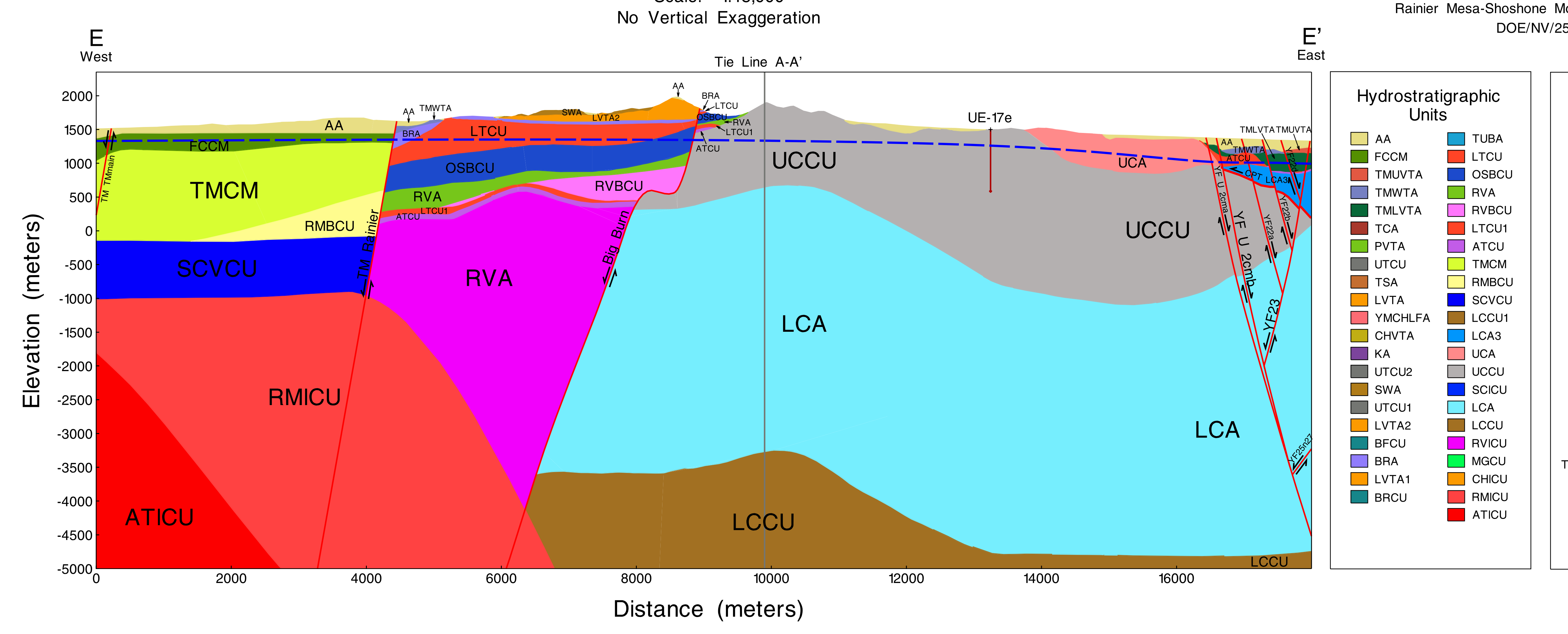

Hydrostratigraphic Model and Alternatives for the Groundwater Flow 25946-146

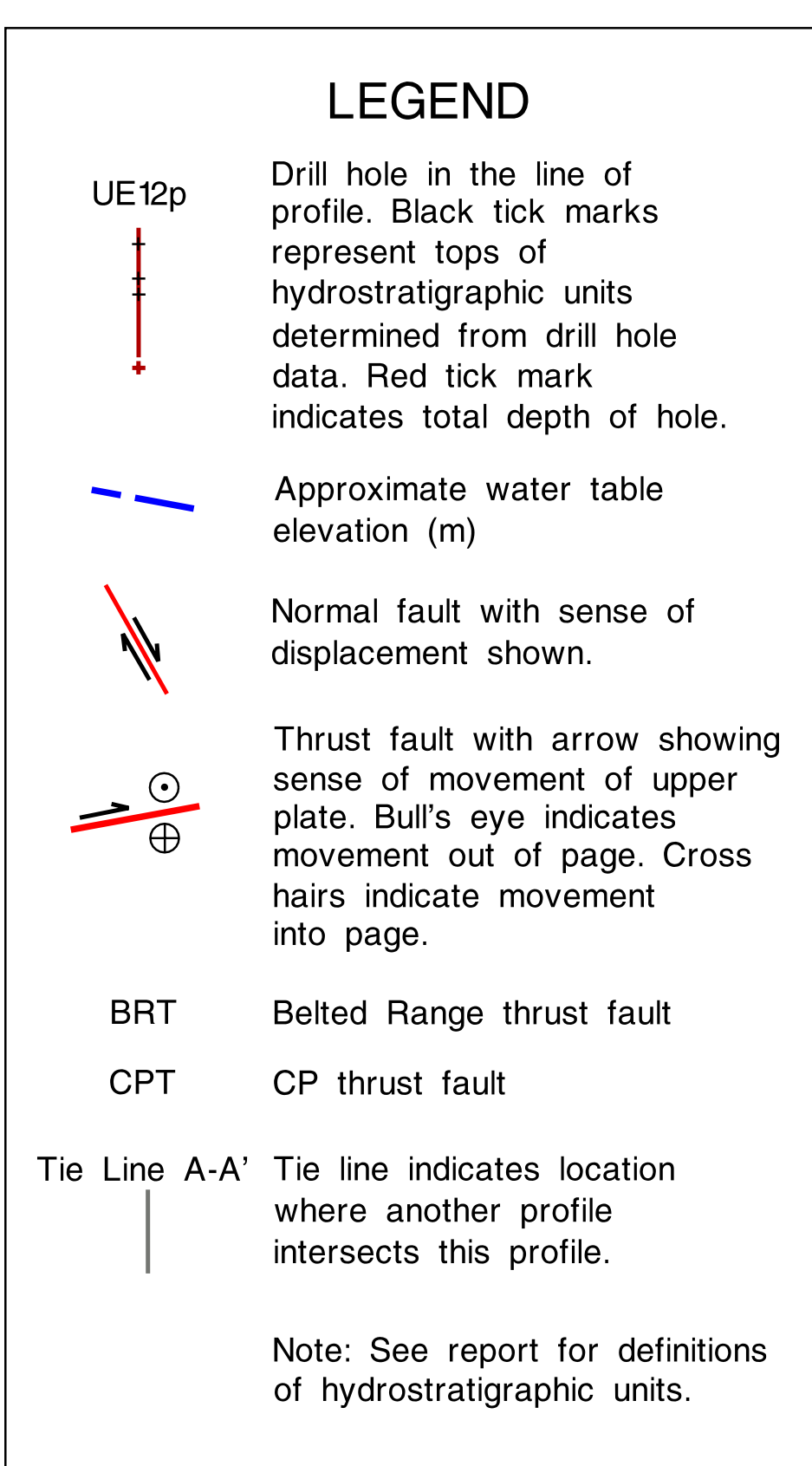


West-East Model Profile (F-F') through the Northern End of Shoshone Mountain at Well ER-16-1

A Hydrostratigraphic Model and Alternatives for the Groundwater Flow and Contaminant Transport Model of Corrective Action Unit 99:

$$
\text { Scale: } 1: 48,000
$$

No Vertical Exaggeration

$\underset{\text { East }}{\text { F }^{\prime}}$

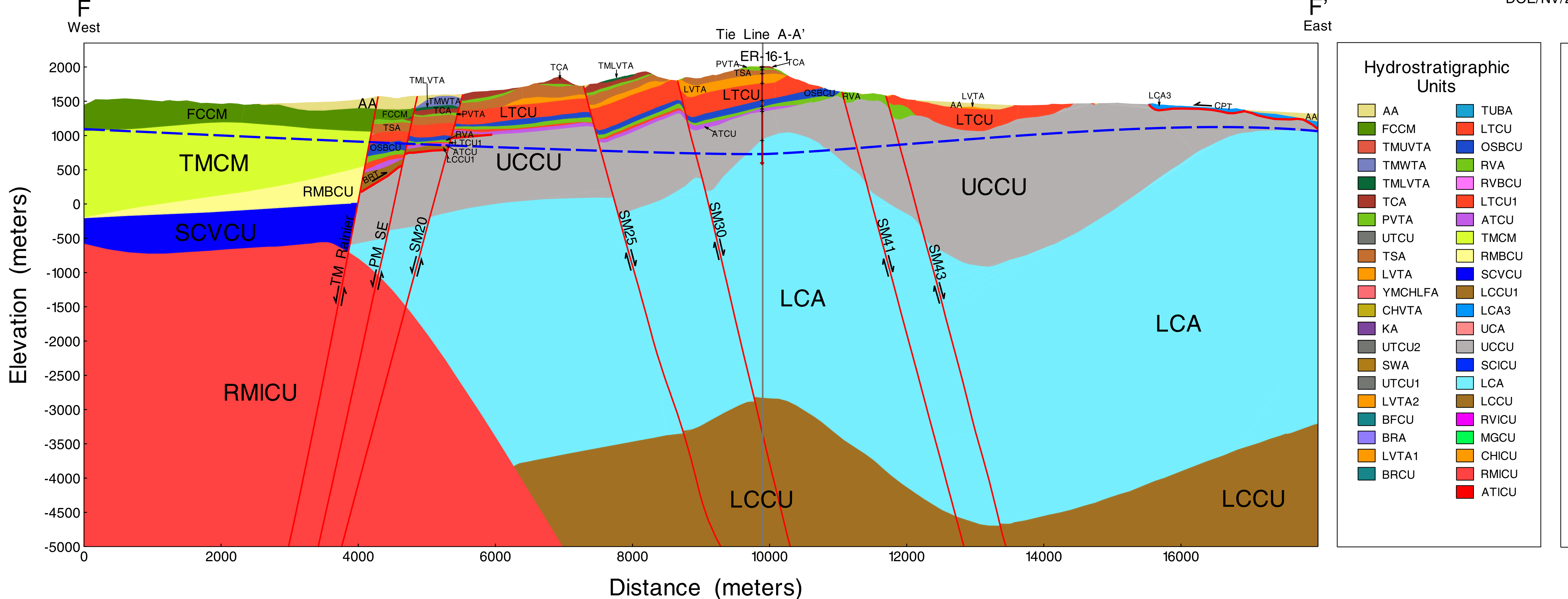

DE/NV/25946-146

Distance (meters) 
West-East Model Profile (G-G') through Mid Valley at Drill Hole UE-14b Scale: $1: 48,000$ No Vertical Exaggeration

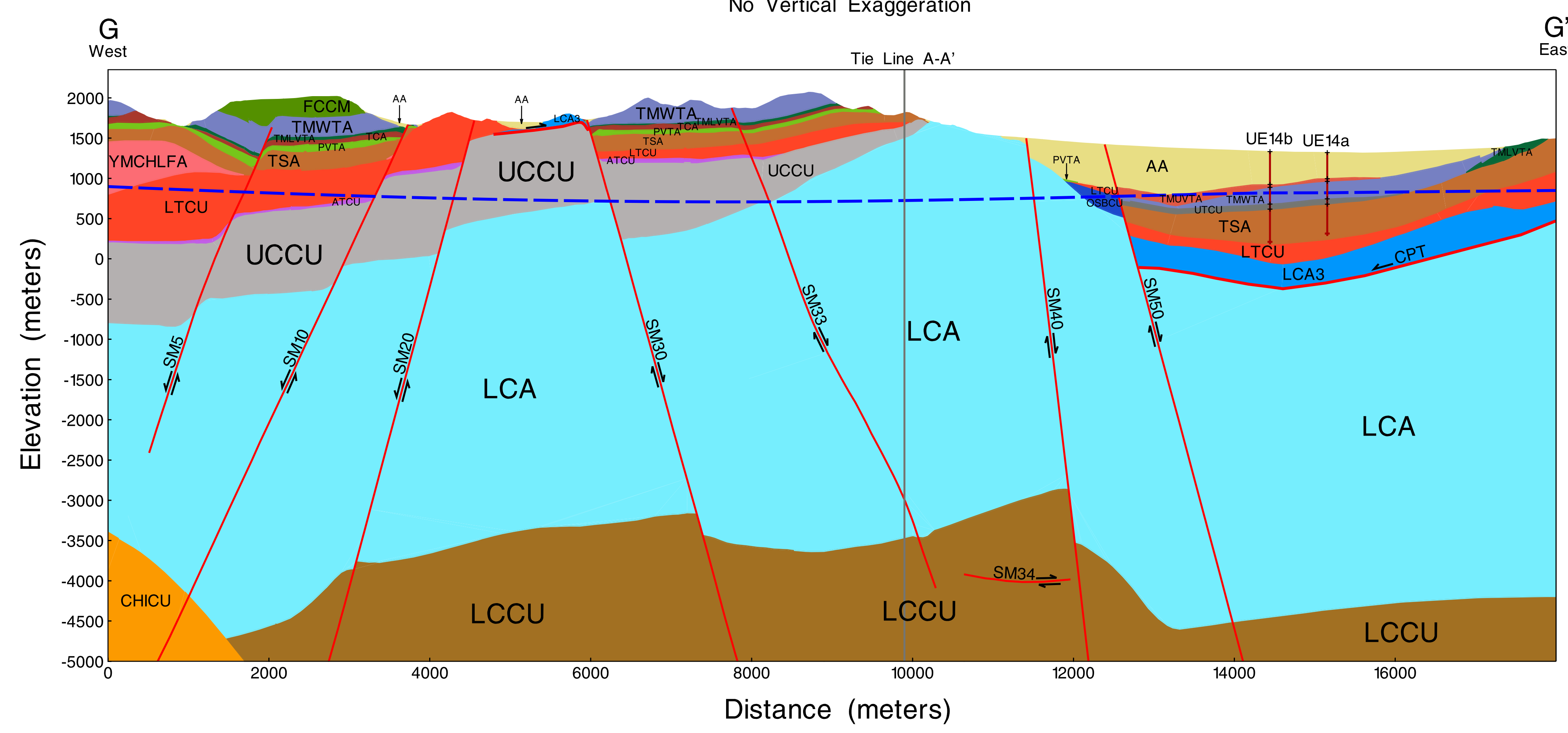

A Hydrostratigraphic Model and Alternatives for the Groundwater Flow Contaminant Transport Model of Corrective Action Unit 99 $\underset{\text { East }}{\text { G' }}$

\begin{tabular}{|c|c|}
\hline \multicolumn{2}{|c|}{$\begin{array}{l}\text { Hydrostratigraphic } \\
\text { Units }\end{array}$} \\
\hline $\begin{array}{l}\square \text { AA } \\
\square \text { FCCM } \\
\square \text { TMUVTA } \\
\square \text { TMWTA } \\
\text { TMLVTA } \\
\square_{\text {TCA }} \\
\square \text { PVTA } \\
\square \text { UTCU } \\
\square \text { TSA } \\
\square \text { LVTA } \\
\square \text { rMCHLFA } \\
\square \text { CHVTA } \\
\square \text { KA } \\
\square \text { uTCU2 } \\
\square \text { SWA } \\
\square \text { UTCU1 } \\
\square \text { LVTA2 } \\
\square \text { BFCU } \\
\square \text { BRA } \\
\square \text { LVTA1 } \\
\text { BRCU }\end{array}$ & 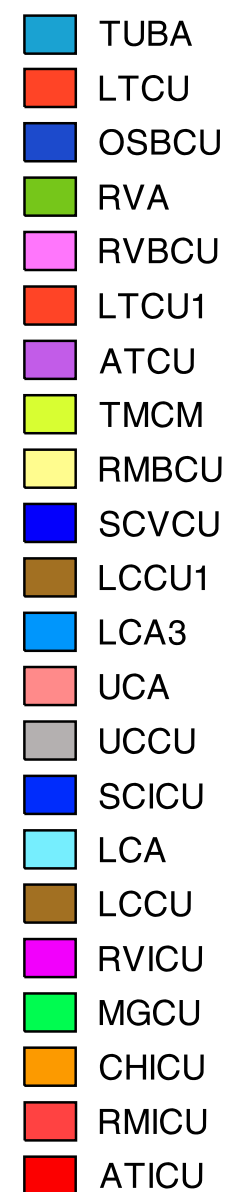 \\
\hline
\end{tabular}
DE/NV/25946-146 


\section{Plate 1}

\section{Geologic Map of the Rainier Mesa-Shoshone Mountain Model Area}



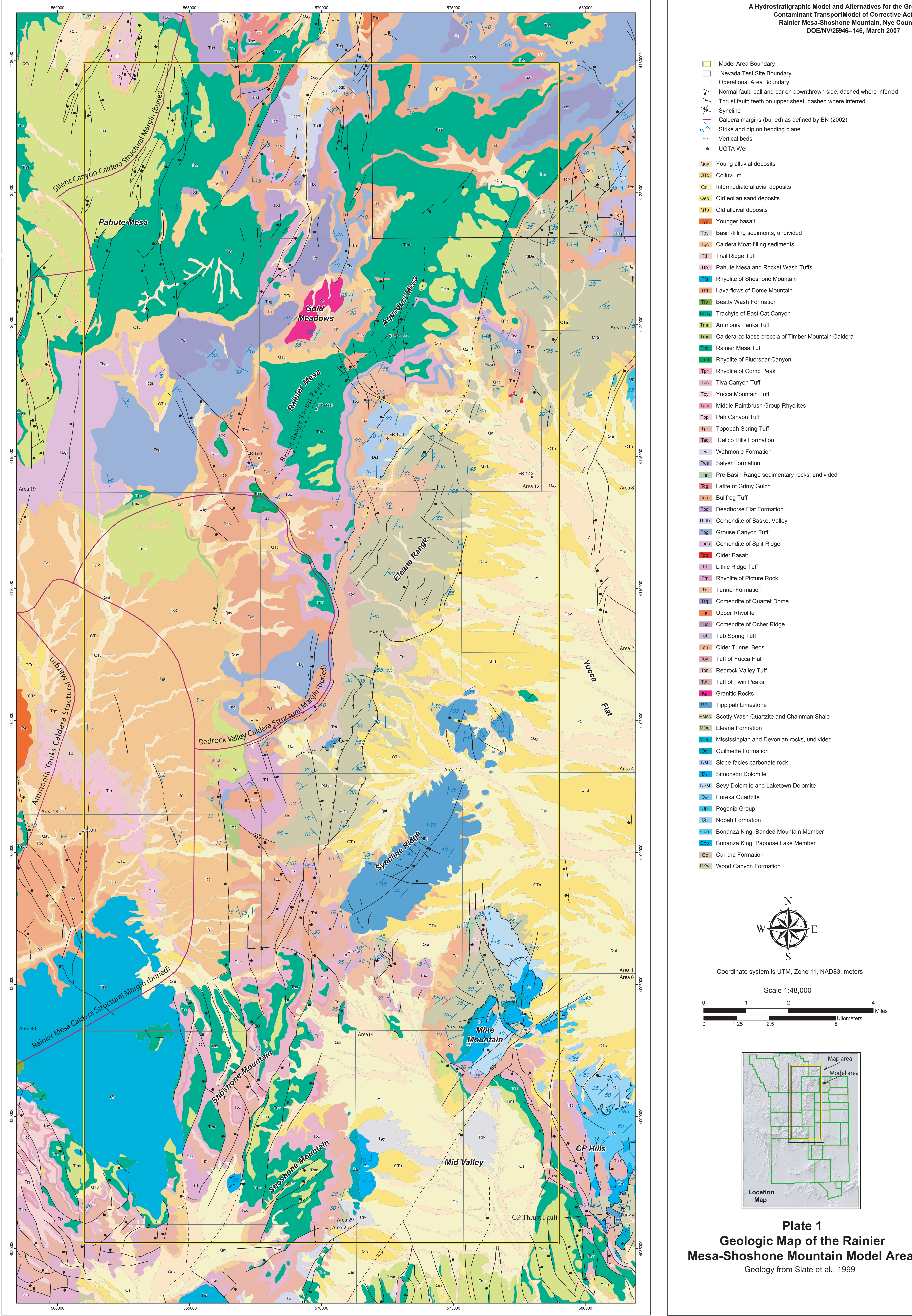

Plate 1

Geologic Map of the Rainier Mesa-Shoshone Mountain Model Area 


\section{Plate 2}

Hydrostratigraphic Surface Map of the Rainier Mesa-Shoshone Mountain Model Area 



A Hydrostratigraphic Model and Alternatives for the Groundwater Flow an
Contaminant TransportModel of Corrective Action Unit 99:
Rainier Mesa-Shoshone Mountain, Nye County, Nevada
DOE/NV/25946--146, March 2007

\section{Legend}

A A' Profile location

---- NTS boundary

NTS Operational Area boundary

- RM-SM UGTA wells

\begin{tabular}{|cc}
\hline \multicolumn{3}{|c|}{$\begin{array}{c}\text { Hydrostratigraphic } \\
\text { Units }\end{array}$} \\
$\square$ AA & $\square$ TUBA \\
$\square$ FCCM & $\square$ LTCU \\
$\square$ TMUVTA & $\square$ OSBCU \\
$\square$ TMWTA & $\square$ RVA \\
TMLVTAA & $\square$ RVBCU \\
$\square$ TCA & $\square$ LTCU1 \\
$\square$ PVTA & $\square$ ATCU \\
$\square$ UTCU & $\square$ TMCM \\
$\square$ TSA & $\square$ RMBCU \\
$\square$ LVTA & $\square$ SCVCU \\
$\square$ YMCHLFA & $\square$ LCCU1 \\
$\square$ CHTTA & $\square$ LCA3 \\
$\square$ KA & $\square$ UCA \\
$\square$ UTCU2 & $\square$ UCCU \\
$\square$ SWA & SCICU \\
$\square$ UTCU1 & $\square$ LCA \\
$\square$ LVTA2 & $\square$ LCCU \\
$\square$ BFCU & $\square$ RVICU \\
$\square$ BRA & $\square$ MGCU \\
$\square$ LVTA1 & $\square$ CHICU \\
$\square$ BRCU & $\square$ RMICU \\
& $\square$ ATICU \\
& \\
\hline
\end{tabular}

$\mathrm{N}$<smiles>C=CC</smiles>

UTM Zone 11 NAD 27 meters

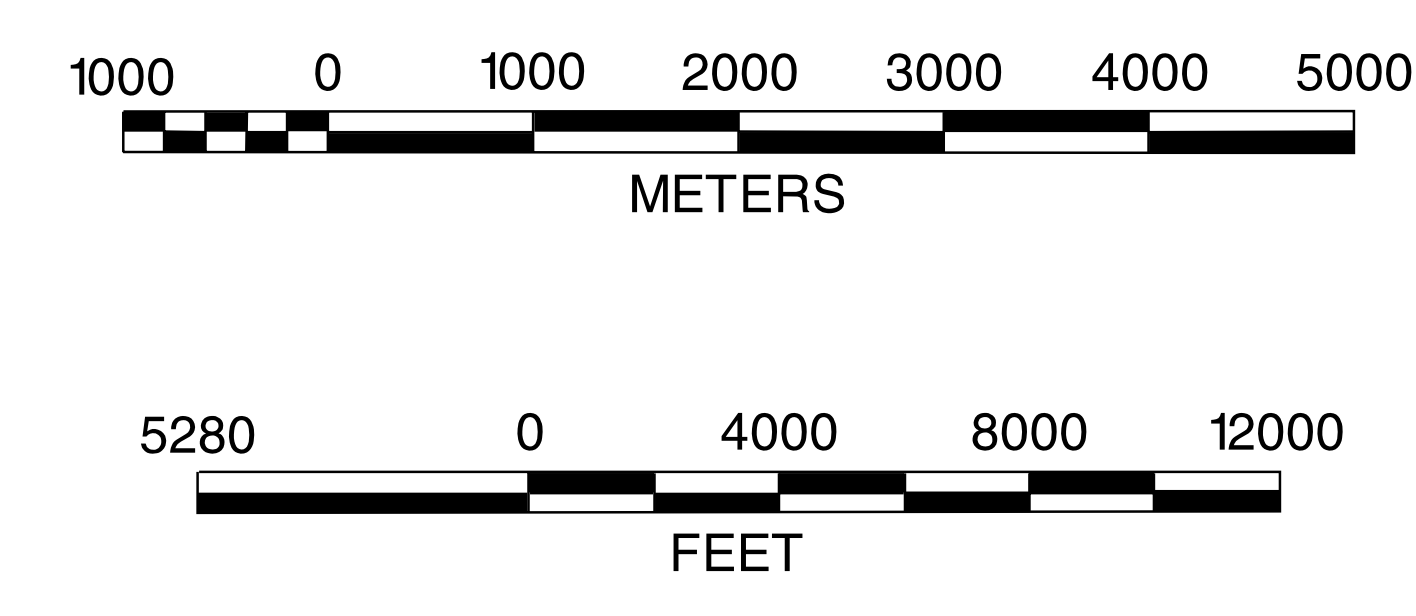

Plate 2

Hydrostratigraphic Surface Map of the Rainier Mesa - Shoshone Mountain Model Area 


\section{Plate 3}

Generalized Geologic Map Showing Locations of Drill Holes Utilized for Construction of the RM-SM Hydrostratigraphic Framework Model 


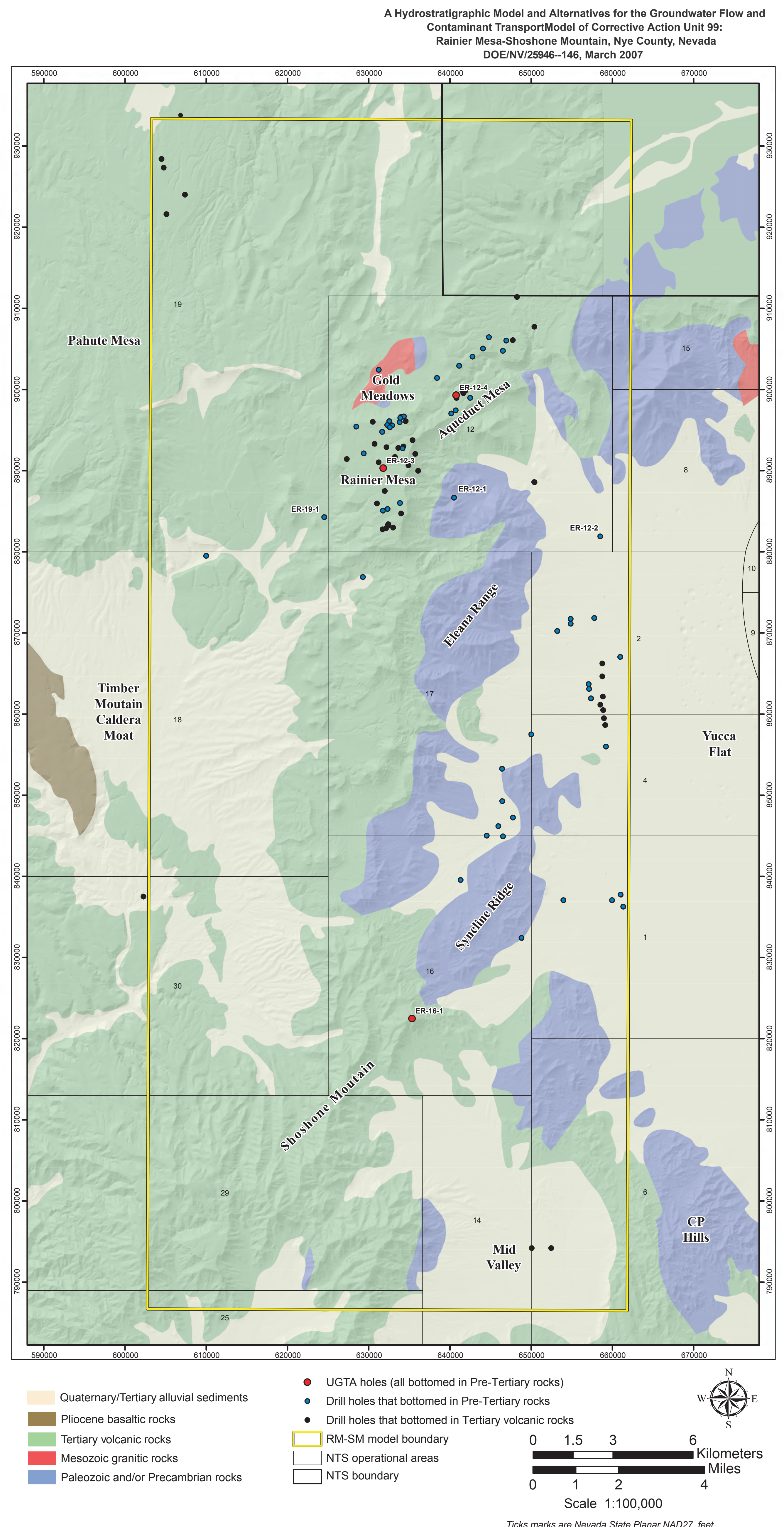

Plate 3

Generalized Geologic Map Showing Locations of Drill Holes Utilized for Construction of the RM-SM Hydrostratigraphic Framework Model 